Micael Rosa Silva

\title{
As mutações de Dioniso em Nietzsche: da Visão dionisíaca de mundo ao "Gênio do coração"
}

\author{
Tese de Doutorado
}

Tese apresentada ao Programa de PósGraduação em Filosofia da Puc-Rio como requisito parcial para obtenção do grau de Doutor em Filosofia.

Orientador: Prof. Pedro Duarte de Andrade

VOLUME I

Rio de Janeiro

Setembro de 2018 


\title{
Micael Rosa Silva
}

\section{As mutações de Dioniso em Nietzsche: da Visão dionisíaca de mundo ao "Gênio do coração"}

\begin{abstract}
Tese apresentada como requisito parcial para obtenção do grau de Doutor pelo Programa de Pós-Graduação em Filosofia do departamento de Filosofia do Centro de Teologia e Ciências Humanas da PUC-Rio. Aprovada pela Comissão Examinadora abaixo assinada.
\end{abstract}

\author{
Prof. Pedro Duarte de Andrade \\ Orientador \\ Departamento de Filosofia - PUC-Rio \\ Profa. Marcela Figueiredo Cibella de Oliveira \\ Departamento de Filosofia - PUC-Rio \\ Prof. José Fernandes Weber \\ Universidade Estadual de Londrina - UEL \\ Prof. Alexandre da Silva Costa \\ Universidade Federal Fluminense - UFF \\ Profa. Maria Helena Lisboa da Cunha \\ Universidade do Estado do Rio de Janeiro - UERJ
}

Profa Monah Winograd

Coordenadora Setorial de Pós-Graduação de Pesquisa do Centro de Teologia e Ciências Humanas - PUC-Rio

Rio de Janeiro, 28 de setembro de 2018. 
Todos os direitos reservados. É proibida a reprodução total ou parcial do trabalho sem autorização da universidade, do autor e do orientador.

\section{Micael Rosa silva}

Possui graduação em FILOSOFIA pela Universidade Estadual de Londrina - UEL (2007), obteve o título de Mestre em Filosofa pelo programa de pós-graduação em Filosofia Contemporânea da Universidade Estadual do Rio de Janeiro - UERJ (2013). Atualmente é professor de filosofia efetivo no Colégio de Aplicação da Universidade Estadual de Londrina - UEL. Desenvolve pesquisas nas áreas de ensino de filosofia, estética e filosofia da arte, onde se concentram suas publicações.

Ficha Catalográfica

Silva, Micael Rosa

As mutações de Dioniso: da visão dionisíaca de mundo ao "gênio do coração" / Micael Rosa Silva; orientador: Pedro Duarte de Andrade. -2018.

2 v. ; $30 \mathrm{~cm}$

Tese (doutorado)-Pontifícia Universidade Católica do Rio de Janeiro, Departamento de Filosofia, 2018. Inclui bibliografia

1. Filosofia - Teses. 2. Arte. 3. Nietzsche. 4. Cultura. 5. Dioniso. 6. Tragédia. I. Duarte, Pedro. II. Pontifícia Universidade Católica do Rio de Janeiro. Departamento de Filosofia. III. Título. 
Para Lourdes, Nestor, Rebeca, Milca, Felipe e Kety - ou seja - Minha Família Buscapé. 


\section{Agradecimentos}

À PUC-Rio pelos auxílios concedidos, fomento fundamental para desenvolvimento dessa pesquisa.

Ao Professor Pedro Duarte de Andrade por aceitar orientar este trabalho, pelas aulas inspiradoras e, sobretudo, pela confiança depositada para tal empreita.

Ao Professor João Constâncio da Universidade Nova de Lisboa pela cordial receptividade em seu Instituto de Filosofia e pelas brilhantes aulas nesta Universidade. O tempo foi curto, mas experiência foi excepcionalmente rica.

À Professora Maria Helena Lisboa, uma vez orientadora, sempre orientadora!

À Professora Marcela de Oliveira por aceitar o convite de avaliar esse trabalho.

Ao Professor José Fernandes Weber por acompanhar, desde a graduação, minhas "tagarelices filosóficas", sempre inspirando com sapiência e bom humor.

Ao Professor Alexandre Costa, por aceitar participar da avaliação deste trabalho, pela sua leitura minuciosa e, principalmente, por ser uma espécie de "interlocutor fantasma" quando estou lendo, pensando e escrevendo sobre os gregos antigos.

Ao amigo Rogério Cesar Fornes por sempre ceder um cantinho de sua casa e pela sua companhia sempre, ou quase sempre, enriquecedora.

Ao amigo Ronie Péterson por ser meu conselheiro privado e sempre me socorrer nas dúvidas dos mais diversos assuntos.

Ao amigo Marcelino Pereira pela parceria de sempre, por ajudar com algumas das traduções e por questionar o sentido, ou falta de sentido, desta empreita.

À amiga Vanessa Duron pelo reencontro, pela calorosa acolhida em Lisboa, por estar sempre disposta a ajudar, pelos bons vinhos e pelos bate-papos às margens do Tejo.

À Edna Sampaio, assistente do departamento de filosofia, por sua cordialidade.

Aos amigos Cléo Meirelles, Ruy Osório, Ronaldo, Luciano Alves, Beatriz Zanuto, Dayane, Camila, Fabrício, Ítalo, Igor e Danilo Santos por nossas conversas, as realmente edificantes.

Aos demais professores do Departamento de filosofia da Puc-Rio.

A todos os meus colegas professores pelo incentivo e reconhecimento.

Aos meus queridos alunos que entenderam a minha ausência neste período.

O presente trabalho foi realizado com apoio da Coordenação de Aperfeiçoamento de Pessoal de Nível Superior - Brasil (CAPES) - Código de financiamento 001 


\section{Nota de (Des)agradecimento}

É necessário expressar uma nota de "repúdio" ao Governo do Estado do Paraná, especificamente na pessoa do Sr. Beto Richa, por negar por quatro vezes minhas solicitações de afastamento - previsto em lei - para a realização deste doutorado, dificultando, assim, imensamente a realização deste e demonstrando descaso pela educação e pelos professores em sua gestão. 


\section{Resumo}

Silva, Micael Rosa; Duarte de Andrade, Pedro (Orientador). As mutações de Dioniso: da Visão dionisíaca de mundo ao "gênio do coração". Rio de Janeiro, 2018. 427p. Tese de doutorado - Departamento de Filosofia, Pontifícia Universidade Católica do Rio de Janeiro.

Esta tese tem como objeto de estudo as múltiplas formas que o símbolo "Dioniso" assume ao longo do pensamento nietzschiano. Podemos dizer que Dioniso acompanha Nietzsche durante toda sua produção intelectual, prefigurando a imagem mais importante de sua obra, se relacionando direta ou indiretamente com todos os grandes temas de sua filosofia. No entanto, o significado de Dioniso não é o mesmo durante toda a filosofia nietzschiana; pelo contrário, sua significação sofre uma radical transformação. Primeiramente, Nietzsche encontra em Dioniso, e em seu oposto Apolo, a chave para compreender a visão de mundo dos gregos antigos, e com isso, o meio para decifrar a própria existência. Em seus primeiros escritos, que compreendem a fase conhecida como "metafísica do artista", o dionisíaco é essencial para elaboração de uma teoria estética que reconhecia no elemento musical das tragédias gregas o momento de superioridade da cultura ocidental. Todavia, o filósofo rompe com seus próprios preceitos, suspende temporariamente as menções a Dioniso e inicia a elaboração de uma filosofia trágica, isto é, combatente a toda forma de negação da vida. O segundo Dioniso renasce na obra nietzschiana despido de qualquer roupagem metafísica; o dionisíaco passa a ser ligado à imanência, aos instintos e, fundamentalmente, à afirmação da existência e ao louvor do instante. Sabendo disso, nosso trabalho divide-se em quatro partes que, juntas, formam um todo, uma verdadeira tragoedia nietzschiana: primeira parte, quem era o deus antigo Dioniso; segunda, quais são os desdobramentos filosóficos de $O$ Nascimento da tragédia; terceira, o que vem à cena, enquanto Dioniso se cala; e por fim, quais as nuances do Dioniso renascido e qual sua importância, segundo Nietzsche, para a cultura e para a vida.

\section{Palavras chave}

Arte; cultura; Dioniso; Nietzsche; tragédia; 


\section{Abstract}

Silva, Micael Rosa; Duarte de Andrade, Pedro (Advisor). The Dionysus's mutations: from The Dionysian Vision of the world to "Genius of the Heart". Rio de Janeiro, 2018. 427p. Tese - Departamento de Filosofia, Pontifícia Universidade Católica do Rio de Janeiro.

The objective of this thesis is to study the forms that "Dionysius" assumes during Nietzsche's thoughts. He follows Nietzsche throughout his intellectual production, connecting directly or indirectly to all the major themes of his philosophy. However, the meaning of Dionysus is not the same throughout his work; on the contrary, its significance undergoes a radical transformation. First, Nietzsche finds in Dionysius a key to understand the old greeks world's view and deciphering one's own existence. In his early writings, which comprised a stage known as the "artist's metaphysics", the Dionysian is essential to an aesthetic theory that recognized in the musical element of greek tragedies, the high point of Western culture. However, the philosopher breaks with his own precepts, get distance from schopenhaurian pessimism and that of Wagnerian aesthetics. Suspends, temporarily, the mentions to the god and begins the elaboration of a tragic philosophy, that is, fighting all ways of denial of life. The second Dionysus is reborn in the Nietzschean work unclad of garb. He is now related to immanence, to instincts, to the affirmation of existence and to the praise of the instant. Considering that, this thesis is divided into four parts, together, forming a whole, a true Nietzschean tragoedia: first, who was the ancient god Dionysus; second, what are the philosophical unfoldings of The Birth of tragedy; third, what comes to the scene when Dionysus is silent; and, finally, what are the nuances of the reborn Dionysus and what is his importance, according to Nietzsche, for the culture and for life.

\section{Keywords}

Art; cultur; Dionysius, Nietzsche; tragedy. 


\section{Sumário}

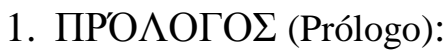

1.1. De muitas formas se reveste o divino ..................................... 12

1.2. O re-descobrimento da Grécia ............................................... 18

1.3. Estilo em Nietzsche e a possibilidade de filosofar

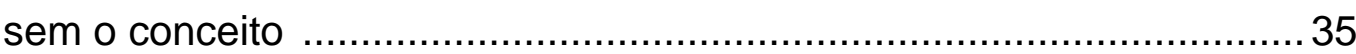

1.4. Incipit tragoedia - estrutura e conteúdo ..................................... 44

2. П'APO $\triangle \mathrm{O} \Sigma$ (Párodo):

2.1. Do Oriente vem o berro do bode ...........................................53

2.2. O deus das entranhas da Grécia ..........................................6 67

2.3. O deus minoico e micênico 'di-wo-nu-so'................................ 72

2.4. Um deus... Muitas máscaras ................................................... 77

2.5. Um deus... Muitos nomes ....................................................... 82

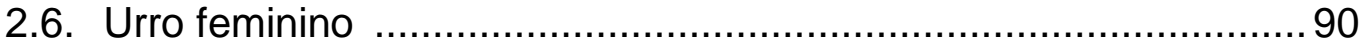

2.7. Ariadne e seus amores labirínticos .......................................... 105

3. 'ЕПEI $\Sigma \mathrm{O} \Delta \mathrm{ION} \Pi \mathrm{\Pi P} \Omega \mathrm{TON}$ (Primeiro Episódio):

3.1. Dioniso e a realidade por trás do véu f...................................... 117

3.2. Kant e Schopenhauer, a sabedoria dionisíaca expressa em conceitos ................................................................ 129

3.2.1. Kant, um abalo sísmico ................................................ 131

3.2.2. O dionisíaco entre a imaginação e a razão ............................143

3.2.3. Dioniso e Apolo como vontade e representação ..................... 157

3.2.4. Para além das ideias, a música... ..................................... 173

3.3. O herói dilacerado e o fluxo da vida eterna .............................. 182

3.4. Eurípides entre Zagreus e o homem comum (ou entre Penteu e o povo): ......................................................... 185

3.4.1. Eurípides entre mito e razão (ou entre Medeia e o Jasão) .......203

3.5. A doença Sócrates ou a doença de Sócrates? A Dicotomia entre 0 instinto e a razão .............................................................. 227

3.5.1. Sócrates dionisíaco? A filosofia levada à iminência da vida .....239 


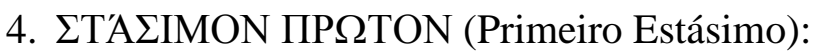

4.1. Wagner e a esperança do renascimento do dionisíaco na Alemanha ........................................................................ 245

4.2. Parsifal: eis o tilintar de duas espadas que se cruzam ..............251

5. 'EПEI $\Sigma$ O $\Delta \mathrm{ION} \Delta \mathrm{E}^{\prime} \mathrm{YTEPON}$ (Segundo Episódio):

5.1. O monumento de uma crise (e o silêncio de Dioniso) ...............258

5.1.1. Um cálice vazio - a crítica à embriaguez .............................266

5.1.2. A re-significação do Gênio ............................................. 276

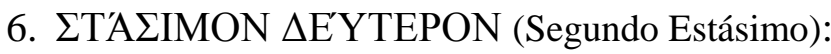

6.1. A re-significação da música .............................................. 284

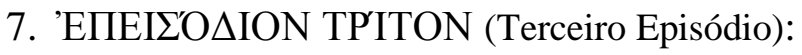

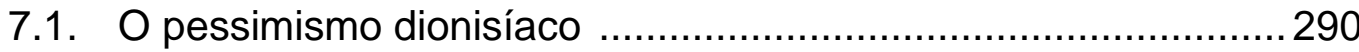

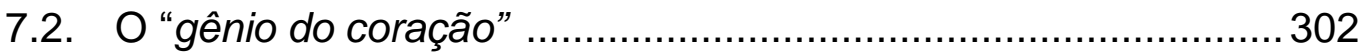

7.2.1. O "gênio do coração" como espelho d’água e ternura ............... 308

7.2.2. O "gênio do coração" como sedutor e educador: ...................... 319

7.2.3. O "gênio do coração" como filósofo ...................................... 335

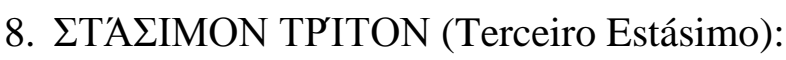

8.1. Zaratustra e o filosofar ditirâmbico: 352

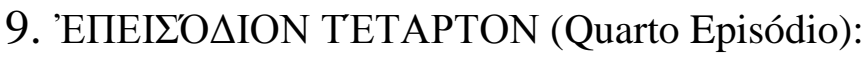

9.1. O último brinde: a arte como embriaguez 361

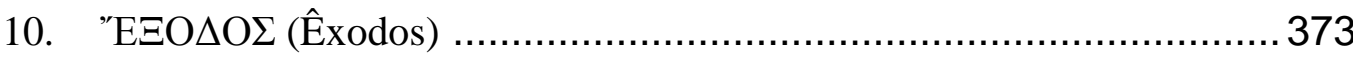

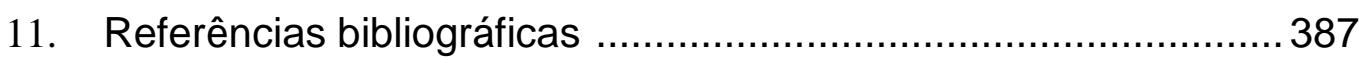

12. Apêndices ............................................................... 396 
"O paradoxo é a paixão do pensamento: o pensador sem paradoxo é como um amante sem paixão, um tipo medíocre". Søren Kierkegaard - Johannes Climacus 


\section{ПРОАОГОГ}

\section{1.}

De muitas formas se reveste o divino

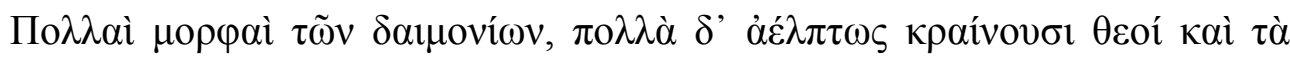

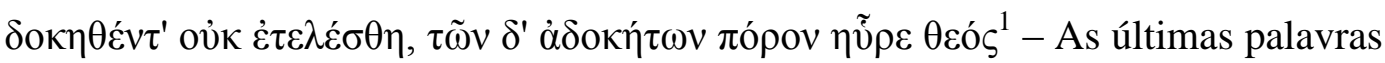
proferidas pelo Corifeu no êxodo ${ }^{2}$ da peça Bacantes de Eurípides são altamente significativas: o canto encerra a trama que apresentou a epifania do deus das mil máscaras. É certo que a natureza própria do divino envolve a manifestação multiforme - os deuses revelam-se das mais diferentes maneiras - mas, a menção às "muitas formas do divino" assume relevância ainda maior quando direcionadas a Dioniso e aos mistérios de seus caminhos. O deus de muitos nomes é, sem exagero, a entidade mítica mais sedutora de toda cultura herdada da Antiguidade. Exerce grande deslumbramento certamente pelo seu caráter múltiplo e contraditório: apresenta-se como mancebo e como ancião, ora varonil, ora efeminado, revestido como animal e como homem; nasce do fogo e com o fogo efervesce o vinho que jorra intensamente, ao mesmo tempo, para a coreia do Tíaso e para a loucura sangrenta em que afoga suas presas.

Não é de se estranhar que esse poder de sedução atingisse o interesse daqueles que voltavam os olhos à Grécia antiga; a divindade sempre foi objeto dos eruditos e mitólogos. A partir dos estudos clássicos, sejam historiográficos, filológicos, ou mesmo mediante contemplação das obras de arte da Antiguidade, acumulou-se um conhecimento, de certo modo, aprofundado sobre Dioniso, de seus mitos, ritos e cultos. No entanto, podemos dizer que este saber acumulado nunca alcançou, antes de Nietzsche, o cunho de problema de primeira ordem na história do pensamento. Nietzsche foi o primeiro a inserir Dioniso na história da

\footnotetext{
1 "De muitas formas se reveste o divino; muitas vezes agem os deuses ao revés do que esperamos. O que esperávamos não foi cumprido; e para o inesperado a divindade descobre o caminho. Assim termina o drama”. Eurípides. Bacantes. Versos 1387 a 1392.

${ }^{2}$ Segundo a clássica divisão estrutural das tragédias feita por Aristóteles [Poética, 1452b], o

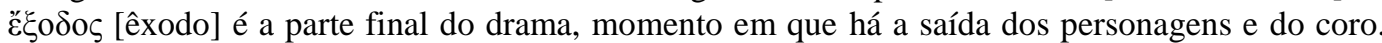
Eurípides termina regularmente as suas tragédias com um discurso efetuado pelo corifeu. Em Alceste, Medeia, Andrômaca e Bacantes o verso final do êxodo, com ligeiras alterações, é o mesmo.
} 
filosofia como uma questão de gravidade. Sabemos que Dioniso ocupa um lugar de destaque no pensamento do filósofo, designando um papel fundamental para edificação de seu pensamento estético-filosófico desde os primeiros escritos, acompanhando-o na totalidade de sua obra. Sendo recorrente nos últimos textos publicados em vida e nos fragmentos póstumos, utilizado, até mesmo, como heterônimo na forma de assinatura em algumas cartas.

O fascínio de Nietzsche por Dioniso é tão grande que em alguns momentos em suas obras a referência ao nume possui tons vatídicos, como, por exemplo, no final do parágrafo 20 de sua primeira obra publicada, O Nascimento da tragédia, ao refletir sobre a importância da cultura grega para a renovação da cultura alemã, anuncia com entusiasmo uma nova arte dionisíaca: "Coroai-vos de heras, empunhai o tirso, e não vos admireis de que o tigre e a pantera se deitem carinhosamente junto dos vossos pés". E em seguida exorta: "Tereis de acompanhar o cortejo dionisíaco que vai da Índia à Grécia. Armai-vos para duros combates, mas acreditais nas maravilhas de vosso deus!"3 Há nestas palavras, sem dúvida, um encanto pelo mito; mas, afinal, quem é, no imaginário nietzschiano, esse deus-tentador a quem confessa ter dedicado as suas primícias? ${ }^{4}$ Qual é o verdadeiro significado filosófico que Dioniso desempenha na apropriação de mundo feita pelo filósofo? E, sobretudo, ao desvendar a Grécia antiga pelo seu tesouro literário, como Nietzsche enxerga e conjectura o deus dos ditirambos?

Pensando nisso, o objetivo mais geral deste trabalho é entender quais os significados filosóficos de Dioniso no decorrer da obra nietzschiana. É impreterível, para isso, investigar qual a relação e a distinção entre o nome da divindade e o adjetivo "dionisíaco". Nossa tarefa será ampla, pois sabemos que a designação que os termos ocupam na obra nietzschiana oscila, muda completamente, como o próprio truque do deus em se transmutar entre uma máscara e outra. Com a intenção de proporcionar a maior intelecção do nosso objeto, estruturamos nosso trabalho da seguinte forma: primeiro analisaremos os documentos históricos sobre a religião e as lendas de Dioniso; segundo,

\footnotetext{
${ }^{3}$ NIETZSCHE. O Nascimento da tragédia, §20. [As edições e suas respectivas traduções podem ser conferidas na Bibliografia]

${ }^{4}$ Cf. NIETZSCHE. Além do bem e do mal, §295.
} 
averiguaremos a significação que o símbolo cumpre nas obras de juventude do filósofo, a partir do manuscrito A visão dionisíaca de mundo; terceiro, compreenderemos os motivos que levaram o filósofo a calar-se temporariamente em relação à divindade; e por fim, sondaremos qual a acepção de Dioniso e do dionisíaco nas chamdas "obras tardias" de Nietzsche, cuja metáfora mais intrigante é o "Gênio do coração" presente em Além do bem e do mal.

A forma como Nietzsche elabora e desenha Dioniso muito se deve à sua erudição na tradição helênica, mas também, à sua própria imaginação. Seu imaginário é provocado pela complexidade imensurável do mito, multifacetada em um sem-número de significados que lhe foram atribuídos ao longo do tempo. Dentre essa multiplicidade de sentidos destacam-se aqueles suscitados pelo frenesi da orgia: sibilante, desvairado, desmedido. Ele é o deus duas vezes nascido, segundo a mais conhecida de suas representações ${ }^{5}$, filho de Zeus e da mortal Sêmele, uma das descendentes de Cadmo, o fundador de Tebas. Dioniso tem sua gestação interrompida, pois Sêmele, caindo no plano ciumento de vingança de Hera, exige receber seu divino amante em todo seu esplendor, provando assim para suas irmãs a veracidade de seu relacionamento. Zeus, revelando-se em sua glória, acaba fulminando a princesa tebana, obrigando o infante deus a uma segunda gestação: retirado pelo pai do corpo maternal consumido pelo fogo, termina sua maturação costurado na coxa de Zeus como sendo um segundo ventre.

O duplo nascimento possui uma similaridade com a origem do deus titânico Krónos; ambas as narrativas apresentam uma compreensão simbólica elementar da natureza: a Mãe-terra fecundada pelo esplendor do deus do céu; no caso do

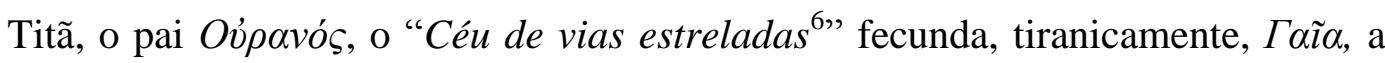
"Mãe-terra"; já no caso de Dioniso, seu nascimento confunde-se com a própria vida retirada das entranhas da Terra fecundada por Júpiter celestial. A geração proveniente do abraço simbólico entre o céu e a terra alude à compreensão de uma vida naturalista, puramente terrena; a vida é entendida, portanto, como o perene ciclo de nascimento, morte e renascimento, nada é derradeiro, tudo é cíclico. A origem tétrica de Dioniso aponta para a morte e para a destruição como condições

\footnotetext{
${ }^{5}$ Cf. EURÍPIDES. Bacantes. Versos 1 a 63.

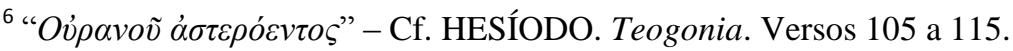


necessárias ao fluxo vital. A sabedoria dionisíaca, preconizada com seu parto precoce, é a sabedoria do Uno vivente: o que nasce deve estar pronto para um doloroso declínio ${ }^{7}$ em direção à obscuridade e profundidade da terra; para que então, uma força telúrica, análoga ao ventre materno, faça emergir vida novamente.

Outro aspecto importante sobre o duplo nascimento está ligado aos poderes divinos de Dioniso; uma simples ascendência paterna não lhe outorgaria a divindade, visto que, nas demais narrativas os filhos gerados da união entre deuses e mortais, habitualmente chamados de semideuses, mesmo possuindo distintas

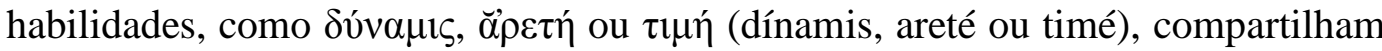
de uma natureza humana, portanto, perecíveis. Acolhido pelo pai e completando sua gestação na poderosa coxa, Dioniso terá sua divindade assegurada. A coxa de Zeus, como o segundo ventre, lhe acrescenta poderes extraordinários. A simbologia da coxa remete à força, da mesma forma que Atená adquire sua sabedoria e divindade da cabeça de Zeus. Além dos poderes iniciáticos, a segunda gestação na perna do pai supremo lhe confere o perfil andrógino, pois aquilo que lhe seria referência masculina, a força muscular paterna, confunde-se com o que é propriamente feminino, o útero materno. "O auto-sacrifício, característico da vitalidade masculina, costurando em si o rebento, tem um significado sexual e matrilinear" $"$.

O feminino no dionisismo possui grande destaque, não apenas no que diz respeito às mulheres frenéticas do Tíaso, mas também pela ligação intensa que o deus mantém com sua mãe e, principalmente, com Ariadne [Ápió $\delta v \eta v]$. Não são poucas as menções que Nietzsche faz ao relacionamento buliçoso de amor e sofrimento entre Dioniso e Ariadne ${ }^{9}$. Na Odisseia de Homero ${ }^{10}$, ela é apresentada como filha mortal de Minos, em apenas cinco versos. Conta-nos o poeta que Teseu a levava de Creta a Atenas, embora, na ilha de Día [Naxos], Ártemis, a pedido de Dioniso, os impede de prosseguir. Singelo, o excerto homérico não

\footnotetext{
${ }^{7}$ Cf. NIETZSCHE. O Nascimento da tragédia, §17.

${ }^{8}$ Cf. BRANDÃO, Junito. Mitologia grega, Vol. I. p. 120 -122.

${ }^{9}$ A atração de Nietzsche pela relação de Dioniso e Ariadne é tamanha, que leva Gilles Deleuze a publicar em seu livro Crítica e clínica um artigo intitulado "Os mistérios de Ariadne segundo Nietzsche" readaptação do texto "Mistère d'Ariane", originalmente publicado em 1963 e versa sobre a filosofia de nietzschiana a partir da tríade Teseu-Ariadne-Dioniso. [Por nós será investigado na seção "Ariadne e seus labirintos"].

${ }^{10}$ Canto XI, versos 252-256.
} 
detalha os fatos ocorridos na ilha de Día ${ }^{11}$. Mas, a partir de outras fontes, é sabido que Ariadne, primeiramente, amou Teseu a quem, obstinadamente, ajudou a fugir do labirinto mediante promessa de ser levada em núpcias a Atenas. Todavia, pelo amante é abandonada na ilha, onde, em meio à solidão, presencia um culto dionisíaco; seduzida pela beleza do deus, apaixona-se, encontrando nele outro labirinto $^{12}$. Dioniso, deus dos excessos, ama-a intensamente, consumando, assim, a boda.

Outras epifanias do relacionamento de Dioniso e Ariadne sustentam uma união matrimonial em que Ariadne pertenceria ao deus como esposa, o que caracterizaria sua fuga com Teseu uma terrível traição, além de uma afronta aos princípios femininos; sua perfídia despertou a fúria do cônjuge que a denuncia para Ártemis, deusa responsável pela punição capital - morte de parto. Há outras interpretações em que Ariadne é enterrada, ainda prenhe, em uma gruta, levando consigo no ventre o filho imaturo ao subterrâneo; por isso foi louvada em Creta como uma grande deusa, Rainha do submundo, ou mesmo, como a Senhora do labirinto. O labirinto estabelece uma correspondência com o subterrâneo: tanto um quanto o outro, simbolizavam lugares de escuridão e morte, neste sentido, a filha de Minos é a divindade que vence o Minotauro e analogamente supera a morte. Nas descrições de Creta, a associação entre Dioniso e Ariadne é ainda mais evidente visto o paralelismo do falecimento de Ariadne com o filho prematuro no ventre e o parto antecipado de Sêmele: as duas genitoras na morte ${ }^{13}$.

A ligação com Ariadne, símilar à ligação com Sêmele, faz Dioniso ser conhecido, em alguns ritos, como o libertador do submundo, isso por haver retirado sua mãe do reino dos mortos e a levado novamente entre os mortais. Do mesmo modo, foi considerado o iniciador e condutor de almas; chamado de $\chi \theta$ óvı $\theta \varepsilon \varepsilon^{14} \varsigma^{14}$ dirigia a dança dos mortos, a dança dos iniciados nos centros das pradarias subterrâneas ${ }^{15}$. Todavia, as representações "subterrâneas" do deus, nas quais ele desce ao submundo, seja para resgatar sua mãe, seja para ir em busca de Ariadne, ou mesmo, para permanecer periodicamente, têm um significado de

\footnotetext{
${ }^{11}$ Em algumas interpretações, como veremos à frente, Ártemis castiga Ariadne com a morte devido à influência de Dioniso.

${ }^{12}$ Cf. DELEUZE, Gilles. Os mistérios de Ariadne segundo Nietzsche.

${ }^{13}$ Cf. KERÉNYI, Carl. Dioniso - Imagem arquetípica da vida indestrutível. p.79-95.

${ }^{14}$ Deus chthoniano; subterrâneo; do radical $\chi \theta \dot{\omega} v$ (terra).

${ }^{15}$ Cf. CHEVALIER, Jean; GHEERBRANT, Alain. Dicionnaire des symboles. p. 291-300.
} 
germinação; cada descida do deus ao soturno Reino de Hades simbolizava a alternância das estações: do inverno estéril ao verão fértil, do perecimento à ressurreição. Nos rituais iniciáticos, Dioniso era a imagem da fertilidade, seu dilaceramento, às vezes figurado pelo sacrifício sangrento, era a súplica por uma estação fecunda; em muitos cultos, o sangue expiatório, de animal ou mancebo, era aspergido no solo a fim de torná-lo fértil. A morte dá vida à semente que germina para morrer.

Por mais que pareçam perversos e violentos, os cultos orgiásticos possuíam esse caráter fecundante; seu papel é fazer a terra prolífica e a vida abundante. Por isso sua efígie é, em muitos territórios, inclusive em Elêusis, um falo ereto, símbolo universal de fertilidade. Concomitantemente à fertilidade, Dioniso simboliza o fim das inibições, fim da consciência coibidora e do contentamento conservador; consequentemente, é a divindade do excesso e da embriaguez; é o deus que arrebata multidões em um frêmito de dança e música. Presenteia seus adeptos com as primícias da terra, sobretudo com o fruto da videira; desse modo, pretende, através do êxtase embriagante, elevar o homem ao sagrado, mesmo que por apenas um momento, o homem é divinizado. Dioniso é a dissolução do eu, por trás de suas muitas máscaras não há "eu”, só o caos primordial. Tais aspectos tornam Dioniso um emblema na filosofia nietzschiana de afirmação da vida. Nietzsche encontra nas excêntricas máscaras do deus as chaves necessárias para desvendar os enigmas da existência e para exprimir sua compreensão de Mundo.

Até aqui apenas balbuciamos a respeito de Dioniso, ainda há muitos de seus mistérios para perscrutar. Algumas questões de maior importância, que até agora foram singelamente mencionadas, voltarão a ser discutidas com o critério que se exige. Além disso, outras epifanias, narrativas e interpretações do mito, rito e culto dionisíaco até então não abordadas, contudo, que possuem relevância simbólica para a nossa pesquisa, seja pela riqueza filológica, ou por se relacionar direta ou indiretamente com o pensamento nietzschiano, serão discutidas no Párodo deste trabalho. 


\section{2. \\ O re-descobrimento da Grécia}

O encanto de Nietzsche pelo dionisismo é resultado de seu vasto conhecimento sobre o mundo grego Antigo. Sua formação clássica tem início aos 14 anos quando, em 1858, é admitido na prestigiosa Escola de Pforta, onde recebe uma rigorosa educação de língua e literatura alemã, de latim e de literatura e história grega. Em uma carta de novembro daquele ano, relata a seu amigo Wilhelm Pinder a rigidez dos estudos, o que lhe exigia o empenho em traduções completas: "tanto na história prussiana como na grega se faz um processo muito detalhado e nós precisamos trabalhar seriamente" "16 . A organização das horas de estágio de estudo obedecia a uma disciplina que não existia em outras instituições de ensino ${ }^{17}$. Desde seu ingresso em Pforta até adquirir seu diploma do Gymnasium, em setembro de 1864, Nietzsche teve um amplo contato com a cultura grega, incluindo a leitura aprofundada de Homero, de Sófocles, de Ésquilo e dos poetas líricos. Aos 20 anos, publicou sua dissertação ginasial, escrita em latim, sobre Teógnis de Mégara, conferindo-lhe então, o Abitur e o acesso à Universidade de Bonn.

De fato, a rígida disciplina em schulpforta era o reflexo de uma educação essencialmente humanista e esclarecida, que tinha em vista uma formação cujo conceito principal era a totalidade, ou seja, atingir em seus alunos uma emancipação intelectual e espiritual, diferentemente de um ensino meramente técnico e pragmático. Esse princípio tradicional e cosmopolita do Gymnasium distinguia-se das escolas que começaram a surgir na Alemanha em meados do século XIX, as Realschulen e as Wolksshulen que fundavam sua pedagogia apenas

\footnotetext{
${ }^{16}$ Cf. Carta ao amigo de infância Wilhelm Pinder de novembro de 1858. [Todas as cartas mencionadas que consideramos relevantes, poderão ser conferidas no Apêndice deste trabalho, elas estão divididas por capítulo e enumeradas com letras gregas, esta carta, por exemplo, é o "Apêndice $\alpha$ " do 1. Прoגoros].

${ }^{17}$ A organização letiva de Shulpforta era dividida desta maneira: os calouros eram admitidos na turma da terceira inferior [Untertertia], no próximo ano, após rigorosos exames, se aprovados, passariam para a classe terceira superior [Obertertia], assim cada ano sucessivamente, segunda inferior e superior, primeira inferior e superior. Os seis anos seguiam em um regime de internato bastante rígido, de modo que o aluno poderia se ausentar apenas durante quatro horas nos domingos. Todos os alunos acordavam às cinco horas para o café e para o oratório, terminado o dia de estudos apenas às sete horas da noite. Nietzsche escreve em algumas cartas para sua mãe e para os amigos, Wilhelm Pinder e Gustav Krug, sobre a disciplina em Pforta, primeiramente de forma favorável, mas depois, criticamente.
} 
na instrução de novos profissionais burocráticos ou para a indústria ${ }^{18}$. No entanto, acreditava-se que para obter uma educação tradicional, voltada para o preparo cultural universal e erudito, era necessário um estudo centrado nos clássicos. O retorno aos Antigos, sobretudo aos gregos, era imprescindível para a formação cultural do jovem alemão. Nietzsche é herdeiro dessa ideia: voltar aos Antigos helênicos é condição intrínseca para a universeller Bildung ${ }^{19}$. A Grécia foi, desde o século XVIII, a grande referência para a cultura alemã em formação.

A importante influência que a cultura clássica, especialmente a cultura grega, exerceu na educação alemã, ocorreu devido ao pensamento reformista de Humboldt, que estabeleceu as bases para o desenvolvimento de uma escola humanista, tais como Pforta, as chamadas de Humanistische Gymnasium. Estas escolas, respondendo às necessidades de um povo que ainda buscava sua identidade cultural, reagiu contra a forte presença francesa, concedendo maior espaço à língua e à literatura grega. Humboldt e outros intelectuais alemães promoveram, em meados do século XVIII, um projeto de regeneração cultural na Alemanha. A ideia era o desenvolvimento de uma cultura propriamente alemã, que criasse uma arte com traços de identidade nacional. E o caminho foi estabelecer a Grécia antiga como inspiração suprema para tal identidade cultural. Há, de modo geral, nesses intelectuais, a defesa de uma afinidade profunda entre o mundo helênico e a Alemanha moderna ${ }^{20}$, uma espécie de palingenesia nostálgica entre os povos que simbolizaria esperanças para o futuro da cultura moderna.

Essa ideia de regeneração da cultura alemã a partir da cultura grega contou com inúmeros entusiastas, dentre os quais podemos destacar Lessing, Herder, Humboldt, Goethe e Schiller, mas teve como precursor Johann Joachim Winckelmann. Podemos dizer que ele foi o "primeiro helenista alemão", sendo o responsável por desvelar a Grécia antiga aos modernos. A ideia que se faz de

\footnotetext{
${ }^{18}$ Essas escolas técnicas que surgiram a partir de 1830, começaram a receber grande número de jovens da classe média, depois de um crescimento industrial na Alemanha, mas é rejeitada por uma antiga aristocracia.

${ }^{19}$ Nietzsche escreve em seu diário no período de Porfta: “Agora me afeta um cruel desejo por conhecimento, por formação cultural universal [universeller Bildung]; Humboldt me induziu nesse caminho" NIETZSCHE. WdB, III p 73. Apud. LEMOS, Fabiano. Soldados e Centauros: Educação, filosofia e messianismo no jovem Nietzsche, 1858-1869. p. 41.

${ }^{20}$ Entende-se "moderno" aqui o período que compreende o final do século XVIII e início do século XIX, marcado pela ruptura introduzida na filosofia por Kant e os pós-kantianos. Portanto seguimos a interpretação de Michel Foucault feita por Roberto Machado. Cf. MACHADO, Roberto. O Nascimento do Trágico: De Schiller a Nietzsche. p. 8.
} 
mundo grego e de arte grega como anteriores ao mundo romano foi uma elaboração winckelmanniana. Antes desse pensador, toda noção sobre os gregos estava vinculada à cultura romana. Desde o Renascimento, voltar aos Antigos significava voltar a Roma. Toda cultura grega era intermediada pela cultura latina; Roma se destacava imponente frente a Atenas. A originalidade de Winckelmann foi justamente fazer a inversão, para ele "Antigos" era tão somente a cultura grega clássica, a mais bela cultura já existente e, portanto, deveria ser modelo para os modernos. O elogio à beleza grega dizia respeito tanto à natureza, ou seja, ao clima, aos costumes e aos corpos dos jovens, mas, principalmente, às artes.

Não há exagero em afirmar que a ideia, até hoje aceita, de uma cultura grega marcada pela serenidade e pela beleza ideal, é uma elaboração propriamente winckelmanniana; sua concepção de mundo grego, de arte grega, passa a ser uma nova pátria inspiradora para os alemães, e futuramente, para toda a Europa. A influência de Winckelmann é tão grande que suas reflexões sobre a arte e cultura grega foram fundamentais para o desenvolvimento do classicismo alemão, a ponto de Goethe escrever: "Winckelmann é igual a Colombo, quando este ainda não descobrira o novo mundo, mas já o intuía. Não aprendemos nada quando o lemos, mas nos tornamos algo"21. Sua influência está presente também no idealismo alemão, sobretudo, na estética de Hegel, além de inspirar Lessing e Herder a buscar uma estética nacional; A Grécia de Winckelmann marcou profundamente o Romantismo alemão, a poesia nostálgica de Friedrich Hölderlin e dos irmãos Schlegel; além disso, foi imprescindível para as interpretações da civilização helênica feitas por Jacob Burckhardt e Nietzsche.

A Grécia clássica torna-se um grande pilar espiritual para os alemães, uma espécie de identidade cultural, da mesma forma que Roma havia sido para os renascentistas. Desse modo, podemos dizer que Winckelmann inaugura um "Renascimento tardio" em solo alemão, o que pode ser explicado da seguinte forma: na Alemanha não existia a ideia de "Antigos", isso, porque a reforma luterana não admitia uma Renascença. Ora, o princípio mais importante para Lutero era o sagrado Evangelho; no Renascimento, não apenas o elogio à razão e a divinização do humano distorciam as sagradas Escrituras, como também, toda

\footnotetext{
${ }^{21}$ GOETHE, Johann Wolfgang von. In ECKERMANN, Johann Peter. "Conversations of Goethe. February 1826", Conversations of Goethe with Eckermann and Soret. p. 187 a 200.
} 
herança romano-cristã do catolicismo medieval maculavam a verdadeira palavra de Cristo. Destarte, blindados pelo luteranismo contra a Cultura Antiga, nos inúmeros principados e ducados germânicos o que imperava era o barroco. Todavia, esse isolamento cultural e renúncia da cultura romana clássica, como afirma Gerd Bornheim, transformou-se aos poucos em amargura, coisa como um complexo de inferioridade ${ }^{22}$; terreno perfeito para Winckelmann instaurar o retorno à Grécia.

Depois de estudar durante anos no curso de teologia em Halle, onde teve o primeiro contato com os líricos gregos, ser professor primário e bibliotecário do conde Buenau, no castelo de Noethnitz em Dresden, Winckelmann, com a intenção de ir a Roma para ter mais convívio com os Antigos, converteu-se ao catolicismo. Na cidade italiana teve um contato impactante com a arte barroca, da qual se tornaria severo crítico. Em 1755, escreve sua primeira obra, Reflexões sobre a imitação da arte grega na pintura e na escultura e, em 1763, publica História da Arte na Antiguidade, obra que lhe atribuiu o título de precursor da história da arte, pois, pela primeira vez, a história da arte aparece como elemento crucial para o entendimento do que é a arte. Já no escrito de 1755, apresenta a concepção de superioridade da Grécia em relação aos demais povos, no que diz respeito à beleza e às artes. Portanto, é essa a cultura que deveria ser modelo de formação ao jovem moderno. A Grécia passou a ser definida pelo conceito de perfeição e beleza. A formação do artista moderno deveria ocorrer pela imitação das obras clássicas gregas.

Winckelmann, motivado por um entusiasmo, que é evidente em suas obras, almejava tornar a beleza grega algo vivo em seu tempo. Ele entendia que a beleza era cultuada pelo povo helênico; nessa perspectiva, o embelezamento dos corpos era inspirado na natureza, todos os costumes da época visavam tal embelezamento: o exercício físico, as roupas e até mesmos as atividades nas academias: "as introduções a muitos diálogos de Platão, que ele situou nos ginásios atenienses, nos dão uma imagem da nobreza de alma da juventude, e nos permitem deduzir comportamentos e atitudes análogos nesses locais e em seus

\footnotetext{
${ }^{22}$ BORNHEIM, Gerd. "Introdução à leitura de Winckelmann". In: WINCKELMANN, Johann Joachim. Reflexões sobre a Arte Antiga. p. 10.
} 
exercícios físicos" ${ }^{23}$; por conseguinte, toda deformação do corpo era cuidadosamente evitada. Essa divinização da natureza e dos corpos foi crucial para o desenvolvimento da arte grega, pois, as escolas dos artistas eram os ginásios, onde belos jovens, protegidos do pudor público, se exercitavam completamente nus; ali frequentavam também os sábios - Sócrates, para ensinar os jovens, por exemplo - e os artistas que estudavam o movimento dos músculos, os contornos dos corpos e as marcas deixadas pelos lutadores na $\operatorname{areia}^{24}$.

Havia uma ingenuidade moral em relação ao corpo e à nudez; até mesmo nos teatros, descreve Winckelmann, dançavam desnudos os mais belos jovens. Durante os jogos de Elêusis, Frineia banhava-se diante dos olhos de todos, quando saía da água dava aos artistas o protótipo de uma Vênus Anadiômena. Nesse ambiente de pureza, sem o peso moral da modernidade, a nudez servia de alimento espiritual para os artistas, cada festa era oportunidade para que os gênios conhecessem com mais precisão a Natureza. Todavia, a perfeição da arte grega não se limitava apenas à imitação, os escultores e pintores representavam uma realidade idealizada, isto é, essas frequentes oportunidades de observação do mundo ao seu redor, levaram os artífices gregos ainda mais longe, eles começaram a formar certas ideias gerais acerca da beleza, tanto de partes isoladas do corpo como de suas relações, ideias destinadas a elevar-se além do próprio natural, cujo protótipo era uma natureza concebida apenas no intelecto ${ }^{25}$. Em suma, para Winckelmann, a regra da arte grega era reproduzir a natureza o melhor possível, representando-a mais bela que realmente é.

Neste ponto reside a crítica de Winckelmann à arte barroca, mais precisamente a Bernini, a saber, segundo o artista italiano, para se chegar ao conhecimento do belo artístico perfeito, deveria se partir do estudo e imitação da natureza; já na perspectiva winckelmanniana, a mera imitação não seria o caminho mais apropriado para se atingir o belo ideal, pois a criação artística não seria apenas a cópia da natureza, mas resultaria de um jogo com o intelecto, produzindo assim, uma obra idealizada, aperfeiçoada e de beleza universal. Estudar a arte grega, sobretudo, a escultura, seria um "atalho" para os enigmas da

${ }^{23}$ WINCKELMANN, Johann Joachim. "Reflexões sobre a imitação dos gregos". Apud LICHTENSTEIN, Jacqueline A Pintura, textos essenciais. p. 34.

${ }^{24}$ Idem.

${ }^{25}$ Cf. Idem. p. 35. 
criação. Os gregos conseguiam atingir a representação da beleza ideal, porque seguiam uma fórmula, nas palavras de Winckelmann: "O caráter geral que distingue as obras-primas dos gregos é, afinal, uma nobre simplicidade e uma serena grandeza, tanto na atitude quanto na expressão" ${ }^{\text {26 }}$. Essa ideia supõe que o divino, o belo e o nobre sempre se manifestam calma e serenamente. A cultura grega era, portanto, a mais nobre, pois seu epítome era o equilíbrio e a serenidade.

Um dos maiores exemplos de nobreza e serenidade entre as obras gregas é expresso, segundo análise de Winckelmann, no célebre grupo de estátuas de Laocoonte; o grupo de estátuas representam Laocoonte, o sacerdote troiano de Apolo, e seus dois filhos sendo atacados por duas enormes serpentes marinhas; a perfeição da estátua revela, através dos tendões e músculos do abdômen contraídos, a enorme dor das vítimas, mas, se verificamos a expressão facial, não encontraremos nenhum desespero, a boca não manifesta gritos horríveis; ao contrário da terrível agonia e horror pela situação caótica, há apenas um sereno gemido de angústia. Existe um perfeito equilíbrio entre a dor do corpo e a grandeza da alma ${ }^{27}$; mesmo mordido e asfixiado pelo animal, que estrangula também os filhos, o que se revela é uma serena grandeza, como se, para os gregos, a situação aflitiva se instalasse apenas na superfície, enquanto a essência permanecesse sempre calma ${ }^{28}$. Há uma sabedoria estóica nessa interpretação: mesmo diante de paixões mais violentas a nobre alma mantém-se calma, em estado de repouso e harmonia.

A perfeição artística do grupo de Laocoonte faz com que seu sofrimento nos penetre profundamente, mas, ao mesmo tempo, nos impele a suportar a aflição, como a grande alma ali representada. Isso, porque, segundo Winckelmann, o que está manifestado não é um estado patológico, ou a violência, etretanto, acima de tudo, o equilíbrio. Quando as obras retratavam apenas o patológico, ou eram por

\footnotetext{
26 "Das allgemeine vorzügliche Kennzeichen der griechischen Meisterstïcke ist endlich eine edle Einfalt und eine stille Größe, sowohl in der Stellung als im Ausdruck”. WINCKELMANN, Johann Joachim. Gedanken über die Nachahmung der griechischen Werke in der Malerei und Bildhauerkunst.p. 142.

${ }^{27}$ Cf. WINCKELMANN, Johann Joachim. "Reflexões sobre a imitação das obras gregas em pintura e escultura". Apud LICHTENSTEIN, Jacqueline. A Pintura, textos essenciais, Vol. 11 As escolas e o problema do estilop. 44 a 46.

28 "Assim como as profundezas do mar permanecem calmas, por mais furiosa que esteja a superfície, da mesma forma a expressão nas figuras dos gregos mostra, mesmo nas maiores paixões, uma alma magnânima e ponderada." Idem. p. 45.
} 
demais violentas, incorriam em um defeito que os Antigos chamavam de Parentirsus, em grego algo como "mau pathos"; por isso, no grupo de estátuas o artista, para demonstrar a sabedoria da alma nobre, representa Laocoonte em situação de tamanha dor, embora em um estado de repouso. Esse repouso exprime uma alma serena, contudo, ativa. Sua serenidade não se trata de indiferença ou a expressão de uma imobilidade morta; ao contrário, a célebre escultura simboliza a predominância da vida dinâmica, o império da moderação sobre o caos e a imperfeição. Esses preceitos não haviam sido assimilados pelos artistas de seu tempo, diz Winckelmann; eles louvavam apenas ações extraordinárias e atitudes desmedidas.

Contudo, é na estátua Apolo de Belvedere que Winckelmann aprecia a personificação de toda arte e cultura grega; a escultura seria a representação máxima da sabedoria antiga e o maior exemplo de perfeição artística. Encantado pela estátua escreve um pequeno texto entre 1755 e 1756, posteriormente incorporado à História da arte antiga, cuja primeira publicação foi em 1764; nesse texto, a descrição de Apolo é feita de forma poética, a obra se torna arquétipo artístico da divinização do humano, por isso, a linguagem utilizada pode ser comparada a de um hino, sem a formalidade conceitual, em apenas um parágrafo repleto de imagens e metáforas: "Vai com teu espírito ao reino da beleza incorpórea e busca tornar-te o criador de uma natureza celestial, para moldar o espírito com as belezas que se elevam além da natureza; aqui nada é mortal, nada há quanto exija a miséria humana" ${ }^{, 29}$. Apolo perfaz o mais elevado Ideal de arte, o artista materializa o Ideal de beleza, tornando-o visível. A estátua do Vaticano personifica a serenidade da nobre alma helênica e passa a ser parâmetro para conceber o espírito antigo, inaugurando a compreensão apolínea de Grécia clássica.

Essa expressão artística da alma nobre grega não poderia ser atingida simplesmente com a representação da natureza, "o artista deveria sentir em si mesmo a força de espírito que o fazia exprimir-se através do mármore ${ }^{\text {30 }}$. Havia uma sabedoria na arte grega, de modo que o sábio e o artista eram um só, o que

\footnotetext{
${ }^{29}$ WINCKELMANN, Johann Joachim. Apud RUFINONI, Priscila R. Entre o sublime retórico e o sublime moderno: o Apolo de Winckelmann. Revista de filosofia moderna e contemporânea. V. 1, n. 2 Brasília: 2013. p. 343.

${ }^{30}$ Idem. p. 345.
} 
proporcionava a criação de obras mais belas que as comuns. Essa sabedoria tornou a cultura grega única, superior e inimitável. Por consequência, segundo Winckelmann, o único caminho para a Alemanha de sua época se tornar tão grande, e se possível inimitável, seria imitando os Antigos $^{31}$. À primeira impressão, essa formulação parece apresentar um paradoxo: para a cultura alemã tornar-se inimitável deveria imitar a cultura grega, caracterizada como inimitável. Contudo, a imitação não se refere a simples cópia servil, mas sim, ao pensar como os sábios gregos e criar como eles. Imitar o processo pelo qual se atinge o عĩ $\delta o \varsigma$ da obra; a arte deve representar no plano sensível a beleza metafísica ideal. Isso os mestres Michelangêlo ${ }^{32}$ e Rafael souberam fazer, traduzindo em suas obras a excelência grega.

O impacto das ideias de Winckelmann foi enorme e singularmente expressivo quando comparado à brevidade de sua existência: depois de longa estadia em Roma, viaja à Alemanha para visitar alguns amigos, logo que chega à sua pátria, vendo "a terrível e deprimente paisagem"33 , é tomado por uma terrível depressão e melancolia, decide, então, imediatamente retornar. Passando pela cidade de Trieste, é assassinado, aos 50 anos, em 1768. Seu legado foi estreitar a fronteira entre a Alemanha e o mediterrâneo, tornando a Grécia clássica a maior referência para formação humanista alemã. Dentro desse legado podemos considerar Goethe como herdeiro direto do helenismo winckelmanniano; a cultura grega ocupa lugar de destaque em seu classicismo, principalmente depois de sua estadia na Itália entre 1786 e 1788. Neste período, finaliza várias obras, até então inacabadas, baseadas no teatro grego, como Ifigênia em Táuride e Egmont. Nestas obras, de "gênero grego" ${ }^{34}$, Goethe traduz o ideal de beleza e serenidade, pensado por Winckelmann em relação à pintura e à escultura, para a poesia e ao teatro.

\footnotetext{
${ }^{31}$ Idem. p. 343.

${ }^{32}$ Sobre a influência grega em Michelângelo, Winckelmann escreve: "Compartilho aqui uma descrição do famoso torso em Belvedere, chamado torso em geral por Michelangelo, porque este artista particularmente valorizava esta peça e muito a estudou. Trata-se de uma mutilada escultura de Hércules sentado, como é bem sabido, e o mestre é Apolônio, filho de Nestor, de Atenas. Esta descrição volta-se apenas ao Ideal desta estátua, uma vez que é idealista, e trata de uma peça de imagem síntese, semelhante a outras estátuas”. Idem. p. 323.

${ }^{33}$ BORNHEIN, Gerd. Op. Cit. p. 14.

${ }^{34}$ Assim que Goethe define as obras em uma carta a Schiller de 19 de janeiro de 1802. Cf. MACHADO, Roberto. O Nascimento do trágico: de Schiller a Nietzsche. p. 31.
} 
A Grécia representa, para Goethe, o ideal humanista no qual a cultura moderna deveria se espelhar, para assim, desenvolver todas suas virtualidades. Há em suas peças teatrais uma evidente mudança, quanto à forma e o conteúdo, que buscam introduzir o princípio apolíneo de Winckelmann na interpretação do espírito grego. Além de Goethe, Friedrich Schiller foi outro adepto do movimento de valorização do ideal grego, de beleza e serenidade como premissas para a arte alemã, sendo talvez mais influenciado pelo amigo Goethe do que pelo entusiasmo de Winckelmann. A nostalgia de Schiller pelos Antigos é evidentemente menor, tem sua maior expressão na peça A Noiva de Messina, que segue a influência das tragédias. Além disso, em comunhão com Goethe, defendia uma atemporalidade de leis artísticas, ou seja, que a arte é determinada por um ideal estético que os gregos já haviam materializado em suas obras, portanto, caberia aos modernos o estudo destas leis para a constituição de uma teoria da arte moderna: compreendese a forma da arte antiga e adapta-se tal forma aos conteúdos que a época moderna oferece aos escritores.

A partir da segunda metade do século XVIII, o mundo helênico converteuse no grande alimento espiritual para a Alemanha. O sul, o mar mediterrâneo, a Grécia tornou-se "o país dos desejos"35 dos poetas e dramaturgos germânicos e o capitel dórico da cultura alemã. Nietzsche é um dos expoentes desse ideal, em seus primeiros escritos é explícito o enaltecimento da Antiguidade grega, para ele "a verdadeira e única pátria da cultura"36. Convicto de que o convívio com os clássicos era essencial para educação [Bildung] dos jovens, Nietzsche reconhece a importância do projeto winckelmanniano e dos poetas responsáveis por sua difusão: "em que tempo e em que homens o espírito alemão se esforçou mais vigorosamente por aprender dos gregos; e se admitirmos, com confiança, que esse louvor único deveria ser atribuído à nobilíssima luta de Goethe, Schiller e Winckelmann pela cultura" ${ }^{\text {37 }}$. Tamanha era sua fé na civilização grega como modelo de engrandecimento para cultura alemã, que se refere a esses homens como guias e mistagogos, únicos capazes de conduzir à Antiguidade clássica.

\footnotetext{
${ }^{35}$ GOETHE. Iphiénie em Tauride, I, 1. Apud NIETZSCHE. Sobre o futuro de nossos estabelecimentos de ensino, $2^{\mathrm{a}}$ Conferência.

${ }^{36}$ Idem. p. 77.

${ }^{37}$ NIETZSCHE. O Nascimento da tragédia, §20.
} 
Adepto e defensor do projeto inaugurado por Winckelmann, Nietzsche percebe um distanciamento entre a cultura alemã oitocentista e os ideais helênicos, sobretudo nas instituições de ensino, o que tornou a força educativa de sua época mais baixa e débil. Segundo sua análise, os ginásios haviam desprezado o estudo dos clássicos, por isso, estavam inaptos para a cultura verdadeira e autêntica. $\mathrm{O}$ ensino superior encontrava-se igualmente em decadência, pois entre os professores, das mais altas universidades, começou uma atitude de rápido desdém para com os gregos, "e com isso indo, por vezes, a uma renúncia cética dos ideais helênicos e até uma completa inversão do verdadeiro propósito de todos os estudos sobre a Antiguidade ${ }^{, 38}$. Desse modo, crítico de seu tempo e preocupado com os rumos da cultura, Nietzsche exorta seus contemporâneos para necessidade de renascimento da Antiguidade: "pois só nela encontramos nossa esperança de uma renovação e purificação do espírito alemão"39. A purificação do gênio alemão só seria possível a partir de um laço com o gênio grego ${ }^{40}$.

É evidente que as primeiras obras de Nietzsche estão inseridas no empreendimento iniciado por Winckelmann, e mais: elas são o esforço de uma reaproximação com o mundo Antigo. No entanto, a compreensão que a Grécia assumirá no pensamento nietzschiano é diferente daquela imaginada nas Reflexões sobre a imitação das obras gregas na pintura e na escultura, consequentemente, distinta também da concepção de grego popularizada por Goethe. Nietzsche não aceita a elucidação do mundo heleno como uma "nobre simplicidade e uma serena grandeza"; ele acredita que a definição do espírito grego feita unicamente pelo princípio apolíneo é um erro. A caracterização da Grécia apenas pela serenidade e pela beleza é achatada, não há nela espaço para a época de Heráclito

\footnotetext{
${ }^{38}$ Idem.

${ }^{39}$ Idem.

40 “Uma renovação e uma purificação verdadeiras do ginásio só virão de uma renovação e de uma purificação do espírito alemão que sejam profundas e poderosas. Misterioso e difícil de compreender é o laço que une verdadeiramente o ser profundo da Alemanha e o gênio grego. Mas enquanto a necessidade mais nobre do verdadeiro gênio alemão não procurar a mão deste gênio grego como um firme apoio no rio da barbárie, enquanto este espírito alemão não exprimir aquela nostalgia angustiante pelos gregos, enquanto a perspectiva da pátria grega, penosamente alcançada, fonte de deleite para Goethe e para Schiller, não se tiver tornado lugar de peregrinação para os homens melhores, e mais bem dotados, nesse caso, o ginásio se proporá, na cultura clássica um objetivo incoerente, que flutua ao sabor dos ventos". NIETZSCHE. Sobre o futuro de nossos estabelecimentos de ensino. In: Escritos sobre educação. p. 83 -84.
} 
e Empédocles ${ }^{41}$, ou seja, falta espaço para o grotesco, para o terrível, para a contradição e para os excessos. O que Nietzsche promove é uma inversão: mesmo com a superfície aparentemente calma, as profundezas permanecem sempre furiosas, isto é, a serenidade só poderia ser pensada como aparência superficial que oculta outro princípio mais profundo e mais essencial - o dionisíaco.

Além de Nietzsche, outros intelectuais foram enfeitiçados pela nostalgia winckelmanniana, todavia, rompendo com a visão puramente apolínea da Grécia antiga, por exemplo, Schelling, A. W. Schlegel e Jacob Burckhardt. Este último, professor da Basileia, que exerceu forte influência em Nietzsche, já desenvolvia estudos sobre o fenômeno dionisíaco na civilização grega ${ }^{42}$.

Dentre os intelectuais alemães intensamente marcados pela Grécia clássica, mas que não a caracterizava exclusivamente pelo princípio de serenidade apolínea, não podemos deixar de mencionar Friedrich Hölderlin, eleito por Nietzsche como seu poeta favorito ${ }^{43}$. Hölderlin pode ser considerado como o mais grego entre os românticos alemães; as categorias que se destacam na sua nostálgica visão de mundo grego são: o sombrio, o funesto e, maiormente, a tristeza. Para ele, a Grécia é uma pátria perpetuamente ausente aos modernos e seus heróis, mortos ${ }^{44}$. Destaca-se, ainda, em sua produção sobre os gregos, além de inúmeros versos e poesias, o estudo sobre o amor nas obras de Platão, traduzidas por Schleiermacher; o estudo do pensamento pré-platônico, principalmente de Empédocles, personagem que alimentará o seu imaginário sobre a relação "homem e divino" na Antiguidade; e a análise das tragédias de Sófocles com as "Observações sobre Édipo" e "Observações de Antígona",

\footnotetext{
41 "Das "Hellenische" seit Winckelmann: stärkste Verflachung. Dann der christlich-germanische Dünkel, ganz darüber hinaus zu sein. Zeitalter Heraklits Empedokles usw. war unbekannt". [O "helênico" desde Winckelmann: o mais forte trivialidade. Depois a arrogância germano-cristã de haver superado completamente o helênico. A era de Heráclito Empedocles etc. era desconhecido]. NIETZSCHE. Fragmento Póstumo de 1869, 3[76].

42 "Fui o primeiro que levou a sério, para a compreensão do velho, ainda rico e até transbordante instinto helênico, esse maravilhoso fenômeno que leva o nome de Dionísio: ele é explicável apenas por um excesso de força. Quem se ocupa dos gregos, como Jacob Burckhardt, da Basiléia, o mais profundo conhecedor atual de sua cultura, soube de imediato que isso era uma realização: Burckhardt acrescentou à sua Cultura dos gregos uma seção específica sobre o fenômeno" NIETZSCHE. Crepúsculo dos ídolos - "O que devo aos antigos", §4.

${ }^{43}$ Cf. Carta de Nietzsche a Erwin Rohde de 3 de setembro 1869. [Apêndice $\beta$ ]

44 "Que estas lágrimas sejam, pois, as últimas vertidas pela sagrada Grécia! Oh Parcas fazer soar suas tesouras, já que meu coração pertence aos mortos”. HÖLDERLIN, Friedrich. Grécia. In: Poesias completas. Trad. Federico Gorbea. Ediciones 29, Madrid: 1977.
} 
estudo que resultou na tentativa de criação de uma linguagem poética capaz de revelar-se uma tragédia moderna.

A dedicação de Hölderlin aos gregos era explícita, a ponto de declarar no prefácio da penúltima versão de seu romance Hipérion: "A Grécia foi meu primeiro amor e creio que pode-se afirmar que será o meu último"45. Esse amor resultou em inúmeros estudos e traduções, incluindo as traduções de Píndaro e de Sófocles, bastante criticadas na época. Todavia, entre os seus trabalhos, aquele ao qual dedicou maior esmero foi A Morte de Empédocles, seu único drama, composto de três versões, todas estranhamente inacabadas. Sua intenção era criar uma tragédia única, que reunisse traços da Antiguidade e da modernidade, mas com um tema autenticamente próprio. Para isso, entre 1798 e 1800 dedicou-se exclusivamente à elaboração do texto dramático e de dois ensaios sobre o assunto: O Transformar-se no passar [das Werden im Wergehen] e Fundamento de Empédocles [Grund zum Empedokles], escritos entre a primeira e a segunda versão. Sua inspiração foi a lenda difundida por Diógenes Laércio ${ }^{46}$, na qual o pensador originário teria se atirado em uma das crateras flamejantes do vulcão Etna.

Hölderlin, em A morte de Empédocles, aspirava elaborar uma tragédia capaz de contrastar o homem grego ao homem moderno em relação ao divino. Para ele, o grego possuía uma sensibilidade aguçada para perceber as várias formas de manifestação do divino, seja em si ou na natureza. Havia um equilíbrio entre o Estado, o indivíduo e a religião; o homem vivia em perpétua presença dos deuses, período, denominado por ele, como "Gottestag"; por isso, o espírito grego era radiante. Cristo seria, nessa perspectiva, a última manifestação divina; ao se afastar da humanidade, subindo aos céus, mesmo deixando a esperança de seu retorno, instaura um mal-estar proporcionado por um impreenchível vazio ontológico, período chamado de "Gottesnacht" "47. Empédocles seria o personagem que reuniria, em si, as características capazes de proporcionar uma revolução espiritual entre os modernos; Hölderlin acreditava na força unificadora do amor para reavivar a humanidade; a excêntrica morte do pré-socrático expressava, no

\footnotetext{
${ }^{45}$ CURIONI, Marise Massab. Sobre o Empédocles de Holderlin. In: HOLDERLIN, Friedrich. A Morte de Empédocles. (Trad. Marise Massab). p. 35-36.

${ }^{46}$ Cf. LAÉRCIO, Diógenes. Vidas e Doutrinas dos Filósofos Ilustres. P. 240 a 246.

${ }^{47}$ Ver a poesia de Hölderlin, Pão e Vinho.
} 
drama, essa força congregadora e a possibilidade de nova intimidade com o divino.

Apesar de seu amor à Grécia, Hölderlin não acreditava que os gregos constituiriam um modelo a ser imitado, como previa Winckelmann, também não considerava que um único princípio como a serenidade fosse suficiente para definir o mundo heleno; pelo contrário, Hölderlin enxergava um jogo entre duas forças conflituosas: o "fogo apolíneo" ou "pathos sagrado" e a "sobriedade de Juno"; o fogo a que se refere o poeta é o fogo do Oriente, a pira dos céus, uma força ilimitada e aórgica - portanto, apolíneo assume um sentido oposto à serenidade - já a sobriedade juniana é o elemento ocidental, a clareza representacional que os gregos tiveram que aprender para traduzir aquilo que lhes era próprio, uma pulsão selvagem. Homero representa a lucidez de Juno, ele é capaz de transformar o canto aórgico das musas em poesia, ou seja, o aedo traduziu as forças primordiais da natureza, o fogo oriental, em arte. Para Hölderlin, o "pathos sagrado" era intrínseco ao homem grego, fazia parte de sua natureza, enquanto a sobriedade juniana era o elemento estrangeiro e cultural ${ }^{48}$.

A filosofia do jovem Nietzsche está inserida neste contexto cultural inaugurado por Winckelmann: desde a época do ginásio, a Grécia clássica era tema central de seus escritos e a fonte necessária para melhor entender a sua época. Mas, como vimos, a concepção nietzschiana de mundo grego afasta-se daquela defendida pelos pensadores que iniciaram a valorização da cultura grega como modelo para a arte alemã moderna. A diferença crucial é que, para Nietzsche, o princípio de "nobre simplicidade e serena grandeza" apenas encobria uma realidade mais profunda, ou seja, a serenidade apolínea do mundo helênico só poderia ser compreendida em relação a um aspecto mais visceral, o dionisíaco. Se Winckelmann desvelou a Grécia antiga pela pintura e pela escultura, atribuindo-lhe como princípio a beleza e a serenidade, e se Goethe e Schiller traduziram tais princípios para a literatura e o teatro, coube a Nietzsche

\footnotetext{
${ }^{48}$ Hölderlin explica, em uma famosa carta a seu amigo Böhlendorff, de 4 dezembro 1801, tornamo-nos mestres do que nos é estranho mais facilmente, ao mesmo tempo que é muito difícil a conquista do que é próprio. Por isso, os gregos antigos se tornaram mestres naquilo que lhes era estranho, a clareza de representação. A oposição aqui é, justamente, entre aquilo que é natural e o que é cultura. Importante ressaltar que, na mesma carta, Hölderlin assevera que os alemães modernos se constituíam de modo contrário ao grego antigo: o que para o grego era natural, para os modernos era cultura e vice-versa. Por isso os gregos não deveriam ser imitados.
} 
decifrar o elemento dissonante por trás da aparente harmonia apolínea. A chave que permitiu desvendar o enigma dionisíaco foi interpretar os gregos através da arte musical.

Sob a forte influência de Schopenhauer ${ }^{49}$, que valorizava a música sobre todas as demais formas de arte, o jovem Nietzsche a destaca para pensar os gregos. Nessa perspectiva, as tragédias áticas só poderiam ser compreendidas a partir do elemento musical. Com a música, quem entra em evidência é Dioniso, divindade que representa, no domínio da arte, em oposição a Apolo, a experiência da embriaguez, da desmesura, do êxtase primaveril e da loucura mística. Se por um lado, Apolo simboliza, no mundo heleno, o brilho solar e a bela aparência do sonho, de modo que o princípio apolíneo diz respeito à calma, à serenidade e ao equilíbrio; por outro lado, Dioniso simboliza a volúpia do vinho, a dança frenética do tíaso estrangeiro, ao mesmo tempo em que a experiência dionisíaca está ligada ao excesso e ao desregramento para com todas as medidas. Entender o mundo apolíneo como belo, calmo e cintilante, pressupõe concebê-lo como proteção contra o sombrio e o terrível da vida. A bela e nobre simplicidade grega seria apenas um invólucro que embeleza e torna desejável uma realidade atroz dionisíaca.

A preocupação com o elemento dionisíaco já estava presente, no pensamento de Nietzsche, desde o período em que era estudante de filologia em Leipzig. Há menções sobre o dionisíaco em cartas que datam de $1867^{50}$; há, ainda, um importante fragmento do outono de $1869^{51}$ que remonta a origem do drama antigo às incompreensíveis manifestações dos instintos populares [Volkstrieben]

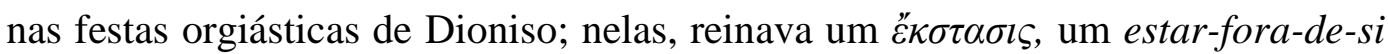
[Ausser-sich-sein]. Mas foi em 1870, já como professor de filologia clássica na Universidade da Basiléia, com as conferências públicas O Drama musical grego e Sócrates e a tragédia que as ideias sobre a relação entre o culto dionisíaco e a arte grega são apresentadas. Posteriormente, em agosto do mesmo ano, com o texto $A$ visão dionisíaca do mundo, emerge o pensamento nietzschiano mais próprio,

\footnotetext{
${ }^{49}$ Nietzsche descobre a filosofia de Schopenhauer em outubro de 1865 em Leipzig. Em uma carta à sua mãe, de 31 de janeiro de 1866, descreve a influência da filosofia schopenhaueriana em seu pensamento: "Este filósofo ocupa um lugar muito importante em minhas ideias e em meus estudos, e meu respeito por ele aumenta de uma maneira inigualável". [Apêndice $\gamma$ ]

${ }^{50}$ Carta ao amigo Erwin Rohde de 03 de novembro de 1867. [Apêndice $\delta$ ]

${ }^{51}$ Cf. NIETZSCHE. Frafmento póstumo de 1869,1[1].
} 
quando pela primeira vez são elaboradas as concepções metafísicas do princípio apolíneo, do princípio dionisíaco e de toda uma visão artística de mundo. Ideias aprofundadas e desenvolvidas a cabo em sua grande obra de 1872 .

O Nascimento da tragédia, que promulga Apolo e Dioniso como instintos da natureza ligados à arte, é escrito com a intenção de ser uma obra filológica. Ainda que as ideias ali não fossem totalmente originais - sofreram influências de Kant, Hölderlin, Schopenhauer e Richard Wagner - a intenção de Nietzsche é que seu primeiro livro seja um manifesto de esperança para os alemães e de renovação para os novos filólogos ${ }^{52}$. No entanto, a recepção causou as mais distintas reações, como revela uma carta à sua mãe e irmã: "A respeito de meu livro, estão todos agitados, felizmente, a maioria do que escuto, estão pelo entusiasmo, outros pela ira" $^{\sharp 3}$. Na verdade, dentro da comunidade filológica, o livro foi recebido negativamente: além da recusa de Ritschl em aceitar a interpretação da Grécia presente na obra, a principal revista científica de filologia da época, Litterarische Zentralblatt, nega a publicação da resenha feita pelo amigo Rohde, e, ao contrário, surgem resenhas furiosas, como as escritas por Wilamowitz ${ }^{54}$, criticando a abordagem filosófica schopenhaueriana e a linguagem filológica não convencional.

Friedrich Wilhelm Ritschl era considerado por Nietzsche como seu grande mentor. Havia sido seu professor de filologia em Bonn e, segundo o filósofo, devido à qualidade de suas aulas, teria abandonado a faculdade de teologia para segui-lo até Leipzig. O respeito e a admiração de ambos eram recíprocos: Ritschl reconhecia em Nietzsche um jovem intelectual brilhante: publicou os primeiros escritos filológicos de seu pupilo, foi responsável pelo título de doutor honoris causa e, também, pela indicação à cátedra de filologia na Universidade da Basiléia $^{55}$. Apesar disso, quando Nietzsche questiona o silêncio de seu mestre em relação ao Nascimento da tragédia, Ritschl esclarece categórico, embora

\footnotetext{
${ }^{52}$ Em 30 de janeiro de 1872, Nietzsche escreve uma carta a Ritschl ver [Apêndice $\varepsilon$ ].

${ }^{53}$ Carta a Franziska e Elizabeth Nietzsche de 24 de janeiro de 1872. [Apêndice $\zeta$ ]

${ }^{54}$ Ulrich von Wilamowitz-Mõllendorff, notável filólogo alemão, havia sido colega de Nietzsche em Bonn, em maio de 1872, ainda como um desconhecido recém-doutor de vinte quatro anos, publica uma resenha intitulada Filologia do futuro com o objetivo de denunciar $O$ Nascimento da tragédia e inicia um interessante e polêmico debate com Erwin Rohde e Richard Wagner sobre o livro nietzschiano. Sobre a polêmica: Cf. MACHADO, Roberto. Nietzsche e a polêmica sobre o nascimento da tragédia.

${ }^{55} \mathrm{Cf}$. Anexo da carta a Wilhelm Vischer-Bilfinger de 1 de fevereiro de 1869. [Apêndice $\eta$ ]
} 
cordialmente, que não apoiaria o projeto de seu ex-aluno em submeter a filologia à arte e à filosofia ${ }^{56}$. Mas a confiança do jovem professor Nietzsche em sua primeira obra parecia inabalável, embora soubesse que seu livro o convertera no filólogo mais escandaloso do seu tempo ${ }^{57}$, previa que precisaria de décadas para que os filólogos pudessem entender um livro, ao mesmo tempo, esotérico e científico $^{58}$.

A diferença fundamental entre $O$ Nascimento da tragédia e os demais trabalhos de filologia da época é, acima de tudo, o seu estilo; Nietzsche recusavase a escrever preso à lógica, com inúmeras citações, ou seja, no modelo cientificista que se tornou convencional entre os filólogos. Diferentemente, acreditava que essa maneira fria de se escrever, voltada exclusivamente à análise científica de documentos estreitava a visão da Antiguidade. Por outro lado, o propósito de Nietzsche era escrever de forma criativa, ampliando as considerações e elevando os pontos de vista filológicos. Para isso, a fórmula encontrada, e aplicada na elaboração de sua primeira obra, foi submeter as análises filológicas a uma perspectiva filosófica de mundo. Para Nietzsche, através da arte e da filosofia, não somente por meio da explicação gramatical e da crítica do texto, seria possível fazer uma compreensão coerente da Antiguidade clássica; a exegese histórica estaria atrelada à interpretação artística e à reflexão filosófica. Essa ideia, na obra de 1872, traz mais uma polêmica: interpretar o mundo antigo também pela música.

$\mathrm{O}$ que entra em evidência com $O$ Nascimento da tragédia é uma nova possibilidade de conexão com a Grécia clássica, não mais exclusivamente científico-filológica, mas também artística; ou sendo mais preciso, musical: a música dionisíaca é o elo encantado entre o mundo helênico das tragédias e o drama wagneriano. A preocupação em elaborar um pensamento capaz de conciliar ciência, música e filosofia leva Nietzsche a escrever "agora, dentro de mim, ciência, arte e filosofia crescem juntos de tal forma que algum dia, certamente, vou parir centauros" $" 59$. E receoso com o resultado, em seu livro, dessa conciliação indaga a seu amigo Rohde: "Temo sempre que os filólogos não o queiram ler por

\footnotetext{
${ }^{56} \mathrm{Cf}$. Carta de Ritschl em resposta a Nietzsche, 14 de fevereiro de 1872. [Apêndice $\theta$ ]

${ }^{57}$ Cf.. Carta de Nietzsche a Malwida von Meysenbug de 7 novembro de 1872. [Apêndice $\boldsymbol{l}$ ]

${ }^{58} \mathrm{Cf}$. Carta a Ritschl de 6 de abril de 1872. [Apêndice $\boldsymbol{\kappa}$ ].

${ }^{59} \mathrm{Cf}$. Carta a Erwin Rohde de 15 de fevereiro de 1870. [Apêndice $\lambda$ ]
} 
causa da música, os músicos por causa da filologia e os filósofos por causa da música e filologia"60. A aliança entre filologia, arte e filosofia, faz com que Nietzsche possa ver a ciência pela ótica do artista, isto é, criticar a unilateralidade da interpretação filológica tradicional, mas também, possibilita-o a urdir um novo estilo artístico de escrita livre das amarras lógico-conceituais.

A preocupação de Nietzsche em encontrar um estilo próprio o acompanha desde quando estudava filologia em Leipzig; nesse período, ele já criticava a escrita seca e rígida, subjugada pelo logicismo. Sua intenção era encontrar um estilo que fosse comparado ao improviso do piano ${ }^{61}$. Sem dúvida, $O$ Nascimento da tragédia é fruto da inquietação nietzschiana em escrever de uma forma mais artística e menos conceitual. $\mathrm{Na}$ exposição argumentativa do filósofo, são privilegiadas imagens capazes de sinalizar um fato em um horizonte interpretativo mais amplo e mais abrangente, contrariando a rigidez da argumentação conceitual, que buscava uma demonstração silogística rigorosa. Apolo e Dioniso são os exemplos definitivos da linguagem escolhida por Nietzsche para sua primeira obra: ao expressar sua compreensão da Grécia clássica, da Alemanha moderna, das artes e da vida, não recorre à linguagem tradicional, que visa, através das regras lógicas, a elaborar conceitos definitivos; mas sua estratégia é expressar artística, e filosoficamente, por meio de imagens altamente simbólicas.

A audácia do jovem Nietzsche em inovar no campo da produção filológica, pode não ter sido aprovada, de imediato, pela maioria dos intelectuais de sua época, no entanto, o projeto de escrita artística, próxima aos ditirambos dionisíacos, tornou-se característica fundamental de suas obras futuras, principalmente aquelas publicadas após 1876. O estilo nietzschiano em si, mais próximo à poesia do que à gramática, já é uma forma de filosofar a contrapelo da tradição; o cuidado em escrever artisticamente intensifica-se ao longo de sua produção intelectual, ao ponto de Nietzsche reconhecer que sua primeira obra já não obedecia as suas exigências, diz que em $O$ Nascimento da tragédia deveria cantar e não falar: "é pena que eu não me atrevesse a dizer como poeta aquilo que tinha então a dizer: talvez eu pudesse fazê-lo!",62. A complexidade da linguagem

\footnotetext{
${ }^{60}$ Carta a Erwin Rohde de 23 de novembro de 1871.

${ }^{61} \mathrm{Cf}$. Carta a Carl von Gersdorff de 6 de abril de 1867. [Apêndice $\mu$ ]

${ }^{62}$ NIETZSCHE. O Nascimento da tragédia. "Tentativa de autocrítica", §3.
} 
nietzschiana nos impele a uma missão arriscada, mas indispensável: fazer uma ponderação - mesmo que sucinta, pois nossos objetivos neste trabalho são outros - a respeito do estilo em Nietzsche, afinal Dioniso seria um conceito nietzschiano?

\section{3. Estilo em Nietzsche e a possibilidade de filosofar sem o "conceito":}

O estilo de escrita produzido por Nietzsche leva a uma nova forma de filosofar que se opõe às pretensões totalizantes e esquemáticas dos sistemas tradicionais. Depois de Nietzsche há uma reformulação radical de como se pensam e se expressam os problemas filosóficos; seria uma ingenuidade acreditar que se possa fazer filosofia hoje como, por exemplo, Descartes, Spinoza ou Kant faziam. Para atestarmos tal afirmação é só lembrarmos que, de modo geral, os filósofos contemporâneos, pós Zaratustra, em algum momento de suas produções filosóficas, apresentam os questionamentos e estruturam o pensamento de uma forma não sistemática: o estilo poético de Heidegger, nos ditos últimos textos; o elogio à literatura feito por Wittgenstein; a inclinação de Adorno e Walter Benjamin aos fragmentos e textos ensaísticos são sucedâneos da constatação nietzschiana de falência de uma linguagem filosófica que se pretende finalista de pensamento e capaz de encerrar, através de sua lógica, uma Verdade absoluta.

No entanto, uma análise mais apurada dos desdobramentos do estilo nietzschiano, insere-nos em um terreno desconfortável, uma vez que tal estilo erige-se não apenas como uma nova possibilidade de pensar e expressar problemas, mas edifica-se, principalmente, como uma grave crítica à linguagem representacional - que se estabeleceu na tradição - e, por consequência, à unilateralidade de se filosofar por meio de conceitos. O desconforto está, justamente, em entender que a "linguagem conceitual" busca expressar a essência das coisas, ou seja, o conceito diz exatamente o que a "coisa é", por outro lado, a intenção de Nietzsche não é expressar as essências das coisas, todavia, ao mesmo tempo, pretende uma compreensão e uma explicitação das coisas através da linguagem verbal que cunha nomes e termos; a dificuldade aqui está em 
estabelecer até que ponto é possível, com coerência, fazer uma crítica à dimensão conceitual da filosofia, se para fazê-la, inevitavelmente, devemos fazê-la no domínio de uma linguagem que acaba por criar conceitos.

Essa contradição é ainda mais incômoda quando nos deparamos fazendo estudos e análises desses problemas; nós pesquisadores, necessariamente, em algum momento, reconheceremos que o que fazemos é incoerente no seu aspecto mais fundamental: ao defrontar com estes temas voltamos a uma linguagem que foi abandonada e estabelecemos conceitos cristalizados sobre a crítica ao conceito; depois do reconhecimento da falência da ideia de sistema, escrevemos, sob o crivo da academia, de forma sistemática. Contudo, deixando de lado a intransponibilidade dessa antinomia, nossa intenção agora é investigar o estilo nietzschiano com uma inclinação de leitura: desde seus primeiros escritos o que se privilegia é uma linguagem que se vale de símbolos e representações intuitivas, esquivando-se, portanto, de uma linguagem representativa e conceitual. Com um olhar aguçado para pensadores gregos originários, Nietzsche tem todo o material para criar uma filosofia que pensa e se expressa alegoricamente, sem a produção de "conceitos rígidos", ou seja, que não admite uma flexibilização. Tal estilo no decorrer de sua obra assumirá um caráter de gravidade.

Aristóteles, em sua obra Metafísica, mais precisamente no terceiro capítulo do livro gamma, pondera que o filósofo é aquele que estuda a essência das coisas; o filósofo é capaz de enunciar os princípios mais firmes de todas as coisas, isto, justamente por conhecer o "ente enquanto ente" e, portanto, cabe a ele inquirir a respeito dos princípios silogísticos. Pautado no silogismo, o filósofo tem em mãos os princípios necessários para não se enganar sobre as coisas. Todavia, dentre tais princípios silogísticos, o mais importante, segundo Aristóteles, é o que se define desta forma: "É impossível que o mesmo seja atribuído e não seja atribuído ao mesmo tempo a um mesmo subjacente e conforme ao mesmo aspecto"63. O que lemos é a definição aristotélica do que mais tarde foi chamado de "princípio de não-contradição", considerado pelo próprio filósofo como o mais firme de todos os princípios lógicos, pois ele encerra a definição de determinada coisa com a

\footnotetext{
${ }^{63}$ Cf. ARISTÓTELES. Metafísica. 1005b, 17-25.
} 
ideia de que é impossível, para quem quer que seja, considerar que um mesmo fato é e não é ao mesmo tempo.

Com a estruturação do princípio lógico de não-contradição ${ }^{64}$, Aristóteles difunde para a tradição um modo de pensar que tem como prerrogativa encerrar a compreensão de algum objeto a partir de uma definição que esgote todas as possibilidades de entendimento. Decorrente disso, tradicionalmente, entende-se que para se fazer filosofia é necessário um modelo de pensamento que, por meio de uma subsunção de particulares em uma ideia geral, cria-se uma noção abstrata e definitiva da coisa pensada. Em outras palavras, pensar e escrever filosoficamente implica, para a tradição ocidental, a construção sistemática de conceitos que finalizam e concluem a operação de subsunção em uma definição universal $^{65}$. Por sua vez, essas noções universais e abstratas têm a função de representar cabalmente os entes; é exatamente esse exercício que denominamos "produzir conceitos". Como vimos, os conceitos tradicionais não admitem, em hipótese alguma, a contradição: conceber que alguma coisa pode, ao mesmo tempo, ser e não ser é ferir o mais firme de todos os princípios lógicos. Assim, utilizamos a lógica e o princípio de não-contradição como instrumento pelo qual é possível reconhecer um erro: se um enunciado admite a contradição, é equivocado.

Esta forma de representar por meio de conceitos totalizantes e rígidos, sustentados pelo princípio de não-contradição, pretende esquadrinhar a essência rígida das coisas. Contudo, extemporâneo à tradição difundida por Aristóteles, Nietzsche encontra em outros gregos, anteriores aos pensadores do século V e IV da Grécia democrática, a inspiração necessária para pensar outro modelo de linguagem divergente do modelo lógico-conceitual aristotélico: "a vida dos gregos brilha somente onde cai o raio do mito; fora disso ela é sombria. E precisamente do mito que os filósofos gregos se privam" ${ }^{\text {"66 }}$, pois é, exatamente, na linguagem poética dos mitos arcaicos, onde encontramos uma força simbólica, que por sua vez é suprimida, pouco a pouco, pelos postulados da filosofia e a

\footnotetext{
${ }^{64}$ É importante lembrar que tal princípio de "não-contradição" (assim como o princípio de identidade) já estava presente no pensamento de Parmênides o que é possível constatar em seu fragmento mais famoso: "o ser é e o não-ser não é".

${ }^{65}$ Essa noção de conceituação também está presente no pensamento de Platão; a ideia platônica é a essência universal que subsume tudo que existe de forma plural enquanto representação.

${ }^{66}$ NIETZSCHE. Humano, demasiado humano. \$261.
} 
necessidade de uma Verdade una, que chegasse ao centro de todo Ser, resolvendo o enigma do mundo. Entratanto, entre os filósofos gregos existe uma lacuna que separa os pensadores originários daqueles que seguem a escola socrática da lógica e do conceito; os primeiros pensavam e descreviam o mundo a partir de uma linguagem mais próxima àquela do mito. Dentre estes pensadores, quem mais chama atenção quanto ao estilo é, sem dúvida, Heráclito de Éfeso.

Heráclito é o pensador do vir-a-ser, da voragem e inocência do devir, por isso, é o pensador que se exprime por meio de uma linguagem que está além de um engessamento lógico-conceitual. A linguagem obscura heraclítica, poeticamente estilizada, está intimamente ligada ao modo como enxerga a realidade: o efésio não reconhece o dualismo entre um mundo físico e outro metafísico, como seus predecessores ${ }^{67}$; não podendo ser de outro modo, a consequência radical foi negar o Ser e a própria essência das coisas. O cosmos de Heráclito é apenas o vir a ser, o constante perecer e ressurgir das coisas, ou,

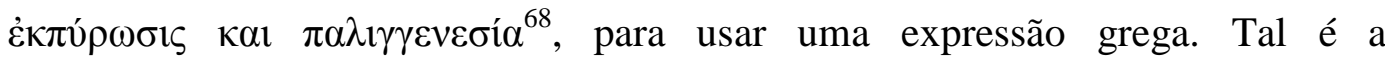
instabilidade do que supostamente é efetivo: tudo vem a ser, mas, jamais é; as polaridades dos opostos se convergem como em uma dança vertiginosa de um demiurgo que cria e destrói. Essa assombrosa e tremulante visão do universo reflete-se radicalmente na escrita do filósofo e na sua compreensão de como deve ser a escrita; é o que nos evidencia uma citação de Heráclito feita por Nietzsche de forma interpretativa pessoal:

Vejo apenas o vir a ser, não vos deixeis enganar! É devido à sua miopia, e não às essências, que credes ver no mar do vir a ser e do perecimento alguma terra firme. Vós empregais os nomes das coisas como se tivessem uma rígida duração: mas até mesmo a correnteza, na qual pondes vossos pés pela segunda vez, não é a mesma que na primeira vez ${ }^{69}$.

A tendência em estabelecer conceitos, "empregar nome às coisas" é uma crença supérflua na imutabilidade das coisas, ou mesmo acreditar na possibilidade de representação da universalidade e imutabilidade das essências. Por outro lado,

\footnotetext{
${ }^{67}$ Anaximandro, por exemplo, diferenciava um mundo de qualidades determinadas e um mundo de qualidades indeterminadas, sendo o último, origem metafísica do primeiro. Cf. NIETZSCHE. $A$ filosofia na época trágica dos gregos. §5.

68 "Ekpurōsis", crença da destruição periódica do cosmos pelo fogo. O cosmos então ressurgiria (palingénese) para ser novamente destruído no fim de outro ciclo.

${ }^{69}$ NIETZSCHE. Op. Cit.. $\$ 5$.
} 
a linguagem evocada aqui, se alicerça em uma capacidade proeminente de simbolizar intuitivamente; ainda há a representação, mas absolutamente distinta do representar que se vale de conceitos e combinações lógicas; não há conceitos na escrita de Heráclito, pelo contrário, o que ali se diz, foi antes adquirido intuitivamente; a razão se torna secundária, e não há nenhum equívoco em contradizê-la. A visão de mundo alcançada pela intuição nega radicalmente o princípio de não-contradição, o que faz Aristóteles acusar o pensador de Éfeso de ir contra as regras lógicas da razão; a metafísica aristotélica rechaça a percepção de mundo em questão. Não obstante, o que está em jogo no imaginário heraclítico não pode ser exprimido com a rigidez lógica, é necessária a representação intuitiva transformada em imagens.

Segundo Nietzsche, a representação intuitiva abrange dois níveis: o do mundo que se precipita a nós através de nossa experiência e do que possibilita toda e qualquer experiência desse mundo, isto é, o tempo e o espaço. A compreensão intuitiva de Heráclito é de que o tempo só existe na medida em que destruiu o seu instante predecendente, para logo ser ele próprio também destruído; da mesma forma o espaço e tudo que existe nele e no tempo, só possuem uma existência relativa, prestes a ser destruída e substituída por outra do mesmo status. Além disso, o que se mostra mais relevante aqui, é que essa Verdade de mundo, para Heráclito, é de evidência tão imediata e acessível a todos, que acaba sendo difícil se alcançar conceitual e racionalmente ${ }^{70}$. Nas palavras de Heráclito exprime-se a Verdade de forma oracular ${ }^{71}$, o que se diz, não se diz calculando; é necessário lentidão e cautela para interpretar, pois a Verdade apreendida na intuição é expressa velada em imagens e não "galgada pela escada de corda da lógica" $" 72$.

Embora sua linguagem seja obscura, não podemos dizer que a filosofia presente nos fragmentos taciturnos de Heráclito precisava ser iluminada pela explicitação da argumentação conceitual pós-socrática. Nestes fragmentos, encontramos um modo profundo de pensar e representar filosoficamente a realidade que não conhecia a necessidade dos conceitos acabados. É neste modo

\footnotetext{
${ }^{70}$ Cf. Idem.

${ }^{71}$ Heráclito entendia a força de expressão do Oráculo, como podemos constatar no Fragmento 93: "O Senhor cujo oráculo está em Delfos não declara nem oculta, mas assinala".

${ }^{72}$ NIETZSCHE. A filosofia na época trágica dos gregos. §9.
} 
mais originário de linguagem que Nietzsche encontra a inspiração necessária para elaborar seu estilo que prima por imagens simbólicas e alegóricas ao invés da conceituação sistemática tradicional. $O$ Nascimento da tragédia inaugura esse "projeto" de linguagem.

Logo nas reflexões introdutórias de sua primeira grande obra publicada, Nietzsche nos esclarece: "Teremos ganho muito a favor da ciência estética se chegarmos não apenas à intelecção lógica, mas à certeza imediata da introvisão de que o contínuo desenvolvimento da arte está ligado à duplicidade do apolíneo e do dionisíaco"73. Além da apresentação do tema central de sua obra, o que o filósofo nos evidencia é o estilo com o qual apreende e exprime suas ideias: não são apenas as inferências lógicas [logischen Einsicht] que serão privilegiadas na construção de sua visão de mundo, mas também as certezas imediatas da intuição [zur unmittelbaren Sicherheit der Anschauung], como aquelas reconhecidas na linguagem de Heráclito. Por conseguinte, o estilo desenvolvido por Nietzsche não se exprimirá por meio de um sistema lógico conceitual, mas sim, via uma linguagem que apreende a realidade intuitivamente e a simboliza em imagens.

Isso é o que podemos constatar ainda nas primeiras linhas da primeira seção d'O Nascimento da tragédia, quando o autor, ao se referir às figuras de Apolo e Dioniso, escreve: "Tomamos estas denominações dos gregos, que tornam perceptíveis à mente perspicaz os profundos ensinamentos secretos de sua visão da arte, não, a bem dizer, por meio de conceitos, mas nas figuras penetrantemente claras de seu mundo dos deuses $" 74$. Fica evidente que a intenção não é representar por meio de noções abstratas ou elaborar conceitos [Begriffen], porém, a tentativa de uma filosofia que, na medida do possível, volte a uma linguagem mais figurativa; percebe intuitivamente, sem intermédio de cálculos lógicos e se exprime através de imagens simbólicas ${ }^{75}$. Para Nietzsche, o processo de produção de símbolos é uma atividade essencialmente artística, simbolizar,

\footnotetext{
${ }^{73}$ NIETZSCHE. O Nascimento da tragédia. §1. No original em alemão: [Wir werden viel für die ästhetische Wissenschaft gewonnen haben, wenn wir nicht nur zur logischen Einsicht, sondern zur unmittelbaren Sicherheit der Anschauung gekommen sind, dass die Fortentwickelung der Kunst an die Duplicität des Apollinischen und des Dionysischen].

${ }^{74}$ Idem.

75 "A força inconsciente produtora de forma mostra-se na procriação: aqui age uma pulsão artística. Parece ser a mesma pulsão artística que leva o artista a idealizar a natureza e que leva a cada homem à visão figurada de si próprio e da natureza”. NIETZSCHE. Fragmento póstumo de $1872,16[13]$.
} 
segundo o filósofo, consiste engendrar uma imagem no lugar da coisa. Há um jogo entre sensação, imaginação e intelecto.

Interessante que Nietzsche, em um fragmento póstumo do mesmo período de $O$ Nascimento da tragédia, afirma que o conceito, em seu nascimento, é um fenômeno artístico, porém, no final do mesmo fragmento, pondera que " $o$ conceito é o tipo de um grande número de fenômenos" ${ }^{, 76}$. Na perspectiva nietzschiana, o conceito passa por dois momentos em seu desenvolvimento: primeiro, no seu nascimento, o conceito é como a arte, uma projeção simbólica de imagens; no segundo momento, o conceito torna-se uma espécie de signo que expressa um grande número de fenômenos, isto é, o conceito reúne em um mesmo símbolo diferentes fenômenos, há um processo de abstração, generalização e fixação conceitual. Por meio deste processo, certas qualidades e características dos fenômenos particulares são separadas e comparadas a outro fenômeno, formando representações gerais que podem ser atribuídas a vários objetos, deixando em segundo plano as peculiaridades e qualidades únicas de cada objeto $^{77}$. Cabe à abstração e a lógica formar leis que tornem possíveis tais generalizações.

A palavra e o conceito são, originalmente, projeções de imagens, atividade de simbolização do mundo interior e exterior. A partir de um processo de desenvolvimento da abstração, pelo qual o símbolo da linguagem torna-se "um meio de apenas lembrar o conceito", a palavra assume um caráter tanto de um signo mnemônico, para lembrar de um conteúdo de representação, quanto de generalização de fenômenos e da experiência. Decorrente desse processo, a palavra e o conceito deixam de ser um fenômeno artístico. Neste sentido, o conceito passa e ser descrito pelo filósofo como um "símbolo gasto pelo uso". O envelhecimento e empobrecimento do símbolo ocorrem devido à fixação do signo pela memória, daí resulta o conceito, compreendido como um tipo grosseiro e rudimentar de signo. A atividade conceitual consiste, portanto, em apreender um fenômeno omitindo e abstraindo as características particulares da experiência. A linguagem se forma mediante esse processo gradual de fixação e generalização.

\footnotetext{
${ }^{76}$ Idem. 1872, 8[41].

${ }^{77}$ Cf. CAVALCANTI, Anna Hartmann. Símbolo e alegoria. A gênese de concepção de linguagem em Nietzsche.
} 
Para Nietzsche, a linguagem conceitual é uma linguagem superficial que apresenta um mundo generalizado e cristalizado; ela está ligada a uma função comunicativa que tem como base uma estrutura fixada na memória e na consciência. A configuração desta estrutura engessa e limita o campo de significação da própria linguagem. Por outro lado, existe outro modelo de expressão que possui a capacidade de preservar a riqueza da intuição imediata da realidade, uma linguagem que se vale de imagens simbólicas e alegorias. Esta linguagem simbólica, mais próxima à poética do que ao conceito, comunica por imagens que potencializam o sentido. O que ocorre é uma transposição artística da experiência intuitiva. Este ato artístico ${ }^{78}$ consiste em criar, a partir da sensação, uma forma de imagens específicas, as alegorias e símbolos. No estilo nietzschiano, o símbolo é como um modo de expressão único, capaz de comunicar conteúdos dificilmente acessíveis à linguagem comum.

Desse modo, ao lermos nos escritos nietzschianos os termos recorrentes de seu pensamento, tais como Dioniso e Apolo, não devemos ingenuamente entendêlos como "conceitos nietzschianos" no sentido tradicional. Há uma preocupação do filósofo com o sentido das palavras, elas evocam uma reflexão filosófica, justamente, por não empregarem uma fixação lógico-conceitual; quando se fixa o conceito, a potência do pensamento desaparece. A sistematização e generalização fazem com que o sentido mesmo das coisas, o espanto e a instauração do problema se percam. No entanto, a ingenuidade persiste se afirmamos, categoricamente, que ali não se segue a via expositiva e representativa da linguagem formal. Seria impossível, para Nietzsche, significar no plano da justificação, ou seja, apresentar uma compreensão de realidade, de outro modo, se não pela linguagem que acaba por cunhar termos. Apesar disso, o estilo em questão segue um caminho distinto do enunciativo e expositivo do sistema conceitual tradicional.

Estas considerações, aqui brevemente apresentadas, contribuem para afirmarmos que Nietzsche privilegia, em sua filosofia, expressar não por meio de conceitos acabados e cristalizados, mas sim através de uma linguagem simbólica.

\footnotetext{
78 "Direi ao mesmo tempo algo geral sobre a minha arte do estilo. Comunicar um estado, uma tensão interna de páthos por meio de signos - eis o sentido de todo estilo." NIETZSCHE. Ecce homo - "Porque escrevo livros tão bons" §4.
} 
No entanto, como nos alerta Derrida, sobre a questão do estilo em Nietzsche, só podemos falar no plural $^{79}$; há um jogo entre vários estilos ao longo de sua produção filosófica, não obstante, sempre com um olhar desconfiado para os sistemas e a conceituação lógica tradicional. O problema que se levanta ao afirmamos, definitivamente, que não há conceito na produção do filósofo é que ao estudarmos e pensarmos os grandes temas discutidos por ele acabamos, nós mesmos, estabelecendo "conceitos nietzschianos", o que é incontornável. Mesmo ao se exprimir simbolicamente, mediante imagens e alegorias, o que se expressa acaba se tornando uma definição e explicitação da realidade através de um termo. Tal inconsistência é reconhecida pelo próprio filósofo, o que faz com que, ironicamente, também postule nome às coisas:

esse meu mundo dionisíaco do eternamente-criar-a-si-próprio, do eternamentedestruir-a-si-próprio, esse mundo secreto da dupla volúpia, esse meu 'para além de bem e mal', sem alvo (...) quereis um nome para esse mundo? (...) Esse mundo é a vontade de poder - e nada além disso $!^{80}$

Reconhecendo o mundo de modo verossímil àquele apreendido intuitivamente por Heráclito, Nietzsche parece sentir a necessidade de empregar um nome para designá-lo. Com uma tonalidade aparentemente irônica, questiona: “quereis um nome?". Ele compreende a intransponibilidade do problema em explicitar sua visão de mundo sem o uso da linguagem formal, e acaba cunhando um nome: vontade de poder. O que faz, de certo modo, é conceituar sua visão da realidade. Em virtude disso, em Ecce homo, define o termo "dionisíaco" exatamente como um conceito, ao fazê-lo, está se referindo, justamente, à sua obra menos conceitual, aquela que foi escrita e fala a linguagem dos ditirambos, Assim falou Zaratustra: "meu conceito de 'dionisíaco' tornou-se ali ato supremo" [Mein Begriff ,, dionysisch“ wurde hier höchste That $]^{81}$.

Contudo, não podemos dizer, em absoluto, que este é um conceito nos moldes da tradição ocidental difundida por Aristóteles, pois, não se pretende atingir a essência e a Verdade absoluta das coisas. Existe uma compreensão, e explicitação da compreensão, por meio da linguagem verbal, mas que não encerrará, de uma vez por todas, tudo aquilo que o significado pode dizer; algo

\footnotetext{
${ }^{79}$ Cf. DERRIDA, Jacques. Eperons Les Styles de Nietzsche.

${ }^{80}$ NIETZSCHE. Fragmento póstumo de 1885, 38[12].

${ }^{81}$ Ibidem. Ecce homo. Assim falou Zaratustra, §6. Grifo nosso.
} 
fica encoberto e velado, isto é, o meio pelo qual se exprime o sentido, se dá ao mesmo tempo em que algo permanece obscuro. O "conceito", só poderia ser entendido como o Kepavvós heraclítico ${ }^{82}$, o lampejo que esclarece, apenas momentaneamente, para tão logo, ser novamente abraçado pela escuridão. A dinâmica de significação em Nietzsche implica uma crítica ao modo como a conceituação pretende-se finalizadora de conhecimento. Isso só é possível a partir de um estilo, que se pretende filosófico, porém, não tem compromisso com a totalidade. Além disso, o conceito da tradição é rígido, permanente. Por outro lado, Dioniso-símbolo-conceitual é dinâmico; apesar de manter uma base significativa, se modifica. Aliás, entender essas transmutações "conceituais" é o objetivo mesmo deste trabalho.

\section{4.}

\section{Incipit tragoedia - estrutura e conteúdo:}

A tragédia grega foi dividida estruturalmente por Aristóteles, no capítulo

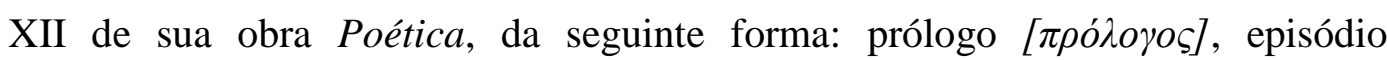

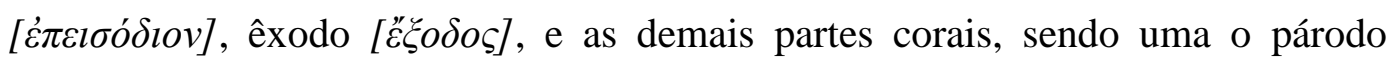

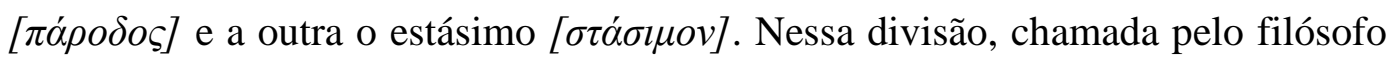
de quantitativa, o prólogo corresponde à abertura da tragédia, com o anúncio do tema antes da entrada da orquestra; o párodo é a primeira entrada do coro no palco, nesse momento o canto tem função de iniciar a trama; os episódios são as partes entre os coros onde ocorrem os diálogos e o desenrolar da estória, os episódios sempre são sucedidos pelos estásimos, que correspondem às entradas do coro ao longo da peça. As tragédias gregas mais conhecidas possuem, geralmente, quatro ou cinco episódios, seguidas pelo mesmo número de estásimos. Édipo Rei e Medeia, por exemplo, possuem quatro episódios e quatro estásimos, já em Bacantes são cinco episódios e cinco estásimos. Por fim, o êxodo é a saída final do coro, a conclusão da trama, encerrada, em geral, pela fala do corifeu.

Pelo fato de o objeto principal desta pesquisa ser Dioniso e suas múltiplas significações no decorrer da obra de Nietzsche, e sabendo que a divindade está

\footnotetext{
${ }^{82}$ Cf. HERÁCLITO. Fragmento 64.
} 
essencialmente ligada à origem da tragédia grega, decidimos dividir estruturalmente este trabalho com a nomenclatura utilizada por Aristóteles, e até hoje aceita para classificar as partes do teatro trágico. Dessa forma, ao invés de estruturarmos este projeto convencionalmente com os termos introdução, capítulo, subcapítulo e conclusão, utilizaremos os termos aristotélicos acima mencionados, de modo que nossa introdução será chamada de prólogo; o primeiro capítulo, ou capítulo de apresentação receberá o nome de párodo; o capítulo subsequente, será o primeiro episódio seguido por um terceiro capítulo que, devido à sua proximidade conceitual com o anterior, será nosso primeiro estásimo; o mesmo ocorrerá com o segundo episódio e segundo estásimo. Como no antigo teatro os estásimos correspondem à entrada do coro, nos nossos também terão como tema central, de uma forma ou outra, sempre a música. Por fim, encerraremos a tese com o termo êxodo, substituindo a tradicional "conclusão".

É obvio que nossa intenção não é escrever uma tragédia, mas, tão somente, fazer uma mera homenagem à informalidade da escrita nietzschiana e ao deus dilacerado em todas as tragédias; trata-se de uma relação metafórica que contribuirá para a intelecção do objeto da pesquisa. Desse modo, no que diz respeito à estrutura, o $\pi \alpha ́ \rho o \delta o \varsigma$ apresentará as muitas teofanias de Dioniso. Em

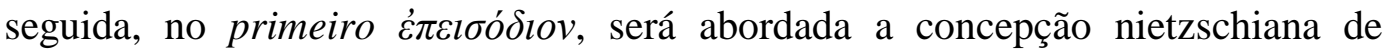
tragédia dos primeiros escritos. O primeiro $\sigma \tau \alpha ́ \sigma l \mu o v$ é dedicado ao renascimento do espírito dionisíaco na Alemanha moderna na figura de Wagner e a posterior

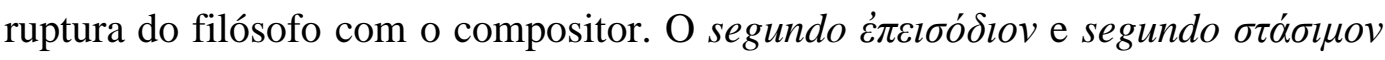
abordarão a virada do pensamento nietzschiano a partir de Humano, demasiado humano, o radical abandono da metafísica, o silêncio em relação a Dioniso e a

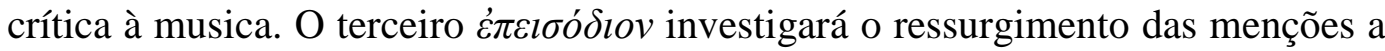
Dioniso e a ressignificação do dionisíaco a partir dos escritos de 1882 . O terceiro

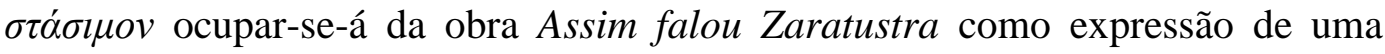

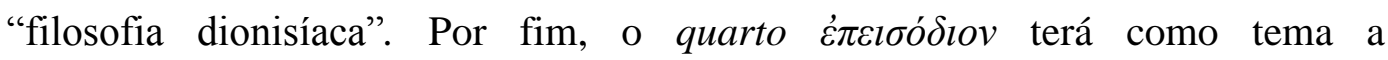
ressignificação da embriaguez dionisíaca nos últimos escritos de Nietzsche.

Tal estrutura contará com o seguinte conteúdo:

Пó $\rho o \delta o \varsigma$ - Na primeira parte de nossa empreita, a preocupação ainda não é assimilar os múltiplos significados filosóficos que Dioniso desempenha ao longo 
da obra nietzschiana, mas nosso arrojo é sondar o que chamou a atenção de Nietzsche nos antigos mitos e ritos do deus do vinho. Mesmo admitindo a pretensão do intento, instiga-nos compreender quais são os atributos da divindade, quais as singularidades do culto dionisíaco e qual papel exerceu nas civilizações antigas, seja na cultura grega ou na bárbara. Para tal, apoiar-nos-emos nos egrégios estudos realizados por Walter Friedrich G. H. Otto e nos estudos realizados pelos helenistas por ele influenciados, Károly Kerényi e Marcel Detienne; também nas importantes contribuições feitas por Henri Jeanmaire, JeanPierre Vernant e Junito de Souza Brandão. Além desses, investigaremos as concepções sobre o estrangeirismo da religião dionisíaca de Erwin Rohde e Martin Persson Nilsson. A escolha desses nomes não é casual, os consideramos responsáveis pelos mais notáveis trabalhos feitos a respeito do dionisismo.

Desse modo, o desígnio do párodo é destacar as características que tornam Dioniso a entidade mais sedutora e igualmente complexa da Antiguidade. Primeiramente, situaremos o exotismo dos cultos dionisíacos; Dioniso é o deus sempre estrangeiro, orientais são suas primícias. Ainda será necessário salientar os diferentes mitos de sua manifestação: a divindade oriental trácia; o deus órfico que caminha junto às panteras; o deus das lendas tebanas; quais são as nuances entre as diversas epifanias da deidade? Quais as peculiaridades de seus muitos epítetos? Outro elemento que desempenhará grande importância em nossa investigação é a ambiguidade de Dioniso, representada por sua presença que sempre oscila entre máscaras. Suas máscaras possibilitam Dioniso seduzir e enfeitiçar os mortais, levando-os ao frenesi narcótico ou à demência; portanto o vinho, o êxtase e a loucura terão grande relevância doravante. Além disso, a excêntrica relação que a divindade exerce para com as mulheres também é um aspecto importante que desenvolveremos. E, por fim, qual sua relação com Ariadne?

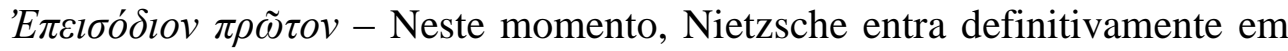
cena. A designação que o termo Dioniso - e todos os termos a ele relacionados efetua nos primeiros escritos nietzschianos será o centro de gravidade desta parte do trabalho, em torno do qual circundam os mais importantes temas do pensamento do ainda jovem filósofo/filólogo. Nosso ponto de partida encontrarse-á nas interpretações do panfleto A visão dionisíaca do mundo [Die Dionysische 
Weltanschauung], redigido entre junho e agosto de 1870 em Maderanerthal, nos Alpes suíços, enquanto Nietzsche se recuperava de uma moléstia adquirida quando serviu, como enfermeiro, na guerra Franco-Prussiana. Escrito originalmente, segundo o próprio autor, como um ensaio apenas para si, a fim de tranquilizar-se em meio à Batalha Wörth que iniciava ${ }^{83}$, o panfleto contém as primeiras meditações do filósofo sobre o dionisíaco e o apolíneo, inclui também a elaboração germinal de uma visão artística do mundo entrelaçada com sua compreensão da civilização helênica e da finalidade da tragédia grega.

As ideias inscritas no ensaio de 1870 constituem o primeiro pensamento filosófico de Nietzsche; lapidadas e apresentadas mais consistentemente, compõem as bases de sua primeira grande obra, O Nascimento da tragédia, ou helenismo e pessimismo, publicada em 1872. Há, nesta obra, quatro grandes ideias principais, onde todos os outros temas, de certa forma, estão a elas subordinados. São essas ideias: a origem, a estruturação e o conteúdo da tragédia ática; a finalidade metafísica da tragédia; o ocaso do teatro trágico; e o ressurgimento do espírito trágico na modernidade alemã nas peças de Richard Wagner. Todas estas quatro ideias centrais só podem ser compreendidas tendo como fio condutor o jogo de tensão entre a pulsão dionisíaca e a pulsão apolínea, portanto, são conteúdos indispensáveis de nosso primeiro episódio - com exceção da análise dos dramas wagnerianos e sua relação com o dionisíaco que será assunto integrante da parte subsequente, o primeiro estásimo.

Primeiro $\sigma \tau \alpha \dot{\sigma} \sigma \mu o v$ - Richard Wagner tem papel fundamental na elaboração do pensamento a respeito do dionisíaco dos primeiros escritos nietzschianos. A filosofia da música do compositor, conhecida por Nietzsche a partir da leitura, por volta de novembro de 1870, de um ensaio sobre Beethoven, sobretudo, aprendida nas várias preleções particulares na casa de Wagner, ouvidas na condição de um apaixonado discípulo e tomadas como tirocínio, marca definitivamente a obra do

\footnotetext{
83 "No verão escrevi para mim um grande ensaio para tranquilizar-me em meio à tormenta que começava". Carta a Erwin Rohde de 23 de novembro de 1870. Em 7 de novembro de 1870, escreve ao amigo Carl von Gersdorff a mesma referência, onde podemos ler: "Este verão escrevi um ensaio, "A Visão dionisíaca do mundo", que considera um aspecto da Antiguidade grega a qual podemos aproximar agora graças a nossos filósofos. Trata-se de estudos que fiz, em primeiro lugar apenas para mim. Somente desejo que o tempo me deixe amadurecer, como é devido, e poder produzir logo algo a partir dessa plenitude". O mesmo ainda pode ser conferido na carta a Richard Wagner de 10 de novembro de 1870. [Apêndice $v$ ].
} 
filósofo ${ }^{84}$; inúmeras cartas e, inequivocamente, o prefácio dedicado ao músico em O Nascimento da tragédia atestam a influência wagneriana. Nas tragédias antigas, as imagens míticas, representadas no palco, tornavam suportável a força destrutível da música dionisíaca, tornando possível o efeito trágico, ou seja, o "consolo metafísico" e a eterna alegria ligada à existência. Os dramas wagnerianos, segundo Nietzsche, refletiam o ressurgimento da música dionisíaca e, consequentemente, do efeito trágico na modernidade alemã; representava, então, a nova esperança de renovação da cultura.

Nosso objetivo é evidenciar quais elementos da criação estética de Wagner que o elegeram, segundo a perspectiva de Nietzsche, como um artista trágico par excellence. Quais foram as características de seu libreto e de sua composição musical que o fizeram dissoar da produção artística comum à sua época? Nossa preocupação está em elucidar que a proposta nietzschiana em estabelecer a música wagneriana como o renascimento do espírito dionisíaco, há muito tempo abstruso, na Europa oitocentista não é uma questão de mero entusiasmo e admiração pelo compositor, mas antes, um problema filosófico de primeira grandeza: uma legítima crítica à cultura e à sociedade moderna. A obra de arte total [Gesamtkunstwerk], idealizada por Wagner, era a esperança de um dionisismo capaz de renovar a cultura alemã e se colocar à frente da então chamada "cultura socrática" ou "cultura de ópera"; nessa ótica, "a arte é tarefa suprema e atividade propriamente metafísica desta vida" ${ }^{, 5}$, transformadora e capaz de tornar a existência superabundante. A segunda parte desta seção examinará a decepção seguida da radical crítica de Nietzsche contras as ideias do compositor, assim como os desdobramentos filosóficos desta ruptura.

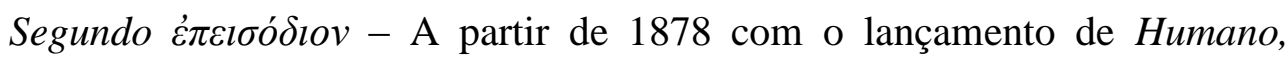
demasiado humano, há uma transformação no pensamento nietzschiano. Como ele mesmo escreve em Ecce homo, este livro dedicado a "espiritos livres" é o monumento de uma crise, expressa uma vitória; é um monumento de uma rigorosa disciplina de si, um voltar para si e libertar-se de tudo o que não pertence

\footnotetext{
${ }^{84}$ Cf. Carta ao amigo Gustav Krug de 4 de agosto de 1869. [Apêndice $\xi$ ]

${ }^{85}$ NIETZSCHE. Nascimento da tragédia. Prefácio a Richard Wagner.
} 
à própria natureza. Escrito em um momento de doença ${ }^{86}$ e solidão, a obra de 1878 representa um amadurecimento no pensamento nietzschiano caracterizado pelo afastamento da "cega vontade de moral de Schopenhauer" ${ }^{\prime 87}$, como do romantismo presente em Wagner. Neste novo modelo de pensamento, além do ataque à moral cristã é nítido o ataque à metafísica; é abandonado até mesmo o cerne de sua filosofia da arte, a "metafísica do artista", como é possível constatar escrito em um fragmento póstumo de 1877: "Eu quero expressamente declarar aos leitores de minhas obras anteriores que eu abandonei as posições metafísico-estéticas que aí dominam essencialmente: elas são agradáveis, porém insustentáveis" ${ }^{88}$.

Em Humano, demasiado humano, Nietzsche se cala em relação a Dioniso, não há uma linha sequer sobre a divindade grega, nem mesmo encontramos referências expressivas ao deus, ou ao dionisíaco, em suas cartas e fragmentos póstumos que compreendem o período de 1876 a 1880; pelo contrário, o que surge é uma crítica ao estado metafísico da embriaguez e, consequentemente, à concepção de arte elogiada anteriormente no período de $O$ Nascimento da tragédia; críticas que, acima de tudo, se direcionam à filosofia da arte e ao pessimismo de Schopenhauer, como à estética musical e à ascese wagneriana; entra em xeque, então, até mesmo a concepção de arte dionisíaca. Nessa parte do trabalho, o que estará em destaque é o sentido da radical ruptura de pensamento, a tentativa de elaboração de uma nova filosofia da arte e a crítica à cultura moderna presentes nos escritos do chamado "período intermediário" da produção nietzschiana.

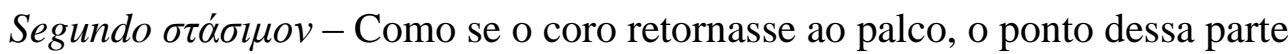
do trabalho será novamente a música. Mas agora será investigada a "re-

\footnotetext{
${ }^{86}$ Nietzsche explica no parágrafo 5, na seção dedicada a Humano, demasiado humano em Ecce homo que este livro foi redigido em principal em Sorreno; sua conclusão foi na Basiléia em condições bem desfavoráveis, Nietzsche com a cabeça enfaixada e dolorida com problemas na visão ditava a seu amigo Peter Gast, o qual escrevia e corrigia.

${ }^{87}$ NIETZSCHE. Humano, demasiado humano. "Prólogo" §1.

${ }^{88 ،}$ “Lesern meiner früheren Schriften will ich ausdrücklich erklären, daß ich die metaphysischkünstlerischen Ansichten, welche jene im Wesentlichen beherrschen, aufgegeben habe: sie sind angenehm, aber unhaltbar". NIETZSCHE. Fragmentos Póstumos de 1876-1877, 23[159]. (Quando a tradução dos fragmentos for de nossa autoria, citaremos o original a título de conferência - ao menos quando for uma citação muito longa, nesse caso, a tradução pode ser confrontada com o "Digitale Kritische Gesamtausgabeem" no site do Nietzsche source: http://www.nietzschesource.org/\#eKGWB).
} 
significação" que Nietzsche faz à música em dicotomia ao elogio dessa arte nos primeiros escritos.

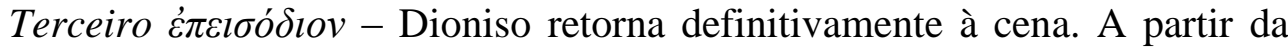
publicação de A Gaia ciência [Die fröhliche Wissenschaft], em agosto de 1882, as menções ao dionisíaco reaparecem como parte integrante da filosofia nietzschiana; também são constantes, a contar de 1883, notas sobre Dioniso, as quais vão se tornando, a cada ano, sucessivamente mais frequentes. Do mesmo modo, nas cartas escritas por Nietzsche entre 1887 e 1889, Dioniso torna-se sempre presente, atestando fundamental importância para a composição de seu pensamento tardio. No entanto, é importante sublinhar que a imagem de Dioniso, apresentada a datar da publicação de 1882, carrega um significado singularmente distinto daquele elaborado no período de juventude; há uma mutação radical na acepção que a divindade emprega: antes essencialmente metafísica; agora imanente, combativa a toda e qualquer forma de dualismo ontológico. Nesse ato, nosso foco é esse deus transmutado; pretendemos desvelar qual sua nova significação e quais relações estabelece com os demais temas da filosofia de Nietzsche.

Para interpretar os significados das novas máscaras de Dioniso, duas são nossas chaves de leitura, a primeira: o aforismo 370 de A Gaia ciência, no qual, de maneira profética, Nietzsche anuncia o pessimismo dionisíaco, apresentado em completa oposição ao "pessimismo romântico"; esse último seria símbolo máximo de empobrecimento da vida, cuja forma mais expressiva teria sido a ascese presente na filosofia da vontade de Schopenhauer e na música de Wagner; já o pessimismo do futuro, o dionisíaco, adjetiva uma necessidade de superabundância de vida.

A segunda chave de leitura é o enigmático aforismo 295 de Além do bem e do mal. Nesse texto, Dioniso é evocado como o Gênio do coração [Das Genie des Herzens] - justificando, assim, o título de nossa tese. Nas belas palavras de Nietzsche "o gênio do coração, que a tudo estridente e presumido faz calar e ensina a ouvir, que alisa as almas ásperas e lhes dá um novo anseio a saborearestender-se imóveis como espelho d'água para que nelas se reflita o profundo céu". Em nossa interpretação, Dioniso apresentado como Gênio do coração, como 
o deus-tentador, alude a três temas estreitamente interligados no pensamento nietzschiano: o primeiro, Dioniso é símbolo de uma filosofia da imanência, mais precisamente, de uma filosofia que privilegia o corpo frente a todo incorpóreo; segundo, Dioniso é símbolo da transvaloração de todos os valores e, portanto, é destruidor de velhos ídolos e criador de novas sentenças; terceiro, Dioniso é símbolo supremo da vontade de poder, do inocente devir no mundo que eternamente cria a si próprio e eternamente destrói a si próprio.

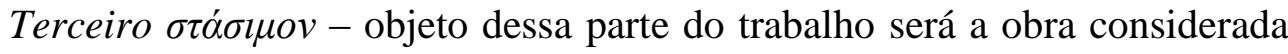
pelo seu autor como uma verdadeira sinfonia: Assim falou Zaratustra. Para Nietzsche, o dionisíaco nesta obra é ato supremo ${ }^{89}$. A personagem Zaratustra é a tipologia mais afirmativa, é aquele que tem a mais dura percepção da realidade e não encontra objeção nenhuma ao existir, ao contrário, diz Sim até mesmo à beira do abismo. Esta é a ideia exata de Dioniso. Sabendo disso, o objetivo aqui é refletir sobre a linguagem utilizada: Nietzsche procura o modo de dizer dos ditirambos, dos cantos dionisíacos; por isso Dioniso ali se torna ato supremo. Além disso, demonstrar-se-á qual o papel da solidão nessa obra.

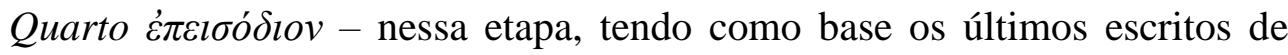
Nietzsche, principalmente Crepúsculo dos ídolos, demonstraremos qual é o novo significado da embriaguez dionisíaca. Intimamente ligada à criação artística, e diferente da intoxicação do período do Nascimento da tragédia, agora a embriaguez é um estado estético imprescindível.

Todas essas ideias acima arroladas serão como um fio condutor para o desenvolvimento deste trabalho. Devido à forma breve em que foram apresentadas, pode transparecer que as questões e os problemas a serem trabalhados possuem um caráter meramente hermenêutico, ou seja, que nossa intenção é apenas reconstruir analiticamente o pensamento nietzschiano no que diz respeito ao significado do símbolo Dioniso nos diferentes momentos de sua

\footnotetext{
${ }^{89}$ Idem. §6. p. 85.
} 
obra. Não obstante, além de uma compreensão conceitual e análise sistemática dos problemas já conhecidos da produção de Nietzsche e seus encadeamentos com o tema Dioniso, tencionamos uma constante reflexão, problematização e contextualização da filosofia nietzschiana; principalmente porque consideramos Nietzsche um filósofo visceralmente ligado à vida; do mesmo modo, Dioniso como o deus mais terreno e o que mais ama os homens e seus labirintos. Tais reflexões sempre permearão o campo das artes, fundamentalmente, no tocante à música: como nas tragédias antigas, os nossos estásimos representam o retorno do coro ao palco. 


\section{2}

\section{П'АPO $\Delta O \Sigma$}

\section{1.}

Do Oriente vem o berro do bode:

O dionisismo celebrado nos mais diferentes cultos e ritos, sem dúvida, não é uma singularidade helênica. Há relatos de rituais dionisíacos em todos os confins do velho mundo. Nietzsche fala, em $O$ Nascimento da tragédia, de uma proveniência estrangeira das festas dionisíacas. Para ele, existia um abismo que separava os "gregos dionisíacos" dos "bárbaros dionisíacos". Entre os bárbaros, quase por toda parte, o objeto dos seus regozijos dionisíacos era uma licença sexual desenfreada, cujo fluxo desmedido sobrepujava os laços consanguíneos e a venerada moral familiar; era a bestialidade mais selvagem da natureza humana que, desacorrentada, atingiria àquele misto horrível de volúpia e crueldade "que parece ter o sabor de bebida cozida por feiticeiras”. Segundo a análise nietzschiana, contra o desregramento febril destas festas, cujo conhecimento chegava aos gregos por todos os caminhos da terra e do mar, estiveram eles protegidos, durante algum tempo, pela figura de Apolo que se opunha, através da arte dórica, à grotesca e brutal violência dionisíaca ${ }^{1}$.

Ainda de acordo com a concepção nietzschiana, a resistência de Apolo tornou-se cada vez mais difícil e acabou por ser impossível quando, “das raízes

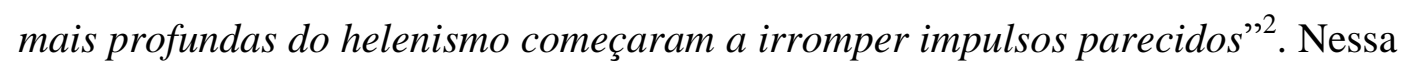
perspectiva, já existia entre os gregos o instinto dionisíaco, adormecido e selado pela cultura apolínea; mas, as origens mesmas das práticas dionisíacas seriam bárbaras, estranhas à língua helênica; a religião de Dioniso teria migrado do Oriente à Grécia antiga. Nesse sentido, Nietzsche parece estar de acordo com a tradição dos helenistas de sua época que entendiam Dioniso como uma divindade estrangeira e que seu reconhecimento se impôs após relutância extrema. Primeiro, pensava-se que teria entrado diretamente à Grécia pela Trácia; mas depois, crê-se haver encontrado indícios de que teria chegado pelo mar Egeu desde a Frígia ou Lídia. No entanto, há outra hipótese: o movimento que originou a chegada de

\footnotetext{
${ }^{1}$ Cf. NIETZSCHE. O Nascimento da tragédia. §2.

${ }^{2}$ Idem.
} 
Dioniso correspondeu, tão somente, ao novo despertar de um culto antigo; as ideias e ritos ligados a seu nome haviam existido já entre os povos pré-helênicos ${ }^{3}$.

Como podemos perceber são muitas as interpretações sobre as origens de Dioniso, mas duas teses protagonizam o debate sobre o berço do deus: a tese de que os cultos a Dioniso tenham se originado no Oriente e, como dissemos, chegaram à Grécia vindos da Lídia, Frígia ou Trácia; a outra tese defende que Dioniso seja uma divindade propriamente grega, então o núcleo de seus ritos e os atributos de sua deidade estiveram presentes desde os primórdios da civilização grega. Erwin Rohde foi um dos helenistas que mais se destacaram na defesa do estrangeirismo de Dioniso. As ideias defendidas em sua obra Psyche $e^{4}$ entraram em voga no final do século XIX e foram por muito tempo aceitas entre os helenistas; Rohde defendia um "culto trácio ao delírio", estranho à sensibilidade helênica e, devido à sua aterradora violência, encontrou fortes resistências em seu movimento de entrada na Grécia através das montanhas da Trácia. Os ritos ao deus trácio, batizado pelos helenos de Dioniso, discrepavam drasticamente, em todos os aspectos dos cultos tributados aos deuses gregos, tal como os descritos por Homero $^{5}$.

Para Rohde, os próprios gregos já haviam manifestado com frequência que o berço dos cultos de Dioniso era a Trácia ${ }^{6}$. Segundo seu relato, as festas dionisíacas eram celebradas nas cimeiras das montanhas, baixo à penumbra da noite e à bruxuleante resplandecência das tochas; o rito era acompanhado por músicas barulhentas, pelo som estridente dos chifres feitos de bronze, pelo ressoar dos tambores e, quase sempre, pela melodia de flautas que incitavam o devaneio. A multidão, excitada pela selvagem música, dançava enlouquecida entre sibilantes gritos. Rohde pondera que provavelmente não se entoassem cantos devido à violência da dança; diferentemente do ritmo suave e mesurado das celebrações gregas, o que se via eram movimentos delirantes e turbilhões furiosos. A maior parte dos fiéis que faziam parte deste rito, entregando-se ao frenesi até o esgotamento, eram mulheres; elas se vestiam com pele de raposa e de cervo,

\footnotetext{
${ }^{3}$ Cf. OTTO, Walter F.. Dioniso mito y culto - "A patria de Dioniso". Trad. Cristina García Ohlrich. Ediciones Siruelà, Madri: 2001. p. 44 a 51.

${ }^{4}$ Psyche: Seelencult und Unsterblichkeitsglaube der Griechen. 1894.

${ }^{5}$ Cf. ROHDE, Erwin. Psyche: Seelencult und Unsterblichkeitsglaube der Griechen. p. 301. [Apêndice $\alpha$ ]

${ }^{6}$. Cf. Idem. p. 299-300. [Apêndice $\beta$ ]
} 
adornando a cabeça com chifres. Não faltavam os animais: a dança com serpentes e as bestas sacrificadas, despedaçadas com as mãos e devoradas cruas ${ }^{7}$.

O sentido religioso dessas brutais festas que suscitavam uma violenta exaltação das emoções, na análise de Rohde, consistia na crença que somente por meio da excitação de todas suas faculdades o homem poderia obter contato com os deuses. O cortejo acreditava que o deus se fazia presente entre os furiosos adoradores. Entretanto, os discípulos de Dioniso, excitados pelo frenesi do rito, não se contentavam apenas "em ver o seu deus", mas aspiravam fundir-se com ele; "lutavam para romper as ataduras da estreita prisão corporal de suas almas". . Quando em meio à loucura, sentindo-se possuídos pelo deus selvagem, lançavam-se em direção aos animais destinados ao sacrifício, estraçalhando-os com os dentes e devorando-os ainda vivos, pois, delirantes, acreditavam ser, naquele momento, o próprio deus; por isso se ornavam com chifres e peles, para representar a figura divina. No entanto, Rohde insiste que os gregos da época das festas trácias, tanto quanto os seus posteriores, souberam manter-se afastados dos excessos do culto oriental. Apenas tardiamente haveria a irrupção dionisíaca na Grécia.

O equilíbrio das emoções e a conduta que jamais perde sua serenidade eram as marcas definitivas do povo grego, portanto, não poderiam se conciliar com o antagonismo dos excessos emocionais das festas trácias orgiásticas. Rohde encontra em Homero um dos fundamentos para sustentação de sua tese; para ele, não encontraremos nos poemas homéricos, nem o mais leve rastro, de uma sobretensão [Ueberspannung] de sentimentos religiosos como o que os gregos dionisíacos de uma época posterior chegaram a conhecer e venerar, pois viam nela uma loucura de ordem divina. Dioniso não aparece nas obras de Homero como um deus olímpico; com certeza já se conhecia a existência do deus, mas os cantos homéricos não deixam o conhecer como deus do vinho, nem como a divindade celebrada nas festas das cimeiras. Mesmo que o Canto VI da Ilíada contenha o

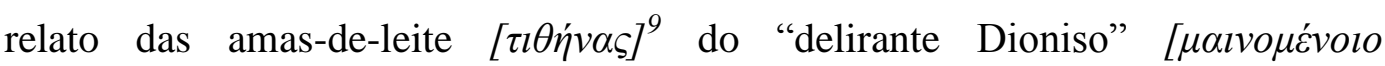

\footnotetext{
${ }^{7}$ Cf. Idem. p. 302.

8 "sie sprengen die enge Leibeshaft ihrer Seele" Idem. p. 307.

${ }^{9}$ Com o nome $\tau \imath \theta \dot{\eta} v \alpha \varsigma$, se designa as ninfas que amamentaram o infante Dioniso no monte Nisa.
} 
$\Delta \iota \omega v v ́ \sigma o l o]$ e dos tirsos [ $\theta \dot{v} \sigma \theta \lambda \alpha]$, a imagem não é, nem próxima, do deus que faz delirar os homens, e intervém no destino daqueles que atravessam suas veredas.

Nessa interpretação, o silêncio de Homero em relação a Dioniso indica que o deus trácio não havia ainda alcançado a vida e a fé dos gregos, para mais do que algumas práticas locais. O culto estrangeiro e exótico só entrou na Grécia após um processo lento e paulatino; a religião de origem trácia teve que vencer resistências até se estender vitoriosa pelo continente e ilhas helênicas e, por fim, estabelecer na vida grega uma profunda significação, tornando Dioniso adorado como distribuidor do embriagante sumo da vinha e protetor demoníaco da fertilidade dos campos $^{10}$. Essa tese de Rohde permite-lhe explicar, historicamente, os elementos de rejeição, de perseguição, de relutância e de irrupção presentes nas lendas e nos ritos dionisíacos. Sua visão de Grécia clássica, sem dúvida, provém da concepção inaugurada por Winckelmann, cuja característica fundamental é a serenidade; os gregos rejeitaram os excessos do culto primitivo trácio, justamente por não se caracterizarem mais como uma cultura primitiva.

É nítida na argumentação das seções Der thrakische Dionysosdienst e Dionysische Religion in Griechenland, da obra Psyche, uma forte influência das ideias nietzschianas, sobretudo dos escritos de juventude. Erwin Rohde e Nietzsche foram amigos confidentes e interlocutores entusiastas sobre o mundo grego antigo. Quando, ao publicar o Nascimento da tragédia, Nietzsche é atacado com inúmeras críticas, inclusive pelo ainda jovem filólogo WilamowitzMoellendorffo, é ao amigo Rohde que pede apoio, solicitando-lhe a publicação de uma resenha em defesa das ideias de sua primeira obra. O que é aceito de imediato. Ainda que Psyche seja uma obra de maturidade, publicada após o rompimento com o filósofo em 1887, no período em que Nietzsche começava a se encontrar incapaz devido à demência, é possível identificar similaridades na descrição do dionisismo de ambos, tais como: o estrangeirismo da origem de Dioniso, assim como a resistência grega em aceitar as violentas celebrações bárbaras; o caráter eruptivo da entrada de Dioniso na Grécia e sua posterior helenização.

\footnotetext{
${ }^{10}$ ROHDE, Erwin. Op. Cit. p. 332. [Apêndice $\gamma$ ].
} 
Contudo, não podemos considerar Rohde meramente como um intérprete e defensor das ideias nietzschianas; a construção do "dionisíaco", feita em Psyche, apesar das similaridades acima mencionadas, se afasta significativamente da concepção de $O$ Nascimento da tragédia. O principal objetivo de sua obra é demonstrar a história da crença na imortalidade da alma entre os antigos - na qual os ritos orgiásticos cumprem papel fundamental - e se distancia, portanto, por completo dos objetivos de Nietzsche. Além disso, na elaboração rohdeniana, apenas os mitos da épica homérica refletem os modelos eternos da vida, ou seja, traduzem os ideais helênicos, enquanto os mitos em torno de Dioniso são desprovidos de uma cosmovisão; ideia que acentua ainda mais o contraste com o pensamento metafísico nietzschiano, onde o "mito trágico" assume a profundidade de uma "sabedoria dionisíaca" para a vida. Todavia, o mais importante é saber que ao fazer essa distinção entre os mitos homéricos e os mitos de Dioniso, mais uma vez, Rohde desata qualquer vinculação entre a origem do dionisíaco e o solo grego.

Rohde, para justificar sua tese do estrangeirismo oriental e da resistência grega ao culto dionisíaco, recorre a uma série de mitos, chamados de mitos de resistência ${ }^{11}$; o núcleo destes mitos é uma loucura ainda mais exacerbada, já não há animais para o sacrifício, mas os próprios filhos ${ }^{12}$ são as primícias oferecidas ao deus. Ante a este ambiente de horror e sacrifícios humanos, há uma repulsa dos gregos e uma recusa das mulheres e reis protagonistas de tais lendas. Como Dioniso rompe tal resistência? Com uma incursão violenta. De acordo com Rohde, houve uma epidemia ${ }^{13}$ religiosa. Se a resistência foi simbolizada pelas mulheres que não aceitavam o tumulto entusiástico dos ritos trácios, então foram também as mulheres responsáveis pela irrupção de Dioniso na Grécia ${ }^{14}$; em um primeiro momento, como a deusa Hera, as mulheres são defensoras do matrimônio e, portanto, da ordem social, posteriormente, tomadas por Dioniso, passam a romper com as regras e hierarquias do casamento; por isso, nas lendas

\footnotetext{
${ }^{11}$ Cf. Idem. p. 327 a 333.

${ }^{12}$ Rohde faz referência ao caso de Penteu que é brutalmente assassinado por sua mãe, Agave.

${ }^{13}$ ROHDE, Erwin. Op. Cit. p. 330. [Apêndice $\delta$ ].

${ }^{14}$ Die Weiber waren es, die der neu eindringende Cult in einem wahren Taumel der Begeisterung fortgerissen zu haben scheint, ihnen zunächst mag er seine Einführung zu verdanken gehabt haben. [Foram as mulheres, ao que parece, que se deixaram levar por um verdadeiro tumulto de entusiasmo pelo novo culto, a elas eram, sem dúvida, devido, em parte muito importante, a introdução desses ritos na Grécia.] Idem.
} 
gregas, Hera é hostil com Dioniso, perseguindo sempre o deus símbolo da desordem social ${ }^{15}$.

Por conseguinte, com a definitiva irrupção dionisíaca na Grécia houve, segundo Rohde, uma "helenização" de Dioniso e, ao mesmo tempo, uma "dionização" da Grécia: o êxtase adapta-se à ordem social, os ritos, agora passam a seguir um calendário; o deus é definitivamente associado ao vinho, um atributo não presente nas epifanias trácias. Dioniso helenizado passa a ser representado artisticamente pelas tragédias, se convertendo em um meio de expressão do espírito grego. Em outras palavras, o que ocorre com Dioniso é uma "humanização"16 [humanisirt]. Delfos seria o símbolo máximo desta helenização/humanização, pois os cultos alí celebrados tornam-se mais moderados, o êxtase é suavizado, ocorrem apenas em datas específicas. O rito, difundido pelo oráculo, passa a fazer parte da cidade e da civilização, atingindo regiões onde não se ouvia falar dele, mas agora, serenizado e moralizado. Nessa perspectiva, foi o deus trácio das orgias montanhosas noturnas o primeiro senhor de Delfos; Apolo chega posteriormente ao oráculo, surge como um intruso.

Apesar do culto dionisíaco disseminado pelo oráculo de Delfos já ser curado dos excessos trácios, adaptado à serenidade e à sensibilidade da vida cotidiana helênica e à alegre luminosidade que caracterizava as festas da Ática, conservavase ainda uma profunda raiz de sua natureza primitiva: o êxtase e o orgiástico afloravam-se, às vezes, na forma de uma ameaça e tentação. Mesmo depois da fusão dos cultos dionisíacos e apolíneos, os impulsos da religião de Dioniso, devido à sua força, "contaminaram" o espírito grego, fazendo penetrar entre os helenos o cultivo da loucura [ $\mu \alpha v i \alpha]$. Acreditava-se que só era possível a união entre homem e deus através da loucura orgiástica. Nesse sentido, as práticas ritualísticas assumem, cada vez mais, o caráter místico e espiritual; elas foram imprescindíveis para o reavivamento das crenças populares no poder do espírito, na adivinhação e na possibilidade de se comunicarem com os deuses através do

\footnotetext{
${ }^{15}$ Nesse ponto, encontramos outra aproximação entre o Dioniso de Rohde e o de Nietzsche, uma vez que em $O$ Nascimento da tragédia há uma oposição entre o instinto apolíneo "sociopolítico" e

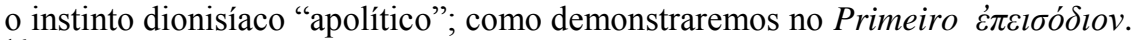

16 "Es war nicht mehr ganz der alte thrakische Dionysos, der den übrigen grossen Göttern des griechischen Olymps, als einer ihresgleichen, zur Seite trat. Sein Wesen hellenisirt und humanisirt sich" ["Já não era inteiramente o antigo Dionísio trácio que se juntou aos outros grandes deuses gregos do Olimpo como um de seus semelhantes. Sua natureza havia sido helenizada.]. ROHDE, Erwin. Op Cit. p. 332.
} 
êxtase. O êxtase possibilitaria a separação do corpo e da alma. Dioniso seria o responsável por despertar nos antigos a crença na imortalidade da alma.

A hipótese de Rohde é uma genealogia do dualismo corpo e alma na Grécia clássica, onde a religião dionisíaca, vinda do Oriente e, epidemicamente, alastrada entre os gregos seria o fundamento: o rito extático dionisíaco leva ao nascimento da mística - Dioniso estaria ligado ao mundo do "demonismo", associado aos cultos de Hécate e em geral às divindades chtônicas [ $\chi \theta$ óvios] e vegetativas, além de ser introdutor da mântica [Mantik] entre os gregos - há desde estes ritos um fio de continuidade, passando pelos sábios, profetas, sacerdotes do século VII, até os órficos, Pitágoras e, finalmente, Platão. As teorias filosóficas e metafísicas sobre a imortalidade da alma teriam sua origem na religião dionisíaca, cuja doutrina mística proclamava nos mistérios de seu culto a natureza divina da alma e sua abundância emanada do próprio deus. O êxtase dionisíaco tem, portanto, um fundo metafísico que eleva o homem ao divino e ao eterno. No entanto, na perspectiva de Rohde, esse êxtase dionisíaco possui um caráter negativo: Dioniso é a semente de uma religiosidade carregada de valores negadores da vida.

Rohde se identifica negativamente com Dioniso porque os princípios de seu culto dissolvem as faculdades racionais humanas e, portanto, são negadoras da existência. Nos rituais dionisíacos havia uma acentuada valoração das "sensações do divino e do eterno" só possíveis mediante ao êxtase do indivíduo, como se a alma encontrasse, momentaneamente, sua suprema felicidade através da libertação do cárcere corpóreo em um delirante arrebatamento, para tão logo se ver nas ataduras corporais novamente. Uma religião assim acaba por gerar um sentimento de desprezo pela vida, vendo o corpo como uma espécie de inimigo da alma divina. Nesse ponto, a compreensão de Rohde converge, embora apenas parcialmente, com a interpretação de $O$ Nascimento da tragédia: o enlevo dionisíaco tem um cunho metafísico; para Nietzsche, o êxtase dionisíaco proporcionaria uma espécie de contentamento, o "consolo metafísico", que por sua vez, em nada se baseava na imortalidade ou divindade da alma, mas sim em uma experiência estética e existencial.

Erwin Rohde destitui a natureza filosófica do "dionisíaco", concedida antes por Nietzsche; o que ele faz é uma pintura histórica da divindade, atribuindo-lhe 
uma importância fundamental na formação da cultura grega. Dioniso seria um deus do Oriente, a única divindade estrangeira que possui destaque em seu livro. O deus invade a Grécia como uma epidemia ${ }^{17}$; da mesma forma como na Idade Média a Peste Negra teria provocado a loucura, o cortejo de enfermos e sadios com impulso incontrolável de dançar freneticamente, Dioniso também teria irrompido as fronteiras gregas a partir da Trácia como uma doença popular, provocando as "invasões dóricas". Com suas formulações sobre estrangeirismo da origem de Dioniso em voga no século XIX, Rohde abre caminho para outros helenistas e estudiosos da religião pensarem e defenderem teorias sobre as origens não gregas do dionisismo. Entre estes nomes, um que se destaca é Martin Persson Nilsson; considerando insuficiente a explicação de uma origem única trácia, Nilsson propõe a ideia de uma divindade de origem compósita.

Para Nilsson, em History of greek religion (1925), os mitos e ritos de Dioniso são fontes históricas capazes de produzir informações sobre a religião e civilização gregas, desde o período micênico-minoico até a época greco-romana. A característica fundamental de seus estudos é sempre deitar os mitos ou cultos em um "exemplo social", atribuindo-lhes um sentido de "realidade social" Desse modo, ao analisar um mito ou um culto procura-se a realidade social em que está refletido e investiga-se como o fenômeno religioso e a sociedade evoluíram ao longo do tempo; por exemplo: o Olimpo homérico é reflexo da estrutura sócio-política da era micênica: o relacionamento de Zeus com os demais deuses demonstra as relações do Rei com seus vassalos; outros exemplos são os cultos da Grécia clássica, estruturados para remontar e legitimar o poder da pólis, sejam em Atenas, Esparta ou em outra polis; Édipo Rei reflete sobre os problemas morais de determinada realidade social. Os mitos e os cultos, nessa perspectiva,

\footnotetext{
${ }^{17}$ Segundo Marcel Detienne, foi lendo as Prétidas que Erwin Rohde pode imaginar a expansão do dionisismo à maneira de uma epidemia de danças convulsivas. Mas no sentido grego, "epidemia" pertence ao vocabulário da teofania: As epidemias são sacrifícios oferecidos às potências divinas: quando estas descem à terra, quando assistem a uma festa, quando estão presentes em um sacrifício, ou quando são hospedadas em uma cidade e por algum tempo permanecem, elas "epidemizam" a terra. São os deuses migrantes que têm direito às epidemias. $\mathrm{O}$ deus mais epidêmico dentre os gregos é certamente Dioniso, que tem na parúsia uma forma de ação privilegiada. DETIENNE. Marcel. Dioniso a céu aberto. Trad. Carmem Cavalcanti. Rio de Janeiro: Jorge Zahar Editor, 1988. p. 12 a 14.

${ }^{18}$ Cf. NILSSON, Martin Persson. Historia de la religión griega. Buenos Aires: Eudeba, 1963. p $53-73$.
} 
são entendidos como receptáculos morais, políticos, ideológicos, de uma sociedade.

Para compreender em que terreno social Nilsson assentará Dioniso, é preciso salientar que em sua obra há uma distinção entre "mito etiológico" e "mito inventado" $" 19$; o primeiro busca o sentido de tudo que cerca o homem e chama sua atenção: a natureza, o cosmos, a própria cultura humana, enfim, procura uma explicação para tudo ao redor do homem. Já o mito inventado, como sugere o termo, remonta ao conto popular, contos de épocas antigas; surgem do simples prazer de contar histórias e fazem parte da "infância da raça humana"20. Para Nilsson, os temas de contos populares são presentes na mitologia grega; na verdade, a épica seria uma evolução dos contos primitivos: o racionalismo helênico provocou uma reelaboração dos elementos demasiados fantásticos dos contos populares, selecionando e purificando as narrativas primitivas; em outras palavras, o mito grego nasceu do conto popular, transformado por um processo de humanização. O mito heroico não passa de uma projeção do mundo micênico e de seu modelo social impresso na tradição épica remodelada por Homero.

Em um sentido evolutivo, o mundo homérico-micênico representaria, segundo Nilsson, o momento mais elevado da história da cultura grega; isso porque o modelo social e teórico em questão estaria repleto de valores que Nilsson estabelece como superiores: no que diz respeito à raça, os indo-europeus; no que diz respeito à classe social, os guerreiros aristocratas; no que diz respeito ao gênero, uma cultura dominada por homens e dominada por valores masculinos; além dos valores oriundos do filtro homérico, a racionalidade e o humanismo. Estes valores dão superioridade frente a outros mitos que não refletem nenhuma realidade social, a saber, mitos arcaicos dominados pelo espírito fantasioso, movidos pelo medo e incompreensão do mundo natural. Portanto, a chave interpretativa, que permite Nilsson classificar cada mito como individualmente é sua relação com a realidade, quanto mais fantasioso o mito, mais distante de um ideal de modelo humano e, consequentemente, mais primitivo. Por outro lado, quanto menos fantasioso e mais racional, mais civilizado é o mito.

\footnotetext{
${ }^{19}$ Os termos aqui são os mesmos da tradução em espanhol da edição argentina de 1963.

${ }^{20}$ NILSSON, Martin Persson. Op. Cit. p. 67.
} 
Partindo destes pressupostos, Nilsson situa Dioniso como uma divindade primitiva e estrangeira. Tal conjectura explicaria porque o deus aparece em pouquíssimas passagens em Homero; as epifanias de Dioniso estariam em dissonância com o mundo micênico-homérico e sua lógica diferente da lógica do mundo autenticamente grego. A religião dionisíaca estaria ligada a um modo de pensar primitivo, altamente fantástica e sobrenatural; seus ritos e cultos, repletos de seres fantásticos e demônios, eram orientados para o controle mágico da natureza, como por exemplo, nos "ritos de fertilidade". Além disso, Dioniso se situaria em oposição aos valores da mitologia micênico-homérica, pois no que diz respeito à raça, é sempre a religião estrangeira, do mediterrâneo, pré-grega, por assim dizer; no que diz respeito ao gênero, é uma religião emocional e feminina, sempre ligada às deusas símbolos da mulher e da fertilidade; e no que diz respeito à classe social, é uma religião popular, em seus ritos sempre há uma destituição das convenções sociais e dos títulos políticos.

Os estudiosos da religião de Dioniso que defenderam a origem não-grega de seus cultos, sempre estabeleceram a Trácia como ponto de partida para a penetração no mundo helênico; no entanto, mapearam duas principais vias de entrada, sendo uma via terrestre, seguindo o caminho Trácia, Tessália, Beócia, Ática chegando a Tebas e a Delfos; e, outra, uma via marinha, que partindo da Trácia, atingiria o Peloponeso e a Ásia Menor, através das ilhas do Egeu e Creta, chegando a Atenas através dos dêmoi meridionais, como Icária e Erígone ${ }^{21}$. A novidade de Nilsson é confirmar as duas rotas de entrada, mas não para um único Dioniso trácio. Sua hipótese defende a existência de duas divindades diferentes, consequentemente, cultos diferentes e rotas diferentes até a Grécia. Desde Erwin Rohde, os filólogos alemães clássicos, como Wilamowitz e Otto Kern, definiram a Trácia como origem única dos ritos orgiásticos dionisíacos; Nilsson, douto, de erudição ímpar, concebe duas religiões distintas: uma religião trácia de um Dioniso extático e outra de origem frígia de um Dioniso vegetativo [Vegetationsgott].

No estudo da religião proveniente da Trácia, aquela ligada a um Dioniso extático, Nilsson segue os mesmos caminhos já trilhados pelos filólogos

\footnotetext{
${ }^{21}$ Cf. SÁNCHEZ, Diego Mariño. Injertando a Dioniso: Las interpretaciones del dios, de nuestros días a la Antigüedad. p. 221.
} 
oitocentistas alemães; entretanto, sua novidade consiste em atribuir um maior rigor aos aspectos histórico-sociais como justificativa do processo de migração do culto à Grécia. O fator para irrupção dionisíaca no mundo pós-homérico teria sido uma crise social no início do período Arcaico, marcado pelo empobrecimento entre os camponeses devido ao aumento demográfico, o que acarretou uma polarização das classes sociais e a colonização que espalhou o povo grego pela costa do Mediterrâneo. Assim como Rohde, a interpretação de Nilsson defende que a entrada da religião dionisíaca foi epidêmica: o êxtase é contagioso e, como uma enfermidade, contagia os gregos, primeiramente as mulheres, mais receptivas e mais susceptíveis a uma religião por essência emocional; as orgias dionisíacas eram uma questão, primeiramente, feminina, mas por sequência, contagiavam o "povo inferior", transtornados pela crise social ${ }^{22}$.

Quando os rituais orgiásticos passam a fazer parte da realidade grega deixam de possuir um significado utilitário como aqueles dos rituais de fertilidade, ainda que em épocas anteriores existissem cultos de fertilidade de caráter extático, que serviram de ponto de apoio para a religião recém-ingressada na Grécia. O significado do êxtase estava ligado bem mais aos efeitos psíquicos que provocava e ao misticismo como movimento sacramental. Todo o culto

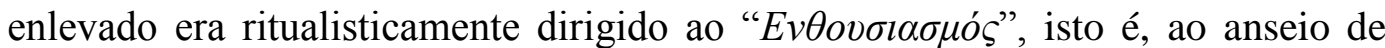
"inspiração divina"23; todos os elementos do rito: o fundo coletivo, a celebrações nos cumes $[\text { o } \rho \varepsilon l \beta \alpha \sigma i \alpha]^{24}$, a máscara ritual, as peles de animais, as bebidas narcóticas, a dança frenética, o $\sigma \pi \alpha \rho \alpha \gamma \mu o ́ \varsigma^{25}$ geralmente seguido da omofagia e a

22 “...seine emotionelle Religion gehörte dem niederen Volkstum an...”[ sua religião emocional pertencia ao povo inferior] NILSSON, Martim Persson. Geschichte der Griechischen Religion. Apud. SÁNCHEZ, Diego Mariño. Op. Cit. p. 223.

23 "Não é qualquer um que pode operar milagres e ser um vidente, mas a maior parte dos homens é propensa ao êxtase, especialmente como parte de uma grande multidão que arrasta consigo o indivíduo e provoca nele a sensação de estar infuso de um poder superior, divino. Este é o significado literal da palavra grega "entusiasmo", o estado no qual o "deus está dentro no homem". NILSSON, Martim Persson. Historia de la religión griega. p. 256.

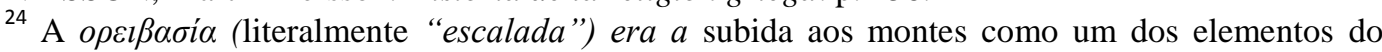
ritual dionisíaco. Distanciando-se da reclusão doméstica e da civilização urbana, na liberdade dos altos bosques aconteciam as cerimonias agrárias. Alí havia espaço para as danças entusiásticas das

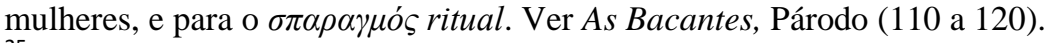

${ }^{25} \Sigma \pi \alpha \rho \alpha \gamma \mu o ́ \varsigma$ [sparagmós] proveniente de $\sigma \pi \alpha \rho \alpha ́ \sigma \sigma \omega,-\alpha ́ \tau \tau \omega$ literalmente: rasgo, (provavelmente analogia para - $\alpha \zeta(\omega)$. Também $\sigma \pi \alpha ́ \rho \alpha \gamma \mu \alpha^{\prime}$ (pedaços). Nome de um rito particularmente violento ligado aos mistérios de Dioniso, onde se despedaçava a vítima (animal selvagem ou ser humano) com as mãos, seguido, geralmente, pela omofagia (manducação da carne crua, ainda ensanguentada). O $\sigma \pi \alpha \rho \alpha \gamma \mu o ́ \varsigma$ é descrito em As Bacantes de Eurípides quando Penteu é despedaçado em sacrifício. Ver V Episódio (1060 a 1130). 
auto-violência, significam o rompimento das barreiras da vida cotidiana e a ascensão do ser humano à esfera do divino, sempre por intermédio da $\mu \alpha v i ́ \alpha$.

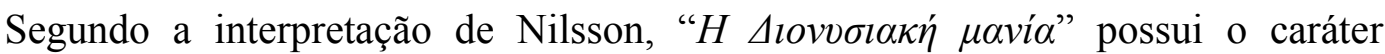
ambíguo, era tanto identificada com o psicopatológico como associada aos "mistérios" intrínsecos ao culto.

A $\mu \alpha v i ́ \alpha$ e o fluxo de sentimento religioso almeja superar o obstáculo que separa o homem do deus; há um esforço para penetrar o plano divino que só se satisfaz, em última instância, com a anulação de consciência através do entusiasmo, que é o objetivo de todo misticismo. Não obstante, apesar de se tratar de uma "epidemia psicopática", a $\mu \alpha v i ́ \alpha$, na forma do êxtase, também detém um cunho antropológico: o sentimento religioso dispõe de raízes profundas, faz parte dos instintos humanos; segundo Nilsson "é a expressão desse anseio adormecido, que existe em qualquer homem, por mais humilde que seja sua condição, de entrar em comunhão com o divino, de sentir-se elevado desde o temporal até o espiritual ${ }^{26}$. Apesar disso, o helenista faz uma distinção, como seus antecessores, inclusive Nietzsche e Rohde, entre o culto orgiástico puro, presente originalmente na Trácia, do culto "domesticado" grego. A domesticação, por assim dizer, ocorre em Delfos, lugar historiográfico de conciliação entre a religião de Apolo e a religião de Dioniso; havendo uma moderação em suas práticas extáticas ${ }^{27}$.

Diferente de Rohde, o Dioniso de Nilsson não seria responsável pela Unsterblichkeitsglaube; apesar dos ritos dionisíacos versarem para o ciclo da vida e da natureza, não há indícios históricos suficientes para atribuir à religião extática o movimento de morte e ressurreição. A crença na imortalidade teria suas origens mais prováveis centradas no renascimento do culto aos heróis e, principalmente, nos mistérios Elêusis e no orfismo, cultos estreitamente ligados ao dionisismo místico, mas isso não comprova que a religião vinda da Trácia teria introduzido tal crença na Grécia antiga; a teologia órfica, seus ritos e crenças submetem ao dionisismo uma completa reinterpretação religiosa, tornado sua teogonia, cosmogonia e antropogonia distintas e independentes, com epifanias próprias. As ideias de nascimento e morte, germinação e degeneração, como resultado das

\footnotetext{
${ }^{26}$ NILSSON, Martim Persson. Op. Cit. p. 256.

27 "Foi Apolo quem venceu a epidemia, não se opondo, nem suprimindo, senão reconhecendo-a e ordenando-a: um êxtase ordenado perde seu elemento perigoso. Isso foi o que conseguiu fazer o caráter institucional de Apolo..." NILSSON, Martim Persson. Ibidem. p. 259.
} 
transformações na natureza formam a base do culto a Dioniso, porém a crença na imortalidade era associada à esperança em uma vida melhor depois desta, uma recompensa para a alma imortal e não fazia parte do culto extático.

Como dissemos anteriormente, Nilsson defendia a existência de duas religiões dionisíacas distintas: aquela caracterizada pelo êxtase desenfreado em seus ritos, proveniente da Trácia, teria atravessado as fronteiras gregas por terra, demarcando culturalmente os montes Citerão entre Tebas e Corinto, Lafystio em Orcômeno e Pernasso em Delfos; e outra religião vinda da Frígia cuja marca fundamental era o culto à vegetação [Vegetationskult]. Esse Dioniso "vegetativo" concentra os elementos de uma religião arcaica, pré-helênica, baseada nas cerimônias de fertilidade; chegaria a todo Mediterrâneo oriental e "invadiria" a Grécia pelo mar. Tratava-se de um culto proveniente da Frígia e da Lídia, sendo o responsável por revivificar a essência dos mitos primitivos no mundo póshomérico. A imagem mítica desse lydisch-phrygischen Dionysos ${ }^{28}$ é a do deus infante: abandonado por sua mãe Sêmele, símbolo grego da oriental Mãe-Terra, perseguido pelos titãs é obrigado a se esconder e passa a ser criado pelas ninfas, seres vinculadas intimamente ao ciclo da natureza e à fertilidade vegetal.

Nesses cultos dionisíacos havia sempre a identificação com o movimento nascimento-morte-ressurreição e com elementos primaveris. Diferentemente do ritual extático, o objetivo desses cultos era utilitário: estimular a fecundidade vegetativa. Embora o ritual extático - assim como todos os ritos primitivos tivesse em sua origem a finalidade prática de suscitar a fertilidade da natureza, situava-se às margens desse Dioniso vegetativo. Essa divindade está sempre associada às árvores, principalmente às frutíferas. Desse modo, os rudimentos de seu culto: o tíaso, a máscara, as ramas, são sempre interpretadas com uma perspectiva da vegetação; da mesma forma os ídolos dionisíacos sempre remetem ao Baumkult. Até mesmo sua vinculação com o falo e sua caracterização como o deus do vinho assumem o caráter de uma divindade que provê a uberdade. Há, portanto, uma descaracterização de Dioniso como o deus das orgias, tal como o

\footnotetext{
${ }^{28}$ NILSSON, Martim Persson. Geschichte der Griechischen Religion. Apud. SÁNCHEZ, Diego Mariño. Op. Cit. p. 225.
} 
havia pintado Rohde. Como exemplos dos Vegetationskult, Nilsson cita uma série de ritos Áticos: as Antestérias, as Leneanas, as Dionisas rurais e a Liknites ${ }^{29}$.

Os pontos de vista até aqui apresentados dão como certo que Dioniso entrou na Grécia como um estrangeiro vindo do Oriente e que seu reconhecimento se impôs após vencer uma resistência extrema. Como apresentamos anteriormente, pensava-se que havia entrado diretamente na Grécia oriundo da Trácia, depois, se formulou a hipótese que teria chegado da Frígia e da Lídia; por fim, Nilsson ligou ambas as hipóteses. No entanto, concentraremos nossa atenção, a partir de agora, em uma terceira linha de pensamento: a religião dionisíaca tem suas origens nas entranhas da própria pátria grega. $\mathrm{O}$ movimento que proporcionou a chegada de Dioniso corresponde, unicamente, "ao novo despertar de um culto antigo"30. Os helenistas que estruturaram e defenderam o estrangeirismo do dionisismo, tais como Wilamowitz ${ }^{31}$, Rohde, Nilsson, entre outros notáveis, se pautaram, principalmente, na quase total ausência de referências ao deus e seus ritos nos textos homéricos; Walter F. Otto contestará essa visão e terá como argumento mais importante, justamente, a épica homérica.

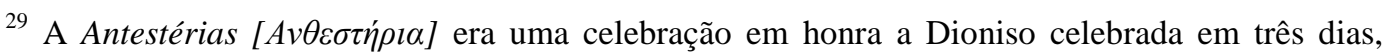
marcava o fim do inverno o início da primavera; é provável que o termo derive da palavra grega [áv$\theta o \varsigma]$ que significa, de modo geral, flor, estabelecendo então uma relação com o aparecimento

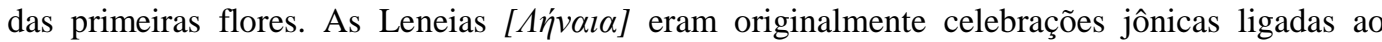
campo e à colheita; quando chegam a Atenas passam a ser celebradas em janeiro com festivais de

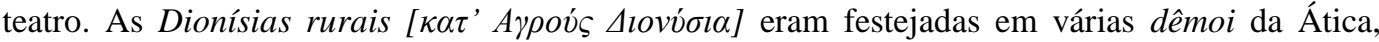
nelas se celebrava o $\kappa \tilde{\omega} \mu о \varsigma$, as procissões dos falos; quem participava do kómos era chamado de $\kappa \omega \mu \alpha \sigma \tau \alpha i$; dessas procissões surgiram as comédias [ $\kappa \omega \mu \omega \delta i \alpha]$, como indica a etimologia komo +

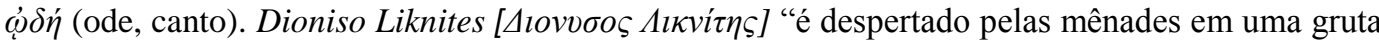
no monte Parnaso, que dominava no alto de Delfos. Esse despertar tinha a forma de uma cerimônia mística, somente o epiteto Liknites indicava que liknon era seu receptáculo". KERÉNYI, Carl. Dioniso. p. 40-41. O significado do ritual está intimamente ligado à agricultura e à fertilidade: o termo Liknites deriva de híkvov, (literalmente berço), nome também dado à joeira, uma espécie de peneira que separa o joio do trigo, torna-se símbolo do berço do deus infante, mistificado pela religião de Dioniso, liga-o aos ciclos agrícolas.

${ }^{30}$ OTTO, Walter F. Dioniso Mito y culto. p. 45.

${ }^{31}$ Ulrich von Wilamowitz-Moellendorff, o mesmo filólogo que ataca $O$ Nascimento da tragédia, torna-se um helenista bastante influente; ele defende em sua obra Der Glaube der Hellenen que os gregos não poderiam ter incorporado a religião dionisíaca antes do século VIII a.C. e que o triunfo sobre a resistência não poderia ocorrer antes de 700 a.C.; os gregos asiáticos haviam o conhecido com anterioridade, como é natural, mas a sociedade da qual e para a qual fala Homero queria saber tão pouco dele, até que se viu obrigada a ceder. Cf. OTTO, Walter F. Ibidem.
} 


\section{2. \\ O deus das entranhas da Grécia:}

Nossa preocupação, nesta etapa do trabalho, é investigar as teorias que negam o estrangeirismo de Dioniso e, consequentemente, defendem a origem grega da religião dionisíaca. Para tal, utilizaremos como fio condutor os argumentos do controverso filólogo alemão Walter F. Otto, autor da fabulosa obra Dionysos, Mythos und Kultus (1933). No entanto, antes de explorarmos a pátria de Dioniso, é necessário elucidar brevemente a concepção interpretativa da mitologia grega por ele elaborada: Para Otto, a religião é o meio pelo qual ocorre a revelação do ser sacrossanto; ou seja, todos os fenômenos religiosos são compreendidos como a forma, através da qual, o Divino se revela aos seres humanos. Por sua vez, essa revelação está intimamente ligada à vivência humana: “Os deuses não podem ser inventados, nem concebidos, nem representados, mas tão somente vivenciados" ${ }^{\sharp 2}$. A radicalidade desse pensamento realoca a natureza humana para o plano do divino: uma vez que o Divino só pode se comunicar com o Divino, logo já habita no homem, se ele é capaz de percebê-lo.

O Divino totaliza em si mesmo o Ser do Mundo, e a religião o meio para o homem se fazer partícipe dele. Segundo essa ideia, a religião encontra suas origens quando, em um tempo passado, ocorre uma revelação súbita. A diversidade cultural para a qual cada ramo da humanidade o divino revelou-se a seu modo; dando forma à sua existência como produto de uma multiplicidade de revelações primitivas. Entretanto, os gregos em relação às demais culturas estão dotados de um privilégio, já que se destacam como o "mais rico e produtivo espiritualmente de todos os povos". O que está em evidência na metodologia de Otto é o fundo metafísico no qual é assentada a religião, ela é entendida como a revelação do "ser". Dessa forma, sua interpretação da mitologia grega é completamente desvinculada do crivo sociológico, psicológico e historiográfico ${ }^{33}$.

\footnotetext{
${ }^{32}$ OTTO, Walter F. Teofania. O Espirito da religião dos gregos antigos. p. 19 - 20.

33 "Em um mundo pleno do divino, o homem grego não olha para seu íntimo em busca da origem de seus impulsos e de suas responsabilidades; volta os olhos para a amplitude do Ser, e onde falamos de disposição interior, encontra a realidade viva dos deuses. Os psicólogos, cujos conceitos estão completamente enclausurados na estreiteza da vida humana, tiram daí a conclusão bisonha de que, naquela altura, o homem ainda não tinha descoberto a profundeza de sua vida espiritual interior. A Verdade, porém, é que a experiência viva do objetivo, ou seja, dos deuses,
} 
Essa leitura "ontológica" da tradição proporciona a Otto a compreensão do Espírito [Geist] grego, isto é, do modo como o povo grego recebeu a revelação do Divino, ou melhor, de como houve a conexão entre o material e o espiritual, fazendo surgir uma cosmovisão.

Os mitos e os cultos são, portanto, a forma como essa cosmovisão [Weltanschauung] se manifesta por meio de gestos e palavras. A cosmovisão homérica, baseada no mundo das divindades olímpicas é, para Otto, modelo de manifestação mais clara do espírito grego, a primeira grande revelação da natureza divina. Os deuses descritos por Homero não são personificações de virtudes individuais, eles nos abrem os olhos para o essencial e para o verdadeiro; os deuses são revelações do Ser das coisas: expressam a beleza, a Verdade e a realidade em toda sua plenitude. Apesar de a cosmovisão homérica evidenciar o espírito grego baseado em uma série de ideais cujos símbolos são as divindades olímpicas, seu principal marco é uma ruptura com o mundo primitivo. Existe um abismo que separa a cosmovisão primitiva da greco-homérica. O "espírito primitivo" é dominado pelo poder da natureza que, por sua vez, é concebida como um complexo de forças misteriosas. A religião primitiva basear-se-ia na crença de controle dessas forças. Assim sendo, o centro desta religiosidade é a magia. Dioniso pertence essencialmente a esse mundo primitivo.

Enquanto a "cosmovisão primitiva" cria uma rede simbólica que traz a seus mitos, divindades e cultos uma associação com a noite, a terra, o feminino, o sangue, a cosmovisão homérica associa-se, pelo contrário, com a luz, o sol e a masculinidade. Esta dicotomia nos permite classificar os fenômenos religiosos distintamente: ao primitivo pertence o culto dos mortos, os ritos de purificação, as divindades femininas e próximas dos seres humanos; já os mitos, rituais e deuses olímpicos, por outro lado, estão situados distante da terra, do homem comum e da morte. Dioniso, por pertencer ao mundo primitivo, concentra todo o antiolímpico: a loucura, anseio ao infinito, o feminino, etc. Mesmo assim, Otto pondera que Dioniso é bem conhecido na epopeia homérica, entretanto, para a casta de heróis, inspirados por Atenas, ele tinha pouca importância; por isso não desempenha

portadores da totalidade do Ser, o protegia da perigosa e infortunada autocontemplação que em nossa época converteu-se em ciências". OTTO, Walter F. Ibidem. "Os deuses se manifestam no que move intimamente o homem". p. 69-70. 
papel significativo na Ilíada nem na Odisseia; mas isso não significa que ele tenha se tornado familiar na Grécia apenas séculos posteriores ${ }^{34}$; a prova de seu passado grego são os elementos de seu culto descritos claramente por Homero.

Para Otto, a épica homérica é o testemunho mais importante da Antiguidade do Dioniso grego. Contrariando a interpretação corrente, acredita que Homero já está familiarizado com os cultos dionisíacos. Como já vimos, no núcleo das epifanias dionisíacas se encontra a figura de um deus frenético, perseguido desde recém-nascido, criado por mulheres que se consideram suas amas-de-leite $[\tau \imath \theta \dot{\eta} v \alpha s]^{35}$. Era comum em certas celebrações dionisíacas organizarem perseguições que geralmente acabavam com um final sangrento. Para Otto, todos estes elementos da religião dionisíaca estão contidos, em detalhes, na Ilíada de Homero. O ponto de partida para confirmar sua teoria é a análise de uma

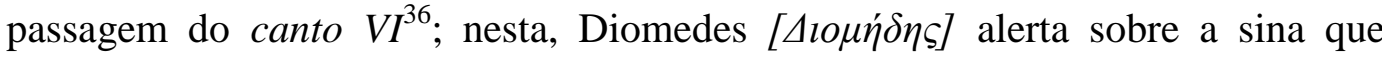
aguarda todos que lutam contra os deuses, ao fazê-lo se refere ao forte Licurgo

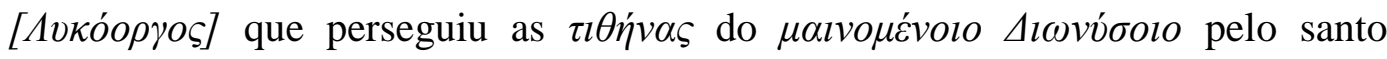

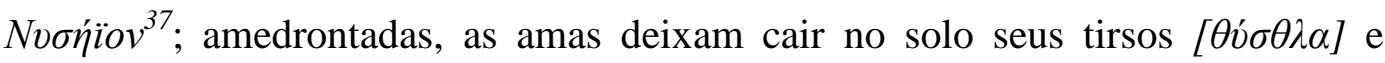
Dioniso pávido [ $\varphi \circ \beta \eta \theta \varepsilon i ́ s]$ foge para o mar, onde é acolhido pelos braços de Tétis

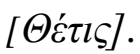

As acompanhantes de Dioniso não são descritas nesses versos explicitamente como dominadas pelo delírio. Mas Otto identifica um verso que revelaria a familiaridade do círculo homérico com a figura da Ménade: trata-se do

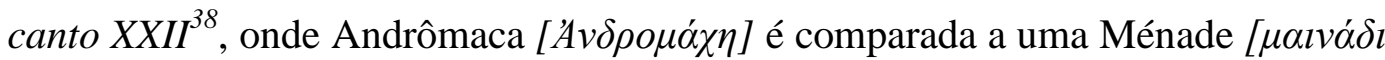
I $\sigma \eta]$ ao ir, fora de si, em direção aos muros de Troia. Na interpretação de Otto, o termo que retrata Andrômaca foi utilizado porque era bem conhecido de todos; diferente do que pensavam outros intérpretes, seria um erro entender a expressão apenas como referência a uma mulher louca, pelo contrário, só pode aludir às bacantes. Outro exemplo, encontra-se também no canto $V I^{39}$ quando Andrômaca é, outra vez, comparada às Ménades, agora com o verbo $\mu \alpha \imath v o \mu \varepsilon ́ v \eta$. A forma

\footnotetext{
${ }^{34}$ Cf. OTTO, Walter F. Ibidem. "Dioniso o deus do retorno ao mundo primigênio". p. 160.

${ }^{35} \mathrm{~T}$ t $\theta$ v́vac: são as ninfas que amamentaram e cuidaram do infante Dioniso.

${ }^{36}$ Verso 130. Cf. OTTO, Walter F. Dioniso mito y culto. p. 46.

${ }^{37}$ Nvøíiov: o monte sagrado de Nisa, de geografía puramente mítica.

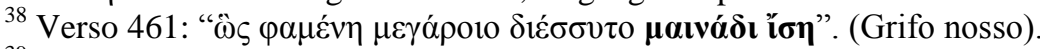

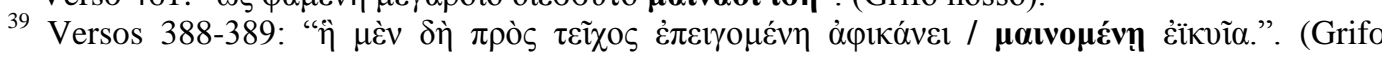
nosso).
} 
como Homero "fala" aqui, se reflete diretamente no Hino homérico a Deméter ${ }^{40}$ onde o "frenesi" de Demeter é descrito em dois momentos: primeiro com o particípio $\mu \alpha \iota v o \mu \varepsilon ́ v \eta$, quando ouve o choro de Perséfone, segundo com o substantivo $\mu \alpha \iota v \grave{\alpha} \varsigma$, quando corre para encontrar a filha ressurgida do Submundo.

Com a argumentação acima, Otto pretende demonstrar que a imagem do "frenético" Dioniso, e de suas "frenéticas" acompanhantes, constituem figuras altamente familiares para Homero. Mas e o deus do vinho? Helenistas predecessores ponderaram que o aedo, que tantas vezes menciona o vinho, jamais situa Dioniso como o senhor da bebida inebriante e, portanto, ela não pertence à natureza originária da divindade. Contudo, Otto recorre novamente à epopeia para delatar o conhecimento entre os helenos de Dioniso como o senhor da videira: uma das referências que conecta Dioniso ao vinho é o relato sobre a ânfora de ouro que, segundo a Odisseia ${ }^{41}$, Dioniso presenteia Tétis. Entretanto, há uma passagem na Ilíada que denota, com maior clareza, o distribuidor do vinho:

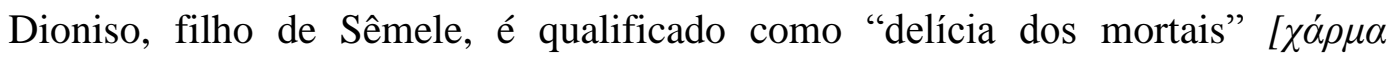

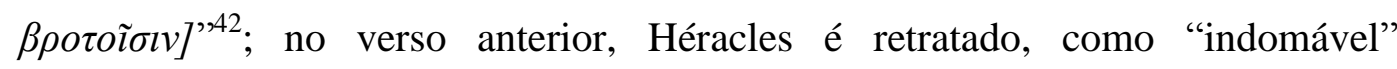

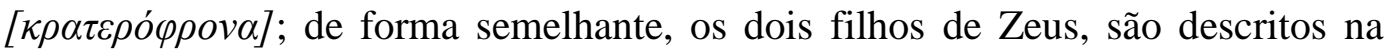
Teogonia ${ }^{43}$ por Hesíodo, onde Dioniso é chamado de "o pleno de graça" $[\pi \circ \lambda v \gamma \eta \theta \dot{\varepsilon} \alpha]$.

Estas exposições feitas pelos dois rapsodos mais famosos testemunham uma afinidade entre o povo grego e Dioniso; ele é pintado como aquele que traz a alegria para os homens; aliás, pode ser considerado o deus mais próximo dos seres humanos, pois nasceu mortal, de uma genitora mortal, para depois se tornar um deus poderoso, capaz de ascender sua mãe dos mortos à imortalidade. A épica homérica prova ter conhecimento cabal dessas personificações, inclusive confirma sua vinculação com outras deidades da tradição mitológica, como, por exemplo,

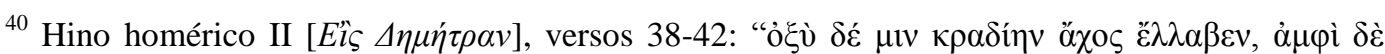

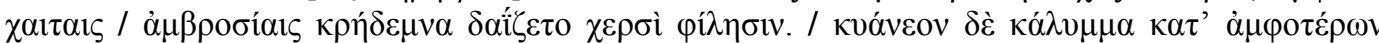

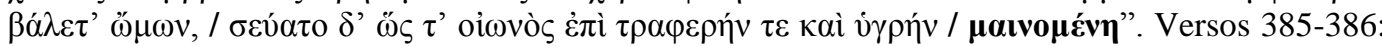

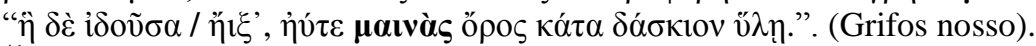

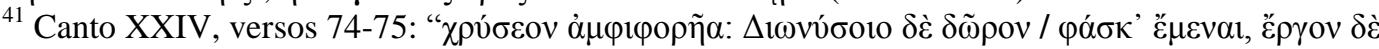

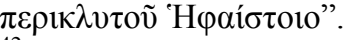

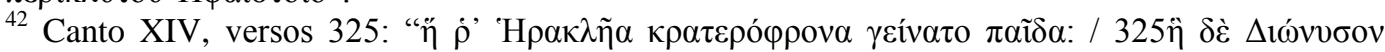

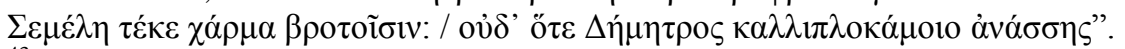

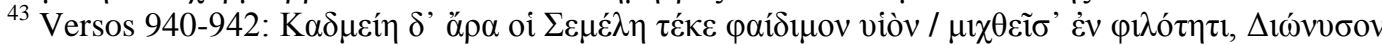

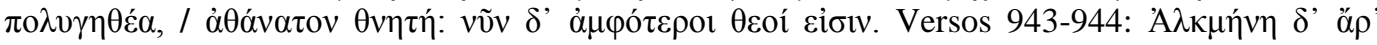

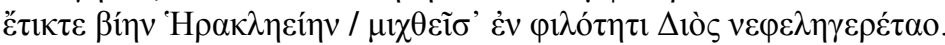


no caso de afeição que estabelece com Tétis, quando ela o acolhe em seus braços depois de fugir do furioso Licurgo ${ }^{44}$. Tamanha é a estima por Tétis que Dioniso a

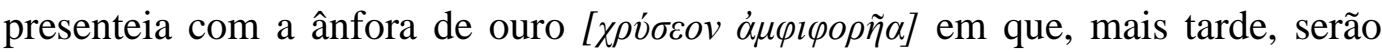
depositados os restos de Aquiles $^{45}$; essa amizade mostra que o mar não era um ambiente estrangeiro para o deus. Segundo Otto, as narrativas homéricas coloca Dioniso em convívio com outras divindades olímpicas: a ânfora dourada, produzida por Hefesto, indicaria uma amizade entre ambos ${ }^{46}$.

Também o estreito relacionamento com Ariadne - que será mais bem explorado na seção "Urro feminino" - alude ao contato dos gregos com outro importante elemento do culto dionisíaco: Na "Nekyia [vékvı $]^{47}$ de Odisseu", Ariadne é apresentada como a rainha do séquito dionisíaco. A bela filha do Rei Minos foi raptada e conduzida a Atenas por Teseu, mas antes de sua chegada é morta por Ártemis, enraivecida pelos fuxicos de Dioniso ${ }^{48}$. Essa referência, além

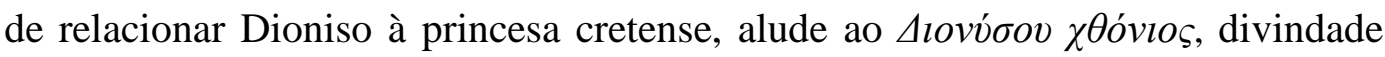
dos rituais chtônicos que, por sua vez, eram fundados nas lendas de katábasis do deus que desce ao submundo para resgatar sua amada. Nos cerimoniais chtonianos, Dioniso era cultuado como divindade capaz de conduzir as almas dos mortos entre o mundo inferior e superior. Todas essas sucintas referências, para Otto ${ }^{49}$, demonstram que Homero não só conhecia Dioniso, como praticamente todos os elementos e características de seu mito. Além disso, não há nenhum indício de

\footnotetext{
${ }^{44}$ Homero. Ilíada, Canto VI, Versos 130-135.

${ }^{45}$ Homero. Odisseia, Canto XXIV, Verso 73.

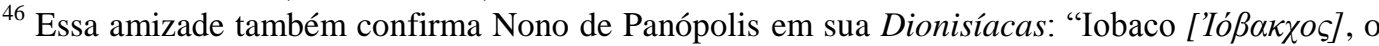

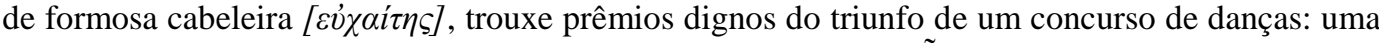

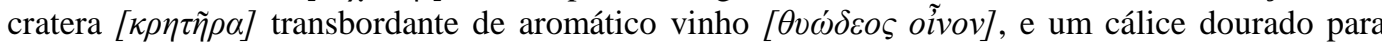

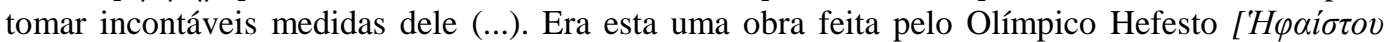

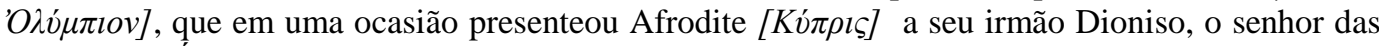
uvas". PANÓPOLIS, Nono de. Dionisíacas. Cantos XIX: Vol. 2. Trad. David Hernandes de La Fuente. Gredos: Madrid 2001.

${ }^{47} H$ vékvı $\alpha$, significa, na literatura mítica grega, o rito no qual os mortos eram invocados para serem indagados sobre o pós-vida, o presente, o passado ou sobre acontecimentos futuros. O termo provavelmente tem origem na raiz protoindo-europeia "*nek", que também da origem à

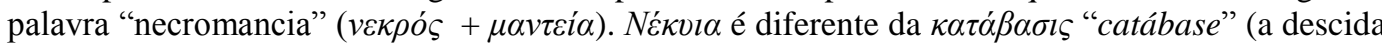
de alguém vivo ao reino dos mortos) e da ává $\beta \alpha \sigma l \varsigma$ "anábase" (o retorno de um vivo do submundo). Odisseu, instruído por Circe, pratica a nekyia aspergindo em um foço a mistura de mel, vinho, água e farinha, além de sangue de animais sacrificiais. Depois de proferir rezas a Hades e Perséfone, consegue contato com as almas de Alpenor, seu nauta morto, de sua mãe, do sábio Tirésias, e visa a várias outras personagens míticas, inclusive Ariadne. Cf. HOMERO. Odisseia Canto XI, versos 20-325.

${ }^{48}$ Canto XI, versos 320-585

${ }^{49}$ Cf. OTTO, Walter F. Dioniso mito y culto. p. 48-50.
} 
que seu culto tenha sido percebido como estrangeiro e uma novidade para os gregos.

Apoiando-se na épica homérica, Otto encontra os argumentos para refutar a corrente do estrangeirismo do culto dionisíaco, embora admita a existência contundente de rituais orgiásticos trácios, mas, seguro de sua teoria, defende que a religião de Dioniso poderia ter feito o caminho de migração inverso, ou seja, da Grécia à Trácia; os trácios seriam susceptíveis a incorporar o dionisismo grego, da mesma forma que se tornaram amantes do vinho ao descobrirem a vinha ${ }^{50}$. As ideias de Otto sobre a origem de Dioniso datam de 1933, elas estabelecem uma ruptura com o que era comumente aceito até então. No entanto, o que se inicia apenas como conjecturas interpretativas e a fortíssima intuição de um erudito polêmico, porém formidável, a partir da década de 1950, passa a ser considerada a leitura mais evidente das origens do dionisismo: a tese de um rito que chega mais tarde à Grécia, vindo do exterior, efetivando desde o Oriente uma irrupção em solo grego, não é mais aceita. Isso devido à descoberta arqueológica de tabletes micênicos e minoicos, do segundo milênio, que sugerem o nome de Dioniso.

\section{3. O deus minoico e micênico 'di-wo-nu-so':}

Em 1886, o arqueólogo inglês Sir Arthur Evans identificou um tablete de argila contendo uma escrita arcaica. Sabendo que a plaqueta era originária de Creta, Evans dirige-se à ilha em uma expedição arqueológica. Para seu espanto, descobre que era comum o uso das pequenas plaquetas de argila como uma espécie de amuleto pelas mulheres da ilha. Em 1899, depois de muitas tentativas, Evans consegue comprar o terreno cujas ruínas supostamente originavam tais objetos. Mais de três mil tabletes foram encontrados nas escavações destas ruinas, chamadas de Palácio de Knossos. Acredita-se que os tabletes foram cozidos por incêndios no palácio, mas a sua data de destruição ainda é tema de debate entre os especialistas que divergem entre 1400 e 1200 a.C.; Em 1894, devido à característica da escrita, Evans cunha o nome de Linear e em 1903 estabelece uma

\footnotetext{
${ }^{50}$ Idem. p. 51 .
} 
distinção entre dois tipos de alfabetos, nominando-os de Linear $A$ e Linear B, sendo a segunda derivada da primeira. Além de Knossos, posteriormente foram encontrados mais tabletes em Pilos, Tebas, Micenas, Chania e Tirinto ${ }^{51}$.

Os objetos descobertos por Evans durante muito tempo permaneceram mudos; acreditava-se que mesmo se fosse possível decifrar os caracteres dessa escrita, a língua nelas registrada continuaria incompreensível. O mistério persistiu até 1953, quando pelos microfones da BBC de Londres, o arquiteto Michael Ventris anunciou que havia decifrado o enigma: os tabletes estavam escritos em uma matriz grega; conclusão que chegou após minuciosa análise dos signos e sua correspondência com logogramas. Vertis, com a ajuda do filólogo e professor de grego Jhon Chadwick, publicou para comunidade científica o fantástico Documents in mycenaean Greek (1956). Na obra, além de toda informação cientifico-metodológica, Vertis e Chadwick trazem detalhes impressionantes sobre a escrita micênico-minoica e uma análise rigorosa dos tabletes encontrados em Knossos e também em outros centros de escavações, principalmente os de Pilos $^{52}$, onde foram encontradas cerca de 1200 plaquetas, no chamado Palácio de Nestor. Vertis comprova então, que a Linear B era uma escrita arcaica da língua grega.

As descobertas arqueológicas dos tabletes e a decifração da escrita Linear B tornaram as teorias sobre o estrangeirismo de Dioniso desatualizadas, isso, porque foi encontrado em algumas placas micênicas de Pilos o nome do deus: trata-se dos tabletes catalogados como Py Xa 102 e Py Xb $1419^{53}$. No primeiro, um tablete

\footnotetext{
${ }^{51}$ Cf. BERNABÉ, Alberto e LUJÁN, Eugénio. Introducción al griego micénico: gramática, selección de texto y glosario. p. 3-19.

52 Os tabletes de Pilos procedem do chamado "Palácio de Nestor", ruínas de um complexo residencial do período micênico, descobertas em 1939 por uma equipe de arqueólogos liderada por Carl William Blegen. O nome do local foi dado em homenagem ao Rei Nestor de Pilos, um dos importantes personagens da guerra de Tróia, descrita na Ilíada; segundo a obra de Homero, no palácio de Nestor que foi decidida a aliança dos aqueus. Nas escavações de Pilos, foram encontrados 1200 tabletes em argila com inscrições em Linear B; elas foram parcialmente decifradas em pelo filólogo Emmett Leslie Bennett que publica, em 1951, a obra The Pylos Tablets contendo o catálogo com 80 símbolos distinguindo ideogramas, silabogramas de signos numéricos. Em 1954, Bennett envia a segunda edição de sua obra a Vertis e Chadwick, possibilitando-os a revisão de seu trabalho. Cf. VENTRIS, Michael e CHADWICK, John. Documents in Mycenaean Greek. Cambridge at the university press, 1973. "Preface to Second edition" p. XIV-XVI.

53 Os tabletes são catalogados designando inequivocamente a seguintes indicações: primeiras letras, onde foram encontradas Kn (Knossos), My (Mecenas), Py (Pilos), Th (Tebas), Ti (Tirinto), etc. A letra maiúscula subsequente classifica o grupo, podendo ser de "armas", "pessoas", "oferendas", um nódulo, inscrição em vaso ou um ideograma. A letra minúscula refere ao
} 
danificado, está inscrito unicamente o nome do deus na forma genitiva di-wo-nuso-jo; é impossível ler o que seguiria, mas acredita-se que poderia ser uma indicação de quantidade, uma medida ${ }^{54}$. Os primeiros intérpretes duvidavam que o nome inscrito fizesse referência a uma divindade ${ }^{55}$; na verdade se olhássemos isoladamente para essa plaqueta, não teríamos documentos históricos suficientes para atestar o culto dionisíaco na civilização micênica; principalmente porque, com exceção de escritas pintadas em vasos cerâmicos, quase todos os textos micênico-minoicos estudados eram inventários administrativos, de bens recebidos, enviados ou armazenados nos palácios. Por outro lado, seria duvidoso que um homem tivesse o mesmo nome de um deus, sem que o deus fosse conhecido.

No entanto, com a decifração do segundo tablete, acima mencionado, encontraram-se mais evidências para diminuir a dúvida dos intérpretes: no $\mathrm{Py} \mathrm{Xb}$ 1419 podemos ler "di-wo-ni-so-jo [.../ tu-ni-jo] [... // no-pe-ne-o [... wo-no-wa-tisi $\left[\ldots{ }^{, 56}\right.$ Encontramos portanto, novamente na forma genitiva, o nome Dioniso como pagamento a um homem [tu-ni-jo], os danos na plaqueta impedem a compreensão da sequência, provavelmente indicaria a quantidade. Porém, o mais elucidativo é o conteúdo da escrita no verso da plaqueta: "no-pe-ne-o" termo que até hoje gera muita divergência e nenhum consenso; e "wo-no-wa-ti-si", isto é, oinoatisi, palavra que pela sua forma vocal dificilmente poderia significar outra coisa que não "vinho" [oĩvoc]. Kerényi identifica nesse silabograma "mulheres de Onoia", onde mulher denominaria, com toda probabilidade, "consagradas a Dioniso", como aquelas, que mais tarde, constituíram na Grécia um dos elementos fundamentais do cultos dionisíaco: suas sacerdotisas ${ }^{57}$. Em suma, a placa indica a existência, desde a era micênica, de Dioniso como o "senhor do vinho".

Outro documento encontrado em Pilos que ressalta a presença do culto a Dioniso no segundo milênio é o Py $\mathrm{Cn} 3$, onde podemos ler, nas duas primeiras

subgrupo que diz respeito ao formato da peça (formato de folha de palmeira ou de página). E o número é o catálogo de cada museu, podendo ser seguido por outro número que é a linha onde se encontra determinada palavra. Cf. BERNABÉ, Alberto e LUJÁN, Eugénio. Op. Cit. 7-10.

${ }^{54}$ Cf. KERÉNYI, Carl. Dioniso: imagem arquetípica da vida indestrutível. p. 61.

55 "DIONYSUS is a surprising name to find, and there is no evidence to prove that it is divine. It occurs only once in the genitive case on a Pylos fragmente Xa 06: di-wo-nu-so-jo" VENTRIS, Michael e CHADWICK, John. Op. Cit. p. 127. (Xa 06 é a antiga catalogação).

${ }^{56}$ KERÉNYI, Carl. Op. Cit. p. 61.

57 "Em Atenas as quarenta Geraraí, em Élis as Dezesseis Damas, e em Delfos, as Tíades". Idem. 
linhas, a inscrição "jo-i-je-si , me-za-na, e-re-u-te-re, di-wi-je-we , qo-o"58, a escrita faz menção a "Eleuthér, filho de Zeus a quem são sacrificados touros"59; Eleuthér é associado a Dioniso, especialmente porque é expressamente chamado de "filho de Zeus". Essa interpretação dos documentos micênicos demonstra que o culto a Dioniso e à sua linhagem divina já eram bem conhecidos no século XIII. Apesar de nossa explanação se encaminhar para a "certeza" da existência da religião dionisíaca na pré-história grega, devemos ressaltar que a natureza divina de “di-wo-nu-so-jo”, da plaqueta Py Xa 102, só foi atribuída devido à associação com "wo-no-wa-ti-si" em Py Xb 1419 em virtude de outro documento: Py Vn 48, onde "wo-no-wa-ti-si" aparece em um contexto religioso seguido da palavra "kara-wi-po-ro" que equivaleria ao título religioso "sacerdotisa"60. Além disso, há outros vários documentos em Linear B que manifestam sobre o tema.

Nos tabletes Py Na 427 e Py Fr 1216, podemos ler "pa-ko" e "pa-ko-we", respectivamente; em algumas interpretações seria a forma em Linear B do nome

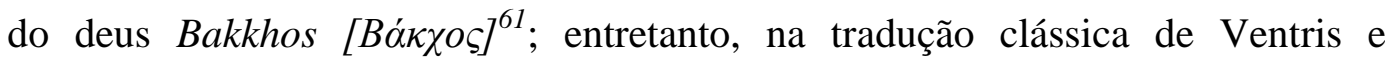
Chadwick os termos não teriam ligação com o deus do vinho, mas significariam "unguento" ou "óleo aromático"62. Já nas placas Py Ea 756, 776 e Py Gn 431, encontramos o nome próprio "sa-ke-re-u", na Py An 218 "da-i-ja-ke-re-u", no primeiro silabograma encontramos, foneticamente, um dos nomes pelo qual

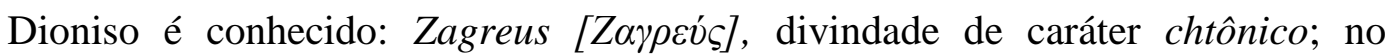
segundo, há a uma derivação que indica um sacerdote "divisor de terras",63, referência evidente a quem conduz o culto de um deus que atua nas cavidades da terra. Se de fato os artefatos provenientes de Pilos fazem alusão a Zagreus, comprovaríamos uma conexão cultural entre o continente e a civilização minoica: em Creta Dioniso era visto como filho de Zeus e Perséfone, por isso chamado de Chtônio. Ademais, existem vários documentos de Knossos que atestam essa conexão.

\footnotetext{
${ }^{58}$ É possível conferir a transliteração de todos os tabletes Linear B catalogados no site: "http://minoan.deaditerranean.com/linear-b-transliterations/".

${ }^{59}$ KERÉNYI, Carl. Op. Cit. p. 62.

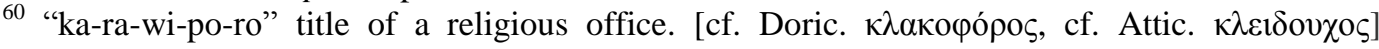
'priestess'. VENTRIS, Michael e CHADWICK, John. Op. Cit. p. 551.

${ }^{61}$ Cf. DABDAB, J. A. Trabulsi. Dionisismo, poder e sociedade na Grécia até o fim da era clássica. Belo Horizonte: Editora UFMG, 2004. p. 25.

${ }^{62}$ VENTRIS, Michael e CHADWICK, John. Op. Cit. p. 568.

63 "da-i-ja-ke-re-u: the interpretation 'divider of lands' has been enthusiastically welcomed by those who see this document as concerned with allocations ofland...”. idem. p. 424.
} 
Se Sakereu é o nome próprio do deus chtônico encontrado em Pilos; em Creta os louvores eram destinados a Zagreus, divindade ambígua, relacionada tanto à caça, como ao subterrâneo. Além dessa intrigante relação entre o continente e a ilha, existem outros documentos que mostram a presença do dionisismo na civilização minoica. O tablete Kn As 603 apresenta o nome "pe-teu", interpretado por Kerényi como "Penteu", que compreende pénthos, alguém que é "cheio de sofrimento"; o nome pressupõe o mito do deus que padece e depois triunfa sobre o sofrimento, ideia frequente nos cultos de Dioniso ${ }^{64}$. Também podemos destacar Kn V 466, onde se encontra a inscrição "si-ra-no", muito provavelmente, referência a Sileno ${ }^{65}$, o ser fálico, híbrido, metade homem e metade animal, companheiro de Dioniso. Outra menção pode ser verificada em Kn As 1516, 18, onde achamos o nome " $i-w a-k o " 66$, cuja leitura grega pode ser Íakos, também referência a uma das máscaras de Dioniso, a do deus luminoso Íaco, proclamado nos rituais secretos da Grécia tardia e celebrado abertamente em Knossos ${ }^{67}$.

É certo que quando nos defrontamos com os tabletes do segundo milênio, somos transportados para um mundo muito antigo e fantástico; a interpretação dos signos impressos nessas plaquetas milenares, feitas pelos entusiastas de Dioniso, também nos flama a crer na proveniência do culto dionisíaco das "entranhas da Grécia”. Os achados arqueológicos e sua decifração, no início da segunda metade do século XX, tornaram-se indispensáveis para provar a existência de um Dioniso micênico-minoico, que seria a mesma divindade grega da época dórica cretense: o deus do vinho, deus das mulheres, deus do touro e deus da profundidade da terra. No entanto, todas as afirmações oriundas dos tabletes de argila encontrados nos palácios, não devem ser tomadas como provas definitivas ou certezas apressadas sobre a religião micênico-minoica; as interpretações destes documentos são sempre ambíguas, principalmente pelo estado atual das fontes. Além disso, os documentos carecem de uma comprovação textual, ou seja, não existem textos para além de pequenos fragmentos, o que exige maior prudência nas conclusões.

\footnotetext{
${ }^{64}$ KERÉNYI, Carl. Op. Cit. p. 62.

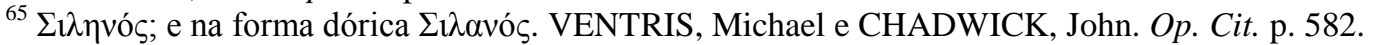

${ }^{66}$ Variações de i-wa-ko podem ser encontradas em Kn V 60, 2; Kn Uf 120; Py Jn 310; Py Ub 1317.

${ }^{67}$ Cf. KERÉNYI, Carl. Op. Cit. p 68-70.
} 
Ainda que resguardados de toda prudência, depois da descoberta dos documentos micênicos e minoicos é muito difícil não aceitar a origem grega de Dioniso; os gregos mesmos nunca a contestaram. Mas, ainda que reconheçamos definitivamente a Grécia como o berço e a pátria de Dioniso, não podemos negar sua efígie de estrangeiro. Suas epifanias são quase sempre marcadas por confronto, pelo hostil desdém, pela negação e pela perseguição. Nas suas histórias é mal recebido e considerado demasiado exótico para os princípios dos lugares onde se manifesta; até mesmo quando aparece em Tebas, onde teria nascido, e nascido duas vezes. A situação de estrangeiro marca profundamente a personalidade do deus, tanto pela relação que estabelece, como por sua tendência de se revelar mascarado; sua natureza de deus que não para de oscilar entre a presença e ausência, o torna sempre estranho, um nome a ser identificado; uma máscara que o esconde tanto quanto o revela. A máscara de Dioniso ${ }^{68}$ assegura seu caráter de ksénos [ร̌́vos] ${ }^{69}$ e deve, portanto, ser mais um elemento por nós analisado.

\section{4. \\ Um deus... Muitas máscaras:}

Dioniso é sempre a divindade que chega e sua chegada é muito mais imperiosa que de qualquer outro deus. Essa característica marcante de seu mito lhe confere a imagem de estrangeiro que surge furtivamente, para tão logo fazer notar sua presença. Aparece como estranho, um rosto a ser descoberto. Esse atributo, próprio das entidades epifânicas, decorre porque o deus desaparece incompreensivelmente do convívio de seu círculo, misteriosamente regressa às

\footnotetext{
68 "Alguns pescadores de Metimna trouxeram em suas redes, de alto-mar, uma máscara

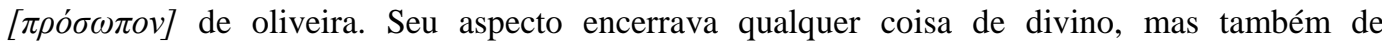
estranho/estrangeiro e que não se adaptava a nenhum dos deuses gregos. Os mitimneus perguntaram, pois, à Pítia quem, deus ou herói, aquela figura representava. Ela lhes ordenou que a

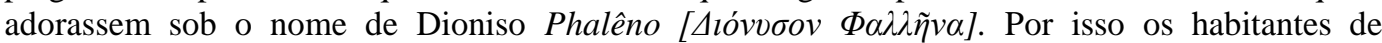
Metimna conservaram o ksóanon trazido da mar, honrando-o com sacrifícios e orações, enquanto enviavam uma cópia de bronze para Delfos". DETIENNE. Marcel. Dioniso a céu aberto. p. 22. Detienne nessa passagem cita PAUSÂNIAS, Description of the Greece, [X. 19.3.].

${ }^{69}$ A denominação Ksénos segundo Detienne possui dois sentidos: primeiro do estrangeiro que não se refere ao não-grego, ao bárbaro de fala ininteligível, mas ao cidadão de uma comunidade vizinha. O ksenós deriva da distância que separa duas cidades. O segundo sentido vem de Pausânias: "que não é próprio de nenhum dos deuses gregos". Idem. p. 21 e 25.
} 
profundidades da terra ou do mar, some com a passagem das estações e, subitamente, retorna. Tão inesperada como sua desaparição é sua chegada e, quando ressurge, é novamente o ksénos que rompe, seduz e transforma a rotina vigente. A efígie de estrangeiro persiste, porque sempre Dioniso se revela com diferentes máscaras; nunca é o mesmo! A máscara é o símbolo dionisíaco mais expressivo: ela revela seu caráter irruptivo e a sua labiríntica ambiguidade. A máscara reflete, naqueles que a miram, a loucura, provocando inevitavelmente a vertigem e o desfalecimento, uma vez que extingue todas as fronteiras da vida regulada.

A máscara não era exclusividade do culto dionisíaco: existem registros de $\pi \rho o ́ \sigma \omega \pi \alpha^{70}$ rituais provenientes de outras divindades gregas. Foram conservadas, por exemplo, um número significativo de máscaras do santuário de Ártemis Ortia em Esparta; a deusa era responsável por todos os rituais de iniciação dos jovens e a máscara era componente essencial dos celebrantes. Em Pheneos, norte da Arcádia, se guardava a máscara de Deméter Cidaria [ $\Delta \eta \dot{\eta} \mu \eta \rho \rho \varsigma K l \delta \alpha \rho i \alpha \varsigma$ ] no alto de uma esfera, ela era utilizada pelo sacerdote, no chamado Grande Rito [ $\mu \varepsilon i \zeta o v \iota$

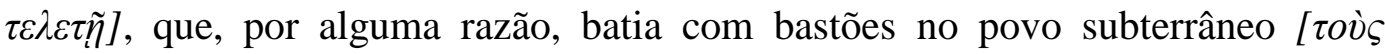

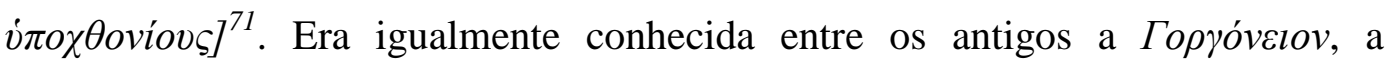
máscara de Gorgó; de aspecto aterrorizante, sempre apresentada de face, mesclava elementos humanos e bestiais; a Górgona era representada em vasos, em acrotério nos frontões dos templos, em escudos e até mesmo em moedas; seu significado era associado ao pavor que gela os corações ${ }^{72}$. Contudo, não há dúvida, que "o deus das máscaras" seja antonomásia sui generis de Dioniso.

A teofania de Dioniso só pode ser simbolizada por uma entidade mascarada, sua súbita intrusão promove uma turbulência no status quo e a transformação da normalidade. A máscara é epíteto da divindade que obriga a ser outro, e não mais o que se convencionou a ser. Neste jogo, a máscara tem seu duplo papel: primeiro,

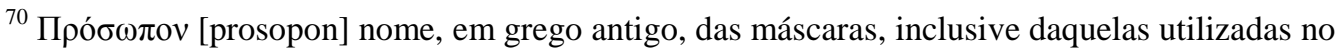
teatro arcaico. Etimologicamnete: $\pi \rho o ́ \varsigma$ ( "em direção") + Ø廿 ("olho").

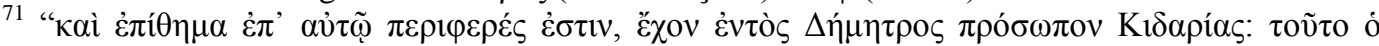

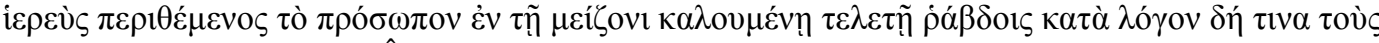

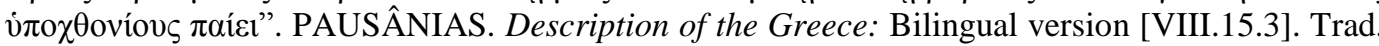
W. H. S. Jones. United Kingdom: Delphi Classics, 2014. Versão Kindle.

${ }^{72}$ Sobre os deuses gregos mascarados, sobretudo Ártemis e Gorgó Cf. VERNANT, Jean-Pierre. A morte nos olhos: figurações do outro na Grécia antiga, Ártemis, Gorgó. Trad. Clovis Marques. Rio de Janeiro: Jorge Zahar Editor, 1985.
} 
ela é o rosto diferente, a troca de papéis, uma vez mascarado há uma supressão do 'eu' enquanto sujeito das relações costumeiras, e o que vigora é a fuga para a experimentação da estranheza; segundo, a máscara é proteção para o homem que é arrancado de si mesmo e projetado no êxtase inebriante; disfarçado, o celebrante está seguro para se lançar no transe e no delírio orgiástico. Da mesma forma que a máscara protege Dioniso de seus algozes, também protege os iniciados dos olhos inquisidores de práticas que suplantam os costumes morais; mas, fundamentalmente, a máscara é a subjetividade que previne contra a completa anulação durante a fusão extática com o divino; a cada troca de máscara, uma nova subjetividade salvaguarda o indivíduo durante a imersão no caos.

Não são poucos os documentos que registram Dioniso associado à máscara; além do relato de Pausânias sobre a máscara Phaleno feita de madeira e encontrada no mar, podemos destacar as máscaras dionisíacas provenientes de Naxos feitas de galhos e ramos da figueira ${ }^{73}$. A partir da segunda metade do século VI a.C. as máscaras, antes de madeira, passam a ser copiadas em material mais resistente, principalmente o mármore; no templo de Dioniso em Icária foi encontrada uma feita desse material, em tamanho maior que o natural. Esse ídolo era também formado por uma túnica, revelando então, que era utilizado em rituais de libação, o que nos comprova as pinturas de vasos: juntamente com o ídolo de Icária, havia uma estátua de Dioniso sentando em uma espécie de trono, empunhando um cântaro na mão direita ${ }^{74}$. Em Atenas prestava-se culto à estátua

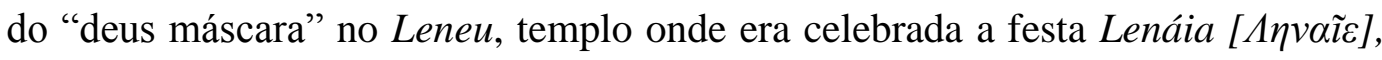
em honra ao aniversário de Dioniso e ao nascimento do vinho ${ }^{75}$.

Segundo a interpretação de Otto ${ }^{76}$, não era qualquer ser sobre-humano que se representava com máscaras, mas apenas aqueles ligados ao "reino natural, ao terrestre". Nas celebrações em honra aos numes ligados a terra, se organizavam danças ritualísticas executadas por pessoas mascaradas; o seu uso visava repelir o mal, fertilizar o solo para o crescimento vegetal; além disso, para os crentes, estava encarnado na máscara os misteriosos poderes das divindades terrestres, por isso, ela era conservada em lugares sagrados. A máscara não apenas escondia o

\footnotetext{
${ }^{73}$ OTTO, Walter F. Dioniso mito y culto. p. 68.

${ }^{74}$ Cf. OTTO, Walter F. Ibidem \& KERÉNYI, Carl. Op. Cit. p. 243 e 244.

${ }^{75}$ Cf. KERÉNYI, Carl. Op. Cit. p. 243 e 244

${ }^{76}$ OTTO, Walter F. Op. Cit. p. 69-71.
} 
homem, mas era um instrumento santo, impregnado de poder divino. Em alguns casos, os deuses representados pela máscara manifestavam-se através dela com avassaladora imediatidade. Nessa perspectiva, os extraordinários seres mascarados, ao contrário dos deuses olímpicos, encontravam-se sempre próximos: a máscara é própria dos deuses que, durante longos ou breves períodos, caminham entre os homens. O milagre da presença divina é, precisamente, o que confere sentido a ela. É claro, dentre todas, a de Dioniso era a mais perturbadora.

Dioniso é, por excelência, o deus mais próximo dos homens. Seus mitos e ritos são indissociáveis das andanças feitas junto aos humanos, ora disfarçado de mortal, ora exigindo o reconhecimento de sua natureza celestial. Dessa forma, a máscara se faz indispensável em sua parúsia e, consequentemente, nas suas celebrações. Por conseguinte, é importante salientar que em muitas representações é nítida a diferença da expressão de Dioniso em relação aos outros deuses de cortejo: é comum que as demais divindades sejam retratadas para os observadores de perfil, todavia, Dioniso, desde os tempos remotos, é apresentado com máscaras encarando desconcertantemente o espectador, de modo que é conhecido, por algumas pinturas em vaso ${ }^{77}$, como “o que observa”. As interpretações dessas pinturas aludem para o deus que se manifesta de forma imperiosa, como aquele que nos perscruta, desnudando até mesmo nosso íntimo mais profundo. Esse modelo de máscara sempre possui uma face híbrida, com aparência mista de homem e animal. Os olhos que nos fitam esgazeando são suas cracterísticas marcantes.

Os olhos das máscaras dionisíacas possuem uma simbologia importante, eles miram de frente, são implacáveis, eles proporcionam um encontro do qual não há possibilidade de se esquivar; como pondera Otto, a máscara é "um frente a frente que conjura e apressa"78, ela representa em si mesma um encontro, não há nada além do encontro frontal: não há nada por trás da máscara, assim como também não há antes e nem depois, apenas a entrega total, como aquela em um instante carnavalesco. Assim sendo, é símbolo supremo daquilo que está e ao

\footnotetext{
${ }^{77}$ Por exemplo, nos vasos chamados por Frickenhaus de Lenäenvasen, em referência à festa Lenáia neles pintadas. Nesta coleção de vasos, podemos observar mulheres celebrando 'o parto do vinho' diante de um ídolo central formado pela máscara "que observa", a túnica e ramos de hera; elas estão recolhendo o vinho em conchas, confirmando que o nascimento do vinho está consumado. KERÉNYI, Carl. Op. Cit. p. 245.

${ }^{78}$ OTTO, Walter F. Op. Cit. p. 70.
} 
mesmo tempo não está, em outras palavras, da união entre a presença e a ausência absoluta. Para melhor entender, é só lembrarmo-nos das máscaras mortuárias que presentificam o inexorável ausente. Similarmente, a máscara revela que a aparição de Dioniso está ligada ao enigma de sua ambiguidade sempre contraditória. Por essas características, Nietzsche o chama de Gênio do coração, o grande segredo e deus-tentador ladrão de consciências, cuja voz - e monstruoso olhar - repleta de segundas intenções, perscruta até os desvãos das almas ${ }^{79}$.

Nietzsche não poderia escolher outra divindade senão o "deus das máscaras" como o símbolo mais importante dos principais temas de sua filosofia: "tudo que é profundo ama máscaras", diz em um fragmento ${ }^{80}$. As máscaras evidenciam a mais vertiginosa solidão; a tentativa, já fadada ao fracasso, de desvelar a identidade do "Eu"; tanto em Nietzsche como nas teofanias de Dioniso, a máscara remete à completa ausência de fundo último, atrás de cada máscara há sempre outra, sucessivamente, e jamais uma realidade concreta. Com a "morte de Deus", pondera Deleuze ${ }^{81}$, o "eu" se dissolve ou se volatiza, mas, de certa maneira, entra em jogo a possibilidade de outros papéis e outras $\pi \rho o ́ \sigma \omega \pi \alpha$ : “no fundo todos os nomes da história eu sou" ${ }^{82}$, diz Nietzsche em uma de suas cartas, revelando possuir uma psicologia e ser uma tipologia das máscaras ${ }^{83}$. Alegoricamente, Dioniso proporciona, entre os que cruzam seu caminho, o prazer na dissolução de tudo que, aparentemente, se mostrava sólido: não há mais "eu", não há mais normas rígidas, pelo contrário, há prazer na destruição e na constatação da finitude.

\footnotetext{
${ }^{79}$ Cf. NIETZSCHE. Além do bem e do mal. §295.

80 "Alles, was tief ist, liebt die Maske". NIETZSCHE. Jenseits von Gut und Böse. §40.

81 "Conclusões sobre a vontade de potência e o eterno retorno" feitas por Gilles Deleuze em um colóquio sobre Nietzsche em julho de 1964. Posteriormente publicada em DELEUZE, Gilles. A Ilha deserta: e outros textos. p. 155-156.

${ }^{82}$ Cf. Carta de Nietzsche a Burckehart de 06 de janeiro de 1889. [Apêndice $\varepsilon$ ]

${ }^{83}$ Pois toda a psicologia de Nietzsche, não somente a sua, mas aquela que ele faz, é uma psicologia da máscara, uma tipologia das máscaras; e, atrás de cada máscara, ainda uma outra. Mas é metodológica a razão mais geral pela qual há tantas coisas ocultas em Nietzsche e sua obra. Nunca uma coisa tem um só sentido. Cada coisa tem vários sentidos que exprimem as forças e o devir das forças que agem nela. E mais: não há "coisa", mas somente interpretações, e a pluralidade de sentidos. Interpretações que se ocultam em outras, como máscaras encaixadas, linguagens incluídas umas nas outras. DELEUZE, Gilles. Op. Cit. p. 156-157.
} 


\section{5 .}

\section{Um deus... Muitos nomes:}

As muitas máscaras de Dioniso também dizem respeito às diferentes lendas, ritos, cultos e, consequentemente, aos muitos nomes pelo qual o deus foi chamado na Antiguidade. A pluralidade de epítetos e a polifonia de seu nome já têm início com as múltiplas formas empregadas e as diferentes interpretações etimológicas: $\Delta$ ióvv̄бos (Diónysos) é a forma mais comum na Antiguidade clássica, mas possui muitas variáveis, em Homero, por exemplo, aparece preferencialmente como

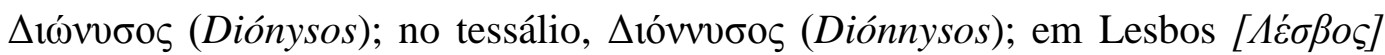

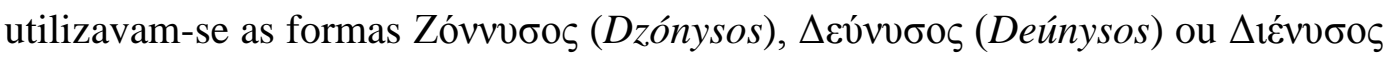

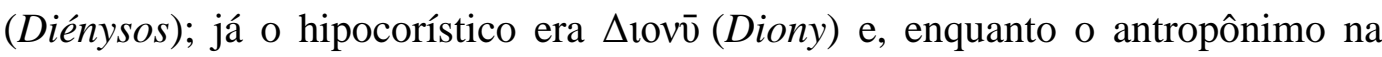
Ilha de Tasos, $\Delta \varepsilon \operatorname{cov}_{\bar{v}} \varsigma$ (Deonys). A forma, bastante utilizada nas transliterações de

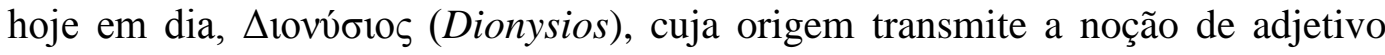
"que se refere a Dioniso", só foi usada a partir do século V a.C., mas somente para designar seres humanos e nunca a divindade ${ }^{84}$. Do ponto de vista etimológico, ainda há muitas suspeitas, mas algumas ideias se destacam.

Uma das primeiras interpretações etimológicas acerca do nome Dioniso foi feita por Paul Kretschmer ${ }^{85}$, sugerindo que $v v \sigma o \varsigma$ seria uma forma trácia para

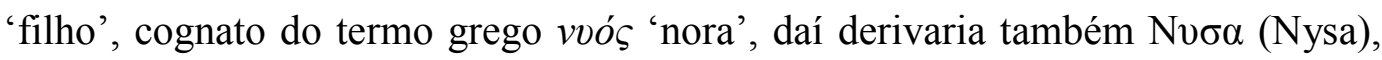
montanha onde teria crescido o deus; de modo que a expressão original seria algo como "filho do céu" "86. Já para Otto, as diferentes formas dialetais derivariam da

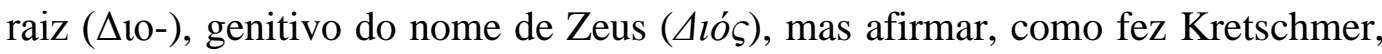

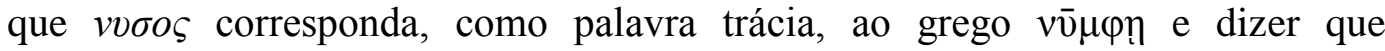
signifique "filho", "apesar da indubitável probabilidade linguista, é não só indemonstrável como improvável"87; entretanto, até hoje, "filho de Zeus" é o étimo mais aceito ${ }^{88}$. Outra interpretação etimológica bastante relevante associa o

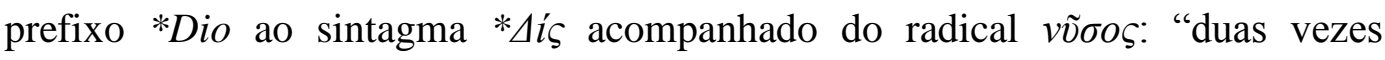

\footnotetext{
${ }^{84}$ Cf. BRANDÃO, Junito de Souza. Dicionário mítico-etimológico. Petrópolis: Vozes, 2014. p. 172.

${ }^{85}$ KRETSCHMER. Aus der Anomia. Berlim, 1980.

${ }^{86}$ Cf. Idem. p. 173.

${ }^{87}$ OTTO, Walter F. Op. Cit. p. 51.

${ }^{88}$ Nas Bacantes de Eurípides, Dioniso é chamado diversas vezes de "filho de Zeus", como por

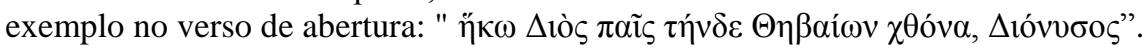


$n \bar{y}$ sos ", portanto a origem do nome da divindade estaria ligada à excentricidade de seu duplo nascimento; reforçando esta interpretação, encontramos em Eurípides a

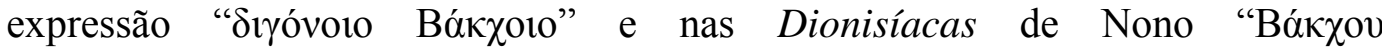

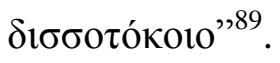

Como podemos perceber, não é possível estabelecer uma etimologia segura do nome Dioniso, todas as interpretações estão no terreno especulativo e são cercadas de temeridade. Além disso, tal qual indicamos nas seções anteriores, Dioniso é a divindade que se manifesta sob diversas alcunhas e é conhecido por muitos nomes. Essa variedade de nomes revelam teofanias díspares e, mesmo possuindo um núcleo comum, se diferenciam ou pela narrativa mítica, ou por alguma característica ritualística ou, até mesmo, por uma peculiaridade do seu culto, variações decorrentes de acordo com a região onde era adorado. Dentre a multiplicidade de epítetos o que mais se destaca junto com "Dioniso" é, sem dúvida, Baco; ainda que Detienne considere Baco como um deus vivo, enquanto Dioniso aparece intelectualizado ${ }^{90}$, é importante salientar que Baco, do grego

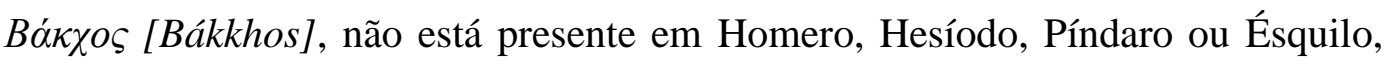
mas surge na literatura grega somente no século V a.C., a partir de Heródoto, ganhando evidência em Édipo Rei de Sófocles e, sobretudo, nas Bacantes de Eurípides.

Diferente do que muitos pensam, Baco é um termo grego e não romano, o nome latino Bacchus é, como assevera Brandão, mera transliteração do termo

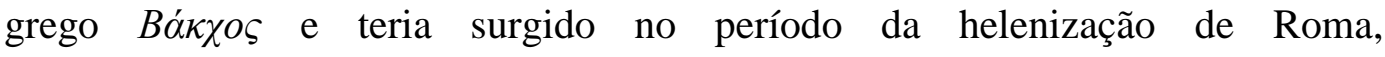
consequentemente, do sincretismo religioso greco-latino, suplantando, então, o Líber dos romanos ${ }^{91}$. Da mesma forma que é impossível estabelecer uma

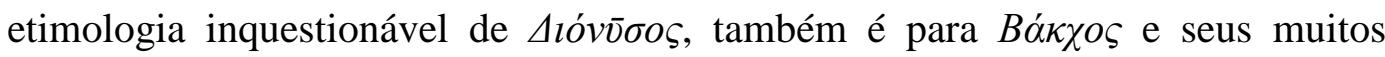

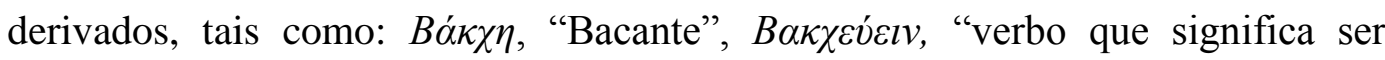

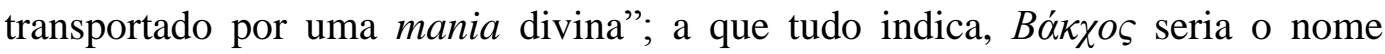
tebano do deus companheiro das Mênades. Após as lendas de Tebas serem difundidas por Sófocles (Édipo Rei) e Eurípides (Bacantes) ${ }^{92}$, Baco passa a ser,

\footnotetext{
${ }^{89}$ Cf. Verso 560 de Hipólito e Livro I, verso 4 de Dionisíacas, respectivamente.

${ }^{90}$ DETIENNE, Marcel. Op. Cit. "Prolegômenos", p. 7.

${ }^{91}$ Cf. BRANDÃO, Junito. Mitologia grega, Vol. II. p. 117.

92 Podemos ler entre os versos 205 a 210 de Édipo Rei a apresentação de Baco da seguinte forma:

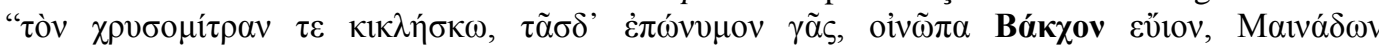


definitivamente, o epônimo do deus orgiástico das montanhas e do vinho. Mas além de Baco, há outros epítetos que são importantes representações de Dioniso na Grécia antiga e geralmente são destacados pelos estudiosos da divindade, nomeadamente: Íaco, Brômio e Zagreus, aos quais dedicaremos algumas considerações.

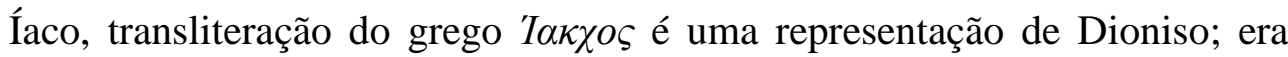
comum seu ídolo carrear as procissões dos iniciados nos Mistérios de Elêusis.

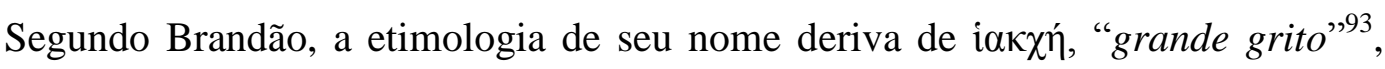
pois, durante o séquito, seu nome era clamado em gritos pelos celebrantes noturnos. Íaco era associado a uma entidade extática que projetava a alma dos muitos peregrinos que marchavam a Elêusis em uma espécie de entusiasmo coletivo, como um "antegozo"94 durante as comitivas que antecediam os ritos de iniciação. Na comédia de Aristófanes As Rãs, a imagem de Íaco é a da divindade condutora do cortejo, como se fosse o corifeu divino do Coro dos Iniciados que suplicavam a ele da seguinte forma: "Íaco! Tu que és adorado nesta região desolada, Íaco, ó Íaco! Presida as suas danças sobre a grama entre os iniciados em seus mistérios! Agite em sua fronte a coroa de mirto, mostre esta dança ousada, alegre, cheia de graça, sagrada e querida pelos fiéis!"95. Na comédia, Íaco é o amigo da dança, o deus do refrigério que anima a perna dos velhos e incita à alegria ${ }^{96}$.

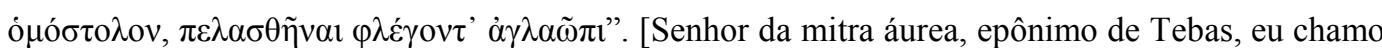
Baco em chamas, rosto-vinho, Evoé quando evocado, ministro das Mênades, com tocha ardente, contra em chamas, rosto-vinho, Evoé quando evocado, companheiro das Mênades, com tocha

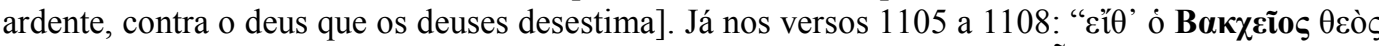

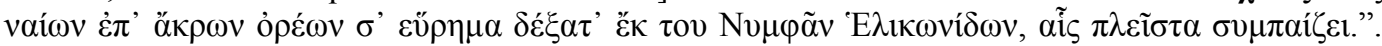
[ou ao deus do frenesi bacante, cuja morada é o pico das montanhas, uma das ninfas do Hélicon seu par no prazer - te ofertou, recém-achado?]. Em Antígona nos versos 150 a 154: " $\theta \varepsilon \tilde{\omega} v$ ḋ̀ vooù

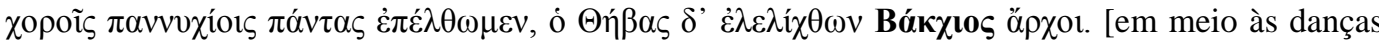
que entram pela noite, e seja Baco, o que faz tremer a terra de Tebas, nosso guia]. Mais a frente

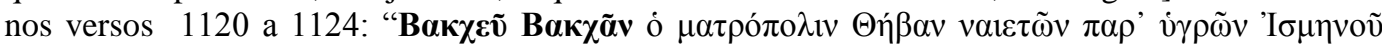

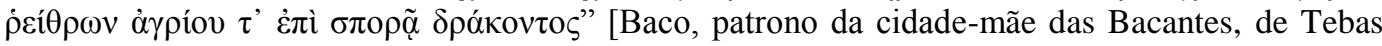
que se alonga pelo caminho líquido do (rio) Ismeno sobre a semente do dragão feroz!]. Grifo nosso.

${ }^{93}$ BRANDÃO, Junito. Op. Cit. p. 118.

${ }^{94}$ Ibidem.

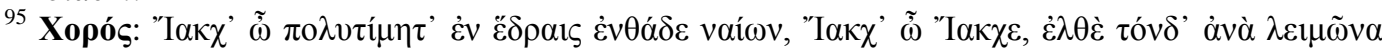

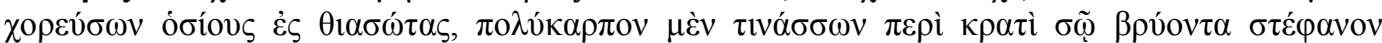

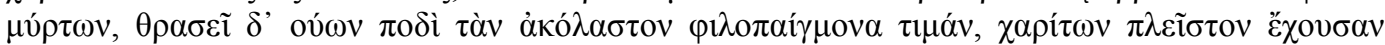

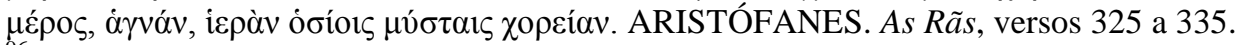

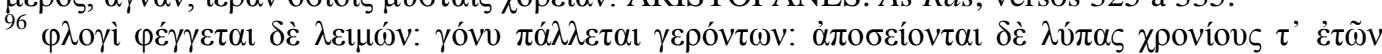

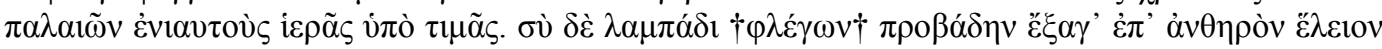


Íaco além de proclamado como "amigo da dança" e condutor do préstito é, também, proclamado como o guia noturno, aquele que ilumina os caminhos dos noctâmbulos em meio às trevas; portanto era igualmente associado às estrelas

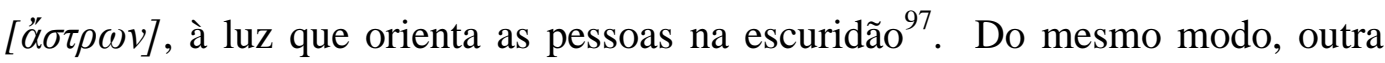
representação que assume entre os gregos é a do tocheiro: seu nome era invocado em brado com uma insistência ininterrupta, seu ídolo seguia à frente como o fogo responsável por guiar os notívagos. Na figura de Íaco guardava-se a ligação de Dioniso com a luz guia e o fogo; Kerényi nos lembra de que a arma de Dioniso é o fogo, as Bacantes eram capazes de transportar o fogo nas mãos nuas sem se queimarem $^{98}$. Em Atenas, a celebração que exibia a estátua de Ílaco tocheiro acontecia no final do verão e marcava o início dos Mistérios Maiores de Elêusis, nela o Íaco invocado, "o duplo de Dioniso", era a estrela cintilante dos mistérios noturnos ${ }^{99}$; a tocha cuja flama anunciava radicais transformação: nada resiste ao fogo! Muda-se a estação, a vida amadurece, festejam-se os ciclos.

Já Brômio é, segundo Brandão, um dos epítetos de Dioniso mais comuns nas invocações entoadas em forma de canto semelhante aos hinos litúrgicos.

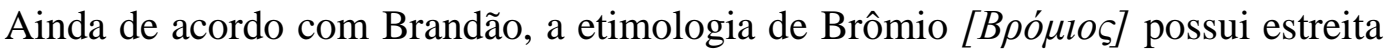

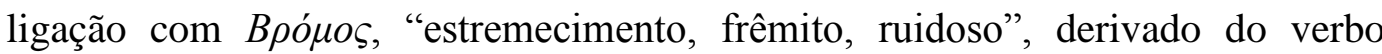

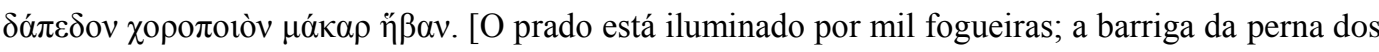
anciãos recupera seu vigor antigo; eles afastam os achaques da idade e esquecem o peso dos anos para participar das solenidades. Salve você, que brilha com uma luminosidade cintilante, à frente de uma juventude ágil neste prado fresco e enfeitado de flores!] Idem, versos 344 a 352. Também

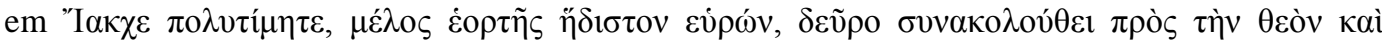

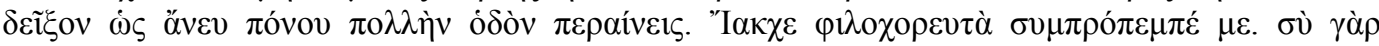

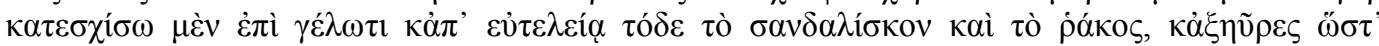

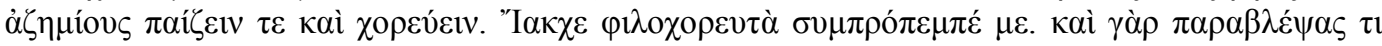

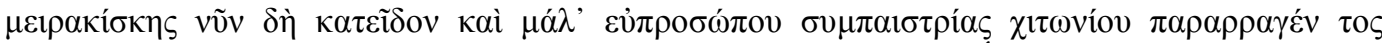

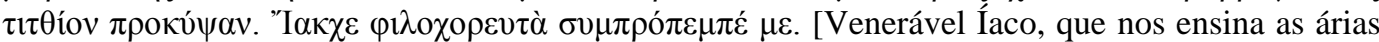
suaves que ressoam nesta festa, acompanhe-nos até a morada da deusa, e mostre que você sabe percorrer uma longa rota sem fadiga! Íaco, amigo da dança, venha conosco! Foi você quem despedaçou assim este coturno e rasgou estas roupas humildes que fazem rir, e cujo modesto manto nos permite dançar com mais desenvoltura. Íaco, amigo da dança, venha conosco! Agora mesmo nossos olhos indiscretos perceberam uma moça de rara beleza; ela brincava com suas companheiras, e sua túnica rasgada nos deixou entrever seu pescoço. Íaco, amigo da dança, venha conosco!]. Versos 399 a 416.

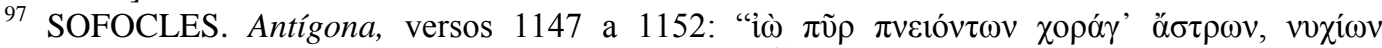

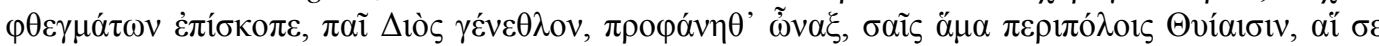

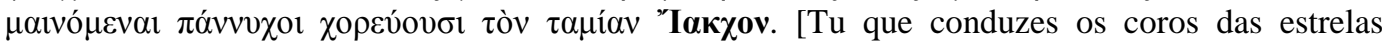
flamígeras, guardião das vozes noturnas, criança de Zeus, mostra-te a nós com o séquito das Tíades, que, transportadas, te festejam com danças toda a noite, a ti, Íaco, o distribuidor de bens!].

${ }^{98}$ KERÉNYI, Karl. Op. Cit. p. 69.

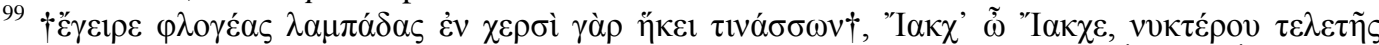

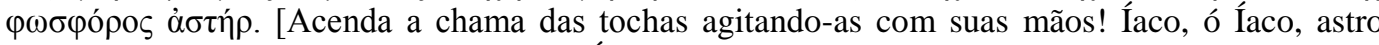
brilhante dos mistérios noturnos!] ARISTÓFANES. Op. Cit., versos 340 a 343.
} 
$\beta \rho \varepsilon \mu \varepsilon l v$, que significa "fremir", "rugir"100. O significado do nome se relaciona perfeitamente ao estado de agito e tremor que tomava conta dos adoradores de Brômio em transe, da mesma forma em que se relaciona aos sons estridentes vindos, ou da gritaria, ou da música frenética comuns nestas celebrações. O clamor a Brômio aparece diversas vezes em Bacantes de Eurípides, onde seu nome é evocado ora aos gritos ${ }^{101}$, ora na forma de cânticos entoados pelo coro das bacantes $^{102}$; nesta obra, o nome de Brômio é sempre associado a elementos do mito de Dioniso, seja como filho prematuro de Zeus e Sêmele, quem foi fulminada pelo raio divino ${ }^{103}$; seja como o próprio Dioniso, vindo das montanhas frígias $^{104}$; seja como o deus da dança e do Tíaso, que enlouquece as mulheres ${ }^{105}$.

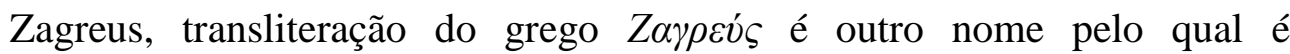
identificado o deus do frenesi narcótico e orgiástico; analisar as particularidades de suas lendas é de fundamental importância para aprofundarmo-nos na polifonia de mitos que cercam Dioniso. Zagreus é um deus muito antigo no mundo mediterrâneo, acredita-se que o seu culto seja proveniente da ilha de Creta e que tenha sido adorado desde a civilização minoica. A etimologia de seu nome, já defendida por Wilamowitz e sustentada por Kerényi, vem do grego "grande caçador", ou "captor de animais de caça" 106. Apesar de existirem poucos registros históricos sobre seu culto na Grécia, já no século VI a.C., Ésquilo, em

${ }^{100}$ BRANDÃO, Junito. Op. Cit. p. 118.

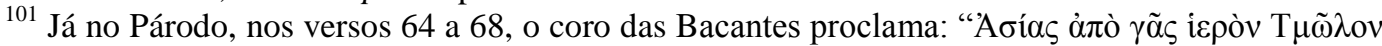

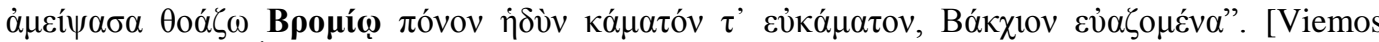
apressadas lá da Ásia e do sagrado Tmolo — doce esforço gostoso de sofrer, pois é por Brômio.

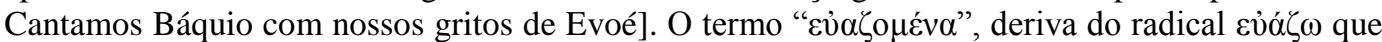
significa "chorar", "clamar”; daí a onomatopeia દủaí (euaí), um grito de júbilo em honra de Baco.

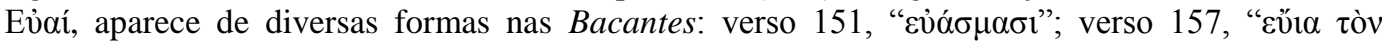

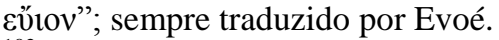

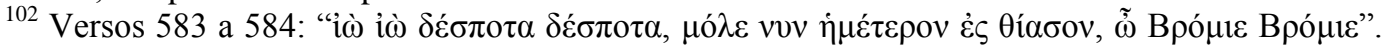
[Iô! Iô! Senhor! Senhor! Vem a nós, ao nosso Tíaso, ó Brômio, Brômio!].

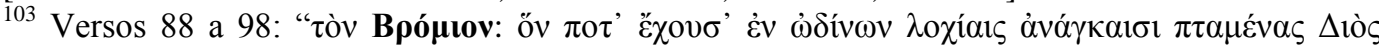

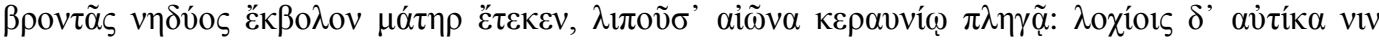

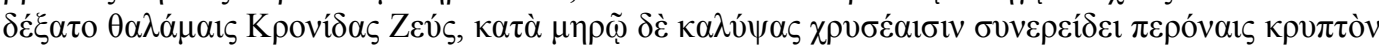
$\dot{\alpha} \varphi$ ' "H $\rho \varsigma^{\prime}$ ". [Vem logo, Brômio, tu, que nos transes das dores naturais durante o parto, quando caiu o raio fulminante vindo de Zeus, saíste antes do tempo do ventre de Sêmele, tua mãe, pois ela, em sua infelicidade, perdeu a vida transformada em cinzas!]

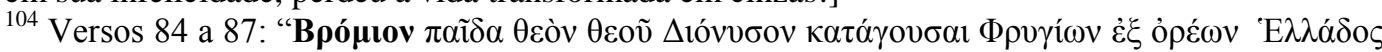

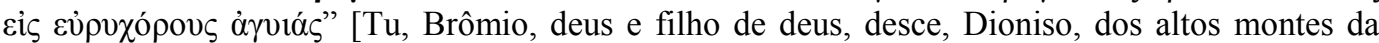
Frígia distante para cá, para as cidades gregas onde os coros te acolhem com total intimidade!]

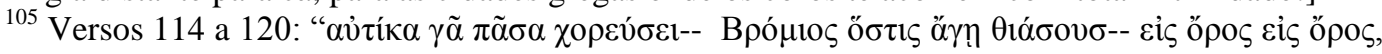

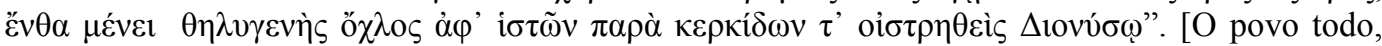
sem demora, irá dançar em sua honra, - quem quer que dirija os tíasos, outro Brómio é - para a montanha, para a montanha, lá onde está das mulheres a multidão, dos teares e lançadeiras apartada e por Dioniso enlouquecida!].

${ }^{106}$ KERÉNYI, Carl. Op. Cit. p. 72 e 73. 
algumas peças perdidas, das quais só nos chegaram seus fragmentos, descreve Zagreus como uma divindade chtônica, identificando-o com Hades subterrâneo ${ }^{107}$. Em outras lendas, Zagreus era visto como filho de Zeus e Perséfone, igualmente identificado como chtônico. Eurípides, na tragédia Os cretenses, menciona ritos bárbaros a Zagreus em uma cova onde se dilaceravam animais e se comia carne crua $^{108}$

Embora as características bárbaras destes ritos omófagos associem o "grande caçador" aos rituais dionisíacos, foi apenas com os Órficos que a religião cretense se fundiu com as divindades do panteão grego, fazendo de Zagreus o primeiro Dioniso. Segundo esse sincretismo órfico-dionisíaco, Zeus desposou a mãe de Perséfone e posteriormente a mesma Perséfone, sua filha, gerando então Zagreus. Existem vários fragmentos antigos, com diferentes versões desta lenda, optamos por reproduzir, inicialmente, a versão contada por Kerányi devido à riqueza historiográfica de suas fontes: Deméter veio de Creta à Sicília, onde em uma caverna esconde a filha Perséfone, ordenando que duas serpentes the protegessem. Na caverna, a jovem passava o tempo trabalhando com a lã; enquanto se distraía ao pintar o mundo inteiro nos mantos, Zeus, na forma de víbora, aproximou-se e gerou na própria filha o deus que, segundo as histórias órficas, deveria ser seu sucessor, o quinto soberano do mundo. A Criança divina nasce na caverna materna dotada de chifres que indicariam a sua natureza chtônica ${ }^{109}$.

Para proteger o filho que o sucederia dos ciúmes de sua esposa Hera, Zeus confiou o divino infante aos cuidados dos Curetes ${ }^{110}$, que o esconde na floresta; assim mesmo, Hera descobre o esconderijo do jovem deus e instiga os Titãs a raptá-lo e matá-lo. Com o rosto coberto com pó de gesso para não serem descobertos, os Titãs atraíram o pequeno Zagreus com brinquedos místicos, ossinhos, peão, chocalho, argolas, maçãs de ouro, berrante, espelho e madeira. De

\footnotetext{
${ }^{107}$ Ésquilo. Nauck, TGF, Fragmento 5, 228. Apud. KERÉNYI, Carl. Op. Cit.p. 74

108 "Eurípides chama de Zeus Ideu o deus da cova de Ida. Porém não é de Zeus, mas só de Dioniso que podemos afirmar: Nenhum deus grego chega perto dele no horror de seus epítetos, que atestam uma selvageria absolutamente impiedosa”. KERÉNYI, Carl. Op. Cit. p. 75.

${ }^{109}$ Cf. KERÉNYI, Karl. A Mitologia dos gregos: Vol. I, A história dos deuses e do homem. p. 226227.

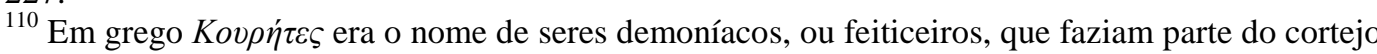
de Zeus-menino, protegendo-o durante sua infância. Eles dançavam batendo as lanças no escudo de bronze. Cf. BRANDÃO, Junito. Dicionário mítico-etimológico - Curetes. p. 155.
} 
posse do pequenino, os enviados da ciumenta deusa, o despedaçaram, cozinharam sua carne em um caldeirão e o devoraram, reduzindo a cinzas as partes não aproveitadas; Zeus, atraído pelo cheiro do cozido, ao perceber o acontecido fulmina os algozes de seu filho ${ }^{111}$. Todas as narrativas contam que apenas um órgão que não foi devorado pelos Titãs e nem pelo fogo: o coração da tenra vítima. Há algumas variações do fim desta narrativa, mas todas convergem para a sobrevivência do deus menino e o renascimento do segundo Dioniso. Alguns relatos dizem que o coraçãozinho foi salvo por Atenas, outros por Deméter e outros pela princesa Sêmele.

Para Kerényi, sentir-nos-íamos inclinados a considerar o infanticídio e a refeição cometida pelo Titãs como imagens associadas ao canibalismo, sugerindo rituais antropofágicos, não fosse o fato de que a criança dilacerada, fervida e devorada era ornada com chifres, o que nos leva a entender que a vítima, na verdade, era um cabrito ou uma vitelazinha ${ }^{112}$. Outra interpretação importante do mito, é que na imagem "atração, morte e cozimento" de Zagreus, há vários indícios de ritos iniciáticos. Uma vez que Dioniso não morre propriamente, mas renasce do próprio coração, identificamos no filho de Zeus sua imortalidade, donde, certamente, provém sua relação com a divindade egípcia Osíris, "o despedaçado que retorna à vida"113, e com Hades, "o imortal deus da morte", de modo que cada "morte" sua é, na realidade, uma catábase, a descida de alguém vivo ao Reino dos Mortos, seguida, tão logo, de uma anábase, o retorno de alguém vivo do submundo; elemento básico de muitos rituais chtônicos que eram centrados na consulta aos mortos, ou invocação dos deuses subterrâneos.

Além disso, polvilhar o rosto com o pó de gesso, como fizeram os Titãs, ou cobrir a face e o corpo com cinzas fazia parte de ritos arcaicos de iniciação. De acordo com Brandão, “os neófitos se cobriam de cinzas ou pó de gesso para se assemelharem aos eídola, aos fantasmas, o que traduz a morte ritual"; por isso,

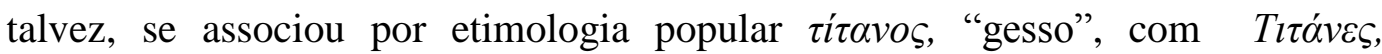
"Titãs"114. Outra consideração importante é que, para a religião órfica tardia,

\footnotetext{
${ }^{111}$ Cf. Idem-Dioniso. p. 173 - 175.

112 KERÉNYI, Karl. Op. Cit. 228.

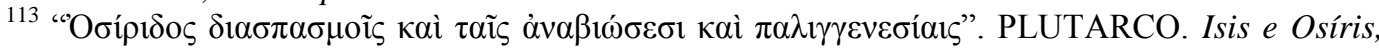
$364 \mathrm{~F}$.

${ }^{114}$ BRANDÃO, Junito. Dicionário mítico-etimológico - Dioniso. p. 173.
} 
depois de Zeus trucidar com seu raio os Titãs, das cinzas surgiu a substância da qual foram feitos os homens, o que explicaria, ainda segundo Brandão, a natureza ambivalente do homem: bem e mal, sendo a parte titânica de matriz maldosa, mas como aqueles haviam devorado a carne de Dioniso-Zagreus, a este se deve o que existe de bom em cada ser humano ${ }^{115}$. Contava-se também outra versão, onde os membros mutilados e cozidos do primeiro Dioniso, filho de Deméter, foram encontrados e enterrados pelos "nascidos da terra", mas por intermédio da mãe, que junta seus membros, renasce com o nome de Enos, o deus da videira ${ }^{116}$.

Os brinquedos mencionados no mito órfico de Zagreus constituem outro elemento de fundamental importância para compreensão dos rituais iniciáticos: as argolas, geralmente de marfim, que formavam pequenos chocalhos para pendurar nos pescoços das crianças, chamadas de crepundia, junto com os ossinhos e o peão, possuíam um significado preciso nas $\tau \varepsilon \lambda \varepsilon \tau \eta ́$ s: produzir os sons e ruídos necessários para qualquer ritual de iniciação; para invocar um deus, para cumprir o entusiasmo, isto é, para fazer presente a divindade e ser preenchida por ela são necessários os sons dos tambores e das flautas (ou vozes), os brinquedos que atraíram o deus jovenzinho possuem esta simbologia musical: agitam-se os chocalhos, batem-se os ossinhos produzindo, por fim, uma sonoridade frenética, capaz de atrair os deuses e os espíritos, da mesma forma que os Titãs atraem o delicado menino, distraído pelos sons e pelos reflexos no espelhinho. Além do mais, é comum em diversas religiões a presença destes materiais devido à crença de que possuam um poder apotropaico, ou seja, de espantar influências malignas.

Esse primeiro Dioniso, o Zagreus órfico, também povoa o imaginário nietzschiano do período de $O$ Nascimento da tragédia; nessa obra, Nietzsche recorre à simbologia marcante do dilaceramento da criança divina para ilustrar seu pensamento estético-metafísico: segundo o filósofo, o primeiro Dioniso sofre e experimenta, em si, os padecimentos da individuação; na sua interpretação o esquartejamento em múltiplas partes representa o verdadeiro sofrimento dionisíaco: "o estado de individuação"; a causa primordial de todo sofrer é a existência do mundo fragmentado em indivíduos, como demonstra o mito ao narrar a tristeza inconsolável de Deméter devido ao desmembramento do filho e

\footnotetext{
115 idem.

116 KERÉNYI, Karl. Op. Cit. 229.
} 
sua radiante alegria quando descobre que pode dar à luz mais uma vez a Dioniso $^{117}$. Por trás dessa interpretação há um dos eixos centrais do pensamento metafísico do jovem Nietzsche, a dicotomia entre Uno primordial e principio individuationis, noção similar à dicotomia kantiana coisa em si e fenômeno e, portanto, será por nós examinada no primeiro episódio.

Além dos epítetos Zagreus, Brômio e Íaco analisados sucintamente até aqui, existem diversos outros nomes e sobrenomes que poderíamos mencionar, tais

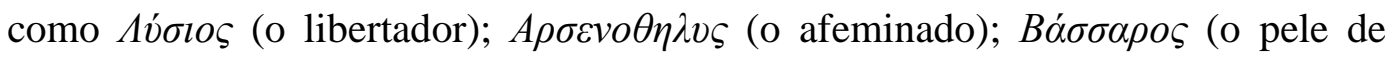

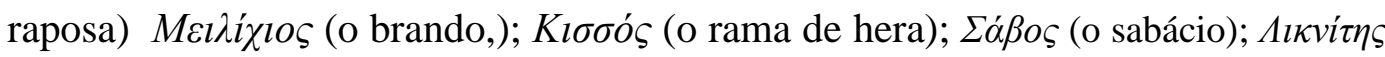

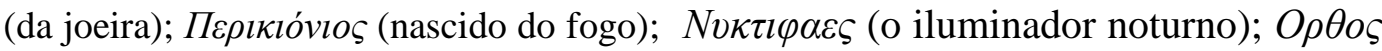
(o erecto); dentre muitos outros. Entretanto, o que podemos perceber claramente nos epítetos brevemente explorados nesta seção é a íntima relação que Dioniso estabelece com as mulheres; podemos dizer, sem exagero, que o universo dionisíaco é o universo feminino; seja essa relação de Íaco e Brômio com as Bacantes e as Mênades, seja Zagreus com suas muitas mães, Deméter, Perséfone, Sêmele símbolo da Mãe-terra, seja o deus-menino homérico criado por suas amasde-leite; Dioniso é o senhor das mulheres e dos mistérios feminis. Se seu poder alcança os homens, é primeiro por intermédio delas. Destarte, nossa próxima seção dedicar-se-á em examinar melhor tal correspondência.

\section{6. Urro feminino:}

Segundo as interpretações que aludem a uma proveniência estrangeira do culto a Dioniso, foram primeiramente as mulheres que resistiram à sua entrada na Grécia. As celebrações orgíacas praticadas desenfreadamente pelas mulheres traco-frígias nas montanhas rompiam brutalmente, sob o olhar das gregas, com as práticas e costumes então estabelecidos; por isso, nos mitos de resistência sempre

\footnotetext{
${ }^{117}$ Cf. NIETZSCHE. O Nascimento da tragédia, §10, p. 70. Cf. também Fragmento Póstumo de 1871 7[55] onde se lê: "Zagreus als Individuation. Demeter freut sich wieder in Hoffnung auf eine neue Geburt des Dionysos. Diese Freude - als die Verkünderin der Geburt des Genius - ist die hellenische Heiterkeit." [Zagreus como individuação. Deméter volta a se alegrar com a esperança de um novo nascimento de Dioniso. Essa alegria - como anúncio do nascimento do gênio - é a serenidade grega].
} 
é alguma mulher, ou um grupo delas, que renegam o deus, o esnobam e o perseguem. No entanto, contraditoriamente - como tudo relacionado a esse deus das contradições - são as mesmas mulheres as primeiras que se deixaram arrastar em uma verdadeira agitação de entusiasmo pela nova religião e, consequentemente, a elas se deve, sem dúvida, a introdução e enraizamento destes rituais na Grécia antiga ${ }^{118}$. Nos cultos dionisíacos, as mulheres ficavam sozinhas; nenhum homem poderia estar presente enquanto elas dançavam e giravam, vestidas em túnicas, ornadas de hera e carregando o Tirso, representando em suas próprias pessoas os papéis das deusas companheiras de Dioniso.

Nesses cultos, as mulheres, mais do que dançavam, corriam freneticamente ao som de tambores, tamborins e flautas. Além de incorporarem as deusas, essas devotas também assumiam o papel de outras mulheres que, em outro tempo, segundo os mitos de Dioniso, o perseguiram ou simplesmente negaram a sua natureza divina e, como resultado, foram arrastadas pelo seu poder e tomadas por sua manía; por isso, que as mulheres que o seguiam eram chamadas de Mênades [Malvó $\delta \varepsilon \varsigma]$, palavra que etimologicamente é formada pelo sufixo-adjetivo "ados", acrescido ao verbo $\mu \alpha i v \omega$, "tornar-se furioso", que por sua vez, relaciona-se com a palavra $\mu \alpha v i \alpha$. Neste sentido, as Mênades eram aquelas que, tomadas pela loucura, em sua acepção mais ampla, ou seja, de amor raivoso, das paixões primitivas, da cólera turbulenta, passavam a seguir o $\mu \propto \imath v o \mu \varepsilon ́ v o ı o ~ \Delta \imath \omega v v ́ \sigma o \imath{ }^{119}$, cognome que significa "Dioniso enfurecido", mas, principalmente, "aquele que enfurece", ou "aquele que torna louco", que afeta provocando as intensidades; nunca apenas "maníaco", no sentido ordinário do termo.

Um dos mitos que narra uma inicial rejeição seguida de uma completa possessão dionisíaca é recontado por Kerényi ${ }^{120}$ : Mínias, o rei de Orcômeno na Beócia, tinha três filhas extremamente diligentes: elas censuravam as mulheres que deixavam a cidade em direção à montanha para oferecer honras a Dioniso. Certa vez, o próprio deus surgiu diante das irmãs altivas na forma de uma donzela e as repreendeu brandamente para que não negligenciassem os ritos secretos. As filhas de Mínias não obedeceram, então, Dioniso se transformou em touro, em

\footnotetext{
${ }^{118}$ Ver seção 2.1.

${ }^{119}$ HOMERO. Ilíada. Canto VI, verso 132.

${ }^{120}$ Cf. KERÉNYI, Karl. A Mitologia dos gregos: Vol. I, A história dos deuses e do homem. p. 234.
} 
leão e finalmente em um leopardo; fez crescer hera e sarmentos nas cadeiras de tecer, serpentes aninharam-se nas cestas de lã. Amedrontadas, as três mulheres tiraram a sorte para saber qual delas ofereceria o filho em holocausto; a criança sorteada foi feita em pedaços pela própria mãe e pelas tias. Ornadas com grinaldas e folhas de louro, as irmãs passaram a vagar pelas montanhas, até serem metamorfoseadas, cada qual em um animal noctívago: uma em morcego, a segunda em coruja e a terceira em um mocho-real ou em corvo.

É conhecida outra história sobre as irmãs de Sêmele, tias de Dioniso: os seus nomes eram Agave, Autônoe e Ino. Incluindo a mãe, as quatro eram as amas do deus. Cada uma das irmãs, igual à Sêmele, tiveram um filho: Ino teve Melicerta; Autônoe teve Actéon, filho que teve morte trágica, foi devorado pelos próprios cães, sobrando apenas os ossos que tiveram de ser recolhidos pela sua mãe; Agave, a "sublime", teve Penteu, o mancebo perseguido como caça por essas três mulheres tomadas pela loucura dionisíaca. Como bem sabemos, nas Bacantes de Eurípides é minuciado que a loucura das três irmãs foi um castigo por se recusarem a acreditar na divindade do sobrinho. Como suplício elas foram obrigadas a cultuar Dioniso no ermo, como Mênades genuínas; cegas pelo frêmito dionisíaco confundiram o filho de Agave com um leão, e saíram-lhe à caça,

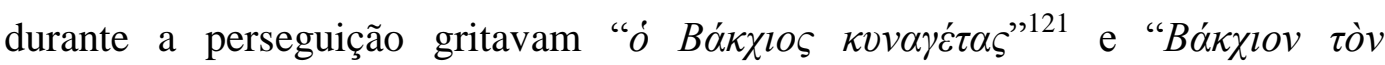

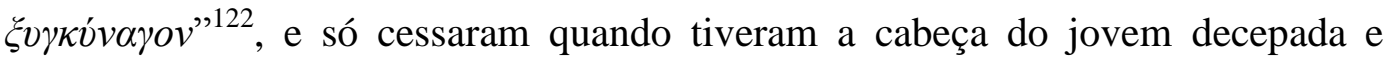
espetada numa lança como troféu. Cumprindo elas o papel de cão de caça [ $\kappa v ́ v \varepsilon \varsigma$, $\left.\theta \eta \rho \omega ́ \mu \varepsilon \theta^{\prime}\right]^{123}$.

As mulheres desses mitos servem, certamente, como modelos às fiéis que conduziam os rituais dionisíacos: primeiramente perseguiam a presa, despedaçavam-na e, na maioria das vezes, devoravam sua carne crua, alusão à perseguição das mulheres a Dioniso; no segundo momento, urravam e saltitavam possuídas pelo poder do deus, como aquelas dos mitos, castigadas com a loucura dionisíaca. Contudo, a ligação de Dioniso com o universo feminino não é apenas esta, até então descrita - "primeiro negligência, seguido do castigo e devoção" A relação entre a divindade e o feminil é muito mais ampla e, quase sempre,

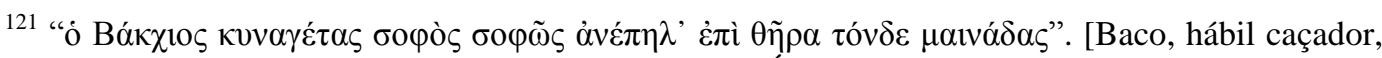
habilmente incitou à caça desta fera as Mênades]. EURÍPIDES. Bacantes, 1189-1191.

${ }_{122}$ Idem. versos $1145-1146$.

${ }^{123}$ Idem. versos 731. 
paradoxal. Se nas epifanias de outros deuses notamos a companhia de seres de mesmo sexo, no círculo mais próximo e no séquito de Dioniso estão quase que exclusivamente mulheres. Apesar de falarmos de um nume poderoso, lutador vitorioso, capaz de trucidar seus inimigos, ao mesmo tempo falamos de um ser que "celebra sua mais sublime vitória nos braços da mulher perfeita, e mesmo possuindo um caráter guerreiro, o seu heroísmo, como tal, é outro"124.

Assim sendo, a natureza de Dioniso é sempre ambígua, ele é descrito ora varonil, ora efeminado e, muitas vezes, andrógino, ou seja, assumindo, ao mesmo tempo, características masculinas e femininas. Encontramos vários textos que revelam sua natureza ambígua, por exemplo, em um fragmento de Ésquilo, o deus é descrito como ó yóvvls, "o feminino"125. Nas Bacantes ${ }^{126}$, é chamado de

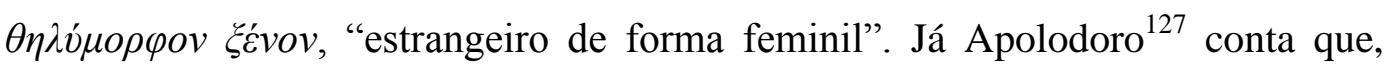
quando Zeus retirou o infante Dioniso de sua coxa, para protegê-lo do ciúme de Hera, o envia, por Hermes, para ser criado por Ino e Atamante como uma garota. Ainda que estivesse agindo como menina, Hera descobre seu paradeiro e vinga-se cruelmente de seus tutores: ensandece o casal que tinha dois filhos; o pai persegue o primogênito, Learco, como se fosse um veado, matando-o. Ino lança Melicerta, o mais moço, em um caldeirão de água fervente, em seguida joga-se juntamente com o filho morto no mar. Essa história é repetida por Nono que descreve a infância feminina do jovem deus, criado como uma garota ${ }^{128}$.

\footnotetext{
${ }^{124}$ OTTO, Walter F.. Dioniso mito y culto. p. 129.

${ }^{125}$ Ésquilo. Fragmento 61. Apud. OTTO, Walter F. Op. Cit. p. 129.

${ }^{126}$ Verso 353.

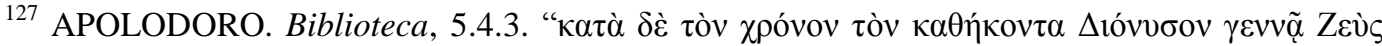

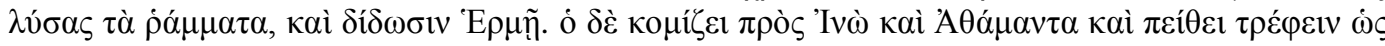

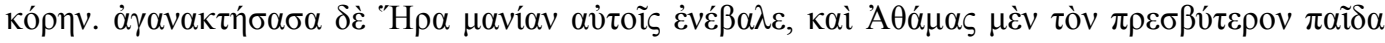

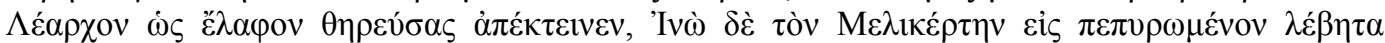

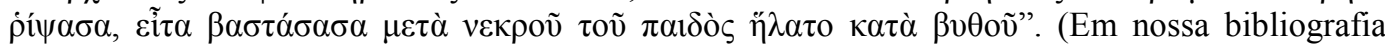
como Apollodorus. The Library).

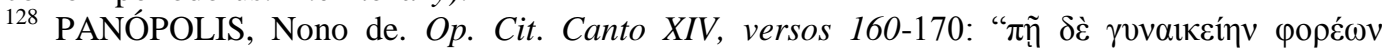

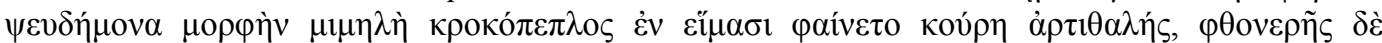

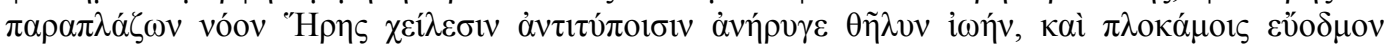

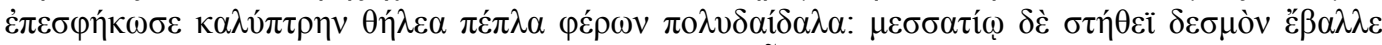

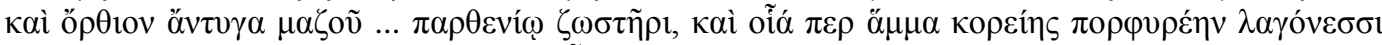

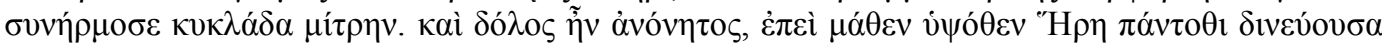

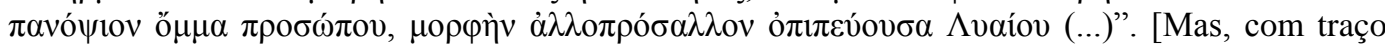
feminino se mostrava vestido igual a uma menina em túnica, e para desviar a atenção dos ciúmes de Hera, imitava com os lábios a voz de feminil. Usava um véu perfumado em seus cabelos e vestia um peplo de modo a ajustar seus seios (...)].
} 
Por isso, Otto compara Dioniso à figura de Páris a "eternamente duvidosa figura do homem iluminado pelo espírito de Afrodite"129. O jovem príncipe de Tróia é um guerreiro viril, mas sucumbe diante do poderoso Menelau. Da mesma forma, quando enfrenta um ser masculino mais duro, Dioniso também sucumbe, como conta-nos a Ilíada sobre seu enfrentamento com Licurgo. Além disso, a semelhança entre os dois é ainda mais evidente se observarmos que ambos são

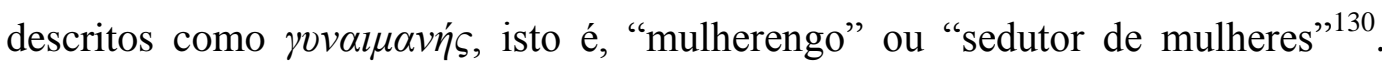
Entretanto, a maneira como Páris e Dioniso "seduzem as mulheres" é

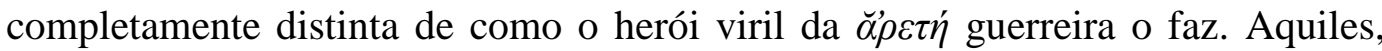
por exemplo, comete um sequestro truculento quando toma para si Briseis: ele assassina seus três irmãos, destrói o templo de seu deus e a leva como espólio de guerra. Igualmente, Agamenon toma para si Criseis, e quando se vê obrigado pelo oráculo a devolvê-la exige, tiranamente, Briseis como compensação ${ }^{131}$. Aquiles ama, verdadeiramente, Briseis, mas é machista sua relação com as mulheres.

Diferentemente age Páris com as mulheres. Embora o jovem príncipe também tenha sequestrado Helena, levando-a sorrateiramente de seu primeiro marido, a relação que estabelece com a amada é completamente distinta daquelas

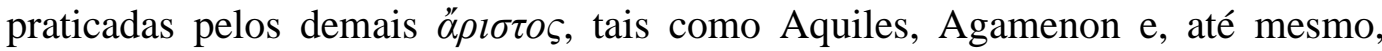
Menelau. Helena não é, para Páris, apenas um espólio, ou seja, apenas uma mulher para satisfazer seus desejos, nem mesmo uma bela e submissa esposa, mas sim, uma dádiva divina, é um presente de Afrodite $^{132}$. Não há no relacionamento dos amantes de Tróia a dominação masculina, pelo contrário, houve o consentimento da donzela em tudo que tange à união amorosa: para a consumação do tálamo, proporcionado por Afrodite; para a primeira vez que gozaram de seus corpos na ilha de Cranaé ${ }^{133}$; houve assentimento até mesmo quando foi raptada, é

\footnotetext{
${ }^{129}$ OTTO. Op Cit.p. 130.

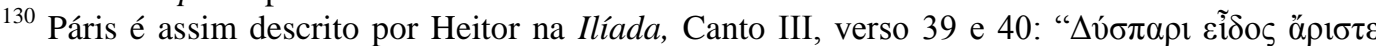

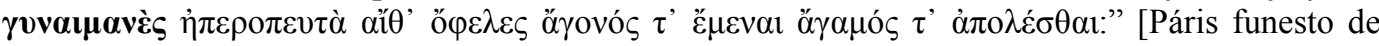
belas feições sedutor de mulheres! Bem melhor fora se nunca tivesses nascido ou se a morte antes das núpcias te houvesse levado]; e mais tarde igualmente no Livro XIII, verso 769 a 770:

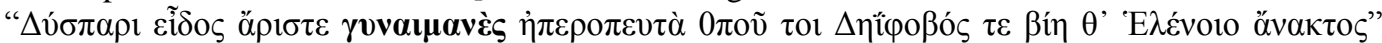
[Páris funesto de belas feições sedutor de mulheres onde se encontra Deífobo e Heleno senhor poderoso?] Já o deus é assim chamado na seção dedicada a Dioniso no Hino homérico à Deméter,

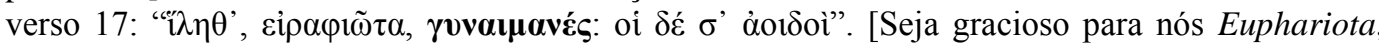
sedutor de mulheres: nós o cantamos]. (Grifo nosso).

${ }^{131}$ HOMERO. Ilíada, Canto I, versos 319-329.

${ }^{132}$ Cf. HOMERO. Ilíada, Canto III, versos 380-450.

${ }^{133}$ Cf. Idem. verso 445.
} 
isso o que ela confessa a Príamo, quando percebe os problemas que o amor proibido trouxe aos troianos ${ }^{134}$. Por esses motivos, o amor de Páris pode ser considerado feminino, ele ama como as mulheres amam. Assim também é a forma de Dioniso amar.

Apesar de ser confundido como o deus da lascívia e possuir epítetos de

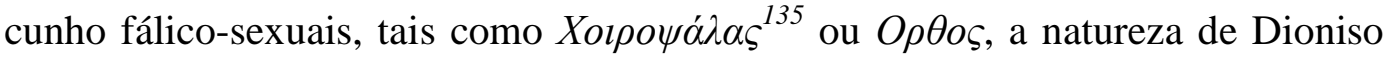
claramente não se associa à luxúria desmedida. Com um breve exame de seus mitos, podemos perceber que sua relação com as mulheres distingue-se, completamente, de todos os deuses autenticamente masculinos. Zeus, por exemplo, utilizava-se de vários artifícios para possuir sexualmente outras deusas ou mortais, na maioria das vezes sem o consentimento delas. Hades também fazia valer sua condição de poderoso deus masculino para raptar amantes e aprisionálas no submundo. Diferente desses deuses, cujos amores esvairiam-se como se fossem meras posses, prontas para o descarte, Dioniso une-se para sempre à sua amada, Ariadne; seu amor é enlevado, é o amor que embriaga, em nossa análise, um amor feminino. É exatamente esse amor o sentimento que tomava conta dos corações das mulheres dionisíacas. Ao contrário do que se possa pensar, o cerne das celebrações dionisíacas orgiásticas não era o mero impulso erótico.

Eurípides, nas Bacantes, deixa-nos claro que a fúria das Mênades em nada se relacionava com a excitação sexual, isso é explícito, por exemplo, quando o mensageiro narra a fúria de Agave quando ele tentou agarrá-la ${ }^{136}$. Segundo Nono, as bacantes escondiam uma serpente em baixo da roupa para se protegerem dos ataques concupiscentes dos homens ${ }^{137}$. Portanto, o amor dessas mulheres não se

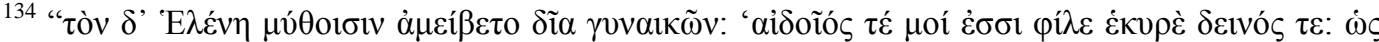

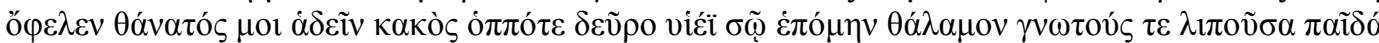

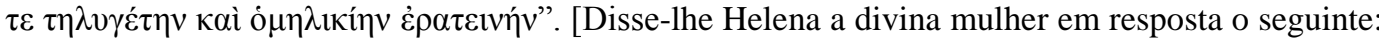
"Sinto por ti caro sogro respeito e vergonha a um só tempo. Bem melhor fora se a Morte terrível me houvesse levado antes de haver consentido em seguir o teu filho deixando o lar e o esposo minha única filha e as gentis companheiras"]. HOMERO. Ilíada, Canto III, versos 171-175.

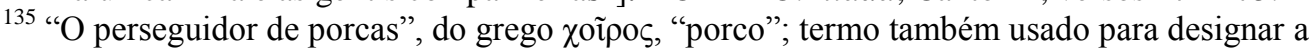
genitália femina.

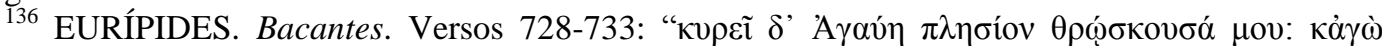

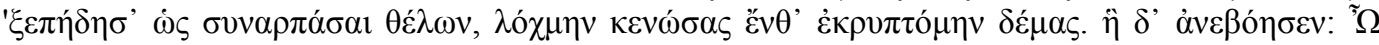

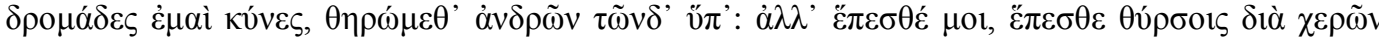
$\dot{\omega} \pi \lambda \iota \sigma \mu \varepsilon ́ v \alpha \iota$ ". [Ao meu alcance passou Agave saltando; Pretendendo agarrá-la, de um pulo, a moita deixei, onde oculto me encontrava. Ela clamou: "Ó céleres pernas minhas, por homens somos acossadas! Acorram, acorram, com vossas mãos armadas de tirso!]".

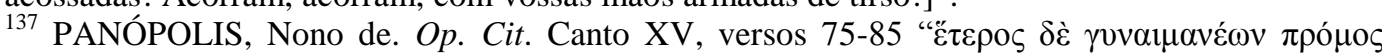

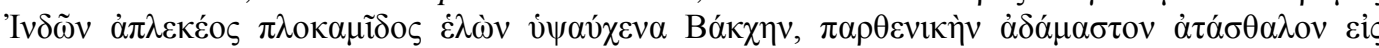


resumia à volúpia, mas sim, era caracterizado por uma índole mais excelsa. Para Otto $^{138}$, por trás da magia, da beleza, da maternidade, da música, da profecia e da morte encontramos a origem das mulheres dionisíacas; por isso, é inconcebível admitir que elas fossem movidas somente pela mesma prepotência do desejo erótico que movem os homens. Para o amor autenticamente feminino, os desejos são secundários e, invariavelmente, são suplantados diante do sublime sentimento maternal. As seguidoras de Dioniso são mães ou amas-de-leite, estas são suas efígies. Nos bosques, alimentam nos seios as crias selvagens. As Ninfas e Mênades sempre são representadas amamentando meninos, embora, Dioniso seja o rebento mais supremo.

Sem dúvida, presenciamos hoje mudanças de paradigmas que dissolveram as fronteiras tradicionais que delimitavam, nitidamente, as características fundamentais do que é ser homem e ser mulher. Todavia, historicamente, o homem foi qualificado como viril, criado para paixões egocêntricas; enquanto a natureza feminina reunia toda beleza, doçura, sensibilidade, sedução e espírito maternal, que protege e alimenta a terna vida. Seu sofrimento e cuidado revelam toda riqueza de sua essência. As mulheres dionisíacas representavam este universo feminino: Dioniso era, primeiramente, o tenro infante entregue por Zeus aos cuidados das ninfas, transformadas, então, em suas amas. Daí provém a

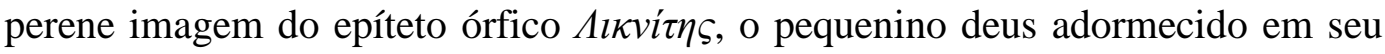
berço em forma de joeira, acordado e acalentado pelas Mênades no monte Parnaso. A criação de Dioniso, responsabilidade principalmente de mulheres, justifica seu caráter feminino e, como resultado, sua forma de amar distinta daquela convencional dos deuses e heróis legitimamente masculinos.

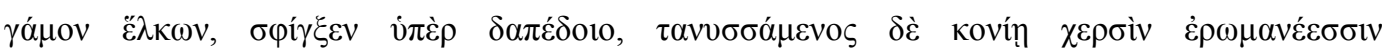

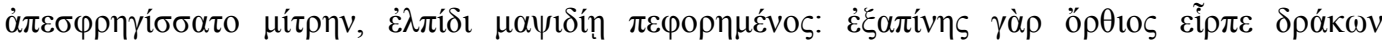

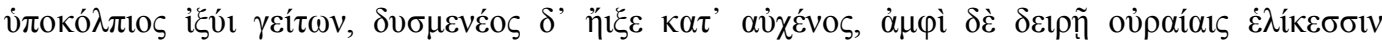

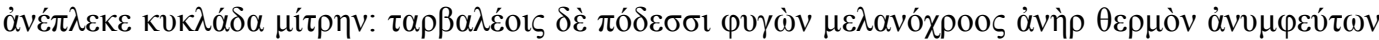

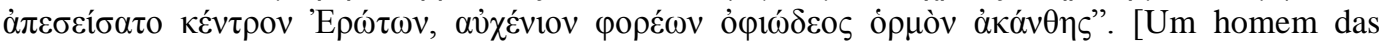
florestas, louco pelas mulheres, agarrou pelos cabelos uma Bacante, e arrastou a indomável donzela para uma união. Ele a aprisionava contra o solo, e estendido sobre a terra desabrochava seu vestido com mãos cheias de desejo. Quando, de repente, uma serpente que estava oculta no colo da garota ergueu a cabeça e se lançou contra o adversário. O animal enroscou em torno da garganta dando voltas em espiral e aquele homem moreno, escapando aterrorizado, esqueceu o ardente dardo do desejo não saciado, pois o pescoço estava comprimido e ameaçado por uma picada de serpente].

${ }^{138}$ Cf. OTTO, Walter F. Op. Cit. p. 130-131. 
O Tíaso era constituído, portanto, primordialmente, por mães e por amas-deleite. Conquanto, seria um erro afirmar que era totalmente casto o comportamento delas. Existia entre estas mulheres uma excitação selvagem e, em certo sentido, feroz; seguramente, havia uma licenciosidade. As companheiras de Dioniso refletiam um mundo feminino primitivo, onde não existiam normas e convenções iguais as de uma sociedade posterior, conhecidamente patriarcal e machista; elas sobrepujavam todos os valores provenientes da deusa do matrimônio, Hera. Os deveres conjugais, a submissão ao marido, o decoro doméstico não eram vistos como algo natural, longe disso, romper com estes preceitos, assumir o comando das ações, se dirigir aos cumes com tochas nas mãos, enchendo os bosques com gritos frenéticos, significava o retorno à primitiva natureza feminina. Por esta razão, Hera, e suas seguidoras, odeiam e perseguem Dioniso, desde o seu nascimento. Nessa perspectiva, as mulheres arrebatadas por Dioniso podem, certamente, ser comparadas às mulheres contemporâneas que lutam constantemente para se libertarem da histórica opressão masculina.

Como já dissemos, uma das principais marcas da epifania de Dioniso é a contradição e o paradoxismo. No tocante às mulheres, essa característica intensifica-se radicalmente: na figura protetora e carinhosa das mães e nutrizes que o acompanham, também se manifesta o horror e a destruição. Por mais que o amor seja traço essencial para essas mulheres, quando possuídas pelo delírio dionisíaco, elas se transformam em sanguinárias predadoras e despedaçam aquilo a que mais amam: a tenra vida. A imagem da mãe que, arrastada pelo gênio maligno do deus, sacrifica do modo mais cruel o próprio rebento, se repete das mais variadas formas, sempre com tons terríficos. Outra estória - além das que já mencionamos - conta a vingança de Procne que cozinhou o próprio filho para servir como refeição ao marido que teria violentado sua irmã, Filomena ${ }^{139}$. Os mitos dionisíacos que contêm o infanticídio e a omofagia, além de aludirem à perseguição e dilaceramento do jovem deus, também nos revela algo importante: a destruição sobrevém a todos que convivem ao redor de Dioniso.

\footnotetext{
${ }^{139}$ O Rei de Atenas Pandíon, após obter sucesso em uma guerra graças à ajuda do rei Tereu da Trácia, oferece como recompensa a mão de sua filha Procne. O casal tem um filho, Ítis. No entanto, Tereu se apaixona pela cunhada Filomena e a violenta. Para que a jovem não pudesse dizer o que aconteceu, corta-lhe a língua. Filomena borda em uma tapeçaria o próprio infortúnio e envia à irmã. Procne, no dia de Dioniso, festa onde as mulheres poderiam sair sem a vigilância dos maridos, liberta Filomena e, enfurecida, mata o filho e serve a carne ao pai. Em seguida foge com a irmã. Cf. BRANDÃO, Junito de Souza. Dicionário mítico-etimológico. p. 263.
} 
A destruição é símbolo indissociável da manifestação dionisíaca. Todos que estabelecem parentesco com Dioniso são acometidos por alguma forma de terrível desmantelamento; a contar por sua mãe, "arrasada pelo fogo, sem sequer haver chegado a contemplar o sorriso de seu filho celestial"140; seguida pelas ninfas, suas amas, que entretidas com o menino divino são surpreendidas por Licurgo, que se lança contra elas empunhando uma "maça de touro", o tradicional machado duplo utilizado nos sacrifícios, promovendo, com isso, um banho de sangue ${ }^{141}$. Sem mencionarmos os vários homens e mulheres que tiveram suas vidas destruídas ao se defrontarem com os delírios do deus. Até mesmo o seu nascimento está envolto num trágico dilaceramento. Esse lado obscuro, que acompanha todas as personagens dionisíacas, demonstra os aspectos mais profundos da existência, a divindade exalta a vida em sua complexidade oferecendo, aos seus, um misto de bênçãos e delícias seguidas de horror e destruição. O prazer no destruir: destrói-se o superficial para deparar-se com os abismos do Ser.

Ao descrevermos a ligação com o feminino, não podemos deixar de anotar que Dioniso é o "deus dos mistérios", portanto, seu séquito não poderia ser outro, senão formado, majoritariamente, por mulheres. Suas seguidoras são iniciadas nos segredos da vida e, por consequência, são o símbolo máximo do que é "misterioso". Não são poucas as alegorias que vinculam o "secreto" com o feminino; dentre elas, podemos destacar a imagem da Esfinge, efígie suprema dos enigmas. Esse ser híbrido, busto de moça e corpo de besta feroz, encerra, em si mesma, sempre um duplo sentido: beleza e ferocidade; sedução e horror; porém sua natureza é, indiscutivelmente, feminina e sua simbologia é, certamente, o oculto. Por isso, é descrita em Édipo Rei como a "virgem de garras curvas $e$ cantos misteriosos" ${ }^{142}$. A existência da Esfinge está intimamente conectada à manutenção do mistério, uma vez que Édipo desvenda os seus "versos tenebrosos" ${ }^{\text {,143 }}$, o animal se joga do precipício. Ora, se o enigma foi desvendado e se não há mais o segredo, já não há mais um sentido para a fera continuar vivendo.

\footnotetext{
${ }^{140}$ OTTO, Walter F. Op. Cit. p. 132.

${ }^{141}$ Cf. KERÉNYI, Carl. Dioniso: imagem arquetípica da vida indestrutível. p. 153-154.

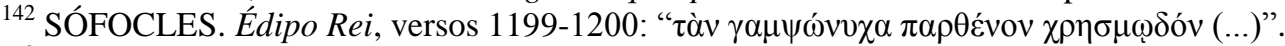

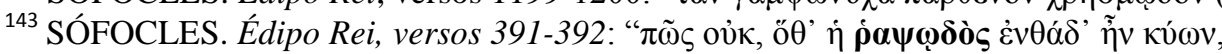

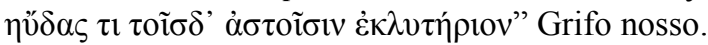


Além da Esfinge, outro símbolo feminil para "o insondável” é a deusa Isis. Considerada a divindade iniciadora dos mistérios da vida e da morte, encarna, na mitologia egípcia, o princípio feminino. Segundo Plutarco, na cidade egípcia de Sais encontrava-se o templo erguido a Isis, onde havia a inscrição: "Eu sou tudo, o que há, o que será; nenhum mortal jamais levantou meu véu"144. Por trás do véu de Isis encontraríamos o espírito da Verdade, aos mortais, perenemente, oculto. Inspirado nesta inscrição, Schiller escreve o poema A imagem velada de Sais $^{145}$, o qual põe em cena um jovem tomado pelo desejo de observar por trás do véu da deusa, porque o hierofante havia lhe dito que ali se escondia a Verdade. Ele entra à noite no templo e, a fim de desvendar os enigmas do existir, desvela a estátua. Foi encontrado inconsciente no dia seguinte e, mergulhado em tristeza profunda, morre sem nunca ter dito o que descobriu. Os segredos da existência são guardados por uma entidade essencialmente feminina. As mulheres, por analogia, são inescrutáveis. Quando miramos os olhos de uma mulher, só enxergamos o mistério.

A ligação, inseparável, entre as mulheres e o mistério é ainda mais nítida quando evidenciamos as Pítias, sacerdotisas do Oráculo de Delfos, responsáveis por anunciar as mensagens divinas em ritos proféticos, mas sempre de forma enigmática, ou seja, nunca anunciavam a Verdade celestial de forma esclarecedora, apenas davam sinais, muitas vezes, incompreensíveis. Sabemos que as Pítias profetizavam inspiradas por Apolo, todavia, o deus da luz era, no fundo, um intruso em Delfos, o primeiro senhor do santuário foi Dioniso ${ }^{146}$. Dos cultos extáticos dionisíacos nasce a "mântica do entusiasmo"147, espécie de profecia que, diferentemente dos profetas homéricos, não necessitava aguardar diversos signos da vontade divina, mas atingia o mundo dos deuses por meio do entusiasmo. As Mênades foram o veículo de entrada desse tipo de mântica no Oráculo de Delfos. Apolo, só com o tempo, substitui sua antiga prática de adivinhação por meio da

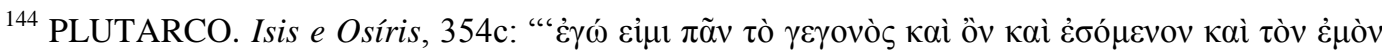

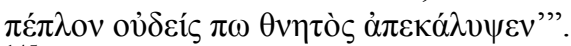

${ }^{145}$ Das verschleierte Bild zu Saïs.

146 "Es war im Alterthum unvergessen, dass in Delphi, dem strahlenden Mittelpunkt seines Cultus, Apollo ein Eindringling war; unter den älteren Göttergewalten, die er dort zurückdrängte, wird auch Dionysos genannt" [Nunca foi esquecido na antiguidade que em Delfos, o centro radiante de sua adoração, Apolo era um invasor; entre os deuses mais antigos que ele expulsou, também estava Dionísio]. ROHDE, Erwin. Op. Cit. p. 341-342.

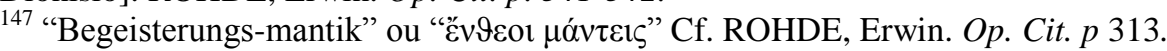


intepretação de signos para abraçar a mântica através do êxtase, incorporando assim, em sua própria religião um elemento dionisíaco.

Por conseguinte, a prática das Pítias era, em essência, dionisíaca. Essas profetisas eram escolhidas quando crianças e mantidas virgens para a arte profética. Durante os rituais respiravam o hálito inebriante que saía das rachaduras da terra, neste momento de arrebatamento tudo que a Pitonisa proclamava, com sua frenética boca, era como se fosse anunciado pelo próprio deus através dela. Também era comum às Pítias ingerir substâncias narcóticas que as colocavam em estado de है $\vee \vartheta \varepsilon o \varsigma$, elas poderiam apenas mastigar folhas com propriedades excitantes ou, até mesmo, beber o sangue de animais sacrificados ${ }^{148}$. Nesse momento, a sacerdotisa e a divindade se tornavam um; os versos oraculares vinham do Ser do próprio deus. Entretanto, a Verdade proferida era sempre obscura, por mais avassaladora que fosse a revelação, era dita em tons nebulosos; aquilo que se anuncia é, no sentido estrito do termo, um oráculo ${ }^{149}$. Era necessário interpretar a voz misteriosa dessas mulheres sacras, ou se perder como Édipo. Contudo, queremos chamar a atenção para Pítia como mais um símbolo feminino do mistério.

Dioniso escolhe a companhia das mulheres - e muitas vezes ele próprio está revestido com características femininas - porque nos seus caminhos prevalece o desconhecido, o oculto. A cada máscara retirada, encontra-se sucessivamente outra, e no âmago, há apenas o enigmático. O deus evoca, em cada um que segue seus preceitos, uma Verdade que só pode ser "representada" por um ser feminil, pois ela é, em essência, inescrutável. Por conseguinte, é importante ressaltar que esse mesmo raciocínio sobre o feminino está presente no pensamento nietzschiano. Não são poucas as referências do filósofo às mulheres; poderíamos afirmar, sem dúvida, que existe uma filosofia da mulher e do feminino no autor.

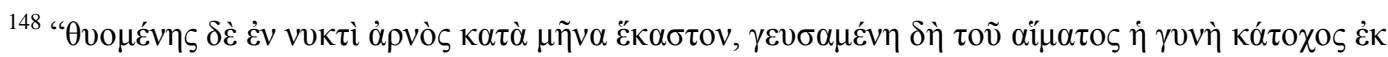

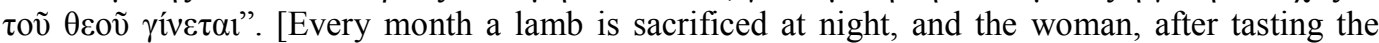
blood, becomes inspired by the god]. PAUSÂNIAS. Op. Cit. [XXIV.1.1].

${ }^{149}$ O termo Oráculo origina, do latim, Oraculum, formado pelo verbo "Orare" (falara, orar) e pelo sufixo "culus/culum" (adjetivo diminutivo como em "versículo"). Em nossa interpretação, "aquilo que se fala, mas de forma curta", ou seja, uma Verdade avassaladora, conquanto dita em poucas palavras; aquilo que sai da boca em tons divinatórios. Lembrar da anedota sobre a morte de Ésquilo: o dramaturgo consultou o Oráculo e este profetiza que morreria enquanto estivesse dormindo e uma casa caísse em sua cabeça. Tentando fugir do agouro, Ésquilo passa a dormir no relento, quando um dia lhe atinge na cabeça uma tartaruga, vinda das garras de uma águia.
} 
No entanto, por hora, concentrar-nos-emos apenas na "mulher" enquanto imagem nietzschiana para o insondável, a fim de compará-la com a epifania dionisíaca. Para tal, inicialmente, recorreremos à metáfora que inaugura a obra Além do bem e do mal, onde nas primeiras linhas, Nietzsche utiliza-se de uma suposição, em forma de pergunta, identificando a Verdade como uma mulher:

Supondo que a Verdade seja uma mulher - não seria bem fundada a suspeita de que todos os filósofos, na medida em que foram dogmáticos, entenderam pouco de mulheres? De que a terrível seriedade, a desajeitada insistência com que até agora se aproximaram da Verdade, foram meios inábeis e impróprios para conquistar uma dama? ${ }^{150}$

A provocação de Nietzsche com a imagem da Verdade feminina é, antes de tudo, uma crítica à postura, predominantemente, dogmática da filosofia. Afirmar que a Verdade é mulher significa dizer que ela é misteriosa, sedutora e, parodiando Heráclito, ama se esconder. Assim sendo, essa "donzela" se furta ao objetivo dogmático de posse absoluta; jamais os filósofos a conquistariam, pois o exacerbado desejo de conquista os impediram de perceber as nuances do que é convencionalmente feminino - o mistério. Para Nietzsche, a "Verdade-mulher" compreende as principais virtudes feminais: é artista da dissimulação, gênio dos ornamentos, superficial 151 . Portanto, é inaceitável a "vontade de Verdade, de 'Verdade a todo custo', esse desvario adolescente no amor à Verdade"152; características que se tornaram evidentes na história da filosofia e dos sistemas metafísicos. Nessa perspectiva, não é possível crer que a Verdade continue Verdade quando se lhe retira o véu; precisamente, porque a natureza ${ }^{153}$ se esconde atrás de enigmas e incertezas e, como mulher, tem razões para não deixar ver suas razões ${ }^{154}$.

No prólogo de A Gaia ciência, a "Verdade" da suposição nietzschiana, "Vielleicht ist die Wahrheit ein Weib" "155, ganha a sugestão de um nome grego: Baubo $[B \alpha v \beta \omega ́]$, a divindade que teria alegrado Deméter em meio a seu pranto. Baubo é um nome derivado do verbo $\beta \alpha v \beta \alpha ́ v$, "fazer dormir", o ofício da "babá".

\footnotetext{
${ }^{150}$ NIETZSCHE. Além do bem e do mal. Prólogo.

${ }^{151}$ Cf. NIETZSCHE. A Gaia Ciência, §361 artistisch; Além do bem e do mal, §145 Genie des Putzes; \$232 Oberflächliches, respectivamente.

152 NIETZSCHE. A Gaia Ciência, Prólogo, \$4.

153 Para Nietzsche a mulher enquanto mistério simboliza indissociavelmente a Verdade [die Wahrheit], a natureza [die Natur] e a vida [das Leben].

${ }^{154}$ Cf. NIETZSCHE. Idem.

155 "Talvez a verdade seja uma mulher".
} 
Era uma divindade estranhamente representada sem cabeça e com o rosto no torso. De acordo com a mais conhecida de suas lendas, depois de Perséfone ter sido sequestrada e levada ao submundo por Hades, sua mãe, Deméter, acompanhada pelo pequeno Íaco, percorreu a terra inteira em sua procura. Desesperada por não encontrá-la, a deusa do cultivo não para de chorar, tornando o solo alagado e infértil. Baubo, para consolá-la, levanta e abaixa a saia em um lapso, exibindo-lhe a jocosa genitália. Íaco aplaudiu o gesto grosseiro e Deméter gargalha cerrando o pranto ${ }^{156}$. Mas por que Nietzsche escolhe "Baubo" como nome grego para a Verdade? Em primeiro lugar, porque se trata de uma deusa, por excelência, feminina. Em segundo, porque a divindade tanto revela quanto esconde os mistérios mulheris.

Baubo, apesar de possuir um corpo disforme para os padrões antropomórficos - não possui cabeça, às vezes é representada com os olhos nos seios e a boca como a própria vagina - é uma figura feminina. Considerada a deusa do ventre e do humor obsceno. Diferente de outras deusas, sua feminilidade não está ligada à fertilidade materna, mas precisamente, à fisiologia de seu corpo e à ausência de pudor na protuberância de seus órgãos sexuais. Para Nietzsche, é a representação perfeita para a "Verdade-mulher", pois ao levantar a saia, a divindade se revela, embora muito ainda permaneça oculto. A saia de Baubo corresponderia ao fino véu de Isis, quando levantado, ressaltaria o caráter abissal da Verdade. E diante da impossibilidade de acesso total aos segredos da realidade, se alegra e sorri. O levantar da saia também alude ao termo grego $\dot{\alpha} \lambda \dot{\eta} \theta \varepsilon l \alpha$, que se convencionou a ser traduzido como "Verdade". Porém, o sentido estrito da palavra, transmite a ideia de "desencobrimento" ou "não-velamento". Na medida em que algo é desvelado, como em um jogo intrínseco, parte ainda se resguarda encoberto.

Nietzsche, em alguns momentos de sua obra, denomina a Verdade como uma velha senhora, de horrível aparência, como por exemplo, no aforismo 377 de A Gaia ciência, onde indaga: "Já existiu velha mais medonha, entre todas as velhas - (deveria então ser "a Verdade": uma questão para filósofos)""157. Essa

\footnotetext{
${ }^{156}$ Cf. BRANDÃO, Junito de Souza. Dicionário mítico-etimológico. "Baubo”, p. 100.

157 "Gab es je noch ein scheusslicheres altes Weib unter allen alten Weibern? (- es müsste denn etwa "die Wahrheit" sein: eine Frage für Philosophen)". Ver também Fragmento póstumo de 1888,
} 
imagem indica que a Verdade se mantém oculta justamente por ser pavorosa, sua feição repulsiva exige que seja encoberta pelo véu da aparência e da arte. Respeitar esse pudor seria, segundo Hadot, "respeitar a medida que permite coexistir a vontade de verdade e a vontade de aparência, que assim permite apreender que verdade e mentira, morte e vida, horror e beleza são indissolúveis" ${ }^{\text {"158 }}$. Por outro lado, nós não podemos considerar Baubo apenas como mulher horripilante; contraditoriamente, a metáfora nietzschiana indica que a deusa também é sedutora, leve, graciosa e evocadora do riso. Tais características são decorrentes de sua natureza misteriosa; Baubo é o nome perfeito para a Verdade, pois revela que a Verdade é mulher e, por sua vez, é mulher porque é misteriosa.

Os atributos de Baubo estabelecem uma forte ligação com certas peculiaridades de Dioniso. Ambos são considerados potências obscuras, que se revelam ao mesmo tempo em que se escondem: um com a máscara e a outra com a saia. As divindades são, no contexto nietzschiano, tipologias afirmativas ligadas ao alegrar-se e ao sorriso. Sem mencionar que os dois admitem, em si mesmos, a contradição. Além disso, se Dioniso é o feminino deus das mulheres, é porque nelas se estampa o mistério. Da mesma forma, se Baubo é o nome de mulher para a Verdade, é porque ela só pode ser entendida como mistério. Percebemos, portanto, uma fórmula no pensamento nietzschiano que anela, sob o mesmo campo semântico, "mulher-mistério-verdade". No entanto, há outra imagem na obra de Nietzsche, muito similar a essa da fórmula, que ressalta sua visão de mulher enquanto símbolo do enigmático; trata-se da imagem descrita no belíssimo aforismo Vita femina, de A Gaia ciência, o qual citamos integralmente devido à sua admirável estilística poética e ao conteúdo fundamental para nossa argumentação:

Vita femina [A vida é uma mulher] - Para ver a beleza última de uma obra não bastam todo o saber e toda a disposição; os mais raros e felizes acasos são necessários, para que o véu de nuvens se afaste uma vez desses cumes e nós os vejamos refulgir ao sol. Não apenas devemos estar no lugar certo para presenciar isso: nossa alma teve de arrancar ela própria o véu de suas alturas e necessitar de uma expressão e símbolo exterior, como que para ter um ponto de apoio e continuar senhora de si. Mas é tão raro que tudo isto suceda ao mesmo tempo, que me inclino a crer que as maiores alturas de tudo o que é bom, seja de uma obra, um

16[40, 6]: "Die Wahrheit ist häßlich: wir haben die Kunst, damit wir nicht an der Wahrheit zu Grunde gehn". [A Verdade é feia: temos a arte para não perecer por causa da Verdade].

${ }^{158}$ HADOT, Pierre. O Véu de Isis - Ensaio sobre a história da ideia de natureza. p. 317. 
ato, a humanidade, a natureza, permaneceram algo oculto e velado para a maioria e mesmo para os melhores dos seres humanos até hoje: - o que se revela para nós, no entanto, revela-se-nos apenas uma vez! — Os gregos bem que rezavam: "Duas e três vezes tudo o que é belo!”. Ah, eles tinham aí uma boa razão para evocar os deuses, pois a profana realidade não nos dá o belo, ou o dá somente uma vez! Quero dizer que o mundo é pleno de coisas belas, e contudo pobre, muito pobre de belos instantes e revelações de tais coisas. Mas talvez esteja nisso o mais forte encanto da vida: há sobre ela, entretecido de ouro, um véu de belas possibilidades, cheio de promessa, resistência, pudor, desdém, compaixão, sedução. Sim, a vida é uma mulher! ${ }^{159}$

A Vida é uma mulher na medida em que, tanto uma como a outra, são enigmáticas e, deveras, inescrutáveis. A mulher descrita aqui, se esconde por baixo do véu que deixa transparecer, sutilmente, a beleza feminil de seu rosto, porém, sem o deixar refulgir completamente. Assim também é a Vida, não se permite perscrutar, pelo contrário, é exímia sedutora, justamente, em virtude de seu pudor e seus mistérios. Cobiçamos a Vida assim como os apaixonados cobiçam suas musas, mas tal qual a donzela que permanece inatingível em seu pedestal, a Vida se mantém incognoscível; é impossível fazer dela objeto de conhecimento, principalmente porque é volúvel e assustadoramente imprevisível. É exatamente essa natureza impetuosa, que torna inexequível a previsão futura, até mesmo a temporalmente mais breve, que faz, segundo Nietzsche, a Vida mais encantadora. Assim experimentou o personagem Zaratustra: "Em teus olhos olhei há pouco, ó vida! E parecia que eu afundava no insondável”160. Mirá-la com a pretensão do cálculo é fado já fracassado, pois nos seus olhos reflete apenas o abismo do eu.

Ainda que nossa intenção seja, tão somente, ilustrar que, para Nietzsche, o mistério é um dos aspectos mais intrínsecos à mulher, e com isso, estabelecer um parentesco entre o pensamento nietzschiano e o culto dionisíaco, predominantemente mulheril; devemos explicar que o "feminino" é um tema complexo para o filósofo e muitas vezes ambíguo, se não, paradoxal. Em alguns textos podemos encontrar ideias aparentemente misóginas ${ }^{161}$, contudo, essas ideias, de nenhuma forma, devem ser consideradas definitivas. Pelo contrário, há diversos elogios à mulher e ao femíneo ao longo de sua obra. Em Ecce homo, por

\footnotetext{
${ }^{159}$ NIETZSCHE. A Gaia Ciência, §339.

${ }^{160}$ NIETZSCHE. Assim falou Zaratustra - O canto da dança. p. 103. No original se lê: "In dein Auge schaute ich jüngst, oh Leben! Und in's Unergründliche schien ich mir da zu sinken".

${ }^{161}$ Cf. Além do bem e do mal. \$239.
} 
exemplo, o filósofo supõe que seu conhecimento sobre as "pequenas mulheres" [Weiblein] é parte de seu dom dionisíaco, e se reconhece como o primeiro psicólogo do "eternamente-feminino"162. As imagens que Nietzsche traz à reflexão sobre o feminino são, muitas vezes, atreladas à mitologia dionisíaca ${ }^{163}$, e como não poderia deixar de ser, recorre, em vários momentos, a Ariadne, eterna amante de Dioniso, como figura alegórica de sua filosofia. Por isso, e pela importância da personagem no dionisismo, nosso próximo tema será sobre Ariadne.

\section{7.}

\section{Ariadne e seus amores labirínticos:}

Ariadne é conhecida, expressamente, como esposa de Dioniso. De acordo com a maioria dos relatos, nasceu como uma princesa mortal, mas devido ao amor de seu divino amante, recebe a graça de compartilhar com ele a imortalidade com perene juventude; tal qual ocorrera com Sêmele na qualidade de mãe: foi resgatada do Reino dos mortos pelo filho e agraciada, por Zeus, com a vida eterna entre os deuses olímpicos. Dentre as lendas que mencionam Ariadne, prevalecem

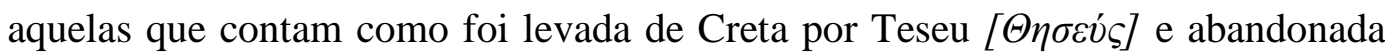
na orla deserta de uma ilha, entretanto, em meio aos seus lamentos, escuta as frenéticas vozes do séquito báquico, quando Dioniso lhe aparece e a enaltece como a soberana de seu reino. Em outras narrativas, já era a amante do deus quando Teseu chegou à Creta para, em segredo, fugirem, mas durante a fuga, teve que pagar por sua infidelidade com um terrível fim. Ariadne representa a essência

\footnotetext{
162 "Posso, aliás, arriscar a suposição de que conheço as mulherezinhas? É parte de meu dom dionisíaco. Quem sabe? Talvez eu seja o primeiro psicólogo do eterno-feminino. Todas elas me amam - uma velha história: excetuando as mulherezinhas vitimadas, as "emancipadas", as não aparelhadas para ter filhos.”. NIETZSCHE. Ecce homo - Por que escrevo livros tão bons. §5. p. 56.

${ }^{163}$ Podemos ler, por exemplo: "Felizmente não estou disposto a deixar-me despedaçar: a mulher realizada despedaça quando ama... Eu conheço essas adoráveis mênades... Ah, que perigoso, insinuante, subterrâneo bichinho de rapina! E tão agradável, além disso!... Uma pequena mulher correndo atrás de sua vingança seria capaz de atropelar o próprio destino". idem.
} 
da mulher dionisíaca e da imagem perfeita da beleza, porém, assim como as Mênades, seu caminho transita entre a alegria, a dor e a morte ${ }^{164}$.

Outro aspecto do mito e do culto que permitem reconhecer uma afinidade entre Ariadne e o cortejo de Dioniso é sua predileção pela dança: segundo a descrição homérica do escudo de Aquiles, Hefesto havia talhado, no objeto de guerra, um recinto com piso de dança, muito semelhante ao que Dédalo havia feito no palácio de Knosso em louvor de Ariadne, a formosa de tranças venustas $^{165}$. De acordo com a Odisseia ${ }^{166}$, ela era filha do "maligno Minos", rei que havia ordenado a Dédalo a construção do labirinto para aprisionar o Minotauro. Homero conhecia a história de como Teseu e seu bando de sete garotos e sete garotas foram salvos graças ao famoso novelo que a princesa segurava na mão ao executar complexas danças. O novelo foi dádiva da donzela, e ela só consegue salvá-los, conduzindo-os à saída do labirinto, devido às danças executadas através de voltas e contravoltas. Isso nos revela duas coisas: em primeiro lugar, que Ariadne foi exaltada como a "Senhora do labirinto"; em segundo lugar, que o labirinto era tanto um local de dança, como um lugar de morte.

Pautado em uma plaqueta minoica encontrada em Knosso, Kerényi defende a existência de uma grande figura feminina do mundo dionisíaco; embora não se encontre nenhum nome próprio, Kerényi assevera que se trata da primeira personagem divina da mitologia grega que pôde ser reconhecida em Creta. Na plaqueta de argila encontra-se a seguinte inscrição em Linear B: pa-si te-o-i / meri ... da-pu-ri-to-jo / po-ti-ni-ja me-ri; o que equivaleria em grego antigo: " $\pi \tilde{\alpha} \sigma l$

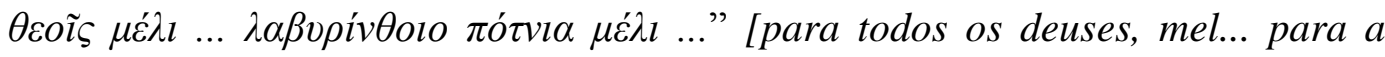
senhora do labirinto, mel $]^{167}$. De acordo com os termos usados, a mesma quantidade de mel é representada pela figura de um vaso, de um lado em oferenda a "todos os deuses"; e do outro lado, em oferenda à "Senhora do labirinto". Isso indicaria, caso a plaqueta faça referência a Ariadne, que ela foi uma grande deusa. Contudo, tal indicação é contraditória, pois, se de um lado seu parentesco mais

\footnotetext{
${ }^{164}$ Cf. OTTO, Walter F. Op Cit. p. 133.

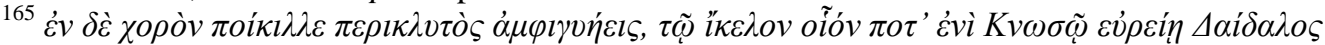

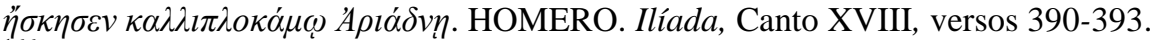

${ }^{166}$ HOMERO. Odisseia, Livro XI, versos 321-322.

${ }^{167}$ KERÉNYI, Carl. Op. Cit. p. 79.
} 
próximo é com Afrodite, "o divino arquétipo da graça" $" 168$, então, de outro lado, ela é mortal, uma vez que, na mais famosa de suas lendas, foi morta por Ártemis a pedido de Dioniso.

No que diz respeito a sua relação com Afrodite, Plutarco nos documenta que

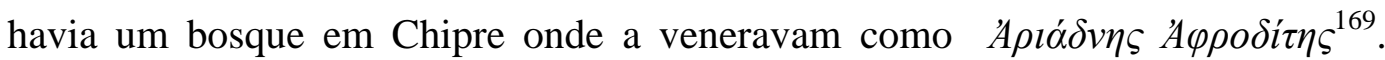
Também podemos perceber um forte vínculo entre elas, se analisarmos o nome "Ariadne": sua origem é uma variação dialetal de Ariagne, proveniente do predicado " $\alpha \gamma v \eta$ "; segundo Otto, predicado que se aplicava, precisamente, a Afrodite. Para mais, o termo deve ser traduzido como "inatingível" ou "intacta", evitando conotações equivocadas de âmbito religioso e moral, tais como "santíssima” ou "pura". Com o termo " $\alpha \gamma v \eta \eta$ " devemos pensar na intangibilidade da natureza afastada do homem e, por denotar proximidade ao divino, associa-se ao que é digno de veneração. Esse predicado, diz Otto, é atribuído exclusivamente às divindades femininas e, tão somente, àquelas que pertencem ao misterioso reino da terra, da água, do devir e da morte ${ }^{170}$. Sabendo disso, podemos estabelecer um vínculo de Ariadne, não só com Afrodite, mas igualmente, com Ártemis, Perséfone (ou Kó $\eta$ ) e Deméter, pois há uma afinidade de natureza que liga todas elas.

Em Ariadne se reflete Ártemis, Afrodite e, como demonstra seu triste fim e seu sinistro culto, a deusa da morte, Perséfone. Em relação a Ártemis, encontramos na natureza de Ariadne a imagem da "deusa sempre virgem", ou da donzela que não pôde consumar o casamento ${ }^{171}$, seja porque foi abandonada por Teseu, ou seja, porque morre antes de se casar com Dioniso, obrigando-o a resgatá-la no submundo. A imagem da princesa é sempre de grande beleza vestal, e sua castidade é sugerida, até mesmo, pelo significado de seu nome. Essa característica faz com que seja vista também como uma "Afrodite mortal". Por

\footnotetext{
${ }^{168}$ OTTO, Walter F. Op Cit. p. 134.

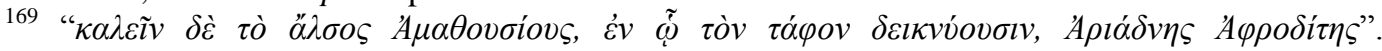
PLUTARCO. Theseus, 20.4.

${ }^{170}$ Cf. OTTO, Walter F. Op Cit.

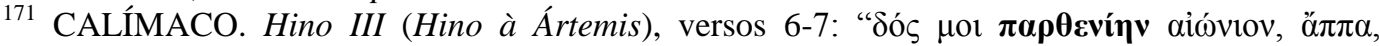

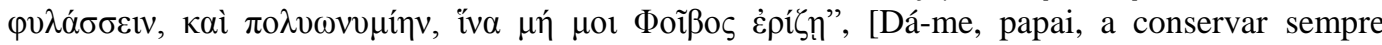

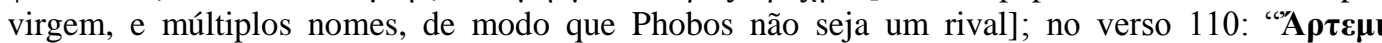

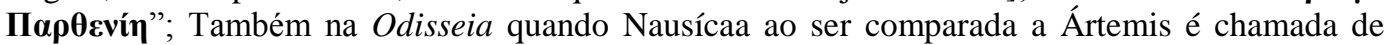

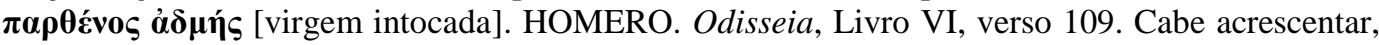

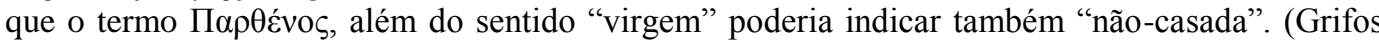
nosso).
} 
essa razão, fora de Creta, tomou a forma da deusa do amor. Em outra versão da história do labirinto, contada por Plutarco, foi Afrodite a guia de Teseu em sua jornada $^{172}$. Todavia, não estava a deusa em todo seu divino esplendor guiando o herói; ou ela conduziu Ariadne com seu poder, ou encarnou na filha do rei para tal missão. Outro relato afirma que Ariadne teria dado uma estátua de Afrodite a Teseu, fazendo com que os libertos executassem a dança do labirinto em sua honra $^{173}$.

Ainda assim, dentre as grandes deusas a quem Ariadne espelha, é com Perséfone que tem mais similitude, podemos dizer, sem exagero, que elas são uma só pessoa ${ }^{174}$. Isso porque é indissociável do mito, tanto de uma como da outra, o declínio ao Mundo inferior. O principal relato sobre o falecimento de Ariadne é feito na Odisseia ${ }^{175}$, nessa passagem a heroína, filha do pernicioso Minos, foi noiva infiel de Dioniso. Apaixonada por Teseu, foge em sua companhia de Creta aos montes sagrados de Atenas, mas na praia da ilha $\Delta$ in é abandonada pelo amado e, em seguida, é morta por Ártemis - a deusa que pune mulheres pela perda da virgindade, ou pela infidelidade, com as dores do parto e a morte no delivramento - após ser denunciada por Dioniso. A descrição de Homero só pode ser plenamente compreendida se presumirmos que existia uma relação estreitamente amorosa entre o deus delator e Ariadne; ela seria sua primeira esposa, ou, ao menos, ele teria um desejo intenso de possuí-la e, como estratégia, testemunhou contra a moça, já visando a salvá-la do ínfero mundo.

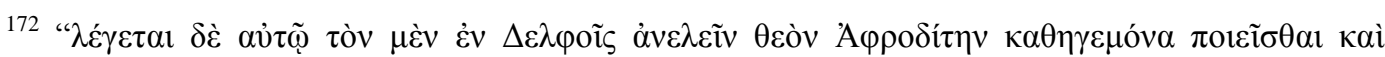

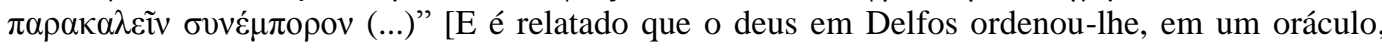
para fazer Afrodite sua guia, e convidá-la a acompanhá-lo em sua jornada (...)] PLUTARCO. Theseu, 18.2.

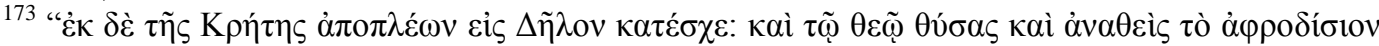

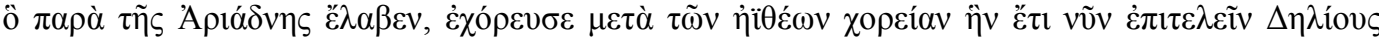

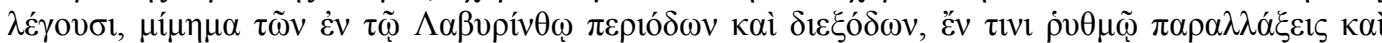

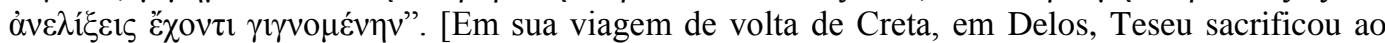
deus e dedicou em seu templo a imagem de Afrodite que tinha recebido de Ariadne, dançou com seus jovens uma dança que dizem é ainda executada por aquele povo, sendo uma imitação das passagens circulares no Labirinto, e consistindo de certas involuções e evoluções rítmicas. Ibidem, 21.1.

${ }^{174}$ Cf. KERÉNYI, Carl. Op. Cit. p. 94.

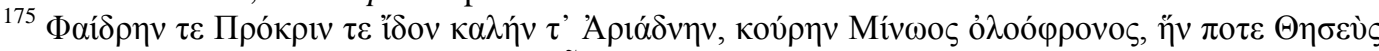

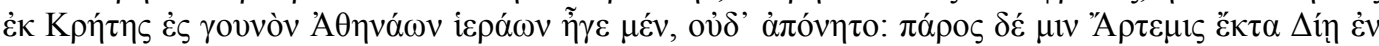

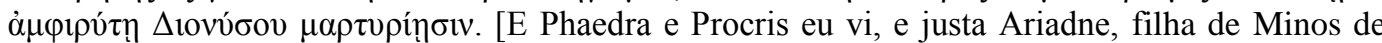
espírito pernicioso, a quem uma vez Teseu se viu forçado a levar de Creta para a colina sagrada de Atenas; mas ele não tinha alegria por ela. Por causa do testemunho de Dionísio, Ártemis matou-a no mar de Dia] HOMERO. Odisseia, Livro XI, versos 321-325.
} 
Eurípides, na tragédia Hipólito, confirma tal casamento, quando Fedra, irmã

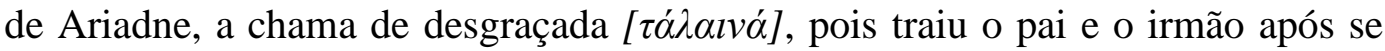
apaixonar por Teseu, embora fosse esposa de Dioniso ${ }^{176}$. Portanto, sua morte seria realmente um castigo aplicado por Ártemis devido à sua infidelidade; isso nos leva a crer que ela estava grávida durante sua passagem em Día. Tal infortúnio, a coloca em paralelo com outras duas histórias de partos tétricos: primeiro com o nascimento do próprio Dioniso, é clara a analogia da morte de Ariadne com o parto prematuro de Sêmele, que foi consumida pelo raio de Zeus. A segunda analogia pode ser feita com a morte de Corônis, a mãe de Asclépio. Corônis havia sido fecundada por Apolo, e mesmo ele colocando um corvo branco para guardála, ela o traíra com um amante mortal. Como consequência, a pedido de Apolo, também foi flechada por Ártemis e morreu antes mesmo de parir Asclépio; no entanto, o rebento foi retirado pelo divino pai do útero materno já falecido. Como castigo, o deus transformou a branca ave no corvo negro ${ }^{177}$.

Apesar dos relatos sobre as peripécias de Ariadne não serem contundentes, ou seja, existem diversas histórias, que não são concordes entre si. Plutarco narra diferentes acontecimentos em Día [ou Nógov] ${ }^{178}$ : em uma das versões ela se enforcou [ $\dot{\alpha} \pi \dot{\alpha} \gamma \xi \alpha \sigma \theta \alpha i]$ porque foi abandonada por Teseu; outra conta que ela foi levada à Día pelo marinheiro de Dioniso, Oivó $\rho \omega$, pois Teseu amava intensamente Aigle $\left[A i_{y} \gamma \lambda \eta\right]^{179}$. Há também o conto do casal que viajava em um barco e durante uma tormenta saem de seu curso. Teseu, temendo a segurança de Ariadne, que estava grávida, leva-a para a terra firme. No entanto, ao socorrer a nau nas fortes ondas, é arrastado novamente para o mar. As mulheres da ilha, portanto, levaram-na em seus cuidados, tentando consolá-la da solidão, traziamlhe cartas forjadas, como se fossem escritas por Teseu, todavia, nada adiantou, morreu com dores no trabalho de parto e foi enterrada com o filho no ventre ${ }^{180}$. Dizia também que Teseu voltou, e, muito aflito, deixou uma soma em dinheiro

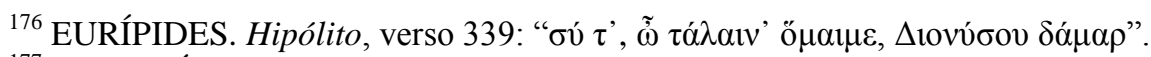

${ }^{177}$ Cf. KERÉNYI, Carl. Op. Cit. p. 93-99. Também em OTTO, Walter F. Op Cit. p. 134-135

${ }^{178}$ Os náxios declaravam que os invasores trácios teriam chamdo Naxos originalmente de Día. Cf. SíCULO, Diodoro. Biblioteca histórica. Livro V, 51. 2-3.

${ }^{179}$ PLUTARCO. Theseu, 20.1.

${ }^{180}$ Idem, 20.3.
} 
com o povo da ilha, ordenando-os a construir duas estátuas, uma de prata e outra de bronze, e oferecer sacrifícios a Ariadne ${ }^{181}$.

A partir dessas histórias, não podemos confirmar se Ariadne carregava um filho de Dioniso ou de Teseu. Apesar disso, elas demonstram que Ariadne desempenha um papel autenticamente feminino e intimamente ligado ao mito de Dioniso: a maternidade. O instinto maternal pode ser comprovado pelo terno vínculo que estabelece aos jovens salvos do labirinto graças à sua intervenção. Foi em honra a ela que os meninos e meninas resgatados dedicaram suas danças. Foi também pensando no elemento materno de Ariadne que na festa ateniense de

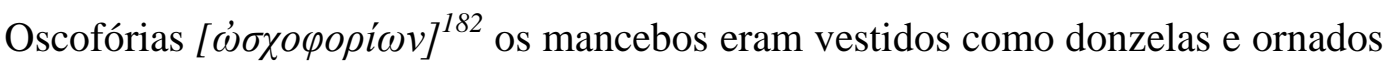
com uvas maduras, para que imitassem as mães dos recém-nascidos mortos. Uma variação dessa prática ocorria em um culto, de fundo dionisíaco, onde jovens garotos se deitavam e imitavam os gritos e os gestos de mulheres em trabalho de parto $^{183}$. Tais rituais eram inspirados em Ariadne, entretanto, possuíam, sem dúvida, a marca de Dioniso, o deus que veio da morte ao mundo, ainda como feto, “cujo primeiro movimento no ventre constitui a manifestação mais direta da vida - uma coisa que só as mulheres podem experimentar" ${ }^{\prime 184}$.

O aspecto lúgubre do mito de Ariadne a associa, como dissemos, a Perséfone, reconhecidamente, à "Senhora do submundo"" 185 . A intersecção entre

\footnotetext{
${ }^{181}$ Idem, 20.4.

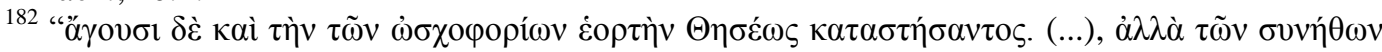

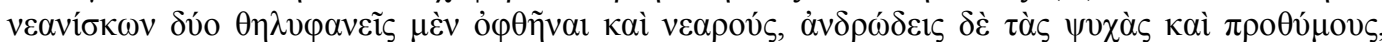

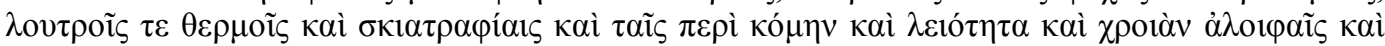

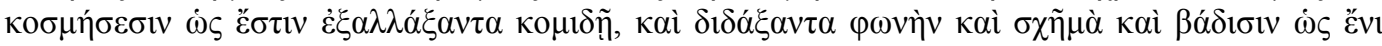

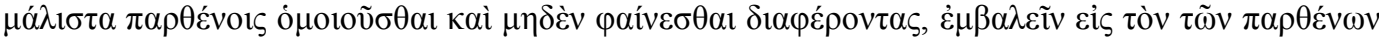

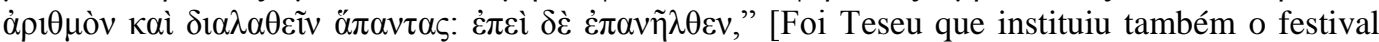
ateniense do Oscofória. (...), mas escolheu dois jovens que tinha caras novas e de menina, mas espíritos ansiosos e viris, e mudaram a aparência quase inteiramente, dando-lhes banhos e mantendo fora do sol, organizando seus cabelos, e, suavizando e embelezando suas peles com ungüentos; Ele também os ensinou a imitar donzelas, tanto quanto possível em seu discurso, seu vestido, e sua marcha, para não deixar nenhuma diferença que poderia ser observada, e depois os matriculou entre as moças que iriam a Creta, e não foi descoberto por ninguém]. PLUTARCO. Theseu, 23.2.

183 “(...) i

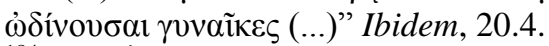

${ }^{184}$ KERÉNYI, Carl. Op. Cit. p. 94.

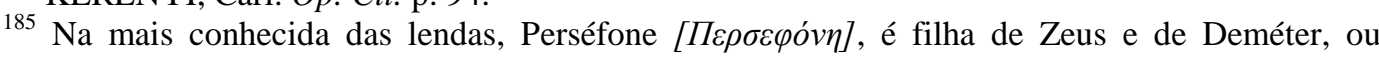
segundo uma versão mais recente, de Zeus e de Estige, então chamada de Core [Kó $\eta$ ]. Jovem bela e honrada, como indicam as duas variações de seu nome, chama a atenção de seu tio Hades que passa a desejá-la. Um dia com a ajuda, o beneplácito e o auxílio de Zeus, o senhor do subterrâneo a rapta e a leva ao seu reino e utiliza toda sorte de artimanha para mantê-la lá, tornando-a Senhora do submundo. Cf. BRANDÃO, Junito. Dicionário mítico-etimológico - Core,
} 
elas é, certamente, a pavorosa sombra da morte. Sabemos que é próprio do dionisismo que aqueles que se aproximam do deus, inevitavelmente, se fundem, de um modo extraordinário, em vida e morte. Consequentemente, Ariadne pertence a esse jogo de mortalidade e eternidade, seu perecimento é intrínseco à natureza de seu mito e culto. Em todo lugar em que era venerada existia a tumba e o tânatos como os elementos centrais. Em Argos, por exemplo, havia um túmulo de Ariadne o qual, de fato, cumpria a função de altar, onde lhe eram feitas oblações como a uma rainha do mundo chtônico. O próprio local era um santuário subterrâneo no qual se celebrava o "deus cretense", Dioniso ${ }^{186}$. Com isso, percebemos que Ariadne era uma entidade sombria; sua epifania evocava o falecer e o ressuscitar, de modo que não podemos dissociá-la de Perséfone, cuja catábase e anábase constituíram a marca fundamental dos Mistérios Elêusis.

A ideia, que mais tarde será traduzida nas tragédias, de indestrutibilidade da vida em meio à destruição e à morte é, precisamente, o que sobrepõe Ariadne e Perséfone como uma só pessoa: as duas são personagens que figuram a transitoriedade entre o mundo dos vivos e dos mortos, ambas são veneradas como divindades chtônicas. Tal proximidade se torna ainda mais evidente se recorrermos ao chamado mito órfico do nascimento de Dioniso-Zagreus; nesta história de origem cretense, como vimos, o deus é fruto do relacionamento incestuoso entre Perséfone e Zeus, que teria seduzido a filha, transmutado em uma serpente. O filho dessa relação é o menino nascido com cornos e feição taurina, despedaçado pelos titãs ainda jovenzinho. Os chifres do deus menino indicavam sua natureza chtônica e, obviamente, de sua mãe também. A forma ritual deste mito era a dilaceração de um boi ou algum animal cornígera. Igualmente, em Knosso, touros eram sacrificados em rituais dedicados à "Senhora do labirinto".

Os sacrifícios de animais tão grandes como os touros, destroçados pelos dentes e pelas unhas dos participantes ${ }^{187}$, eram comuns tanto nos ritos dionisíacos, referência ao filho subterrâneo e prematuro de Perséfone, quanto nos rituais do

p. 145; Perséfone, p. 503-504. Sobre sua relação com Deméter, Cf. BRANDÃO, Junito. Mitologia grega, Vol. I. p. 300-311.

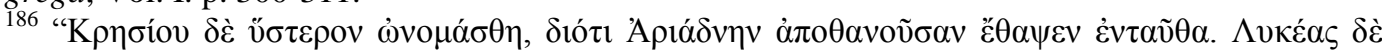

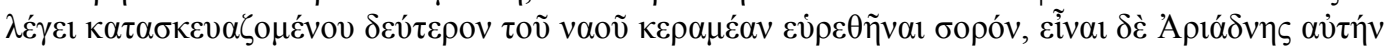
(...)". [Este lugar foi chamado depois de o recinto do deus cretense, porque, quando Ariadne morreu, Dionísio a enterrou aqui. Para Lyceas, quando o templo estava sendo reconstruído, um caixão de barro foi encontrado, esse era Ariadne. (...)]. PAUSÂNIAS. Op. Cit. [II.23.8].

${ }^{187}$ Cf. KERÉNYI, Carl. Op. Cit. p. 74-75. Também Cf. p. 100-101. 
labirinto em Knosso, que faziam forte alusão ao Minotauro e, consequentemente, a Ariadne. Esses ritos sacrificiais possuíam um duplo e ambíguo significado. Se por um lado simbolizavam a morte terrível, então, por outro lado, o renascimento e a vida. Por isso que os habitantes de Naxos, segundo narra Plutarco, viam e celebravam Ariadne sob duas formas: uma tétrica, vista como a mortal, isto é, aquela que foi abandonada por Teseu na ilha e acaba morta, selando o mesmo destino que os animais sacrificados; e outra jubilosa, símbolo de imortalidade e força vital, aquela que Dioniso torna sua divina esposa. Como é de se esperar, a primeira era celebrada com tristeza e luto e a segunda com festa e alegria ${ }^{188}$. Esta variedade de sentidos e estes contrastes provam que Ariadne pertencia ao reino dionisíaco; e como o deus, oscilava entre o funesto e o luminoso.

O lado obscuro de Ariadne está ligado ao seu cruel destino e, principalmente, ao que ele nos suscita. Porém, ela pode igualmente ser considerada cintilante. Em Creta ela também era chamada de Arídela, "toda clara"; é que ela podia se mostrar toda clara no céu. Kerényi, pautando-se em detalhes de moedas de Knosso, datáveis do século V a.C., conclui que cabe pouca dúvida sobre o caráter lunar de Ariadne ${ }^{189}$. Já em uma versão menos sinistra de sua história, Teseu a abandona em uma ilhota, enquanto estava dormindo, então Dioniso a acorda de seu sono profundo e lhe oferece um diadema de ouro, cinzelado por Hefesto, que hoje esplende no céu como "tiara de Ariadne", a constelação corona borealis ${ }^{190}$. Aceitando o presente, consumam-se as núpcias e a apoteose da mulher terrena. Ariadne é levada ao firmamento, dando-nos o vestígio de sua ligação com o domínio celeste. Em uma variação, o presente salvador, não teria sido apenas o novelo, mas também uma coroa luminosa, que Dioniso lhe oferecera como presente de casamento, fazendo dela a representação de um verdadeiro farol feminino: imagem da mulher como fio condutor e luz, ideal para guiar-nos nas trevas interiores ${ }^{191}$.

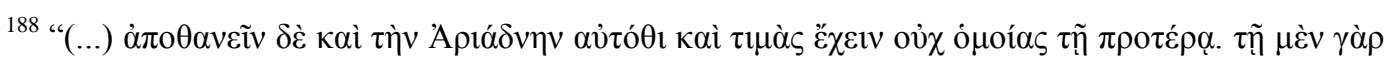

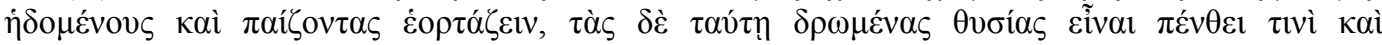

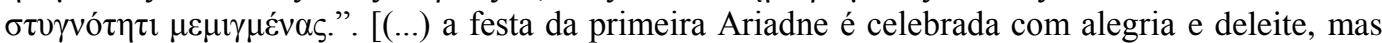
os sacrifícios realizados em honra da segunda são com tristeza e luto]. PLUTARCO. Op Cit. 20.5 ${ }^{189}$ Cf. KERÉNYI, Carl. Op. Cit. p. 95.

190 Idem. p. 96.

${ }^{191}$ Cf. BRANDÃO, Junito. Dicionário mítico-etimológico-Ariadne. p. 78.
} 
Em outro relato sobre o matrimônio, Dioniso apareceu em sonhos a Teseu, perturbando-o com ameaças e obrigando-o a fugir. Na mesma noite, o deus leva Ariadne para o alto de uma montanha, aí ambos deseparecem, primeiro ele e depois ela ${ }^{192}$. Mais do que um "desaparecimento", o acontecimento é uma aparição, ou seja, a ascenção de Ariadne ao mundo celestial e a sua divinização. A partir de então é adorada como a grande deusa Lunar do mundo Egeu. Apesar de sua união com Dioniso a torná-la muito maior que a lua - sua grandiosidade não pode se resumir ao mero fenômeno lunar - o luminoso astro noturno passa a ser uma de suas mais conhecidas representações. Sua natureza reunia, assim como a Lua, tanto o lado escuro e sombrio, como o lado refulgente. Nietzsche, em um poema incompleto, parece compreender essa ambiguidade de Ariadne e escreve: "Casamento - e de repente, o céu está caindo em escuridão. Ariadne"193. Não podemos afirmar com segurança se o filósofo está se referindo ao "divino matrimônio", mas a imagem suscitada contém todos os elementos do mito: a união, o céu escuro e Ariadne, como o altivo luminar que surge no firmamento, a excelsa guia para quem caminha em dédalos tenebrosos.

Mesmo que a referência a Ariadne no poema de Nietzsche não seja evidente, é certo que a Senhora do labirinto é um símbolo recorrente em sua filosofia. Isso não poderia ser diferente, visto a relevância que desempenha no mito de Dioniso, e a grande importância deste na obra do filósofo. Ela prefigura, no pensamento nietzschiano, o próprio labirinto: "Oh Ariadne, você mesma é o labirinto: não se volta a sair de ti" ${ }^{, 194}$. Nesse sentido, assume o mesmo caráter da mulher nietzschiana símbolo do mistério. E Ariadne possui a nuance do esfíngico justamente porque, em seus caminhos, esconde a verdade, tornando-a inacessível. Um homem labiríntico, diz Nietzsche, jamais busca a verdade, mas apenas a sua Ariadne ${ }^{195}$; a verdade aqui é o conhecimento metafísico, absoluto, galgado apenas na lógica e que justifica a existência; enquanto Ariadne é o humano no seu sentido mais imanente, ou seja, o ser que aceita a inescrutabilidade do 'eu'; ama o seu

\footnotetext{
${ }^{192}$ SíCULO, Diodoro. Biblioteca histórica. Livro V, 51,4.

${ }^{193}$ Originalmente escrito desta forma: “(...) 3. Die Hochzeit. — und plötzlich, während der Himmel dunkel herniederfällt 4. Ariadne.”. NIETZSCHE. Fragmento póstumode 1885 1[163].

${ }^{194}$ Cf. NIETZSCHE. Fragmento póstumo, outono de 1887, 10[95]. (Ver nota "118" da seção 7.2.2.).

195 "Ein labyrinthischer Mensch sucht niemals die Wahrheit, sondern immer nur seine Ariadne". Idem. 1882, 4[55].
} 
destino e não foge de sua finitude, pelo contrário, ao "ascender para os céus", diviniza o que no homem é mais próprio, sua mortalidade nadificante.

Diferente é Teseu: tem necessidade de fio condutor, de justificativa e finalidade. Por isso, Nietzsche, em um fragmento póstumo, ensaia o final de uma peça satírica onde o herói é descrito como absurdo, ciumento e virtuoso ${ }^{196}$. Esses atributos foram mais do que suficientes para Deleuze descrever Teseu como modelo do poder de negar, o espírito de negação e grande escroque. No fabuloso artigo Mistère d'Ariane, o filósofo francês analisa, a partir do triângulo TeseuAriadne-Dioniso, a relação entre vida reativa, que nega e se esmaga sob o peso dos valores morais; e a vida afirmativa, apta a transformar a si mesma. Nesta interpretação, o fio que conduz Teseu é o fio da moral, por sua vez, a moral é o labirinto: disfarce do ideal ascético e religioso ${ }^{197}$. No interior do labirinto se encontra o touro, alegoria do animal que ama a terra. Para demonstrar a superioridade da fera em relação a Teseu, Deleuze cita Zaratustra: "Deveria fazer como o touro; e a sua felicidade deveria cheirar à terra e não a desprezo pela terra. Gostaria de vê-lo semelhante ao touro branco, quando, resfolegando e mugindo, precede a relha do arado; e seu mugido ainda deveria ser um louvor a tudo o que é terrestre!"198.

Sendo assim, o Minotauro assume a afígie afirmativa. Ele é simetricamente oposto a Teseu, o emblema de um tipo que assume todas as características do homem criticado por Nietzsche como decadente: se o herói é a racionalidade exarcebada, então o touro é o instinto, a carne marcada; se um é a lógica, guiado pelo fio dos conceitos, então o outro é a voz dos mitos; se Teseu é ressentido, ciumento, vingativo; então a besta é o verdadeiro Sim e o amante do destino, da vida terrena. Nesse sentido, o Minotauro, tal como é interpretado por Nietzsche e Deleuze, tem como melhor representação literária a personagem Astérion de Jorge Luis Borges. No pequeno conto La casa de Asterión, o Minotauro é, na verdade, um menino que brinca e se diverte. Sua casa, o labirinto, é lugar de quietude e solidão. Além disso, a personagem de Borges se reconhece como um filósofo,

\footnotetext{
${ }^{196}$ Cf. Idem, 1887, 9[115], §3. (Cf. nota 119 da seção 7.2.2.).

${ }^{197}$ DELEUZE, Gilles. Os mistérios de Ariadne segundo Nietzsche. p. 9. [A primeira versão do artigo foi editada em Bulletin de la Société française d'études nietzschéennes, $\mathrm{n}^{\circ}$ 2, mar. 1963, sob o título "Mistère d'Ariane".

${ }^{198}$ Idem. p. 8 e 9.
} 
todavia, um filósofo que não se guia pelos conceitos e pela linguagem logicotradicional, ele diz não reconhecer as diferenças das palavras ${ }^{199}$. Por outro lado, esse touro-menino-filósofo é símbolo do criador; ele cria a si mesmo: imagina-se como outro de si e juntos brincam e riem amavelmente. Sem contar que Asterión acredita ser o criador das estrelas e do sol; ele cria sentido para o mundo, contudo, sem a necessidade de criar valores suprassensíveis, mantém os pés aqui embaixo, na terra ${ }^{200}$. É um amante do destino, nem mesmo resiste à espada de bronze de Teseu.

Ao matar o touro, o herói confirma sua inferioridade. Em seu ato estaria negando a vida, esmagando-a sob um peso de valores considerados superiores. Enquanto ama Teseu, Ariadne participa desse empreendimento de negação da vida. Ela é a irmã da besta, mas a única relação que estabelece com ela é de ressentimento, a principal marca do "Espírito negador". Sua canção não é outra coisa senão um lamento ${ }^{201}$. Ariadne é quem segura o fio da moralidade no labirinto. Mas quando é abandonada pelo amado, inicia sua transformação; sente que Dioniso se aproxima. Ele é o deus-touro, porque sua efigie é a verdadeira afirmação, ele nada carrega e de nada se encarrega, mas alivia tudo que vive. Abraçada por Dioniso, a negação se transforma, converte-se no trovão de uma afirmação pura ${ }^{202}$; sob suas carícias se torna leve, antes era pesada, mas então se alivia. É, pelo deus, alçada ao céu. Não é somente Ariadne que muda, mas todos os seus símbolos agora são outros: seu cântico deixa de ser expressão de ressentimento; o labirinto deixa de ser o lugar da moral; o labirinto é o próprio Dioniso-touro: "Sou o teu labirinto".

\footnotetext{
199 "No me interesa lo que un hombre pueda trasmitir a otros hombres; como el filósofo, pienso que nada es comunicable por el arte de la escritura. Las enojosas y triviales minucias no tienen cabida en mi espíritu, que está capacitado para lo grande; jamás he retenido la diferencia entre una letra y otra". BORGES. Jorge Luis. La Casa de Asterión. In. Obras completas. p. 569.

200 "Todo está muchas veces, catorce veces, pero dos cosas hay en el mundo que parecen estar una sola vez: arriba, el intrincado sol; abajo, Asterión. Quizá yo he creado las estrellas y el sol y la enorme casa, pero ya no me acuerdo". Idem. p. 560

${ }^{201}$ Cf. "Klage der Ariadne" [Lamento de Ariadne] no escrito poetico Ditirambos de Dioniso.

${ }^{202}$ DELEUZE, Gilles. Op. Cit. p. 11.
} 
Nietzsche pergunta em Ecce homo: "Quem, além de mim, sabe o que é Ariadne?". No entanto, essa pergunta deveria ser estendida a Dioniso: Quem, além de Nietzsche, soube o que é Dioniso? O deus estrangeiro, nascido das entranhas da Grécia; o deus do vinho; o deus da dança; o deus das mil máscaras; o deus das mulheres; o senhor de Ariadne! São muitos os atributos e os epítetos dessa divindade, e Nietzsche soube dar a cada um deles a importância de problema filosófico de primeira grandeza. Podemos dizer que Nietzsche redirecionou a reflexão sobre o elo "arte e vida" ao reivindicar o dionisíaco como símbolo supremo de sua filosofia. Mas como nas teofanias antigas desse deus, de diferentes formas aparece na obra do filósofo. Nossa tarefa, agora, será investigá-

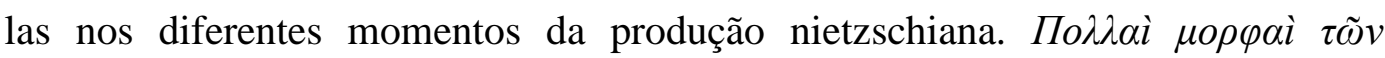

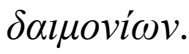




\section{3}

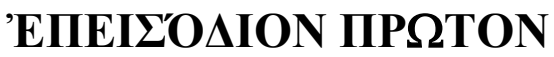

\section{1. Dioniso e a realidade por trás do véu:}

Entre julho e agosto de 1870, em plena guerra franco-prussiana Nietzsche redige seu manuscrito A Visão dionisíaca de mundo. O jovem professor, recémadmitido na Universidade de Basileia, após um agitado semestre, encontra o tempo necessário para finalizar seu texto apenas durante as férias. Depois de uma breve estadia na residência dos Wagner, em Tribschen, dirige-se com sua irmã para Maderanertal, a mais de 1300 metros do nível do mar, nos Alpes suíços. Apesar do cenário reconfortante, a mente do filósofo estava dividida entre a preocupação com a guerra e os enigmas do mundo grego antigo ${ }^{1}$. Em oito de agosto daquele ano, ainda hospedado nos Alpes, Nietzsche envia uma carta ao presidente da Universidade de Basileia, Wilhelm Vischer-Bilfinger, solicitando licença de seu cargo de docente para servir à Prússia na guerra. Concedido o afastamento, serve como enfermeiro de treze de agosto a dois de setembro; mesmo que tenha passado, efetivamente, apenas uma semana na frente de batalha, ficou profundamente marcado. Somente após a experiência da guerra, nas comemorações do natal, o manuscrito foi entregue como presente à Cosima e a Wagner então com o título "O nascimento do pensamento trágico".

No escrito entregue aos Wagner as elaborações de Nietzsche já haviam atingido a concretude de um pensamento próprio, que matizadas e aprofundadas tornaram-se a base de sua primeira obra. $\mathrm{O}$ argumento inicial de $A$ visão dionisíaca de mundo é, em essência, o mesmo argumento que inaugura $O$ nascimento da tragédia, e configura a tese central de sua primeira teoria estética. No texto de 1870 escreve: "Os gregos, que nos seus deuses expressam e ao mesmo tempo calam a doutrina secreta de sua visão de mundo, estabeleceram

\footnotetext{
1 "Enquanto o troar da batalha de Wörth se espalhava por sobre a Europa, o cismador de ideias e amigo de enigmas, a quem coube a paternidade deste livro, achava-se, algures em um recanto dos Alpes, muito entretido em cismas e enigmas e, por consequência, muito preocupado e despreocupado ao mesmo tempo, anotando os seus pensamentos sobre os gregos" NIETZSCHE. $O$ Nascimento da tragédia "Tentativa de autocrítica", §13.
} 
como dupla fonte de sua arte duas divindades, Apolo e Dionísio"2. Já no livro publicado em 1872: "Teremos ganho muito a favor da ciência estética se chegarmos não apenas à intelecção lógica mas à certeza imediata da introvisão de que o contínuo desenvolvimento da arte está ligado à duplicidade do apolíneo e do dionisíaco"3. Recorrendo ao seu entusiasmo pela Grécia antiga e utilizando seu vasto conhecimento da literatura e mitologia grega, Nietzsche toma emprestado o nome dos deuses gregos e transforma as deidades em símbolos que permitem tornar cognoscível a arte e, em última instância, a própria existência.

Apolo e Dioniso representam, na dimensão estética, oposições de estilos que caminham paralelas e, quase sempre, [entre si]. Na formulação nietzschiana, esses deuses são empregados como símbolos, ou seja, a forma encontrada para expressar conteúdos artísticos reais das obras de arte e, até mesmo, da vida. Decorrentes desses símbolos, mediante uma substantivação dos adjetivos "dionisíaco" e "apolíneo", Nietzsche constrói um modelo teórico que permite compreender e avaliar, sob a ótica da arte, simultaneamente, a cultura grega antiga, a cultura ocidental moderna e, consequentemente, o próprio ser humano. Assim, o filósofo reúne as principais características míticas dessas divindades para utilizá-las como chave de interpretação da realidade. É claro que, ao fazê-lo, reduz essas entidades a poucos traços característicos, deixando de lado grande parte da riqueza religiosa que envolvia os seus cultos antigos, porque sua intenção não é meramente hermenêutica, mas sim, erigir uma teoria metafísica capaz de tornar visíveis processos profundos da criação artística e do existir.

É importante salientar que no período de elaboração de $A$ Visão dionisíaca de mundo e, mais tarde, na preparação de $O$ Nascimento da tragédia, Nietzsche se preocupava em entender a noção de "símbolo", estabelecendo qual o seu papel na linguagem. O termo foi mencionado pela primeira vez em anotações que remontam ao inverno de 1869 e à primavera de 1870, onde o "Symbol" é definido

\footnotetext{
2 "Die Griechen, die die Geheimlehren ihrer Weltanschauung in ihren Göttern aussprechen und zugleich verschweigen, haben als den Doppelquell ihrer Kunst zwei Gottheiten aufgestellt, Apollo und Dionysos". NIETZSCHE. Die dionysische Weltanschauung. §1. Em português, utilizamos a tradução de Marcos Sinesio Pereira Fernandes e Marica Cristina dos Santos Souza, edição Martins Fontes, 2005.

${ }^{3}$ Cf. nota 73 da seção 1.3 .
} 
como "a transferência de uma coisa em uma esfera totalmente diferente",; dessa forma, na linguagem, as palavras não seriam mais que símbolos, visto que não corresponderiam completa e nem necessariamente às coisas. O pensamento, por sua vez, não seria mais que a atualização e a relação de símbolos linguísticos ${ }^{5}$. Nessa perspectiva, simbolizar seria o mesmo que interpretar, reduzindo por intermédio de imagens incompletas o conteúdo vivenciado. Portanto, existiria um relevante distanciamento entre o símbolo e a coisa simbolizada, o que tornaria o modo de expressão por meio de palavras limitado. A música, por outro lado, seria a linguagem para o universal, uma forma de expressão, como veremos posteriormente, incomparavelmente mais rica e precisa ${ }^{6}$.

No entanto, tal formulação sobre a linguagem não é permanente, em uma série de fragmentos, escritos entre o final de 1870 e a primavera de 1872, Nietzsche modifica seu entendimento sobre o "símbolo", ampliando seu campo de significação. Agora o termo é associado à projeção artística. Para ele: "todas as imagens artísticas não são mais que símbolos"”. Associados à arte e, principalmente, à música, os símbolos passam a representar uma linguagem mais rica, facilmente comunicável e imediatamente compreensível ${ }^{8}$. Diz respeito a uma forma singular de se expressar, capaz de transmitir conteúdos que, para a linguagem comum, são inacessíveis. Os mitos antigos eram, nesse ponto, junto à música, o maior exemplo de uma linguagem simbólica ${ }^{9}$. A visão de mundo através de símbolos é o pré-requisito para uma grande arte e, por isso, as narrativas míticas estabeleciam uma compreensão da realidade mais precisa. A humanidade que enxerga o mundo de modo unicamente abstrato, e não em símbolos, é incapaz de compreender a criação artística ${ }^{10}$, e consequentemente, a

\footnotetext{
4 "Symbol die Übertragung eines Dinges in eine ganz verschiedene Sphaere". NIETZSCHE. Fragmento póstumo 3[20].

5 "Das Denken ist Symbolerinnerung". NIETZSCHE. Fragmento póstumo 5[80].

${ }^{6}$ NIETZSCHE. Fragmento póstumo de 1871, 12[1].

7 “Alle künstlerischen Bilder sind nur Symbole”. NIETZSCHE. Idem 1872, 8[41].

${ }^{8}$ Cf. Idem. 1871, 9[88].

${ }^{9} \mathrm{O}$ mesmo efeito que a música proporcionava aos modernos enquanto linguagem simbólica universal, os mitos proporcionavam aos gregos antigos. Sobre isso Nietzsche escreve: "Für uns ist die Musik zum Mythus, zu einer Welt von Symbolen geworden: wir verhalten uns zur Musik, wie der Grieche zu seinen symbolischen Mythen" [Para nós, a música se tornou um mito, um mundo de símbolos: nós nos comportamos em relação à música, assim como os gregos com seus mitos simbólicos.]. Idem. 1871 9[92].

10 "Eine Menschheit, die die Welt nur abstrakt, nicht in Symbolen sieht, ist kunstunfähig. Wir haben die Idee an Stelle des Symbols, daher die Tendenz als künstlerischen Leitstern" [Uma
} 
vida. Por conseguinte, o conceito é visto como a morte da arte, na medida em que reduz a possibilidade de real interpretação dos fundamentos da existência ${ }^{11}$. A abstração conceitual possui uma origem tardia, sendo assim, é menos expressiva. Isso não significa que Nietzsche abandona totalmente a intelecção lógica e os conceitos como explicitação de ideias, mas a estratégia empregada foi submetê-los à força significativa dos símbolos.

Dioniso e Apolo são, portanto, símbolos que expressam uma visão de mundo artística, impossível de ser exprimida unicamente por meio de noções abstratas; é exatamente essa a acepção que as deidades desempenham na obra de Nietzsche, fundamentalmente naquelas escritas no período de $O$ Nascimento da tragédia. Para dar real sentido à ciência estética, isto é, para trazer à superfície os ocultos e profundos processos da criação artística, é impreterível retornar às figuras altamente significativas dos deuses gregos. A linguagem do simbolismo mítico é a condição para tornar perceptível à mente o eterno jogo das pulsões criadoras. Esses deuses da arte também são fundamentais para explicar o ciclo do “todo existente”, uma vez que, para estética nietzschiana, “o mundo e a vida só podem ser justificados como um fenômeno estético" 12 . Nesse ponto reside, precisamente, o núcleo da "metafísica do artista", o tema estético, aos olhos do filósofo, adquire a abrangência de um problema ontológico fundamental: não só a cultura enquanto produto humano é arte, mas o devir também é entendido como manifestação artística, de modo que o próprio homem não é mais o artista, mas a obra de $\operatorname{arte}^{13}$.

Neste contexto, os deuses da arte, Apolo e Dioniso, são eleitos como símbolos perfeitos, pois tornam claro à nossa compreensão a existência, no mundo helênico, de uma enorme contraposição entre duas formas de arte, diametralmente opostas devido à singularidade de sua natureza, de sua origem e do objetivo peculiar que lhes são intrínsecos. Apolo, reconhecidamente o deus da representação onírica, o "aparente" deus do sol e da luz, que revela no brilho sua

humanidade que vê o mundo apenas abstratamente, não em símbolos, é incapaz de arte. Nós temos a idếia no lugar do símbolo, daí a tendência como uma estrela guia artística]. Idem.

11 "In sofern ist der Begriff der Tod der Kunst" [Nesse sentido, o conceito é a morte da arte]. Idem. $1871,9[88]$.

${ }^{12}$ NIETZSCHE. O Nascimento da tragédia. §24.

${ }_{13}$ "Der Mensch ist nicht mehr Künstler, er ist Kunstwerk geworden". NIETZSCHE. A Visão dionisíaca de mundo. §1; O Nascimento da tragédia. §1. 
beleza e eterna juventude ${ }^{14}$, simboliza as artes figurativas [Bildner], ou plásticas; Dioniso, por sua vez, como o deus das bebidas narcóticas, do êxtase primaveril e dos bramidos noturnos, simboliza a arte não-figurada [unbildlichen], ou musical $^{15}$. Essas duas formas de arte estão, na maior parte do tempo, em oposição [Gengesatz] porque resultam de impulsos [Trieb] antagônicos que surgem da natureza, denominados como "o apolíneo" e "o dionisíaco". Tais forças correspondem, respectivamente, ao mundo artístico do sonho e da embriaguez. Elas agem como princípios pulsionais responsáveis pela constituição da civilização grega, pelo decurso mesmo da história e pelas diversas manifestações da cultura.

Sabendo disso, cabe-nos agora discorrer sobre a pulsão apolínea e a pulsão dionisíaca como poderes artísticos que, sem a mediação do artista humano, irrompem do seio da natureza e justificam todo criar e todo destruir. O reino da pulsão apolínea é a bela aparência do mundo dos sonhos, em cuja produção, diz Nietzsche, cada homem é um artista consumado, pois, ao sonhar, cria imagens com contornos perfeitos. O apolíneo se refere às faculdades criadoras de forma, sobretudo, às formas plenas de beleza, serenidade e mediania, portanto, é precondição para qualquer arte plástica. $\mathrm{O}$ artista tem no sonho sua maior inspiração, já que sabe descobrir nas figuras oníricas a verdadeira interpretação da vida. Nietzsche pondera que em nossa natureza mais íntima encontra-se um prazer indispensável e uma alegria profunda na experiência de sonhar, não apenas quando nos deparamos com sonhos belos, mas igualmente o grave, o triste, o sinistro, o tenebroso, pois o prazer está subordinado à criação das formas oníricas e a sua contemplação [angeschaut] ${ }^{16}$. Os gregos, povo de alma artística, souberam mais do que ninguém representar na figura de Apolo um ardente desejo de sonho e, analogamente, pela imaginação, pela adivinhação e pela arte em geral, via das quais a vida tornou-se possível e digna de ser vivida.

É importante saber que a força onírica da pulsão apolínea não se restringe, segundo Nietzsche, apenas às artes plásticas tradicionais, como a escultura e a pintura, mas, também é pressuposto de uma parte importante da poesia. O maior

\footnotetext{
${ }^{14}$ Cf. NIETZSCHE. A Visão dionisíaca de mundo. §1.

${ }^{15} \mathrm{Cf}$. NIETZSCHE. O Nascimento da tragédia. $\$ 1$.

${ }^{16}$ NIETZSCHE. A Visão dionisíaca de mundo. §1.
} 
exemplo de literatura apolínea são os poemas de Homero, o "grego sonhador". Assim sendo, a modalidade poética que pertence ao domínio de Apolo é a épica e a epopeia, diferente da poesia lírica que pertence ao mundo dionisíaco. Entre esses dois tipos de poesia - a épica e a lírica - existe um imenso abismo: o poeta épico se assemelha ao escultor, ao passo que ambos estão imersos na intuição pura de imagens. Já o lírico, Arquíloco, por exemplo, se assemelha ao músico dionisíaco, pois, como veremos posteriormente, não recorre a nenhuma imagem, sua obra é eco direto do sofrimento primordial. Homero, "o artista ingênuo", segundo a definição de Schiller adotada por Nietzsche ${ }^{17}$, vem para dar contornos apolíneos aos deuses helênicos. A religião homérica é artística, porque ao divinizar os acontecimentos históricos em suas narrativas, o rapsodo torna belo o passado dos gregos, a partir de um processo apolíneo de transformação dos fatos em arte da beleza.

No entanto, para melhor compreender o lugar da religião homérica na cultura grega, devemos enfatizar que Nietzsche considera o apolíneo como a "esplêndida imagem divina do principium individuationis" ". Essa designação é extraída da obra magna schopenhauriana $O$ Mundo como vontade $e$ representação, onde o princípio de individuação diz respeito ao princípio da razão suficiente que torna o conhecimento possível ao indivíduo como tal ${ }^{19}$. O mundo fenomênico esfacelado em uma multiplicidade de seres singulares só pode ser cognoscível ao sujeito do conhecimento mediante o princípio de individuação. Para Schopenhauer, esse princípio corresponde, portanto, ao princípio da causalidade, ao espaço e ao tempo, na medida em que unicamente por intermédio destes, o individual pode ser concebido ${ }^{20}$.

Além disso, Schopenhauer sustenta que o indivíduo comum, ofuscado pelo "véu de Maia", percebe o sofrimento e a dor do mundo por toda parte, mas não

\footnotetext{
${ }^{17}$ Ibidem. O Nascimento da tragédia. §3 e §4.

${ }^{18}$ Idem. $\$ 1$.

${ }^{19}$ SCHOPENHAUER, Arthur. O Mundo como vontade e representação. §52. O termo também aparece nas seções $\S 43$ e $\S 51$.

20 "A multiplicidade de tais indivíduos é concebível unicamente mediante o tempo e o espaço, seu surgir e desaparecer unicamente mediante a causalidade, em cujas formas reconhecemos somente as diversas modalidades do princípio de razão, principio último de toda finitude, toda individuação, forma geral da representação, tal como esta se dá na consciência do indivíduo como tal”. Idem. §30. Esse tema será retomado na seção dedicada especificamente à filosofia schopenhaueriana.
} 
entende seu real fundo metafísico. Envolto e confiante no principium individuationis, fica tranquilo, acreditando que é possível escapar dos infortúnios e tormentos da vida. É comum que o homem, enquanto ser racional, crie para si, a partir desse princípio, um modelo de realidade onde a vida possa ser justificada; sua existência fenomênica possa ser conservada e a terrífica finitude seja vista apenas como uma fábula; em outras palavras, o homem cego para a essência aflitiva da vida, forja um sentido aparente que passa a ser o motriz para o existir. Até então, apenas nos recônditos recantos de sua consciência, diz Schopenhauer, agita-se um obscuro pressentimento de que entre o indivíduo e a dor do mundo há uma ligação que o princípio de individuação não estaria em condições de realmente o livrar. Da menor sensação de que, por um acaso qualquer, o principium individuationis possa ser quebrado, ou que o princípio da razão sofra uma supressão, resulta o terrível arrepio de horror ${ }^{21}$.

Apoiando-se nesses pressupostos, Nietzsche interpreta o principium individuationis schopenhauriano como uma potência metafísica que obriga a vida a singularizar-se e multiplicar-se, atribuindo forma e contornos precisos às coisas, cujos gestos e olhares nos transmitem todo prazer e toda beleza que há na sabedoria da "aparência", concedendo-lhe, então, uma identidade intrínseca à pulsão apolínea. Essa é, exatamente, a caracterização artística do apolíneo: a individuação que se revela por meio de um véu de aparência que, por sua vez, encobre uma realidade atroz; há um embelezamento superficial que dissimula a realidade mais profunda, tornando-a aprazível e desejável. Tal proposta metafísica, de $O$ Nascimento da tragédia, não titubeia em afirmar que "por trás da realidade em que existimos e vivemos se esconde outra muito diferente, e, que, por consequência, a primeira não passa de uma aparição da segunda" ${ }^{22}$. Quando o véu é rasgado, quando a máscara de Apolo sucumbe, o capitel dórico da serenidade apolínea desmorona e dá lugar novamente às contradições do caótico núcleo da existência.

Ao apresentar a dicotomia "aparência-essência", Nietzsche está admitindo a hipótese ontológica de uma unidade originária fundamental, denominada Uno

\footnotetext{
${ }^{21}$ Cf. Idem. $\$ 63$.

22 "O homem de propensão filosófica tem mesmo a premonição de que também sob essa realidade, na qual vivemos e somos, se encontra oculta uma outra, inteiramente diversa, que portanto também é uma aparência". NIETZSCHE. Op. Cit. §1.
} 
primordial, [Ur-eine $]^{23}$. Ele é o verdadeiro Ser existente por trás da realidade fenomênica, e pode ser concebido similarmente à coisa-em-si da filosofia kantiana, à vontade do pensamento schopenhauriano, e até mesmo, ao ö $\pi \varepsilon \imath \rho o v$ de Anaximandro, no sentido em que corresponde ao núcleo essencial do mundo e de tudo que existe. O Uno primordial carrega em si a dor e o sofrimento originário, e necessita individualizar-se na aparência para se livrar das suas íntimas contradições. Nele há, em potência, determinações particulares que o possibilitam se manifestar, enquanto fenômeno, nas incontáveis formas de existência individual. $\mathrm{Na}$ formulação nietzschiana, existe um querer originário de transfiguração do caos e da dor originária em um prazer primordial, só possível mediante a aparência apolínea. Uma vez que a contradição é a essência do Uno primordial, ele pode ser ao mesmo tempo a dor e o prazer supremos: quando mergulha no fenômeno [die Erscheinung], é prazer supremo ${ }^{24}$, mas se os preceitos da aparência são quebrados, e tudo aquilo que existe na multiplicidade é visto como realmente é, finito, transitório e fadado ao dilaceramento individual, a dor suprema passa a ser destacada. Quando a verdade escondida por trás do véu torna-se visível é inevitável o sentimento do sofrimento primordial e, consequentemente, de pavor.

A arte apolínea tem origem nessa problemática. Nietzsche concebe o povo heleno como portador de uma sensibilidade extremamente aguçada para a dor. Os gregos eram capazes de enxergar as contradições por trás do véu da aparência; esta susceptibilidade tornava o grego passível de todo espetáculo cruel da existência, no qual o infortúnio, a luta, a morte e o caos estavam sempre em evidência: "Aquela inaudita desconfiança ante os poderes titânicos da natureza, aquela Moira a reinar impiedosa sobre todos os conhecimentos, aquele abutre a roer o grande amigo dos homens que foi Prometeu, aquele horrível destino do sagaz Édipo" ${ }^{25}$. As emoções tão delicadas e a disposição ao sofrimento poderiam levar os gregos a não suportarem a existência e ao risco mortal de submeterem-se

\footnotetext{
23 “Agora, graças ao evangelho da harmonia universal, cada qual se sente não só unificado, conciliado, fundido com o seu próximo, mas um só, como se o véu de Maia tivesse sido rasgado e, reduzido a tiras, esvoaçasse diante do misterioso Uno-primordial". Idem.

${ }_{24}$ "Insofern der Widerspruch das Wesen des Ureinen ist, kann es auch zugleich höchster Schmerz und höchste Lust sein: das Versenken in die Erscheinung ist höchste Lust" [Na medida em que a contradição é a essência do Ureine, também pode ser a mais alta dor e o maior prazer ao mesmo tempo: a submegir-se na aparência é o prazer supremo.]. NIETZSCHE. Fragmento póstumo de 1870 - 1871, 7[157].

${ }^{25}$ NIETZSCHE. O Nascimento da tragédia. §3.
} 
aos ensinamentos da sabedoria de Sileno ${ }^{26}$, cujo pessimismo apregoava o viver como uma doença maligna e a morte como a única cura. Todavia, para conseguirem viver, tiveram que encontrar refúgio na arte, mais precisamente, na arte apolínea de Homero. O verdadeiro propósito estético de Apolo foi criar uma arte que embelezasse a existência e tornasse a vida, mais do que suportável, intensamente desejável. Com as inumeráveis ilusões da bela aparência, que fez cada instante ser digno de ser vivido, inverteu-se a sabedoria de Sileno, e o lema do grego passou a ser: "a pior coisa é a morte breve, e depois, a condenação à morte",27.

Desta forma, os deuses olímpicos surgiram para velar e mascarar a realidade contraditória dos gregos. Podemos destacar que, neste caso, arte e religião estão intimamente ligadas, provêm do mesmo instinto e da mesma problemática. Homero apresenta-se como antídoto ao passado hostil dos gregos. Através de sua arte, o pavor bárbaro é velado. Nietzsche escreve em um texto da mesma época de O Nascimento da tragédia, chamado A Disputa em Homero, sobre esta influência do aedo no mundo grego:

\begin{abstract}
Mas o que se encontra por trás do mundo homérico, como local de nascimento de tudo o que é helênico? Neste mundo, somos elevados pela extraordinária precisão artística, pela tranquilidade e pureza das linhas, muito acima da pura confusão material: suas cores aparecem mais claras, suaves, acolhedoras, por meio de uma ilusão artística, seus homens, nesta iluminação colorida e acolhedora, melhores e mais simpáticos; mas para onde olharíamos, se nos encaminhássemos para trás, para o mundo pré-homérico, sem a condução e a proteção da mão de Homero? Olharíamos apenas para a noite e o terrível, para o produto de uma fantasia acostumada ao horrível. Que existência terrestre refletem estes medonhos e perversos mitos teogônicos? - Uma vida dominada pelos filhos da noite, a guerra, a obsessão, o engano, a velhice e a morte. ${ }^{28}$
\end{abstract}

Homero, o artista ingênuo, converteu, segundo Nietzsche, os mitos gregos em arte; sua ingenuidade representou o apogeu da cultura apolínea, de modo que a luz, a serenidade e a bela forma de seus deuses sempre vencem o monstruoso, o

\footnotetext{
26 "Segundo a lenda antiga, o rei Midas perseguiu na floresta o velho "Sileno", companheiro de Dioniso, e durante muito tempo sem poder alcançá-lo. Quando conseguiu, por fim, apoderar-se dele, o rei perguntou-lhe qual era a coisa a qual o homem deveria preferir a tudo e considerar sem par, isto é o bem supremo. Imóvel e obstinado o demônio não respondia. Até que, por fim, coagido pelo vencedor, desatou a rir e proferiu as seguintes palavras: Raça Efêmera, e miserável, filha do acaso e da dor! $\mathrm{E}$ tu, por que me obrigas a revelar-te o que mais te valeria ignorar? O que tu deverias preferir não o podes escolher: é não Ter nascido, não "seres", seres "nada". Já que isso te é impossível, o melhor que podes desejar é morrer, morrer depressa". Idem.

${ }^{27}$ Idem.

${ }^{28}$ NIETZSCHE. Cinco prefácios para cinco livros não escritos: "A disputa em Homero". p. 67.
} 
horror profundo e o grotesco. A poderosa ilusão dos sonhos jubilosos fez-se vitoriosa frente à mais apurada sensibilidade para o sofrimento ${ }^{29}$. Todavia, este velamento estético proporcionado pela aparência apolínea, apenas camufla uma realidade que não pode ser desprezada: o mundo titânico, pré-apolíneo. A vitória conquistada pela "ilusão dos sonhos" e pela bela aparência, não é definitiva. Pelo contrário, o autoconhecimento, a conservação dos limites da personalidade e o respeito pela medida são exigências inquestionáveis para a manutenção da serenidade. Uma vez que esses preceitos são quebrados e seus limites ultrapassados, o resultado é um retorno à dor originária. Nietzsche ilustra tais transgressões aludindo aos personagens Édipo e Prometeu, o primeiro pela excessiva sagacidade, que lhe proporciona desvendar o enigma da Esfinge, o que lhe causou uma sorte de horrores; e, no caso de Prometeu, o seu amor titânico pela humanidade foi a causa de seu destino desgraçado, ter seu fígado devorado pelos abutres ${ }^{30}$. Acrescentamos aqui que, nos dois casos, o autoconhecimento é ignorado, uma vez que Édipo ignorou sua real identidade e Prometeu achou-se irmão dos homens.

Quando os preceitos de Apolo são rompidos, quando o principium individuationis é quebrado e o véu da aparência é rasgado, o caos do Uno primordial torna-se evidente novamente, em consequência, o sentimento de horror se materializa tomando conta daquele que se depara com o sofrimento originário. Mas, se a esse horror fosse acrescentado um prazeroso sentimento arrebatador, ou seja, se ao pavor de ver ruir a serenidade aparente adiciona-se uma espécie de êxtase vindo do mais íntimo do homem, poderíamos entrever o efeito mesmo da pulsão dionisíaca ${ }^{31}$. Esse efeito, como já sabemos, é conhecido por nós, em analogia ao estado fisiológico da embriaguez. $\mathrm{O}$ estado inebriante é perfeito para designar a força dionisíaca proveniente da natureza, porque, seja pela influência da bebida narcótica, seja pela força despótica da aproximação da primavera, há uma total supressão do sujeito e a aniquilação da subjetividade. Se por um lado a pulsão apolínea é a verdadeira imagem do princípio de individuação, a pulsão dionisíaca corresponde à completa anulação desse princípio e, consequentemente,

\footnotetext{
${ }^{29}$ Cf. NIETZSCHE. O Nascimento da tragédia. §3.

${ }^{30}$ Cf. Idem. $\$ 4$.

${ }^{31}$ Cf. Idem. $\$ 1$.
} 
de tudo que existe enquanto pluralidade. Portanto, no campo estético, o dionisíaco é associado à criação sem formas, às artes musicais.

Dioniso como a deidade símbolo do caos, da desmesura, da deformidade, da fúria sexual, do fluxo da vida, da fecundidade da terra e da noite criadora de sons, reflete, perfeitamente, a força metafísica oposta à pulsão apolínea: enquanto o apolíneo é a disposição do Ser originário em individualizar-se e se manifestar de forma múltipla, o dionisíaco é a força que constrange os indivíduos a fundirem-se e se tornarem um só novamente. Sob os poderes da pulsão dionisíaca há uma dissolução do particular e do "eu", o homem e a natureza se unem, resultando um sentimento misto de assombro e prazer.

Mas para entender como o dionisíaco transformou-se em um fenômeno estético, devemos frisar que Nietzsche, em $O$ Nascimento da tragédia, faz referência a dois "Dionisos", distintos um do outro devido à origem e à natureza de seus rituais: o dionisíaco bárbaro-asiático e o dionisíaco helenizado. Nos ritos dionisíacos bárbaros, havia um furor sexual desenfreado, um retorno à bestialidade e uma crueldade exacerbada. Nestas festas a fusão entre o homem e a natureza era completamente destituída de arte. Nas práticas estrangeiras havia um arrebatamento primaveril que culminava na anulação das hierarquias políticas e dos laços familiares. A loucura proporcionada pela bebida narcótica acompanhada da música frenética terminava com o derramamento de sangue e o despedaçamento de algumas vítimas.

Contra esse dionisíaco grotesco, a Grécia estava protegida por Apolo. A serenidade da aparência não permitia um desvelamento a partir destes ritos bárbaros. A arte dórica, assim como a religião homérica, ambas pautadas nos princípios de beleza, medida e serenidade, blindava os gregos contra a invasão dos cultos e ritos bárbaros. Os helenos vendo as barbáries grosseiras como principal elemento do dionisíaco estrangeiro, condenaram também a música destas celebrações, sentiam pavor ao ouvirem os cantos extáticos, na forma de um coro demoníaco que sempre batia à porta do mundo helênico. Na literatura homérica não havia espaço para esse deus brutal - como observamos no Párado deste trabalho, são raras as menções ao deus do vinho na épica homérica - menos ainda, para os seus costumes violentos. Com essa especulação de um dionisismo 
estrangeiro extático, Nietzsche abre caminho para as teorias filológicas da religião de Dioniso, feitas por Rohde e Wilamowitz, que despontaram no final do século XIX. Nestas teorias, assim como n'O Nascimento da tragédia, o dionisíaco irrompe as fronteiras gregas, alastrando suas práticas como uma epidemia.

Apolo não consegue defender a Grécia de seu oponente bárbaro por muito tempo: a tensão entre as forças apolíneas e dionisíacas necessariamente se estabelecem entre pausas, recuos e superação dos recuos. Elas nunca se anulam, não há hegemonia e não há síntese. Quando um dos princípios se manifesta em desigualdade, os resultados são nefastos. Assim sendo, a estratégia tomada para conter o orgiástico origina então, o que Nietzsche considera como a obra de arte superior e o momento cultural de maior elevação na história do Ocidente. Nietzsche afirma que o novo antídoto contra este dionisíaco estrangeiro foi então integrar, não mais reprimir. A partir de uma união reconciliadora entre o apolíneo e o dionisíaco, faz-se com que o último também se transforme em uma pulsão estética, ou seja, por mais uma vez o grego é salvo pela arte. Tudo que existia de desenfreado no culto é contido pela mediania de Apolo. O dionisíaco se espiritualiza, expurgando os excessos e possibilitando uma embriaguez sem perda de lucidez. A clareza, a medida e até mesmo a serenidade, passam a ser elementos do deus de Delfos compartilhados ao deus estrangeiro, transfigurando todo dionisíaco bárbaro em arte.

Esta reconciliação entre o apolíneo e o dionisíaco representa, para Nietzsche, o apogeu da civilização grega, "esta aliança é o momento mais importante da história do culto grego" ${ }^{\$ 2}$. Com Apolo e Dioniso juntos surge a arte superior: o teatro de tragédia, que é ao mesmo tempo apolíneo e dionisíaco. A tragédia configura-se como sonho e embriaguez, forma e caos, luz e noite, aparência e essência, imagem e música. Esta oposição entre forma e música é definida por Nietzsche como "um coro dionisíaco que incessantemente se descarrega num mundo apolíneo de imagens" ${ }^{33}$.

Cabe-nos agora descrever o porquê de a tragédia grega ser considerada, por Nietzsche, como a forma de arte superior, e o porquê dela representar, na história

\footnotetext{
${ }^{32}$ NIETZSCHE. Idem, $\$ 2$.

${ }^{33}$ NIETZSCHE. Idem, $\$ 8$.
} 
ocidental, o momento no qual o homem atingiu sua maior vitória cultural. Para explicitar essas questões, será indispensável demonstrar a íntima relação que o filósofo estabelece entre arte e vida. No entanto, para melhor intelecção do objeto que esta tese se propõe, é necessário, de imediato, investigar qual é, de fato, a contribuição da filosofia kantiana e do pensamento schopenhauriano para a elaboração do "dionisíaco" e dos demais temas de O Nascimento da tragédia. Instiga-nos saber qual o significado de Nietzsche ter considerado o pensamento desses específicos filósofos como "a filosofia dionisíaca expressa em conceitos". Uma desafiadora proposta que será desenvolvida em nossa próxima seção.

\section{2.}

\section{Kant e Schopenhauer, a sabedoria dionisíaca expressa em conceitos:}

Catorze anos após a publicação de $O$ Nascimento da tragédia, no prefácio escrito como tentativa de autocrítica, Nietzsche lamenta profundamente ter recorrido a formulações kantianas e schopenhaurianas para exprimir suas intuições, reconhecidas então como diametralmente opostas à Kant e Schopenhauer ${ }^{34}$; entretanto, no período mesmo de elaboração da obra, os pensamentos destes filósofos se estabelecem como os verdadeiros pilares das ideias ali desenvolvidas. Nietzsche reconheceu tanto em Kant como em Schopenhauer uma incrível perspicácia, eles foram capazes de utilizar dos artifícios da ciência para demonstrar os limites e a relatividade do conhecimento e, com isso, negar definitivamente a pretensão da ciência à validade universal. A audácia desses espíritos proporcionou uma vitória sobre o que era o substrato da então cultura: "o otimismo oculto na essência da lógica",35. Por meio da crítica ao cientificismo de ambos os filósofos, Nietzsche crê ver as questões éticas, estéticas e, até mesmo, as epistemológicas de um modo incomparavelmente mais profundo,

\footnotetext{
${ }^{34}$ NIETZSCHE. O Nascimento da tragédia. "Tentativa de autocrítica”, §6.

${ }^{35}$ Idem. $§ 15$, e $\S 18$.
} 
de forma que possam, seguramente, ser designadas como a "sabedoria dionisíaca expressa em conceitos" $" 36$.

Para Nietzsche, a filosofia kantiana e, subsequentemente, a schopenhauriana representam o renascimento da cultura trágica na Alemanha, agora não por via da arte, mas através do pensamento filosófico, originado da mesma fonte das tragédias: o "fundamento dionisíaco". Estes pensadores são considerados como aqueles que expressam a sabedoria dionisíaca na forma de conceitos, porque, o dionisíaco - seja em sua compreensão cosmológica, seja em seu entendimento estético - é o responsável por dilacerar ${ }^{37}$ tudo que existe enquanto múltiplo, isto é, romper com o principium individuationis deflagrando, portanto, uma realidade mais essencial, o Uno primordial. Analogamente, o pensamento de Kant e o pensamento de Schopenhauer, a partir de uma demonstração dos limites da razão, desvelam uma realidade por trás da multiplicidade aparente, em outras palavras, a base de ambos os sistemas filosóficos é a demonstração de que a representação fenomênica nada mais é do que a manifestação de algo mais essencial. Para o primeiro o 'numenon' ou 'coisa-em-si', e para o segundo a 'Vontade'.

Como podemos perceber a questão não é simples: o futuro crítico severo do kantianismo e do pessimismo schopenhauriano, no período em que redige sua primeira obra, reconhece nestas mesmas filosofias a arrebatadora força dionisíaca. Os testemunhos das cartas do jovem e ainda estudante Nietzsche nos revelam o entusiasmo e a esperança de renovação da cultura depositada nestes filósofos ${ }^{38}$. A grande revolução foi que, a partir de Kant, "o reino da metafísica e com ele a província da 'verdade absoluta' foram, irreversivelmente, deslocados para uma categoria junto à poesia e à religião. Quem deseja conhecer algo, que se limite

\footnotetext{
${ }^{36}$ No original em alemão lê-se: "die wir geradezu als die in Begriffe gefasste dionysische Weisheit bezeichnen können”. Cf. Idem, §19.

37 É importante salientar que o "dilaceramento" do principium individuationis é sempre momentâneo. Nunca há a hegemonia do apolíneo ou do dionisíaco. Nietzsche compreende ambos em uma perene guerra, onde a vitória é sempre provisória; A existência de um pressupõe, necessariamente, a existência do outro. O que ocorre é uma articulação de forças na forma de uma pausa, um recuo e a superação do recuo, tanto de um como do outro. Como veremos à frente, quando o dionisíaco é suplantado da tragédia grega, não impera o apolíneo; os dois são expulsos, inaugurando, na cultura, um período nefasto.

${ }^{38}$ Inicialmente a intenção de Nietzsche era escrever sua tese doutoral sobre o conceito de 'orgânico' a partir de Kant. Mesmo tendo organizado bastante material, abandona o projeto por não considerar o tema uma questão profunda. Cf. Carta a Erwin Rohde de 3 ou 4 de maio de 1868. [Apêndice $\alpha$ ]
} 
agora a uma relatividade consciente do saber,"39. A radicalidade deste pensamento pode ser considerada, por si só, como a conceituação da sabedoria dionisíaca, no entanto, o legado da novidade kantiana, fomentado por Schopenhauer e por diversos pós-kantianos, é o que realmente chama a atenção de Nietzsche. Tal legado é por ele denominado como "o desespero da verdade" perigo que acompanha todo pensador que inicia seu caminho a partir de Kant. Assim sendo, veremos como esse sombrio cenário pós-Kant é, caracteristicamente, dionisíaco.

\subsection{1.}

\section{Kant, um abalo sísmico:}

O cenário moderno deixado por Kant é de devastação na forma de "um ceticismo e um relativismo corrosivos e destruidores" ${ }^{\text {41 }}$. Segundo Nietzsche, qualquer pensador que fosse robusto e completo de sofrimento, e não simplesmente uma "máquina de pensar e de calcular",42, estaria submetido aos efeitos devastadores da filosofia kantiana. Nessa análise, apenas as "naturezas de bronze"43 puderam suportar esse clima da cultura alemã. Esse foi o caso de Schopenhauer, reconhecido como "o guia, que conduz da caverna do descontentamento cético ou da renúncia crítica ao auge da contemplação trágica" ${ }^{44}$; teria decifrado a vida e a existência se servindo da ciência, mas sem se deixar por ela prejudicar, pois sabia dos seus limites e que, sem um olhar profundo, a ciência tornaria o curso da nossa vida mais confuso e labiríntico. Porém, esta 'natureza de bronze' não pertencia a homens com uma sensibilidade

\footnotetext{
${ }^{39}$ NIETZSCHE. Carta ao amigo Paul Deussen do início de maio de 1868.

${ }^{40}$ [Verzweiflung an der Wahrheit]. NIETZSCHE. Schopenhauer como educador, $\$ 3$.

${ }^{41}$ Idem.

${ }^{42}$ Idem.

${ }^{43}$ [Naturen von Erz]. Idem.

${ }^{44}$ [der Führer nämlich, welcher aus der Höhle des skeptischen Unmuths oder der kritisirenden Entsagung hinauf zur Höhe der tragischen Betrachtung leitet]. Em seguida Nietzsche completa fazendo uma alusão a famosa passagem kantiana da conclusão da Crítica da razão prática "den nächtlichen Himmel mit seinen Sternen endlos über uns, und der sich selbst, als der erste, diesen Weg geführt hat. Das ist seine Grösse, dass er dem Bilde des Lebens als einem Ganzen sich gegenüberstellte, um es als Ganzes zu deuten;" [como o céu noturno e as infinitas estrelas acima de nós, ele foi o homem que primeiro deu a si próprio este caminho e o percorreu. Eis aí a sua grandeza: ter-se colocado diante da imagem da vida como diante de uma totalidade, para interpretá-la como totalidade]. NIETZSCHE. Idem $§ 3$.
} 
natural, como por exemplo, os poetas Hölderlin e Kleist que não suportaram o corolário da filosofia kantiana e sucumbiram frente ao acima mencionado desespero da verdade. Kleist, em especial, relata em cartas como foi afetado por Kant em seu "íntimo mais sagrado":

Há pouco, estabeleci conhecimento com a filosofia kantiana, e é preciso agora te comunicar um pensamento extraído dela, pois não tenho porque temer que ela viesse a te romper tão profundamente ou tão dolorosamente quanto a mim. - Não podemos resolver se o que chamamos de verdade é realmente a verdade, ou se unicamente isto nos parece assim. Neste segundo caso, a verdade que coligimos aqui não é mais nada depois da morte, e todo esforço para adquirir um bem que nos siga até mesmo no túmulo é vão. - Se a ponta deste pensamento não toca teu coração, não te rias, porém, de alguém que aí se sente abençoado o mais profundamente, no seu íntimo mais sagrado. Meu objetivo único, meu objetivo supremo afundou e eu não tenho nenhum outro ${ }^{45}$.

Recentemente conheci a filosofia mais recente, a kantiana, e posso transmitir-lhe agora uma de suas ideias principais, sem medo de que fiques tão arrasada como ocorreu comigo. Sei que você não é uma especialista no tema, então tentarei dizerlhe da maneira mais clara quanto me é possível [...] Se nós todos víssemos o mundo através de lentes verdes, estaríamos forçados a julgar que tudo que enxergamos é esverdeado, e nunca estaríamos seguros se nossos olhos veem as coisas como elas realmente são, ou se agregamos algo de si próprio ao que vemos. Dessa forma que ocorre com nosso entendimento. Nós não podemos decidir se o que chamamos de verdade é, de fato, a verdade, ou se simplesmente nos aparece sê-lo assim. Por isso, a verdade que aprendemos aqui não é a verdade após nossa morte, e tudo é um vão esforço para possuir o que nunca conseguiremos. [...] Ah Wilhelmine, se isso não dominar o seu coração, ao menos não caçoe de quem se feriu o mais profundamente. [...] Desde que percebi que a realização da verdade não será conhecida aqui na Terra, não toquei outro livro. Eu passo ocioso no meu quarto, sentado na frente da janela, fugindo de casa com um desconforto interno que me leva às tabernas ou cafés, procurando distração, mas sem alívio. [...] Este pensamento único se torna uma ansiedade que me queima: seu único propósito desabou ${ }^{46}$.

O desespero de não suportar permanecer na dúvida e ter perdido as esperanças após a leitura das Críticas kantianas contribuíram para que, em 21 de novembro de 1811, Heinrich von Kleist cometesse suicídio junto com sua companheira, atirando primeiro nela e em seguida no próprio peito. Desse modo, cheio de incertezas, é o modo como o poeta atualiza a "crise Kant" em seu tempo; aos olhos de Nietzsche, tratava-se de um espírito vulcânico, repleto de um incurável sofrimento e, por isso, trágico ${ }^{47}$. Embora muitos comentadores se assegurem que a interpretação kleistiana das Críticas é equivocada e que o horror

45 Carta de Heinrich von Kleist à irmã Ulrike de 23 de maio de 1801. Apud. NIETZSCHE. Schopenhauer como educador. $\$ 3$.

${ }^{46}$ Carta de Heinrich von Kleist à Wilhelmine von Zenge de 20 de março de 1801. KLEIST, Heinrich von. An Abyss Deep Enough: Letters of Heinrich von Kleist, with a Selection of Essays and Anecdotes. p. 95-96.

${ }^{47}$ Cf. NIETZSCHE. Fragmento póstumo de 1878 29[1]. 
enxergado pelo poeta nas obras kantianas estaria associado apenas à sua alma angustiada, o fato é que Kant demonstrou uma ruptura irreversível entre sujeito e objeto, entre conhecimento e realidade e entre metafísica e ciência, tornando evidente um 'solipsismo cognitivo', isto é, a incognoscibilidade da coisa-em-si acaba por nos enclausurar em nossa própria representação do mundo; de modo que a recepção da primeira Crítica possa ser comparada a um abalo sísmico na tradição.

Com a publicação da Crítica da razão pura, em 1781, Kant irá reestruturar as bases do conhecimento, situando o verdadeiro lugar da metafísica, antes tida como a rainha dentre todas as formas de saber, contudo, na época, rechaçada, vista com muita desconfiança. A matemática e a lógica desde o tempo dos gregos antigos eram vistas como uma ciência segura ${ }^{48}$ e no século XVII a física passa a ser, cada vez mais, considerada como tal, atingindo seu ponto mais elevado com a publicação de Principia Philosophiae Naturalis de Isaac Newton. A filosofia buscava alcançar um estatuto igualmente sólido que lhe conferisse o mesmo rigor confiável das ciências, mas, para isso, seria necessário que ela superasse o teatro de disputas infindáveis ${ }^{49}$ entre os distintos sistemas metafísicos que sucessivamente se opunham entre si. Cada metafísica apresentava as suas teses como algo indubitável e irrefutável, o que correspondia a um dogmatismo; no entanto, surgiam em oposição outras filosofias, cujas teses metafísicas também eram dogmáticas, resultando assim uma constante luta de sistemas ${ }^{50}$.

A estratégia kantiana não foi abandonar a metafísica - uma vez que a compreendia como uma espécie de conhecimento que a razão não pode ignorar ${ }^{51}$ - mas foi criar uma crítica, quer dizer, um modelo filosófico que averigua, com o rigor de um tribunal, o que a razão e o entendimento podem realmente conhecer independentemente de toda a experiência, isto é, Kant vai demonstrar os limites do "conhecimento puro", do "conhecimento a priori". Para a metafísica adquirir a mesma posição de segurança das ciências seria necessário um "conhecimento puro" de algum objeto da experiência e que nele se encontrasse as garantias de

\footnotetext{
${ }^{48}$ KANT, Immanuel. Crítica da razão pura. B X, p. 5.

${ }^{49}$ Ibidem. A VIII, p. 29.

${ }^{50}$ Podemos exemplificar com o embate entre os sistemas metafísicos cartesiano, leibniziano e wolffiano.

${ }^{51}$ Cf. KANT, Immanuel. Op. Cit.
} 
necessidade e de universalidade. O problema é que se o conhecimento é a posteriori, ou seja, haurido na experiência, então seu domínio é apenas contingente e particular; por outro lado, se o conhecimento é a priori, então possui a garantia de universalidade, porém sua análise não acrescenta nada mais do que aquilo que já é inferido pela própria noção do objeto. Aqui encontramos, respectivamente, a distinção kantiana entre os juízos sintéticos e os juízos analíticos.

Para melhor compreender o itinerário kantiano, devemo-nos atentar que nos juízos analíticos o predicado está contido implicitamente no sujeito e a ligação entre o sujeito e o predicado é pensada por identidade; aqueles juízos, porém, em que a mesma ligação é pensada sem identidade são os chamados juízos sintéticos. No primeiro caso, o predicado nada acrescenta ao conceito do sujeito; quando digo "todos os corpos são extensos", exemplifica Kant, enuncio um juízo analítico. Ora, no próprio conceito de corpo já está contida a noção de extensão, portanto, com essa proposição analítica não é possível inferir novos conhecimentos para além do dado a priori. Esse foi um dos enganos dos metafísicos dogmáticos, acreditaram ser possível criar um novo saber, mas na verdade apenas explicitaram o que já era subentendido ${ }^{52}$. Já os juízos sintéticos acrescentam ao conceito do sujeito um predicado que nele não estava pensado e dele não podia ser extraído por qualquer decomposição ${ }^{53}$. Os juízos empíricos, como tais, são todos sintéticos; recorrendo à experiência amplia-se o conhecimento, todavia, sem a validade científica, pois, como dissemos, são proposições particulares e contingentes.

\footnotetext{
${ }^{52}$ Esse foi o caso, por exemplo, da prova ontológica da existência de Deus, feita por Descartes, a partir da ideia inata de perfeição; o argumento cartesiano não infere novidade, porque, grosso modo, a noção predicativa "perfeito" já está contida, preliminarmente, no sujeito "Deus". Cf. DESCARTES, René. Meditações metafísicas. Terceira meditação.

${ }^{53}$ O exemplo dado por Kant para um juízo sintético é "todos os corpos são pesados", porque: "quando digo que todos os corpos são pesados, aqui o predicado é algo de completamente diferente do que penso no simples conceito de um corpo em geral. [...]embora eu já não incluía no conceito de um corpo em geral o predicado do peso, esse conceito indica, todavia, um objeto da experiência obtido mediante uma parte desta experiência, à qual posso ainda acrescentar outras partes dessa mesma experiência, diferentes das que pertencem ao conceito de objeto. Ampliando agora o conhecimento e voltando os olhos para a experiência de onde abstraí esse conceito de corpo, encontro também o peso sempre ligado aos caracteres precedentes e, por conseguinte, acrescento-o sinteticamente, como predicado, a esse conceito. E pois sobre a experiência que se funda a possibilidade de síntese do predicado do peso com o conceito de corpo, porque ambos os conceitos, embora não contidos um no outro, pertencem, contudo, um ao outro, se bem apenas de modo contingente, como partes de um todo, a saber, o da experiência, que é, ela própria, uma ligação sintética das intuições”. KANT, Immanuel. Idem, B 12. p. 70.
} 
Um conhecimento metafísico válido cientificamente será aquele que não repousa na experiência particular e nem é meramente redutível à análise. O que se busca são proposições racionais que encontrem na intuição o objeto do conhecimento. Será o que Kant designará como juízo sintético a priori ${ }^{54}$. Tal juízo une, concomitantemente, a universalidade e a necessidade com a fecundidade do conhecimento; dito de outra maneira: estão compreendidos em um juízo sua 'aprioridade' e sua 'sinteticidade'. Os juízos sintéticos a priori são possíveis mediante a síntese, realizada pela faculdade do entendimento, entre uma intuição pura e o conceito puro. Para Kant, trata-se de uma intuição "pura", porque nela não se encontrará representações que pertença à sensação, apenas deverá encontrar formas apriorísticas imediatas ${ }^{55}$. A síntese a priori é sempre independente da experiência, mas aplicável aos objetos da experiência. Dessa forma, o grande problema da Crítica da razão pura e a tarefa central da "estética transcendental" resumir-se-ão em examinar como são possíveis os juízos sintéticos a priori.

A síntese a priori que se pretende encontrar diz respeito à estrutura cognitiva do sujeito; ao demonstrar a possibilidade do conhecimento sintético puro, Kant realiza aquilo que denomina de "a revolução copernicana na metafísica" ${ }^{, 56}$. Assim como Nicolau Copérnico imprimiu uma viragem na concepção das órbitas celestes, o filósofo de Königsberg alterará o lugar do

\footnotetext{
${ }^{54}$ Para Kant, todas as ciências teóricas da razão (os juízos matemáticos, a ciência da natureza (física) e a metafísica, pelo menos em relação aos seus fins), consistem em juízos sintéticos $a$ priori. Cf. KANT, Immanuel. Idem. B 16 a B 18. p. $72-75$.

${ }_{55}^{5}$ Cf. Idem. B 34. p. 88.

56 "Devia pensar que o exemplo da matemática e da física que, por efeito de uma revolução súbita, se converteram no que hoje são, seria suficientemente notável para nos levar a meditar na importância da alteração do método que lhes foi tão proveitosa e para, pelo menos neste ponto, tentar imitá-las, tanto quanto o permite a sua analogia, como conhecimentos racionais, com a metafísica. Até hoje admitia-se que o nosso conhecimento se devia regular pelos objetos; porém, todas as tentativas para descobrir a priori, mediante conceitos, algo que ampliasse o nosso conhecimento, malogravam-se com este pressuposto. Tentemos, pois, uma vez, experimentar se não se resolverão melhor as tarefas da metafísica, admitindo que os objetos se deveriam regular pelo nosso conhecimento, o que assim já concorda melhor com o que desejamos, a saber, a possibilidade de um conhecimento a priori desses objetos, que estabeleça algo sobre eles antes de nos serem dados. Trata-se aqui de uma semelhança com a primeira ideia de Copérnico; não podendo prosseguir na explicação dos movimentos celestes enquanto admitia que toda a multidão de estrelas se movia em torno do espectador, tentou se não daria melhor resultado fazer antes girar o espectador e deixar os astros imóveis. Ora, na metafísica, pode-se tentar o mesmo, no que diz respeito à intuição dos objetos. Se a intuição tivesse de se guiar pela natureza dos objetos, não vejo como deles se poderia conhecer algo a priori; se, pelo contrário, o objeto (enquanto objeto dos sentidos) se guiar pela natureza da nossa faculdade de intuição, posso perfeitamente representar essa possibilidade". KANT, Immanuel. Idem. B XVI e B XVII. p. 44 - 45.
} 
sujeito no processo de cognição do objeto, de modo que o sujeito substituirá o objeto tornando-se o centro a ser por ele (o objeto) orbitado. Isto significa que, diferentemente da tradição metafísica dogmática, a preocupação não será mais com a coisa apreendida, todavia, será com as possibilidades de conhecimento da coisa. Com isso, a intuição deixa de se guiar pela natureza dos objetos, que por sua vez, passam a ser orientados pela nossa faculdade de intuir. Agora voltamonos para o sujeito, procurando neste as faculdades que tornam possível o conhecimento. Há, portanto, uma ideia de submissão necessária do objeto ao sujeito, onde a faculdade do entendimento é legisladora ${ }^{57}$. Nesta proposta, nós concebemos a priori aquilo que colocamos nas coisas: as intuições puras (o espaço e o tempo) e os conceitos puros.

No entanto, a coisa, tal como a conhecemos, não é simplesmente uma imagem de um objeto real. A coisa compreendida é aquilo que me aparece enquanto fenômeno, ou seja, enquanto um objeto da intuição que recebe determinadas configurações das faculdades de cognição. Da mesma forma, a realidade em que vivemos nos é acessível apenas como nos aparece graças às mesmas faculdades, consequentemente, trata-se de uma realidade fenomênica. $\mathrm{O}$ mundo científico é igualmente fenomênico, surge exclusivamente da representação do sujeito. Por outro lado, o objeto considerado em si mesmo, independentemente das condições cognitivas do sujeito, nos é impossível de ser conhecido. Em suma, a totalidade daquilo que conhecemos é mera representação fornecida pelo nosso aparato cognitivo e dada na experiência pelas formas a priori do espaço e tempo. Fora de nosso intelecto, a coisa-em-si, que a sensibilidade supõe como a fonte dos fenômenos, é incognoscível; o entendimento pode, tão somente, pensá-la, e quando pensada é o que Kant designa como númeno ${ }^{58}$. O entendimento é capaz de conhecer, de ciência, mas invariavelmente limitado ao domínio da experiência possível.

Para Nietzsche, a novidade do pensamento kantiano representa uma profunda revolução na filosofia, cuja consequência mais radical fora o

\footnotetext{
${ }^{57}$ DELEUZE, Gilles. A filosofia crítica de Kant. p. 21.

${ }^{58}$ [noumenon]. Cf. KANT, Immanuel. Idem. Capítulo III, B 295 / A 236. p. 283 - 299.
} 
desmantelamento da metafísica enquanto enunciado científico ${ }^{59}$, resultando disso um assustador cenário de vazio devido à desconfiança da ciência como o fundamento da verdade. Tal é a impressão nietzschiana que ele não titubeia em afirmar que "se as ciências estão certas, então não podemos nos apoiar nos princípios kantianos: se Kant está correto, então as ciências estão erradas",60. Essa conclusão circular se deve à ideia de que toda construção de mundo que se possa fazer, inclusive as científicas, são "antropomorfismos", isto é, o homem constrói a realidade de acordo com seu aparato cognitivo; o mundo é simplesmente como nos aparece. A Crítica kantiana simboliza, portanto, o fim da filosofia e da ciência inauguradas na idade média como teologia, e sacramentada pelos filósofos modernos como dogmatismo metafísico ${ }^{61}$. Por este motivo, Nietzsche vê em Kant a sabedoria dionisíaca expressa em conceitos; ademais, a renúncia do conhecimento radicalizada pós-Kant faz ressurgir entre os modernos uma espécie de pessimismo identitário ao espírito trágico ${ }^{62}$.

A revolução do pensamento proporcionada por Kant, além de se configurar como o dionisíaco no seu sentido mais dilacerante, pois aniquila toda possibilidade de justificação metafisico-dogmática da realidade, representa também o fim da filosofia na forma de uma "renúncia, distintivamente, trágica"63 que, por sua vez, acaba por suprimir o sujeito em uma espécie de vazio solipsista e, por consequência, ateísta. Este cenário é claramente perceptível se analisarmos o ambiente filosófico desolador legado pela primeira Crítica nas últimas décadas do século XVIII na Alemanha: a crença inabalável na autoridade da razão que tem início, segundo Nietzsche, pela figura de Sócrates (como especificaremos em nossa seção "3.4.") e convertida no soberano padrão de verdade pelos intelectuais do Iluminismo europeu, passa a ser duramente questionada. Os pensadores passaram a questionar a razão porque perceberam que a filosofia e a ciência

\footnotetext{
59 "A consequência da teoria kantiana. Fim da metafísica como ciência” [Die Konsequenzen der Kantischen Lehre. Ende der Metaphysik als Wissenschaft]. NIETZSCHE. Fragmento póstumo de $187219[51]$.

60 "Es ist zu beweisen, daß alle Weltconstruktionen Anthropomorphismen sind: ja alle Wissenschaften, wenn Kant Recht hat. Freilich giebt es hier einen Cirkelschluß - haben die Wissenschaften Recht, so stehen wir nicht auf Kant's Grundlage: hat Kant Recht, so haben die Wissenschaften Unrecht". Idem. de 1872 19[125].

${ }^{61}$ Cf. Idem. de 1872 19[28].

${ }^{62}$ Das tragische, ja, verzichtete auf Kants Wissen. Fragmento póstumo de 1872, 19[248].

${ }^{63}$ Sobre a impossibilidade da metafísica, o fim da filosofia e a renúncia trágica [Die tragische Resignation] após Kant, Nietzsche faz um esboço em Fragmento póstumo de 1872, 19[319].
} 
moderna estavam prejudicando a moral, a religião e o estado; o reinado iluminista da razão, desde os métodos mecanicistas da ciência e das exigências críticas da filosofia, conduziria direto ao ateísmo, ou fatalismo e ao anarquismo ${ }^{64}$.

Apesar de Kant impor críticas à razão, limitando o seu poder de cognição, era considerado popularmente, juntamente com Spinoza, como a égide da autoridade da razão. Porém, as filosofias tanto de Kant, quanto de Spinoza possuíam efeitos perigosos: se de um lado o postulado da coisa-em-si kantiana fosse levado às últimas consequências, então, o resultado seria, inevitavelmente, o solipsismo; por outro lado, se o princípio de "razão suficiente" de Spinoza excluísse a frívola linguagem religiosa, então, o resultado seria o fatalismo e o ateísmo. Assim, as duas filosofias de maior impacto na modernidade pareciam destruir a moral, a religião e o estado $^{65}$, de modo que, uma desconfiança perturbadora passa a abalar a crença na razão: por que deveríamos ouvi-la se ela mina todas as certezas necessárias para a conduta da vida? Os pensadores defrontados com esses modelos de racionalidade acabavam em um dilema doloroso. Agora eles se viam diante ou de um ceticismo racional, ou de um fideísmo irracional. Tal impasse era asfixiante - sobretudo para os iluministas pois, seria intolerável que escolhessem renunciar à crença ou à razão em detrimento uma da outra.

Esse dilema impossível já havia perturbado David Hume. Na conclusão do primeiro livro de seu Tratado da natureza humana, o empirista revela existir um conflito irresolúvel entre as reivindicações da razão e da fé, da filosofia e da vida. A única conclusão a qual poderia chegar seria o ceticismo de que não conhecia nada mais do que suas impressões passageiras; no entanto, as exigências da vida prática o obrigaram a esquecer dessas “especulações extravagantes”, cuja

\footnotetext{
${ }^{64}$ Cf. BEISER, Frederick C. The Fate of reason: German philosophy from Kant to Fichte, "Introduction". p. 2 - 10.

65 "O modelo spinozista definiu a razão pelo "princípio de razão suficiente", que foi interpretado de forma estritamente mecanicista, de modo que podemos ler: "para qualquer evento B deve haver algum evento anterior A, de tal forma que dado A, B ocorre de necessidade". Entretanto, se esse princípio é universalizado, ele leva ao ateísmo e ao fatalismo; Para Deus e a liberdade devem ser agências auto-causantes [self-causing agencies], causas que atuam sem uma causa anterior. O modelo kantiano explicou a razão em termos de sua atividade a priori e declarou que essa razão conhece a priori apenas o que ela cria ou o que ela faz em conformidade com as suas leis. Se esse princípio é generalizado, de modo que o conhecimento só é possível através da razão, então resulta em solipsismo; pois tudo o que sabemos são os produtos de nossa própria atividade, mas nenhuma realidade independente delas". Idem, p. 2 e 3.
} 
imperiosidade desapareceu depois de um jogo de gamão com os amigos ${ }^{66}$. Kant, despertado do sono dogmático por Hume, faz ressurgir esse dilema; de um lado há a nossa representação do objeto empírico, de outro lado, o objeto transcendental que mantem-se no mais absoluto desconhecimento. Para os críticos de Kant, essa formulação implicaria um ceticismo radical, cuja razão obrigaria a duvidar de toda realidade exterior, incluindo outras mentes, Deus e, até mesmo, das impressões interiores; restando, como a única realidade que ainda poderia ser afirmada, o próprio nada. Essa foi a preocupação de Friedrich Heinrich Jacobi, o mais duro crítico da estética transcendental kantiana.

Para Jacobi, a consequência mais perigosa da Crítica da razão pura era o niilismo [Nihilismus]. Ele foi o primeiro a utilizar esse termo, que, por sua vez, era entendido como uma recorrência inevitável da filosofia kantiana e da investigação racional. Entendia que, após a derrocada da metafísica racionalista das escolas leibniziana e wolffiana que admitiam o conhecimento a priori da existência de Deus, da providência e da imortalidade, o racionalismo passou a negar a existência divina, a liberdade e a existência permanente de nós mesmos; o resultado eminente desse novo "criticismo racional" seria a nossa conversão em niilistas. O termo niilista era utilizado por Jacobi para designar uma posição epistemológica específica: trata-se de um idealista radical que nega a existência de toda a realidade, independentemente do conteúdo imediato da consciência; Tudo o que existe para o niilista são, portanto, seus próprios estados conscientes momentâneos, suas impressões ou representações fugazes. Porém, em meio a essas representações é necessário adicionar o "nada". Justificando a raiz latina do termo, o niilista é quem nega a existência de tudo e afirma o nada ${ }^{67}$.

Contudo, além de um sentido estritamente epistemológico, o termo assume um significado ético, pois o niilista não nega somente a existência das coisas, mas também dos valores; ora se não existe o absoluto, logo desaparecem também as obrigações morais. Se tudo que existe são passageiros estados de consciência, então a única fonte dos valores encontra-se dentro de si mesmo, de modo que o imperativo das ações se resume ao querer. Nesse sentido, o niilismo é

\footnotetext{
${ }^{66}$ Cf. idem.

${ }^{67} \mathrm{Ou}$, como diz Jacobi, o niilista vive em um mundo "out of nothing, to nothing, for nothing and in nothing”. JACOBI. Werke, III, 22. Apud. BEISER, Frederick C.. Idem, p.82.
} 
indissociável do egoísmo, uma vez que tudo o que existe são apenas o próprio estado momentâneo de consciência, o niilista se importa somente consigo, a única fonte de valor são os seus desejos particulares. Para Jacobi, a única possibilidade de fuga do niilismo seria a partir do "realismo", isto é, a crença na existência independente e efetiva de todos os tipos de coisas, sejam as coisas materiais, outras mentes ou Deus. O realismo é entendido como a verdadeira antítese do niilismo, suas bases assentam-se na compreensão intuitiva imediata da realidade externa; claro que se trata de uma intuição que não pode ser demonstrada, ela é aceita, portanto, meramente pela crença. A salvação do niilismo seria um salto de fé, um salto mortale ${ }^{68}$.

Importante saber que a preocupação de Jacobi não se limitava apenas às filosofias 'racionalistas' de Kant e Spinoza, seu ataque estendia-se à investigação racional como um todo; sua tese era radical: a razão leva ao niilismo! Por conseguinte, se sabemos que a ciência natural, no século XVIII, é o grande paradigma da razão, então, somos obrigados a concluir que a ciência natural seria a preocupante fonte do niilismo. Na formulação de Jacobi, o cientificismo que não convergisse com o realismo pautado na crença $^{69}$, culminaria, inexoravelmente, na destruição dos valores morais e religiosos essenciais. Quanto mais as ciências progrediam descobrindo os fundamentos da realidade, da ação humana e das causas dos fenômenos naturais, mais se apoiavam nas concepções materialista, determinista e ateísta. Nessa perspectiva, a razão esclarecida inicia na modernidade um processo irreversível de ateísmo. O esclarecimento seria o responsável pela morte de Deus - tese que será defendida mais tarde por Nietzsche. Para Jacobi, a crença no mundo "fora de nós", pautada no que efetivamente sentimos, são os verdadeiros fundamentos do conhecimento.

Apesar de Nietzsche não chegar à "Crise Kant” por intermédio de Jacobi antes os poetas Hölderlin e Kleist são sua via de acesso ao terrível cenário legado pelo criticismo kantiano - entre eles existem, curiosamente, várias perspectivas

\footnotetext{
${ }^{68}$ Cf. BEISER, Frederick C.. Idem, p. 46.

${ }^{69}$ Jacobi afirma na sua obra David Hume e a crença: realismo e idealismo que "Todo conhecimento humano provém da revelação e da crença". Kant estava ciente das críticas de Jacobi, que o classificava como "idealista transcendental". Jacobi havia the enviado um exemplar de seu trabalho. Em resposta, Kant escreve no segundo prefácio da Crítica da razão pura: "não deixa de ser um escândalo para a filosofia e para o senso comum em geral que se admita apenas a título de crença a existência das coisas exteriores a nós”. Cf. KANT. Idem, B XXXIX. p. 58.
} 
em comum: a intenção de Jacobi era derrubar a presunção racionalista de compreender a totalidade das coisas por meio do conceito e da lógica. E por isso, seu estilo confunde-se com o estilo nietzschiano na medida em que ambos se valem de ironias, de metáforas e de descrições caricaturais sarcásticas, que beiram ao cômico. O modo como edificam seu pensamento é aquele de quem filosofa contra $\operatorname{algo} o^{70}$, é necessário destruir o adversário e demonstrar quão equivocados são seus postulados. Os sentimentos, em ambos, são fortes aliados do pensamento. Outra similitude importante é a conclusão a que chegaram dos perigos da síntese kantiana: Nietzsche, igual a Jacobi, considera que a revolução copernicana reduz o sujeito do conhecimento ao solipsismo ${ }^{71}$. Embora Nietzsche não considere Kant um racionalista que opera em favor das ciências, ao contrário, defende que ele teria demolido o otimismo científico, o mais relevante é que assente com Jacobi sobre a ameaça do niilismo como consequência da primeira Crítica.

Apesar de todas as semelhanças, é evidente que Nietzsche não concordaria com a defesa da crença, feita por Jacobi, como solução à ameaça niilista. Ainda que nessa crença haja um aspecto de perspectivismo, visto que o seu alicerce são os sentimentos ${ }^{72}$ e, de certa forma, como interpreto o que sinto, sua finalidade é claramente moral e religiosa, a justificação filosófica da fé é sua verdadeira intenção, o que a tornaria, no olhar nietzschiano, inadmissível. No entanto, a preocupação com o niilismo, será uma constante no pensamento de Nietzsche. Podemos dizer que a grande tarefa de sua filosofia será combater todas as formas de niilismo. Entretanto, o problema é que Kant, ao mesmo tempo em que representa a sabedoria dionisíaca por romper com o cientificismo exacerbado e com a metafísica dogmática, também abre as portas à negação niilista: ora, se não há mais verdade, se não há uma natureza absoluta das coisas, se não há nem a garantia da "coisa-em-si", então não há mais valores para as coisas, falta-nos as

\footnotetext{
70 "Outra coisa é a guerra! Sou por natureza guerreiro. Agredir é parte dos meus instintos. (...) A minha prática da guerra pode-se resumir em quatro princípios. Primeiro: ataco somente causas vitoriosas. (...) Segundo: ataco somente causas em que não encontraria aliados, em que estou só (...). Terceiro: nunca ataco pessoas - sirvo-me da pessoa só como de uma lente de aumento, com o qual se pode tornar visível uma miséria geral, porém dissimulado, pouco palpável. (...) Quarto: ataco somente coisas em que está excluída qualquer diferença pessoal, em que não existe pano de fundo de experiências ruins. NIETZSCHE. Ecce homo. "Porque sou tão sábio", §7, p. 29 - 30.

71 “Gefahren: von Kant her. Vereinsamung". NIETZSCHE. Fragmento póstumo de 1874, 34[47].

${ }^{72}$ Sensação proveniente dos sentidos e dos sentimentos do espírito. Cf. JACOBI, Friedrich Heinrich. David Hume e a crença ou Idealismo e Realismo.
} 
respostas para os "porquês?", esvai-se o sentido da vida e resta-nos apenas o nada. Esse vazio é, segundo o filósofo, a forma mais extrema de niilismo ${ }^{73}$.

Diante desse dilema, a solução proposta será o baluarte da filosofia nietzschiana: "a existência do mundo só pode ser justificada enquanto fenômeno estético" ${ }^{, 74}$. Nietzsche percebe que a filosofia kantiana, embora seja comparada à sabedoria dionisíaca, exerceu uma influência prejudicial ${ }^{75}$ : perdida a fé na metafísica e sem a "coisa-em-si" como um princípio apaziguador, o que restou foi um ceticismo niilista no qual ninguém pode suportar viver. Seria necessário agora transcender a esse ceticismo, esquecê-lo. A nossa salvação, pensa Nietzsche, não estaria no conhecer, mas no criar $^{76}$. Após a primeira Crítica percebemos que não poderíamos conhecer a verdadeira natureza de nenhuma causalidade; a única forma de superar o efeito nadificante de um ceticismo absoluto é fazendo da vida obra de arte. A epígrafe de seu pensamento será: "Somente a arte pode nos salvar ${ }^{277}$. Contudo, Kant exercerá - juntamente com Schopenhauer - para além do domínio epistemológico, uma fundamental influência na formulação estéticoexistencial nietzschiana.

A Crítica da faculdade do juízo terá papel essencial na visão de mundo baseada no binômio demiúrgico Apolo-Dioniso. Dessa forma, vemo-nos

\footnotetext{
73 " $\mathrm{Da} ß$ es keine Wahrheit giebt; daß es keine absolute Beschaffenheit der Dinge, kein "Ding an sich" giebt — dies ist selbst ein Nihilism, und zwar der extremste" ["O fato de não haver nenhuma verdade: o fato de não haver nenhuma constituição absoluta das coisas, nenhuma "coisa em si" isso é por si mesmo um niilismo, e o mais extremo]. NIETZSCHE. Fragmento póstumo de 1887, $9[35]$.

${ }_{74}^{74}$ Ibidem. O Nascimento da tragédia, §24, p. 141. ]

${ }_{75}^{75}$ Cf. Ibidem. Fragmento póstumo de 1872, 19[28].

76 "Gegen Kant ist dann immer noch einzuwenden, daß, alle seine Sätze zugegeben, doch noch die volle Möglichkeit bestehen bleibt, daß die Welt so ist, wie sie uns erscheint. Persönlich ist übrigens diese ganze Position unbrauchbar. In dieser Skepsis kann niemand leben. Wir müssen über diese Skepsis hinaus, wir müssen sie vergessen! (...) Nicht im Erkennen, im Schaffen liegt unser Heil! Im höchsten Scheine, in der edelsten Wallung liegt unsre Größe. Geht uns das Weltall nichts an, so wollen wir das Recht haben es zu verachten". [Ainda é censurável para Kant que, quando todas as suas sentenças tenham sido admitidas, ainda persista a possibilidade de que o mundo seja como nos parece. Pessoalmente, a propósito, dessa posição é inútil. Ninguém pode viver com esse ceticismo. Temos que ir além desse ceticismo, temos que esquecer isso! (...) Não no conhecimento, mas na criação está a nossa salvação!Nossa grandeza está na aparência suprema, na emoção mais nobre. Se o universo não nos interessa, queremos ter o direito de desprezá-lo]. Idem de 1872, 19[125].

77 "Nur die Kunst vermag uns zu retten." NIETZSCHE. Fragmento póstumo de 1872, 19[319]. Ver também: "Wir kennen nicht das wahre Wesen einer einzigen Kausalität. Absolute Skepsis: Nothwendigkeit der Kunst und Illusion" [Não conhecemos a verdadeira essência de uma única causalidade. Ceticismo absoluto: necessidade de arte e de ilusão]. Idem. de 1872, 19[121].
} 
obrigados a investigar em que sentido a concepção estética ${ }^{78}$ kantiana está presente em $O$ Nascimento da tragédia. Mais especificamente, interessa-nos elucidar em que medida o sentimento do belo, descrito por Kant, coteja com o princípio apolíneo formulado por Nietzsche, do mesmo modo que o sublime se relaciona com o princípio dionisíaco, conectando, então, a terceira Crítica com a intepretação artístico-ontológica nietzschiana. Tal investigação nos dará outra dimensão sobre o pensamento kantiano designado como a "sabedoria dionisíaca expressa em conceitos". Além disso, demonstraremos que na elaboração kantiana sobre o sublime existe uma ideia prematura do trágico que, por sua vez, se desdobrará na grande questão filosófica sobre a tragédia desenvolvida nas obras de juventude de Nietzsche.

\subsection{2.}

\section{O dionisíaco entre a imaginação e a razão:}

A terceira Crítica, dedicada à capacidade de julgar foi dividida, grosso modo, em duas partes: a "Crítica da faculdade de juízo estética" e a "Crítica da faculdade de juízo teleológica"; a primeira parte, no que lhe concerne, se ocupará, no primeiro livro, de uma seção sobre a analítica do belo, seguida de uma seção sobre a analítica do sublime. Como uma espécie de extensão da sua primeira Crítica, Kant fundamentará a experiência estética, não nas qualidades dos objetos que supostamente afetam o sujeito, mas nos sentimentos suscitados da relação entre suas faculdades. Nesse ponto já podemos estabelecer uma conexão entre Kant e Nietzsche, posto que o apolíneo e o dionisíaco são compreendidos esteticamente a partir dos estados fisiológicos do sonho e da embriaguez e, fundamentalmente, a partir dos sentimentos de dor e prazer produzidos nos indivíduos. O apolíneo proporciona o prazer da bela aparência e o deleite do sonho em contramedida ao desprazer da individuação, isto é, da dor em separar-se da unidade originária; enquanto o dionisíaco propicia a agonia pela perda da

\footnotetext{
${ }^{78}$ Agora nos referimos ao termo "estética" enquanto filosofia do belo e do sublime, tal como aparece na Crítica da faculdade do juízo; não mais no sentido da estética transcendental que, em resumo, pensa os conceitos de espaço e tempo na Crítica da razão pura.
} 
individuação, ou seja, o horror pela dissolução do indivíduo, porém, concomitantemente ao prazer extático ${ }^{79}$.

Tal conexão se estabelece, não porque Nietzsche fundamenta a experiência estética na disposição das faculdades do sujeito, mas, por entender que a base dessa experiência são os sentimentos de prazer e desprazer. Se para um filósofo esses sentimentos emanam da relação entre as faculdades, para o outro, são efeitos no sujeito do jogo entre as pulsões metafísicas. Outra curiosa semelhança é que, segundo a Crítica da faculdade do juízo, o belo distingue-se do sublime na medida em que o primeiro corresponde a uma sensação simples de prazer mediante uma serena contemplação [ruhiger Kontemplation] $]^{80}$, enquanto o segundo refere-se a um movimento do ânimo [Bewegung des Gemüts] ${ }^{81}$, uma sucessão de sentimentos opostos: primeiro o horror e depois o deleite. Já em $O$ Nascimento da tragédia, o apolíneo é responsável por produzir no sujeito o aprazimento por intermédio das formas belas, ao passo que o dionisíaco abarca um misto de sentimentos: o pavor seguido do prazer extático. Assim, a serenidade, que é por excelência um princípio apolíneo, o ligará ao belo kantiano; e a embriaguez dionisíaca, que age diretamente sobre o ânimo, se ligará ao sublime.

Para aprofundar essa provável influência de Kant nas concepções de juventude nietzschianas, é importante apresentarmos, mesmo que de modo geral, como a Crítica da faculdade do juízo explica analiticamente o belo e o sublime. $\mathrm{Na}$ introdução da obra, os juízos estéticos são apresentados como exemplos de juízos reflexivos [reflektierende Urteilskraft], compreendidos estruturalmente em oposição aos juízos determinantes [bestimmende Urteilskraft]. Nesta modalidade de juízos determinantes, as regras do entendimento ou a lei moral da razão estão dadas de antemão, todo julgar se reduz a um ato de subsunção quase automático, como em um processo de dedução lógica, onde se parte do geral para o particular. Por exemplo, quando o entendimento postula "para toda mudança há uma causa" (lei geral da natureza) a faculdade de julgar determinante irá indicar a condição da subsunção em conceitos. O julgar reflexivo, ao contrário, terá de buscar uma regra

\footnotetext{
${ }^{79}$ Cf. NIETZSCHE. O Nascimento da tragédia, $\$ 1$.

${ }^{80}$ KANT, Immanuel. Crítica da faculdade do juízo, §24, "Da divisão de uma investigação do sentimento do sublime". p. 93.

${ }^{81}$ Idem.
} 
geral tendo como ponto de partida e única referência o próprio particular ${ }^{82}$. Os juízos estéticos sobre o belo e o sublime são, à vista disso, todos reflexivos: partese dos sentimentos subjetivos e particulares em busca da regra geral ${ }^{83}$.

Por conseguinte, o ajuizamento estético fundamenta-se nas condições internas do sujeito que, por sua vez, permitem a eclosão de tais sensações. No caso do juízo de beleza, para distinguirmos se algo é belo ou não, não nos referimos ao entendimento do objeto em vista de seu conhecimento, mas à imaginação e aos sentimentos de prazer e desprazer ${ }^{84}$. O belo seria a complacência provocada por determinado objeto da representação, contudo, independente de qualquer interesse ${ }^{85}$. Importante dizer que o juízo do belo diz respeito à forma, aos contornos que limitam o objeto. Há, segundo Kant, do ponto de vista do sistema transcendental, uma relação harmoniosa em um jogo livre [freien Spiels] entre duas faculdades: a imaginação e o entendimento. A imaginação é responsável por organizar os dados sensíveis e apresentá-los segundo uma forma que se adeque às condições do entendimento. Ocorre, portanto, um acordo interno entre o aspecto sensível do sujeito - a imaginação livre de conceitos - e o aspecto inteligível - o entendimento, embora sem proposições teóricas ${ }^{86}$. Esse acordo harmonioso resulta um deleite subjetivo, entendido como o prazer estético da beleza.

Se desconsiderarmos a explicação pautada no sistema transcendental, então podemos certamente vincular certas características do belo kantiano ao apolíneo nietzschiano. A destacar que ambos, tanto o juízo descrito por Kant, quanto a entidade metafísica formulada por Nietzsche, dizem respeito à forma. $\mathrm{O}$ apolíneo é responsável pelo princípio de individuação que, no fundo, é o criador de contornos e responsável por impor limites a tudo que existe de maneira individual. No campo artístico, o apolíneo representa as artes com delineamento e "linhas". As narrativas de Homero são, segundo Nietzsche, exemplo da arte apolínea precisamente devido a sua forma: ainda que os eventos descritos envolvessem o

\footnotetext{
${ }^{82}$ Cf. Ibidem. "Introdução", §IV, "Da faculdade do juízo como uma faculdade legislante a priori".

${ }^{83} \mathrm{Em}$ busca também, é claro, da possibilidade de comunicabilidade universal. Cf. Ibidem, §9, "Investigação da questão, se no juízo de gosto o sentimento de prazer precede o ajuizamento do objeto ou se este ajuizamento precede o prazer". p. 62.

${ }^{84}$ Ibidem, $\S 1$, "O juízo de gosto é estético". p. 47 e 46.

${ }^{85}$ Ibidem, §5, "Comparação dos três modos especificamente diversos de complacência". p. 55.

${ }^{86} \mathrm{Um}$ entendimento não-conceitual, ou, mais especificamente, um entendimento com conceitos indeterminados. Cf. Idem, §23, "Passagem da faculdade de ajuizamento do belo à de ajuizamento do sublime". p. 90.
} 
horror, a guerra, o destino implacável e terríveis mortes, o que prevalecia nos relatos homéricos era a serenidade da bela forma ${ }^{87}$. Em suma, o principal elemento apolíneo é a beleza ${ }^{88}$. Em $O$ Nascimento da tragédia, quase todas as ocorrências do termo schön estão relacionadas aos efeitos apolíneos suscitados no sujeito. Tal como Kant define o belo, o efeito apolíneo que se destaca, seja mediante ao mundo figurativo ou às artes figurativas, é "a excitação do agrado pelas belas formas" $" 89$.

Por outro lado, a manifestação do sublime no sujeito, de acordo com a analítica kantiana, está relacionada a um objeto (da natureza) sem forma e sem delimitação. A complacência do sublime também se distingue muito do belo quanto à espécie, isso porque, como vimos preliminarmente, enquanto o primeiro comporta simplesmente um sentimento de "promoção da vida", o sublime é um prazer que apenas surge indiretamente, ou seja, ele é produzido posteriormente a uma momentânea inibição das forças vitais ${ }^{90}$, onde o sujeito é alternadamente repelido e maravilhado pelo objeto. Entretanto, a diferença interna mais importante entre os juízos é que agora o prazer estético origina-se não de um acordo harmonioso entre as faculdades, porém, de uma relação, ao menos no princípio, conflitante entre a imaginação - mesma faculdade de apresentação do sensível - e a razão, a faculdade de conceber ideias das quais não é possível existir representação sensível. Sendo assim, há entre essas faculdades uma desarmônica incompatibilidade, de tal modo que a relação entre elas produz desacordo.

A explicação transcendental kantiana diz que o sublime surge quando a imaginação fracassa na tentativa de sintetizar em uma forma a totalidade de um objeto sensível. Reconhecendo sua incapacidade de abarcar a representação do múltiplo, pede socorro à razão, faculdade capaz de pensar para além do domínio sensível regulado pelas leis causais da natureza. O momentâneo desprazer, medo, ou inibição das forças vitais [Hemmung der Lebenskräfte] ${ }^{91}$ é resultado desse fracasso da imaginação em seus esforços. E o prazer que surge em seguida

\footnotetext{
${ }^{87}$ Cf. NIETZSCHE. O Nascimento da tragédia. §3, p. 37.

${ }^{88}$ Em referência a Apolo, Nietzsche é categórico: "Die "Schönheit" ist sein Element". Ibidem. A visão dionisíaca de mundo. $\$ 1$.

${ }^{89}$ Ibidem. O Nascimento da tragédia. §16, p. 98.

${ }^{90}$ KANT. Op. Cit. p. 90.

${ }^{91}$ KANT, Immanuel. Idem, p. 90.
} 
provém do reconhecimento, mediante este insucesso, da capacidade suprassensível e da vocação moral em nós. Essa alternância de sentimentos contrários pode ser ilustrada com a interpretação da imagem presente na conclusão da Crítica da razão prática, onde Kant confessa que duas coisas enchem o ânimo de admiração e veneração: "o céu estrelado sobre mim e a lei moral em mim" $"$. Ao defrontar-se com o sem-número de estrelas e infinidade de mundos, devido ao fracasso da imaginação em sintetizar tamanha grandeza, acomete-se o pavor; mas com o socorro da razão, descobrimos a moral em nós, eclodindo então, tamanho prazer.

Para melhor entender essas ponderações, é importante destacar que Kant concebe dois tipos distintos de sublime: o matemático (descritos nos parágrafos $\S 25$ a §27) e o dinâmico da natureza (descrito nos parágrafos §28 e §29). A divisão é feita, pois, o sentimento de promoção da vida decorre, não apenas do sujeito perceber que é capaz de pensar o infinito, mas porque a apreensão da natureza para além dos limites sensíveis está relacionada à moralidade. Além disso, visto que o sublime comporta, como característica própria, o movimento do ânimo ao ajuizar o objeto, pode referir a esse movimento pela faculdade da imaginação à faculdade do conhecimento (ao uso teórico da razão), ou à faculdade do desejo ${ }^{93}$, no uso prático da razão. No primeiro caso o que está em avaliação é a "grandeza" do objeto e corresponde ao sublime matemático; no segundo, está em avaliação a potência do objeto e diz respeito ao sublime dinâmico. Desse modo, o sublime matemático eclode diante de objetos da natureza que suscitam à imaginação uma ideia de infinitude; já o dinâmico, sobrevém quando o sujeito imagina-se diante de uma força descomunal da natureza, que poderia facilmente destruí-lo.

\footnotetext{
${ }^{92}$ A passagem a que nos referimos é a seguinte: "Duas coisas enchem o ânimo de admiração e veneração sempre novas e crescentes, quando mais frequentemente e como maior assiduidade delas se ocupa a reflexão: o céu estrelado sobre mim e a lei moral em mim (...). A primeira começa no lugar que eu ocupo no mundo exterior dos sentidos e estende a conexão em que me encontro até ao imensamente grande, com mundos sobre mundos e sistemas de sistemas, nos tempos ilimitados de seu periódico movimento, do seu começo e de sua duração. A segunda começa no meu invisível eu (...) eleva infinitamente o meu valor como inteligência, por meio da minha personalidade, na qual a lei moral descobre uma vida (...) que se estende até o infinito". KANT, Immanuel. Crítica da razão prática, "Conclusão". p. 183 e 184.

${ }^{93}$ Optamos por traduzir [Begehrungsvermögen] por "faculdade do desejo" ao invés de "faculdade da apetição", como na edição brasileira que estamos a utilizar. A oração completa no original é: "Einbildungskraft entweder auf das Erkenntnis- oder auf das Begehrungsvermögen bezogen". KANT. Crítica da faculdade do juízo. §24, "Da divisão de uma investigação do sentimento do sublime", p. 93.
} 
Em termos mais específicos, Kant denominará o sublime matemático como o "absolutamente grande" ou "grande acima de qualquer comparação". Nesse sentido o sublime não pode ser um objeto da experiência. A imaginação por sua aspiração ao infinito, ao tentar apreender a ideia de totalidade, chega ao seu limite e falha, justamente por ser-lhe impossível apresentar uma ideia que está no âmbito do suprassensível. Em meio ao momentâneo desprazer diante do fracasso da imaginação para apresentar o infinitamente grandioso, que extrapola o sensível, ela recorre ao conhecimento e faz com que o sujeito tenha consciência da capacidade ilimitada da razão. Em outras palavras, a razão exige que a grandeza absoluta seja apresentada em uma intuição sensível, fazendo com que a imaginação chegue ao limiar daquilo que é capaz de apresentar. Mas como é impossível para a faculdade das imagens sensíveis executar o que lhe é exigido, pois os objetos da sensibilidade estão sujeitos às condições da experiência possível, cria-se uma tensão. No entanto, ao fracassar, percebemos que somos capazes de pensar o infinito, transformando então o desconforto em prazer.

Esse sentimento de prazer, de promoção da vida, decorre da consciência de que somos capazes de superar os limites da imaginação e atingir o suprassensível através do uso teórico da razão. A grandeza dessa faculdade nos torna maiores do que qualquer grandeza na natureza. Como exposto na conclusão da segunda Crítica: mesmo se comparados à infinita grandeza dos astros celestes, podemos considerar que nossa vida, graças à capacidade da razão, estende-se ao infinito. Da mesma forma que a apreciação do céu noturno e seus infinitos mundos, está igualmente relacionada ao sublime-matemático a admiração de cordilheiras e montanhas regulares, ou dos infindáveis mares, etc. Não obstante, é essencial salientar que o sublime, para Kant, é um fenômeno subjetivo, isto é, que a verdadeira sublimidade está apenas no ânimo daquele que ajuíza e não nos objetos da natureza. O sublime é, portanto, um sentimento. Os objetos sensíveis no espaço e tempo, como as montanhas ou o oceano, apenas despertam o sentimento em nós. O sublime está contido nas ideias da razão. A contemplação do grandioso na natureza eleva-nos do domínio sensível às ideias suprassensíveis.

Já em relação ao sublime dinâmico [Dynamisch-Erhabenen], o que está em jogo entre nossas faculdades é a potência [Macht] proveniente de descomunais fenômenos da natureza que, a princípio, seriam capazes de nos aniquilar. Neste 
contexto, a imaginação sucumbe frente à manifestação de uma força monstruosa. O aspecto sensível do sujeito se encontra em efetivo risco de ser destruído pela violência ameaçadora da natureza. Mas diante do colapso da faculdade sensível encontramos no plano suprassensível nosso verdadeiro valor. Como no caso do sublime matemático, somos socorridos pela razão que revela seu poder absoluto na forma de uma força moral e uma convicção da liberdade. Em consequência, eclode um sentimento que nos revela a nossa destinação enquanto ser moral, e por isso, superiores em relação à natureza. Logo no início de suas considerações no parágrafo $\$ 28$, ao diferenciar potência e força $[\text { Gewalt }]^{94}$, Kant resume claramente que a natureza ajuizada esteticamente como potência, mas incapaz de exercer força sobre nós, é dinamicamente-sublime; isto quer dizer, que o homem encontra no aspecto prático da razão uma resistência que a natureza não pode suplantar.

Em outras palavras, o sublime dinâmico consiste em um movimento do ânimo que transforma o pavor e a repulsão inicial, provocados por uma potência ameaçadora da natureza, em uma prazerosa atração; ocorre, portanto, o domínio do medo, isso porque a razão demonstra sua superioridade em relação ao mundo sensível. Nessa situação, em um primeiro momento, a capacidade de resistência do homem parece insignificante diante de manifestações poderosas, tais como: "nuvens carregadas acumulando-se no céu, avançando com relâmpagos e estampidos; com vulcões em sua inteira força destruidora; furacões com a devastação deixada para trás; ou o ilimitado oceano revolto". No entanto, se o espectador encontrar-se em segurança, então esses espetáculos quanto mais terríveis, mais atraentes se tornarão. Esses fenômenos são denominados de sublimes justamente por fazer-nos conhecer a nossa limitação física diante da incomensurabilidade da natureza, ao mesmo tempo em que mostra, em nossa faculdade racional, outro padrão de medida não-sensível, que por sua vez, revelanos independentes da natureza, e por isso, superiores a ela.

Essa apresentação geral do sublime kantiano feita até aqui, já seria suficiente para estabelecermos uma aproximação com o dionisíaco do período de

\footnotetext{
${ }^{94}$ Neste contexto, força seria a capacidade de resistir à potência. Kant explica da seguinte forma "Poder [Macht] é uma faculdade que se sobrepõe a grandes obstáculos. Esta chama-se força [Gewalt] quando se sobrepõe também à resistência daquilo que possui ele próprio poder. A natureza, considerada no juízo estético como poder que não possui nenhuma força sobre nós, é dinamicamente-sublime. KANT. Idem, §28, “Da natureza como um poder”. p. 106.
} 
O Nascimento da tragédia. Tanto um quanto o outro estão associados a um dinamismo de sentimentos opostos, e ainda, referem-se a um objeto cuja representação é impossível por meio de formas. Contudo, essa intimidade é ainda mais próxima. Podemos dizer que Nietzsche, a partir de uma leitura estritamente schopenhauriana, busca na conceituação estética do sublime feita, não só por Kant, mas por diversos pensadores modernos, a fundamentação teórica para sua visão sobre os helenos, a tragédia e o dionisíaco. Se olharmos para o escrito que dá título, em parte, à nossa tese, ao invés da obra de 1872, então essa conexão torna-se ainda mais evidente. No $\$ 3$ de A visão dionisíaca de mundo, o movimento que envolve o arrebatamento do estado dionisíaco - primeiro com a aniquilação das formas e dos limites da existência comuns e, segundo, com o retorno à consciência da realidade cotidiana - será compreendido como o processo de sublimidade que alterna entre a atraente excitação e a repugnância.

Para Nietzsche, há um abismo do esquecimento que separa o mundo da realidade cotidiana e o mundo dionisíaco. Durante o êxtase dionisíaco, impera um elemento letárgico: a realidade passa a ser vista apenas como uma vivência passada. Porém, assim que essa lacuna é desfeita e a consciência volta a dar-se conta da realidade comum, eclode uma disposição de humor ascética, um sentimento de repugnância [Ekel]. Nesse mundo cotidiano o horrível está por toda parte: a morte é iminente, a existência do ser humano é um absurdo, nada faz sentido. Essas terríveis características tornam-se mais nítidas quando a consciência desperta da embriaguez; da mesma forma que o ébrio ao despertar de sua bebedeira encontra na ressaca o angustiante mal-estar, aquele que experimenta "a sabedoria do deus silvestre", ao despertar para a existência cotidiana percebe como ela é atroz, o resultado é então, apenas a repugnância. A saída para esse perigoso sentimento negador não seria abafar ou reprimir o estado dionisíaco, mas converter a repulsa sobre o horrível e o absurdo da existência em representações [Vorstellungen] que tornam a vida possível de ser vivida: o sublime e o ridículo ${ }^{95}$.

Aqui está a ideia central da "metafísica do artista": a arte como salvação de todo pessimismo negador da existência. Nesse sentido, o sublime será interpretado

\footnotetext{
${ }^{95}$ NIETZSCHE. A visão dionisíaca de mundo. §3. A mesma ideia aparece em $O$ Nascimento da tragédia, §7, onde Nietzsche substitui o termo "ridículo" [das Lächerlich] pela categoria estética "cômico" [das Komische].
} 
artisticamente, Nietzsche o descreverá como a "domesticação artística do horrível", enquanto o ridículo - ou o cômico - como a "descarga artística da repugnância do absurdo" $" 96$. Esse emprego nietzschiano do sublime realmente aproxima-se ao de Kant: trata-se de produzir um prazeroso sentimento afirmativo frente ao terrível, ao ameaçador e ao absurdo. Agora o sentimento não é mais o fruto moral do jogo entre as faculdades transcendentais, mas o efeito da obra de arte que imita a embriaguez, que flerta com o êxtase dionisíaco. O sublime estaria ligado, portanto, à tragédia, ao passo que o "ridículo", descrito acima, à comédia; modos artísticos que se entrelaçam, unidos pelo jogo que fazem com a embriaguez. Além disso, o sublime e o cômico não correspondem ao belo, ao contrário, estão um passo à frente do mundo das aparências. Na linguagem metafísica de A visão dionisíaca de mundo, essas formas de arte, também representam um velamento da verdade, embora, mais transparente do que a beleza.

O sublime e o cômico, a tragédia e a comédia representam, no campo artístico, um mundo intermediário entre a verdade e a beleza apolínea. Neste intervalo, é possível jogar com a embriaguez dionisíaca sem o risco de ser completamente tragado por ela. Esse jogo é comum ao homem dionisíaco, o instintivo poeta-cantor-dançarino. $\mathrm{Na}$ interpretação de Nietzsche, quanto mais os gregos antigos tornavam-se cientes do monstruoso sofrimento inerente a todo existente, mais a imagem de beleza e serenidade dos deuses do Olimpo corria o risco de sucumbir. Na obra de arte tragi-cômica ${ }^{97}$ os deuses foram salvos, pois deixaram de ser apenas belos e passaram a corresponder ora à sublimidade, ora ao cômico $^{98}$. Nessa análise, Ésquilo e Sófocles foram os poetas que melhor mostraram em seu tempo como poder viver mediante a sublimidade do período trágico dos gregos. O sublime aparece a Ésquilo, diz Nietzsche, como a ideia de "justiça grandiosa": "homem e deus estão na mais estreita comunidade subjetiva: o divino-justo-moral e o feliz estão para ele unitariamente enlaçados um no

\footnotetext{
${ }^{96}$ Respectivamente: "künstlerische Bändigung des Entsetzliche" e "die künstlerische Entladung vom Ekel des Absurden". Cf. NIETZSCHE. A visão dionisíaca de mundo. §3.

97 "tragisch-komischen Kunstwerk". Idem.

${ }^{98}$ Interessante saber que Nietzsche pondera que os deuses tinham se separado em dois grupos, somente poucos pairavam no intermédio, como divindades ora sublimes, ora cômicas. Sobretudo Dioniso mesmo recebeu este caráter ambíguo. Cf. Idem.
} 
outro" ${ }^{99}$. Os deuses são reconstruídos segundo a norma de administração da justiça e nisso consiste o sublime.

O que Nietzsche quer dizer é que Ésquilo reconstrói os deuses mediante a norma da justiça. Zeus, por exemplo, quando expulsa os titãs do monte Olimpo, ou quando castiga Prometeu ao sofrimento eterno, o faz sob o pretexto da justiça. $\mathrm{Na}$ tragédia esquiliana o sentimento de repugnância frente ao horrível da existência dilui-se no sublime assombro diante da sabedoria da ordenação do mundo. Até mesmo os deuses são considerados do ponto de vista da equidade, eles sofrem como os homens e estão igualmente submetidos ao governo impiedoso da Moira. Já em Sófocles é o contrário, o poeta suscita a sublimidade na impenetrabilidade da administração da justiça pelos deuses: "o caráter imerecido de um horrível destino pareceu-lhe sublime, os enigmas verdadeiramente insolúveis da existência humana eram as suas musas trágicas" ${ }^{100}$. O sofrimento é, então, transfigurado em algo santificante. Édipo, por exemplo, destinado à miséria e ao excesso de desgraças, no fim, por seus tremendos sofrimentos, exerce à sua volta um efeito de serenojovialidade ${ }^{101}$. O sentimento de desprezo à vida devido ao grotesco e à falta de sentido se converte em uma serena alegria de viver.

$\mathrm{Na}$ interpretação nietzschiana, em Ésquilo, o problema é a falta de conhecimento sobre os deuses no homem, enquanto a falta de conhecimento de si no homem é o problema em Sófocles. Para o primeiro, o divino e o mortal são medidos na mesma balança da justiça, para o segundo, a distância entre o humano e o divino é imensurável. O sublime, ou seja, a descarga artística do horror, na tragédia esquiliana está no espanto [Schauer] diante da sabedoria do mundo ordenado, a qual é difícil de ser compreendida devido aos limites do homem. Em Sófocles, esse espanto, e consequentemente a descarga sublime, é ainda maior, porque a sabedoria sobre o mundo, sobre os deuses, e até o conhecimento de si é inatingível. Mas em ambos os casos, só é possível transformar o desgosto devido à constatação da eminente nulidade da existência em uma prazerosa vontade de

\footnotetext{
${ }^{99}$ Idem.

${ }^{100}$ Idem

101 "Sófocles, em seu Édipo, entoa, qual um prelúdio, o hino triunfal do santo". NIETZSCHE. $O$ Nascimento da tragédia. \$9, p. 64. (Basta lembrarmo-nos da sereno-jovialidade que resplandece da morte do herói em Édipo em Colono).
} 
viver, porque há o reconhecimento de que o horrível e o absurdo são apenas em aparência. Nietzsche, inspirado por Schopenhauer, assevera que todo real dilui-se em aparência e atrás desta manifesta-se a essência unitária do mundo. Logo, a nulidade não é efetiva, é apenas aparente. O fluxo da vida essencial é perene.

O sublime em Nietzsche deixa de ser, como em Kant, apenas fenomenológico, e passa a possuir contornos metafísicos. A tragédia proporciona um gozo estético, porque imita as manifestações do Uno originário. Ao espectador trágico é feita a exigência dionisíaca: tudo que se apresenta a ele deve ser encarado como encantamento. É preciso que ele veja em cena mais do que meros símbolos, aparências do devir essencial. É necessário que ele sinta em si, por meio do êxtase, as contradições da vontade, o núcleo metafísico do mundo. O que só pode ser proporcionado através da música. O sublime em Nietzsche se funda, portanto, em uma embriaguez da essência ${ }^{102}$ que só é possível mediante ao arrebatamento musical. Essa ideia é confirmada pelo filósofo quando associa o elemento dionisíaco da tragédia à obra de Richard Wagner ${ }^{103}$. Para Nietzsche, o compositor teria atribuído à música o caráter de "sublime", em contraposição ao agradavelmente belo. Nela gozaríamos de um estado originário paradisíaco que só pode ser compreendido se vinculado ao sentimento moral do sublime ${ }^{104}$.

Apesar de a relação entre o sublime kantiano e o pensamento estético nietzschiano do chamado "período de juventude" ser claramente possível, ainda mais se levarmos em conta os indícios deixados pelo próprio filósofo; para que a comparação não seja precipitada é necessário destacar alguns detalhes. O debate filosófico moderno sobre o sublime não foi uma especificidade de Kant, até mesmo antes dele outros autores como Joseph Addison e Edmund Burke ${ }^{105}$ já haviam formulado teorias sobre o efeito estético do grandioso na natureza. Além

\footnotetext{
102 "Wenn das Schöne auf einem Traum des Wesens beruht, so das Erhabene auf einem Rausche des Wesens". NIETZSCHE. Fragmento póstumo de 1870/1871, 7[46].

${ }^{103}$ A relação entre Richard Wagner e o trágico e todos os seus desdobramentos será explorada no nosso Primeiro Estásimo.

${ }^{104}$ Nietzsche nos deixa claro essa ideia no Fragmento póstumo de 1871 9[106].

${ }^{105}$ Joseph Addison expõe sua noção de sublime grandioso em Pleasures of the imagination (1712) e The Spectator, esta última obra, organizada em 8 volumes, foi copilada a partir de uma série de publicações diárias entre 1711 e 1714. Addison, assim como outros poetas britânicos (Anthony Ashley-Cooper e John Dennis) tiveram como ponto de partida para a descrição estética do sublime, o sentimento de horror e harmonia ao viajarem pelos Alpes. Diretamente influenciado por eles e pela poesia Edmund Burke escreve em 1747 sua obra A Philosophical Enquiry into the Origin of Our Ideas of the Sublime and Beautiful, onde sistematiza a diferença entre sublime e belo.
} 
disso, não devemos deixar de mencionar que para Kant a sublimidade só é possível quando o sujeito encontra-se em segurança, e a "fúria" do objeto não pode atingir-lhe. Já no que se refere ao dionisíaco, o indivíduo corre o efetivo risco de aniquilação frente à verdade de mundo que é forçado a experimentar, sua única segurança é a proteção apolínea. Outro aspecto importante é que Nietzsche gradualmente abandona o termo. Nos textos e fragmentos que precedem sua primeira obra, a palavra "sublime" é utilizada no sentido kantiano e, como vimos, em intimidade com o dionisíaco. Porém, na obra de 1872 apenas duas vezes o termo aparece em sua compreensão estética ${ }^{106}$.

Contudo, a diferença fundamental consiste no fato de o sublime kantiano não se aplicar à arte; não é possível a sublimidade mediante a contemplação artística, o sentimento resulta apenas de objetos da natureza. Desse modo, a concepção nietzschiana se aproximaria mais de outros pensadores, também influenciados profundamente por Kant, mas que reformularam, a seu modo, a noção de sublime. Esse é o caso, por exemplo, de Schiller, pensador de enorme importância para as reflexões de Nietzsche sobre o trágico ${ }^{107}$. Para Schiller, grosso modo, o objeto sublime seria de uma dupla espécie: "ou o referimos à nossa faculdade de apreensão [Fassungskraft] e somos derrotados na tentativa de dele formar uma imagem ou um conceito; ou o referimos à nossa faculdade vital [Lebenskraft] e o consideramos como um poder contra o qual o nosso se reduz a nada" ${ }^{\prime 108}$. No entanto, embora em ambos os casos ele nos evoque o doloroso sentimento de nossa limitação, não fugimos dele. Igualmente em Kant, somos atraídos por ele com irresistível violência. Deleitamo-nos com o infinito sensível, pois somos capazes de pensar o que os sentidos não mais apreendem e o entendimento não mais compreende ${ }^{109}$.

Para Schiller, somos entusiasmados pelo terrível porque podemos querer o que os impulsos repelem e rejeitar o que eles desejam, ou seja, o aspecto racional do homem, consequentemente seu aspecto moral e a liberdade, sobressaem em

\footnotetext{
${ }^{106} \mathrm{O}$ termo erhaben, ou suas declinações, ocorrem 28 vezes em $O$ Nascimento da tragédia. Podemos dizer que em apenas duas dessas ocorrências o termo é empregado em correspondência ao dionisíaco. Nas demais ocorrências, é utilizado apenas como adjetivo.

${ }^{107}$ Nietzsche refere-se a Schiller ao menos 11 vezes em $O$ Nascimento da tragédia. Na maioria da vezes para dialogar com as ideias schillerianas sobre a tragédia.

${ }^{108}$ SCHILLER, Friedrich. "Sobre o sublime", §16. In: Textos sobre o belo, o sublime e o trágico. p. 222.

${ }^{109}$ Cf. Idem. Vemos aqui a distinção kantiana entre matemático-sublime e dinâmico-sublime.
} 
relação ao sensível, de modo que "deixamos a imaginação encontrar o seu mestre no reino dos fenômenos, pois finita é somente uma força sensível que triunfa sobre uma outra sensível, mas a natureza, em toda a sua ausência de limites, não pode atingir o absolutamente grande em nós próprios" ${ }^{\prime 10}$. O homem pode submeter-se de bom grado à necessidade física o seu bem-estar, suportar voluntariamente o que não pode mudar. Dessa forma, lembra-se que os seus princípios não estão submetidos à violência da natureza: "o homem está nas mãos dela, mas a vontade do homem está nas dele"111. O prazer no sublime schilleriano está ligado, portanto, à consciência de tornar-se livre a ponto de estar resguardado de toda fúria da natureza, porque antes que possa ser atingido, já foi ação de sua livre vontade preservar-se. O que faz dessa submissão um ato de liberdade e não uma resignação é a resistência da razão em nós.

Como podemos perceber, a formulação schilleriana sobre o sublime é muito próxima à de Kant. Ele apenas a reformula com uma nomenclatura própria. Transforma o sublime matemático e dinâmico em sublime teórico e prático, ou o contemplativo e o patético. Apesar disso, Schiller dá um passo à frente e relaciona a sublimidade ao trágico. O sentimento em questão é provocado por uma situação aterrorizante, cuja representação faz sentir-nos impotentes e em perigo iminente de ser dilacerado. Mas, ao mesmo tempo, é preciso que o objeto terrífico possibilite à nossa superioridade racional uma resistência moral. Nesse sentido, ao contrário de Kant, não é necessário encontrar-se sensivelmente em segurança, longe disso, a ruína física deve ser iminente. Entretanto, a superioridade racional é inabalável, prevalece, então, uma segurança moral interior. O sublime é entendido como uma correspondência entre o sofrimento físico e a resistência moral ao sofrimento. Por mais que o indivíduo encontre-se em risco imediato de ser dilacerado fisicamente, nunca o é moralmente. Por conseguinte, a sorte de sofrimento e o dilaceramento dos heróis trágicos seriam bons exemplos dessa concepção de sublime.

Schiller mesmo exemplifica o herói sublime através da imagem de Prometeu. Diferentemente de Hércules, que com sua grandiosa força física venceu o pavoroso, Prometeu sucumbiu diante dos deuses, foi acorrentado no Cáucaso,

${ }^{110}$ Idem. p. 223.
${ }^{111}$ Idem. 
mas não se prostrou moralmente diante de seu ato e não admitiu o seu erro. $\mathrm{Na}$ interpretação schilleriana, Hercules é Grande, enquanto Prometeu é Sublime. Por mais pavoroso que o objeto deva ser não pode suscitar o pavor e a repulsa, caso contrário, vê-se anulado o juízo estético. O herói trágico representa, precisamente, esta margem entre o pavoroso e o pavor onde encontra-se o sublime. $\mathrm{Na}$ arte trágica há, em primeiro lugar, uma apresentação viva do sofrimento, sucedida por uma apresentação da independência moral no sofrimento. Essa é a grande originalidade de Schiller: interpretar a teoria da tragédia a partir da noção do sublime. Com isso ele deixa de ser um sentimento que resulta unicamente da natureza e também passa a pertencer ao âmbito artístico. A arte trágica é em essência a arte do sublime, porque retira toda a sua força do conflito existente entre a sensibilidade e a liberdade e, consequentemente, da superação espiritual deste conflito.

Apesar de sua interpretação de tragédia ser fortemente influenciada pala Poética de Aristóteles, leitura predominante em sua época, Schiller pensa o sublime como efeito do gênero poético trágico, embora estranho ao teatro grego antigo. A tragédia ática, por conceder ao destino a verdadeira responsabilidade pelos desdobramentos do enredo, acaba por representar uma submissão completa do homem à fatalidade, contrariando assim as premissas condicionais para a sublimidade: a superioridade da razão e a liberdade moral. Por conseguinte, o que Schiller tem em mente é uma tragédia moderna, expressão dos conflitos morais do homem moderno. O herói sublime é aquele que mesmo agrilhoado à finitude e às agoniantes intempéries da vida, prevalece ao sofrimento graças à sua liberdade $\mathrm{e}$ às suas escolhas morais. Sabendo disso, poderíamos, equivocadamente, concluir que a concepção schilleriana de trágico afasta-se completamente do pensamento nietzschiano, já que a ideia aristotélica de purificação das emoções estaria presente na forma de uma moralização das escolhas. Todavia, é evidente a influência em Nietzsche, sobretudo no que se refere ao sublime e ao trágico.

Schiller foi fundamental para a elaboração do pensamento trágico nietzschiano. O poeta era visto como o precursor da libertação alemã do mundo neolatino $^{112}$, ou seja, era considerado, ao lado de Goethe, como o guia que iniciou

${ }^{112}$ Cf. NIETZSCHE. Fragmentos póstumos de 1871, 9[147]. 
a criação de uma identidade cultural na Alemanha ${ }^{113}$. É claro que Nietzsche preserva certa originalidade na sua visão artística de mundo. Mas ao pensar nos efeitos estéticos no sujeito daquilo que chamou de apolíneo e de dionisíaco, tinha em mente a concepção schilleriana do sublime e, consequentemente, as definições feitas por Kant. A transposição feita é nítida: o belo baseia-se no sonho da essência, isto é, na aparência apolínea; o sublime se funda em uma embriaguez da essência $^{114}$. A tragédia é, ao mesmo tempo, beleza ${ }^{115}$ e sublimidade. Porém, devemos ressaltar que o aspecto sublime da tragédia só é possível mediante a música. Essa ideia traz à cena a filosofia de Schopenhauer: a arte - a música em máximo grau - como paliativo à dor e ao sofrimento inerentes ao mundo. Logo, cabe-nos agora investigar o pensamento schopenhauriano a fim de demonstrar os porquês deste também ser considerado como "a sabedoria dionisíaca expressa em conceitos".

\subsection{3. \\ Dioniso e Apolo como vontade e representação}

O pensamento nietzschiano, como já é sabido e discutido por uma infinidade de literatura especializada, é profundamente marcado por Schopenhauer. Podemos dizer que o modo como Nietzsche faz filosofia é sempre uma interlocução com o "mestre": em um primeiro momento sob uma predominante influência; posteriormente, passa a filosofar em oposição, combatendo tudo que identifica como metafísica ou pessimismo schopenhauriano. Tal relação tem início nos primeiros dias de novembro de 1865, quando o jovem estudante Nietzsche adquire, em um relicário em Leipzig, a obra $O$ Mundo como vontade e representação. A leitura apaixonada mudou definitivamente sua visão da existência ${ }^{116}$. As teorias schopenhaurianas tornaram-se o seu fundamento

\footnotetext{
${ }^{113}$ Existem várias referências a este respeito, sobretudo nos fragmentos de 1871 do "grupo 9"; neste período Nietzsche faz uma leitura minuciosa da correspondência entre Schiller e Goethe. Dentre estes fragmentos, destacamos o 9[34].

${ }^{114}$ Cf. Fragmentos póstumos de 1871, 7[46].

${ }^{115}$ Cf. Idem, 1871 7[94].

${ }^{116}$ Cf. Carta a Franziska Nietzsche de 31 de janeiro de 1866 [Cf. Apêndice 1. $\gamma$ ]; a carta Hermann Mushacke de alguns dias antes de 15 de julho de 1867 [Apêndice $\beta$ ] e as cartas a Carl von Gersdorff de 1 de dezembro de 1867 e 11 de março de 1870. [Apêndice $\gamma$ ]
} 
intelectual, uma referência necessária para a construção de um pensamento próprio. No sistema filosófico que descobrira, Nietzsche encontrou respostas para muitas de suas inquietações, de modo que Schopenhauer transformou-se em uma espécie de guia e educador. São inúmeras as cartas em que confessa sua euforia com a leitura do filósofo ${ }^{117}$, a ponto de incentivar os amigos próximos a se "converterem" em uma espécie de schopenhaurianismo ${ }^{118}$. Mais tarde, enquanto professor da Basileia, revela o desejo de substituir a cátedra de filologia pela de filosofia devido a inclinações filosóficas que foram claramente acentuadas após a leitura de Kant e Schopenhauer ${ }^{119}$.

Não há equívoco em dizer que a primeira formulação do dionisíaco é uma herança direta da "filosofia da música" de Schopenhauer. Na interpretação nietzschiana de tragédia, toda primazia atribuída à arte musical é absorvida da metafísica schopenhauriana. Nietzsche compartilhava com Richard Wagner a ideia de que Schopenhauer teria sido o único pensador que havia compreendido verdadeiramente a essência da música ${ }^{120}$. Além disso, o filósofo fornecia em sua obra uma excelente chave de interpretação do pensamento kantiano. Aliás, o ponto de partida do sistema schopenhauriano é a mesma divisão cognitiva feita por Kant entre o mundo dos fenômenos e a coisa-em-si. Ambos os filósofos, ao imporem limites ao conhecimento, representariam, segundo Nietzsche, o fim do então otimismo cientificista, e especialmente Schopenhauer, oferecia a possibilidade de um caminho distinto para o acesso à verdade: fornecia a via das artes e, fundamentalmente, a via da música. Por esses motivos, o pensamento de $O$ mundo como vontade e representação corresponde à "sabedoria dionisíaca expressa em conceitos"; e será agora brevemente analisado.

\footnotetext{
${ }^{117}$ Cf. As cartas a Carl von Gersdorff de 7 de abril de 1866 e do final de agosto de 1866 [Apêndice $\delta$ ]. Carta a Hermann Mushacke de 11 de julho de 1866 [Apêndice $\varepsilon$ ].

${ }^{118}$ Nietzsche escreve em uma carta sobre os sofrimentos de seus afazeres: "Alguma vez também sussurro escondido em baixo da barriga do cavalo: "Schopenhauer, me ajude"; e quando chego em casa, esgotado e coberto de suor, me tranquilizo ao olhar para o seu retrato que tenho sobre minha mesa, ou abrindo o Parerga, que agora, junto a Byron, são para mim, mais simpáticos que nunca". Carta a Erwin Rohde de 3 de novembro de 1867. Além disso, Nietzsche apresentava aos amigos a filosofia de Schopenhauer para "convertê-los", isso ocorreu com Paul Dussen (1845 -1919), que se tornou um dos maiores especialistas e entusiastas de Schopenhauer e de filosofia e religião indiana. Sobre isso cf. carta a Carl von Gersdorff de 15 de agosto de 1866 [Apêndice \]; carta a Paul Deussen de 2 de junho de 1868 [Apêndice $\eta$ ]; carta a Erwin Rohde de 6 de junho de 1868 [Apêndice $\theta$ ].

${ }_{119}$ Cf. A famosa carta a Wilhelm Vischer-Bilfinger, solicitando a substituição da cátedra, possivelmente do início de janeiro de 1871. [Apêndice $\imath$ ]

${ }^{120}$ Cf. Carta a Erwin Rohde de 9 de novembro de 1868. [Apêndice $\boldsymbol{\kappa}$ ]
} 
"O mundo é minha representação" $"$. Com essas palavras Schopenhauer inaugura, em sua obra capital, a investigação sobre o enigma: "o que é o mundo?”. Essa afirmação já nos revela que o modo como o filósofo explicitará sua compreensão da realidade partirá da teoria do conhecimento de $\mathrm{Kant}^{122}$; isto significa que irá estabelecer uma diferenciação entre o conhecimento subjetivo da coisa e a coisa. Há, então, nesse mundo enquanto representação, a relação indissociável entre o sujeito e o objeto. A realidade, em toda a sua pluralidade, apresenta-se ao sujeito enquanto um objeto do conhecimento; toda realidade é apenas uma representação cognitiva adquirida empiricamente. Neste sentido, o corpo, entendido como o "objeto imediato do conhecimento" ${ }^{123}$, é o ponto de partida para a apreensão cognitiva do mundo. A porta de entrada para todo conhecimento é o corpo do sujeito. Schopenhauer diz que "aquele que tudo conhece, mas não é conhecido por ninguém é o sujeito" ${ }^{124}$, ele é o sustentáculo do mundo, pois tudo o que existe, só existe como seu objeto. O mundo como representação é, portanto, a relação entre essas duas metades necessárias e inseparáveis.

O que está em pauta é o enigma do mundo visto a partir do sujeito: caso esse indivíduo que conhece desaparecesse, então o mundo como representação não mais existiria. Essas postulações iniciais são extraídas inteiramente da filosofia kantiana: o sujeito se reconhece em seu limite na medida em que conhece o objeto, em outras palavras, o sujeito finda onde começa o objeto. Esse reconhecimento só é possível devido às formas gerais e essenciais de todo objeto, as quais se encontram a priori na consciência: o tempo, espaço e causalidade. Em conformidade a isso, para Schopenhauer, todo conhecimento ou é empírico ou é fundado sobre uma intuição a priori de uma experiência possível; destarte, o conhecimento é sempre imanente e nunca transcendente. O corpo é, dessa forma, imprescindível para todo conhecer: o filósofo não é nenhuma "cabeça de anjo

121 "Die Welt ist meine Vorstellung". SCHOPENHAUER, Arthur. O Mundo como vontade $e$ representação. $\$ 1$, p. 43.

122 "Contudo, por mais que o meu ponto de partida seja o que o grande Kant realizou, o estudo sério de seus escritos fez-me descobrir erros significativos neles (...)". Idem. "Prefácio à primeira edição". p. 22.

123 "Aqui, portanto, o corpo nos é objeto imediato, isto é, aquela representação que constitui para o sujeito o ponto de partida do conhecimento". Idem. $\$ 6$, p. 62.

${ }^{124}$ Idem. §2, p. 45. 
alada destituída de corpo"125. Por isso, devemos entender a metafísica schopenhauriana como imanente, ou seja, não existe nenhum ente exterior à experiência dos sentidos que justifique o conhecimento; logo, trata-se aqui de uma metafísica crítica àquela dogmática e distante da definição dada por Kant ${ }^{126}$.

O tempo, o espaço e a causalidade, chamados de "princípio da razão", são também uma forma de representação. Eles determinam as condições formais do objeto, deduzem-se do sujeito e encontram-se a priori na sua consciência. A essência do princípio da razão no tempo é a sucessão [Succession]; a essência do princípio de razão no espaço é o que se chama de posição $[\text { Lage }]^{127}$. Como sabemos, Schopenhauer designará o espaço e o tempo servindo-se da antiga expressão escolástica principium individuationis. O tempo e o espaço são os únicos pelos quais aquilo que é uno e igual conforme a sua essência aparece como pluralidade de coisas que coexistem e se sucedem $^{128}$. Essa multiplicidade de objetos que se relacionam só é possível porque também existe a matéria. A essência da matéria é o seu "Ato" [Wirken]. Nenhuma outra essência lhe é possível nem sequer pensável. Apenas como "Ato" ela preenche o espaço e o tempo. A relação "causa e efeito" é a essência inteira da matéria ${ }^{129}$. Desse modo, a lei da causalidade só tem sentido pela sua relação com o tempo e o espaço, e com a matéria, que resulta da união dos dois.

O que Schopenhauer quer dizer é que a pluralidade, isto é, a multiplicidade de seres individualizados, é necessariamente condicionada por espaço e tempo e só pode ser pensável neles; por isso recorre à denominação principium individuationis. Por sua vez, todo nosso conhecimento a priori está expresso no tempo e espaço e na relação causal. Todavia, essa forma do princípio da razão diz

\footnotetext{
125 “(...) seu conhecimento, sustentáculo condicionante do mundo inteiro como representação, é no todo intermediado por um corpo, cujas afecções, como se mostrou, são para o entendimento o ponto de partida da intuição do mundo". Idem. §18, p. 156.

126 "Em primeiro lugar, no tocante às fontes do conhecimento metafísico, elas não podem, já segundo o seu conceito, ser empíricas. Os seus princípios / (a que pertencem não só os seus axiomas, mas também os seus conceitos fundamentais) nunca devem, pois, ser tirados da experiência: ele deve ser um conhecimento, não físico, mas metafísico, isto é, que vai além da experiência". KANT. Prolegómenos a toda a metafísica futura. §1, p. 23 - 24.

${ }^{127}$ Cf. Idem. §4, p. 49. M. F. Sá Correia opta por "situação" como tradução para Lage.

${ }^{128}$ Cf. Idem. §23, p. 171.

${ }^{129}$ Cf. Idem. \$4, p. 50. M. F. Jair Barboza traduz o termo Wirken como "Fazer-efeito", consideramos que essa tradução prejudica sobremaneira a compreensão do texto. Já a edição de Sá Correia opta por "atividade" como tradução para o termo (Cf. p. 15). Acreditamos que "Ato" torna mais inteligível o que se diz.
} 
respeito, apenas, à cognoscibilidade das coisas, não a elas mesmas. Estamos apenas nos referindo à forma de nosso conhecimento, não à propriedade da coisaem-si. Existe, portanto, outro aspecto da realidade para além da representação. Ao pensar sobre este "outro lado" e desenvolver sua teoria sobre a essência das coisas, Schopenhauer afasta-se da filosofia kantiana, dá um salto além, e descreve o númeno - o qual Kant afirmava ser incognoscível - como o "mundo enquanto vontade" ${ }^{130}$. O "livro segundo" da obra $O$ Mundo como vontade e representação investiga os objetos em sua essência, livre de todas as formas do conhecimento e, por consequência, fora da representação. Trata-se da investigação sobre a coisaem-si enquanto um elemento fora da oposição sujeito-objeto. Aquilo que Schopenhauer chamará de vontade [Wille] - o âmago fundamental de todos os entes.

A representação corresponde, em termos schopenhaurianos, ao mundo fenomênico de Kant. Ela é a manifestação, a objetivação da vontade ${ }^{131}$. Já a vontade é a coisa-em-si, a essência por trás de cada objeto que existe na pluralidade e, portanto, é o núcleo ontológico do mundo. A vontade é primordial. Ela dá origem e condiciona tudo que existe enquanto representação ${ }^{132}$. Schopenhauer é muito cuidadoso e preciso com sua linguagem, diz claramente que pretende conservar a expressão "coisa-em-si" de Kant como uma fórmula consagrada $^{133}$, todavia, para que se possa pensar na essência do mundo objetivamente, seria necessário emprestar um nome e uma noção de alguma coisa objetivamente dada, ou seja, de um de seus fenômenos; e o mais perfeito para isso é a "vontade humana", que é, dentre todos os fenômenos, a objetivação máxima e mais perfeita da vontade. Portanto trata-se apenas de um empréstimo, o conceito de vontade tem uma extensão muito maior; a vontade humana seria, do plano

\footnotetext{
${ }^{130}$ Doravante, a fim de evitar qualquer confusão, utilizaremos o termo vontade destacado em itálico para em referência à coisa-em-si schopenhauriana diferenciando-a da vontade individual do homem, geralmente entendida como o "querer".

131 “Objektität des Willens”. Cf. Idem. §18, p. 157.

${ }^{132}$ Nas claras palavras de Schopenhauer: "Fenômeno se chama representação, e nada mais. Toda representação, não importa seu tipo, todo OBJETO é FENÔMENO. COISA-EM-SI, entretanto, é apenas a VONTADE. Como tal não é absolutamente representação, mas toto genere diferente dela. É a partir daquela que se tem todo objeto, fenômeno, visibilidade, OBJETIDADE. Ela é o mais íntimo, o núcleo de cada particular, bem como do todo. Aparece em cada força da natureza que faz efeito cegamente, na ação ponderada do ser humano: se ambas diferem, isso concerne tãosomente ao grau da aparição, não à essência do que aparece". Idem. §21, p. 168 - 169. (Grifos do tradutor).

${ }^{133}$ Cf. Idem. §22, p. 169.
} 
fenomênico, o que mais se aproximaria daquilo que se pretende descrever, trata-se de um símbolo para algo até então desconhecido. Assim, o conceito de vontade é o único, entre todos os conceitos possíveis, que não tem sua origem na representação intuitiva, pelo contrário, “vem da própria consciência do indivíduo, na qual ele se conhece, na sua essência, de maneira direta, visto que aqui quem conhece coincide-se com o que é conhecido"134.

Esse indivíduo do conhecimento, que apreende o mundo como sua representação, reconhecerá o seu corpo de duas formas distintas: por um lado, como um objeto fenomenal submetido às leis do princípio da razão, como um objeto em meio a tantos outros objetos; por outro lado, como um impulso, como a manifestação de uma força, de um querer que movimenta as próprias ações, um ímpeto o qual denominamos vontade. Na metafísica imanente schopenhauriana, o corpo é a vontade objetivada; o meu corpo é a condição de conhecimento da vontade enquanto essência das coisas. Os movimentos voluntários do corpo, nesse sentido, não são efeitos de uma causa que é coisa-em-si, mas são os seus próprios atos tornando-se visíveis. A vontade é, portanto, o fundamento de todo querer humano. Além disso, ela também é a essência íntima de cada fenômeno: está, portanto, por trás do querer dos animais; da força que faz germinar a planta ou cristalizar o mineral; se manifesta no magnetismo e na gravidade. Enfim, são infinitos os fenômenos, contudo, um único fundo. Para Schopenhauer, o conhecimento da vontade não é intelectual, nem mesmo podemos saber o que ela é nela mesma; mas a partir de uma intuição interna, corporal, chegamos ao outro lado das coisas.

A vontade é o âmago metafísico das coisas. Ela dá origem a todo o múltiplo existente; porém, em si mesma é indivisível, a unidade é um de seus atributos. Como ela se encontra fora do domínio do principium individuationis, não admite a multiplicidade. Nestes termos, existe uma união entre todos os entes fenomênicos, uma unidade essencial que compreende toda a matéria, desde o inorgânico até o homem. Toda pluralidade da representação compartilha o mesmo fundo. Nietzsche compreendeu essa unicidade ontológica da vontade e, como

${ }^{134}$ Idem. 
sabemos, refere-se a ela utilizando o termo Uno-primordial ${ }^{135}$. A natureza desse Uno originário é a contradição. Nele há uma luta perene que resulta uma dor suprema e um prazer supremo ${ }^{136}$. A individuação, ou seja, a existência aparente no espaço e tempo é resultado dessa batalha primordial ${ }^{137}$. Nietzsche entende que o Uno trava uma luta eterna consigo mesmo, dando origem à aparência ${ }^{138}$. Essa formulação metafísica nietzschiana é assimilada inteiramente do sistema schopenhauriano: a vontade é caracterizada por uma discórdia essencial consigo mesma. Há nela um $\alpha \gamma \omega ́ v$ íntimo e infinito, que se manifesta na forma de uma guerra perpétua pela existência: "Cada grau de objetivação da Vontade combate com outros por matéria, espaço e tempo"139.

A discórdia essencial da vontade "crava continuamente os dentes na própria carne" ${ }^{\text {140, }}$, porém, a efetiva batalha só é possível no plano da representação, onde sua objetivação, fragmentada em incontáveis objetos, protagoniza uma guerra infindável. Para Schopenhauer, a vontade manifesta-se em diferentes graus de acordo com a visibilidade de sua objetivação. Assim, há inúmeros graus de manifestação da vontade: nos seres inorgânicos, por exemplo, manifesta-se em grau mais fraco, enquanto no homem atinge o grau mais elevado

\footnotetext{
135 [Ureine]. É importante destacar que Nietzsche, predominantemente em sua obra, identifica a vontade como a coisa-em-si, consequentemente, coloca-a em correspondência com o Ureine. No entanto, em algumas passagens - principalmente nos fragmentos póstumos - faz uma crítica a essa simples correlação. Nesses momentos entende a vontade como uma forma adequada do fenômeno. É possível identificar em alguns textos, que a vontade seria um terceiro elemento entre o Unoprimordial e a representação. Cf. Fragmentos póstumos de 1871 7[165], 7[174] e 12[1].

136 "Insofern der Widerspruch das Wesen des Ureinen ist, kann es auch zugleich höchster Schmerz und höchste Lust sein: (...)". [Enquanto a contradição é a essência do Uno-primordial, pode ser também ao mesmo tempo dor suprema e prazer supremo: (...)]. NIETZSCHE. Fragmento póstumo de 1871, 7[157]. Cf. também 7[174].

137 "Das Leidende, Kämpfende, sich Zerreißende ist immer nur der eine Wille: er ist der vollkommene Widerspruch als Urgrund des Daseins. Die Individuation ist also Resultat des Leidens, nicht Ursache". [O que sofre, o que luta, o que se desgarra é sempre somente a vontade una: ela é a contradição perfeita como fundamento primordial da existência. A individuação é, portanto, o resultado do sofrimento, não causa]. NIETZSCHE. Fragmentos póstumo de 1871, $7[117]$

${ }^{138}$ O filósofo deixa-nos evidente como adotou a teoria schopenhauriana da vontade, dando-lhe uma roupagem artístico-ontológica: "Com efeito, quanto mais percebo na natureza aqueles onipotentes impulsos artísticos e neles um poderoso anelo pela aparência [Schein], pela redenção através da aparência, tanto mais me sinto impelido à suposição metafísica de que o verdadeiramente-existente [Wahrhaft-Seiende] e Uno-primordial, enquanto o eterno-padecente e pleno de contradição necessita, para a sua constante redenção, também da visão extasiante, da aparência prazerosa - aparência esta que nós, inteiramente envolvidos nela e dela consistentes, somos obrigados a sentir como o verdadeiramente não existente [Nichtseiende], isto é, como um ininterrupto vir-a-ser no tempo, espaço e causalidade, em outros termos, como realidade empírica". NIETZSCHE. O Nascimento da tragédia §4, p. 39.

${ }^{139}$ SCHOPENHAUER, Arthur. Op. Cit. \$27, p. 211.

${ }^{140}$ Idem.
} 
de objetivação. A luta essencial está presente em todos os graus, na maior parte das vezes, um contra outro. Por isso, em toda parte da natureza enxergamos o combate. No conflito, a matéria muda continuamente sua forma atendendo aos vitoriosos: desde o grau mais elementar, como o ferro que sucumbe ao magnetismo, ou em maior escala, como os planetas, cujos orbes resultam da tensão constante entre as forças centrípeta e centrífuga. No entanto, a mais nítida visibilidade dessa luta universal se dá justamente entre os animais: a necessidade de se alimentar faz de cada indivíduo ora presa, ora predador, uma verdadeira disputa por matéria, pois cada criatura viva só pode manter-se viva à custa de outra $^{141}$, vegetal ou mesmo animal.

Apesar de a vontade objetivar-se no "querer viver" que faz perpetuar todas as espécies; manifestar-se nas forças que regem o mundo como a gravidade e a eletricidade; e ser responsável por todas as formas de organismos, não devemos nos equivocar e concluir que nela exista algum $\tau \dot{\lambda} \lambda o \varsigma$. Não há finalidade na vontade, ela é sem fundamento, sem causa e desprovida de determinação. Consequentemente, por estar fora do espaço e tempo, também não se submete às leis da causalidade, logo, a liberdade é outro de seus atributos ${ }^{142}$. Como fundamento do mundo, a vontade é inconsciente, uma força obscura e um ímpeto cego, isto é, ela age como um impulso desprovido de motivo; ao objetivar-se ela não é guiada por consciência, às vezes age acompanhada de conhecimento, entretanto, como o conhecimento também é uma de suas manifestações, nunca é conduzida por ele. Atua, portanto, cegamente sem razão e sem alvo ${ }^{143}$. Desse modo, a vontade é absolutamente livre e se determina por inteira a si mesma, não havendo lei alguma para ela ${ }^{144}$. Diferentemente da vontade humana, que por ser uma forma de objetivação da coisa-em-si, é completamente governada por ela.

\footnotetext{
${ }^{141}$ Para Schopenhauer é no gênero humano em que "manifesta em si próprio aquela luta e a autodiscórdia da Vontade da maneira mais clara e terrível quando o homem se torna o homo homini lupu". SCHOPENHAUER. Idem. \$27, p. 212.

142 "Vontade, que, por não ser ela mesma fenômeno, representação ou objeto, mas coisa-em-si, não está submetida ao princípio de razão, a forma de todo objeto; portanto não é determinada como consequência por um fundamento, logo, não conhece necessidade; em outras palavras, é LIVRE”. SCHOPENHAUER. Idem. §55, p. 372. (Grifo do tradutor).

143 "No fundo, tudo isso se assenta no fato de a Vontade ter de devorar a si mesma, já que nada existe de exterior a ela, e ela é uma Vontade faminta. Daí a caça, a angústia, o sofrimento". Idem. $\S 28$, p. 219.

${ }^{144}$ Idem. p. 370
} 
Se por um lado, a vontade enquanto conteúdo de toda aparência ${ }^{145}$ é, em si mesma, livre; por outro lado, o fenômeno é irrestritamente o contrário: encontrase inteiramente submetido ao princípio de razão. Tudo o que compõe a natureza e todos os fenômenos que fazem parte dela estão submetidos à necessidade absoluta. O mundo como representação, na totalidade de seus objetos, está fixado e inalteravelmente determinado por uma cadeia de nexos causais. Por conclusão, a liberdade no plano dos fenômenos, ou a "liberdade empírica", não passa de uma mera ilusão. Tudo segue, implacavelmente, uma rede de causa e efeito, onde cada objeto tem o seu devido lugar. Essa questão deslocada à vontade humana abre discussão sobre um dos temas mais polêmicos da filosofia moral de Schopenhauer. Em um primeiro momento da sua obra capital, ele afirma que a liberdade das escolhas humanas e a liberdade dos atos individuais são igualmente ilusórias, pois a volição desses atos estaria submetida ao governo da vontade e submetida às leis do princípio da razão. Em um segundo momento da mesma obra, na clara tentativa de salvar a filosofia moral kantiana ${ }^{146}$, alude para a existência do livre arbitrio em uma forma de convivência entre necessidade e liberdade.

No "livro segundo", Schopenhauer afirma que nos indivíduos a ação e todas as escolhas são regidas pela vontade. Apesar de cada indivíduo julgar-se a priori absolutamente livre em todos os seus atos, e ainda, acreditar que é capaz de mudar o curso da sua vida. É apenas a posteriori que ele constata que não é livre; independentemente dos projetos e reflexões, ninguém é capaz de modificar em nada o conjunto dos seus atos, longe disso, "de uma ponta à outra da vida, ele deve revelar um caráter que não aprovou e continuar uma vida já começada" ${ }^{\text {"147. }}$. Contudo, no decorrer da obra, ao indagar sobre questões morais, o filósofo amplia sua perspectiva sobre a liberdade humana e deixa de afirmar categoricamente que o livre arbítrio, no plano da representação, é mera ilusão. Primeiramente, admite a capacidade de deliberação e a aptidão em tomar decisões eletivas, isso devido ao acréscimo do conhecimento abstrato ou racional. Assim, diferentemente dos

\footnotetext{
${ }^{145}$ [der Gehalt aller Erscheinung ist]. Cf. Idem. §55, p. 371.

${ }^{146}$ Em referência à Crítica da razão pura, Schopenhauer diz: "Foi Kant, todavia, cujo mérito a este respeito é em especial magnânimo, o primeiro a demonstrar a coexistência dessa necessidade com a liberdade da Vontade em si, isto é, exterior ao fenômeno". Idem. p. 374 e 375 . Cf. também, $\S 28$, p. 221, onde é destacado o "mérito imortal de Kant" ao expor a diferença entre liberdade e necessidade.

${ }^{147}$ Cf. Idem. §23, p. 173.
} 
animais, o homem pode fazer escolhas mediante motivos que não são imediatos. Porém, para Schopenhauer, essa decisão ainda não deve ser vista como liberdade, mas como uma "batalha de motivos, sem com isso, subtraí-lo ao império deles". No fim, o motivo mais forte nos determina com toda necessidade ${ }^{148}$.

Não obstante, no "livro quarto", Schopenhauer admite a possibilidade de uma espécie de liberdade do homem no plano da aparência. Trata-se de uma liberdade da vontade individual, viável somente mediante a "negação do quererviver" ${ }^{149}$. Para entender esse postulado é necessário esclarecer que, para o autor, a vontade é fonte de toda a dor e de todo o sofrimento dos seres fenomênicos. Viver é sofrer! Tal é a máxima schopenhauriana. A vontade é fonte inesgotável de sofrimento, primeiro, porque ela é, em última instância, o fundo da vontade humana que, por sua vez, é definida como uma eterna carência. Segundo, porque, graças ao encadeamento causal das coisas, a maioria dos desejos nunca encontra sua satisfação; logo, a vontade é mais vezes contrariada do que satisfeita. A fórmula é simples: quanto mais intenso e violento é o querer, mais intenso e violento será o sofrimento. Para Schopenhauer, todo sofrer é uma vontade contrariada por não estar satisfeita. A dor física não tem outro princípio, visto que o corpo - que nada mais é do que a vontade tornada objeto - almeja seu bemestar $^{150}$. Até mesmo a dor espiritual, "a mais aguda das dores", teria sua origem no obstáculo que a vontade encontra para a sua satisfação em um bem-estar.

Nesse contexto, o sofrimento e a dor são perenes, assim como, a felicidade e o bem-estar não passam de uma ilusão; isso porque, mesmo que haja a satisfação de um desejo, esta nunca é duradoura. Cada querer é, sucessivamente, um pretexto para outro querer. Em outras palavras, a vida humana resume-se em sofrer devido à carência e ao esforço contínuo para satisfazer essa carência; se caso a falta seja

\footnotetext{
${ }^{148}$ Cf. Idem. $§ 55$, p. $385-389$ e $\$ 70$, p 510.

${ }^{149}$ [Von der nunmehr, in den Gränzen unserer Betrachtungsweise, hinlänglich dargestellten Verneinung des Willens zum Leben, welche der einzige in der Erscheinung hervortretende Akt seiner Freiheit] "Nada mais difere tão amplamente da negação da Vontade de vida exposta suficientemente nos limites do nosso modo de consideração, e que constitui o único ato de liberdade da Vontade a entrar em cena no fenômeno". Idem, §69, p. 504. Na tradução de M. F. Sá Correia: "Até aqui, dentro dos limites do nosso assunto, expusemos de modo suficiente a negação do querer-viver, o único ato de nossa liberdade que se manifesta no fenômeno". Cf. p. 416.

${ }^{150}$ Cf. Idem. §65, p. 643. Cf. também: "o sofrimento não se origina imediata e necessariamente de não-ter, mas antes de querer-ter e não ter". (Idem. §16, p. 138.) e "todo sofrimento propriamente dito provém da desproporção entre o que por nós é exigido e aquilo que nos é dado" (Idem. p. 144).
} 
prontamente preenchida, então ocorre, imediatamente, a transição para um novo desejo e assim incessantemente. Por outro lado, a ausência de um novo objeto do querer, mesmo que essa ausência decorra de uma rápida e fácil satisfação da vontade $^{151}$, resulta então, o tédio e vazio aterrador; de modo que a existência só possa ser entendida como um fardo insuportável. Nesses termos, a vida humana assemelha-se ao pêndulo, oscilando daqui para acolá, entre o sofrimento e o tédio. Viver é um movimento pendular perpétuo, sem direito a repouso, ora impera a dor e outrora o aborrecimento. Tal compreensão da vida pode ser igualmente ilustrada pela seguinte anedota: "após o homem ter posto todo sofrimento e tormento no inferno, nada restou para o céu senão o tédio"152.

A interpretação schopenhauriana é drástica: por natureza, a vida não admite nenhuma felicidade verdadeira, longe disso, ela é essencialmente, em diversos aspectos, um tormento completo e um estado de infelicidade radical. O mundo é assim, porque a coisa-em-si, da qual ele é fenômeno, é dessa forma. O sofrimento se justifica, pois há uma autoafirmação da vontade no fenômeno, o mundo é tão somente espelho desse querer; por consequência, toda finitude, toda dor e todo tormento contidos no mundo são expressões daquilo que a vontade quer ${ }^{153}$. Em conformidade a isso, cada um de nós carrega todo suplício do mundo como se fosse seu próprio. O sofrimento do mundo é maior no indivíduo, quanto maior for o grau de sua afirmação da vontade, isto é, quanto maior for a sua "vontade de vida"154. A afirmação do "querer-viver" é, na natureza, a afirmação do corpo, um impulso para preservar a existência individual a todo custo, porém, com uma única meta: a conservação da espécie, uma vez que o indivíduo em si é nulo para a vontade. A afirmação do querer-viver é uma forma de a vontade afirmar a si mesma. Portanto quanto maior é a afirmação do desejo de viver, maior é o sofrimento.

O analgésico para tamanho sofrimento será moral. É justamente nesse ponto que a liberdade individual encontra seu espaço no sistema schopenhauriano. A virtude, diz o filósofo, resulta do conhecimento, só que não é do conhecimento

\footnotetext{
${ }^{151}$ Por exemplo: depois de desejar incessantemente, meu time de futebol vence, saciando temporariamente meu querer. Caso não me sobressaia imediatamente outro desejo, o que eclodirá é o sofrimento na forma de tédio.

${ }^{152}$ Idem. §57, p. 402.

${ }_{153}$ Cf. Ibidem. §63, p. 449.

${ }^{154}$ M. F. Sá Correia traduz [Willens zum Leben] como "querer-viver".
} 
abstrato, daquele que se comunica através de conceitos racionais. Mas de uma sabedoria que permite enxergar além da individuação e perceber que o sofrer é universal: a dor do outro é a sua mesma. O homem, que no íntimo de cada ser reconhece a si mesmo, considera que as aflições infinitas de tudo aquilo que vive tem o mesmo fundo, portanto, ele faz da miséria do mundo a sua própria. Esse homem conhece a essência das coisas e o esforço estéril que é a luta dos seres fenomênicos, sabe que a existência é uma contradição e um suplício contínuo, em um universo que se dissipa sem cessar. O efeito desse saber íntimo das coisas é perceber que afirmar a vida significa aumentar o peso sobre o ser, então a única saída é uma abnegação voluntária, uma vírgula, um estado de calma e de paragem absoluta do querer, o que o filósofo entende como a "negação da vontade de vida" ${ }^{\text {155 }}$. Esse ascetismo, ou seja, a completa negação do desejo de vida, expressa um ato de liberdade, porque ocorre uma provisória supressão da vontade ${ }^{156}$.

A ascese, a negação do querer viver, é o princípio moral schopenhauriano e único ato de liberdade. Todavia, é importante salientar que a moral schopenhauriana não é prescritiva, ele não pretende pregar moral às pessoas. Não seria possível ordenar à vontade, eternamente livre, nenhuma lei e nenhum dever. Pelo contrário, as ações justas, os bons atos e as obras de amor são consequências exclusivas do conhecimento intuitivo do sofrimento alheio. A dor do outro se torna compreensível a partir da experimentação da minha própria dor, resultando, então, o puro amor [⿳亠㐅八 $\gamma \dot{\alpha} \pi \eta]$, ou melhor, o fundamento de qualquer virtude: a compaixão [Mitleid]. Para Schopenhauer, ao reconhecer a universalidade do sofrimento, isto é, que não existe diferença fundamental entre os indivíduos, mas sim uma identidade íntima - pois o outro, no fundo, também é um querer-viver surge o sentimento da compaixão e, a partir dele, a mais nobre virtude de poupar o outro da pena. A compaixão seria o verdadeiro colocar-se no lugar do outro, sentir o que o outro sente, seja ele homem ou animal, e fazer de tudo para livrá-lo de

\footnotetext{
155 "Se, portanto, quem ainda se encontra envolvido no principio individuationis conhece apenas coisas isoladas e sua relação com a própria pessoa, coisas que renovadamente se tornam MOTIVOS para seu querer, ao contrário, aquele conhecimento do todo e da essência das coisas torna-se QUIETIVO de toda e qualquer volição. Doravante a Vontade efetua uma viragem diante da vida: fica terrificada em face dos prazeres nos quais reconhece a afirmação desta. $\mathrm{O}$ homem, então, atinge o estado de voluntária renúncia, resignação, verdadeira serenidade e completa destituição de Vontade". Ibidem. §68, p. 481 e 482.

${ }^{156}$ Nietzsche compreende a seriedade dessa formulação de mundo e desde jovem debate a possibilidade de sua efetividade. Cf. Carta a Carl von Gersdorff de 16 de janeiro de 1867. [ Apêndice $\lambda]$
} 
qualquer tormento. $\mathrm{O}$ ápice da vida ética é, precisamente, saciar a dor do mundo. Essa é a tarefa daqueles a quem Schopenhauer chama de santos.

Essa sua formulação ética contradiz o pensamento moral kantiano, que aceita como verdadeira virtude somente aquelas que são provenientes da razão. Kant diria que as ações motivadas por inclinações, como a piedade ou qualquer sentimento, não possuiria validade moral ${ }^{157}$. Já para Schopenhauer, os verdadeiros agentes morais são os santos; os mártires que, por compaixão, suportam voluntariamente o suplício com a intenção de suprimir o sofrimento do mundo. A característica de toda santidade é, para Schopenhauer, a auto-abnegação. Na medida em que esses homens de conhecimento profundo assimilam o sofrimento comum dos indivíduos, nasce neles um desgosto contra o querer-viver e uma predisposição à resignação. A ascese representa uma batalha constante do santo para efetivar a mortificação da vontade, um cuidado doloroso para renovar a renúncia aos prazeres. Este é o único ato de liberdade no fenômeno, só possível a partir do conhecimento intuitivo profundo de si mesmo, e de como a vontade se objetiva no corpo na forma do querer.

Esse pensamento schopenhauriano sobre a liberdade resultou diversos debates e muitas críticas. O próprio filósofo não se furta em admitir a "contradição" em seu sistema moral ao defender a liberdade no mundo fenomênico. Dentre as diversas críticas problematizadas por seus comentadores podemos citar - apenas a título de curiosidade, pois não é nosso objetivo aprofundar nessa discussão, caso o fizéssemos, desviaríamos em demasia do foco dessa seção - que para Schopenhauer não seria qualquer ser humano capaz de atingir a plena negação da vontade de vida, consequentemente, atingir a liberdade. Apenas os santos, indivíduos distintos teriam a aptidão de aceitar o sofrimento e negar o querer viver. Além disso, se não podemos modificar o querer, como responsabilizar moralmente alguém? Ora, são diversas as possibilidades de caminho nesse terreno arenoso. Nietzsche também permeou marginalmente o problema da liberdade em $O$ Mundo como vontade e representação.

157 "Em consequência, não hesitaremos, contradizendo KANT diretamente - que só quer reconhecer toda verdadeira bondade e toda virtude se elas provêm da reflexão abstrata, e em verdade do conceito de dever e imperativo categórico, explanando ele a compaixão sentida como uma fraqueza e de modo algum uma virtude- não hesitaremos, ia dizer, em declarar contra Kant que o mero conceito é infrutífero para a autêntica virtude, assim como o é para a arte". SCHOPENHAUER. Op. Cit. § 67, p. $477-478$. 
Ainda que Schopenhauer tenha sido o grande guia intelectual de $O$ Nascimento da tragédia, Nietzsche oferece críticas à formulação de liberdade como negação da vontade de vida. A liberdade não é destaque na obra nietzschiana de 1872, na verdade, o tema aparece somente duas vezes de forma sutil, sempre ligado à experiência extática, por exemplo, quando diz que a música e a dança ditirâmbica evoca, nos ritos dionisíacos, o estado de liberdade, o homem não é mais escravo da aparência, mas, urgido ao Uno, sente-se livre ${ }^{158}$. Entretanto, quando se refere, em alguns fragmentos, à liberdade moral é sempre a entendendo como uma ilusão, ou melhor, como uma crença. Na representação somos, segundo Nietzsche, sempre impelidos a agir pelos instintos, nunca atingimos a essência da ação ${ }^{159}$. A crença na liberdade criou uma quemérica ideia de "bem"160; a história do mundo teria se movido como se existisse a "vontade livre" e a "responsabilidade"; sem essas crenças seria impossível qualquer pressuposto moral. Foi necessário então, submeter a rígida lei da causalidade, que podemos conceituar perfeitamente, ao pensamento que acompanha a ação livre ${ }^{161}$; ou seja, a crença na liberdade tornou-se uma categoria mais forte e importante.

Essa concepção nietzschiana, em alguns fragmentos posteriores se torna um tanto mais radical: em uma nota de 1873 , por exemplo, ele nos deixa claro que considera tanto o conceito de "personalidade" quanto o de "liberdade moral" como ilusões necessárias ${ }^{162}$, sem as quais seria impossível atribuir qualquer imputabilidade ao agente moral. Já em 1880, declara ironicamente: “Quanto mais

\footnotetext{
158 “Agora o escravo é homem livre, agora se rompem todas as rígidas e hostis delimitações que a necessidade, a arbitrariedade ou a "moda impudente" estabeleceram entre os homens. Agora, graças ao evangelho da harmonia universal, cada qual se sente não só unificado, conciliado, fundido com o seu próximo, mas um só, como se o véu de Maia tivesse sido rasgado e, reduzido a tiras, esvoaçasse diante do misterioso Uno-primordial”. NIETZSCHE. O Nascimento da tragédia. $\S 1$, p. 31.

${ }_{159}$ "Die Welt der Vorstellungen ist das Mittel, uns in der Welt der That festzuhalten und uns zu Handlungen im Dienste des Instinkts zu zwingen. Die Vorstellung ist Motiv zur That: während sie das Wesen der Handlung gar nicht berührt"'OO mundo da representação é o meio de nos manter no mundo da ação e nos obrigar a agir a serviço do instinto. A representação é motivo para a ação: enquanto ele não toca a essência da ação]. NIETZSCHE. Fragmentos póstumos de 1870 5[77].

160 "Der Glaube der Freiheit und der Verantwortlichkeit erzeugt nun den Wahn des "Guten" d.h. des rein Gewollten, ohne Egoismus Gewollten". [A crença na liberdade e responsabilidade agora gera a ilusão de "bem", isto é, do puramente desejado, isto é, desejado sem egoísmo] Idem. 1871, $7[149]$.

${ }^{161}$ Idem. 1871, 7[144].

162 "Begriff der Persönlichkeit, ja der der moralischen Freiheit nothwendige Illusionen, so daß selbst unsere Wahrheitstriebe auf dem Fundament der Lüge ruhn" [O conceito de personalidade, e inclusive o de liberdade moral, são ilusões necessárias, de modo que nosso impulsos dencansem no fundamento da mentira]. Idem. 1873, 29[4].
} 
conhecimento e razão tenho, mais diminui minha fé na liberdade, não nos resta muito para escolher" ${ }^{\prime 163}$. No entanto, essa perspectiva não é definitiva em Nietzsche. A liberdade, como a maioria dos temas que versam sua filosofia, é controversa e possui alternâncias significavas ${ }^{164}$; é possível encontrar escritos em que o filósofo não nega a liberdade ${ }^{165}$. Porém, o problema da livre vontade terá, em sua obra, sempre a tônica de uma crítica à moral que cria conceitos metafísicos, em si vazios de significado - "bem e mal", "pecado", "sujeito" -, mas decisivos para formação de um tipo de homem "moralizado" e repleto de culpa. Além disso, há a perspectiva da liberdade estético-criativa que possibilita a Nietzsche formular sua filosofia dionisíaca por excelência: trata-se da iniciativa artística que permite ao "homem livre" criar continuamente e afirmar integralmente a vida.

A afirmação integral da vida é parte essencial da filosofia de Nietzsche desde sua juventude. Por esse motivo, mesmo na época em que se considerava discípulo de Schopenhauer, não deixou de dispensar agudas críticas à negação e à ascese do mestre; ainda nesse período já considerava a resignação como algo ignorante e senil ${ }^{166}$. Mais tarde entenderá, definitivamente, essa forma de abnegação como o extremo oposto de qualquer postura dionisíaca ${ }^{167}$. Contudo, se Nietzsche, de certo modo, já entendia a moral ascética como contrária ao pensamento trágico, então por que considera a filosofia schopenhauriana,

\footnotetext{
163 "Je mehr Erkenntnisse und Vernunft ich habe, um so mehr nimmt der Glaube an die Freiheit $a b$, es steht uns nicht viel zu wählen offen". idem. 1880, 2[23].

164 Não nos aprofundaremos neste tema por motivos óbvios: entendemos que ele por si só já equivale a uma tese de imensa profundidade e, por conseguinte, desviaria o foco de nossos estudos.

${ }^{165}$ Conferir, por exemplo, Fragmentos póstumos de 1875, 5[25]; 5[146]; 6[24]; 6[49] sobre a liberdade de pensamento dos gregos antigos; Fragmentos póstumos de 1876, 16[16]; 17[73] sobre atos de liberdade; Fragmentos póstumos de 1876 do grupo 18 sobre a liberdade de espírito.

166 “Dein letzter Brief z.B. verwirft meinen Standpunkt der Resignation als unjugendlich scil”. Cf. NIETZSCHE. Carta a Paul Dussen do final de abril e princípio de maio de 1868. (É importante esclarecer que Nietzsche fala em vários momentos de uma "resignação trágica" que está intimamente ligada à necessidade de arte frente ao otimismo inaugurado por Sócrates. Essa resignação não possui, portanto, o mesmo significado de Schopenhauer. Cf. O Nascimento da tragédia. $\$ 15$, p. 96).

${ }^{167}$ No prefácio autocrítico de 1886 , Nietzsche reconhece que ainda que estivesse influenciado por Schopenhauer, o seu ascetismo encontrava-se adverso às suas inquietações: "O que pensava, afinal, Schopenhauer sobre a tragédia? - diz ele em $O$ Mundo como vontade e representação - "O que dá a todo o trágico o empuxo peculiar para a elevação é o surgir do conhecimento de que o mundo e a vida não podem proporcionar verdadeira satisfação e, portanto, não são dignos de nosso apego: nisto consiste o espírito trágico - ele conduz à resignação"; quão diversamente falava Dioniso comigo!, quão longe de mim se achava justamente então todo esse resignacionismo!". NIETZSCHE. O Nascimento da tragédia. “Tentativa de autocrítica”, §6, p. 20.
} 
precisamente, como a expressão em conceitos da sabedoria dionisíaca? Ora, porque, como observamos inicialmente, Schopenhauer, seguindo o trajeto de Kant, aniquilou o contentamento de existir apoiado nas aeternae veritatis do cientificismo, uma vez que demonstrou os intransponíveis limites do conhecimento. O tendencioso otimismo científico, que faz crer que todos os enigmas do mundo são desveláveis através da lógica, após Schopenhauer, é substituído por uma sabedoria instintiva que, livre das ilusões das ciências, procura no quadro do universo apreender o sofrimento eterno como algo intrínseco. Isso Nietzsche chamou de cultura trágica ${ }^{168}$.

No sistema schopenhauriano, a razão e o conhecimento são apenas representações da vontade. Portanto, são impotentes para ir além do fenômeno e compreender o fundamento último das coisas. Nessa perspectiva, o homem por ser racional não é superior em relação aos outros animais da natureza, nem mesmo ocupa o topo de uma hierarquia devido à sua natureza. Antes disso, o que mais o distingue dos demais entes é sua predisposição ao sofrimento, pois, para Schopenhauer, quanto maior em proporção a consciência se eleva maior é o tormento. Por conseguinte, quanto mais o indivíduo conhece distintamente, isto é, quanto mais inteligente ele é, maior é o seu sofrimento ${ }^{169}$. Sendo assim, a razão está subordinada à vontade, não passa de mais um de seus instrumentos para perpetuação da espécie. Ela é definida como a capacidade, exclusiva do homem, de formular noções abstratas, os conceitos ${ }^{170}$. Conquanto, a razão como uma mera manifestação momentânea da coisa-em-si, é incapaz de compreender imediatamente e em absoluto a realidade ${ }^{171}$. Por isso, o saber que dela é fruto, o conhecimento lógico-científico, é secundário e preso à representação. O que será melhor compreendido quando apresentarmos, a seguir, os conceitos de ideia platônica e arte.

\footnotetext{
${ }^{168}$ Cf. Idem. §18, p. 110 e 111.

${ }^{169}$ Cf. SCHOPENHAUER, Arthur. Op. Cit. §56. P, 399 e 400.

170 "A diferença capital entre todas as nossas representações é a entre intuitivas e abstratas. Estas últimas constituem apenas UMA classe de representações, os conceitos - que são sobre a face da terra propriedade exclusiva do homem, cuja capacidade para formulá-los o distingue dos animais , e desde sempre foi nomeada RAZÃO”. Idem. §3, p. 47. (Grifo do tradutor).

171 "Sim, a minha filosofia não estatui uma vez sequer a fábula, tão astutamente divisada pelos professores de filosofia e tão indispensável para eles, de uma razão que conhece, intui, apreende imediata e absolutamente, que se precisa apenas impor no princípio aos leitores para, por assim dizer, galopar da maneira mais agradável possível no domínio além da possibilidade de toda experiência, para sempre barrado ao nosso conhecimento". Ibidem. "Prefácio à segunda edição". p. 36.
} 


\subsection{4.}

\section{Para além das ideias, a música...}

O sistema de $O$ Mundo como vontade e representação poderia, igualmente ao primogênito nietzschiano, ser comparado a um centauro $^{172}$, pois as influências cinzeladas nesta obra são diversas, aparentemente estranhas umas às outras, porém no todo formam um belo, complexo e harmonioso ser: além da teoria do conhecimento kantiana como ponto de partida; a aproximação dos preceitos budistas e cristãos à sua moral; Schopenhauer também buscará na metafísica platônica fundamentos para sua estética. Desse modo, inspirado por Platão, o filósofo chamará de ideia aquilo que mais se aproxima da vontade, ou seja, a manifestação mais adequada da coisa-em-si. Por se referir a uma objetivação, a ideia platônica também é uma forma de representação, porém bastante especial: trata-se das formas eternas das coisas [ewigen Formen der Dinge] tal como entendeu Platão em sua gnosiologia. Assim como existe diferentes graus de objetivação da vontade expressos na multiplicidade de indivíduos, existe igualmente os seus protótipos [Musterbilder], que carregam a identidade dos objetos particulares fora do espaço, tempo e causalidade. As ideias são universais, fixas, não estão submetidas à mudança; a sua existência é sempre atual. Enquanto os fenômenos nascem e morrem continuamente, a ideia está fora do movimento do vir-a-ser ${ }^{173}$.

Todos os fenômenos possuem ideias, todavia, estas são completamente independentes da existência temporal dos indivíduos. A relação que eles estabelecem é unicamente a de um arquétipo e suas cópias. Por outro lado, a ideia platônica é necessariamente uma representação, porque diz respeito, na relação sujeito-objeto, ao objeto, à coisa conhecida. Logo, elas não são a essência em si, estão ainda no plano dos fenômenos: elas objetivam o caráter plural das coisas, sem se submeterem à pluralidade. Na cosmologia schopenhauriana, enquanto a multiplicidade de seres que surgem e desaparecem no ciclo perpetuo da aparência - as pedras, as plantas, os animais, os homens - são objetivações INDIRETAS da

\footnotetext{
${ }^{172}$ Ver nota 59 da seção 1.1. "O re-descobrimento da Grécia”.

${ }^{173}$ Cf. Idem. §25, p. 36.
} 
vontade; a ideia eterna e imutável, representada nos fenômenos, é uma manifestação DIRETA. Desse modo, podemos entender a concepção de mundo em três esferas: o núcleo íntimo do universo, a vontade como coisa-em-si; as ideias platônicas que são a manifestação imediata e a representação mais próxima da essência do mundo; e, por fim, os fenômenos condicionados ao princípio da razão, meras objetividades mediatas e passageiras.

Nessa forma de ver a realidade, o conhecimento, tanto o intuitivo quanto o abstrato-conceitual, estão submetidos às leis do princípio da razão, e são, consequentemente, formas de representação e mais um instrumento a serviço da vontade. Eles se manifestam no indivíduo com o único propósito da perpetuação. Para Schopenhauer, esses conhecimentos estão restringidos ao plano fenomênico do tempo, espaço e causalidade. Logo, os pressupostos das ciências são igualmente limitados às relações dos objetos no principium individuationis. Entretanto, além do entendimento dessas relações fenomênicas, o conhecimento também é capaz de apreender a ideia. E o mais importante: o conhecimento das ideias é desvinculado dos propósitos da vontade. As ideias são conhecidas quando a individualidade do sujeito se dissolve e ele se livra do jugo inerente à sua existência até então. Ao tornar a ideia objeto do conhecimento, ele se torna isento do querer-viver. Nesse momento de apreensão das ideias, há uma representação intuitiva, e não uma cognição abstrato-conceitual produzida pela razão. Portanto, não se trata de um artifício lógico-científico, mas de uma apreensão originária.

Os conceitos, ou representações abstratas, são secundários no processo do conhecimento; eles só possuem conteúdo e significação a partir de uma representação intuitiva. Por sua vez, na elaboração schopenhauriana, o conhecimento intuitivo pertence sempre ao entendimento e não à razão; as noções abstratas, ou seja, os conceitos da razão são apenas uma forma de organizar, fixar, classificar e combinar os dados imediatos do entendimento ${ }^{174}$. É importante esclarecer que Schopenhauer reformula a concepção kantiana de entendimento: na Critica da razão pura o entendimento não é intuitivo, Kant atribuiu à outra faculdade a responsabilidade pela intuição, seria a sensibilidade encarregada pelo acesso imediato dos dados empíricos. Ao lado da sensibilidade que nos dá a

\footnotetext{
${ }^{174}$ Idem. §6, p. 65.
} 
intuição temos, para Kant, o entendimento que nos fornece o conceito ${ }^{175}$; a razão, no que lhe concerne, é incumbida de analisar os conceitos que já possuímos das coisas, conferindo ao conhecimento do entendimento maior unidade, através do que chamamos, comumente, de raciocínio ${ }^{176}$. O entendimento é para Schopenhauer o que a sensibilidade é para Kant, não se distinguem um do outro.

Ao vincular a intuição ao entendimento, o filósofo está dizendo que ela é sempre intelectual e, à vista disso, é sempre representativa. As noções abstratas são secundárias porque necessariamente derivam da intuição. No processo do conhecimento, primeiro o entendimento recebe os dados sensíveis, em seguida transforma-os em uma representação intuitiva, uma intuição empírica da realidade. Somente no terceiro momento as intuições dão lugar ao conhecimento abstrato racional. É preciso que as intuições tornem-se conceitos para que, a partir dos princípios da razão, o conhecimento converta-se em durável e efetivamente aplicável. Destarte, a apreensão das ideias se dá unicamente pela intuição. O conhecimento dessas formas eternas equipara-se a olhar por trás do véu de Maya, isto é, compreender intuitivamente a essência das coisas, o que ocorre com total desprendimento do princípio da razão. Para Schopenhauer, é dessa forma, como representação intuitiva imediata, que acontece a contemplação estética. Assim sendo, na medida em que a arte diz respeito à ideia, à manifestação imediata da vontade, a ciência concerne ao conhecimento fenomênico, a uma manifestação mediata.

Além disso, enquanto o conhecimento científico é regido pelas questiúnculas da pragmática, que em suma, estão submetidas aos desígnios da vontade; o conhecimento artístico contempla a própria coisa-em-si espelhada em sua objetivação mais adequada, as ideias eternas. Nesse momento de contemplação estética, o homem assume a condição de puro sujeito do conhecimento, encontrando-se liberto dos grilhões da vontade e destituído de sua

175 "A capacidade de receber representações (receptividade), graças à maneira como somos afetados pelos objetos, denomina-se sensibilidade. Por intermédio, pois, da sensibilidade são-nos dados objetos e só ela nos fornece intuições; mas é o entendimento que pensa esses objetos e é dele que provêm os conceitos". KANT, Immanuel. Critica da faculdade do juízo. A 17 / B 31, §1, p. 87.

176 "Todo o nosso conhecimento começa pelos sentidos, daí passa para o entendimento e termina na razão, acima da qual nada se encontra em nós mais elevado que elabore a matéria da intuição e a traga à mais alta unidade do pensamento". Idem. A 299 / B 356, p. 324. 
individualidade desejosa ${ }^{177}$. O homem-artista qualificado para tal feito é chamado, por Schopenhauer, de gênio. Tais homens são aqueles que, devido ao grau de aptidão, ou comtemplam ou criam a arte. Neste sentido, o gênio com elevada capacidade é aquele que reproduz artisticamente o conhecimento adquirido diretamente das ideias $^{178}$; ele tem a habilidade de ascender do espaço e tempo e permanecer na intuição pura. O prazer estético advém como decorrência dessa ascensão. $\mathrm{O}$ deleite artístico decorre por dois motivos: primeiro, porque o gênio contempla os objetos em sua essência, resultando um prazer objetivo; segundo, porque experimenta a libertação da volúpia da vontade, uma supressão dos desejos e, consequentemente, uma privação, mesmo que momentânea, do sofrimento e do tédio, daí um prazer subjetivo.

$\mathrm{Na}$ interpretação de Nietzsche, essa concepção estética caracteriza-se como um ato de bravura contra o otimismo contido no cientificismo. Ele acredita que Schopenhauer representa uma inversão: a substituição da ciência como alvo supremo por uma compreensão intuitiva da imagem do mundo, a única forma de apreender esteticamente o sofrimento eterno como sendo o próprio. Essa inversão ousou chamar de cultura trágica ${ }^{179}$. Por esse ângulo, Schopenhauer teria destruído a secularização e, ao mesmo tempo, a força barbarizante da ciência ${ }^{180}$. Antes dessa vitória, a exigência de desvelamento científico-racional a todo custo teria resultado em um duplo esquecimento: da religião e da relação entre a arte e a vida. Porém, o pessimismo, diz Nietzsche, invocaria novamente a necessidade de uma religião e de arte. A nova religião seria profunda, fruto dos seguintes efeitos do pessimismo: 1) o tema da imortalidade, junto com o medo da morte, desaparecera; 2) o completo divórcio entre corpo e alma se suprima; 3) se compreenda radicalmente que não é possível superar a miséria da existência mediante correções de caráter paliativo; 4) acabou a relação com um deus; 5) a compaixão (não como amor ao eu, mas como união de tudo que vive e sofre) ${ }^{181}$.

\footnotetext{
${ }^{177}$ SCHOPENHAUER. Op. Cit. §34, p. 245.

178 "Ela [a obra do gênio] repete as Ideias eternas apreendidas por pura contemplação, o essencial e permanente dos fenômenos do mundo, que, conforme o estofo em que é repetido, expõe-se como arte plástica, poesia ou música. Sua única origem é o conhecimento das Ideias, seu único fim é a comunicação deste conhecimento". SCHOPENHAUER. Op. Cit. §36, p. 253.

${ }^{179}$ NIETZSCHE. Op. Cit. §18, p. 110 e 111.

180 "Er zertrümmert die Verweltlichung, und ebenso die barbarisirende Kraft der Wissenschaften". NIETZSCHE. Fragmento póstumo de 1873 28[6].

${ }^{181}$ Idem.
} 
A religião a que Nietzsche se refere é arcaica, trata-se dos mitos antigos que expressavam a verdade ao mesmo tempo em que preservavam algo de mistério. Nesse modelo antigo de religião não havia a promessa da imortalidade, nem mesmo a separação da alma e do corpo. Pelo contrário, tudo era expresso por uma linguagem com símbolos corporais e instintivos. Essa religião foi substituída pelo racionalismo socrático e, em sequência, pelos enunciados lógicos das explicações científicas, que não permitiam que nenhum mistério permanecesse oculto, tudo deveria ser desnudo, desvelado ${ }^{182}$. Nos mitos os deuses eram palpáveis, no sentido de que não havia diferença entre o divino e a natureza, a Teogonia, por exemplo, confunde-se com a Cosmogonia, a divindade é o sol, o rio, a morte. Para essa crença antiga, o sofrimento intrínseco à vida, a miséria da condição humana só poderia ser contornada artisticamente, nunca pela moral. Assim fizeram os gregos, se protegeram da aguda sensibilidade para a dor através da arte. Schopenhauer figurava, nesse momento do pensamento nietzschiano, a esperança de uma nova justificação estética para vida, uma vez que teria demonstrado a falência da ciência. Esse é o significado da nova religião.

Mesmo desconsiderando os rumos turbulentos em que se direcionou a relação de Nietzsche com a filosofia schopenhauriana, podemos assegurar que seu prognóstico fracassou. Nenhuma estética ou criticismo foram capazes de frear o otimismo eufórico e a cega confiança na ciência. Pelo contrário, nossa época, como nenhuma outra, é identificada por uma completa dependência científica. A ciência se fez indispensável em todos os âmbitos da vida: desde a medicina até a necessidade de varrer o universo infinito - no sentido macrocósmico e microcósmico - em busca de desvelamento. A previsão nietzschiana não poderia ter tido maior fracasso: a ciência tornou-se nossa religião: o medo da finitude fazse buscar a imortalidade, não mais nos reino dos céus, mas através dos avanços técnico-científicos; o corpo é suplantado, a cada dia, não pela moralidade da alma, agora por uma insaciabilidade hedonista que nos torna incapazes de vivenciar autenticamente nem o sofrimento e nem o tédio. Nossa miséria converteu-se na impossibilidade de sofrer; não há mais deus, porém curvamo-nos à tecnologia e preservamos os dogmas e a religiosidade; o individualismo e o egoísmo selvagem

\footnotetext{
${ }^{182}$ Essa ideia é desenvolvida por Nietzsche no aforismo §261, “Os tiranos do espírito" de Humano, demasiado humano.
} 
são alguns sucedâneos do vazio latente que estampa o homem pós-Fausto de hoje em dia.

Posteriormente em sua obra, Nietzsche corrige suas previsões e concede um lugar bem diferente ao cientificismo. Nessa reavaliação, entende que o pessimismo radicalmente ateísta de Schopenhauer conduziu a Europa ao desmoronamento da fé religiosa, entretanto, a necessidade de verdade a todo custo converteu-se em consciência científica, em um inesgotável anseio intelectual ${ }^{183}$, claramente refletido hoje em dia. No entanto, desconsiderando por hora as reviravoltas do pensamento nietzschiano, evidenciamos, até aqui, a esperança de uma renovação da cultura depositadas na filosofia schopenhauriana. Nietzsche defendia, até mesmo, o estudo de Schopenhauer nas universidades e em cursos populares ${ }^{184}$; era através do mestre que ele reconhecia a si próprio ${ }^{185}$. Logo, a composição filosófica daquilo que Dioniso e o dionisíaco simbolizam não poderia possuir outro fundamento. A sabedoria dionisíaca encontrada em Schopenhauer não se resume à superação do então otimismo científico; ela ultrapassa a crítica da cognação e diz respeito à toda uma visão da realidade, a um sistema que coloca a arte, sobretudo a música, em primazia para a apreensão do mundo.

No "livro terceiro" de O Mundo como vontade e representação, Schopenhauer faz a apresentação de sua concepção de arte como manifestação imediata da vontade através da ideia platônica; o objeto artístico, aquilo que o artista se esforça para representar, e deve conhecer antes de produzir sua obra, é a ideia. Assim, embora a arte tenha certa similitude com o conceito, uma vez que ambos, em um processo de subsunção, representam como unidade a pluralidade de coisas reais, a grande diferença entre eles é que, enquanto o conceito é abstrato

\footnotetext{
${ }^{183}$ Cf. NIETZSCHE. A Gaia ciência. \$357. p. 256

184 "Preisaufgaben, von Universitäten an Studenten gestellt, über Schopenhauer! Populäre Vorträge über Schopenhauer! Es fehlt an aller Würde. Wie die Wissenschaft zu dem werden konnte, was sie jetzt ist, ist nur aus der Entwicklung der Religion deutlich zu machen". [Tarefas sobre Schopenhauer proposta pelas universidades aos estudantes! Palestras populares sobre Schopenhauer. Falta dignidade em tudo. Apenas pelo desenvolvimento da religião pode se esclarecer como a ciência tornou-se o que é agora]. NIETZSCHE. Fragmento póstumo de 1873, $28[5]$.

185 "Ich bin fern davon zu glauben, dass ich Schopenhauer richtig verstanden habe, sondern nur mich selber habe ich durch Schopenhauer ein weniges besser verstehen gelernt; das ist es, weshalb ich ihm die grösste Dankbarkeit schuldig bin". [Estou longe de acreditar que entendi corretamente a Schopenhauer, mas é unicamente através do Schopenhauer eu aprendi um pouco melhor de mim mesmo; É por isso que devo-lhe a maior gratidão]. NIETZSCHE. Fragmento póstumo de 1873, $34[13]$
} 
e discursivo, completamente indeterminado quanto ao seu conteúdo; a ideia é absolutamente concreta e intuitiva, por mais que represente uma infinidade de coisas particulares, é inteiramente determinada, porque é conhecida unicamente por quem se destituiu da individualidade e elevou-se como puro sujeito do conhecimento. Nesse contexto, a finalidade da arte é comunicar a ideia. Cada estilo artístico, diz Schopenhauer, ao reproduzir a ideia, espelha a vontade em distintos graus de manifestação; a arquitetura, por exemplo, revela o mais baixo grau, enquanto a tragédia faz-nos ver a objetivação da vontade no mais alto $\operatorname{grau}^{186}$.

Contudo, quando nos referimos à música, estamos falando de um estilo artístico especial, completamente dissociado dos demais. Nela não encontramos a reprodução da ideia de algum ser, tal como ele se manifesta no mundo. Diferentemente das outras artes, que tem como finalidade estimular o homem a conhecer as ideias, a música é mais elevada e majestosa. Ela diz respeito a uma linguagem universal: é capaz de comunicar os sentimentos mais profundos e mesmo assim se fazer inteiramente compreendida. Do ponto de vista da metafísica schopenhauriana, a música mantém uma relação muito mais íntima com a essência do mundo, ela é infinitamente mais precisa e verdadeira ao expressar tal verdade, por isso, é compreendida imediatamente por qualquer um. Na relação modelo e cópia, ainda corresponda à cópia, embora à cópia de um modelo que, devido a sua natureza, nunca pode constituir-se como o objeto da representação. Em outras palavras, ela é a reprodução da vontade como tal, a objetividade direta, sem qualquer mediação, da coisa-em-si. Assim sendo, a música está para além das ideias, transpassa-as em aproximação do núcleo essencial do mundo ${ }^{187}$.

Como se encontra para além das ideias, a música é completamente independente do fenômeno, ignora-os por inteiro. Ela poderia, diz Schopenhauer, existir mesmo se não houvesse $\mathrm{o}$ mundo ${ }^{188}$. Por ser tão direta objetivação da vontade, assemelha-se às ideias, porém, nunca pode ser comparada às outras artes, pois estas não passam de meras cópias de ideias. Por isso, a influência e os efeitos da música no homem são incomparavelmente mais fortes e mais penetrantes do

\footnotetext{
${ }^{186}$ Os graus de manifestação da vontade nas artes oscilam de acordo com a capacidade de cada estilo exprimir a luta da vontade com ela mesma: Cf. SCHOPENHAUER. Op. Cit. §49 a §51.

${ }^{187}$ Cf. Ibidem. $\$ 52$, p. $336-338$.

${ }^{188}$ Idem. p. 338.
} 
que qualquer outra manifestação artística. O compositor, por exemplo, revela-nos a essência íntima da realidade, faz-se intérprete da sabedoria mais profunda, utiliza uma linguagem que a razão não compreende ${ }^{189}$, todavia, por ser expressão direta do coração do mundo está no ponto mais alto de uma linguagem universal ${ }^{190}$. Por sequência, no que se refere ao prazer estético, à consolação através da música é inigualavelmente mais poderosa que a do restante das artes. Tomado pela melodia, o indivíduo não é mais controlado pela vontade, há uma inversão, mesmo que por poucos instantes, passa a contemplar o Em-si da existência; nesse momento, sobrevém um entusiasmo artístico que o faz esquecer das penúrias da vida. Não é uma resolução definitiva para a dor, mas uma consolação $^{191}$.

Schopenhauer, em sua metafísica do belo ${ }^{192}$, elabora uma espécie de cosmologia da música, onde promove um exame das frequências dos sons (do grave ao agudo), da melodia, da harmonia e, até mesmo dos andamentos das árias, sempre associando esses elementos musicais às formas de manifestação da vontade na natureza. A música realmente ocupa lugar de destaque em seu sistema estético, sua supremacia é a maior herança deixada para a estética nietzschiana. Nietzsche absorve a ideia de que a música "faz ressaltar cada quadro e cada cena da vida, conferindo-lhe, imediatamente, uma significação mais alta"193. Ele ainda concorda que ela possui uma potência sublime, sendo uma linguagem capaz de expressar universalmente uma verdade. $\mathrm{Na}$ sua análise, essa extraordinária capacidade de comunicação universal da verdade fluiu apenas duas vezes na história: na criação dos mitos antigos e na sua própria época na figura de Richard Wagner. A música, em sua força sublime de expressão da realidade, a partir de sua sublimidade, possibilita a criação dos mitos ${ }^{194}$. Segundo diz, a música, tal como pensada por Schopenhauer, seria sublime justamente por possuir um caráter

\footnotetext{
${ }^{189}$ Idem. p. 342.

190 “A música, portanto, caso vista como expressão do mundo, é uma linguagem universal no mais supremo grau, que está até mesmo para a universalidade dos conceitos como aproximadamente estes estão para as coisas particulares. Sua universalidade, entretanto, não é de maneira alguma a universalidade vazia da abstração, mas de um tipo totalmente outro, ligada a uma determinidade mais distinta e contínua". Idem. p. 344.

${ }^{191}$ Essa consolação através da arte não é exclusiva da música, contudo, como podemos deduzir, ocorre em grau mais efetivo a partir dela. Ibidem. p. 350.

${ }^{192}$ Metafísica do belo é como Schopenhauer chama sua filosofia estética.

${ }^{193}$ SCHOPENHAUER, Arthur. Apud. NIETZSCHE. Fragmento póstumo de 1872, 14[3].

${ }^{194}$ Cf. NIETZSCHE. Fragmento póstumo de 1872, 14[3] e Fragmento póstumo de 1874 32[44].
} 
extático: revelaria, ao gênio, a eterna dor essencial, mas, no momento mesmo que a revela, proporciona o prazer estético, só possível devido à momentânea liberdade.

Essas breves considerações já seriam o suficiente para demonstrar que as formulações musicais, feitas por Schopenhauer, são o conteúdo bruto que lapidado se torna o dionisíaco nietzschiano: a música em Schopenhauer é a manifestação mais direta do ser primordial, ela nos cativa - ou ao menos o gênio - a contemplar o teatro de objetivação da vontade. Da mesma forma, o dionisíaco é responsável por quebrar o princípio de individuação e revelar o espetáculo do Uno originário, sempre acompanhado da aprazível embriaguez estética. Outra influência schopenhauriana encontrada em Nietzsche é a relação entre a música e a palavra: para Schopenhauer, por não expressar o fenômeno, mas a essência íntima, a música não exprime esta ou aquela alegria, esta ou aquela aflição, dor, regozijo, ou seja, ela não expressa nenhum sentimento singular, porém o Em-si de cada um deles. Por isso, a imaginação é tão facilmente despertada pela música. A nossa fantasia é estimulada pelo turbulento mundo invisível dos sons que nos fala intensa e diretamente; ela se esforça para criar imagens que "incorporem", a partir de coisas do mundo real, como se a música exigisse a presença da imagem ao seu lado. Daí originam-se as palavras nos cantos, que por sua vez, deve ser vista sempre como subordinada à música ${ }^{195}$.

Nietzsche igualmente reconhece a subordinação da palavra à música. Na sua análise, as palavras e as imagens não são eficazes para comunicar o íntimo das coisas, por isso, nas canções elas devem sempre seguir a música, servindo-lhe sempre como suas subordinadas. Apesar disso, no que diz respeito à tragédia grega, mais especificamente, ao seu efeito no indivíduo, a palavra e a imagem desempenham um papel fundamental: agem como uma proteção frente ao poder destruidor da melodia. Sem a proteção de Apolo, ou seja, das palavras, do coro, da imagem, o indivíduo seria arrastado pelo estado extático e teria sua individualidade aniquilada. Na tragédia, quando a música - o elemento dionisíaco

\footnotetext{
195 "Essa é a origem do canto com palavras e, por fim, da ópera - que justamente por isso nunca devem abandonar a sua posição subordinada para se tornar a coisa principal, fazendo da música mero meio de sua expressão, o que se constitui num grande equívoco e numa absurdez perversa. Pois em toda parte a música exprime apenas a quintessência da vida e de seus eventos, nunca estes mesmos, cujas diferenças jamais a afetam". SCHOPENHAUER. O Mundo como vontade $e$ representação. §52. p. 343.
} 
- une-se ao mito, à palavra e à imagem - os elementos apolíneos - é possível ao espectador se jubilar diante do dilaceramento do herói, isso porque, através do suplício do protagonista trágico, experimenta-se o enorme gozo de perceber o fluxo da vida eterna por trás do véu dos fenômenos e da morte aparente. Essa alegria diante do trágico é o que Nietzsche chama de "consolo metafísico" e, tal como o consolo estético schopenhauriano, tem sua efetividade por meio da música. Esse será o tema central de nossa próxima seção.

\section{3.}

\section{O herói dilacerado e o fluxo da vida eterna:}

A tragédia grega concentra em sua essência o jogo entre a pulsão estética apolínea e a dionisíaca. Segundo Nietzsche, ela teve sua origem no coro ditirâmbico, mas sua maturação está ligada ao aparecimento dos elementos apolíneos da imagem: a palavra e o ator, por exemplo. $\mathrm{O}$ ator representava a própria figura de Dioniso, todos os heróis trágicos eram, na verdade, representações do deus dilacerado. Por trás de cada máscara, nas entrelinhas de cada verso, no significado das coreografias meticulosamente exprimidas pelas personagens, encontrava-se Dioniso; o deus era o verdadeiro protagonista de cada ato em cada drama. Apolo, por sua vez, trazia a mediania da palavra nos diálogos, fazendo do teatro inteligível. Somente assim a tragédia torna-se um drama propriamente dito. Sem o elemento apolíneo, diz Nietzsche, o dionisíaco seria impossível de ser vivenciado esteticamente. Quando Apolo e Dioniso entram neste jogo artístico, há uma simultaneidade entre o êxtase narcótico da embriaguez e a lucidez. O elemento apolíneo controla os impulsos destruidores de Dioniso e os tornam belos. É exatamente neste momento que o dionisíaco se torna arte.

Em termos práticos, a música dionisíaca, sem o intermédio dos recursos apolíneos que asseguravam certa serenidade, proporcionava excessos que não eram aceitos pela sociedade grega do quinto século da era antiga. Tais excessos eram de ordem orgiástica, promovia o dilaceramento tanto de ordem psíquica quanto social. Nietzsche usa como exemplo as celebrações bárbaras, ou seja, os ritos dionisíacos estrangeiros marcados por uma excessiva brutalidade: sacrifícios, 
desmembramento de vítimas - animais e humanos - em frenéticos holocaustos. Esses cultos envolviam uma completa destituição de tudo que é socialmente estabelecido. Dessa forma, eram dissolvidas as hierarquias políticas, as convenções familiares e havia, até mesmo, a dissolução dos limites que separam os homens dos demais animais, isto é, os devotos afetados pelo elemento dionisíaco se transformavam em bestas, imitavam as posturas e hábitos dos bichos chegando a inclusive praticavar coito com animais.

Essas práticas, como dissemos, eram abominadas pelos preceitos da religião apolíneo-homérica. A beleza, a serenidade, a medida e o equilíbrio eram os princípios dos deuses olímpicos e, consequentemente, da arte homérica. Entretanto, nada foi capaz de impedir que as práticas dionisíacas extáticas irrompessem as fronteiras gregas. O culto a Dioniso invade como uma ipedemia, contagiando, sobretudo, as mulheres. Quando isso ocorre, os gregos entenderam que a única saída era transformar os ritos dionisíacos, então excesivamente violentos, em ditirambos proclamados e cantados nas celebrações rurais, que mais tarde migraram para os "centros urbanos", até se converteram no teatro de tragédias. Pensando nisso, podemos conjecturar contra Nietzsche, quando ele diz que a tragédia nasceu do coro, dos ditirambos dionisíacos e amadureceu com a inserção dos elementos apolíneos - a cena com ator e diálogo -, pois, na verdade, o ditirambo grego já nasce como apolíneo. Em outras palavras, o coro das festas dionisíacas praticadas na cidade já era uma manifestação artística apolínea. O coro que antecede as celebrações gregas, as Leneias, as Dionísias Urbanas e Rurais, por exemplo, já eram serenizados. A suposição nietzschiana só faz sentido se tomamos como origem da tragédia o espírito mesmo da música e, por consequência, o coro no seu aspecto mais primitivo, ou seja, nos cantos frenéticos do tíaso no alto das montanhas.

Não obstante, a questão primordial da concepção trágica em Nietzsche é a sua função estético-existencial. Para o filósofo, a arte possui uma conexão ontológica fundamental, como vimos anteriormente, o mundo por si só já é uma manifestação artística. Para o filósofo, a tragédia tem a função de transformar todo sentimento de angústia e desgosto pela existência, causados pelos absurdos e horrores da mesma, em uma profunda afirmação da vida. Assim sendo, a tragédia tem o propósito de produzir alegria. O herói trágico, ao ser negado, nos convence 
da alegria prazerosa do existir, a partir da sua aniquilação, o limite da individualidade é abolido, restabelecendo assim, a unidade originária. O prazer de existir, proporcionado pela experiência trágica, coloca o homem na esfera do próprio ser originário, isto é, o homem torna-se o "Uno vivente" e passa a conhecer o prazer do existir. O aniquilamento do herói, ou seja, a luta, a dor e a destruição a que ele é submetido, são imprescindíveis, pois seu dilaceramento desvela uma existência mais profunda, em direção ao Uno primordial, o oposto da mera afirmação individual do herói.

O efeito estético surge quando estes impulsos artísticos, o apolíneo e o dionisíaco, distintos, porém, indissociáveis, atuam paralelamente para uma ação comum: convencer-nos da eterna alegria que está ligada à existência! Essa alegria não deve ser procurada apenas na aparência, mas, principalmente, por atrás dela. Nisso consiste a sabedoria trágica: entender que, no ciclo da existência, tudo quanto nasce deve estar pronto para um doloroso declínio. Ainda que a consequência mais óbvia da constatação da inexorável finitude seja o terror, ele não é dominante, pois a arte proporciona uma consolação metafísica arrebatadora, e nesse curto instante não somos mais um ser pertencente ao espaço e ao tempo, todavia, à própria essência primordial. "A luta, a tortura, o aniquilamento das aparências" diz Nietzsche, "nos parecem doravante como necessárias em frente da intemperante profusão de inumeráveis formas de vida que se chocam e se comprimem na presença da fecundidade superabundante da vontade universal". ${ }^{196}$

As interpretações do filósofo norteiam-se pelo viés de que o efeito da tragédia faz o espectador aceitar a dor e a dilaceração da existência com imensa alegria, uma vez que ele se reconhece como parte indissociável do ser do mundo, e mais, o espectador trágico compreende que o sofrimento e aniquilamento individual em nada afeta o fluxo eterno da vida. Para Nietzsche, a tragédia produz uma alegria com o dilaceramento do indivíduo, porque mediante a essa anulação individual, experimentamos a fusão com o Uno primordial e, momentaneamente, nos confundimos: somos e sentimos toda vontade e prazer de existir deste ser originário. Contemplando a aniquilação do herói trágico, sentimos imensa alegria e prazer, pois mesmo com o indivíduo sendo destruído "sob os turbilhões de

\footnotetext{
${ }^{196}$ NIETZSCHE. O Nascimento da tragédia, $\$ 17$.
} 
fenômenos, a vida eterna continua fluindo" ${ }^{\text {197 }}$. Contudo, é necessário destacar que este prazer proporcionado pelo efeito do mito trágico é dado pela música. Ela, que é a própria volúpia dionisíaca, transporta o espectador além das superfícies, além da bela proteção apolínea, fazendo-o penetrar no íntimo de todas as coisas. Nisso consiste o fenômeno estético da embriaguez; é nele que se assenta o consolo metafísico,

É imprescindível salientar o papel da música nas tragédias áticas. Nós devemos entender o espírito trágico em tons musicais, pois, para Nietzsche, só a música pode transmitir o prazer existente fora da aparência. A morte deixa de ser vista como a mais terrível das dores, a música proporciona o consolo metafísico e, até mesmo, diante do fim iminente, reina a alegria. Neste sentido, Dioniso vem com a embriaguez musical destruindo a individualidade com um irresistível prazer em reconciliação com o plano metafísico. Este poder da música dionisíaca é cheio de perigo, necessita de Apolo. Na tragédia, os elementos apolíneos vêm em socorro do espectador, sem sua intervenção haveria um aniquilamento total.

\section{4. \\ Eurípides entre Zagreus e o homem comum (ou entre Penteu e o povo):}

A tragédia grega surge e perdura em um momento histórico delimitado e datado com muita precisão. Ela nasce no final do século VI em Atenas, atinge seu ápice e com menos de cem anos adultera-se para então desaparecer no quarto século. Aristóteles, ainda que tenha teorizado e esquematizado sobre essa forma de teatro, não a conheceu efetivamente, o homem trágico lhe era inteiramente estranho $^{198}$. O declínio da tragédia é um tema de fundamental importância para Nietzsche, a partir de sua análise ele poderá traçar o percurso da própria cultura ocidental. Segundo o filósofo, a tragédia sucumbiu tragicamente, ou seja, diferente das demais artes antigas que lentamente deixaram de existir sem nenhum motivo conflitante, o drama musical grego antes de se extinguir por completo foi

\footnotetext{
197 Idem. $\$ 18$.

${ }^{198}$ Cf. VERNANT, Jean-Pierre e VIDAL-NAQUET, Pierre. Mito e tragédia na Grécia antiga. p. 7.
} 
totalmente degenerado em relação à sua essência; fazendo com que a imagem que ilustre seus últimos movimentos seja a de uma moribunda que agoniza ante mortem $^{199}$. Quando a tragédia finalmente morre, deixa um enorme vazio, sentido por toda parte. Com ela desaparece também o seu efeito trágico: a alegria diante do dilaceramento, o consolo metafísico proporcionado pela arte dionisíaca é erradicado.

O responsável por perverter e arruinar aquilo que, segundo Nietzsche, representou o momento de superioridade da humanidade, onde se produziu o melhor da cultura, foi Eurípides. O tragediógrafo, sob a influência direta de Sócrates, teria pervertido, em suas peças, a estrutura e o conteúdo da tragédia, desvirtuando então o seu sentido original e ocasionando o seu derradeiro fim. Após a derrocada da tragédia houve um período de lacuna cultural, inclusive a comédia antiga entrou em um processo descendente ${ }^{200}$; até que a poesia pode encontrar novamente o seu lugar no teatro tardio chamado de comédia nova. Este estilo floresceu por volta de 336 a.C.; tinha como principal característica a encenação de tramas românticas de personagens fictícios extraídos da vida contemporânea. Por isso, assemelhava-se mais aos dramas euripidianos do que da comédia aristofanesca; motivo pelo qual os seus autores sentiam uma inclinação passional por Eurípides ${ }^{201}$. O coro, na comédia nova, foi menosprezado, dele restaram apenas meros músicos e dançarinos que indicavam os intervalos das peças. O seu conteúdo visivelmente inferior e seu padrão moral baixo fizeram com que Nietzsche a comparasse com as últimas e degeneradas encenações trágicas $^{202}$.

\footnotetext{
${ }^{199}$ Cf. NIETZSCHE. O Nascimento da tragédia. §11.

200 A Comédia antiga caminhou lado a lado com sua irmã, a tragédia. Atingiram o clímax, para então declinarem. Por volta de 405 a.C., a comédia passa por uma fase de transformação: muito do seu teor crítico e de sua virtude cênica se desvaneceram. Isso porque, devido à guerra, se instalou em Atenas uma crise econômica e uma perigosa instabilidade política, assim, seria prudente, para conter os ânimos abalados, uma moderação no conteúdo crítico e mais modéstia na estrutura dramática. Razões que marcaram o final do quinto século como o momento de transição do apogeu à decadência do teatro.

${ }^{201}$ Um desses autores foi Philemon, quem "declarou que se deixaria enforcar imediatamente para aprender com Eurípides no inferno". Idem.

202 "Mas quando, apesar de tudo, desabrochou um novo gênero, que reverenciava na tragédia a sua predecessora e mestra (...); aquele gênero tardio de arte é conhecido como nova comédia ática. Nela continuou a viver a figura degenerada da tragédia, um monumento a seu penoso e violento passamento". Idem.
} 
São várias as mudanças no teatro produzido por Eurípides que marcam, segundo Nietzsche, a degeneração da tragédia. Entre elas, em comum com a comédia nova, foi levar o espectador, o homem da vida cotidiana, ao palco. Diferentemente de seus antecessores que encenavam a grandiosidade e acontecimentos ousados, Eurípides passou a evidenciar os acontecimentos cotidianos. O que é dramatizado agora é uma mimese da realidade corriqueira. $\mathrm{O}$ homem comum, o espectador se vê no palco, os atores e o enredo são como espelhos que refletem suas vidas. Há, portanto, uma transformação que só é possível mediante a uma adequação de linguagem: ela deve ser capaz de comunicar as expectativas da plateia, deixar de ser enigmática e rebuscada, ou seja, falar das expectativas do povo e como o povo. Em decorrência disso, ocorre uma desmitificação na trama e, consequentemente, sua mediocrização: antes toda encenação representava tão somente o sofrimento de Dioniso, na verdade, o único herói cênico. O deus nunca, até Eurípides, deixou de ser o protagonista trágico; todas as personagens dilaceradas no palco eram exclusivamente máscaras desse Zagreus, o proto-herói.

A idealidade da tragédia $[\tau \rho \alpha \gamma \omega \delta i \alpha]$ é, portanto, o canto [ $\omega \delta \delta \dot{\eta}]$ de suplício

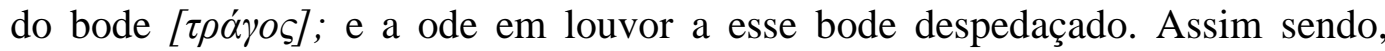
Prometeu, Ajax, Édipo, Antígona, entre tantos outros, são apenas representações da laceração de Dioniso-Zagreus; as súplicas desses heróis nada mais são do que o berro mesmo do bode. Portanto, não podemos falar em subjetividade na tragédia arcaica, nela não é admitido o "sujeito"; somente o divino que se individualiza momentaneamente, para tão logo se desindividualizar; todos os indivíduos não passam, então, de breve aparência ${ }^{203}$. Porém, no palco de Eurípides, segundo a interpretação nietzschiana, o deus do teatro dá lugar ao $\delta \tilde{\eta} \mu o \varsigma$, às paixões e às intrigas humanas, isto é, às tensões superficiais da cotidianidade. $\mathrm{O}$ canto agora pertence à mediocridade da burguesia; a "classe média burguesa, sobre a qual Eurípides edificava todas as suas esperanças políticas", diz Nietzsche, "tomou agora a palavra" ${ }^{204}$. Com certeza, ao pensar sobre esse deprimente rumo do teatro

\footnotetext{
203 “Não sei quem asseverou que todos os indivíduos enquanto indivíduos são cômicos e, portanto, não trágicos de onde se deduz que os gregos não podiam suportar em absoluto indivíduos na cena trágica. "Idem. §10.

${ }^{204}$ É anacronicamente problemática a definição sócio-política que Nietzsche faz na conferência Sócrates e a tragédia: "Der bürgerliche Mittelstand"; porém ele a repete no $\$ 11$ (p. 74) de $O$ Nascimento da tragédia [Die bürgerliche Mittelmässigkeit]. Acreditamos que ele estava fazendo uma
} 
grego, o filósofo tinha em mente a burguesia de sua época que tratava a arte de forma completamente banal; essa classe era incapaz de uma audição trágica, estava embriagada só com as atividades comuns da vida diária.

Todavia, a burguesia grega a qual Nietzsche se refere é aquela massa dominante que, na época de Eurípides, filosofava nas ágoras, administrava as suas posses, possuía o direito de participação política e acreditava estar capacitado a opinar sobre tudo. Esse é então o novo herói trágico: o homem da democracia!

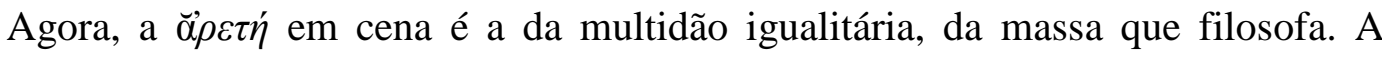
tendência de Eurípides é fazer do palco espelho da ágora, o drama torna-se cópia, uma dramatização mimética do que acontece na pólis; com isso ele perde sua autenticidade, pois, em essência, o drama não é imitação e sim o original ${ }^{205}$. A intenção de Eurípides ao transportar o espectador comum ao palco como protagonista é faculta-lo a compreensão da obra, no entanto, ao fazê-lo acaba por torna-lo negligente, ou seja, o povo torna-se incapaz de se responsabilizar por algo de verdadeiramente grave; o que passa a lhe importar é apenas o gozo fugaz do presente, o passado não lhe desperta admiração e o futuro não lhe interessa; por isso, para esse novo tipo de espectador é insuportável tudo o que é sério e assustador. Estranhamente, atributos a cada dia mais nítidos em nossa sociedade contemporânea $^{206}$.

Apesar das severas críticas, Nietzsche reconhece em Eurípides a virtude de lutar obstinadamente por seus ideais, o dramaturgo teria sacrificado sua vida inteira por eles, encontrando reconhecimento apenas no crepúsculo de sua carreira $^{207}$. Mesmo que ele tenha colocado as expectativas do povo em cena, não o fazia para agradar a plebe. Eurípides era um pensador solitário, de modo algum produzia para agradar a então massa dominante; pelo contrário, ele teve, na maior

analogia à burguesia de sua época e ao tratamento que esta dava à arte. Cf. NIETZSCHE. Sócrates e a tragédia. In. A visão dionisíaca de mundo e outros textos de juventude. p. 39.

205 “'Mimik'. Tendenz der Euripideischen Kunst, während das ächte Drama nicht Nachahmung, sondern Original ist, das das Leben nur blaß und matt erreicht. Das höchste Leben!" [A "mímica" Tendência da arte de Eurípides, enquanto o drama genuíno não é imitação, mas sim o original que a vida só alcança débil e palidamente. A vida suprema!].NIETZSCHE. Fragmento póstumo de $1870,7[151]$.

${ }^{206}$ Permitimo-nos aqui um intervalo na proposta da seção para uma breve nota de compararão do "espectador grego burguês", a que Nietzsche se refere, com a "classe média" contemporânea. Essa, de modo geral, tornou-se assustadoramente incapaz de apreender esteticamente o horrível, o assustador. Qualquer representação artística que ultrapasse o ethos, o conforto e as prerrogativas morais, é considerada profana e imoral.

${ }^{207}$ Cf. NIETZSCHE. Sócrates e a tragédia. 
parte de sua vida, a multidão contra si; a maioria de suas obras foi incompreendida e rechaçada por seus contemporâneos; Em evidência a isso, viuse raramente coroado como vencedor dos concursos: enquanto Sófocles foi laureado campeão dezoito vezes e Ésquilo treze, Eurípides vence o primeiro prêmio apenas cinco vezes, sendo a última ganhada postumamente pela trilogia Bacantes, Ifigênia em Áulis e Alcmeon em Corinto, representadas logo após a sua morte. Dessa forma, não foi por bajulação em vista de glória, nem outra circunstância egoísta que motivou o poeta a encenar as paixões populares, subvertendo assim a tragédia. Entretanto, o motivo foi porque, como espectador, não compreendeu seus antecessores.

Segundo a argumentação de Nietzsche, Eurípides sentia-se acima da massa, quando era julgado negativamente pelo povo, mantinha-se convicto de que suas ideias eram vitoriosas; isso porque, além de poeta, colocava-se como um pensador crítico. Essa característica de seu espírito permitia-lhe sentar junto à plateia como astuto espectador. Desse modo, como audiência crítica, examinou as obras de seus antecessores. No entanto, percebe nelas algo que o incomoda. Nas tragédias de Ésquilo, se depara com uma linguagem demasiada pomposa, ou seja, nelas havia um resgate dos mitos antigos e uma inclinação à fala oracular. Os temas esquilianos giravam em torno de uma religiosidade arcaica, pré-homérica, com a presença desconcertante da $\tilde{v} \beta \rho \varsigma^{208}$. O drama se construía de forma indecifrável e, quando o conflito finalmente se revelava, era impossível concluir uma solução para a trama, deixando uma sensação de dubiedade sobre os valores éticos representados. Como espectador, Eurípides não compreendia o tratamento fausto dos mitos, considerava muita monstruosidade para relações comuns. Tão pouco entendia a estrutura do drama, em especial o significado do coro ${ }^{209}$.

A tragédia antiga era, para o espectador Eurípides, questionável, pois sua linguagem mítica era muito esplendorosa, seus valores éticos eram incompreensíveis e, sobretudo, era conduzida por uma censurável tensão

\footnotetext{
${ }^{208}$ A hýbris e o mito arcaico nas primeiras tragédias podem ser ilustrados pelo relato feito por Plutarco de que Sólon abandonou, indignado, uma das primeiras representações teatrais, antes mesmo da instituição dos concursos. O nomóteta estava preocupado com as consequências de tais encenações na relação entre os cidadãos. Estadista sábio e moralista acreditava que o passado dos ritos brutais e da $\partial \rho \gamma \eta$ heroica estava muito próximo e muito vivo para se tornar, sem risco, cena de espetáculo. Cf. VERNANT, Jean-Pierre e VIDAL-NAQUET, Pierre. Op. Cit. p. 4 e 3.

${ }^{209}$ NIETZSCHE. O Nascimento da tragédia, $\$ 11$.
} 
proporcionada pelo elemento ditirâmbico-musical. Esses aspectos, para ele, teriam criado um abismo entre a plateia e o palco. Então, procurando fazer melhor do que os antecessores criticados, o crítico se fez poeta, cuja obra ergue-se como oposição à tragédia tradicional. E como medida mais radical elaborou um drama em que a música é suplantada, deixando de ser o elemento fundamental. Eurípides pretendia, segundo Nietzsche, alcançar o efeito ditirâmbico mesmo após excisar do drama o elemento dionisíaco, em outras palavras, "ele queria forçar o efeito da música através da poesia" ${ }^{210}$. A sua intenção era reconstruir o teatro trágico a partir de uma moral e visão de mundo não-dionisíacas, a tragédia devia se exprimir como uma forma de arte exclusivamente apolínea. No entanto, ante aos preceitos apolíneos até mesmo as coisas mais terrificantes encantam e provocam prazer pela aparência, pois o que está em caso não é o conteúdo, mas sim a forma. À vista disso, como era de se esperar, o projeto de uma tragédia unicamente apolínea fracassa.

$\mathrm{Na}$ arte trágica, o apolíneo e o dionisíaco não podem ser separados um do outro. Eurípides pretendia atingir a descarga ditirâmbica do mito, mas descartando o dionisíaco, fazendo da música elemento secundário no drama, ou seja, colocando-a estruturalmente como mera acompanhante dos diálogos. É através da palavra que almejava alcançar a violência ditirâmbica ${ }^{211}$. Todavia, o resultado foi apenas a desvirtuação do drama. Isso porque, a palavra, por ser elemento apolíneo, não pode provocar o mesmo efeito de excitação estética da música. Ao perceber isso, a estratégia foi introduzir novos meios de arrebatar esteticamente o público: o poeta inseriu pensamentos paradoxais e frios no lugar da contemplação apolínea; e sentimentos ardentes, no lugar do entusiasmo dionisíaco. Como melhor exemplo, podemos citar os paradoxais pensamentos de Medeia expressos em seus planos calculistas de vingança e em seus frios discursos -, assim como os seus ardentes afetos, que voluptuosamente a tomam, levando-a aos terríveis crimes. Assim sendo, Nietzsche entende que as peças euripidianas são ao mesmo tempo frias e ardentes, aptas para gelar e para inflamar ${ }^{212}$.

\footnotetext{
210 "Für Euripides eine zweite Seite: die dithyrambische Wirkung will er erreichen. Er will die Wirkung der Musik durch Poesie erzwingen". NIETZSCHE. Fragmento póstumo de 1871, 7[129]. Cf. também Fragmento póstumo 7[131].

${ }^{211}$ Cf. Ibidem. 9[12].

${ }^{212}$ Cf. NIETZSCHE. O Nascimento da tragédia. §12.
} 
Não obstante, tais pensamentos e tais afetos eram, na conjectura nietzschiana, limitados, tão-só a mimese da realidade cotidiana e, por isso, de modo algum poderiam ser acolhidos na nobre zona da arte ${ }^{213}$. Além disso, outra peculiaridade da obra de Eurípides, diretamente ligada à estética socrática, e amplamente criticada por Nietzsche, é a clareza e inteligibilidade da trama. O dramaturgo teria aferido a todos os componentes da tragédia - a linguagem, os personagens, a estrutura dramática e a música coral - e os corregido de acordo com a máxima "tudo deve ser inteligível para ser belo". O produto mais evidente dessa reformulação racional foi a incorporação do Prólogo à peça. Toda encenação euripidiana iniciava com uma personagem individual que, após se apresentar, esclarecia os fatos que precederam a trama e, até mesmo, anunciava o que iria acontecer aos protagonistas. Essa personagem do Prólogo, para conceder confiança ao público e garantir a veracidade do mito, deveria ser uma divindade, excluindo assim qualquer dúvida sobre o que iria acontecer. Por exemplo: Afrodite, em Hipólito; Hermes, em Íon; o fantasma de Polidoro, em Hécuba; ou mesmo Dioniso, em Bacantes. Raras exceções, como a criada em Medeia, era alguém comum.

$\mathrm{Na}$ interpretação de Nietzsche, Eurípides revelava no Prólogo os acontecimentos futuros intencionalmente, pois acreditava que o efeito da tragédia não estava na tensão estimulada pela incerteza a respeito do que vai ou não acontecer aqui agora; por outro lado, tal efeito repousa nas grandes cenas dialógicas, nos discursos em que a paixão do protagonista jorrava abundantemente. A ação e a coerência cênica não importavam, só o páthos era sublinhado na apresentação. Tudo que desviasse a atenção das paixões deveria ser eliminado. Assim, para que o ouvinte se entregasse à cena seria impreterível que a peça fosse inteiramente inteligível. Caso o espectador tivesse que se esforçar para compreender este ou aquele personagem, ou que vale este ou aquele conflito, então não seria absorvido pela paixão do herói, nem sentiria compaixão pelas suas desventuras $^{214}$. Por outro lado, os tragediógrafos antigos, nas primeiras cenas de

\footnotetext{
${ }^{213}$ Cf. Idem.

214 "Euripides reflexirte: die Voraussetzungen muß jeder bereits haben, um von vorn herein lebhaft sympathisiren zu können. Muß er sie sich langsam aus- und zusammenrechnen, so geht das Gefühl inzwischen verloren: und was schlimmer ist, er verrechnet sich vielleicht. Darum der Prolog" [Eurípides refletiu: todo mundo já deve ter os pré-requisitos para ser capaz de simpatizar vivamente desde o início. Se ele tem que calcular e lentamente fazer contas, então o sentimento se
} 
suas tragédias, através de artifícios artísticos engenhosos, davam as pistas para a plateia entender a trama, porém isso parecia acontecer como se fosse algo casual. A genialidade desses artistas os permitia revelar as pistas, ao mesmo tempo em que ocultavam o que era formal ${ }^{215}$.

Eurípides, o pensador crítico, quando estava na audiência de Ésquilo e Sófocles sentia-se incomodado, acreditava que o espectador era tomado por uma ansiedade de querer solucionar prontamente os mistérios da trama e resolver imediatamente os conflitos da história, de modo que a beleza poética e as paixões representadas eram perdidas. Para corrigir esse problema e acabar com qualquer confusão dos fatos, o poeta escreve o Prólogo, inaugurando um novo tipo de dramaturgia trágica baseada em uma "estética consciente"216. Não pode haver nenhuma inquietação devido a dúvidas sobre o enredo. A tragédia deve ser perfeitamente clara ao ouvinte. Para isso, ele formulou, além do Prólogo, heróis cujas paixões são integralmente compreensíveis. Enquanto em seus predecessores os personagens são profundos e enigmáticos, suas palavras não desvelam totalmente o seu ser; já os protagonistas euripidianos se desnudam inteiramente; os longos e dialéticos discursos dos heróis, geralmente nos momentos de

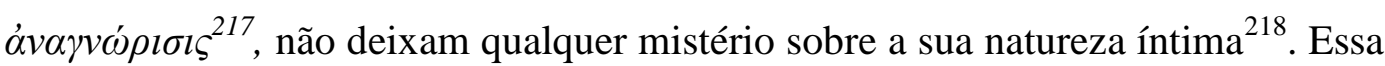
foi, portanto, a grande viragem no teatro trágico: a música é substituída pela dialética e o êxtase dionisíaco pela intelecção.

Essas análises não são uma inovação filológica de Nietzsche, como demonstraremos mais à frente, já estavam presentes nas comédias de Aristófanes. A ênfase que Eurípides atribui ao diálogo e à inteligibilidade são claramente

perde: e o que é pior, ele talvez se equivoque nas contas. É por isso o Prólogo]. NIETZSCHE. Fragmento póstumo de 1869, 1[101]. Cf. também 1[70].

215 Basta lembrar que compreendemos a trama de Édipo rei, por exemplo, sem o auxílio de nenhum elemento formal, eles ficam ocultos à audiência e aprofundamos na trama como se fosse casualmente. Cf. NIETZSCHE. O Nascimento da tragédia. §12.

${ }^{216}$ NIETZSCHE. Sócrates e a tragédia. p. 42.

217 Anagnórise é o momento em que a personagem descobre a essência de sua identidade, provocando a mudança de suas ações. A passagem da ignorância ao conhecimento. Cf. ARISTÓTELES. Poética. XI, 1450a.

${ }^{218}$ Podemos dizer que essa análise filológica da distinção entre a obra de Eurípides e a tragédia antiga inaugura uma discussão estética, que será amplamente discutida no século XIX, sobre qual o assento das artes: ela é objeto de reflexão racional ou exclusivamente dos sentimentos e das afecções corporais? Nesses termos, a tragédia euripidiana é intelectiva, até mesmo as sensações e paixões são objetos artísticos apreendidos racionalmente. Já em Ésquilo e Sófocles, a essência artística do drama está no êxtase corporal, por meio da excitação musical. Para saber mais sobre esse debate na arte contemporânea Cf. DELEUZE, Gilles. Frances Bacon - Lógica da sensação. Trad. José Miranda Justo. Orfeu Negro: Lisboa, 2011. 
percebidas nos seus dramas. Podemos facilmente exemplificar essas características na tragédia $O s$ heráclidas. O drama narra os infortúnios dos filhos do herói Héracles. O Prólogo da peça inicia com o longo discurso do ancião $\mathrm{Iolau}^{219}$. Como regra, o personagem se apresenta, revelando ser o antigo companheiro de armas de Héracles, com quem se aventurou em vários trabalhos; agora, com o herói morto, é guardião de seus filhos. No discurso de abertura, Iolau já nos transparece a sua natureza, não deixando-nos dúvida sobre os seus princípios éticos: "homem justo que veio ao mundo para servir os outros"220. O monólogo inicial também nos esclarece os acontecimentos que antecedem a trama, inserindo o espectador nas desventuras dos jovens heráclidas, para quem é direcionada a compaixão. As crianças, desde a morte do pai, se veem perseguidas pela ira do soberano Eristeu, que as expulsam de toda terra por onde andam e buscam abrigo.

A cena de abertura se passa no templo de Zeus em Atenas, cidade em que os fugitivos esperam refúgio e proteção. O discurso de Iolau só é interrompido quando ele avista Copreu, o arauto do rei inimigo. Com a chegada do algoz, o ancião ordena as crianças que agarrem suas vestes e inicia então uma sequência dialógica que oscila entre insultos e ameaças; mas há também muita ação dramática: o arauto atira o velho ao chão e tenta puxar os meninos à força ${ }^{221}$, mas é interrompido pela entrada do coro que vem em socorro aos gritos de Iolau. O coro prepara a entrada de Demofonte, o rei de Atenas que protagonizará a cena mais dialética da peça: ressaltando o espírito democrático da pólis, o soberano permite que os dois lados argumentem seus motivos. O debate é estruturado em duas rheseis, isto é, em dois longos discursos argumentativos, configurando então o momento de $\alpha \dot{\alpha} \omega ́ v$ (erístico) da peça. Primeiro, o arauto sustenta que os suplicantes foram condenados à morte pelas leis de Argos e termina com tom de intimidação aos atenienses: "não faças o que é vosso costume: escolher os piores

\footnotetext{
${ }^{219}$ O original 'Tó $\alpha \alpha o \varsigma$ justifica nossa grafia. O discurso inicial compreende 50 versos. Cf. versos. 1 a 50. Esse Prólogo é uma das exceções da obra euripidiana, uma vez que a personagem é mortal e não divina. Assim também ocorrerá em Orestes e Elektra.

${ }^{220}$ EURÍPIDES. Os Heráclidas. Versos, 1 a 5. p. 99.

${ }^{221}$ Idem. Versos 50 a 70. P, $100-102$.
} 
amigos quando é possível optar pelos melhores" ${ }^{\text {222 }}$, uma clara ameaça de guerra caso seja contrariado.

A rheseis proferida por Iolau distingue-se da de seu adversário, ela reúne uma clareza racional e intensa paixão. $\mathrm{O}$ velho astuto primeiro reclama os deveres morais do rei ateniense e depois apela para a emoção em uma comovente súplica $^{223}$. Demofonte mesmo diante de terrível dilema - entrar em guerra contra um oponente forte ou entregar à sorte a vida de frágeis inocentes - será o exemplo de racionalidade no drama. O rei explica porque decide proteger os jovens heráclidas e se prontifica para a guerra ${ }^{224}$. Contudo, a trama tem uma viragem quando o oráculo revela que Atenas só será vencedora se uma virgem, filha de nobres, for sacrificada. Demofonte justifica ao velho Iolau que não poderá sacrificar nenhuma ateniense. Então entra em cena Mecaria, uma das filhas de Héracles, até então escondida no templo. A jovem decide entregar-se voluntariamente à imolação. Novamente uma personagem faz uso de um longo discurso racionalista com enorme poder argumentativo para justificar seu autosacrifício $^{225}$. No desenrolar dos acontecimentos, a jovem faz outro monólogo de despedida com grande intensidade patética, deixando-nos claro seu caráter e sua autodeterminação ${ }^{226}$.

Após essas cenas de maior comoção e auge patético da peça, é hora da encenação da batalha. Iolau, idoso e debilitado, demonstrando sua coragem e virtude, decide ir ao combate. Ele roga aos deuses que lhe revigorem as forças pelo menos por um dia para que se vingue do perverso Eristeu ${ }^{227}$. Os deuses concedem ao seu pedido e o tornam jovem novamente, Clara demonstração de que Atenas não poderia sair vencedora se não fosse por intervenção divina. Segundo o relato do Mensageiro, o ancião, recebendo a graça de Hebe, “ostentou a forma vigorosa de seus braços remoçados" 228 . Iolau fez a diferença no confronto e trouxe consigo o melhor dos despojos: o rei de Argos capturado. Eristeu - que no combate havia dado maior prova de covardia ao se negar a lutar um a um

\footnotetext{
${ }^{222}$ Idem. Versos 135 a 175, p. 106 - 107 (toda a rheseis).

${ }^{223}$ Idem. Versos 182 a 320, p. $107-109$.

${ }^{224}$ Idem. Verso 240 a 250, p. 109

${ }^{225}$ Idem. Versos 500 a 534, p. $119-120$.

${ }^{226}$ Idem. Versos 575 a 595, p. 123.

${ }^{227}$ Idem. Versos 740 a 745, p. 134.

${ }^{228}$ Idem. Versos 845 a 875 , p. $137-138$
} 
contra Hilo, primogênito dos heráclidas - é levado como prisioneiro para Atenas, onde é entregue à Acmena, a velha mãe de Héracles que acompanhava os netos por toda a parte durante a fuga, mas só é apresentada aos espectadores no final da trama. Acmena é vingativa e não considera justo que seu perseguidor tenha outra pena senão a morte. Mesmo desaconselhada pelo Servo que a acompanha, está decidida a pôr fim à vida do inimigo argivo.

A tragédia caminha para seu clímax final e se encerra com outra sequência dialética: primeiro entre a anciã, obstinada a matar o rei de Argos, e o Servo, que tenta dissuadi-la, uma vez que trairia a confiança dos atenienses que decidiram poupá-lo da morte. Em seguida, o diálogo ocorre entre Acmena e o próprio Eristeu; o prisioneiro explica os motivos de sua perseguição aos heráclidas e, em seu último discurso, reconhecendo seu derradeiro infortúnio, faz conhecer um oráculo de Apolo e profetiza que seu túmulo será uma futura proteção para Atenas contra os descendentes destas crianças "quando eles aqui voltarem, em grande força, desleais ao favor recebido" ${ }^{229}$. Porém, as palavras do rei são interpretadas, pela velha, como uma ardilosa tentativa de receber todos os sacros ritos de passagem, mantendo então seu corpo imaculado. Acmena ordena aos servos, após matá-lo, lance o corpo de Eristeu aos cães, revelando-se assim como uma mulher implacável, uma Mênade feroz e vingativa. Os servos então arrastam o desditoso rei e a peça termina com a pronúncia do coro: "Avançai companheiro! No que depende de nós, os soberanos conservar-se-ão imaculados",230.

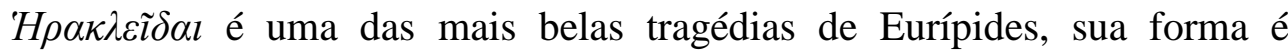
harmoniosa em relação às partes e na divisão dos diálogos; as rheseis, por exemplo, possuem praticamente a mesma quantidade de versos. Quanto ao conteúdo é claramente político ${ }^{231}$, ela ilustra a igualdade de direito ao debate da então democracia ateniense e traz à cena, em quase todos os momentos, o princípio de liberdade como o principal valor ético-político do povo de Atenas, o qual na época encontrava-se ameaçado pelo sítio do exercito inimigo à porta, durante a guerra do Peloponeso. Na obra encontramos todos os elementos

\footnotetext{
${ }^{229}$ Idem. Versos 1030 a 1040, p. 144. Uma alusão às investidas do Peloponeso à Ática, ocorridas na mesma época da apresentação da peça.

${ }^{230}$ Idem. Versos 1054 e 1055. Existe consenso entre os especialistas que foram perdidos alguns versos do coro, deixando muito difícil a interpretação do sentido da fala final.

${ }^{231}$ Uma constante nas tragédias gregas, mas que se torna mais evidente em algumas peças de Eurípides.
} 
criticados por Nietzsche: é explícita a inclinação dialética, toda tensão resume-se ao $\dot{\alpha} \gamma \omega ́ v$ dialógico e às paixões das personagens, claramente evidenciadas nos seus monólogos. Além disso, é uma tragédia que ressalta o racional frente ao instintivo. Todas as personagens, exceto a colérica Acmena, são racionais em seus discursos. O maior exemplo dessa racionalidade é Demofonte, cujo nome a etimologia sugere ser a voz do povo ${ }^{232}$ : o rei de Atenas esquiva-se das emoções e toma sua decisão racionalmente; inclusive emprega o termo "reflexão" antes de enumerar as razões que o levaram a acatar os argumentos de Iolau e proteger os heráclidas ${ }^{233}$.

É igualmente claro o caráter pouco lúgubre do drama, não há, por assim dizer, um efetivo dilaceramento do herói trágico. A comoção está presente apenas no martírio de Mecaria quando se voluntaria ao sacrifício. Todavia, a morte da jovem, apesar de intensamente patética e muito triste, é abrandada pelo discurso racional da garota. Ela até mesmo refuta, em nome da honradez de seu caráter, a proposta de um sorteio para escolha de quem seria a vítima em oblação. A tragédia, portanto, tem um final menos sinistro e mais suave. Ao contrário de uma tensão trágica há momentos cômicos, por exemplo, quando o velho Iolau, ao ir à batalha, sem conseguir andar ao mesmo passo da companhia, ironicamente implica e insulta o jovem que lhe escolta. Essa é outra das críticas nietzschianas às obras de Eurípides: nas peças há, de modo geral, um final feliz e sereno. Nelas a racionalidade é capaz de livrar os protagonistas de qualquer conflito. Quando a

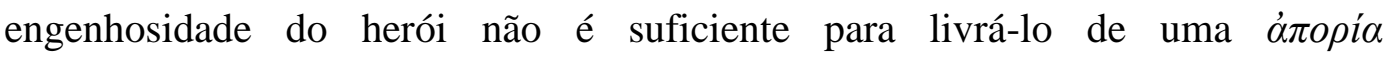
proporcionada pela $\tau \dot{\chi} \chi \eta$, entra em cena então, o deus ex machina para poupá-lo de toda a sorte de infortúnios e garantir-lhe um fim miraculosamente glorioso.

O deus ex machina, ou ḋंò $\mu \eta \chi \alpha v \tilde{\eta} \varsigma$ $\theta \varepsilon o ́ \varsigma$ [deus surgido das máquinas] era um artifício teatral que inseria em cena uma personagem divina, descendo do céu e sobrevoando a $\sigma \kappa \eta v \eta ́$ por meio de um maquinário guindaste [ $\mu \eta \chi \alpha v \eta ́]$, ou então, imóvel sobre o $\theta \varepsilon o \lambda o \gamma \varepsilon \tilde{\varepsilon} o v^{234}$. A divindade, que geralmente era estranha à

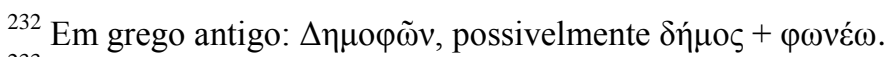

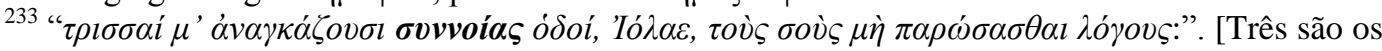
caminhos da minha reflexão e obrigam a não desprezar as tuas palavras, Iolau:]. Idem. Verso 236 e 237. (Grifo nosso).

${ }^{234} \mathrm{O}$ theologeion era uma espécie de sacada acima do $\sigma \kappa \eta v \eta \dot{~[s k e n e], ~ n o ~ a l t o ~ d o ~ t e a t r o ~ a n t i g o, ~ o n d e ~}$ surgiam os atores que representavam deuses. A partir dessa varanda se pronunciava a palavra divina, como sugere a etimologia $[\theta \varepsilon o ́ \varsigma+\lambda o ́ \gamma o \varsigma]$.
} 
narrativa, surgia no final da peça para solucionar o conflito da ação e garantindo, assim, um final feliz aos protagonistas. Como a $\mu \eta \chi \alpha v \eta$ era utilizada para "salvar" o herói no momento mais difícil, quando tudo parecia se destinar à desgraça, o recurso foi criticado por diversos autores desde a antiguidade. Platão o compara à argumentação leviana para uma questão filosófica insolúvel ${ }^{235}$. Aristóteles também é contrário à utilização da $\mu \eta \chi \alpha v \eta ́$ quando ela corrompe o princípio de verossimilhança e de necessidade ${ }^{236}$, ou seja, quando ela extrapola a ação coerente da personagem em relação àquilo que é realmente possível. Porém, o filósofo defende sua utilização "em coisas que se passam fora da ação da peça ou que aconteceram antes dela e que um mortal não conhece ou coisas futuras que devem ser preditas e anunciadas"237, pois na tragédia não deve haver nada de irracional.

Podemos dizer que na tragédia Os Heráclidas o rejuvenescimento de Iolau mediante a teofania de $\mathrm{Hebe}^{238}$ é uma espécie de intervenção ex machina. No entanto, as peças em que é mais evidente a intervenção divina para o desenlace da situação são Orestes e nas Ifigênia(s). A primeira, narra a história de Orestes que assassina a própria mãe, Clitemnestra, para vingar a morte de seu pai, Agamêmnon. No Prólogo da peça, seis dias após o matricídio, Orestes encontra-se prostrado em sono profundo em frente ao palácio argivo, enquanto sua irmã, Elektra, conta, em uma rehseis, sobre a loucura que recai sobre ele ${ }^{239}$. Desde o assassínio da mãe, por decreto em Argos, ninguém poderia acolher os dois. Até que a assembleia do povo decidisse sobre a pena capital por lapidação, todas as portas estariam fechadas e as sentinelas a postos. A única esperança de salvação

\footnotetext{
235 "Entretanto, isto é necessário, uma vez que não temos algo melhor que isto para referirmos à verdade dos nomes primitivos, exceto, se desejares, tal como os tragediógrafos, quando estão em uma certa aporia, fazem uso de invenções engenhosas para erguerem no ar os deuses, e nós, do mesmo modo, os livraremos do embaraço dizendo que foram os deuses que estabeleceram os nomes primitivos, e por esta razão eles são corretos". PLATÃO. Crátilo. [225 d], p. 128.

236 "Tanto nos caracteres como na estrutura dos acontecimentos, deve-se procurar sempre ou o necessário ou o verosímil de maneira que uma personagem diga ou faça o que é necessário ou verosímil e que uma coisa aconteça depois de outra, de acordo com a necessidade ou a verossimilhança. E claro que o desenlace dos enredos deve resultar do próprio enredo e não de uma intervenção ex machina, como na Medeia (...)” ARISTÓTELES. Op. Cit. XV, 1054a, p. 68. ${ }^{237}$ Idem. 1054b, p. 69.

${ }^{238}$ O Servo relata à Acmena a teofania do seguinte modo: [Iolau] "Pediu, então, a Hebe e a Zeus, a graça de rejuvenescer por um só dia e de tirar vingança dos inimigos. Agora vais ter oportunidade de ouvir um prodígio: dois astros colocaram-se sobre o jugo dos cavalos e envolveram o carro numa nuvem escura. (Dizem os mais sábios que era teu filho com Hebe.)". EURÍPIDES. Op. Cit. Versos 850 a 856, p. $137-138$.

${ }^{239}$ Apesar de Elektra não nomear em seu discurso, deixa a entender que Orestes está sendo

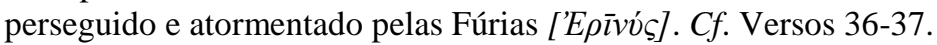


estava no tio, Menelau que voltara da guerra ${ }^{240}$. Todavia, Tíndaro, pai de Clitemnestra, pressiona Menelau a se omitir e instiga a Eclésia a condenar o jovem à degolação pelas próprias mãos. $\mathrm{O}$ desespero leva os irmãos ao plano de matar a tia, Helena, sequestrar e se preciso executar a prima, Hermíone, para punir a omissão do tio.

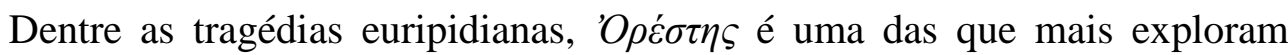
dramaticamente as paixões: o enredo, desde o Prólogo, evidencia plasticamente o terror, a desolação, a dor e a angústia dos protagonistas. Há no decorrer de toda a peça uma intensidade patética. Entretanto, no final encontramos o clímax emotivo durante o $\dot{\alpha} \gamma \omega \dot{v} v$ entre Orestes e Menelau: enquanto este tem o punhal na garganta de Hermíoni e ordena que Elektra incendeie o palácio de Argos, aquele convoca os argivos para que se apressem com as armas. Contudo, em meio ao insolúvel conflito, eis que surge entre o céu e a terra Apolo, com Helena entre os braços, para então desenlaçar a trama. Com Febo ex machina Orestes encontra sua redenção: o perdão dos deuses, o matrimônio com Hermíone e a soberania sobre Argos. Elektra também encontra casamento. A paz é reestabelecida na cidade. O deus admoesta que Menelau encontre nova esposa e ascende com Helena ao firmamento, levando-a para brilhar junto das demais divindades, e inaugura um rito em homenagem a ela. Esse é o sentido do deus das maquinas: surgir do alto do palco para solucionar todo conflito e garantir ao herói um fim triunfante.

Outros exemplos da utilização do deus ex machina feita por Eurípides que não podemos deixar de mencionar, pois ilustram claramente a inesperada intervenção divina para solucionar os conflitos são Ifigênia entre os Tauris e Ifigênia em Áulis. A primeira foi encenada por volta de 414 a. C. e nada sabemos sobre as demais peças que a acompanharam. A segunda foi apresentada em 405 a. C. e garantiu a кó $\imath v o \varsigma^{241}$ póstuma ao tragediógrafo. Ifigênia em Áulis, a peça mais tardia, narra os acontecimentos que antecederam a trama da mais antiga: no seu Prólogo temos Agamêmnon, o líder da coalizão formada contra a cidadela de Troia, e o Velho servente ${ }^{242}$. Os personagens estão diante das tendas gregas em

\footnotetext{
${ }^{240}$ Eurípides altera o mito, uma vez que Menelau permanece por dez anos em Troia. Mas sua volta é essencial para o desenrolar dramático.

${ }^{241}$ Kotinos era a coroa feita com as ramas da oliveira selvagem atribuída aos vencedores dos jogos olímpicos e ao vencedor do concurso de tragédias nas festas dionisíacas.

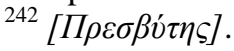


Áulis. O enlace dramático está no dilema posto pelo oráculo de Calcas a Agamêmnon: sacrificar sua própria filha, Ifigênia, para que Ártemis faça o vento soprar permitindo a partida das naus para Ílion. Clitemnestra que trouxe a filha até o acampamento, acreditando levá-la para celebrar as núpcias com Aquiles, quando descobre o real motivo de sua ida, clama ao herói que não permita o sacrifício da jovem. O Pelida compromete-se em ser um o salvador da virgem ${ }^{243}$, porém a natureza altiva de Ifigênia faz com que aceite seu lúgubre destino e o enfrente com convicção.

Diferente de outras peças euripidianas, a teofania não era encenada por um ator que, por meio da $\mu \eta \chi \alpha v \eta$, surgia no alto do palco para encenar a divindade. Em Ifigênia em Áulis, o deus ex machina entra em cena somente no longo relato do Mensageiro ${ }^{244}$. Suas palavras descrevem com certa intensidade patética os acontecimentos no bosque de Ártemis durante o rito sacrificial: "o rei Agamêmnon quando viu a donzela em seu caminho pela brenha para ser sacrificada, deu um gemido e, afastando o rosto, deixou as lágrimas irromperem de seus olhos enquanto segurava seu manto"245. Todos os presentes se entristeceram, mas a coragem de Ifigênia os confortou: "Ó meu pai, eis-me-aqui para fazer a tua ordem; eu ofereço livremente o meu corpo para o meu país e toda a Grécia. Podeis conduzir-me ao altar da deusa para ser imolada lá, pois esta é a ordenança do Oráculo"246. Quando Calcas, o vidente, em meio à oração, estava com o punhal na garganta da vítima, pronto para derramar seu sangue virginal, surge Ártemis ex machina que faz desaparecer a donzela e, em seu lugar, fornece uma corça para ser imolada. Com a graça da deusa os ventos voltam a soprar, permitindo que as naves pan-helênicas seguissem o seu curso até Troia. Dessa forma, apoteótica, termina o drama ${ }^{247}$.

\footnotetext{
${ }^{243}$ Versos 973 e 974.

${ }^{244}$ Versos 1540 a 1610

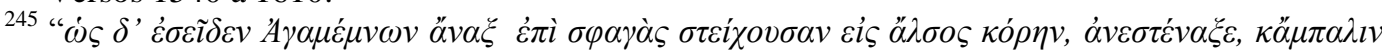

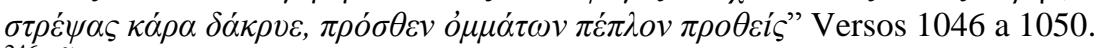

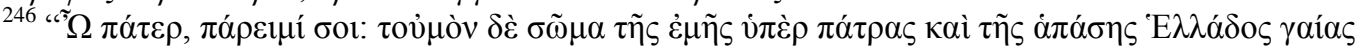
טँ $\pi \varepsilon \rho$

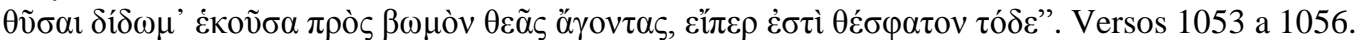

${ }^{247}$ Há diversos estudos que apontam para a adulteração da peça. Os especialistas acreditam que ela tenha sido escrita em quatro mãos, por isso, a pobreza em seu desenvolvimento. Cf. RIBEIRO JR., Wilson Alves. Os autores da Ifigênia em Áulis de Eurípides. In. Codex, vol. 2, n. 2, 2010, p. 5791.
} 
A tragédia Ifigênia entre os Tauros, como dissemos, é apresentada anteriormente, mas narra os acontecimentos posteriores ao arrebatamento em Áulis: Ifigênia, depois de ser salva por Ártemis, é conduzida a uma região bárbara, habitada pelos Tauros, local onde se tornou responsável pelo culto à Senhora dos animais $^{248}$. Hostis, os Tauros sacrificavam à deusa todos os estrangeiros que acabavam por naufragar em suas costas. O Prólogo já nos deixa saber da chegada de Orestes e de seu primo Pílades no local. Eles veem em missão de roubar a imagem de Ártemis, pois o oráculo de Delfos revelara a Orestes que ele só se viria livre das Erínias ${ }^{249}$, que o atormentavam desde o matricídio, se trouxesse para Atenas o ídolo da deusa. Contudo, ao chegarem nessa perigosa região, os protagonistas são presos e levados para serem executados em holocausto pela sacerdotisa. Prestes a sacrificar o irmão, Ifigênia o reconhece. Inicia, então, um engenhoso plano de fuga. Auxiliada pelo coro, Ifigênia engana o rei dizendo que necessita purificar a imagem em um rito com os estrangeiros na praia. Todavia, quando é descoberta a traição, o rei Toas ordena a captura e execução dos fugitivos.

O enredo, narrado pelo Mensageiro, nos oferece muita ação dramática: quando aqueles que acompanhavam Ifigênia e os rapazes finalmente perceberam o plano de fuga, tentam agarrar os jovens, mas esses resistiram com socos e chutes, até se verem livres para embarcar ${ }^{250}$. No entanto, no momento que a partida estava certa, pois já estavam dentro do porto e avançavam para o estuário, se viram tragados por ondas violentas, ao mesmo tempo em que ventos terríveis e repentinos surgiram e impeliram a nau para trás ${ }^{251}$. A reviravolta no mar seria, segundo o Mensageiro, obra de Poseidon, que mantinha, desde a destruição de Troia, ódio pelos Pelópidas ${ }^{252}$. Entregues à terrível sorte nas mãos do rei bárbaro, tudo parecia perdido. No meio tempo em que Toas ameaçava as mulheres do coro e convocava todo o povo para vingar com cruel morte os jovens argivos, surge a

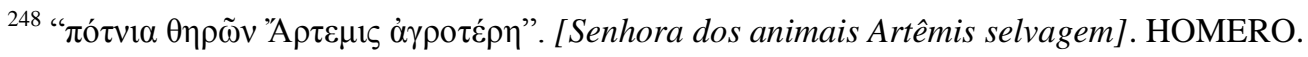
Ilíada, Canto XXI, verso 470.

${ }^{249}$ As 'E $\operatorname{lv} v$ v́ - que perseguiam Orestes, afligindo-o com a loucura desde que cometeu o matricídio - eram as divindades da vingança. Enquanto Nép $\varepsilon \sigma ı \varsigma$ [Sófocles. Elektra, v. 762] era a deusa da vingança que punia os deuses, as Erínias, os as Fúrias, puniam os mortais. Eram elas

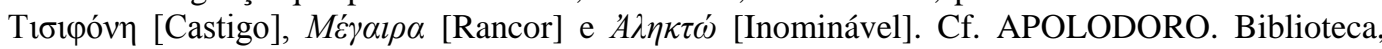
1.1.4.

${ }^{250}$ Versos 1360 a 1380

${ }^{251}$ Versos 1390 a 1395.

${ }^{252}$ Versos 1414 e 1415.
} 
intervenção de Atenas ex machina. A deusa em um longo discurso ${ }^{253}$ ordena ao rei dos Tauros que cesse a perseguição, pois o furto da estátua de Ártemis era plano dos deuses. Poseidon acalma o mar a pedido da divina interventora. E como de costume nos finais euripidianos, ordena a Orestes que inaugure um culto à Ártemis Taurópola em Halas; além disso, anuncia um futuro culto à Ifigênia nos prados sagrados de Bráuron, onde as mulheres renderiam, em seu túmulo, homenagens com tecidos finos.

$\mathrm{O}$ "deus ex machina" foi muito utilizado por Eurípides, das dezoito tragédias que chegaram até nós, ao menos em dez delas há explicitamente o deus das máquinas. Esse recurso foi amplamente estudado e discutido tanto por pensadores antigos quanto por especialistas modernos. Esses autores atribuíram os mais diversos significados: a dificuldade criativa para concluir as peças ${ }^{254}$; produzir o efeito patético ${ }^{255}$; função etiológica ${ }^{256}$. Entretanto, para Nietzsche, trata-se de mais um dos artifícios da obra euripidiana que culminaram na degeneração seguida de morte da tragédia e, consequentemente, com a decadência da cultura ocidental. Para o filósofo, a voz da divindade assegurava a veracidade sobre o que era anunciado, assim, o deus que irrompe o final da trama garante o futuro do herói. Da mesma forma que o Prólogo esboçava o passado, o deu ex machina assegurava, ao espectador, o porvir. Entre estas perspectivas épicas do passado e do futuro estaria situado o presente lírico-dramático, ou seja, nesse intervalo entre a retrospectiva e a prospectiva é onde ocorria o drama propriamente dito ${ }^{257}$. O problema é que a salvação miraculosa do protagonista acaba por redimi-lo de qualquer destino nefasto, desvinculando-o então das características de um herói trágico.

Sem o dilaceramento do herói a tragédia torna-se otimista. Desse modo, não é mais possível o efeito trágico, aquilo que Nietzsche chamou de "consolo metafísico". O otimismo está, para o teatro trágico, em oposição ao elemento

\footnotetext{
${ }^{253}$ Versos 1435 a 1475.

254 "o deus ex machina é um Embaraço, para a aporia do poeta, não para a aporia da situação dramática". SCHMIDT, W. Der Deus ex Machina bei Euripides. Eberhard-Karls-Universitat, Tubingen, 1963. p. 8

${ }^{255}$ Aristófanes. Cf. RABELO, Antonio Manuel Ribeiro. O deus ex machina e o conceito de tyche na economia de Ifigénia entre os Tauros, à luz da teoria aristotélica. HVMANITAS: Lisboa, 1995.

${ }^{256}$ Aristóteles. Cf. Idem.

${ }^{257}$ Cf. NIETZSCHE. O Nascimento da tragédia. §12.
} 
dionisíaco. Isso porque, quando o deus das máquinas salva o herói, o faz sob o pretexto da justiça; o herói em Eurípides é sempre virtuoso, aspecto que lhe garante um fim glorioso. A moral dessas personagens é explicitada não em suas ações, mas nas suas paixões, transparecidas por meio de seus discursos e diálogos ${ }^{258}$; a peça ganha, então, a forma dialética. Como resultado, a música perde o seu espaço. A audição trágica é substituída por longos monólogos e pelo $\not \alpha \gamma \omega ́ v$ dialético; em última instância, o arrebatamento estético é suplantado pela racionalização e reflexão moral. Nessa análise, a "justiça poética"259 no encerramento do drama expurga qualquer possibilidade de êxtase dionisíaco, ou seja, a certeza do epílogo feliz suprime aquela entusiástica alegria de existir proporcionada pelo espetáculo trágico. Eis a propedêutica do novo drama euripidiano: a razão solucionará qualquer aporia e o virtuoso terá um destino feliz!

Existe, portanto, transparecidas nas obras euripidianas um princípio que vincula necessariamente razão, virtude e felicidade. Esse princípio, segundo Nietzsche, não partiu espontaneamente do tragediógrafo, ao contrário, por trás de sua boca havia a influência demoníaca de Sócrates ${ }^{260}$. Entre os Antigos, diz Nietzsche ${ }^{261}$ amparado pelo relato de Aristófanes ${ }^{262}$ e Diógenes Laércio ${ }^{263}$, existia um falatório sobre a afinidade entre Sócrates e Eurípides. Era muito difundido em Atenas que o filósofo ajudava o poeta na composição de seus dramas. Além disso, chegou até nós a anedota de que Sócrates negava-se a frequentar as

\footnotetext{
258 "Gegen die beruhigende Gewalt des Gedankens (...) stellt Euripides die aufregende Gewalt des Gedankens: er appellirt an die Dialektik der Leidenschaft, der Aufklärung: er will die Gewalt des Dithyramb durch das Wort erreichen" [Contra ao poder tranquilizante das palavras (...) Eurípides estabelece o excitante poder do pensamento: ele apela à dialética da paixão, do esclarecimento: ele quer alcançar o poder do ditirambo pela palavra]. NIETZSCHE. Fragmento póstumo de 1871, 9[12]. (Grifo nosso).

259 "Pois agora o herói virtuoso tem de ser dialético; agora tem de haver entre virtude e saber, crença e moral, uma ligação obrigatoriamente visível; agora a solução transcendental da justiça de Ésquilo é rebaixada ao nível do raso e insolente princípio da "justiça poética", com seu habitual deus ex machina". Ibidem. O Nascimento da tragédia. §14, p. 89.

260 "Der welcher sie im Drama vernichtete, Euripides, folgt darin dem dämonischen Einflusse des Sokrates"["Aquele que os destruiu no drama, Eurípides, segue a influência demoníaca de Sócrates"]. Ibidem. Fragmento póstumo de 1870, 7[114]. Cf. também: "Também Eurípides foi, em certo sentido, apenas máscara: a divindade, que falava por sua boca, não era Dioniso, tampouco Apolo, porém um demônio de recentíssimo nascimento, chamado SÓCRATES”. Idem. §12.

${ }^{261}$ Ibidem. Sócrates e a tragédia. In. A visão dionisíaca de mundo e outros textos de juventude. $\mathrm{p}$. 43.

${ }^{262}$ ARISTÓFANES. As rãs. Versos 940 a 943.

263 "Acreditava-se que ele colaborava com Eurípides na composição das peças; por isso Mnesímacos escreve: 'Os Frígios é um novo drama de Eurípides, e Sócrates contribuiu com a lenha para frigir.' (...) e Aristófanes nas Nuvens: 'Ele compõe para Eurípides tragédias cheias de palavrórios, mas também sabedoria." DIÓGENES, Laércio. Vidas e doutrinas dos filósofos ilustres. p. 51 e 52.
} 
apresentações de tragédia, somente comparecia entre os espectadores quando estreava uma nova peça euripidiana ${ }^{264}$. Tais considerações colocam o pensador ateniense como o verdadeiro responsável pela degeneração e colapso da arte trágica. Eurípides seria apenas uma ferramenta para transportar ao palco os seguintes preceitos socráticos: "Virtude é saber; só se peca por ignorância; o virtuoso é o mais feliz"265 Agora o teatro deve ser inteligível, deve demonstrar dialeticamente a relação entre saber, moral e felicidade. O novo otimismo estético converte a máxima socrática "tudo deve ser consciente para ser bom" em "tudo deve ser consciente para ser belo",266.

Contudo, antes de aprofundarmos no otimismo estético socrático e sua nefasta consequência para a cultura ocidental, vamo-nos dedicar, na próxima seção, em demonstrar que as críticas de Nietzsche à obra de Eurípides, apesar de perfeitamente estruturadas como parte de sua análise avaliativa do decurso da cultura, é muito severa. Nossa argumentação será de que os elementos peculiares às peças euripidianas não suprimem por inteiro o espírito trágico, pelo menos em algumas peças. E, acima de tudo, enfatizaremos que ainda existe nessas tragédias uma potência dionisíaca, na forma de uma oposição mito-razão, que foi completamente omitida por Nietzsche.

\subsection{1.}

\section{Eurípides entre o mito e a razão (ou entre Medeia e Jasão):}

$\mathrm{O}$ ataque de Nietzsche à produção euripidiana não se refere à pessoa Eurípides $^{267}$, nem mesmo a suas obras de maneira específica. O filósofo, ao contrário, reconhece a grandiosidade do dramaturgo e, até mesmo, admite nele a boa intenção de lutar contra o declínio que marcou a sua época ${ }^{268}$. No entanto, a crítica ao poeta se faz necessária como um procedimento de avaliação do curso da

\footnotetext{
${ }^{264}$ NIETZSCHE. Op. Cit. p. 43.

${ }^{265}$ Ibidem. O Nascimento da tragédia. 14.

${ }^{266}$ Idem. $\$ 12$.

${ }^{267}$ Cf. Ibidem. Ecce homo. "Porque sou tão sábio", §7. p. 29 e 30. Citado anteriormente.

268 "É a mais injusta incompreensão considerar ele mesmo como raiz e causa desta decadência: antes ele é o primeiro que reconhece esta decadência e que procura lutar sob o protesto dos ditos cultos de seu tempo". Ibidem. Sócrates e a tragédia. In. A visão dionisíaca de mundo e outros textos de juventude. p. 49.
} 
civilização ocidental. Eurípides torna-se, na obra de juventude nietzschiana, um símbolo que permite elucidar o processo de decadência que culminou no empobrecimento da então cultura moderna. A crítica nietzschiana, portanto, é mais do que uma análise filológica pontual da forma e conteúdo do teatro euripidiano, ela consiste em uma reflexão filosófica de uma época, imprescindível para compreensão do movimento histórico-cultural. Entretanto, ao fazê-la, Nietzsche acaba, se não distorcendo, então, ao menos, omitindo alguns elementos do drama de Eurípides. Desse modo, o dionisíaco, nessas peças, é completamente ignorado pelos olhos do filósofo, como se Dioniso, antes o ostensível protagonista, agora vestisse uma $\pi \rho o ́ \sigma \omega \pi o v$ tão distinta à sua natureza, tornando impossível o seu reconhecimento.

É importante dizer que a principal fonte documental utilizada por Nietzsche para a fundamentação de sua crítica, além, é claro, dos próprios textos remanescentes de Eurípides, são as comédias de Aristófanes, sobretudo, Rãs ${ }^{269}$. É visível que praticamente todas as caracterizações do drama euripidiano, feitas pelo filósofo, já estão presentes na peça aristofanesca. Porém, em O Nascimento da tragédia, assim como na conferência Sócrates e a tragédia, as referências ao comediógrafo ocorrem discretamente ${ }^{270}$; ou seja, são apenas breves menções sem a ênfase de que as mesmas especificações da obra euripidiana já haviam sido elaboradas na Antiguidade. Contudo, com a intenção de destacar a natureza dessa tipificação aristofanesca de Eurípides a qual Nietzsche se apropria, vamos fazer uma sucinta análise da comédia Rãs. Para tal, o contexto histórico da peça é fundamental: ela foi apresentada pela primeira vez nas Leneias em 405 a.C., pouco tempo após as mortes de Eurípides e Sófocles ${ }^{271}$. Com um tema notoriamente político, ela é encenada em meio à tensão social: havia divergências quanto à administração de Atenas frente à guerra do Peloponeso. Enquanto alguns

\footnotetext{
${ }^{269}$ Existem escritos que apontam uma predominante influência dos irmãos Schlegel na elaboração nietzschiana sobre a morte da tragédia na figura de Eurípides. Foi somente após a leitura de Vorlesungen über dramatische Kunst und Literatur de August Schlegel que o filósofo teria estabelecido um processo evolutivo do teatro trágico entendendo Ésquilo como ponto de partida, Sófocles como o ápice e Eurípides como o derradeiro declínio. Antes dessa leitura, o jovem Nietzsche aproximava Ésquilo a Eurípides. Essa influência de Schlegel pode ser observada no fragmento póstumo de 1869 1[36]: "Schlegel chama a poesia de Sófocles de bosque sagrado das obscuras deusas do destino, onde desabrocham louros, oliveiras e videiras e onde cantam initerruptamente os rouxinóis". Sobre o assunto Cf. Ibidem. Introdução à tragédia de Sófocles. Trad. Ernani Chaves.

${ }^{270}$ Cf. Ibidem. O Nascimento da tragédia. §11; §13; e §17.

${ }^{271}$ Sófocles morreu em 406 a. C. e Eurípides em 405.
} 
defendiam a conciliação com os inimigos, outros apoiavam a manutenção do conflito $^{272}$.

A Peça traz como personagem central o próprio deus das tragédias e das comédias, Dioniso. A divindade, igual aos heróis épicos de outrora, protagonizará uma longa viagem repleta de perigosas aventuras, sempre ao lado de sue servo, Xântias. O destino da jornada só é revelado aos espectadores depois de cumprida uma parte do caminho, quando Dioniso, com vestimenta hilária, bate a porta do semideus, seu irmão, Héracles. O bravo herói, seguindo a tonalidade humorística, não consegue conter a gargalhada ao ver Dioniso trajado, ao mesmo tempo, com roupas másculas e femininas: uma pele de leão sobre uma túnica amarela, botas de senhora e um porrete nas mãos ${ }^{273}$. Héracles se faz necessário na aventura para fornecer informações valiosas a respeito de como chegar ao Reino de Hades, o verdadeiro destino da empreita ${ }^{274}$. Questionado pelo irmão sobre os motivos que o movem às pradarias infernais, Dioniso responde que após ler Andrômaca ${ }^{275}$, foi tomado por um desejo incontrolável de trazer de volta à vida um poeta de qualidade, capaz de revitalizar o cenário de mediocridade que se instalara em Atenas após a morte de Sófocles e Eurípides ${ }^{276}$.

Durante a catábase há várias cenas de ação cômica. O deus e seu servo são sempre postos à prova: ora fogem de monstros e, outrora, de credores junto com

\footnotetext{
272 "Na cidade, o contencioso político entre as facções oligárquica e democrática mantinha-se agudo, o que se refletia sobre a perseguição contra alguns cidadãos desfalcados de direitos e privilégios. (...). Agitando o facciosismo político, uma questão fundamental continuava na ordem do dia: as vantagens ou desvantagens de levar por diante o conflito, perante as ofertas de tréguas propostas pelo adversário. Nomes como o de Cleofonte, um opositor a qualquer negociação de paz, de Terâmenes, que procurava harmonizar, sob seu controle, oligarcas e democratas e, sobretudo, de Alcibíades, para uns o salvador, única esperança para Atenas, para outros o traidor vendido ao inimigo, davam rosto as diversas tendências que agitavam a cidade". SILVA, Maria de Fátima. Rãs. "Introdução à tradução portuguesa". Sobre o contexto político Cf. também TUCÍDIDES. História da guerra do Peloponeso. Livro VIII.

${ }^{273}$ Cf. ARISTÓFANES. Rãs. Versos 40 a 50.

${ }^{274}$ Dioniso dirigindo-se a Héracles: "Quanto ao motivo que me traz aqui, disfarçado com este enfeite semelhante ao seu, é para ficar sabendo de você, em caso de necessidade, quais são os anfitriões que acolheram você em sua descida ao Inferno; me indique também os portos, as padarias, os prostíbulos, as paradas, os hotéis, as fontes, as rotas, as cidades, os alojamentos, as hospedarias onde há menos percevejos". Idem. Versos 110 a 115.

${ }^{275}$ Umas das tragédias conservadas de Eurípides. Nesse momento, Dioniso admite a preferência de trazer Eurípides de volta dos mortos, ao invés dos outros tragediógrafos. Cf. Idem. Versos 70 a 80. ${ }^{276}$ Aristófanes pela boca do personagem Dioniso faz uma avaliação negativa dos então poetas atenienses: Iofonte, filho de Sófocles, talentoso, mas dependente do pai; Agaton que havia se ausentado da cidade; Xénocles e Pitângelo, de muito duvidosa qualidade; e, por fim, vários seguidores de Eurípides, poetas imitadores e não verdadeiros criadores, sem nenhum talento. Cf. Idem. Versos 79 a 95 .
} 
quem Héracles deixara dívidas em aberto. Sempre que o perigo está à espreita, Dioniso coloca Xântias como o herói, mas quando estão em segurança e surgem as recompensas do submundo, exige tal atributo de volta. Somente no momento em que os viajantes chegam ao termo do percurso, já dentro do palácio de Plutão, Dioniso redime a imagem de afeminado e covarde, resgatando então a efígie que lhe é própria: o deus do teatro. Isso, porque na ocasião em que chegaram todo o Reino de Hades estava sendo agitado por uma disputa entre Ésquilo e Eurípides pelo trono da tragédia ${ }^{277}$. Dioniso será, a convite de Plutão, o juiz que decidirá qual dos poetas é merecedor dessa honra. A partir desse momento a peça consistirá em um agon entre os poetas, com muita rivalidade e sem nenhuma economia nas ofensas, fato que faz necessário a contínua intervenção do árbitro divino. No final, além de conceder o título de melhor entre os poetas trágicos, Dioniso levará o vencedor de volta aos vivos e reestabelecerá os tempos de glória.

No decurso do agon, Aristófanes fez questão de distinguir os tragediógrafos no que se refere à moral de cada um. Ésquilo é descrito como representante da tradição arcaica e dos valores de antigamente. Por outro lado, Eurípides é pintado como representante da imoralidade da época. Essa distinção ética fica clara quando o Criado confessou a Xântias que Eurípides, ao chegar ao Reino de Hades, fez campanha junto dos ladrões, dos parricidas e dos assaltantes. Dessa forma, sempre esteve cercado de fortes aplausos de uma maioria, mas formada por marginais e gente sem princípio; enquanto Ésquilo, embora em menor número, ganhava o apoio de gente séria ${ }^{278}$. Ainda dentro dessa distinção aristofanesca, Ésquilo é visto como o modelo da tragédia na sua forma mais antiga, severa, sacra, próxima dos mitos e de seus valores. Eurípides, ao contrário, figura o poeta revolucionário, amoral e, portanto, símbolo da sociedade degenerada pós-guerra do Peloponeso. Nesse sentido, Nietzsche vai dizer que solução transcendental da justiça de Ésquilo é rebaixada à justiça poética de Eurípides $^{279}$; para o filósofo a metafísica trágica desaparece pouco a pouco na tragédia, e a reflexão moral dos

\footnotetext{
${ }^{277}$ O Criado de Plutão explica a Xântias: "Vigora cá uma lei, a respeito das belas artes: que o melhor, entre os oficiais do mesmo ofício, tome as refeições no Pritaneu e ocupe um lugar de honra ao lado de Plutão" Idem. Versos 760 a 765.

${ }^{278}$ Cf. Idem. Versos 770 a 794.

${ }^{279}$ NIETZSCHE. O Nascimento da tragédia. §14.
} 
poetas torna-se mais superficial. Desaparece, assim, a noção esquiliana de justiça $^{280}$.

Outro aspecto que é destacado no agon entre os poetas e, claramente, absorvido pela crítica nietzschiana a Eurípides, é a questão da abertura dos dramas. Por um lado, Ésquilo privilegiava o silêncio da personagem que surgia solitária, imóvel e enigmática. A cena era carregada de grande suspense e o silêncio só era interrompido pela música coral, que se irrompia longa e perturbadora $^{281}$. Quando a personagem começava a falar, a peça já estava quase na metade $^{282}$. Esse silêncio era, segundo Eurípides-aristofanesco, um artifício para que o espectador ficasse suspenso e à espera. Todavia, o silêncio gerava uma confusão na plateia; a compreensão do drama tornava-se um desafio para o público. Tal qual Nietzsche assevera em $O$ Nascimento da tragédia ${ }^{283}$, Dioniso, o responsável por julgar a disputa, conclui que o efeito da abertura desse modelo de teatro trágico é, primeiramente, a estranheza e incompreensão; seguido, então, de um grande fascínio e a capacidade de despertar, até mesmo aos menos qualificados, enorme comoção, como se os espectadores fossem tomados por um pasmo, sentindo-se ante de algo superior, ainda que o que estivesse em cena não fosse completamente inteligível.

Eurípides, por outro lado, colocava uma personagem no começo do drama para explicar, desde logo, os antecedentes da ação, deixando explicitamente claro à audiência o que estava por acontecer ${ }^{284}$. Na avaliação do personagem Eurípidesaristofanesco, a tragédia esquiliana era pesada, pois recorria a palavras enfáticas; seus Prólogos, por exemplo, eram compactos, metafóricos, mais solenes e

\footnotetext{
280 "Allmählich entschwindet die tragische Metaphysik aus der Tragödie. Die Reflexion der Dichter ist überhaupt oberflächlicher als das Wesen der Tragödie selbst. Gerechtigkeitsbegriff des Aeschylus, die Sophrosyne (unvollkommen erreichter Buddhismus) des Sophokles." [A metafísica trágica desaparece pouco a pouco da tragédia. A reflexão dos poetas é, de modo geral, mais superficial do que a essência própria da tragédia. Conceito de justiça de Ésquilo, Sophrosyne (um budismo imperfeitamente alcançado) de Sófocles] Ibidem. Fragmento póstumo de 1871, 9[32].

${ }^{281}$ Eurípides atacando Ésquilo: "Cuidava-se, por exemplo, de pôr em cena personagens sentados e cobertos com véus, como no Aquiles e na Níobe, sem descobrir o rosto nem dizer uma palavra sequer, simples figurantes mudos”. ARISTÓFANES. Op. Cit. Versos 910 a 914.

${ }^{282}$ Idem. Verso 920.

${ }^{283}$ Cf. NIETZSCHE. O Nascimento da tragédia. §12.

${ }^{284}$ Cf. ARISTÓFANES. Op. Cit. Versos 945 a 950.
} 
surpreendentes do que informativos ${ }^{285}$. Os Prólogos euripidianos, por sua vez, obedeciam a uma estrutura iâmbica que se repetia em cada peça, de modo que todos os versos seguiam uma ordem rítmica simétrica e constante, o que soava como algo previsível e gasto ${ }^{286}$. Além disso, desde o os primeiros versos, ninguém ficava imóvel, todas as pessoas possuíam direito à fala: o jovem, a mulher, o velho, o patrão e o escravo. Em outras palavras, Eurípides trazia à cena os casos domésticos, os temas que fazem parte do quotidiano e são, para a audiência, familiares. Enquanto seu antecessor privilegiava os casos de guerra, distantes e confusos, o poeta de Medeia, ao introduzir uma maior variedade de personagens de sexo, idade e níveis sociais diferentes, todos com o direito de participação ativa e a chance de expressar seus sentimentos e opiniões - erguia no palco a vida próxima $^{287}$.

Ao tornar a tragédia doméstica, ou seja, trazer as intrigas da vida comum ao palco, fez com que a ação ganhasse ritmo, mas, por outro lado, perdesse a sua grandeza e solenidade mítica. Porém, a mudança mais significativa assinalada pelo Eurípides de Rãs, e confirmada pelo árbitro Dioniso, foi introduzir na arte o raciocínio e a reflexão. O poeta-personagem defende que revitalizou a tragédia com a tendência intelectual de sua época. Com isso, o público foi educado a refletir e a raciocinar. Agora até mesmo o mais humilde aprendeu a dar opinião sobre tudo, a relativizar as coisas e governar melhor do que antes ${ }^{288}$. No decorrer do agon, cada poeta defende sua contribuição pedagógica à pólis: Ésquilo trouxe em seu teatro, por meio das narrativas bélicas, o sentimento patriótico e militar; Eurípides ensinou os cidadãos a debater, a criticar e refutar ${ }^{289}$. Nessa perspectiva,

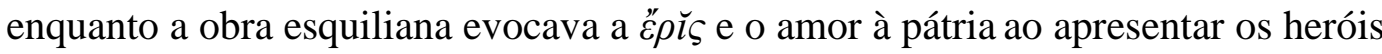

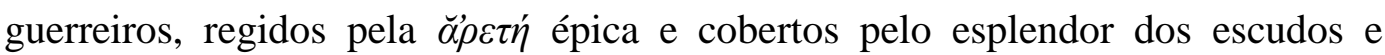

\footnotetext{
${ }^{285}$ Isso fica claro quando Ésquilo cita o monólogo inicial de sua tragédia perdida Coéforas: "Hermes ctónio, como guardião do poder paterno, sê meu protetor e aliado, eu te suplico. Eis-me de volta a casa, a que regresso..." Cf. Idem. Versos 1126 a 1128.

${ }^{286}$ No agon entre os poetas, na medida em que Eurípides cita o início de alguns de seus Prólogos, é interrompido por Ésquilo que, em pilheria, ridiculariza-os, demonstrando o quanto são repetitivos e desnecessários. Cf. Idem. Versos 1201 a 1244.

${ }^{287}$ Cf. Idem. Versos 950 a 970.

${ }^{288}$ Cf. Idem. Versos 971 a 979.

${ }^{289}$ Devido a essa influência que os sofistas ganharam anuência nas ágoras; a obra euripidiana converteu-se em uma espécie de paradigma que dava ao público a qualidade de um verdadeiro critico. Os espectadores que premiaram entusiasticamente Rãs são dessa nova ordem dos tempos um exemplo elucidativo. Cf. SILVA, Maria de Fátima. Rãs. "Introdução à Tradução portuguesa".
} 
$\operatorname{armas}^{290}$; a obra euripidiana encenava as paixões humanas através da voz de suas personagens, principalmente as femininas. Eurípides elevava à $\sigma \kappa \eta v \eta ́$ atos passionais sem censura. Amores proibidos, o adultério e a vingança eram seus temas recorrentes ${ }^{291}$.

Por fim, o último aspecto da obra euripidiana - presente na dramatização cômica de Aristófanes e, igualmente, problematizada por Nietzsche - que vamos destacar é o tema musical. Como bem sabemos, o filósofo afirma que Eurípides adulterou o papel da música, colocando-a submissa à palavra e com isso degenerou o efeito trágico. Em Rãs, o elemento musical também faz parte do agon: Eurípides ridiculariza a música de Ésquilo por ser pobre e repetitiva. O poeta cita uma série de versos de seu antecessor para demonstrar a pobreza do ritmo monótono das vozes acompanhadas da cítara, a sua marca mais característica $^{292}$. Ésquilo diz, para se defender, que sua fonte é tradicional é digna do estilo trágico ${ }^{293}$. Eurípides, ao contrário, é acusado de ter corrompido a música trágica de sua dignidade vinculada a seu sentido original. Ele teria se inspirado em todo o tipo de fonte ${ }^{294}$ e com isso produziu uma obra marcada por uma diversidade caótica. Porém, sua grande novidade foi transferir aos atores a principal responsabilidade musical do drama; isso porque, através das monodias conseguia atingir maior excitação sentimental. Desse modo, evocava com mais facilidade as paixões que desejava representar. Por isso, sua melodia era rica em potencialidade erótica, lúdica e popular.

\footnotetext{
${ }^{290}$ Ésquilo diz sobre suas peças: "Os Sete contra Tebas. Fulano que a visse ficava em pulgas por combater" ["Os sete chefes contra Tebas; todos os espectadores saíam do teatro com o furor guerreiro" Trad. brasileira]; (versos 1022 e 1023); "Depois, com a representação dos Persas, ao celebrar um feito maravilhoso, ensinei-lhes a ânsia de vencerem sempre o inimigo". Versos $1026 \mathrm{e}$ 1027.

${ }^{291}$ Ésquilo repreendendo Eurípides: "Mas obviamente eu não punha em cena Fedras indecorosas, nem Steneboias, e não sei se jamais cantei os amores de uma mulher". Versos 1042 a 1044. Trad. brasileira. "É que levaste esposas distintas de não menos distintos maridos a beber cicuta, ao verem-se desonradas por causa dos teus Belerofontes" Verso 1050. Trad. portuguesa.

${ }^{292}$ Cf. Idem. Versos 1250 a 1295.

${ }^{293}$ Ésquilo sobre suas fontes: "O que importa é que os meus cantos os fui beber à fonte pura e depois os apurei, antes que me apanhassem a colher flores no mesmo prado sagrado que o Frínico". ["Dei àquilo que era belo outra forma igualmente bela, para não parecer que eu estava colhendo no jardim sagrado das Musas as mesmas flores de Frínico" (Trad. brasileira)]. Versos 1297 a 1299.

${ }^{294}$ Ésquilo acusando Eurípides: "Enquanto este gajo aqui pasta em tudo o que é lugar, nas cantigas de putas, nos escólios de Meleto, nas flautadas dos Cários, nas marchas fúnebres, nas músicas de dança". ["Quanto a Eurípides, ele tira seus cantos das conversas de prostitutas, dos de Mêleto, das árias de flauta da Cária, das expressões de dor, das árias de dança" (Trad. brasileira)]. Versos 1300 a 1303.
} 
No encerramento da peça, após os poetas opinarem sobre a situação política ateniense e colocarem na balança alguns de seus "versos de peso", Dioniso, diferente de seu desejo inicial, escolhe Ésquilo para retornar à vida e revitalizar a cidade de Atenas em decadência. Apesar de sua preferência pessoal por Eurípides, o deus do teatro entende a inferioridade do poeta em relação ao seu antecessor para tão nobre missão. Ésquilo, antes de sua 'subida', certifica-se com Plutão de que o trono de melhor poeta do submundo fique com Sófocles ${ }^{295}$ até seu retorno, pois, em termos de talento, a ele seria atribuído o segundo e não a Eurípides ${ }^{296}$. A última fala da comédia é concedida ao coro composto pelos Iniciados de Elêusis. Após uma breve alusão à importância pedagógica do dramaturgo para inspirar bons pensamentos entre os cidadãos, o coro faz uma curta, porém explícita, crítica à guerra e aos políticos da época que insistiam em sua manutenção ${ }^{297}$, evidenciando-nos então, o papel distintamente político conferido ao teatro antigo, o qual sucessivamente foi se enfraquecendo nas novas formas de comédia.

Com essa breve exposição da comédia Rãs, podemos notar que a crítica nietzschiana à estrutura e ao conteúdo dos dramas euripidianos, de certo modo, já havia sido feita na Antiguidade ${ }^{298}$. As transformações que o poeta emprega ao teatro trágico já teria despertado, entre os atenienses do século V a.C., o debate sobre a degeneração da tragédia. Aristófanes torna-se, portanto, a grande referência filológica de Nietzsche; não seria exagero em dizer que a maioria dos argumentos contra as peças de Eurípides foram extraídas de comédias aristofanescas. Como vimos, as apreciações nietzschianas sobre os seguintes elementos das peças de Eurípides: o Prólogo, a explicitação dialógica, o homem comum elevado ao palco como protagonista e o privilégio do discurso em relação à música são símiles às apreciações feitas pelo comediógrafo. Não obstante, considerar, tal como Nietzsche, que esses elementos sejam os maiores

\footnotetext{
${ }^{295}$ Sófocles que estava como mero suplente no agon é mencionado apenas três vezes na peça. Ele não teria se candidatado porque reconhecia a superioridade de Ésquilo. Cf. Versos 786 a 192. A menção aos três tragediógrafos confirma que entre os atenienses eles eram vistos como os mais influentes. Além disso, acredita-se que Sófocles tenha um papel insignificante porque ele teria morrido quando a peça já estava escrita, porém não apresentada.

${ }^{296}$ Cf. Verso 1515.

${ }^{297}$ No caso específico Cleofonte. Cf. Verso 1530.

${ }^{298}$ Apesar das críticas de Nietzsche possuir a mesma base das de Aristófanes, é evidente que elas possuem intenções completamente distintas. O filósofo está preocupado em formular uma teoria filosófica sobre o fim do teatro trágico, enquanto o comediógrafo deseja estabelecer as diferenças entre Eurípides e seus antecessores e, com isso, fazer uma avaliação da degeneração cultural de sua época.
} 
responsáveis pela depravação da tragédia grega e, consequentemente, acarretaram o seu derradeiro fim é, em última análise, um engano. A tese de que o teatro euripidiano suprimiria o dilaceramento trágico e o efeito dionisíaco, presente nos tragediógrafos antecessores, não se sustenta, ou ao menos é muito radical.

De acordo com a nossa análise, esses elementos acima citados, na maioria das vezes, não comprometem a tensão trágica característica dos dramas de Sófocles e Ésquilo. O Prólogo em Eurípides, por exemplo, é um artifício dramático que contextualiza a audiência a respeito de aspectos gerais do mito, como o tempo e o lugar em que se passa a ação; quais divindades e heróis estão envolvidos; quais foram os eventos que culminaram na ação dramática; deixando assim o drama mais inteligível. Apesar disso, o Prólogo não exime os espectadores da tensão e do espanto extático provenientes dos suplícios dos heróis trágicos. É importante salientar que os Prólogos de Eurípides - com exceção de Ifigênia em Áulis, que começa imediatamente com um diálogo entre Agamêmnon e o ancião - seguem sempre o mesmo padrão: um monólogo extensivo seguido de um diálogo que se estende até a entrada do coro no Párodo. O monólogo traz informações sobre os acontecimentos anteriores e o cenário atual, de modo que a audiência pode apreciar, no conjunto, a situação representada no palco. Nesse sentido, o poeta prepara a plateia, desde o início, para os caminhos morais e emocionais que a trama vai seguir, contudo, não isenta o público do êxtase estético.

A peça As Fenícias ilustra perfeitamente nossa posição: trata-se da mais extensa tragédia de Eurípides e contém um dos Prólogos mais longos do autor. Nele, o monólogo de abertura fica a cargo de um ator com máscara de velha mulher, vestes negras e cabelos raspados, demonstrando com isso luto. Após um lamento ao deus Hélio, que traz à cena o mito de Cadmo e as origens dos Labdácidas, conhecemos a identidade da personagem; trata-se de Jocasta. Em seu longo discurso, ela nos faz saber da série de desventuras que caíram sobre sua família: desde o cruel abandono à própria sorte do rebento recém-nascido, até a terrível reviravolta do destino, quando o filho, então crescido, assassina o pai e toma o leito da mãe. O monólogo é muito rico em detalhes, além de narrar um mito já conhecido dos gregos, acrescenta-lhe identidade própria - o fato de Jocasta estar viva e Édipo ter sido encarcerado pelos filhos, por exemplo. Após o 
monólogo inicial, o Prólogo dá vez ao diálogo entre Antígona e um Servo. Enquanto a primeira parte contextualiza sobre os fatos que antecederam a trama, o segundo momento, esclarece ao público o que está prestes a acontecer. No caso de As Fenícias, o diálogo anuncia que o exército argivo está à espreita da cidade de Tebas.

Eurípides não omite o que vai acontecer, pelo contrário, anuncia exatamente o destino das personagens. Em Hipólito, por exemplo, Afrodite deixa claro, no monólogo de abertura, que por decisão sua o mancebo Hipólito e sua madrasta Fedra vão morrer. A deusa além de explicar os fatos que antecederam a trama, declara os motivos de seu arbítrio de vingança e, até mesmo, como vão cair os infames. Já em Medeia, o discurso da ama no Prólogo revela que Medeia pode fazer algo de terrível aos próprios filhos, pois ela está tomada pelo ódio. Todavia, tanto Hipólito, quanto Medeia estão entre as tragédias mais impactantes de Eurípides, essas peças não perdem a tensão pelo fato de, desde o início, já se saber o que acontecerá com os personagens, longe disso, elas evocam o sentimento de implacabilidade trágica em grau máximo. Além disso, devemos lembrar que os mitos representados nas tragédias já eram bem conhecidos pelos gregos da época. O destino dos heróis já era, por assim dizer, popularizado. Em alguns casos, já se sabia do dilaceramento da personagem, pois a mesma história já havia sido interpretada em concursos anteriores. Portanto, o fato de anunciar previamente a ação de forma explicativa, tornando-a mais inteligível, não implica o esgotamento, nem mesmo um abrandamento do efeito trágico.

Além do Prólogo, a crítica de Nietzsche também se direciona ao encerramento das peças euripidianas, como sabemos, o filósofo condena o recurso dramático deus ex machina, entende como um artifício que torna o destino do herói mais sereno, dessa forma, arruína qualquer possibilidade do efeito trágico; o deus das máquinas garante, ao espectador, o futuro do herói, o consolo metafísico é, então, substituído por um "final feliz". Contudo, em algumas obras, a argumentação nietzschiana não se confirma. Há dramas remanescentes de Eurípides em que, ao contrário daqueles que analisamos no tomo acima, o artifício ex machina não salvaguarda o personagem do dilaceramento e, consequentemente, não isenta a audiência da tensão trágica. Dentre elas podemos destacar Hipólito: a peça traz à cena os infortúnios do filho de Teseu. A tragédia, 
uma das mais belas e repleta de significado, conta a trama de vingança de Afrodite contra o jovem Hipólito. A deusa decide punir com a morte o rapaz, porque, de forma arrogante, desdenhava de sua divindade, além disso, renunciava às paixões amorosas e aos prazeres do sexo ${ }^{299}$. Como plano de vingança, Cípres faz com que Fedra, esposa de Teseu, apaixone-se doentiamente pelo enteado, nutrindo por ele um desejo insano.

Em meio aos delírios de paixão, Fedra decide se declarar ao jovem. Casto, Hipólito nega qualquer relacionamento com a bela madrasta. Porém, desesperada, a infeliz mulher se suicida, não antes de escrever um bilhete acusando Hipólito de ter maculado o seu tálamo. Teseu, ciente do conteúdo do bilhete, tomado pela v̋ $\beta \rho \iota$, amaldiçoa o próprio filho, roga aos deuses que o castigue e quando encontra o garoto face a face, sem titubear, expulsa-o de sua pátria, impondo-lhe o exílio. Durante sua partida, em seu carro de cavalos, Hipólito é perseguido por um touro monstruoso, que fora enviado das profundezas do oceano por Poseidon ${ }^{300}$, no desespero da fuga, morre ao se chocar com rochedos a beira-mar. Ao saber da morte do filho, Teseu não se aflige. Entretanto, no final da trama, surge Ártemis ex machina. A deusa tem o papel de revelar os verdadeiros acontecimentos. Mas, diferente do que se possa esperar de uma habitual "divindade máquina", não há a resolução imediata de uma aporia. A verdade apresentada por Ártemis é equiparada à revelação dos eventos no palácio de Édipo, pois o que ocorre na

\footnotetext{
${ }^{299}$ No Prólogo, Afrodite esclarece o porquê de seu ódio por Hipólito: O jovem filho de Teseu,

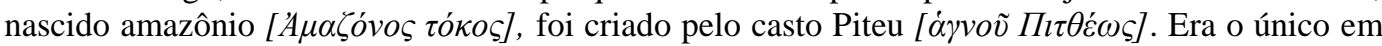

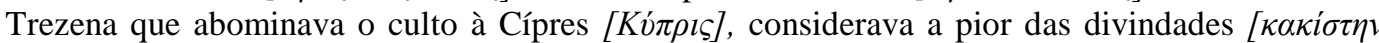
$\delta \alpha u o ́ v \omega v]$ ]: rejeitava as donzelas e das núpcias se horrorizava. Hipólito honrava Artêmis que

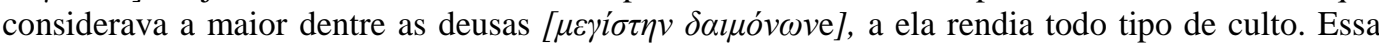
oposição, tão bem acentuada no texto, revela o caráter de Hipólito: nega à deusa do amor e tem devoção extrema à deusa da vida selvagem. Vivia em companhia dessa divindade nos bosques, desfrutando dos prazeres da caça. Nessa descrição inicial, Cípres assevera que não inveja e nem se importa com a preferência do jovem, mas sim, o punirá pelas ofensas cometidas contra ela. Afrodite considera o mancebo arrogante, presunçoso, e como diz: "derruba aquele que pensa

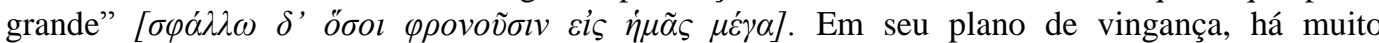
planejado, a deusa, em um único só dia, fará Hipólito experimentar as desgraças proveniente da paixão desmedida. Cf. Versos $1-25$.

${ }^{300}$ Artêmis ex machina explica que o touro só fora enviado, porque Poseidon tinha prometido realizar três imprecações de Teseu, seu filho (vv. 1315 - 1324). Existem várias interpretações acerca do simbolismo do touro, a mais recorrente é que o animal, símbolo de sexualidade e instintos animalescos, represente a energia sexual e fecundante a qual Hipólito renegou.
} 
sequência, antes do $\dot{\alpha} v \alpha \kappa o v ́ \varphi ı \sigma l \varsigma$ ou $\dot{\eta} \sigma v \chi \alpha \dot{\zeta} \zeta \omega^{301}$, a personagem é invadida, mediante a tomada de consciência de seus erros, por um desespero inefável.

No momento em que entra em cena ${ }^{302}$, Ártemis ex machina inquere Teseu sobre o porquê de sua alegria diante de tais acontecimentos, ou seja, após impiamente ser responsável pela morte do filho, persuadido pela falsa história de sua mulher. Após tal questionamento, ela o confronta dizendo como é "clara a sua ruína" ${ }^{303}$, mais à frente, a deusa o chamará de $\kappa \alpha ́ \kappa ı \sigma \tau \varepsilon^{304}$, uma das piores ofensas para um herói. O motivo da teofania de Ártemis é revelar o coração verdadeiramente justo de Hipólito, ao fazê-lo desenrola o clímax dramático da peça. Nessa interpretação, o dilaceramento trágico só atinge o seu ápice devido à revelação de uma divindade ex machina. Sua aparição é fundamental para o

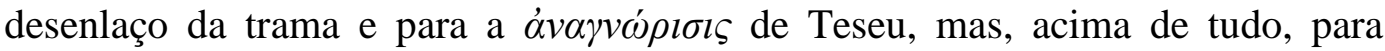
evidenciar uma visão trágica da existência: o curso da vida corre sem qualquer controle humano, alegrias e desgraças são fortuitas, obras da $\tau \dot{v} \chi \eta^{305}$. Esse papel "distorcido" da ex machina fica ainda mais evidente quando entra em cena o cadáver despedaçado do garoto, anunciado da seguinte forma pelo coro:

\author{
Aí vem o infeliz \\ Com as brandas carnes esfaceladas, \\ E desfigurado o rosto formosíssimo \\ Ó dor imensa desta casa! \\ Se viu dobrado o luto \\ enviado pelos deuses! $!^{306}$
}

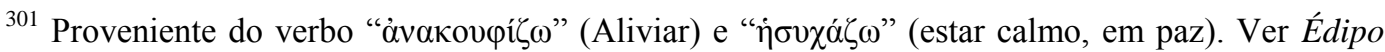
Rei, versos 218 e 620, respectivamente.

${ }^{302}$ Verso 1282.

303 “ф

${ }^{304} \mathrm{O}$ termo deriva de $\kappa \alpha \kappa o ́ \varsigma$ (mesmo adjetivo que Hipólito usa para Afrodite Cf. v. 13) que pode ser traduzido por "mau”, ou, "inútil”. Cf. Verso 1317.

${ }^{305}$ Tó $\chi$ [tyché], geralmente traduzida por "acaso", "sorte", "fortuna", refere-se ao "acontecimento fortuito". Conquanto, na tragédia grega, sobretudo em Eurípides, o termo assume um significado mais complexo: a tyché é um instrumento dos deuses, que jogam com o destino humano. Sobre o assunto, Cf. GIANNOPOULOU, Vasiliki. Tyche: Fortune and Chance in Euripides and Fifthcentury Historiography. University of Oxford, 2001.

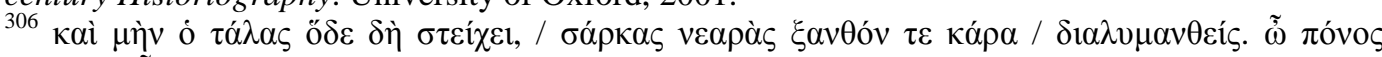

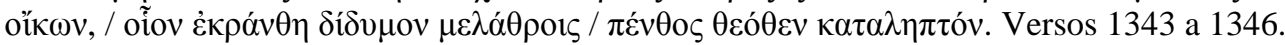


A fala de Hipólito, já morto, mas ainda com as dores do corpo, também dão o tom lúgubre das cenas finais: “Ai, ai, ai, ai! Miserável de mim! Arruinou-me a injusta imprecação de um pai injusto! Estou morto, desgraçado, ai de mim! Agudas dores traspassam a minha cabeça e a confusão se lança sobre meu cérebro. Deixa-me descansar meu corpo destroçado"307. É claro que o diálogo entre Hipólito, Teseu e Ártemis caminha para uma reconciliação: primeiramente, a deusa conforta o rapaz dizendo que Afrodite, nas sombras do Reino de Hades, não mais poderá perturbá-lo; em seguida, a divindade garante que será construído um templo em sua honra e inaugura um culto, onde virgens ofertarão ao infausto mancebo os seus cabelos cortados antes dos suspiros das núpcias. Por fim, o filho perdoa a imprecação do pai, absolvendo-o do sangue derramado. Contudo, apesar do fim supostamente sereno, não é possível dizer que há um “final feliz”. Para nenhuma das personagens humanas há redenção! Mesmo que Ártemis ex machina proponha uma resolução e, até mesmo, exalte Fedra como ilustre mulher ${ }^{308}$, o sentimento final é de completa impotência diante do capricho dos deuses e de absoluta nulidade diante das forças do mundo. Constatação essa indispensável para o arrebatamento trágico-estético, o que na trama só é possível mediante as intervenções da divindade machina ${ }^{309}$.

Outro aspecto do pensamento nietzschiano que consideramos muito radical e difícil de sustentar é atribuir a Eurípides, pelo fato de levar ao palco os dilemas da vida próxima, a responsabilidade pela degeneração da tragédia grega. Para Nietzsche, a obra euripidiana teria marcado a mediocrização do teatro grego no momento em que ele converte a linguagem mítica tradicional em uma linguagem popular; isto é, quando as expectativas do público passam a ser representadas no palco. Nessa perspectiva, a grandiosidade de outros tempos é substituída por intrigas corriqueiras e tramas cotidianas, o próprio deus do teatro, o verdadeiro

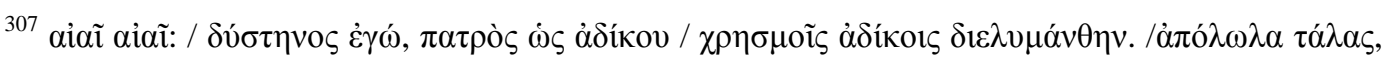

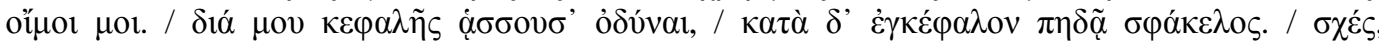
ג்

308 Versos 1429 e 1430.

${ }^{309}$ Além de Hipólito, outra tragédia euripidiana em que a aparição da ex machina não altera em nada a atmosfera trágica da peça, nem mesmo exime o herói do dilaceramento trágico é Medeia. Ainda que, no final da peça, a feiticeira de Cólquida fuja da fúria de seus inimigos no carro do deus-Sol, seu ancestral mítico, em um típico desfecho ex machina, já criticado por Aristóteles (Cf. Poética, 1054b), não há redenção da personagem! Não há abrandamento no drama, Medeia representa, mais do que qualquer outra personagem, o canto do bode despedaçado. Ideia que defenderemos nos parágrafos finais desta seção.
} 
protagonista de todas as tragédias teria sido suplantado pelo cidadão comum. De fato, Eurípides dá voz ao povo em seus dramas. Porém, a avaliação de Nietzsche a esse respeito não se confirma totalmente, porque a tragédia grega é, por definição,

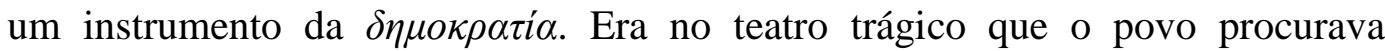
satisfazer seus anseios. Assim como a filosofia, a tragédia é filha da $\pi o ́ \lambda l \varsigma$, sua matéria é o pensamento social próprio da cidade ${ }^{310}$. Esse conteúdo políticopopular da tragédia não é exclusividade da obra euripidiana, ela é visível em Sófocles e, apesar de menos nítida, está presente também em Ésquilo.

Desde que Pisístrato institucionalizou os concursos de tragédias, decretando que eles fossem celebrados nas festas públicas de Atenas, o teatro se tornou um instrumento político de propagação de ideias populares. Esse estilo literário tornou-se fundamental no processo formativo do cidadão, justamente no momento em que a cidade passava por grandes transformações. Seu conteúdo retratava o colapso da aristocracia e a necessidade de novos valores que fossem compatíveis com a democracia em vias de construção. Com uma estratégia política perspicaz, o Estado (primeiramente Pisístrato) fazia uso da religião antiga para reestruturar o pensamento político na cidade. O passado mítico distante, aquele dos deuses e heróis homéricos, dividia o palco com símbolos representativos do povo: o servo, a ama, o guerreiro, muitas vezes em presença coletiva. Desse modo, os cidadãos se reconheciam no palco; os dilemas das famílias aristocráticas e os fracassos dos governantes, ali encenados, já não era algo distante, agora também refletia a sua realidade. Por isso, participar das apresentações como espectador era o mesmo que um ato cívico: a demonstração de pertencimento à $\pi$ á $l \varsigma$ e o compartilhamento de emoções coletivas ${ }^{311}$. Nesse sentido, há uma radicalidade em atribuir exclusivamente a Eurípides a inserção dos anseios do homem comum no palco.

Em seus dramas, Ésquilo - o tragediógrafo mais elogiado por Nietzsche quando comparado a Eurípides - não dá voz ao povo como faz o seu sucessor; os conflitos, em seu palco, não são os problemas corriqueiros do dia-a-dia; o seu coro é composto por figuras representativas que dificilmente podem encarnar o

\footnotetext{
${ }^{310}$ VERNANT, Jean-Pierre e VIDAL-NAQUET, Pierre. Op. Cit. $p .3$.

${ }^{311}$ Sobre a relação entre tragédia grega e política na antiguidade clássica Cf. VERNANT, JeanPierre. (Org.). O homem grego. Lisboa: Presença, 1994 e VERNANT, Jean-Pierre. As origens do pensamento grego. São Paulo: Edusp, 2002.
} 
cidadão $^{312}$. Mesmo assim, as tragédias esquilianas refletem, ao seu modo, os anseios da população. É certo que o povo só está efetivamente presente no palco através de figurantes mudos ${ }^{313}$, no entanto, os dilemas e angústias da nova cidade são estridentes. Ésquilo coloca em cena os excessos da guerra como consequência dos caprichos de uma aristocracia em decadência. O fracasso desses nobres no governo da pólis está atrelado à necessidade de uma nova ordem político-social. Esses temas eram cotidianos, faziam parte do contexto diário do cidadão comum. Por mais que Aristófanes e Nietzsche tenham identificado que o tema central das tragédias esquilianas seja o bélico e, certamente, não corresponda às intrigas da vida ordinária, não significa que seja um tema que se afasta da rotina popular. A guerra fazia parte das aflições do dia-a-dia; a batalha era sempre uma sombria vizinha. A tensão da armada era sentida na carne e nos nervos de toda a cidade.

Ésquilo entendia mais do que qualquer outro a iminência existente na sua época entre a guerra e as ânsias do povo; no palco mapeou essa proximidade de forma sublime. A batalha fazia parte de sua alma! Por isso, no fim da vida se reconheceu como soldado abdicando sua posição de poeta ${ }^{314}$. Além de Ésquilo, a massa democrática também ascende aos palcos nos dramas de Sófocles, agora na forma de uma inversão de valores. Há, na tragédia sofoclidia, uma radical adulteração no sentido de $\dot{\alpha} \rho \varepsilon \tau \dot{\eta}$ : antes o termo estava irremediavelmente ligado à virtude aristocrática e à honra guerreira que busca, acima de tudo, a glória e a

\footnotetext{
${ }^{312}$ Era convencional o coro representar a voz do povo e as ideias comuns, porém, das sete tragédias supérstites de Ésquilo, duas o coro é composto por seres míticos: as ninfas filhas do oceano em Prometeu e as seis Fúrias em Eumênides. Em outras duas é composto por anciãos: os doze velhos argivos, em Agamêmnon e pelos Fiéis, anciãos persas distinguidos por nascimento e mérito em Os Persas. As demais peças o coro é composto por mulheres: por mulheres cativas em Coéforas, por donzelas tebanas em Sete contra Tebas e pelas cinquenta Danaides em Suplicantes.

${ }^{313}$ Em Sete contra tebas, por exemplo, Etéocles lança a sua apóstrofe inicial ao "Povo de Cadmo" [Kód $\delta$ ov $\pi \circ \lambda \tilde{i} \tau \alpha l]$, se referindo a ele como: "o vigia do bem público na proa da cidade, o leme que conduz os assuntos de Estado [ $\pi \rho \tilde{\alpha} \gamma o \varsigma]$ com olhos intocados pelo sono, devem decidir o que exige o momento" (versos 1 a 4). Outro exemplo pode ser visto em Eumênides, quando os juízes vão decidir o futuro de Oreste, o povo está presente, eles não possuem fala, mas são representados por sua deusa Atenas, que discursa e vota. Em Suplicantes, Pelasgo, o rei de Argos, nega conceder abrigo às Danaides antes de consultar a vontade do povo. É por ocasião desse voto que, segundo Vidal-Naquet, pela primeira, vez nos textos que temos, a palavra $\delta \tilde{\eta} \mu \circ \varsigma$ (povo) foi aproximada do

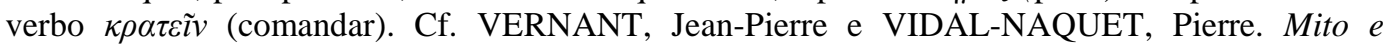
tragédia na Grécia antiga. p. 228.

314 Ésquilo, que havia combatido nas batalhas de Maratona (490) e Salamina (480), quando pressente a chegada da morte, ignora toda a glória conquistada como poeta e escolhe como lembrança para seu epitáfio as seguintes palavras: "Esse memorial encerra Ésquilo, filho de Eufórion, ateniense, morto em Gela, rica em frumento. Os persas de cabelos longos e a baía célebre de Maratona sabem o que foi seu valor". Cf. PAUSÂNIAS. Description of the Greece, [I,14,5]; e VERNANT, Jean-Pierre e VIDAL-NAQUET, Pierre. Idem.
} 
imortalidade do nome, ao lado daqueles que conquistaram grandes feitos. Esses eram os atributos de Édipo, herói que dizimou os algozes que surgiram em seu caminho e, com tremenda astúcia, venceu a terrífica Esfinge. No entanto, no final de sua saga, de nada lhe serviu a $\dot{\alpha} \rho \varepsilon \tau \eta \dot{~}$. Mesmo diante de tantos feitos gloriosos é lembrado apenas como desgraçado, o velho errante de olhos vazados. Há, portanto, em Édipo rei, uma inversão na compreensão do que é excelência; é necessário um novo modelo de virtude que se adeque à realidade do povo comum,

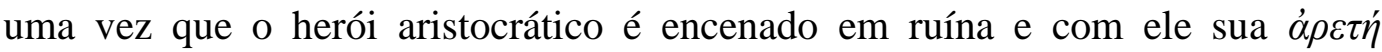
guerreira.

Por mais que o teatro trágico retrate alguns aspectos da pólis e as angústias decorrentes das então mudanças sociais, é um engano pensar que o palco seja um reflexo exato da realidade, que ocorra um mero deslocamento da vida à cena. É um engano ainda maior compreender a tragédia como um instrumento de dominação; as peças não corrompiam o povo a serviço de determinadas ideologias de grupos dominantes. Pelo contrário, antes de dar direções ou respostas, elas problematizavam a realidade vigente, reivindicavam da audiência o pensamento laborioso. Nada é fácil de digerir em seu conteúdo. Por essas razões, o $\theta \alpha v \mu \alpha ́ \zeta \omega$ era uma exigência impreterível para os seus espectadores: assombrar-se, espantarse diante do imprevisível destino era inevitável. Esse é um dos motivos para Nietzsche considerá-la uma arte sublime, dilacerante. Os fundamentos, não só político-sociais, mas, principalmente, os existenciais, antes sólidos, agora são ameaçados. Até mesmo o "eu" subjetivo é diluído. Nesse ponto de vista, aquilo que na obra de Eurípides foi reconhecido como "comum" e "corriqueiro" pode ser considerado filosófico, no sentido mais originário da palavra, isto é, a demolição de todas as certezas pré-concebidas pelo indivíduo já lançado no mundo: ruem os pilares da verdade e desaba o edifício da linguagem.

Dentre os dramas euripidianos que melhor ilustram essa potência estética da tragédia, está Medeia. Ironicamente as críticas de Nietzsche parecem se direcionar especificamente a essa peça, mesmo que nunca a tenha mencionado, os seus elementos adequam-se claramente à formulação nietzschiana: a trama da feiticeira de Cólquida restringe-se, à primeira vista, aos conflitos passionais das personagens; também é visível o esforço para torná-la inteligível, pois, fora o Prólogo que explicita os fatos anteriores à ação, Medeia, em meio a um turbilhão 
de sentimentos contraditórios, faz longos discursos racionais sobre o sofrimento das mulheres ${ }^{315}$; além disso, ela tem o futuro garantido por uma espécie de final ex machina. No entanto, quando se prende a esses aspectos, Nietzsche diz respeito apenas à estrutura da peça, fazendo de sua crítica algo superficial. Não há o aprofundamento na riqueza simbólica do seu conteúdo. Isso fica evidente quando percebemos a complexidade semântica dos signos dicotômicos "Medeia" e "Jasão". Os protagonistas simbolizam dois mundos diametralmente opostos, respectivamente equiparados aos mundos dionisíaco e apolíneo: são irreconciliáveis, estão sempre em luta, mas ocasionalmente cingem-se, para então retornar ao confronto.

Quando traz à cena esses dois símbolos em oposição, ou seja, o drástico conflito entre Medeia e Jasão, Eurípides está representando o próprio percurso histórico do homem no Ocidente, ao fazê-lo, evidencia duas estruturas de linguagem antagônicas e, consequentemente, dois modos de apreensão da realidade incompatíveis: um mítico-arcaico e outro lógico-racional. Na peça, esses dois modos são expressos da seguinte forma: Medeia, como figura propriamente dionisíaca, é $\xi \dot{\varepsilon} v \eta$, a estrangeira de Cólquida, cidade situada nos limites do mundo helênico. Seus costumes são, portanto, mais bárbaros do que gregos, ao menos é assim que ela se sente em terras coríntias ${ }^{316}$. Jasão, por sua vez, é a representação apolínea por excelência: o retrato do herói grego que, movido pela ḋ $\rho \varepsilon \tau \dot{n}$ aristocrática, lidera os argonautas e conduz Argos, sua nau, aos confins do mundo, desafiando os perigos dos mares ${ }^{317}$. Enquanto Jasão é a imagem do homem grego, do discurso ético e da pólis civilizada, Medeia reflete em si o sagrado e o profano. Ao mesmo tempo em que, na sua terra, é sacerdotisa, neta do deus Sol, capaz de reconhecer as vozes divinas nos enlevos da natureza e tornar sacro tudo àquilo que toca; também é capaz de profanar sua tradição: impiamente derrama o sangue, por exemplo, quando desmembra com opróbrio o jovem irmão ${ }^{318}$.

\footnotetext{
${ }^{315}$ Cf. Versos 214 a 266.

${ }^{316}$ Medeia se sente sozinha, sem pátria, "levada como espólio de uma terra bárbara" [Ėk $\gamma \tilde{\eta} \varsigma$

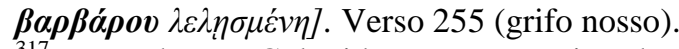

317 Jasão chega a Colquida para a conquista do velo de ouro após atravessar as negras Simplégades

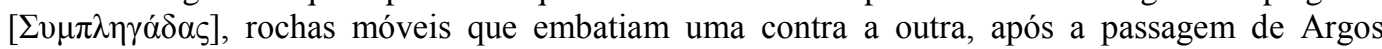
tornaram-se fixas. Cf. Versos 1 a 5.

${ }_{318}$ Medeia profana sua casa quando ajuda Jasão a roubar o velo de ouro e a fugir dos perigos de sua terra. Para isso ela despedaça o irmão, obrigando o pai a recolher os restos mortais e com isso
} 
Esses contrastes extremos, tão bem pintados por Eurípides, além de situarem Medeia e Jasão como antípodas, denunciam dois modelos de interpretação e estruturação da realidade, íntimos no que se refere à identidade grega, porém, opostos e excludentes nas especificidades de suas visões de mundo. O modelo simbolizado por Medeia é aquele que representa o mundo, apreende a vida por meio da "palavra" entendida como $\mu \tilde{v} \theta o \varsigma^{319}$. Por outro lado, o modelo simbolizado por Jasão é aquele que interpreta a realidade através da "palavra"

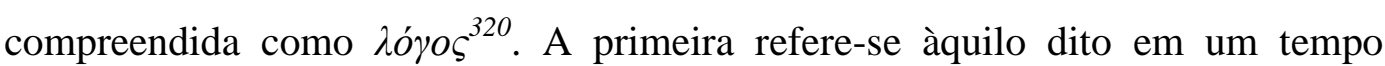
distante, arcaico e, precisamente por isso, tem sua validade. Essa "palavra" explicita um mundo sagrado, seu valor de verdade é avaliado pelo critério dos deuses e, portanto, não se dissipa com o vento, é que é dito e não pode ser esquecido, deve ser levado a sério. Eurípides coloca esse termo na boca de Creonte para que sua ameaça à estrangeira tenha o tom ineludível ${ }^{321}$. Tratam-se de sentenças belas, tudo se diz poeticamente. Nesse sentido, a compreensão mítica da realidade torna até o acontecimento mais grotesco, belo. Isso nos mostra Medeia quando ouve do Mensageiro sobre as desgraças no palácio ${ }^{322}$. Tudo faz parte do plano divino, vida e morte estão entrelaçadas no estágio deífico. Por isso, a contradição não é vista como um erro, mas como parte integrante da vida: besta e homem; amor e ódio; sacro e profano; etc.

Sabendo disso, podemos dizer que a crítica de Nietzsche é muito estranha, pois Eurípides está acusando a incapacidade do homem grego, contemporâneo aos seus dramas, de entender a "palavra" mítica. Medeia é a peça que evidencia um processo de cisão incontornável entre o mundo arcaico, sagrado e o moderno, civilizado. $\mathrm{O} \mu \tilde{v} \theta o \varsigma$ se tornou inaudível, a voz dos deuses incompreensível. Egeu

ganhar tempo. Também derrama o sangue de Pélias, rei de Iolcos, quando convence suas filhas a cozinhar o pai em um caldeirão para que ele recuperasse a juventude. Cf. Versos 465 a 473.

${ }^{319}$ Mũ $\theta$ os [mȳthos]: “word”, “speech”. Cf. A Greek-English Lexicon. LIDDELL, Henry George \& SCOTT, Robert.

${ }^{320} \Lambda$ ó ${ }^{2}$ os [lógos]: on the various senses of the "word". Cf. Idem.

321 "Mas previno-te, se a luz do sol, que há de surgir, vir você e as crianças dentro dos confins

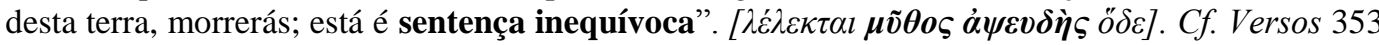
e 354. (Grifo nosso).

${ }^{322}$ Quando Medeia sabe detalhadamente, pela boca do Mensageiro, sobre a morte tenebrosa do rei Creonte e sua filha Gláucia celebra: "Disseste as palavras mais belas e entre os benfeitores e

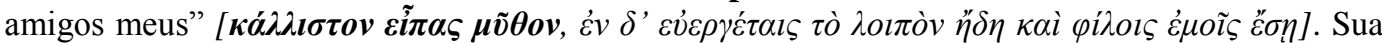
alegria não é mera vingança. Tudo faz parte do plano divino: ela havia clamado aos deuses e foi atendida. Cf. Versos 1127 e 1128. 
não entende mais o oráculo de Febos, precisa da ajuda de uma bárbara para decifrá-lo ${ }^{323}$, porque seu mundo, o mundo de Jasão, é agora interpretado pela

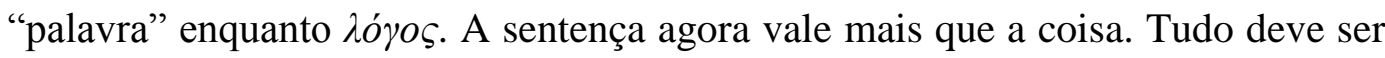
explicitado pelo discurso que, por sua vez, é avaliado pelo critério da lógica. A contradição passou a ser inaceitável, é utilizada como critério para se identificar o erro. A justiça trágica é substituída pelo discurso ético. Morrem-se os deuses primitivos e com eles a poesia. A era de Jasão é a era da retórica. A verdade não está mais nos preceitos sagrados que perpetuavam ao tempo, contudo, na

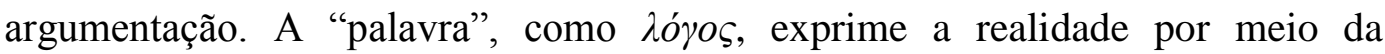
demonstração e do convencimento. Eurípides desenha bem essa diferença: a fala de Jasão tem sempre essa tonalidade, quase promíscua, da indução ${ }^{324}$, até mesmo Medeia, há tanto tempo esposa de grego e em terras gregas, faz uso do lógos como artimanha para a persuasão ${ }^{325}$. Quando o $\lambda o ́ \gamma o \varsigma$ não está no âmbito do convencimento, aparece no da explicitação, não só por Jasão, mas também pela mulher que abandonou ${ }^{326}$.

Apesar de outrora, ainda como princesa e sacerdotisa no mundo bárbaro, Medeia tenha cedido aos encantos do $\lambda o ́ \gamma o \varsigma$ grego, consegue perceber o seu erro $^{327}$. Foi preciso que ela sofresse as dores do abandono para reconhecer que o discurso helênico, comparado à palavra mítica, é vazio, não há nele o valor sacro e, por isso, não é confiável. Agora para estabelecer um novo acordo com um

\footnotetext{
${ }^{323}$ Egeu encontrava-se infértil. Suplica a Apolo para que conceda prole, mas considera a resposta do oráculo "Palavras demasiado sábias para um homem entender". Cf. Verso 675.

${ }^{324}$ Depois de tentar convencer Medeia de que seria melhor para todos, e inclusive justiça, a sua nova núpcia real, o coro ironiza: "Bem enfeitaste, ó Jasão, tuas palavras; mas a mim se me afigura, se bem que contra a tua opinião fale, que, traindo tua esposa, não fizeste justiça" ['Iã $\sigma o v$,

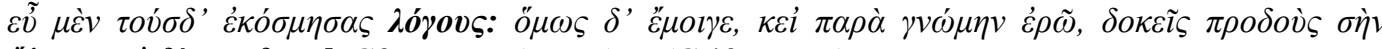

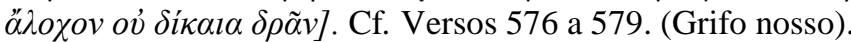

${ }^{325}$ Quando a Medeia é exilada pelo rei, argumenta para que permaneça em Corinto com os filhos, mas a interlocução de Creonte é a seguinte: "Estás a gastar palavras; nunca me persuadiria"

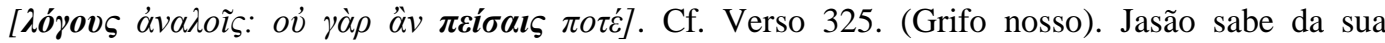
capacidade oratória de persuasão, diz que convencerá facilmente Gláucia a deixar os filhos em Corinto: "Sim, imagino que, a ela, sempre a poderei convencer [ $\pi \varepsilon i \sigma \varepsilon l v]$ " Cf. Verso 944.

${ }^{326}$ Jasão está sempre argumentando e explicando os seus atos a fim de justifica-los, por exemplo, quando medeia diz que tudo que ele conquistou foi com sua ajuda ele responde: "mas te é

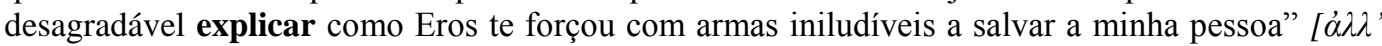

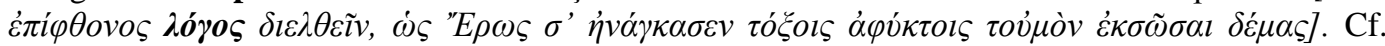
Versos 329 a 331. Também Medeia faz uso da explicitação quando conta os seus planos: "Os meus planos, já os vou explicar a todos. Mas não recebas as minhas palavras prazerosamente" [ $\eta \ddot{\delta} \eta \delta \grave{c}$

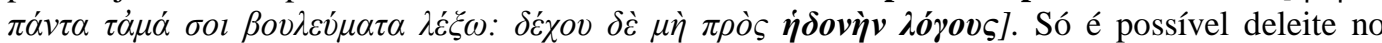
$\mu \tilde{\theta}$ oç. Cf. Verso 772 e 773. (Grifo nosso).

327 "Errei uma vez, quando abandonei a casa paterna, persuadida nas palavras de um grego, que,

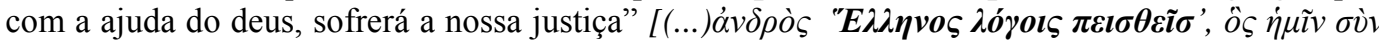

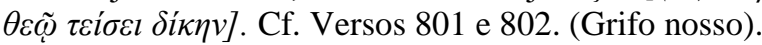


homem da civilização é preciso que ele fale a linguagem do $\mu \tilde{v} \theta o \varsigma$. A única forma de acreditar na promessa de Egeu é fazendo com que ele jure pelos deuses originais $^{328}$. Entretanto, mesmo que tenha reconhecido as diferenças irreconciliáveis entre os dois mundos, e claro, uma nostalgia pela terra de seus ancestrais, o fato é que Medeia havia se civilizado, deixado de ouvir as vozes dos seus numes. Esse foi o argumento de defesa de Jasão ao ser acusado de abandonar aquela que, em sacrifício próprio, teria lhe salvado e lhe proporcionado riqueza e glória: "Recebeste mais do que deste para me salvar, como te vou demonstrar. Em, primeiro lugar, habitas na terra dos Helenos, em vez da dos bárbaros, conheces a justiça e sabes usar das leis, sem recorrer à força”329. Há, portanto, um aspecto de racionalidade na heroína, pois ela havia, em certa medida, se helenizado.

O próprio plano de vingança contra aqueles que a feriram é resultado de sua civilização. Medeia calcula metodicamente cada passo, o que só é possível mediante a sua racionalização. Caso agisse puramente pelos instintos, então simplesmente mataria Jasão. Todavia, arquiteta engenhosamente uma empreita que envolva a todos, inclusive a si mesma. Há nesta argumentação um interessante paradoxo: se o plano de retaliação é fruto de uma racionalidade e direciona-se a Jasão, que por sua vez é o símbolo de um estágio racional da humanidade, então a vingança volta-se contra si mesma. É a elaboração de uma punição contra o próprio raciocínio de conceber a punição. Por esse motivo, Medeia é afetada, tal e qual, pelo seu ato. A profundidade de seu sofrimento e a complexidade de seu caráter ambíguo pode ser vista nitidamente em seu longo monólogo de lamúria, quando se despede dos filhos. A indomável mulher agarrada às tenras crianças e entra em uma espécie de agon consigo mesma: primeiro lamenta o futuro no exílio, sem os filhos, alusão ao terrível destino dos rebentos $^{330}$; depois ao mirar a ternura das crianças repele os cruéis desígnios ${ }^{331}$;

\footnotetext{
328 "Ao passo que, sendo o nosso acordo só em palavras, e sem juramento à face dos deuses. (...)

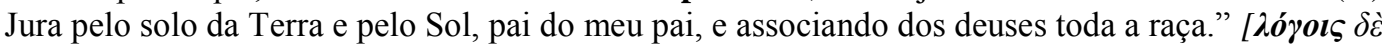

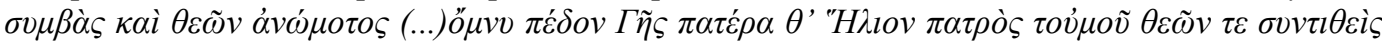

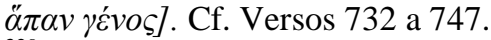

${ }^{329}$ Cf. Versos 535 a 540.

330 "Queridos filhos meus! Agora vos espera para meu desespero um mundo diferente, outra morada onde estareis eternamente sem vossa mãe. E me fazem partir, banida para uma terra estranha, sem haver podido colher as muitas alegrias que esperava de vós". O lamento completo nos versos 1019 a 1040 .
} 
em seguida, retoma os planos, para então reprimi-los novamente ${ }^{332}$, revelando um conflito intenso entre sua natureza, parte dionisíaca, bárbara, que segue os preceitos sagrados da justiça trágica, e parte helênica, pautada no discurso éticoapolíneo que não admite os excessos dos instintos.

A peça de Eurípides é essencialmente trágica e Medeia, a heroína dilacerada. Podemos dizer que, metaforicamente, por trás da sua $\pi \rho o ́ \sigma \omega \pi o v$, Zagreus que é despedaçado. Essa tragicidade da personagem pode ser vivamente percebida quando assistimos à cena final em Medea de Lars Von Trier, com o close perturbador na atriz Kirsten Olesen. No entanto, o drama de Eurípides é trágico, porque evidencia a superação de um paradigma histórico-existencial. O poeta coloca em cena o processo incontornável que transformou o modo de ser do homem no mundo. Não foram apenas as vozes dos deuses que silenciaram; modificou-se até mesmo a apreensão do tempo: o símbolo Medéia representa um tempo arcaico, cíclico, algo próximo do que os antigos chamaram de $\alpha \iota \omega^{333}$; o próprio sacrifício dos filhos revela a ideia de circularidade das coisas, pois aquilo que perece, renascerá e o fluxo da vida permanece, é eterno ${ }^{334}$. Jasão, em seu

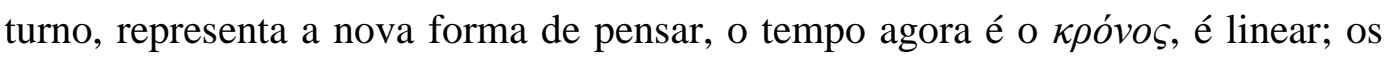
seus anseios são para o agora, por isso, um casamento real lhe é propício, lhe garante a vida cronológica. Além disso, o mundo de Medeia é mágico, ritualístico, em oposição ao novo mundo de Jasão, técnico e científico. Mas, dentre os contrastes, o mais radical é que, enquanto a estrangeira simboliza a bestialidade no homem, ou seja, o corpo em todas as suas intensidades e o instinto como crivo

\footnotetext{
331 “Ai! Ai! Porque fitais em mim os olhos, ó filhos? Porque sorrides pela última vez? Ai! Ai! Que hei de eu fazer? O ânimo fugiu-me, mulheres, desde que vi o olhar límpido dos meus filhos. não, eu não seria capaz. Deixá-las ir, as minhas decisões anteriores. Levarei desta terra os filhos, que são meus. Para que hei de eu, para afligir o pai deles com a sua desgraça, infligir a mim duas vezes os mesmos males?". Cf. Versos 1041 a 1050.

${ }^{332}$ Medeia titubeia e teme ser alvo de escárnio por sua fraqueza: "Ah! Mas que vileza a minha, ter sequer admitido pensamentos de brandura no meu espírito! Ide, ó filhos, para casa". Mas logo em seguida abranda novamente: "Mas não, meu coração, tu, ao menos, não farás isso. Deixa-os, ó desgraçada, poupa as crianças. Vivendo lá conosco, eles serão a tua alegria". Mas novamente muda o ânimo em direção ao final que todos conhecemos: "Não, pelos deuses da vingança que estão no Hades! Jamais dirão de mim que eu entreguei meus filhos à sanha de inimigos! Seja como for, perecerão!". Cf. Versos 1055 a 1080.

${ }^{333}$ Medeia em uma passagem, refere-se à vida como aí́v (verso 243). O termo significa "curso da vida", mas também denota o tempo não cronológico, o tempo das eras, o termo é cognato da palavra latina aevum, "eternidade". Cf. LIDDELL, Henry George \& SCOTT, Robert. Op. Cit.

${ }^{334}$ Essa é a essência do trágico e do "consolo metafísico" em O Nascimento da tragédia. Além disso, a ideia de circularidade fica clara no final ex machina quando a neta do Sol, em posse dos tenros cadáveres, promete instituir em seus sepulcros uma festa e ritos sagrados para sempre celebrados.
} 
da vida ${ }^{335}$, o argonauta simboliza a racionalidade exacerbada, os instintos reprimidos e o advento da metafísica ${ }^{336}$.

O problema é que Eurípides demonstra que a racionalidade de Jasão é cega: ironicamente, no final da trama, após saber da morte da família real, o herói vai depressa até os filhos com a intenção de protegê-los, porém, na inocência de sua razão, pretende esconder os filhos da vingança do povo, mal sabia ele dos feitos horríficos já praticados pela mãe ${ }^{337}$. Não obstante, é importante saber que, diferente de uma crítica incongruente à racionalidade, a obra de Eurípides é uma alusão à impotência do $\lambda o ́ \gamma o \varsigma$. O que está em voga, não só em Medeia, mas na obra euripidiana como um todo, é a acusação, sem nenhuma valoração, da falência do discurso. O trágico em Eurípides é, precisamente, a demonstração da fragilidade do nosso conhecimento, que se pretende universal, contudo, é estruturado em uma linguagem limitada. Eis a tragédia euripidiana: uma linguagem que instaura mundos, que intervém na realidade, fundamenta a política, mas, em si, é falha. A palavra vazia tem mais valor que a coisa. Além de Medeia que confia no juramento frívolo de Jasão, há vários outros exemplos nas peças euripidianas: Teseu que confia na palavra escrita de Fedra e Hipólito incapaz de exprimir a verdade; Admeto, mesmo que relutante, não cumpre o juramento feito à Alceste ante a morte, além disso, quando a mulher retorna do reino de Hades está muda, é impossível ouvir sua voz ${ }^{338}$; Cassandra, em Troianas, possui a verdade, mas lhe é impossível comunicar, seu discurso é desacreditado ${ }^{339}$. Metáforas à debilidade do $\lambda o ́ \gamma o s$.

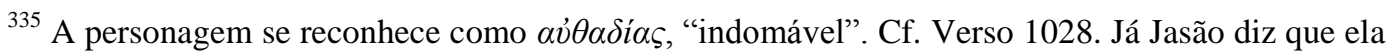

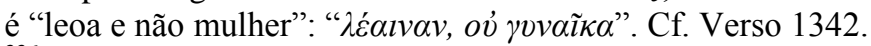

${ }^{336}$ Jasão postula, por exemplo, a ideia de justiça da mesma forma que os filósofos o nas ágoras, não mais em um sentido punitivo, mas como conceito, uma ideia fruto da reflexão. Cf. verso 537. ${ }^{337}$ Cf. Versos 1293 a 1307.

${ }^{338}$ No drama Alceste, Apolo iludi as Parcas para livrar da morte Admeto. No entanto, para ser salvo, alguém deveria, de bom grado, se oferecer para descer ao Hades em seu lugar. A única pessoa que aceita dar a vida em seu lugar é sua esposa, Alceste (versos 1 a 28). Porém, antes de consumar seu sacrifício, exige que Admeto prometa nunca ter outra mulher em seu tálamo (v. 280 a 325). O infeliz esposo concorda e jura jamais ter outra esposa (v. 328 a 343). Contudo, no final da trama, demonstra a vulnerabilidade de sua palavra e quebra o juramento ao aceitar, mesmo que relutante, acolher uma jovem trazida pelo amigo Héracles. Em um típico final feliz, a jovem

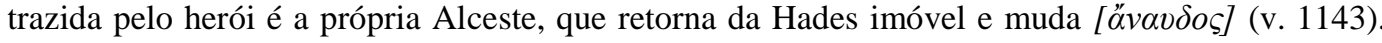
Mais uma alegoria à debilidade do discurso.

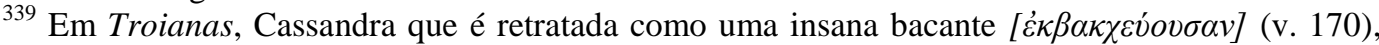
possui o dom da profecia, tudo que sai de sua boca é a própria vontade dos deuses. Entretanto, por se negar ao leito e amores de Apolo, foi amaldiçoada pelo deus, lhe desacreditando os vaticínios. Sua linguagem é ineficaz, inepta para comunicar as verdades que seu espírito desvelou.
} 
No entanto, dentre as obras preservadas de Eurípides, aquela que ilustra mais explicitamente a complexa relação do homem com a linguagem é Helena. A trama traz à cena os mesmos infortúnios da esposa de Menelau antes narrados na Ilíada: três deusas foram buscar Alexandre para ser juiz em um concurso de beleza, o jovem deveria premiar a divindade mais bonita. Pelo feito, teve como recompensa a donzela cuja formosura se destacava entre todas as helênicas. A novidade de Eurípides em relação à épica homérica é que Hera, inconformada pela vitória de Cipris, não permitiu que Páris levasse Helena ao seu leito. A deusa entrega ao príncipe troiano um fantasma vivente ${ }^{340}$, forjado do éter celeste, à semelhança de Helena. A complexidade do enredo é mostrar que a guerra e as incontáveis desgraças que dela decorreram foram devido a uma imagem vazia ${ }^{341}$. A protagonista, fazendo questão de defender sua honra, acaba por estabelecer uma separação entre ela mesma e seu nome $[o ̛ v o \mu \alpha]^{342}$, isto é, uma palavra vaga, desprovida de realidade. Nessa interpretação, Eurípides está ilustrando o abismo que existe entre a linguagem e a realidade. Os termos e sentenças cunham um mundo e um modo de ser nesse mundo, conquanto, também geram uma sorte de conflitos devido à crença imperturbável em sua capacidade de representar a verdade das coisas.

Isso fica claro na peça, pois ninguém percebe a diferença entre a real Helena e seu espectro. Até mesmo o grego Teucro, exilado no Egito, quando encontra a filha de Zeus frente à frente, não a reconhece e ainda considera o $\varepsilon \imath ̋ \delta \lambda \nu v$, que vira anteriormente, uma imagem indubitável ${ }^{343}$. Até mesmo Menelau quando reencontra a verdadeira esposa não é capaz de reconhecê-la como tal, porque mais lhe convence a representação da coisa, que resgatara anteriormente em Troia, do que a presença real da coisa diante de $\mathrm{si}^{344}$. Por mais que Helena se esforce para ser reconhecia como tal, falha. É necessário que o próprio espectro se manifeste

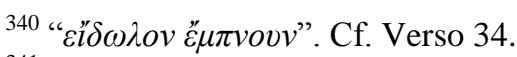

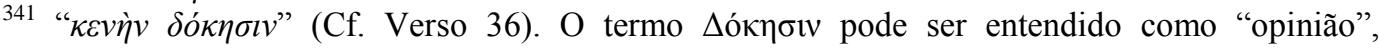
"crença", ou mesmo "conceito" no sentido de uma "aparência", uma "imagem" representada. (Cf. LIDDELL, Henry George \& SCOTT, Robert. An Intermediate Greek-English Lexicon). Dessa forma, Helena assevera que a guerra foi consequência de um conceito, um opinião vazia [Kevìv].

${ }^{342}$ Helena diz no Prólogo: "Para a batalha contra os frígios, não eu, mas o meu nome foi posto como prêmio de guerra aos gregos". Cf. Versos 43344.

343 Aqui temos um interessante jogo de palavras: enquanto Helena considera seu $\varepsilon i ̋ \omega \lambda o v$

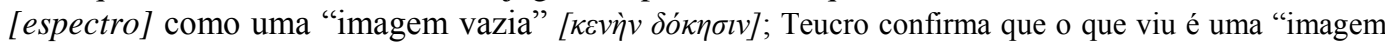

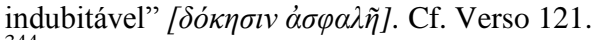

${ }^{344}$ Cf. Versos 559 a 577.
} 
para que ele entenda seu equívoco. O texto, principalmente nas falas de Helena, insiste em contrastar o "nome" do "corpo" que ele representa, nesta diferenciação

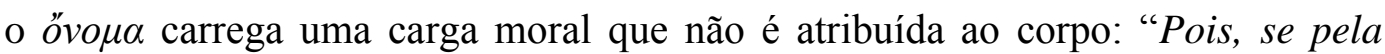

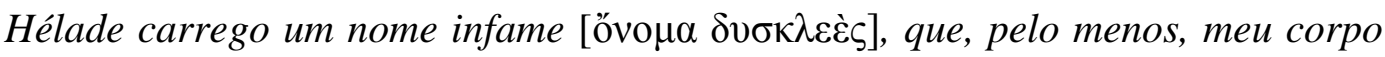
aqui não incorra em vergonha"345. Há nessa perspectiva, a ideia de uma ética fundada no discurso que, por definição, é dicotômica aos instintos corporais. $\mathrm{O}$ "nome" também é o responsabilizado pelos enganos e males ${ }^{346}$. São os enganos, sucedâneos dos limites da linguagem e sua tendência à categorização.

Não devemos deixar de enfatizar que Eurípides escolhe mulheres para cantar algo tão evidente em seu tempo: a dicotomia linguística refletida intimamente na política, na arte e na moral. São essas feiticeiras, amas, mênades, servas, princesas, todas insanas de desejo e paixão, as únicas capazes de exprimir através de imagens complexas e, na medida do possível, sem recorrer ao $\lambda o ́ \gamma o \varsigma$, reflexões tão profundas. Não é de se estranhar que Nietzsche tenha escolhido a imagem das mulheres para simbolizar a verdade, sempre oculta em um véu, e o feminino para ilustrar os mistérios da vida. "Sim! A vida é uma mulher!”, disse $\mathrm{e}^{347}$. Como podemos perceber há mais convergências do que divergências entre o filósofo e o tragediógrafo. Talvez Nietzsche, para valorizar o símbolo Eurípides e desenvolver seus argumentos de juventude, tenha renegado o poeta, deixando para ele somente a preferência dos deuses ${ }^{348}$. Ambos são saudosistas de um mundo arcaico. Eurípides era moderno em relação à era dos mitos. Em sua época, o estágio da religião primitiva já havia sido substituído pela sofística. Os filósofos da poesia obscura já davam lugar à erística e à dialética. A sua obra, portanto, é indissociável desse contexto e do fenômeno racional que então crescia a toda força. Dessa forma, a crítica de Nietzsche à tragédia euripidiana só pode ser compreendida se for colocada paralela à figura de Sócrates e o racionalismo estético que esta representa.

\footnotetext{
${ }^{345}$ Cf. Verso 64 e 65. Cf. também o verso 1100: "De muitos ultrajes já me ultrajastes, exibindo o

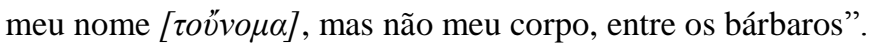

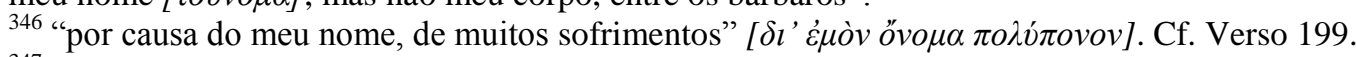

${ }^{347}$ NIETZSCHE. A Gaia ciência. §339.

348 "A sepultura de Eurípides foi atingida por um raio, isto é, as coisas que estão nele são favoritas dos deuses, o lugar é sagrado". [Das Grab des Euripides wurde vom Blitz getroffen, d.h. das Darinliegende ist ein Liebling der Götter, die Stätte heilig]. NIETZSCHE. Fragmento póstumo de 1869, 1[61].
} 


\section{5. A doença Sócrates ou a doença de Sócrates? A Dicotomia entre o instinto e a razão:}

A argumentação nietzschiana contra Eurípides, que o coloca como a marca de degeneração da tragédia, só pode ser completamente compreendida quando o poeta é colocado em paralelo com Sócrates, ou melhor, com aquilo que a figura socrática representa. Eurípides teria sido apenas uma máscara, enquanto a verdadeira voz falando por sua boca era a de um demônio, Sócrates ${ }^{349}$. Nesse sentido, as renovações no teatro trágico, feitas pelo autor de Medeia, obedeciam às exigências de uma nova forma de criação artística estabelecida pelo pensador grego. O desenho que Nietzsche faz de Sócrates o coloca como um espectador desconfiado da tragédia antiga, ele não a compreendia e, por isso, não a estimava. Como solução, passou a exercer forte influência em Eurípides, ajudando-o a compor novas peças que obedecessem ao seu entendimento artístico. Inaugurando, então, aquilo que foi chamado, em $O$ Nascimento da tragédia, de socratismo estético. Não obstante, devemos frisar que a imagem de Sócrates no pensamento nietzschiano, não se refere à pessoa, nem mesmo ao pensamento socrático. O filósofo ateniense, assim como Eurípides, é um símbolo que permite a Nietzsche fazer uma avaliação do curso da história e da cultura no Ocidente.

Nietsche deixa isso claro, diz que "tudo em Sócrates é simbólico",350, e mais: "o socratismo é mais antigo do que Sócrates"351. O filósofo antigo torna-se, então, um personagem que, no imaginário nietzschiano, reúne em si diversos elementos que permitem ilustrar, por meio de alegorias, as transformações na antiguidade como o início de um processo de decadência da civilização ocidental. Esses elementos fazem do símbolo Sócrates o "pai do racionalismo"; "déspota da lógica"; "patrono da dialética"; "aniquilador do drama musical"; "mensageiro pressagiador e arauto da ciência"; "gênio teórico"; "desprezador do instinto e, com isso, da arte"; e "doente da vida". Em suma, Sócrates representa o momento decisivo para o empobrecimento da cultura, isto é, quando houve a inversão de valores entre o instinto e a consciência, quando o poder da sabedoria instintiva foi

\footnotetext{
${ }^{349}$ NIETZSCHE. O Nascimento da tragédia. $\$ 12$.

${ }^{350}$ [wie an ihm eigentlich alles symbolisch ist]. Ibidem. A Visão dionisíaca de mundo. p. 42.

${ }^{351}$ [Der Sokratismus ist älter als Sokrates]. Idem.
} 
negado e suplantado por uma consciência criadora ${ }^{352}$. Agora, com os preceitos da dialética, não existe nada que não possa se exprimir e nada em que não se possa convencer os outros. Essa é a essência da estética socrática: "sabedoria consiste em saber", a razão pode desvelar todos os mistérios e resolver qualquer aporia. Quando estes princípios foram refletidos na arte, foi decretado o fim da trágica grega $^{353}$.

O declínio da tragédia está ligado, portanto, à completa dissolução dos mistérios. Assim que a natureza lógica desenvolveu-se excessivamente, nada mais foi tido como impenetrável. Nesse aspecto, Sócrates pode ser considerado, diz Nietzsche, como "não-místico"354, pois no místico se desenvolve a sabedoria instintiva $^{355}$. Quando a tragédia se torna inteligível, decai seu aspecto enigmático, é rompida a sua relação com os cultos dionisíacos e se perde toda sua potência estética. Sócrates não aceitava o elemento ininteligível do drama musical, não entendia a embriaguez entusiástica que se apoderava artisticamente da audiência. Considerava os efeitos dionisíacos algo irracional: "causas sem efeitos e com efeitos que pareciam não ter causas" ${ }^{356}$. Tais delírios eram perigosos e deveriam ser evitados pelas mentes mais racionais. Os filósofos seriam aqueles que, em primeiro lugar, segundo os imperativos socráticos, teriam de se afastar desse modelo artístico, porque ali nunca se expressava a verdade e, por isso, só interessava aos "pobres de espírito" e se direcionava para "quem não tem muito entendimento". A empreita socrática foi, então, expurgar a parte inebriante da tragédia, torná-la exclusivamente apolínea e, para isso, submeter a música ao diálogo e à disputa retórica.

Eurípides não foi o único a ter sua poesia corrompida pelo discurso socrático. Nietzsche nos conta ${ }^{357}$, amparado por Diógenes Laércio ${ }^{358}$, que Platão,

\footnotetext{
352 "Com ele o instinto se torna o crítico, a consciência se torna criativa". [Bei ihm wird der Instinkt zum Kritiker, das Bewußtsein zum Schöpfer]. Idem. p. 40.

353 "O socratismo é a ininterrupta celebração do sacrifício da tragédia antiga". [Der Sokratismus ist das ununterbrochene Opferfest der alten Tragödie]. Ibidem. Fragmento póstumo de 1870, 3[6].

354 "Sócrates como oponente dos Mistérios: conjurador do medo da morte pela razão" [Sokrates als Gegner der Mysterien: Beschwörer der Todesfurcht durch Gründe]. NIETZSCHE. Fragmento póstumo de 1871,7[96].

${ }^{355} \mathrm{Cf}$. Ibidem. O Nascimento da tragédia. $\$ 13$.

${ }^{356}$ Idem. §14.

357 Idem.

358 “(...) se dedicou à pintura e a escrever poemas (primeiro ditirambos, e depois cantos líricos e tragédias). Dizem que sua voz era fraca (...). Narra-se que Sócrates viu em seus joelhos num sonho
} 
um jovem e promissor tragediógrafo, para tornar-se aprendiz de Sócrates, teve de começar por queimar todos os seus poemas. O mestre, por classificar a tragédia como uma arte aduladora - representava apenas o agradável e nunca o útil exigia que seus discípulos se afastassem dela, evitando, assim, divertimentos tão estranhos à filosofia. Platão foi completamente influenciado pelo socratismo nesse ponto; ele colocava a poesia trágica no mesmo patamar das demais artes miméticas ${ }^{359}$, ou seja, como a reprodução de um simulacro ${ }^{360}$ e, por isso, em um patamar ainda mais inferior que o mundo empírico. No entanto, Platão se esforça para ultrapassar a aparência, trata de exprimir a ideia, ou seja, a essência das coisas subjacentes nesta falsa realidade. Mas ao fazer isso como pensador, acaba atuando na esfera artística, como poeta. Segundo a análise nietzschiana, o diálogo platônico, como estilo literário, nasce da assimilação de todos os gêneros e formas precedentes. O diálogo oscila entre a narrativa, o lirismo e o drama, a prosa e a poesia, atingindo, com isso, uma unidade formal linguística igual às antigas tragédias $^{361}$.

Nessa interpretação, o estilo platônico teria salvado a poesia antiga e legado à posteridade o protótipo de uma nova forma artística, o romance. Entretanto, no que confere ao gênero de Platão, a poesia é subordinada à dialética. Da mesma forma em que a música no drama euripidiano tornou-se uma mera auxiliar da palavra, o elemento poético dos diálogos é subalterno à filosofia, torna-se apenas um veículo para a explicitação de conceitos. Uma relação hierárquica equivalente foi a submissão da filosofia aos preceitos teológicos durante o período medieval. O caráter secundário a que Platão rebaixou a poesia, foi devido à "influência demoníaca de Sócrates" ${ }^{\text {362 }}$. O que está em jogo é que, nesse momento crucial do curso da cultura, o pensamento filosófico ${ }^{363}$ sobrepujou a arte em um processo

um filhote de cisne, cuja plumagem cresceu num instante, e que levantou voo para emitir um doce canto. No dia seguinte Platão lhe foi apresentado como discípulo, e imediatamente Sócrates disse que ele era a ave de seu sonho". (...) Mais tarde enquanto se preparava para um concurso de tragédias, passou a ouvir Sócrates em frente ao teatro de Diônisos, e então jogou às chamas seus poemas exclamando: 'Avança assim Héfaistos! Platão necessita de ti!' [Paródia ao verso 392 do canto XVIII da Íliada]”. LAÉRCIO, Diógenes. Vida e doutrina dos filósofos ilustres, III, 5. p. 86. ${ }^{359}$ Cf. PLAT ̃̃O. A República, 394b e 394c; 395a; Cf. também Leis, 817 b.

${ }^{360}$ Cf. NIETZSCHE. Fragmento póstumo de 1870, 7[124].

${ }^{361}$ Ibidem. O Nascimento da tragédia. $\$ 14$.

362 "unter dem Drucke des dämonischen Sokrates drängte”. Idem.

363 É importante enfatizar que Nietzsche está se referindo a um movimento filosófico grego específico. Aquele cujos principais representantes surgem com a sofística. Há, portanto, para Nietzsche, uma diferença entre o pensamento dos filósofos originários e os da democracia 
que a obrigou a se fundir ao movimento dialético. Na terminologia nietzschiana: houve uma supervalorização do aspecto apolíneo na forma de uma tendência ao logicismo, refletida claramente nos agons euripidianos; e, por consequência, a substituição das profundas emoções dionisíacas em afetos naturalistas. Entra em cena a estética da razão: Sócrates, figura poética de Platão, tal e qual aos heróis de Eurípides, justificam-se através da argumentação racional.

O novo estilo de arte, criado a partir da estética socrática, retrata uma nova compreensão da vida oposta àquela representada pelas antigas tragédias. A dialética promove um otimismo racional que acaba por anular a visão do absurdo da existência. Agora a vida é justificada pela razão, isto significa que tudo pode ser explicado pela lógica. Não há mais espaço para o pessimismo trágico, porque a capacidade de calcular soluciona qualquer situação problemática. A inteligibilidade das coisas não permite o inesperado, fazendo valer a máxima: "apenas se sucumbe por ignorância". Como dissemos anteriormente, Nietzsche pondera que quando esse elemento otimista infiltra no teatro trágico, recobre pouco a pouco todas as regiões dionisíacas até sua completa destruição, acarretando então, a morte da tragédia ${ }^{364}$. O reflexo desse processo na vida é igualmente nefasto, pois ocorre uma desvalorização da própria vida, na forma de uma subordinação de seus valores ao valor do conhecimento. O otimismo socrático é, portanto, uma euforia científica, ou seja, a satisfação em desvelar, por meio de um esquadrinhamento lógico, tudo que tange à realidade, nada deve permanecer encoberto. Nesse sentido, tal otimismo, por definição, é tão inartístico quanto deletério à vida ${ }^{365}$.

O positivismo científico deleita-se com cada descoberta do conhecimento, diferentemente do artista que se deslumbra com o que se preserva oculto. Assim como a ciência acabaria se não houvesse mais nada para conhecer, o espírito artístico desapareceria se os mistérios do mundo fossem todos evidenciados. Essa

ateniense, no que se refere ao conteúdo e a sua forma de exprimir. "Os verdadeiros filósofos gregos são aqueles antes de Sócrates: Algo muda com Sócrates." (Fragmento póstumo de 1888, 14[100]). Os pensadores arcaicos pretendiam ou fortalecer o sentido da verdade frente à poesia (Tales, Parmênides); ou o fortalecimento mítico-místico do artístico (Heráclito, Empédocles, Anaximandro), diferente da tendência de racionalizar e moralizar a religião, o mito e os instintos (Sócrates). Cf. Fragmento póstumo de 1872 - 1873, 23[14].

${ }^{364}$ A imagem de Nietzsche é bastante ilustrativa: "A dialética otimista, com o chicote de seus silogismos, expulsa a música da tragédia”. Ibidem. O Nascimento da tragédia, §14.

${ }^{365}$ Idem. §24. 
é a tendência da lógica socrática, fazer das pessoas uma espécie de 'Édipo esclarecido' que anseia por solucionar todos os enigmas do mundo. Nietzsche vai chamar o estereótipo dessa forma de existência - do cientificismo exacerbado, inaudito antes de Sócrates - de homem teórico. Esse tipo tem sua maior satisfação no processo de desencobrimento que realiza com suas próprias forças; ele encontra mais prazer na perseguição pela verdade do que na posse dela própria. $\mathrm{O}$ homem teórico, cuja primeira personificação foi Sócrates, tem a convicção inabalável de que pelo "fio de Ariadne da causalidade pode penetrar até os abismos mais profundos do Ser"366, em outras palavras, o homem da ciência acredita que através da investigação causal dos fenômenos poderá compreender até as configurações mais íntimas da natureza. Além de julgar possuir um conhecimento fixo, imutável do íntimo das coisas, em última análise, o otimismo teórico crê que pode corrigir o mundo.

Essa crença na infalibilidade do conhecimento é, para Nietzsche, uma ilusão metafísica que brota do instinto próprio da ciência. Algo que só será quebrado depois de milênios, com Kant. Nessa visão, a ciência está atrelada à metafísica, isso a tal ponto que Sócrates, não apenas viveu, porém morreu em nome do conhecimento científico. Foi graças ao discurso racional, fruto do instinto científico, que o filósofo ateniense enfrentou o temor da morte. Depois desse corajoso ato frente ao desconhecido, todos passaram a lembrar de que a finalidade da ciência é justificar a vida, torná-la razoável e fazer a existência parecer compreensível. O aspecto fundamental da argumentação nietzschiana é colocar Sócrates como "ponto solsticial" de um movimento, visível até hoje, que atribuiu à racionalidade o poder de aprofundar na natureza das coisas, de penetrar na essência das causas e de distinguir o erro e a aparência do verdadeiro conhecimento. Desde Sócrates, o mecanismo de produzir conceitos, juízos e silogismos foram considerados a suprema atividade humana, distinta em valor de todas as outras. Agora, até mesmo os preceitos das ações morais recaem ao domínio da dialética do saber e, como tal, podem ser ensinadas ou, ao menos, relativizadas pelo jogo retórico.

${ }^{366}$ Idem. $§ 15$. 
Todavia, existem situações da vida que não podem ser esquadrinhadas pela lógica. Em algum momento, fatalmente nos deparamos com o inexplicável, frente a mistérios que nem mesmo a mais aguçada razão seria capaz de desvendar. Diante dessas situações a poderosa ilusão de universalidade da ciência se desfaz, e com ela todo otimismo do homem teórico. Quando os limites do alcance da ciência são ultrapassados, quando o logicismo "passa a girar em redor de si mesmo e acaba, como a serpente, mordendo a própria cauda"367, irrompe-se então, o absurdo da existência e, consequentemente, vem à tona um outro tipo de saber, o "conhecimento trágico", que por sua vez, é impossível de ser suportado sem o socorro e a proteção da arte. Nessa problemática, podemos observar uma diferenciação hierárquica no pensamento nietzschiano: voltando os olhos para os gregos, o filósofo reconhece na mais alta esfera do mundo [die höchsten Sphären derjenigen Welt] o esforço ávido por conhecimento otimista transformar-se bruscamente em resignação trágica e necessidade de arte; ao passo que, nos níveis mais inferiores [niederen Stufen], essa mesma avidez se manifesta em um sentimento de hostilidade à arte, principalmente à arte dionisíaca.

O que Nietzsche quer dizer é que diante do fracasso do conhecimento científico em fornecer uma compreensão global da realidade, a ausência de sentido para a existência vem à tona, então, afirma-se novamente a necessidade de arte como alternativa para se suportar a vida. Dessa forma, Nietzsche coloca a hipótese de não existir, necessariamente, uma antinomia irredutível entre o socratismo e a arte, e alude à possibilidade de existir um Sócrates artista. A imagem evocada para ilustrar essa suposição encontra-se no Fédon de Platão ${ }^{368}$ : Sócrates havia contado aos amigos da prisão que uma sombra lhe aparecera em diversos sonhos admoestando-lhe sempre com as mesmas palavras: "Sócrates, faça na música!”. Ele havia se tranquilizado até os últimos dias, pois pensava que sua filosofia era a mais elevada arte das Musas [Musenkunst]. Não acreditava que a divindade lhe falava da música popular, no sentido ordinário. Finalmente, por desencargo de consciência, decide praticar aquela música por ele tão menosprezada. As canções improvisadas na prisão foram os únicos sinais de uma dúvida, por sua parte, sobre a natureza e os limites da lógica ${ }^{369}$. A relação

\footnotetext{
${ }^{367}$ Idem.

${ }^{368}$ Cf. PLATÃO. Fédon, $60 \mathrm{e}-61 \mathrm{~b}$.

${ }^{369}$ Cf. NIETZSCHE. O Nascimento da tragédia. §14.
} 
ilustrada aqui assevera que o socrático, por ser nocivo à vida, levado às últimas consequências, acaba por afirmar a necessidade da arte como remédio para todos os males que causou.

A tragédia foi destruída pelo otimismo científico nascido do impulso dialético. Existe, então, uma contradição perene entre a concepção teórica e a concepção trágica de mundo. Contudo, depois de anulada a pretensão a uma aptidão universal do espírito científico, poderá, de acordo com Nietzsche, se nutrir a esperança de um renascimento da tragédia. Esse é o significado do símbolo de "Sócrates adestrando-se na música". O espírito científico deve ser entendido como a fé no saber como pretenso remédio universal para todos os males físicos e morais do mundo. Essa crença inabalável na ciência foi pela primeira vez questionada pelo criticismo de Kant e, subsequentemente, pela filosofia de Schopenhauer. Por isso, eles são considerados - como demonstrado anteriormente - os porta-vozes de uma sabedoria dionisíaca expressa em conceitos. O ambiente de descrença na infalibilidade da razão, legado por esses filósofos, será fundamental para Nietzsche postular a possibilidade de ressurgimento do espírito trágico nas obras de Wagner ${ }^{370}$. O compositor será o responsável por recriar a música dionisíaca fecundante, que faz nascer de si o mito. Essa força criadora da música fora hostilmente enfrentada e corrompida na forma do novo ditirambo ático.

$\mathrm{Na}$ análise nietzschiana, a música dionisíaca foi degenerada e transformada no novo ditirambo ático. Esse novo estilo musical já não mais exprimia a essência íntima do mundo ${ }^{371}$, mas só reproduzia a aparência de modo incompleto, na forma de uma imitação mediada por conceito $^{372}$. Isto significa que a tendência socrática havia expurgado o elemento extático da música. A dissonância responsável pelo efeito inebriante na audiência foi degenerada para uma arquitetura dórica de sons, cuja função é retratar mimeticamente os fenômenos, tais como, a marcha de uma armada, uma tempestade no mar. Com isso, a música despojou-se de sua força criadora de mitos. A ideia nietzschiana é que o novo ditirambo busca a excitação a partir da inteligibilidade e cálculos mentais, isto é, a

\footnotetext{
${ }^{370}$ Tema que desenvolveremos no primeiro estásimo, nosso próximo capítulo.

${ }^{371}$ No sentido schopenhauriano. Ver Seção 3.2.3.

${ }^{372}$ Cf. NIETZSCHE. O Nascimento da tragédia. $\$ 17$.
} 
partir de "analogias externas entre um acontecimento da vida e da natureza e determinadas figuras rítmicas e determinados sons peculiares da música”, ${ }^{, 373}$. Por outro lado, a música dionisíaca se apresenta como um evento puramente intuitivo; o mito, que é produto dessa potência criadora da arte musical, também comunica intuitivamente. Nessa comunicação apreendida corporalmente assenta-se o consolo metafísico, pois nós somos constrangidos a sentir a verdade eterna do mundo.

O novo ditirambo constitui, diz Nietzsche, a vitória da estética socrática ${ }^{374}$, porque a música, desditosamente, distancia de si mesma, para ser mera escrava da aparência. Ela deixa de ser criadora de uma linguagem universal para, então, se rebaixar a ruídos que procuram imitar a realidade fenomênica; por exemplo, uma batalha é representada musicalmente apenas por sons de trombetas e marchas, de modo que nossa atenção prende-se apenas em coisas superficiais. A radical transformação na natureza da música simboliza a hegemonia do mundo teórico, no qual, as deduções silogísticas valem mais do que qualquer experiência legitimamente estética. Apesar de Nietzsche ter previsto uma renovação cultural na Alemanha de seu tempo, hoje vivenciamos de forma onipresente o reinado desse "Prometeu, definitivamente, desacorrentado",375, além de assistirmos a completa devoção do homem moderno ao conhecimento científico, isso no momento histórico que, filosoficamente, é conhecido como era da técnica ${ }^{376}$. Nunca a ideia de que se pode curar a "ferida eterna da existência",377 por meio da ciência foi tão difundida. Hoje, acredita-se que ciência possa garantir a felicidade e consertar o mundo mesmo, mesmo que para isso ela tenha que alterar a essência das coisas.

Tendo em vista esse lugar do cientificismo hoje, e a sua materialização na forma de uma servidão à tecnologia, podemos dizer que as previsões para os rumos da cultura, em $O$ Nascimento da tragédia, fracassaram: em uma linguagem

\footnotetext{
${ }^{373}$ Idem.

${ }^{374}$ Nietzsche ressalta que o instinto astuto de Aristófanes já havia descoberto a verdade quando reuniu, em um objeto comum de ódio, o próprio Sócrates, a tragédia euripidiana e a música dos novos ditirambos. O comediógrafo reconhecera nestes três fenômenos os estigmas de uma cultura degenerada. Cf. Idem.

375 JONAS, Hans. O princípio responsabilidade: ensaio de uma ética para a civilização Tecnológica. p. 26.

${ }^{376}$ Cf. HEIDEGGER, Martin. A Questão da técnica. In. Ensaios e conferências. P. 11 - 25.

${ }^{377}$ NIETZSCHE. Op. Cit. $\$ 18$.
} 
schopenhauriana, Nietzsche afirmara que a Vontade sempre encontra meios para ligar à vida as suas criaturas, então, cria ilusões que as obrigam a continuar vivendo: a ilusão da felicidade socrática que acredita poder sanar a "chaga eterna da vida" por intermédio do conhecimento; outros são iludidos pelo "véu de beleza da arte"; há também quem é consolado pela noção metafísica de que, sob o turbilhão da aparência, segue o fluxo da vida eterna. Dessas três formas de miragens, que impelem o viver, funda-se, diz o filósofo, tudo o que denominamos "cultura". De acordo com a proporção desses estimulantes a cultura será a socrática, ou a artística ou a trágica. Por analogia com períodos históricos, essas culturas serão chamadas, respectivamente de alexandrina, helênica ou budista ${ }^{378}$. O prognóstico nietzschiano era de que o homem hodierno estaria próximo de inverter o trajeto do homem grego, ou seja, em vez de passar da cultura trágica para a alexandrina, a modernidade direcionava-se, do socratismo teórico e do otimismo racional à cultura trágica, resgatando a essência do pessimismo dionisíaco $^{379}$.

Apesar de as previsões do jovem Nietzsche sobre o rumo da cultura ocidental não se confirmarem, fazendo com que mudasse completamente sua posiçãa $^{380}$, as críticas à figura socrática permanecem durante toda a sua produção filosófica. Sócrates será um rico símbolo que possibilitará ao filósofo ilustrar diversos de seus pensamentos. No entanto, a imagem socrática que prevalecerá na obra nietzschiana é a do inimigo da $\operatorname{arte}^{381}$. Em correspondência a essa efígie combativa, Sócrates será também o signo supremo da destruição dos instintos em nome de uma consciência fundadora de $\operatorname{moral}^{382} \mathrm{e}$, consequentemente, expressão de uma vida em decadência, doente. Essas ideias estão presentes desde a

\footnotetext{
${ }^{378}$ Cf. NIETZSCHE. O Nascimento da tragédia, §18.

${ }^{379}$ Cf. Idem, $\$ 19$.

${ }^{380}$ Em suas obras posteriores, Nietzsche reavalia o lugar da ciência afastando-se completamente de suas prerrogativas anteriores de que a cultura do otimismo teórico sucumbiria e daria lugar à cultura trágica.

381 "O socratismo do nosso tempo é a crença no consumado: a arte está acabada e a estética está acabada". [Der Sokratismus unsrer Zeit ist der Glaube an das Fertigsein: die Kunst ist fertig, die Aesthetik ist fertig.] Ibidem. Fragmento póstumo de 1869, 1[8].

${ }^{382}$ Sócrates, abstratamente, humano, antepõe o bem do indivíduo, o conhecimento como finalidade da vida. Destruição dos instintos. [Sokrates abstrakt menschlich stellt das Wohl des Individuums voran, die Erkenntniß zum Zwecke des Lebens. Vernichtung der Instinkte]. NIETZSCHE. Fragmento póstumo de 1873, 21[23].
} 
conferência de 1870, Sócrates e a tragédia ${ }^{383}$, onde o desprezo socrático pela sabedoria própria dos instintos é retratado como responsável pelo declínio da arte. Isso demonstra que, apesar de toda formulação sobre a metafísica do artista, a concepção estética nietzschiana vincula a arte às pulsões imanentes que, não só afetam, mas, também brotam das intensidades corporais. Desse modo, Sócrates sempre evocará, até nos últimos escritos, a dicotomia entre racionalidade e instinto $^{384}$. O ateniense será pintado como antigrego, o instrumento de decomposição daquilo que distinguiram, em superioridade, os helênicos das demais culturas, ou seja, o instinto criador ${ }^{385}$.

Os desdobramentos filosóficos desta dicotomia proposta por Nietzsche é que a racionalidade exacerbada, que invariavelmente depõe contra os afetos corporais, enfraquece a vida, a torna doente. Sócrates é, portanto, a tipologia de uma cultura debilitada. A doença tem seu início quando se faz valer a máxima socrática: "razão = virtude = felicidade", isto é, só é feliz quem é virtuoso, só se atinge a virtude pela razão. Para Nietzsche, a inteligência, a lucidez, e a lógica, produtos da equação acima, foram os remédios dos antigos contra as selvagerias das pulsões. Estas últimas passaram a ser vistas como uma ameaça à civilização, pois devido às violentas contradições dos impulsos, havia o risco de ninguém ser mais senhor de si mesmo. A racionalidade socrática foi então percebida como a salvação. Sócrates foi erótico nesse ponto, conseguiu fascinar a todos: houve um fanatismo de que seria preciso imitá-lo para se prevenir contra os patológicos instintos. Pensava-se que qualquer concessão ao inconsciente e às intensidades instintivas é perigosa. É preciso então ser claro, límpido a qualquer preço. Não obstante, enquanto os gregos acreditavam curar a degenerescência com a racionalidade a todo custo, na verdade cometiam um mal-entendido ${ }^{386}$.

\footnotetext{
383 “O socratismo despreza o instinto e com isso a arte. Ele nega a sabedoria justamente lá onde ela está em seu reinado mais próprio". NIETZSCHE. Sócrates e a tragédia. In. A visão dionisíaca do mundo. p. 40.

${ }^{384}$ Essa dicotomia nas obras posteriores ao Nascimento da tragédia pode ser observada em muitos fragmentos póstumos e no §191 de Além do bem e do mal.

${ }^{385}$ Nietzsche em sua autobiografia reavalia as inovações de sua primeira obra e destaca: "a compreensão do socratismo: Sócrates é considerado, pela primeira vez, como instrumento da decomposição grega, como típico décadent. A 'racionalidade' contra o instinto. A 'racionalidade' a todo o custo como força perigosa, como força que mina a vida!". Ibidem. Ecce homo. "O Nascimento da tragédia", §1.

${ }^{386}$ Cf. Ibidem. Crepúsculo dos ídolos. “O problema de Sócrates”, §1 - §12.
} 
A vida cautelosa, consciente, exclusivamente lógico-racional, sem qualquer espaço para os instintos, e ainda, em resistência a eles é, na análise nietzschiana, uma vida em decadência. Isso se explica do seguinte modo: toda educação encaminhada à moral pautada na razão pretende, em última instância, o controle dos instintos. Sócrates recomendava a dialética como via de acesso às virtudes morais. Com isso, se privilegiava apenas a demonstrabilidade lógica das virtudes, de tal forma que foi excluído delas qualquer relação real com a vida, eliminou-se, até mesmo, o terreno político - da pólis grega - em que eram pautadas. Como resultado, desnaturalizaram-se todos os valores morais. No âmbito da dialética, tais valores não passavam de palavras criadas, destituídas, portanto, de um fundamento intrinsecamente humano. Por exemplo, “o bom”, “o justo" são signos que perderam sua correspondência real, preceitos morais sem nenhuma entidade correlata. Os filósofos tiveram, então, que inventar poeticamente um mundo para justificar a origem desses preceitos e assim validá-los ${ }^{387}$. Os frutos dessa moral dialética, dessa desnaturalização dos valores, foram a dissolução dos instintos gregos e, subsequentemente, a criação de um tipo doente de ser humano: o homem "bom", “ feliz”, "sábio". Consequências que garantem a Sócrates a responsabilidade pelo momento de mais horrenda perversidade da história da humanidade ${ }^{388}$.

Não obstante, para Nietzsche, os feitos catastróficos de Sócrates testemunharam contra a sua natureza, foram a expressão de seu ressentimento para com a vida. Interessante que o filósofo, na seção dedicada a Sócrates em Crepúsculo dos ídolos, parece imitar ironicamente o método dialético para demonstrar a decadência socrática, ele faz, em cada parágrafo, várias perguntas sugestionando cada aspecto da degeneração de Sócrates: "Era Sócrates realmente um grego?"; "a ironia de Sócrates era uma expressão de revolta? de ressentimento plebeu? Goza ele, como oprimido, de sua própria ferocidade nas estocadas do silogismo?"; "Como? a dialética é apenas uma forma de vingança em Sócrates?". A argumentação nietzschiana defende que a dialética foi o único recurso encontrado pelo ateniense, oriundo do "povo mais baixo", da plebe, para

\footnotetext{
387 "bom, justo, sábio, dialético - em uma palavra, o espantalho do filósofo antigo, uma planta arrancada de todo solo; uma humanidade sem nenhum instinto regulador definido; uma virtude que se "demonstra" com argumentos." NIETZSCHE. Fragmento póstumo de 1888, 14[111].

${ }^{388} \mathrm{Cf}$. Idem.
} 
colocar-se em situação de superioridade. Ora, com o uso da dialética se faz o papel de tirano, expõe o adversário ao vencê-lo, deixa ao outro a tarefa de demonstrar que não é um idiota, e retira do interlocutor a potência. Todavia, Sócrates dialético no fundo era apenas um doente. Sua guerra aos instintos e à arte que deles provém, sob o pretexto de buscar a saúde, a virtude e a felicidade foi, na concepção nietzschiana, um velado sintoma de uma terrível doença. Sócrates era doente da vida ${ }^{389}$.

Depois dessa exposição, devemos enfatizar, mais uma vez, que Sócrates é para Nietzsche, assim como é para Platão, um personagem, ou melhor, uma caricatura que, devido aos suas características, permite a comunicação de ideias. Entretanto, os atributos do personagem Sócrates são tantos, que multiplicam as possibilidades de sua interpretação ${ }^{390}$. Desse modo, Nietzsche - como não poderia ser diferente - omite alguns aspectos inerentes à figura socrática para se concentrar apenas naqueles que corroboram sua argumentação. Por conseguinte, ele deixa de lado certas particularidades do filósofo ateniense que, de certa forma, o isentariam da responsabilidade pelo colapso da tragédia grega e, ao contrário disso, o aproximaria de elementos dionisíacos. Sócrates, por exemplo, leva a filosofia às praças, em meio ao povo, isto é, o lugar próprio de Dioniso; tem uma relação identitária, assim como o deus, com o feminino; representa a dissolução sócio-hierárquica na pólis; além de reconhecer, em alguns momentos, o caráter entusiástico da arte. Pensando nisso, vemo-nos obrigados a fazer uma sucinta apresentação dessas peculiaridades em uma espécie de nova apologia de Sócrates.

\footnotetext{
${ }^{389}$ Cf. Ibidem. Crepúsculo dos ídolos. "O problema de Sócrates”, §1 - §12.

${ }^{390}$ Nietzsche reconhece essa pluralidade de atributos do personagem Sócrates e crítica Platão ao subsumi-los: "O Sócrates platônico é uma caricatura no verdadeiro sentido; porque ele está sobrecarregado com atributos que nunca podem ser conectados a uma única pessoa. Platão não é dramaturgo suficiente para capturar a imagem de Sócrates em um diálogo". [Der platonische Sokrates ist im eigentlichen Sinne eine Carricatur; denn er ist überladen mit Eigenschaften, die nie an Einer Person zusammensein können. Plato ist nicht Dramatiker genug, um das Bild des Sokrates auch nur in einem Dialoge festzuhalten]. Ibidem. Fragmento póstumo de 1876, 18[47].
} 


\subsection{1.}

\section{Sócrates dionisíaco? A filosofia levada à iminência da vida:}

Existe outro laço interpretativo da filosofia socrática que, diferentemente das interpretações nietzschianas, a colocam em plena associação com a vida e, por conseguinte, exime Sócrates, até certo ponto, da responsabilidade sobre o declínio da tragédia grega. Nessa linha de pensamento, a figuração de Sócrates, como a personagem que leva os problemas da filosofia à esfera da ágora, se equivale às desventuras que o personagem trágico desempenha em cena. Nesse ponto de vista, Sócrates não destrói a tensão própria do dionisíaco, pelo contrário, a leva até as últimas consequências, na medida em que, tal qual o protagonista trágico, vê na laceração do próprio corpo a dissolução daquilo que ele é. O herói, nesse sentido, é apenas a aparência de uma subjetividade, uma máscara que se individualiza momentaneamente, para tão logo se despedaçar e se diluir junto ao Ser primordial. Esse é um dos sentidos da mutilação do personagem trágico, a aniquilação do

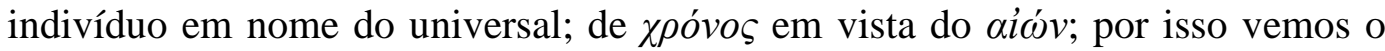
sacrifício de Édipo, a favor de Corinto, e Prometeu, a serviço da humanidade. O suplício do herói sempre desvela algo maior que a mera aparência. Da mesma forma, é possível identificar em Sócrates o auto-sacrifício em prol da coletividade, sua tragicidade foi aceitar a morte em benefício da pólis.

Pensando nisso, poderíamos seguramente atribuir um traço dionisíaco a Sócrates, pois sua metodologia rompe com a fronteira da representação e da coisa, uma vez que em seu modo de fazer política não é vertido apenas no plano do

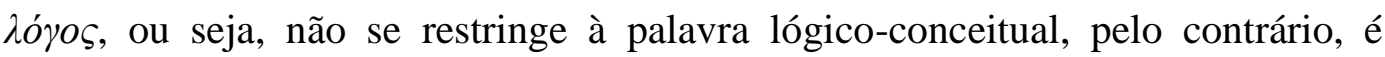
levado às vivências mais instintivas. $\mathrm{O}$ discurso socrático não repousa, portanto, no campo meramente representacional, longe disso, foi o meio pelo qual achou sua condenação. A filosofia de Sócrates - não no seu aspecto teórico, mas enquanto procedimento - foi levada à iminência da vida. Ora, o lugar que Sócrates faz filosofia é onde a vida mesma acontece: em meio às ruas da cidade; no banquete onde se celebra a Dioniso ${ }^{391}$ e, até mesmo, na prisão, local onde a laceração do "bode" é consumada ${ }^{392}$. Além disso, a filosofia socrática é levada ao

\footnotetext{
${ }^{391}$ PLATÃO. O Banquete. 177e.

${ }^{392}$ Metáfora à morte de Sócrates e de demais prisioneiros condenados à pena capital.
} 
povo, aos jovens e às mulheres ${ }^{393}$. Postura que será severamente criticada por Nietzsche, revelando uma prerrogativa estritamente aristocrática de seu pensamento $^{394}$. Porém, devemos mencionar, em defesa de Sócrates, que Dioniso é a divindade que caminha entre homens, inclusive os do campo. Sua divina presença não tem lugar entre o panteão olímpico; além disso, o nume execra os reis e aristocratas ${ }^{395}$. Quando não se encontra nos bosques, enfeitiça com o vinho a plebe.

O personagem Sócrates também é aquele que rompe com os padrões sociais da Grécia clássica. Diferente do que era aceito em Atenas, ele demonstra que o conhecimento poderia ser adquirido por um escravo estrangeiro ${ }^{396}$. É claro que o texto de Platão, que nos testemunha essa posição socrática, tem seus desdobramentos metafísicos ${ }^{397}$, no entanto, a sua interpretação no aspecto social é de que Sócrates não obedece às convenções hierárquicas de sua época, coloca o menino escravo no mesmo patamar de seu senhor, o aristocrata tessálio, Mênon. O filósofo também representa uma fratura nos costumes gregos no que concerne às mulheres. Sócrates aparentemente sente tanta veneração por elas que abole a diferença hierárquica imposta pela sociedade grega machista. Diferentemente de Aristóteles ${ }^{398}$, por exemplo, o personagem platônico considera as mulheres iguais aos homens ${ }^{399}$. Não hesita em atribuir a uma mulher, a sábia Aspásia, a responsabilidade por sua formação intelectual ${ }^{400}$. O feminino ocupa espaço tão importante em sua filosofia, que seu método compara a aquisição de conhecimento com a função mais inerente à mulher, o parto ${ }^{401}$. Além disso, é apenas frente a uma estrangeira que esse tagarela se cala: no banquete, Diotima

\footnotetext{
393 "Sócrates exigia que a filosofia fosse novamente trazida aos homens. Não existe filosofia popular, nem mesmo má filosofia popular" [Sokrates würde verlangen, dass man die Philosophie wieder zu den Menschen herab hole; es giebt keine oder eine ganz schlechte Popularphilosophie]. NIETZSCHE. Fragmento póstumo de 1874, 30[18].

${ }^{394}$ Nietzsche compara a plebe a um povo inferior. Cf. Crepúsculo dos ídolos. "O problema de Sócrates", §3. Em um fragmento de 1872, 23[14],diz que não é possível fundar uma cultura popular sobre a filosofia. Em outro fragmento de 1888, 14[100], afirma que os genuínos filósofos gregos são os aristocráticos pré-socráticos que estão localizados na margem do povo (com Sócrates alguma coisa é alterada).

${ }^{395}$ Lembremo-nos do Rei Licurgo da Trácia, do Rei Cadmo e seu, o príncipe Penteu.

${ }^{396}$ Cf. PLATÃO. Menon, 82b - 84a.

397 A proposta defendida pelo Sócrates platônico, grosso modo, é que o conhecimento não é ensinado, mas lembrado. Alusão à famosa reminiscência platônica.

${ }^{398}$ Cf. ARISTÓTELES. Política, Livro I, 1259a - 1260b.

${ }^{399}$ Cf. PLATÃO. A República, $454 \mathrm{~d}-454 \mathrm{e}$.

${ }^{400}$ Cf. Idem. Menexêno, 235e - 236a

${ }^{401}$ Cf. Idem. Teeteto, $150 \mathrm{~b}$ e $151 \mathrm{c}$.
} 
assume o papel de porta-voz de uma sabedoria divina, é ela quem ensina Sócrates sobre o ês $\rho \varsigma^{402}$.

Em nossa leitura, essas qualidades de Sócrates o aproximam de Dioniso, pois a dissolução das camadas sociais, que colocam lado a lado o mestre e o escravo, e a divinização do feminino são características íntimas da embriaguez dionisíaca. Contudo, das peculiaridades socráticas, aquela que mais está em consonância com o dionisíaco - agora no sentido nietzschiano do termo - é atribuir à arte o caráter entusiástico, distanciando-a, assim, do conhecimento dialético. Essa compreensão artística está presente no diálogo platônico Íon, no qual o personagem Sócrates tem como interlocutor o rapsodo que se considera o melhor declamador dos versos inspirados em Homero, Íon de Éfeso. O filósofo, com sua habitual artimanha dialógica, leva o rapsodo a concluir que sua poesia

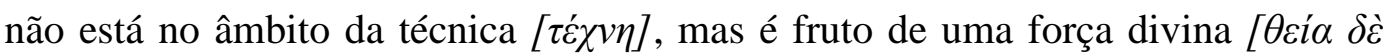
$\delta$ v́vauı $]^{403}$. Isso significa que os poetas não têm conhecimento daquilo que dizem, Íon é incapaz de versar sobre o que faz com conhecimento técnico

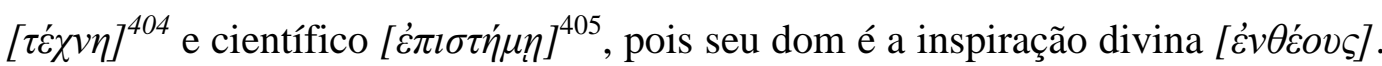
Há nessa perspectiva socrática a ideia de que, para compor, os poetas são

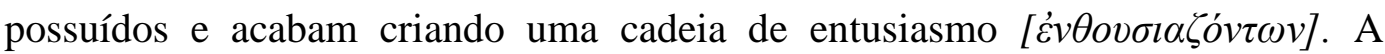
poesia, portanto, não é produto de reflexão ou cognição, mas pura inspiração.

Sócrates compara os poetas ditirâmbicos e os líricos aos sacerdotes Coribantes, na medida em que estes somente dançam quando estão fora de si, e aqueles apenas criam se não estiverem em si. A criação artística ocorre em uma situação de êxtase, enquanto as faculdades cognitivas estão suspensas, ou seja, não há no processo de fruição estética a interferência da razão. Se o Sócrates platônico traz à cena a poesia lírica e o ditirambo, então está também, mesmo que indiretamente, fazendo menção à música. É impossível, portanto, não associarmos o estado de criação descrito à embriaguez dionisíaca, tal como pensada por Nietzsche. A aproximação fica mais evidente quando o filósofo faz uma referência a Bacantes de Eurípides: "os poetas líricos não estão em si quando

\footnotetext{
${ }^{402}$ Cf. Idem. O Banquete.

${ }^{403}$ Cf. Idem. Íon, 533d.

${ }^{404}$ Optamos por evitar traduzir $\tau \dot{\chi} \chi v \eta$ por "arte", para evitar uma ambiguidade na interpretação do que se diz.

${ }^{405}$ Cf. PLATÃO. Op. Cit., 532c.
} 
compõem esses belos poemas; mas, logo que entram na harmonia e no ritmo, são transformados e possuídos como as Bacantes que, quando estão possuídas, bebem rios de leite e mel" ${ }^{\prime 406}$. Diferente da concepção negativa sobre a poesia de $A$ República - a concepção de Platão mais difundida -, na obra Íon, os poetas são reconhecidos como alados, leves e sagrados. São aqueles que, para poder criar, devem ser destituídos do uso da razão. Entretanto, sua irracionalidade não significa que o que fazem se afaste da verdade, pelo contrário, isso nos ensina, argumenta Sócrates, que as coisas admiráveis que dizem, por estar fora do domínio da razão, são divinas.

Afirmar que os versos são palavras ditas pelos próprios deuses significa que a inspiração dos poetas não é outra coisa senão as pulsões do corpo. Se na dicotomia entre instinto e racionalidade um deles é suprimido, então, o outro se impõe. Consequentemente, se no ato de criar, a razão é silenciada, então, são os instintos que falam. Dessa forma, o Sócrates do Íon é uma espécie de antípoda daquele criticado por Nietzsche. Esse Sócrates está próximo às intensidades da vida, ao menos não despreza completamente as vivências instintivas. Ele reconhece a potência da arte e diz invejar os poetas ${ }^{407}$, mesmo que o filósofo esteja sendo irônico em sua afirmação lisonjeadora, uma vez que não abre mão do discurso racional e do logicismo dialético, ele demonstra respeito à poesia. Isso fica visível quando impede Íon de declamar, em vários momentos o rapsodo tenta revelar sua arte, migrar para a esfera artística, ir à poesia; todavia, receoso, Sócrates sempre o persuade a deixar para depois, o constrange a permanecer no campo dialógico, onde tem, em suas mãos, o controle da situação e não corre o risco de perder sua superioridade.

Conquanto, ainda que tenhamos identificado esses atributos que permitem, de certa forma, outorgar a Sócrates um aspecto dionisíaco e, com isso, minimizar as críticas nietzschianas, há uma postura, inerente à imagem do filósofo - figurada em uma de suas últimas atitudes em vida - que elimina o valor de qualquer argumentação em sua defesa. Não estamos nos referindo aqui às suas palavras finais que advertem Críton, logo antes do derradeiro suspiro, sobre uma dívida de

\footnotetext{
${ }^{406}$ Idem. 534a. Cf. também EURÍPIDES. Bacantes, 708 - 711.

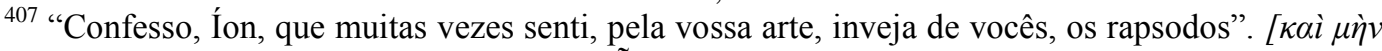

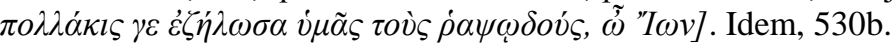


sacrifício a Asclépio, o deus da medicina que não deveria ser esquecida ${ }^{408}$. Um sacrifício em agradecimento a algum deus significa que uma benção foi concedida. Dever um sacrifício ao deus da cura, na hora da morte, significa que a própria morte é a cura, logo, a vida é a doença ${ }^{409}$. Porém, como dissemos, não estamos nos referindo às últimas palavras de Sócrates que, possivelmente, inauguraram a metafísica dualista no Ocidente. Houve naquela prisão, momentos antes, ato ainda mais infame, que por sua vez, foi completamente ignorado por Nietzsche, no entanto, desvela irremediavelmente a natureza anti-dionisíaca de Sócrates, assim como todo o seu ódio contra a vida e às coisas simples desse mundo de cá: Sócrates expulsa, da prisão, as mulheres! $!^{410}$

Esse ato revela que a filosofia socrática levada às ruas da pólis, o lugar onde a vida acontece, não diz respeito às coisas da vida mesma, são sobre essas coisas inerentes à vida que as mulheres falam. Sócrates despreza essas coisas, assim como despreza a própria vida; ele prefere que seu último diálogo filosófico verse sobre temas que considera superior: a alma, as ideias, o bem. Além disso, não aceitá-las no momento que antecede o enigma da morte é o mesmo que não admitir o mistério que o feminino simboliza; para Sócrates, a verdade deveria ser totalmente despida a qualquer preço ${ }^{411}$. Além disso, enxotar as mulheres é o mesmo que afugentar os instintos, pois elas são, alegoricamente, mais instintivas. Sim, essas estrangeiras, sacerdotisas que instruem sobre o amor; essas Pítias de discursos irracionais; essas Mênades da razão são corporalmente mais sensitivas e, por isso, símbolo de saúde.

De acordo com o itinerário de $O$ Nascimento da tragédia, a degeneração da arte iniciada com Sócrates culminou naquilo que o filósofo identificou como cultura de ópera. Nessa perspectiva, o teatro de ópera seria a criação do homem teórico, do crítico leigo e o produto mais estranho da cultura alexandrina. Exatamente por isso, não pode ser considerada, segundo Nietzsche, obra de

\footnotetext{
${ }^{408}$ As últimas palavras de Sócrates forma: "Oh Critón, devemos um galo a Asclepio! Paga-o! Não

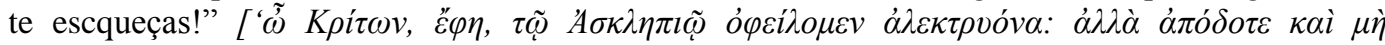
$\dot{\alpha} \mu \varepsilon \lambda \dot{\eta} \sigma \eta \tau \varepsilon . ']$. Cf. Ibidem. Fédon. 118a.

${ }^{409}$ Cf. NIETZSCHE. A Gaia Ciência. "Sócrates moribundo", §340.

${ }^{410}$ Cf. PLATÃO. Op. Cit., 60b; 116b; 117e.

411 "Pronunciar a verdade a qualquer custo é socrático". [Das Aussprechen der Wahrheit um jeden Preis ist sokratisch]. NIETZSCHE. Fragmento póstumo de 1873, 19[97].
} 
genuínos $\operatorname{artistas}^{412}$. Não obstante, em contraposição a esse estilo de música essencialmente burguesa, os ouvidos nietzschianos percebem nas composições wagnerianas a potência dionisíaca e, por consequência, a exigência de uma audição trágica. Isso seria indício da possibilidade de uma renovação da cultura moderna. Richard Wagner será, portanto, de fundamental importância para a concepção do dionisíaco na modernidade. Esse é o tema que ocupará agora a nossa atenção e será desenvolvido na próxima seção.

${ }^{412}$ NIETZSCHE. O Nascimento da tragédia, $\$ 19$. 


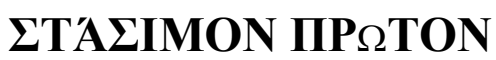

\section{1.}

Wagner e a esperança do renascimento do dionisíaco na Alemanha:

Nietzsche, após analisar, no Nascimento da tragédia, a queda do dionisíaco a partir do racionalismo socrático, volta suas atenções para as influências que tal racionalismo marca na cultura moderna. Para melhor compreensão deste fato, devemos enfatizar a distinção entre cultura socrática e cultura trágica: enquanto a cultura trágica é caracterizada por uma constante afirmação da existência e pelo arrebatamento musical, a cultura socrática é marcada pelo amor ao saber, pela negação do dionisíaco em virtude da razão, tendo como efígie o homem teórico.

Não há maneira mais nítida de caracterizar esta cultura socrática, diz Nietzsche, do que denominá-la "cultura de ópera”. A primazia da palavra e o otimismo do homem teórico são os principais elementos que constitutuem este estilo. Na seção 19 de $O$ Nascimento da tragédia, o filósofo reflete sobre a origem da ópera e escreve: “Ópera é 'obra' do homem teórico, do crítico leigo e não do artista: um dos fenômenos mais estranhos da história de todas as artes". Em termos históricos, a ópera tem seu surgimento no final do século XVI, quando, na Itália, um grupo de intelectuais e músicos, chamado Camerata Fiorentina, procurava uma possibilidade de fazer renascer a antiga arte musical. Uma das estratégias do grupo foi pesquisar profundamente a música grega, principalmente a relação que a melodia estabelecia com a palavra nas tragédias áticas. O novo estilo criado pelo grupo era, portanto, uma tentativa de renascimento da arte trágica.

No entanto, segundo Nietzsche, a ópera não dá continuidade à tragédia, pelo contrário, o homem da ópera cria uma nova forma de arte que se afasta, completamente, da música dionisíaca. A ópera não é mais a racionalização da música. Nesse estilo, o elemento sonoro torna-se escravo do texto, da palavra e da aparência dos fenômenos. Em outras palavras, a música é destituída de seu caráter de acesso à totalidade do mundo, passando a ser mera imitação da 
realidade fenomênica, aproximando-se mais à música literária do que à tragédia propriamente dita.

A ópera do homem teórico-socrático, além destas características, em sua poética, abarca a crença de que é possível criar uma versão menos sombria da existência, ou seja, transmite a ideia de que o homem é naturalmente bom. Ainda que, a partir dessa crença tenha surgido uma oposição ao dogma cristão, no qual o homem está predestinado ao mal e à condenação, estas ideias geram outro dogma: de que o homem em sua origem é bom e virtuoso. Desse modo, é gerada uma visão menos trágica da vida, uma visão de otimismo teórico. Contudo, na análise nietzschiana, houve ao longo do tempo, um certo despertar do instinto dionisíaco, de forma que o espírito alemão apoderou-se de um poder distinto daquele da cultura socrática, e foi capaz, então, de caminhar pelo poderoso "curso solar que vai de Bach a Beethoven, de Beethoven a Wagner"1. Isso, na prática, significa que os compositores alemães desviaram-se da melodia operística que, por sua vez, costurava a música à "tábua aritmética da fuga e da dialética contrapontística"². Com isso eles caminhavam pouco a pouco em direção à música extática. O que atingiu o ápice em Richard Wagner.

O êxtase dionisíaco, aniquilador de individualidades, é reconhecido na obra wagneriana, pois, precisamente, a música volta a ter seu devido lugar: a palavra e a imagem voltam a exercer, como na tragédia, a função que cabia antes ao elemento apolíneo, isto é, proteger o homem da angústia e da aniquilação de si próprio. Seria impossível, diz Nietzsche, escutar a música dionisíaca sem a proteção da "miserável concha de vidro da individualidade humana"3. Para o filósofo, os músicos autênticos saberiam da impossibilidade de escutar o terceiro ato de Tristão e Isolda sem o socorro da palavra e da imagem, se isso ocorresse o risco de sucumbir a "um prodigioso movimento sinfônico, e que, sob um espasmódico desdobrar de todas as asas da alma, não venha a expirar" ${ }^{4}$. A força apolínea salva o espectador de uma total aniquilação acometida por emoções excessivamente fortes. Nesse sentido, a música de Wagner era o verdadeiro modo

\footnotetext{
${ }^{1}$ NIETZSCHE. O Nascimento da tragédia, §19

${ }^{2}$ Idem.

${ }^{3}$ Idem. 21 .

${ }^{4}$ Idem.
} 
para se conhecer a essência do mundo, pois ela consistia em uma linguagem que expressava diretamente a vontade, núcleo do mundo.

As emoções "excessivamente fortes" fazem parte das características essenciais da superioridade de Wagner em relação a seus antecessores. Acerca destas características, Nietzsche fez uma análise na Quarta consideração extemporânea Richard Wagner em Bayreuth, onde descreve a música wagneriana como linguagem do páthos, ou seja, "do querer apaixonado das chamas que se desenrolam no interior do homem". Assim sendo, pode-se dizer que em Richard Wagner em Bayreuth a música passa a fazer conhecer as íntimas contradições humanas. Por outro lado, a música, antes de Wagner, segue as convenções do êthos, isto quer dizer que a música estava associada à medida, não havia permissão para excessos contraditórios de sentimentos: todo excesso e desmedida eram considerados antiéticos. Essa música pré-wagneriana correspondia a estados permanentes dos homens, exatamente o que os gregos consideravam como êthos. Desta forma, o "êthos-musical" representa as composições que se inspiravam em estados únicos e não contraditórios de sentimentos, estados de alegria ou calma, de recolhimento ou de arrependimento; nunca uma mesma frase musical exprimia duas paixões diferentes.

No entanto, com o drama musical wagneriano são ultrapassadas estas limitações, a música passa a exprimir forças múltiplas das paixões. Sua música diz respeito ao páthos. Só ele conseguiu ${ }^{6}$, segundo Nietzsche, unir em uma mesma frase musical as contradições existentes nas paixões, "um verdadeiro arabesco de sons desenhado pela paixão", diz Baudelaire em um texto apologético dedicado à passagem de Wagner em Paris, e ainda se refere à obra Tannhäuser com as incríveis descrições:

Desde os primeiros compassos os nervos vibram em uníssono com a melodia; toda carne que se recorda põe-se a tremer. Todo cérebro bem conformado traz em si dois infinitos, o céu e o inferno, em toda imagem de um desses infinitos reconhecem-se subitamente a metade dele próprio. As titilações satânicas de um vago amor logo

\footnotetext{
${ }^{5}$ Ibidem . Richard Wagner em Bayreuth, §9.

${ }^{6}$ Para Nietzsche, nem mesmo Beethoven representa o páthos na música, mesmo sendo ele quem começa a usar a linguagem proibida da paixão, sua arte estava impregnada das leis e convenções existentes no éthos, e assim tentando falar o páthos com recurso do éthos deixou suas obras um tanto confusas. Só Wagner, diz Nietzsche, consegue fazer a música expressar com veracidade a "dinâmica sonora dos sentimentos e da paixão". Cf. NIETZSCHE. Fragmento póstumo de 1875, $11[5]$.
} 
sucedem a impulsos, deslumbramentos, gritos de vitória, gemidos de gratidão, (...) o gozo carnal conduzido por uma lógica satânica inelutável, às delícias dos crimes ${ }^{7}$.

No século XVII e XVIII, era normal uma ópera durar de quatro a cinco horas, o espectador tinha a liberdade de sair da sala de espetáculos para conversar, comer e até jogar cartas, na maioria das vezes, voltava apenas para os momentos mais famosos. O mais importante para o espectador era a sensação de controle sobre o que estava sendo experimentado. Por isso, existia uma tipificação dos sentimentos: ária di furore (furor), ária parlato (agitação), aria cantabili (ternura). Não se esperava uma vivência extática da totalidade da peça, símile à revelação do verdadeiro Uno existente, porém, tão só a experimentação de partes fragmentadas, de pequenas frases correspondentes a fenômenos particulares.

Investindo toda sua força contra este tipo 'burguês' de espectador, Wagner exigiu o nascimento de um novo público, com qualidade de concentração e sem a ansiedade frente ao mundo das emoções. $\mathrm{O}$ ouvinte teve que aprender a guardar suas inquietudes para si e suas lágrimas para o fim. Nietzsche entusiasmado, vê nesse novo modelo wagneriano a possibilidade de novamente experimentar uma "audição trágica". Agora o espectador poderia novamente ser arrastado por um desenfrado êxtase e, indefeso, ficaria à deriva emocional. Isto era umas das grandes habilidades de Wagner, o 'ataque' dionisíaco ${ }^{8}$. Por isso, a obra de Wagner adquire, para o jovem Nietzsche, o significado de "ressurgimento do trágico". Além disso, o compositor fez da música linguagem da própria natureza:

Nós podemos afirmar, com a maior certeza, que na obra de Wagner, tudo que é vivível no mundo quer se aprofundar e se interiorizar, tudo que é audível procura emergir e manifestar-se à vista e à luz, quer, de alguma forma, corporificar-se. Sua arte o conduz sempre por esses dois caminhos, que vão de um mundo da audição a um mundo enigmaticamente próximo ao drama visual, e inversamente ${ }^{9}$.

No entanto, Wagner não compartilhava com Nietzsche o pensamento de superioridade da música em relação às demais artes, para ele a primazia da música sobre o texto era um erro. O compositor almejava 'uma obra de arte total'. (Gesamtkunstwerk), onde poesia, dança e música estão a serviço do drama

\footnotetext{
${ }^{7}$ BAUDELAIRE. Richard Wagner e Tannhäuser em Paris. p. 53.

${ }^{8} \mathrm{Cf}$. CAZNOK, Yara Borges. Ouvir Wagner e MILLINGTON. Wagner, um compêndio.

${ }^{9}$ NIETZSCHE. Richard Wagner em Bayreuth, §5. Nesta Extemporânea, Nietzsche, ao se referir à música e à palavra, não usa mais as dicotomias Apolo e Dionísio, usa, audível e visível.
} 
musical. Para ser capaz de comunicar os sentimentos e revelar o que traz em si, a música precisa das palavras e dos gestos do mundo visível. Pensando nesta dissonância de ideias com Wagner, e para não refutar o projeto de obra de arte total, Nietzsche reformula seus pensamentos a respeito da relação entre música e palavra na Quarta extemporânea: em sua primeira obra, a música é totalmente autônoma, é expressão simbólica e universal do Ser, enquanto a aparência, ou seja, a palavra, nunca poderia exprimir perfeitamente a profundidade do Ser; já em Richard Wagner em Bayreuth, a música necessita do visível para expressar o páthos.

De acordo com Richard Wagner em Bayreuth, mesmo que a palavra esteja distante da coisa que representa, ela ainda é capaz de expressar a realidade de forma verdadeira, isso, porque o compositor faz uso de uma linguagem que é repensada por meio da sua musicalidade. Para ser capaz de expressar o páthos, a estratégia empregada é escrever os libretos sem os rigores da lógica, privilegiando, então, as expressões populares e proverbiais, caracterizadas por sua carga sentimental. Outra técnica utilizada por Wagner era a aliteração, ou seja, o sentimento evocado pela musicalidade das palavras passa a ser o critério para sua escolha, não se empregava um termo devido ao seu significado semânticoconceitual, todavia, a sonoridade passa ser o critério de sua utilização. Desse modo, o texto estava, invariavelmente, envolvido e submerso na melodia. Compor dessa forma indicava, para Nietzsche, o tal renascimento da audição dionisíaca na Alemanha moderna. Sobre seu método de composição, Wagner faz a seguinte declaração em 1844:

Eu não costumo escolher um assunto a esmo a fim de versificá-lo e então imaginar uma música adequada a ele (...). Não, meu método de produção é diferente disto: em primeiro lugar sinto-me atraído somente por aqueles assuntos que se revelam não apenas poeticamente significativos, mas que tenham também um significado musical. Assim sendo, antes de rabiscar uma cena ou a escrever uma única linha de texto, já estou completamente imerso na aura musical da minha nova criação ${ }^{10}$.

Conquanto, a principal característica da composição de Wagner que, definitivamente, o distingue da cultura estético-socrática, vinculando-o, então, à cultura trágica, é o fato de recorrer ao pensamento mítico. O modo como o homem primitivo, de um tempo mais excelso, construía a imagem de si mesmo,

\footnotetext{
${ }^{10}$ WAGNER, Richard. Apud. MILLINGTON. Wagner, um Compêndio, p. 278.
} 
do seu povo e do seu destino era a partir de um pensamento mitológico. Wagner recorrerá novamente a esse modo: os mitos antigos, principalmente os germânicos, são o tema central de seus dramas. Podemos dizer que, na figura do compositor, mito e música estão unidos novamente. Para Nietzsche, o resultado da união entre a música e o mito, as duas formas mais antigas de conhecimento intuitivo, foi a criação de uma obra que vinculava, novamente a arte e a vida. Pensando nisso, Wagner também corresponderia à possibilidade de uma justificação estética da existência.

Assim sendo, o compositor de Tristão e Isolda corresponde, no primeiro pensamento estético nietzschiano, ao dramaturgo ditirâmbico; isto quer dizer que ao ouvir o drama musical wagneriano, haverá uma "ponte entre o eu e o não-eu", a música transportará o "ouvinte trágico" para fora de si, de sorte que, não reconhecendo as coisas à sua volta e nem a si mesmo, o ouvinte atingirá o ápice das emoções, e, acompanhando a aniquilação do herói no palco. Experimentará, então, uma alegria extremamente forte e uma postura jubilosa em relação à vida. Isto é para Nietzsche o significado definitivo da obra wagneriana: reconquistar a sabedoria trágica, isto é, encontrar a afirmação da vida a partir da transfiguração do indivíduo, mesmo com toda a dor e incerteza da morte.

Com o exposto, verificamos que Wagner exerce na filosofia nietzschiana, do período de $O$ Nascimento da tragédia, uma enorme influência. O compositor, sob a égide de seus personagens representa, nesta primeira fase, o melhor que há para se pensar artisticamente. Como um herói, Wagner quebra as tábuas de preceitos que conduziram a arte, principalmente a música, para uma esfera inferior. Na visão nietzschiana, o compositor prefigura a salvação do melhor que se produziu culturalmente. A obra wagneriana é vista, portanto, como o espelho que reflete a tragédia antiga em solo alemão e, por isso, a esperança de renovação da cultura. Todavia, esse pensamento não é definitivo, pelo contrário, sofre uma radical ruptura, marcando então uma nova fase na filosofia de Nietzsche. Pensando nisto, depois dessa breve análise dos aspectos aos quais Richard Wagner é apresentado como o recriador da arte trágica, vemo-nos obrigados a elucidar a tempestuosa cisão ocorrida entre ambos. Nietzsche, após essa cisão, toma Wagner não mais como a representação moderna do que melhor se pode produzir esteticamente, mas como maior exemplo de uma cultura em decadência. 


\section{2.}

\section{Parsifal: eis o tilintar de duas espadas que se cruzam:}

Em 13 de agosto 1876, um evento ímpar ocorre na Baviera, um acontecimento tão importante que é marcado pela presença de vários representantes da nobreza, tais como o Kaiser Wilhem II; o Rei Luis II, da Baviera; Dom Pedro II, do Brasil ${ }^{11}$; e por compositores como Pyotr Tchaikovsky e Franz Liszt; e ainda, pelo jovem professor de filologia, Nietzsche. Trata-se da inauguração do Richard-Wagner-Festspielhaus, ou simplesmente, Bayreuth Festspielhaus. O teatro foi construído de acordo com as especificações minuciosas do compositor. Ele exigiu mudança no formato das galerias e da localização da orquestra, que passou a ficar em um foço logo à frente do palco. A inauguração do teatro marca o primeiro Festival de Bayreuth, com a estreia de Das Rheingold, abertura da tetralogia Der Ring des Nibelungen, drama composto por Wagner para ser exibido em quatro noites: a primeira noite executava o prelúdio Das Rheingold; na segunda noite Die Walküre; na terceira, Siegfried e por fim, Götterdämmerung. Nietzsche assiste só a primeira parte do prelúdio, retira-se com fortes dores de cabeça e, a partir de então, começa a elaborar uma nova forma de filosofar, radicalmente oposta ao seu pensamento influenciado por Schopenhauer e por Wagner.

Sobre esta ocasião, Nietzsche escreve em Ecce homo, que não havia reconhecido Wagner, o compositor estava ornado de virtudes alemãs, o wagnerismo se assenhoreou de Wagner. ${ }^{12}$ No entanto, para compreender melhor esta ruptura entre o filósofo e o músico, devemos salientar que Nietzsche, antes mesmo do anúncio público de seu novo filosofar em 1878, já havia oferecido críticas ao compositor. Em 1874, por exemplo, antes de publicar a Quarta extemporânea, escreve a seguinte nota em relação a Wagner, por ele conceber a música como obra de arte secundária:

\footnotetext{
${ }^{11}$ Dom Pedro II era um grande admirador de Wagner e um dos ilustres convidados para o festival. Nietzsche ainda se esbarraria com ele em outras duas ocasiões: em Rosenlauibad, um balneário próximo a Meiringen na Suiça, onde, em 1877, o imperador havia se hospedado com sua imperatriz e uma comitiva de 17 pessos (cf. cartõs postais de Nietzsche a mãe e a irmã de $10 \mathrm{de}$ agosto de 1877); e em 1888, Nietzsche assiste um concerto em Monte Carlo onde também se encontrava o imperador. (Cf. Carta de 6 de janeiro de 1888 - [Apêndice $\alpha$ ]).

${ }^{12}$ Cf. NIETZSCHE. Ecce homo, "Humano Demasiado Humano", §2.
} 
Wagner qualifica como um erro o fato de, no gênero artístico ópera, um meio expressão, a música, tenha se tornado a finalidade, enquanto a finalidade de expressão tornava-se um meio. Logo [isso significa que Wagner] tem a música por meio de expressão - muito característico do autor. Há pouco perguntávamos, a propósito de uma sinfonia: se a música é ali um meio de expressão, qual é então a finalidade? Esta não pode, portanto, residir na música: o que é, segundo sua natureza, um meio de expressão deve ter consequentemente alguma coisa para expressar: Wagner pensa no drama. Sem o drama, ele considera a música uma monstruosidade; o que sugere essa pergunta: 'Com que então rima o barulho?' É por essa razão que considerava a Nona Sinfonia a obra mais importante de Beethoven, porque ali, por introdução da palavra, ele dava à música seu sentimento de meio de expressão ${ }^{13}$.

Estas críticas se tornam mais pesadas no livro escrito doze anos após a publicação de Richard Wagner em Bayreuth - O Caso Wagner. Nessa obra, Wagner é atacado por representar a décadence da arte musical. Segundo Nietzsche, o compositor não deveria nem pertencer à história da música, pois dentro desta história ele representaria a ascensão do ator na música. E o que significa isto? A cultura em declínio. "Apenas o ator ainda desperta o grande entusiasmo, é um acontecimento perigoso e capital, este é o sucesso da massa, submeter a música aos efeitos dramáticos. O importante no palco wagneriano é o expressivo a todo custo, isto é, o seu ideal, o ideal da décadence,"14. E é exatamente por fúria contra esse ideal que Nietzsche faz este apelo: "'as três exigências que desta vez, minha ira, minha preocupação e meu amor à arte deram voz? Que o teatro não se torne o senhor das artes. Que o ator não se torne senhor dos autênticos. "Que a música não se torne uma arte da mentira"15.

Os ataques a Wagner não se resumem apenas ao fato de ele ter criado uma "retórica teatral", na tentativa de aumentar desmesuradamente a capacidade de expressão da música ${ }^{16}$. Para Nietzsche, a música se tornou ruim, brutal e artificial. A música wagneriana é fisiologicamente e psicologicamente maléfica. A respeito disto, Nietzsche escreve em A Gaia ciência:

\footnotetext{
${ }^{13}$ NIETZSCHE, Fragmentos póstumos, 1874, 32.

${ }^{14}$ NIETZSCHE. O Caso Wagner, $\S 11$.

${ }^{15}$ Idem. $\$ 11$.

${ }^{16}$ Idem. \$8.
}

Minhas objeções à música de Wagner são fisiológicas: por que disfarçá-las em fórmulas estéticas? Afinal, a estética não passa de fisiologia aplicada. - Meu "fato", meu "petit fait vrai [pequeno fato verdadeiro]", é que já não consigo respirar direito, quando essa música me atinge; logo o meu pé se irrita com ela e se revolta: ela necessita de compasso, dança, marcha - ao som da Kaisermarsch, de Wagner, nem mesmo o jovem Kaiser pode marchar -, ele requer, da música, primeiramente as delícias do bom andar, caminhar, dançar. Mas também não 
protesta meu estômago? Meu coração? Minha circulação? Não se turvam minhas vísceras? Não fico inesperadamente rouco? ... Para ouvir Wagner necessito de pastilhas Gérandel... Então me pergunto: o que quer mesmo da música o meu corpo inteiro? Pois não existe alma ... O seu próprio alívio, creio: como se todas as funções animais fossem aceleradas por ritmos leves, ousados, exuberantes, seguros de si; como se áureas ternas lisas melodias tirassem o peso da brônzea, plúmbea vida. Minha melancolia quer descansar nos esconsos e abismos da perfeição: para isso necessito de música. Mas Wagner torna doente. $-{ }^{17}$

Ainda na obra $O$ Caso Wagner, pondera que este décadent nos estraga a saúde, o encara como uma doença, que torna doente tudo o que toca, assim tornou doente a música. Sua música é doente, pois os problemas que põe no palco são problemas histéricos. "Em sua arte encontram-se misturado de maneira sedutora, aquilo que o mundo hoje tem mais necessidade - os três grandes estímulos dos exaustos: o elemento brutal, o artificial e o inocente (idiota)" ${ }^{\prime 1}$. Atentando para este caráter da crítica nietzschiana, percebemos a relação que foi postulada entre arte e corpo. Assim como aprofundaremos mais tarde nesse trabalho, a arte passou a ser reconhecida por Nietzsche, em dicotomia com a metafísica do artista, como estritamente fisiológica. Nesse sentido, o eixo central da crítica nietzschiana às obras wagnerianas é, definitivamente, o seu ideal ascético. Wagner havia convertido a música em um instrumento de propagar a negação do corpo.

Richard Wagner teria, portanto, mudado de pensamento em relação à supremacia da música a ponto de fazer surgir uma contradição na sua teoria estética. Ao modificar rudemente seu juízo sobre o valor e o status da música, antes concebida como meio, um medium que para crescer necessitava de um fim, o drama. Mas influenciado por Schopenhauer, passa a compreender a música como elevada em relação às demais artes. A música é vista, então, como soberana e independente em si, ela não diz respeito ao fenômeno, como as outras artes, mas fala a linguagem da vontade mesma, e o faz de forma imediata ${ }^{19}$. Ao aumentar de

\footnotetext{
${ }^{17}$ NIETZSCHE. Nietzsche contra Wagner. "No que faço objeções".

18 "die drei grossen Stimulantia der Erschöpften, das Brutale, das Künstliche und das Unschuldige (Idiotische)". Ibidem. O Caso Wagner, §5.

${ }^{19}$ Ana Hartmann, em uma nota explicativa de sua tradução do ensaio Beethoven explica: "Wagner, no período em que escreveu Ópera e drama (1851), colocara em questão a primazia conferida pela estética clássica à música absoluta, puramente instrumental, tendo em vista a concepção de uma obra de arte total. Nesse período, Wagner interpretou a Sinfonia n.9, na qual Beethoven introduz na orquestra o canto coral, como uma confissão dos limites da música absoluta, desenvolvendo a concepção de um drama musical que realizasse plenamente aquilo que fora apenas sugerido pela Nona, ou seja, a união dos efeitos recíprocos da poesia e do canto, da palavra e da música sinfônica. No entanto, no presente ensaio, a partir da filosofia de Schopenhauer, Wagner modifica sua concepção, considerando a música o mais claro comentário de um acontecimento, capaz por isso de revelar a essência da ação dramática". Cf. WAGNER, Richard. Beethoven. Nota 44.
} 
forma prodigiosa o valor da música, ascendeu também o valor do músico. Para Nietzsche, o músico "tornou-se um oráculo, um sacerdote, do "em-si das coisas", um porta-voz do além - já não falava apenas música, esse ventríloquo de Deus falava metafísica: como admirar que um dia falasse em ideais ascéticos?"20

Nietzsche reconhece duas fases em Wagner, uma sob influência do filósofo Feuerbach e outro regido pelas ideias de Schopenhauer. Na primeira, encontra-se na produção wagneriana a afirmação da vida, e no segunda a negação da vontade. Ludwig Feuerbach, com um pensamento particularmente ateu, proclamava uma nova religião para a humanidade. Para ele, deus era concebido apenas como uma projeção das esperanças e das necessidades dos seres humanos, uma religião só faria sentido se afirmasse a supremacia do amor sobre todos os demais preceitos religiosos ${ }^{21}$. A "gloriosa necessidade do amor" feuerbachiana influenciou profundamente o compositor. É nítida essa influência em Das Rheingold (O ouro do Reno) e Sigfried, nestas obras é evidente uma sensualidade nas personagens; não existe negação da vida, do corpo e, nem mesmo, a castidade tão evidente em sua última peça, Parsifal. Para ilustrar isto, é só pensar na personagem Sigfried, o herói filho do adultério e do incesto, desde o nascimento proclama guerra à lei e à moral; afirmando a sexualidade, sua meta é o sacramento do amor livre. No entanto, esta fase da "era dourada do crepúsculo dos ídolos e da velha moral"22 acaba. E como acaba? Veja as palavras de Nietzsche:

Por longo tempo a nave de Wagner seguiu o seu curso. Sem dúvida Wagner buscava nele o seu mais elevado objetivo - Que aconteceu então? Um acidente: a nave foi de encontro a um recife; Wagner encalhou. O recife era a filosofia schopenhauriana; (...) E ele traduziu o Anel schopenhauriano. Tudo vai torto, tudo afunda, o novo mundo é tão ruim quanto o velho ${ }^{23}$.

Nietzsche atribuiu a Schopenhauer os instintos niilistas presentes em Wagner, segundo ele, os ideais ascéticos estariam longe de se colocar independentemente no mundo, antes, necessitam de um amparo, uma proteção. No caso de Wagner, a autoridade é Schopenhauer. O ascetismo presente nas obras wagnerianas tem, portanto, íntima relação com a filosofia ética schopenhauriana e

\footnotetext{
${ }^{20}$ NIETZSCHE. A Genealogia da moral. "Terceira dissertação", §5.

${ }^{21}$ Cf. MILLINGTON. Wagner, um compêndio. p. 29.

${ }^{22}$ NIETZSCHE. $O$ caso Wagner, $\S 4$.

${ }^{23}$ Idem.
} 
a negação da vontade praticada pelos "santos". O raciocínio de Nietzsche é genealógico: influenciado por Kant, que distanciava o belo artístico dos apetites, Schopenhauer concebe a arte como redentora dos desejos, ou como vimos, a contemplação estética agiria como um antídoto para a vontade, e, dessa forma, contra o interesse sexual ${ }^{24}$.

Além da ascese e negação da vida, outro elemento da filosofia schopenhauriana que influencia diretamente as obras de Wagner é a ética pautada na compaixão. Essa questão está presente de forma explícita na sua última obra, Parsifal, e na última parte do ciclo Der Ring des Nibelüngen, o Götterdämmerung. Wagner chega a mudar o texto conclusivo da última área do Crepúsculo dos deuses, devido à leitura de $O$ mundo como vontade $e$ representação. Antes, no libreto original, escrito em 1852, o final da peça aludia à supremacia do amor, os versos carregavam uma forte influência da filosofia de Feuerbach, por isso, ficou conhecido, posteriormente, como "final feuerbachiano". Esses versos foram substituídos por outros impregnados de sofrimento e niilismo. Não só as palavras, mas toda a encenação é envolta na negação: no último ato Brünnhilde se lança na pira funerária de Sigfreid e suicida-se, praticando a autoimolação. O final escolhido por Wagner é conhecido como "final schopenhauriano" 25 e apesar do apelo emocional supostamente trágico, representa, segundo Nietzsche, a negação do espírito trágico e a negação em grau máximo.

Apesar de outras obras como Tannhäuser e Lohengrin possuírem uma certa tendência religiosa, só em Parsifal é representado, de forma acentuada, o ideal ascético que Nietzsche tanto recriminava. Ele esperava que Wagner tivesse se despedido de uma forma mais digna, gostaria que Parsifal tivesse sido uma brincadeira, um drama satírico, no qual o "trágico Wagner" quisesse se despedir encenando uma comédia, tal qual ocorria nos festivais na Grécia antiga. Isso

\footnotetext{
24 “Schopenhauer fez uso da concepção kantiana do problema estético - embora certamente não o contemplasse com olhos kantianos. ( quero apenas sublinhar que Kant, como todos os filósofos, em vez de encarar o problema estético a partir da experiência do artista (do criador), refletiu 1 sobre a arte e o belo apenas do ponto de vista do "espectador", e assim incluiu, sem perceber, o próprio "espectador" no conceito de "belo". Se ao menos esse "espectador" fosse bem conhecido dos filósofos do belo! - (...). "Belo", disse Kant, "é o que agrada sem interesse." Sem interesse!". NIETZSCHE. A Genealogia da moral. "Terceira dissertação", §6.

${ }^{25}$ É importante esclarecer que em nenhum momento Schopenhauer faz algum elogio ao suicídio, pelo contrário, para ele essa escolha capital seria a afirmação máxima da vontade. Cf. SCHOPENHAUER, Arthur. O Mundo como vontade e representação. \$69.
} 
corresponderia à sua grandeza e superioridade. No entanto, não é com este "sarcasmo trágico" que Wagner se despede; preferiu uma obra católica, schopenhauriana, casta e enganadora. Em sua autobiografia, Nietzsche comenta que quando finalmente teve seu livro Humano, demasiado humano em mãos, enviou dois exemplares para Bayreuth, e por um milagre, no sentido do acaso, recebeu simultaneamente um belo exemplar de Parsifal, com a dedicatória: " $A$ meu caro amigo Friedrich Nietzsche, Richard Wagner, conselheiro eclesiástico". Para o filósofo, no cruzamento dessas duas obras pareceu ouvir um ruído ominoso, como o tilintar de duas espadas que se cruzam ${ }^{26}$.

A trama de Parsifal é inspirada por lendas medievais sobre a busca do Santo Graal. Uma das suas principais características é, sem dúvida, a articulação com a moral. Os personagens possuem enraizados os preceitos de bem e mal. Na trama, o reino dos Cavaleiros do Santo Graal, guardiões das últimas relíquias cristãs - o cálice que teria guardado o sangue de Cristo e a lança que o teria ferido representam o reino do bem. O protagonista, Parsifal, assume o papel de herói casto, que impregnado de compaixão nega e combate a sensualidade. Isto é exposto no drama quando a feiticeira Kundry, sob o comando de Klingsor, o maior representante do mal, tenta a todo custo roubar as relíquias sagradas, para isso ela tenta seduzir Parsifal, que reconhece a relação como impura. Há na peça uma voz representando Cristo, o Redentor que salva o herói do sentimento de culpa. O drama Parsifal vai contra a cultura trágica, negando os instintos, Wagner nega a natureza e, consequentemente, nega a vida. Nietzsche abomina o ascetismo no compositor, criticando-o veementemente, como mostra o excerto:

(...) eu fui um dos mais corruptos wagnerianos... Eu fui capaz de levar Wagner a sério... Ah, esse velho feiticeiro! Como nos iludiu! A primeira coisa que sua arte nos oferece é uma lente de aumento: olhando por ela não se acredita nos próprios olhos - tudo fica grande, até Wagner fica grande... Que astuta cascavel! Toda a vida ela nos falou ruidosamente em "dedicação", "fidelidade" e "pureza" com um elogio à castidade tirou-se do mundo - depravado! - E nós acreditamos $(. . .)^{27}$

\footnotetext{
${ }^{26}$ NIETZSCHE. Ecce homo. "Humano, demasiado humano", §5.

${ }^{27}$ NIETZSCHE. O Caso Wagner, $\$ 3$.
} 
As análises da relação de Nietzsche e seu antigo mestre, para terem o cunho de seriedade, nunca devem partir de um viés exclusivamente psico-afetivo, como uma questão de mero ressentimento, por exemplo. Richard Wagner é, na verdade, assim como Sócrates e Eurípides, outro símbolo que permite ao filósofo pensar e avaliar a cultura moderna. É claro que a convivência real com compositor, naqueles que foram os anos mais felizes de Nietzsche ${ }^{28}$, faz desse símbolo algo muito significativo. As críticas ao compositor possuem, portanto, inúmeros desdobramentos: elas vão desde questões estético-musicais a problemas éticopolíticos, além é claro, de evidenciar a degeneração cultural das sociedades ocidentais modernas. Ademais, podemos dizer que Wagner-símbolo feriu mais Nietzsche que o compositor mesmo. Wagner-homem, era para Nietzsche um mestre, uma referência, tal como Ritchel. Este último também decepcionou profundamente Nietzsche, mas não se tornou alvo de censura filosófica. Já Wagner-símbolo, era a esperança de renovação da cultura; a expectativa invernal de um novo sol e uma nova aurora, suas músicas soavam, para o jovem pupilo, como os ditirambos de Dioniso. Ver Wagner em Bayreuth "ornado de virtudes alemãs" 29 , foi o mesmo que ver todos os seus projetos, sonhos e esperanças se consumirem como Valhala.

Pensando nisso, a decepção de Nietzsche foi tamanha, que as suas formulações filosóficas baseadas em Richard Wagner perderam o sentido. Dessa forma, o dionisíaco deixa de ocupar espaço no pensamento nietzschiano. Dioniso como símbolo de uma cultura superior estava muito associado a Wagner. Por consequência, nosso filósofo silenciará, ao menos por um tempo, qualquer referência à "divindade-conceitual”. Os significados e o desarolar desse silêncio será o assunto de nosso próximo Episódio.

\footnotetext{
28 "Com Richard Wagner e com a senhora Cosima Wagner eu estive unido em profunda confiança e íntima harmonia por alguns anos que pertencem aos mais valiosos de minha vida. Se eu agora sou um dos oponentes do movimento wagneriano, então, como é evidente, não é por motivos mesquinhos". ["Mit Richard Wagner und Frau Cosima Wagner war ich einige Jahre, die zu denwerthvollsten meines Lebens gehören, in tiefem Vertrauen und innerstem Einvernehmen verbunden. Wenn ich jetzt zu den Gegnern der Wagner'schen Bewegung gehöre, so liegen, wie es sich von selbst versteht, dahinter keine mesquinen Motive"]. Carta de Netzsche a Karl Knortz de 21 de junho de 1888 .

${ }^{29}$ Cf. Ibidem. Ecce homo. "humano, demasiado humano", §2.
} 


\section{5 \\ 'EחEIZOAION $\Delta E^{\prime} Y T E P O N$}

\section{1. \\ O monumento de uma crise (e o silêncio de Dioniso):}

Eis que as espadas se cruzaram, o som estridente resultante desse furioso encontro ressoa até hoje! De um lado, a espada é o libreto de Parsifal, o último drama de Richard Wagner, enviado a Nietzsche em 3 de janeiro de 1878; do outro lado, o manuscrito - enviado aos Wagner dias antes - de Humano, demasiado humano, a obra nietzschiana que marca um radical desvio de pensamento. Foi um "duro combate" entre amigos que agora se viam como antípodas. As ideias deste livro, publicado pela primeira vez em abril de 1878, já teriam sido embrionariamente concebidas na semana do primeiro Bayreuther Festspiele, em 1876, após Nietzsche se decepcionar profundamente com o compositor ${ }^{1}$. No mesmo ano, o filósofo desfruta de uma licença para se recuperar de um mal que tanto lhe afligia. Ele sofria com terríveis dores de cabeça, cegueira e náuseas. Então, com a intenção de reencontrar a saúde, aceita o convite de uma amiga, a feminista Malvida von Meysenbug, para passar uma temporada em Sorrento, na Itália, juntamente com o amigo Paul Rée e um jovem aluno, Albert Brenner. Juntos, eles formaram uma espécie de "monastério de espírito livres" ${ }^{2}$, um grupo de leituras e discussões que permitiram o amadurecimento da maioria das ideias de Humano, demasiado humano.

A ida para Itália muda completamente a trajetória de Nietzsche. Durante a viagem ele encontra coragem para abandonar a cadeira de professor na Basileia e, respectivamente, seu ofício como filólogo ${ }^{3}$. Foi no sul que descobriu sua verdadeira inclinação, a filosofia do errante solitário. Durante aqueles dias escreveu uma série de rascunhos e notas sob o título Sorrentiner Papiere, e no inverno (1876 - 1877), com dificuldade para enxergar, dita a Brenner o que chamou de Sorrenter Manuscript, ambos, além de gérmen de todo o conteúdo de

\footnotetext{
${ }^{1}$ NIETZSCHE. Ecce homo. "Humano, demasiado humano", §2.

${ }^{2}$ Cf. Carta de Nietzsche a Reinhardt von Seydlitz de 24 setembro de 1876. [Apêndice $\alpha$ ]

${ }^{3}$ Nietzsche solicita sua demissão em maio de 1879. Cf. Carta a Carl Burckhardt de 2 de maio de 1879. [Apêndice $\beta$ ]
} 
Humano, demasiado humano, são os primeiros aforismos de sua vida ${ }^{4}$. Ainda em Sorrento, ocorreu o último encontro entre Nietzsche e os Wagner, o qual selou definitivamente o fim da amizade, contribuindo, então, para o teor ácido das críticas do livro que concebia em segredo ${ }^{5}$. A obra recebeu sua conclusão e forma definitiva no fim naquele inverno, já de volta à Basileia. A saúde de Nietzsche estava ainda pior, as dores de cabeça e nos olhos lhe impossibilitavam de ler e de escrever. Foi necessária a ajuda de seu amigo Heinrich Köselitz, aliás, Peter Gast, para levar ao papel os seus pensamentos, de modo que, em sua autobiografia, se considera apenas o autor enquanto atribui ao amigo o status de verdadeiro escritor ${ }^{6}$.

Humano, demasiado humano é o "monumento de uma crise"7, erigida, como dissemos, em uma época de extrema debilidade: Nietzsche, então com 33 anos, acreditava estar condenado à má herança do pai e, como ele, que havia morrido aos 36 anos, vítima de uma doença cerebral, estaria predestinado a sucumbir precocemente ${ }^{8}$. No entanto, o filósofo encara a doença não como um infortúnio, mas como algo positivo e necessário para sua libertação: “A doença deu-me", diz, "o direito a uma completa inversão de meus hábitos; ela permitiu, ela me ordenou esquecer; ela me presenteou com a obrigação à quietude, ao ócio, ao esperar e ser paciente... Mas isso significa pensar!"9. Nesse sentido, a enfermidade e qualquer outra situação desfavorável são preferíveis à indigna "falta de si". Nietzsche, ao avaliar a importância de sua convalescência, percebe que nunca foi tão feliz consigo mesmo como nas épocas mais doentias e dolorosas de sua vida, pois os males proporcionaram-lhe "uma suprema espécie de cura",

\footnotetext{
${ }^{4} \mathrm{O}$ estilo "aforístico" é a marca definitiva de sua cisão com a filosofia metafísica e sistemática.

5 "Na terra onde os antigos acreditavam ouvir cantarem as sereias, Nietzsche e Wagner se encontraram pela última vez, atraídos por melodias e paixões agora muito diferentes. Foi provavelmente durante esses poucos dias em que viveram um perto do outro que Wagner confessou a Nietzsche os êxtases que experimentava ao pensar no Santo Graal e na Última Ceia. Isso, para Nietzsche, foi a gota d'água... para ele que já não tinha suportado a desilusão do festival de Bayreuth e que, bem antes, havia ensaiado os primeiros passos no sentido de seu próprio caminho. A bela amizade e a solidariedade intelectual, a fraternidade em armas no seio do projeto de Bayreuth, pelo renascimento da civilização helênica na Alemanha graças à magia do teatro musical de Wagner, se extinguiram no Hotel Vittoria”. D’IORIO, Paulo. Nietzsche na Itália. A viagem que mudou os rumos da filosofia. p. 29.

${ }^{6}$ Cf. NIETZSCHE. Ecce homo. "Humano, demasiado humano". §5.

${ }^{7}$ Idem. $\$ 1$.

${ }^{8}$ Cf. Carta a Carl von Gersdorff de 18 de janeiro de 1876.

${ }^{9}$ NIETZSCHE. Op. Cit. $\$ 4$.
} 
isto é, "o retorno a si”"10. Por isso, foi indispensável, para o filósofo, esclarecer a seu antigo mestre e inspirador que seu novo livro é uma obra essencialmente sua: "nele trouxe à luz os mais íntimos sentimentos sobre as pessoas e as coisas e, pela primeira vez, delimitei os contornos de meu próprio pensamento"11.

Humano, demasiado humano é, portanto, o "monumento de uma rigorosa disciplina de si"12. Nietzsche chega a postular que apenas continuou vivo, porque foi capaz de escrevê-lo ${ }^{13}$. A obra representa, em termos pessoais, o abandono da cátedra e, consequentemente da filologia. Em termos filosóficos, representa a ruptura com Richard Wagner. Não há, em todo o livro, sequer uma menção ao compositor, porém, podemos dizer que cada linha é uma estocada na estética wagneriana. Além disso, Nietzsche passa a criticar severamente o pessimismo de Schopenhauer. Os especialistas do pensamento nietzschiano consideram Humano, demasiado humano, como a obra que inaugura o "período positivista" do autor, fase que perdura até $A$ Gaia ciência ${ }^{14}$. Nesse período de produção intelectual, há uma inversão de valores em relação à arte e ao conhecimento, este último passa a ser mais valorizado que o primeiro. Motivo que leva o filósofo a citar, como o prólogo da primeira edição, uma passagem de $O$ Discurso do método de Descartes. Contudo, a principal guinada de pensamento iniciada com essa obra, que de certa forma intermediará todas as demais mudanças em sua filosofia, é o radical e derradeiro corte com a metafísica.

Nietzsche deixa clara sua nova perspectiva, literalmente manda a metafísica aos infernos ${ }^{15}$, e esclarece em um fragmento da época de elaboração da nova obra a mudança: "Quero explicar explicitamente aos leitores de meus escritos anteriores que desisti das visões metafísico-artísticas que essencialmente os dominam: são agradáveis, porém insustentáveis"16. Ao longo de sua produção a aversão às postulações metafísicas se intensifica, até se tornar uma constante; um dos grandes objetivos de sua filosofia tardia será combater esse saber criador de

\footnotetext{
${ }^{10}$ Idem.

${ }^{11}$ Cf. Esboço de Carta aos Wagner do começo de janeiro de 1878. Não sabemos se a carta foi realmente enviada com o manuscrito de Humano. [Apêndice $\gamma$ ]

${ }^{12}$ NIETZSCHE. Op. Cit. $\$ 5$.

${ }^{13} \mathrm{Cf}$. Esboço de Carta aos Wagner do começo de janeiro de 1878. [Apêndice $\gamma$ ]

${ }^{14}$ Cf. CONSTÂNCIO, João. Arte e niilismo. Nietzsche e o enigma do mundo. "Introdução", §4

${ }^{15}$ Cf. NIETZSCHE. O Nascimento da tragédia. "Prefácio de autocrítica” §7.

${ }^{16}$ Ibidem. Fragmento póstumo de 1876 - 1877, 23[159]. Cf. Nota 88 da seção 1.4.
} 
mundos, valores e verdades absolutas. Em decorrência disso, há uma profunda transformação em sua compreensão estética. A arte passa a ser vista como uma coisa humana, demasiadamente humana. As pulsões apolínea e dionisíaca são, portanto, completamente ignoradas. A partir de 1876, até 1880, há um silêncio absoluto em relação a Dioniso, não há nenhuma menção relevante à divindade ou àquilo que ela representa filosoficamente enquanto símbolo. Somente em A Gaia Ciência, obra de 1882, o termo dionisíaco reaparece timidamente para então, ressurgir de forma proeminente nos fragmentos de 1885 que preparam Além do bem e do mal.

Desse modo, podemos dizer que, do ponto de vista do dionisíaco, o pensamento nietzschiano também se divide em três fases: a fase de juventude, que concebe um dionisíaco metafísico; a fase intermediária, iniciada com Humano, demasiado humano, onde o termo é silenciado; e, por fim, o período de ressurgimento do símbolo Dioniso, agora transmutado. Entretanto, é importante salientar que nesse período intermediário não é apenas o dionisíaco que é silenciado, Nietzsche criticará duramente tudo que o termo representa, principalmente, aquilo que o vinculava à estética wagneriana. Assim, a primazia da arte em relação ao conhecimento será repensada, da mesma forma em que a superioridade da música em relação às demais artes deixará de ser uma prerrogativa. Além disso, a noção de gênio será reformulada, na mesma medida em que os efeitos fisiológicos da arte, até então, essencialmente dionisíacos, tais como o entusiasmo, o êxtase, a intoxicação e a embriaguez artística, serão vistos de uma forma estritamente pejorativa. A necessidade de entorpecimento através de uma arte narcótica será pensada como sintoma de espíritos fracos e vazios ${ }^{17}$, que veem nessas produções inebriantes a possibilidade de fuga da realidade considerada adversa.

Sabendo disso, o foco de nossa próxima seção é entender qual é a acepção crítica da embriaguez nos escritos em que o dionisíaco é mascarado, silenciado e, de forma subliminal, criticado. Contudo, antes de iniciarmos tal empreita, se faz necessária uma breve interrogação sobre o sentido do diagnóstico nietzschiano a respeito do "retorno a si mesmo". Interessa-nos questionar qual é o entendimento

\footnotetext{
${ }^{17}$ Cf. NIETZSCHE. Ecce homo. "Humano, demasiado humano". §3.
} 
de subjetividade que o filósofo possui ao aludir a um "eu criador", para um ego que se dissocia e não se confunde com o "outro"18. Tal questionamento se legitima pelo fato do filósofo desconstruir o subjetivismo cartesiano. Não há, para Nietzsche, um "sujeito" que seja o núcleo de uma consciência, consequentemente, não há um “eu autor” de pensamentos. Essa ideia que já está presente, de forma prematura, em $O$ Nascimento da tragédia, naquilo que concerne à dissolução da subjetividade no mito trágico, também pode ser observada nos escritos intermediários, mas é a partir de Além do bem e do mal (1886) que ganha maior intensidade e forma definitiva. Portanto, antes da publicação de Ecce homo (1888), onde o "eu criador" aparece com veemência, Nietzsche já havia suprimido o "eu" enquanto sujeito do pensamento. Isso fica claro no seguinte fragmento de 1885 :

\begin{abstract}
O pensamento na forma em que acorre, é um signo equívoco, que carece de interpretação; mais precisamente, de um estreitamento e limitação, até que, por fim, se torne inequívoco. Ele emerge em mim - de onde? através de que? Não sei. Ele aparece em mim, independentemente de minha vontade, habitualmente envolto e escurecido por uma multidão de sentimentos, desejos, aversões, também de outros pensamentos, frequentemente indistinguíveis de um "querer" ou "sentir". Nós o retiramos dessa multidão, limpamo-lo, colocamo-lo sobre os próprios pés, vemos como se mantém em pé, como caminha. Tudo isso num surpreendente presto e, contudo, totalmente sem o sentimento de pressa: quem faz isso tudo, - não o sei e seguramente sou mais espectador que autor desse processo ${ }^{19}$.
\end{abstract}

Ao fazer uma análise do pensamento, Nietzsche acaba problematizando o "eu" enquanto a unidade que é o sujeito do pensar. O filósofo reconhece a dificuldade deste desconcertante tema, pois acredita que somos treinados "ao pensar, não pensar no pensar" 20 . Todavia, quando se propõe a investigar o próprio pensamento, ele percebe que sua origem é nebulosa ${ }^{21}$. O que nós temos é somente uma ideia equivocada, imprecisa, simplificadora que reduz o pensamento à unidade, quando, com efeito, cada ato de pensar já é uma pluralidade de

\footnotetext{
18 "Apenas meus olhos puseram fim à bibliofagia, leia-se "filologia": estava salvo dos livros, nada mais li durante anos - o maior benefício que me concedi! - Aquele Eu mais ao fundo, quase enterrado, quase emudecido sob a constante imposição de ouvir outros Eus (— isto significa ler!), despertou lentamente, tímida e hesitantemente — mas enfim voltou a falar”. Ibidem. §4. (Grifo nosso).

${ }^{19}$ Ibidem. Fragmento póstumo de 1885, 38[1].

20 "wir sind im Grunde umgekehrt geschult, nämlich beim Denken nicht an's Denken zu denken". Idem.

${ }^{21}$ Idem.
} 
pensamentos distintos. De modo que "em todo pensamento parece estar implicado uma multiplicidade de pessoas"22. Por consequência, a ideia de um "eu singular" que, por sua vez, é o "eu autor" desse processo se dissolve: há ali, no máximo, o "eu espectador" do processo. Isso significa que cada pensamento de que tomamos consciência é decorrente do jogo entre os mais diversos fenômenos mentais e experiências corporais. Tais considerações são cruciais para a completa cisão de Nietzsche com a tradição metafísica: ele não aceita que seja o "eu" a causa do pensar, antes disso, considera o "eи mesmo como uma construção do pensamento" $" 23$. Ideia que também é desenvolvida no seguinte aforismo de Além do bem e do mal:

Que o povo acredite que conhecer é conhecer até o fim; o filósofo tem que dizer a si mesmo: se decomponho o processo que está expresso na proposição "eu penso", obtenho uma série de afirmações temerárias, cuja fundamentação é difícil, talvez impossível - por exemplo, se sou eu que pensa, que tem de haver necessariamente um algo que pensa, que pensar é atividade e efeito de um ser que é pensado como causa, que existe um "Eu", e finalmente que já está estabelecido o que designar como pensar - que eu sei o é pensar ${ }^{24}$.

O "eu” enquanto núcleo subjetivo que é causa do pensamento é, para Nietzsche, fruto da fé na gramática e, sobretudo, da fé na metafísica. O "povo", ou seja, todos aqueles que, graças à crença inabalável na linguagem, acreditam que o conhecimento absoluto é possível - em suma, o "povo”, cujos preconceitos populares foram consagrados teoricamente à filosofia ocidental até então ${ }^{25}$ - toma a proposição "eu penso" como uma certeza imediata e, por consequência, esse "eu" como causa dada do pensar. Eles acreditam ainda que a partir de uma simples analogia com essa proposição todas as demais relações causais poderiam ser compreendidas ${ }^{26}$. Mas isso é, para Nietzsche, uma ficção, pois quando digo "eu penso", ao contrário de uma certeza imediata, tenho uma série de afirmações

\footnotetext{
${ }^{22}$ Devido a essa multiplicidade, Nietzsche compara o pensamento a um tribunal onde "há um juiz, uma contraparte, até um interrogatório das testemunhas, de que me é permitido ouvir um pouco, certamente só um pouco: a maior parte, ao que me parece, se escapa". Idem.

${ }^{23}$ "Was mich am gründlichsten von den Metaphysikern abtrennt, das ist: ich gebe ihnen nicht zu, daß das „Ich" es ist, was denkt: vielmehr nehme ich das Ich selber als eine Construktion des Denkens (...)”. [O que me separa mais profundamente dos metafísicos é isto: eu não aceito que seja o "eu" que pensa: em vez disso, considero o eu mesmo como uma construção do pensamento]. Ibidem. Fragmento póstumo de 1885, 35[35].

${ }^{24}$ Ibidem. Além do bem e do mal. $\$ 16$.

25 "Que pobres têm sido os filósofos até agora quando a eles a linguagem, ao menos a gramática, não lhes sugere totalmente o que neles é 'povo'!” Ibidem. Fragmento póstumo de 1885, 40[6].

${ }^{26}$ Cf. Ibidem. Fragmento póstumo de 1885, 38[3].
} 
metafísicas desprovidas de real fundamento, por exemplo, que existe um 'Eu'. Aí está a diferença entre as pessoas grosseiras e o filósofo: as primeiras são os devotos da gramática e da verdade linguística, por isso agarram-se no "sujeito", no "objeto", no "predicado", na "causalidade"; já o último é quem percebe que a proposição "eu penso" é resultado de uma série de referências e retrospectivas a outros saberes, portanto, não há nela nenhuma certeza imediata.

O "eu" cartesiano é, segundo Nietzsche, um mero produto da lógica e da linguagem, uma unidade metafísica assentada em uma construção gramatical. A subjetividade pautada nesse "ego" organizador da consciência não passa de uma invenção moderna, uma transposição das crenças populares aos enunciados metafísicos. O "eu", portanto, não é causa do cogito, porém, seu efeito. O núcleo da subjetividade é, então, uma construção do pensamento no mesmo grau em que a "matéria", "coisa", "substancia", "indivíduo", "finalidade" são. Esses termos são ficções reguladoras que introduzem no mundo do devir uma espécie de estabilidade e, por conseguinte, de cognoscibilidade por meio da consciência ${ }^{27}$. Não obstante, devemos esclarecer que Nietzsche promove uma inversão no entendimento sobre o lugar da consciência: enquanto a tradição concebia o pensar como o ato supremo da consciência, e esta, em seu turno, como o fundamento do sujeito enquanto unidade do pensamento ${ }^{28}$, para o filósofo "todo pensamento atua para a consciência como um estimulante" ${ }^{, 29}$. Isto significa que a consciência não tem autonomia, ela não pode decidir qual o pensamento que a estimulará no processo que é uma expressão em signos do nosso estado geral.

A consciência tem acesso apenas à superfície de um processo profundo e complexo que é o pensamento. O mesmo acontece com os sentimentos: em si mesmos, diz Nietzsche, eles não significam nada, quando nos assaltam, antes de tudo, os interpretamos, pois suas raízes são completamente inacessíveis ${ }^{30}$. Não temos sequer, um lampejo de consciência dos movimentos internos que resultam os sentimentos e pensamentos. Dessa forma, o "eu" na filosofia nietzschiana

\footnotetext{
${ }^{27}$ Cf. Ibidem. Fragmento póstumo de 1885, 35[35].

${ }^{28} \mathrm{Cf}$. Ibidem. Alem do bem e mal. §54.

29 "für das Bewußtsein wirkt nämlich jeder Gedanke wie ein Stimulans —: in dem allen drückt sich irgend etwas von unserem Gesammtzustande in Zeichen aus". [todo pensamento atua para a consciência como um estimulante - em tudo isso expressa algo do nosso estado geral em signos]. Idem. 38[1].

${ }^{30} \mathrm{Cf}$. Idem.
} 
tardia é uma ilusão que corresponde a momentos em que pensamentos e afetos são interpretados simbolicamente pela consciência, mas que, invariavelmente, estão em interrupta dissolução. Entretanto, se o filósofo é um cético em relação à existência de um sujeito representado por uma unidade subjetiva, então a que ele se refere quando diagnostica, na virada de seu pensamento, o "retorno a si mesmo"? Em que consiste a subjetividade que agora filosofa independentemente? A pista para esses questionamentos está em Assim falou Zaratustra onde o "eu" aparece vinculado ao corpo, àquilo que Nietzsche chamará de "grande razão". No capítulo "Dos desprezadores do corpo", por exemplo, há uma forte alusão a uma espécie de subjetividade corporal:

\begin{abstract}
"Eu", dizes tu, e tens orgulho desta palavra. A coisa maior, porém, em que não queres crer - é teu corpo e sua grande razão: essa não diz $\mathrm{Eu}$, mas faz $\mathrm{Eu}$. O que o sentido sente, o que o espírito conhece, jamais tem fim em si mesmo. Mas sentido e espírito querem te convencer de que são o fim de todas as coisas: tão vaidosos são eles. Instrumentos e brinquedos são sentidos e espíritos: por trás deles está o Simesmo. O Si-mesmo também procura com os olhos do sentido, também escuta com os ouvidos do espírito. O Si-mesmo sempre escuta e procura: compara, submete, conquista, destrói. Domina e é também dominador do Eu. Por trás dos teus pensamentos e sentimentos, irmão, há um poderoso soberano, um sábio desconhecido - ele se chama Si-mesmo. Em teu corpo habita ele, teu corpo é ele ${ }^{31}$.
\end{abstract}

$\mathrm{O}$ entendimento nietzschiano a respeito da subjetividade fica claro na passagem: a grande razão "não diz $E u$, mas $f a z E u$ ", isto significa que o "eu" em questão não é aquele da linguagem, da gramática, não se trata aqui do sujeito que é causa do predicado "penso", fundamentado pela metafísica. O "eu" que é a grande razão não é, então, o simplesmente dito, mas sim o "eu” inerente ao corpo, realizado nas complexas afecções corporais. Nessa perspectiva, o sujeito não possui um corpo, todavia, ele é o corpo. Está definitivamente diluída a distinção entre res cogitans e res extensa, a subjetividade não pode mais ser pensada descolada do corpo. Além disso, é indispensável saber que Nietzsche propõe uma distinção entre o "Eu" [Ich] e o Si-mesmo [Selbst] ${ }^{32}$ : na linguagem de Assim falou Zaratustra esses termos representam a diferença entre dois elementos mentais que juntos correspondem à subjetividade, o Selbst seria responsável por promover, incitar, ou melhor, comandar o pensamento e a reflexão; enquanto o

\footnotetext{
${ }^{31}$ Ibidem. Assim falou Zaratustra. "Dos desprezadores do corpo", p. 35.

32 "Teu Si-mesmo ri de teu Eu e de seus saltos orgulhosos". Idem.
} 
Ich é responsável por executá-los ${ }^{33}$. Como lemos acima, o Si-mesmo é dominador do $\mathrm{Eu}^{34}$, ele está, portanto, por trás do pensamento e dos sentimentos, agindo como uma ponte que liga a mente [Geist] aos afetos do corpo.

Sendo assim, podemos dizer que Nietzsche não é completamente cético em relação ao sujeito, pelo contrário, ele reconhece uma subjetividade de fundo corpóreo que lhe permite falar em um "Eu criador". Essa imagem, de um "eu" que cria, é pintada pelo filósofo também em Assim falou Zaratustra, no capítulo "Dos transmundanos", onde podemos ler: "esse Eu criador, querente, valorador, que é a medida e o valor de todas as coisas. E esse honestíssimo ser, o Eu -, fala do corpo e quer ainda o corpo, mesmo quando poetiza, sonha e esvoeja com asas partidas" ${ }^{35}$. Ainda que essa imagem faça alusão à relação entre o sujeito que é a condição causal de um predicado condicionado ${ }^{36}$ - crio, quero, valoro, enfim, penso - o "eu" aqui não corresponde a uma unidade subjetiva equivalente àquela criticada, pois sua característica é falar das contradições e confusões do corpo. O "eu" que cria e avalia tem como medida suprema o corpo. É precisamente por isso que Nietzsche considera o "retorno a si", a produção de uma filosofia autêntica, que agora ouve tão somente "aquele Eu mais ao fundo", um sintoma de saúde. Ainda assim, devemos destacar que se Nietzsche clama por "eu" criador que, na verdade, é efeito de vivências corporais ele não está dissociado, no todo, daquilo que foi experimentado como doença.

\subsection{1.}

\section{Um cálice vazio - a crítica à embriaguez:}

A estética de $O$ Nascimento da tragédia tem como um dos principais fundamentos a embriaguez [Rausch]. O impulso dionisíaco, como já exposto aqui anteriormente, é compreendido, por analogia, como a manifestação fisiológica da intoxicação inebriante. Nesse sentido, a embriaguez é entendida como uma forma de arrebatamento e um esquecimento momentâneo de si, juntamente com um

\footnotetext{
33 "O Si-mesmo diz para o Eu: "Sente dor aqui!". E esse sofre e reflete em como não mais sofrer - e justamente para isso deve pensar. O Si-mesmo diz para o Eu: "Sente prazer aqui!". E esse se alegra e reflete em como se alegrar mais - e justamente para isso deve pensar". Idem.

${ }^{34}$ No original: "Es herrscht und ist auch des Ich's Beherrscher". Idem

35 Idem. "Dos transmundanos", p. 33.

${ }^{36}$ Sobre Cf. Ibidem. Além do bem e do mal. $\$ 54$.
} 
desenfreado prazer extático. Esse efeito é evocado no homem natural pela bebida narcótica ou pela poderosa aproximação da primavera. Na metafísica do artista, formulada por Nietzsche, a embriaguez diz respeito, tanto ao aspecto metafísicocosmológico, ou seja, ao impulso criador da vontade que, no eterno movimento do vir-a-ser da natureza, rompe com o princípio de individuação, sem a mediação do artista humano; quanto ao aspecto estético propriamente dito, onde o artista dionisíaco é um imitador. Em ambos os casos a embriaguez é apresentada como uma potência aniquiladora de princípios balizadores. Por isso - seja enquanto devir, ou enquanto obra de arte - ela revela a verdade por trás do véu da aparência. Ainda que a verdade desvelada seja o grotesco, o feio, o terrível, o processo é acompanhado de um prazer artístico extático que desconsidera a beleza.

Quando Nietzsche propõe uma filosofia da arte que pensa o prazer estético desvinculado da beleza está, em última análise, imprimindo uma "estética negativa" ${ }^{, 37}$. Esse termo não é atribuído especificamente à filosofia nietzschiana; trata-se de um conceito histórico crítico que reflete a valorização de experiências consideradas, ordinariamente, "negativas". Em outras palavras, uma "estética negativa" propõe uma experiência prazerosa proveniente de algo desagradável, ou seja, a procura de uma satisfação em uma insatisfação ${ }^{38}$. Em $O$ Nascimento da tragédia, esse "contrassenso" está na ideia de que o espectador, ou o artista, extrai seu deleite afirmativo do desgosto, ou seja, extrai o prazer existencial justamente de um espetáculo aflitivo que, por sua vez, é suscetível de lhe fazer sofrer. O espectador trágico, para Nietzsche, experimenta uma alegria superior ao se confrontar com a verdade assustadora expressa pela tragédia. A experiência estética ocorre, precisamente, quando o sujeito se desvencilha do aspecto belo da

\footnotetext{
${ }^{37}$ Cf. KESSLER, Mathieu. L'esthétique de Nietzsche, p. 21.

38 A estética negativa não possui Nietzsche como percursor, nem mesmo á atribuída exclusivamente às tragédias. Hoje ela é verificável além de nas músicas atuais, no cinema, nas galerias e exposições. Historicamente, observa Kessler, "o primeiro entre os manifestos românticos, o Prefácio de Cromwell de Victor Hugo (1827), fornece princípios que têm por objetivo valorizar novas categorias e práticas. Estas transgridem as convenções definindo as experiências estéticas em benefício de outras categorias que até então eram desqualificadas como "negativas": o grotesco e a mistura de gêneros, por exemplo. A escola romântica é, portanto, a primeira a tentar esta inversão de valores estéticos cujo caráter permanente se encontra desta forma colocado em questão". Enquanto no âmbito da filosofia, "Esta transformação do sofrimento, do temor e da humilhação em prazer e em alegria já era perceptível na temática kantiana do sublime fundando uma parte do movimento artístico romântico". KESSLER, Mathieu. Le déclin d'une esthétique negative. In. Op cit. p. 21 - 54.
} 
obra de arte e encontra o gozo no grotesco, no disforme, no feio, portanto, no elemento que o ameaça e, a princípio, pode lhe causar dor. Esse prazer paradoxal, no entanto, só é possível por meio da dissonância musical e, por consequência, da embriaguez ${ }^{39}$.

A embriaguez nesse aspecto especificamente artístico é entendida como o efeito da audição dionisíaca. Ela é, portanto, decorrência da dissonância musical. Apesar de ter um fundo metafísico, aliás, nela reside o cerne da consolação metafísica, a embriaguez é uma experiência corporal. A música dionisíaca suscita no sujeito uma confusão na percepção do espaço e tempo, uma alteração na consciência em seu modo de compreender o mundo. Agora, o sujeito está em contato com a realidade por trás da aparência; então, sente-se unido aos demais seres, mas, também, percebe o terror de sua finitude individual e o sofrimento do espetáculo cruel do Ser primordial. Toda beleza apenas dissimula uma verdade monstruosa. Essa experiência proporciona uma descarga fisiológica que resulta, frente à monstruosa realidade, um prazer inebriante inefável. Ainda que esse deleite estético seja extraído do espetáculo desagradável, do disforme, do desarmônico e, a princípio, despreze a beleza, para Nietzsche, seria insuportável permanecer nesse estado por muito tempo sem a proteção do elemento apolíneo. Por isso, a tragédia grega é a obra de arte superior. Ela proporciona a embriaguez, através da dissonância dionisíaca, todavia, com a proteção das palavras e das imagens apolíneas.

Essa característica, Nietzsche reconheceu nas obras wagnerianas, seus dramas compreendiam, simultaneamente, a música arrebatadora, "a mais alta excitação musical", e a ilusão apolínea que protegeria os espectadores da "autoaniquilação orgiástica" ${ }^{40}$. Como sabemos, esse era o motivo pelo qual o

\footnotetext{
${ }^{39}$ Nietzsche explica sobre o paradoxal sentimento de prazer diante do desagradável: "nesse sentido precisamente o mito trágico nos deve convencer de que mesmo o feio e desarmônico são um jogo artístico que a vontade, na perene plenitude de seu prazer, joga consigo própria. Difícil como é de se apreender, esse fenômeno primordial da arte dionisíaca só por um caminho direto torna-se singularmente inteligível e é imediatamente captado: no maravilhoso significado da dissonância musical: do mesmo modo que apenas a música, colocada junto ao mundo, pode dar uma noção do que se há de entender por justificação do mundo como fenômeno estético. O prazer que o mito trágico gera tem uma pátria idêntica à sensação prazerosa da dissonância na música. O dionisíaco, com o seu prazer primordial percebido inclusive na dor, é a matriz comum da música e do mito trágico". NIETZSCHE. O Nascimento da tragédia. §24.

${ }_{40}$ Nietzsche menciona a ópera wagneriana Tristão e Isolda para ilustrar sua argumentação e a classifica como um drama perfeito. Cf. Ibidem. $\$ 21$.
} 
compositor era considerado a esperança do ressurgimento da cultura trágica ${ }^{41}$. Entretanto, a partir da publicação de Humano, demasiado humano, quando se afasta de Richard Wagner e abandona definitivamente a metafísica do artista, o filósofo rompe também com sua estética da embriaguez. Porém, diferentemente de Wagner, de Schopenhauer e da metafísica - que retornarão aos escritos nietzschianos somente para serem criticados e combatidos - a embriaguez terá, nas obras tardias, novamente o seu lugar e ressurgirá como um fundamento imprescindível às obras de arte, reinaugurando, assim, uma nova "estética negativa". Nietzsche precisou de um intervalo para amadurecer suas ideias e desvincular o estado inebriante das antigas formulações - e de Wagner e Schopenhauer. Por isso, no curto período, entre 1878 e 1882, o que observamos é um ataque à embriaguez como sucedâneo de uma arte 'tempestuosa', assim como uma reavaliação do papel do belo:

\begin{abstract}
A mais nobre espécie de beleza é aquela que não arrebata de vez, que não se vale de assaltos tempestuosos e embriagantes (uma beleza assim desperta facilmente o nojo), mas que lentamente se infiltra, que levamos conosco quase sem perceber e deparamos novamente num sonho, e que afinal, após ter longamente ocupado um lugar modesto em nosso coração, se apodera completamente de nós, enchendo-nos os olhos de lágrimas e o coração de ânsias. - O que ansiamos, ao ver a beleza? Ser belos: imaginamos que haveria muita felicidade ligada a isso. - Mas isto é um erro $^{42}$.
\end{abstract}

Esse aforismo, intitulado A lenta flecha de beleza, ilustra-nos qual será o direcionamento estético nietzschiano a partir de Humano, demasiado humano: a beleza cuja natureza é a mais nobre [Die edelste Art der Schönheit] não é aquela que nos irrompe de uma só vez, portanto, não é a beleza fruto de uma arte que se vale de ataques tempestuosos [stürmische] e embriagantes [berauschende], tal qual ocorria com a arte dionisíaca e, em especial, com os dramas wagnerianos. Nietzsche, nesse excerto, está declarando explicitamente o seu novo

\footnotetext{
41 "Com esse conhecimento se introduz uma cultura que me atrevo a denominar trágica: cuja característica mais importante é que, para o lugar da ciência como alvo supremo, se empurra a sabedoria, a qual, não iludida pelos sedutores desvios das ciências, volta-se com olhar fixo para imagem conjunta do mundo, e com um sentimento simpático de amor procura apreender nela o eterno sofrimento como sofrimento próprio. Imaginemos uma geração a crescer com esse destemor do olhar, com esse heróico pendor para o descomunal, imaginemos o passo arrojado desses matadores de dragões, a orgulhosa temeridade com que dão as costas a todas as doutrinas da fraqueza pregadas pelo otimismo, a fim de 'viver resolutamente' na completude e na plenitude: não seria necessário, porventura, que o homem trágico dessa cultura, na sua auto-educação para o sério e para o horror, devesse desejar uma nova arte, a arte do consolo metafísico, a tragédia, como a Helena a ela devida [...]" Cf. Idem. §18.

${ }^{42}$ NIETZSCHE. Humano, demasiado humano. "Da alma dos artistas", §149.
} 
posicionamento em relação às artes, no qual condena o êxtase inebriante e os excessos. Podemos notar até uma inversão em relação à 'estética negativa' presente em $O$ Nascimento da tragédia, agora o elemento artístico valorizado é a beleza, na medida em que aquilo que causa insatisfação, ou sofrimento - antes tido como a fonte do gozo - é desprezado, como, no caso do texto acima citado, o "nojo", o "desgosto" [Ekel]. Mesmo que o filósofo tenha abandonado a dicotomia ‘apolíneo-dionisíaco', sua nova filosofia da arte configura-se como uma espécie de "apolínio mascarado": ora, a nobreza na arte passou a ser a serenidade, a lentidão, a beleza com a qual deparamo-nos num sonho. Não obstante, a arte neste momento em nada tem haver com as essências das coisas, ela está ligada somente ao ver e ao ouvir ${ }^{43}$.

Abandonada toda perspectiva metafísica da arte, Nietzsche concebe uma nova teoria estética rigorosamente imanente. Essa teoria baseia-se na suposição de que o homem obtém prazer de todos os seus estímulos anímicos [Gemüthserregungen], desfruta de todas as emoções em si, até mesmo as mais dolorosas. Esse é o sentido da embriaguez artística: o indivíduo intoxica-se com seus afetos, encontrando neles o deleite. Dessa forma, a arte excita alegremente ao jogar com a dor, com a lágrima, com a fúria e com o desejo, porém, eximindo o sujeito de quaisquer consequências práticas ${ }^{44}$. Contudo, na nova teoria estética nietzschiana, essa forma de arte embriagante é classificada negativamente. Ela é vista como uma espécie de conforto para os espíritos incautos, um subterfúgio para jovens despreparados que são afligidos pelo de tédio. Em suma, é um tipo de arte que contenta pessoas vazias que precisam de preenchimento. Por outro lado, as pessoas mais sábias e harmoniosas, aspiram uma arte que embeleza o existir, tornando a vida, e elas mesmas, suportáveis. A arte, diz Nietzsche em 1879, “deve ocultar ou reinterpretar tudo que é feio, o que é doloroso, horroroso, nojento, que, apesar de todos os esforços, sempre torna a irromper com a natureza humana"45.

\footnotetext{
${ }^{43}$ É isso que Nietzsche escreve em uma anotação feita em Sorrento, na mesma época em que repensa o tipo mais nobre de beleza: "die Kunst, an Auge und Ohr angeknüpft, hat nichts mit dem Wesen der Dinge zu thun”. NIETZSCHE. Fragmento póstumo de 1877, 24[1].

${ }^{44} \mathrm{Cf}$. Ibidem. Fragmento póstumo de 1876, 23[172].

${ }^{45}$ Ibidem. Humano, demasiado humano II. "Opiniões e sentenças diversas". §174.
} 
O filósofo faz questão de acentuar sua oposição às antigas formulações estéticas: em um caderno de anotações de 1880 diz ter se assustado ao reler antigos escritos seus, dos quais já nem se lembrava. Reconhece neles a linguagem de um fanático ${ }^{46}$. Tal fanatismo o levou a entender por arte "aquele bárbaro, embora fascinante, irromper de coisas ardentes e coloridas de uma alma caótica e indomada" ${ }^{\wedge 7}$. Porém, após seu amadurecimento percebeu que uma arte assim que encontra o seu valor unicamente no entorpecimento, ou seja, em uma elevada tensão que estimula em grau máximo o sujeito, portanto, uma arte avessa ao simples, ao lógico e ao regrado - se faz necessária somente para que indivíduos fracos e desorientados, que anseiam a qualquer custo descarregar suas tensões, não se desafoguem em outros caminhos mais maliciosos ${ }^{48}$. Nietzsche, nesse momento positivista de sua produção, acredita que o cultivo da intelectualidade resultaria em um tipo superior de humano. Ele argumenta hipoteticamente que no estágio desse homem, que dedica suas energias excepcionalmente para fins intelectuais, as "forças como as que determinam a arte, por exemplo, poderiam simplesmente se esgotar; o prazer na mentira, na imprecisão, no simbólico, na embriaguez, no êxtase poderia cair no desprezo" 49.

Essa argumentação não só exemplifica a momentânea aversão nietzschiana à arte extática, como também ilustra-nos a inversão de valores concedidos aos modos de explicitação da realidade: a arte, antes elogiada, agora é inferiorizada em relação ao conhecimento intelectual e a ciência. São muitos os aforismos e fragmentos que desvalorizam o saber instintivo, artístico, frente ao conhecimento lógico e científico. A arte é concebida, de modo geral, como fuga da realidade considerada feia, enquanto o conhecer é responsável por aumentar a beleza do mundo. Em um aforismo de Aurora, Nietzsche não hesita em mencionar a felicidade suprema de Platão e Aristóteles para fundamentar sua tese de que "A felicidade do homem que conhece torna mais ensolarado tudo o que há; põe sua beleza não só em torno das coisas, mas, com o tempo, nas coisas" ${ }^{\text {"50 }}$. Nessa linha de pensamento, as obras de arte inebriantes, entusiásticas são, no grau mais elevado, responsáveis por uma vilipendiosa escapada da realidade e uma

\footnotetext{
${ }^{46}$ Cf. Ibidem. Fragmento póstumo de 1880, 3[1].

${ }^{47}$ Ibidem. Humano, demasiado humano II. "Opiniões e sentenças diversas". §173.

${ }^{48}$ Cf. idem.

${ }^{49}$ Ibidem. Humano, demasiado humano. 234.

${ }^{50}$ Ibidem. Aurora. $\$ 550$.
} 
degenerada alienação de si. Com isso, além do implícito ataque a Wagner, o filósofo também critica a poesia de Byron e Alfred de Musset como uma forma de dissolução em um fora de $s i^{51}$. Somente homens atrasados quereriam a irrealidade da poesia $^{52}$.

Toda essa formulação nietzschiana é ainda mais explícita no aforismo intitulado A fé na embriaguez da obra Aurora: nele, o filósofo pondera que as pessoas de "instantes sublimes e arrebatados", na realidade, sentem-se miseráveis e inconsoláveis devido à fraqueza e ao desvanecimento de suas forças nervosas. Por isso, elas tendem a considerar os instantes de arrebatamento como o "Euautêntico", como o verdadeiro "si", ao mesmo tempo em que consideram aqueles sentimentos de miséria e desconsolo como efeitos do "fora-de-si". A intoxicação [Rausch] é a verdadeira vida para elas, aquilo que abraçam como o genuíno "Eu". É também com a embriaguez, seja ela de natureza moral, intelectual, política, religiosa ou artística, que esses tipos vão se vingar semeando por toda parte a insatisfação consigo mesmos e com os outros, o desprezo pela sua época e, sobretudo, o cansaço do mundo. A esses entusiásticos ébrios, diz Nietzsche, a humanidade deve muita coisa ruim, eles são responsáveis por disseminar, com toda a força, a fé na intoxicação, propagando, corruptamente, que perder-se desenfreadamente, arrebatar-se em excessos é a única forma de experimentar prazer consigo mesmo ${ }^{53}$.

É preciso enfatizar que a embriaguez criticada por Nietzsche não é efeito exclusivo da arte. O filósofo a compreende como um entorpecimento do ânimo, um torpor, uma ausência parcial e momentânea de consciência de si, acompanhada de um prazer extasiante causado, geralmente, pela natureza entusiástica de algo. Nesse sentido, a embriaguez pode ser resultante da arte; do desregramento de afetos e emoções ${ }^{54}$; da produção de conceitos e da dialética ${ }^{55}$;

\footnotetext{
51 "Esses homens dados a convulsões intelectuais, impacientes e sombrios consigo mesmos, como Byron ou Alfred de Musset, que em tudo o que fizeram semelham cavalos desembestados, e que obtêm de sua própria criação apenas um breve ardor e prazer que quase lhes rebenta as veias e, em seguida, um vazio e amargor tanto mais invernais, como devem suportar isto em si? Eles anseiam pela dissolução num "fora de si". Idem. §549.

${ }_{52} \mathrm{Cf}$. Ibidem. Humano, demasiado humano. \$234

${ }^{53}$ Cf. Ibidem. Aurora. $\$ 50$.

${ }^{54}$ Cf. Ibidem. Fragmento póstumo de 1877, 23[172]. Sobre a embriaguez do amor cf. também Humano, demasiado humano II. "Opiniões e sentenças diversas", §400.

${ }^{55}$ Cf. Ibidem. Aurora. $\$ 544$ e sobre a embriaguez nos conceitos e na dialética de Platão cf. Fragmento póstumo de 1885, 2[104].
} 
da religião, que exige a intoxicação e a desmesura na "devoção entusiasmada", no "sacrificar a si mesmo" e no "inebriante pensamento de união com o poderoso, homem ou deus, ao qual se consagra" $" 56$; além disso, é resultante da política, que delicia o povo com a ilusão do poder $^{57}$. Existe uma embriaguez no discurso político - explícito em nossa atual conjuntura - que atordoa as pessoas, sejam os agentes ou os receptores da fala, impedindo-lhes que enxerguem as profundidades das relações sociais para além da rasa superficialidade ideológica. Há, portanto, um êxtase discursivo, uma necessidade de gozo através do conjecturar, que faz do espaço político o lugar do falatório ébrio. As pessoas se veem constrangidas a opinar e, com isso, sentem-se inebriadas com o delírio de efetiva participação política $^{58}$.

O problema com a embriaguez é que ela cria outros mundos, não no sentido dualista metafísico, todavia, enquanto uma fuga da realidade. Ela é um meio de reconforto para pessoas fracas e cansadas, um escape para aqueles que de alguma maneira sentem-se incomodados com a vida tal como é. A religião, a moral, a política muitas vezes se utilizam da intoxicação e do arrebatamento como artifício de consolação. A arte que procura excitar e inebriar também não passa de uma forma de lenimento. Sobre esse caráter lenitivo da arte inebriante, Nietzsche, no aforismo 170 de Andarilho e sua sombra, assevera que na era do trabalho não nos é permitido dedicar à arte as melhores horas do dia, mesmo sabendo que ela é maior e mais digna que a labuta diária. Para o trabalhador, a arte faz parte do ócio, da recreação. O homem moderno não pode oferecer mais do que os resquícios de seu tempo cansado a ela. Isso alterou a posição da arte diante da vida: por exigir grande tempo e energia de seus receptores ela tem contra si tanto a consciência dos laboriosos e capazes, quanto os indolentes sem consciência; os primeiros,

\footnotetext{
${ }^{56}$ Cf. Idem. §215. Sobre o cume da embriaguez de Paulo, o primeiro cristão: cf. Idem. $§ 68$. Nietzsche aponta para a diferença entre a religião grega, que não viam nos seus deuses homéricos como senhores acima deles, nem a si mesmo como sevos abaixo, e o cristianismo, que "esmagou e despedaçou o homem por completo e o mergulhou como em um lodaçal profundo. Essa religião, então, no meio de uma total objeção, fez brilhar o esplendor de uma misericórdia divina, de modo que o homem, aturdido pela graça, saltou um grito de êxtase e por um momento acreditou carregar o céu dentro de si”. Cf. Humano, demasiado humano. \$114.

${ }^{57}$ Cf. Ibidem. Aurora. $\$ 188$ e $\$ 207$.

${ }^{58}$ Poderíamos mencionar também a embriaguez os movimentos políticos e sociais: eles criam termos inebriantes que intoxicam e arrebatam, tonando-se motriz para as suas lutas e causas, no entanto, por trás da excitação inebriante que suscitam, não possuem realidade objetiva, ou então, escamoteiam o seu real significado. Por exemplo, a utilização dos termos "democracia", "empoderamento", "liberdade" como estandartes que legitimam uma luta, mas, em si, carecem de significação.
} 
porque estão fatigados; os últimos, porque sua natureza não tem ligação com a "grande arte" e consideram suas exigências uma pretensão 59 .

Para não acabar se asfixiando sem ar e sem espaço, a "grande arte" teve que se transvestir em uma espécie de aviltamento e assumir características que são naturais da "pequena arte", a arte do descanso, do entretenimento, da divertida recreação. Os grandes artistas também passaram a prometer repouso e distração. Para criar, eles tiveram que utilizar como artifício os "mais poderosos meios de excitação, que sobressaltariam até um semimorto"; agora sua arte provoca "estupefações, embriaguez, convulsões, paroxismos de lágrimas: com eles, subjugam o homem fatigado e o lançam numa vivacidade insone, num extático e atônito ausentar de si" ${ }^{\prime 60}$. O aforismo não só denuncia a embriaguez na arte como uma forma de alijamento, de descanso proporcionado pelo escape de si, mas, também revela o novo posicionamento da estética nietzschiana: a interpretação da arte à luz das transformações das estruturas sociais. Destarte, quando se refere à grande arte [grossen Kunst], o filósofo tem em mente os formadores de espírito, Goethe, por exemplo ${ }^{61}$, porém, quando menciona o seu desflorescer está pensando no drama musical e, por consequência, a obra wagneriana.

Wagner não teria confiança na música, ele abusa das emoções dos ouvintes para conferir à sua arte o aspecto de grandeza. No entanto, ao fazê-lo, acaba adquirindo certo maneirismo, ele carrega seus temas com um desejo furioso de repetição. A música em suas peças tem a amplitude e a duração superdimensionadas, desse modo, segundo o filósofo, o espectador é atormentado, mortificado com o êxtase [Entzücken] ${ }^{62}$. Nietzsche confessa, em um fragmento póstumo de 1881, que o seu novo gosto para música é diametralmente oposto aos excessos wagnerianos, para ele a música deve ser pequena, caso proporcione alguma embriaguez, então que não seja pelo desregramento, mas pela doçura; "uma música menor é, indescritivelmente, mais elevada" elemento de superioridade em Wagner que faz fluir de si pura felicidade, então, não é o atordoamento ou efeito inebriante. Nietzsche, ao analisar a estrutura do

\footnotetext{
${ }^{59} \mathrm{Cf}$. Ibidem. Humano, demasiado humano II. "Andarilho e sua sombra”, §170.

${ }^{60}$ Idem.

${ }^{61}$ Idem. \$227.

${ }^{62} \mathrm{Cf}$. Fragmento póstumo de 1878, 27[90].

63 “und in diesem Falle wird geringe Musik unsäglich gehoben!". Fragmento póstumo de 1881, $12[103]$.
} 
tempo rítmico da música wagneriana ${ }^{64}$, compara a sensação de ouvi-la à sensação de alguém que entra ao poucos na água e deixa de pisar seguramente no fundo e se entrega à mercê do elemento que a balança. A "melodia infinita" desses dramas representa a decadência na arte, pois vicia a audiência aos excessos e confusões de sentimentos, tornando incapaz de se desfrutar do prazer estético por outra via senão pela embriaguez.

Apesar disso, a crítica nietzschiana à embriaguez, como já antecipamos, não é decisiva. O filósofo, no decorrer de sua obra, aos poucos vai retomando o valor estético do entorpecimento até fazer dele um dos principais fundamentos da arte, porém, definitivamente desvinculado de toda metafísica. Já em 1884, Nietzsche amenizava sua aspereza contra a intoxicação, não se trata, todavia, de um elogio integral, mas do reconhecimento de seus aspectos positivos e negativos. Em um fragmento da primavera desse ano, por exemplo, ele define o sentimento da embriaguez em oposição ao "enorme vazio e terrível sentimento de deserto"65. Entorpecidos, sentimos como se o mundo inteiro se aglomerasse em nós e experimentamos a felicidade da superabundância. Encontramos esse sentimento na música, na crueldade do trágico, na cega e deslumbrante exaltação de homens ou acontecimentos particulares. Também conhecemos, formas mais moderadas de embriaguez, tais como: um trabalho que carece de sentido; o sacrificar-se a uma ciência, a um partido político ou a alguma atividade lucrativa. Qualquer fanatismo estúpido, qualquer caminho cíclico que nos constrange a dar voltas possui a força inebriante ${ }^{66}$.

É possível perceber, no fragmento acima mencionado, pontos positivos e negativos da embriaguez. Somente a partir de 1886, a embriaguez artística passará a ser totalmente valorizada por Nietzsche. Tal como demonstra o seguinte fragmento póstumo de 1888: "O sentimento de ebriedade corresponde, na

\footnotetext{
${ }^{64}$ Nietzsche argumenta que a "melodia infinita" na música wagneriana "empenha-se em romper toda uniformidade matemática de tempo e espaço (...). Ele teme a purificação, a cristalização, a passagem da música para o arquitetônico - e, assim, opõe um ritmo de três tempos ao de dois tempos, introduz o compasso de cinco ou sete tempos, repete a mesma frase imediatamente, mas estendida de uma tal forma que tem duração duas ou três vezes maior". Ibidem. Humano, demasiado humano II. "Opiniões e sentenças diversas", §134.

${ }^{65}$ Fragmento póstumo de 1884, 25[13].

${ }^{66} \mathrm{Cf}$. Idem.
} 
realidade, a um mais de força" ${ }^{\text {67 }}$. No entanto, esse será o tema do último tomo desse trabalho, que investigará o dionisíaco e a intoxicação artística na obra Crepúsculo dos ídolos. Agora concentraremo-nos em aprofundar nas transformações da perspectiva nietzschiana em relação à arte. Para isso, é indispensável sublinhar qual será o entendimento do filósofo sobre a figura do "gênio", elaborada no período de Humano, demasiado humano, especialmente na seção "Da alma dos artistas e escritores", contrária àquela pensada anteriormente sob a influência de Wagner e Schopenhauer.

\subsection{2.}

\section{A re-significação do Gênio:}

Como já sabemos, os esboços que culminaram na reviravolta do pensamento nietzschiano surgiram durante o primeiro festival de Bayreuth. $\mathrm{O}$ evento que deveria ser marcado pela força dionisíaca e responsável pela restauração da cultura, na forma de uma espécie de ressurgimento da antiga sabedoria trágica foi, na verdade, uma marca de degeneração da cultura: ao invés de o drama wagneriano irromper a modernidade com o sentido trágico, foi um veículo de mera diversão e entretenimento. $\mathrm{O}$ evento tornou-se a oportunidade da aristocracia exaltar suas superficialidades. Richard Wagner, então ornado de virtudes alemãs, deixava de ser, aos olhos do filósofo, a figura do gênio, o "portador da cruz da humanidade, para redimi-la da grosseria e barbárie",68. Ao contrário de genialidade, foi desesperança que o jovem professor viu refletido no compositor. A decepção com o antigo mestre o levou a repensar a sua concepção de gênio, até então ligada às formulações metafísicas. No capítulo dedicado a Humano, demasiado humano em sua autobiografia, Nietzsche nos esclarece que colocou no gelo um erro após o outro e, com isso, congelou, dentre outros ideais, o "gênio".

No período de $O$ Nascimento da tragédia, a concepção nietzschiana de gênio era fortemente influenciada por Schopenhauer, consequentemente,

\footnotetext{
67 "Das Rauschgefühl, thatsächlich einem Mehr von Kraft entsprechend". Cf. Ibidem. Fragmento póstumo de 1888, 14[117]. (discutiremos sobre nas próximas seções).

${ }^{68}$ Anotação de Schopenhauer feita por Nietzsche In. Fragmento póstumo de 1873, 24[6].
} 
assentada na metafísica ${ }^{69}$. O gênio era então concebido como um indivíduo de caráter superior, como a "meta suprema da natureza",70; a ele foi atribuído o penoso trabalho de moldar o disforme "bloco de pedra" que é a massa. Esse elevado tipo de indivíduo seria inatingível e, verdadeiramente, incompreensível pelas pessoas medíocres ${ }^{71}$. Estas somente teriam direito à existência e à justificação por meio desses grandes seres $^{72}$. Em uma perspectiva estética estritamente pautada na metafísica, o gênio seria o responsável por intuir, em obra de arte, as contradições do Uno-primordial ${ }^{73}$. O gênio é, nesse ângulo, a imagem da contradição e da dor do ser originário refletida na aparência, manifestada na rede do espaço e tempo ${ }^{74}$. Nietzsche defendia que os homens comuns e os gênios contrastavam-se na medida em que, aqueles, presos às determinações do princípio de individuação, não chegavam à consciência de que eram meras obras de arte; enquanto estes, apesar de se reconhecerem como um entre os homens, possuíam a visão extasiante do ser eterno. Os homens teriam apenas um prazer parcial no mundo aparente, já os gênios, por enxergarem por trás do véu, gozariam da alegria extática $^{75}$.

Essas considerações levaram Nietzsche a conceder certo protagonismo social ao gênio; eles seriam os pilares da política, da cultura, da educação e, claro, da metafísica do artista. Dessa forma, a responsabilidade pela formação [Bildung] do espírito é conferida ao gênio. O Estado e as demais instituições sociais deveriam oferecer as condições necessárias para o advento desses seres que, por

\footnotetext{
${ }^{69}$ É necessário dizer que a metafísica nietzschiana de juventude, além de sofrer influência de Schopenhauer, também é inspirada pela filosofia do inconsciente e da linguagem de Edward von Hartmann (1842 - 1906). Cf. CAVALCANTI, Anna Hartmann. Op. Cit.

${ }^{70}$ Cf. Idem. 19[10].

71 "Große Genies sind den Alltagsfliegen unfaßbar und recht eigentlich unberechenbar". [Os grandes gênios são incompreensíveis e, verdadeiramente, imprevisíveis paras as moscas do dia-adia]. Ibidem. Fragmento póstumo de 1870, 2[20].

72 "Um povo recebe de seus gênios o verdadeiro direito à existência, sua justificação; a massa é um bloco de pedra difícil de esculpir: o indivíduo precisa de um trabalho enorme para que se possa retirar dele algo de humano". Ibidem. Fragmento póstumo de 1872, 8[59].

${ }^{73} \mathrm{Em} O$ Nascimento da tragédia (\$5) essa ideia é exemplificada da seguinte forma: "Na verdade, Arquíloco, o homem apaixonadamente ardoroso, no amor e no ódio, é apenas uma visão do gênio, que já não é Arquíloco, porém o gênio universal, e exprime simbolicamente seu sofrimento primigênio naquele símile do homem". Para Nietzsche, o gênio, que é o poeta lírico, não expressa na poesia a sua "eudade" [Ichheit], isto é, a sua subjetividade de homem comum, todavia manifesta em símbolos aquilo que experimentou no estado dionisíaco, ele objetiva em obra de arte as contradições da Vontade.

${ }_{74}^{74}$ Ibidem. Fragmento póstumo de 1870, 7[157].

${ }^{75}$ Cf. Ibidem. Fragmento póstumo de 1871, 10[1].
} 
sua vez, seriam responsáveis pela manutenção dessas instituições ${ }^{76}$. Uma cultura perfeita seria, então, aquela guiada pela "República dos gênios", essa ideia, inspirada em Schopenhauer, é ilustrada pela imagem de gigantes que, através de intervalos desérticos, chamam uns aos outros, sem que os anões, que se arrastam debaixo deles, percebam mais que um ruído confuso e se deem conta do que acontece nas alturas ${ }^{77}$. Graças à história essa república é possível, ela permite tal interação entre os grandes homens separados pelos séculos. Essa comunidade caberia o papel de conferir sentido à humanidade. O deslumbre de Nietzsche pelo gênio nessa época é tão grande que ele chega a conjecturar a possibilidade metafísica de que a vontade, a natureza utilizaria de seus artifícios para separar os gênios em uma "casta intelectual", separada dos homens comuns.

Esse modelo de gênio é congelado. Isto significa que o filósofo mudará por completo a sua concepção de genialidade. Agora, eles não correspondem mais ao grupo de homens seletos, cultuados por se destacarem como alguém que possui algum dom ou graça divina, mas alguém que se esforça por uma meta ${ }^{78}$. Nietzsche considerará que o culto ostentatório ao gênio não passa de um produto de nossa vaidade: porque pensamos bem de nós mesmos, todavia, ao mesmo tempo, reconhecemo-nos incapazes de fazer esboços como os dos grandes pintores, ou de escrever dramas iguais a Shakespeare, persuadimo-nos de que a capacidade para isso é, de alguma forma, extraordinária, algo de miraculoso. Assim, diz Nietzsche, nossa imodéstia e amor-próprio favorece o culto ao gênio. Mas, quando anulamos essa vaidade latente, percebemos que os feitos desses geniosos artistas em nada se diferem do inventor mecânico, do sábio em astronomia ou história, do mestre em táticas militares. Todos esses fazeres têm em comum o esforço desmedido dedicado a atingir uma meta, o zelo com a vida interior e a energia incansável desprendida para combinar os meios de que se dispõe. Toda atividade humana é complexa, não só a do "gênio", porém, nenhuma delas é milagre: é trabalho ${ }^{79}$.

A crença de que apenas no artista, orador ou filósofo sencontra-se a 'intuição' do gênio, que apenas estes seres iluminados teriam a capacidade de

\footnotetext{
${ }^{76}$ Cf. Idem. 7[23].

${ }^{77}$ Cf. Ibidem. A Filosofia na época trágica dos gregos, §1; Vantagens e desvantagens da história para a vida, §9; Fragmento póstumo de 1871, 24[4]; Fragmento póstumo de 1873, 29[52].

78 "O que é um gênio? - querer uma meta elevada e os meios para atingi-la". Ibidem. Humano, demasiado humano II. "Opiniões e sentenças diversas", $\$ 378$.

${ }^{79}$ Sobre o parágrafo Cf. Ibidem. Humano, demasiado humano. $\$ 162$.
} 
perscrutar diretamente a essência das coisas, surge quando as obras de grandes intelectos nos agradam muito, todavia, nossa vaidade nos impede de sentir inveja, fazendo-nos pensar que ali não precisamos competir, pois contemplamos algo “divino". Além disso, diante das obras de arte não temos acesso ao processo de criação, não podemos saber como ela veio a ser feita, acreditamos, então, que elas se impõem como uma perfeição atual. Dessa forma, os artistas são vistos como geniais, pois "tudo que está completo e consumado é digno de admiração, enquanto tudo que está vindo a ser é subestimado". Entretanto, toda essa apreciação ou depreciação não passam de uma infantilidade da razão que insiste em acreditar no aspecto miraculoso, divinal da arte e, assim, ignorar o laborioso devir criativo a que se submetem ${ }^{80}$. Nesse sentido, assevera Nietzsche, “o culto ao gênio é um eco da veneração a príncipes e deuses" $"$. Essa é uma tendência de elevar certos indivíduos ao plano supra-humano e, em decorrência disso, imaginar que existem camadas inteiras do povo mais baixas e grosseiras do que realmente são.

No aforismo 164 de Humano, demasiado humano, Nietzsche pondera que essa crença em espíritos grandes, superiores, fecundos, enfim, supra-humanos, está ligada, com muita frequência, à superstição religiosa ${ }^{82}$. Atribui-se a esses tipos uma visão imediata da essência do mundo, como se eles tivessem a capacidade, sem o labor e o rigor das ciências, de comunicar algo decisivo e definitivo acerca da vida e do homem. Quando a superstição religiosa impregna a mente de um suposto gênio, ao ponto dele não mais hesitar e, então, também se ver como um sobre-humano, uma irresponsabilidade toma conta de si. Ele deixa de fazer críticas a sua obra e, como consequência, terá a raiz de suas forças minada. Ainda nesse texto, em um claro ataque a Wagner, Nietzsche explica que, após um longo prazo em que o gênio passe acreditando que é sobre-humano, o "sentimento de direitos excepcionais, a crença de estar agraciando a todos com seu trato, uma raiva insana frente à tentativa de compará-lo a outros, ou estimá-lo inferior e trazer à luz as falhas de sua obra” tomam conta de si. Por isso, é mais útil, para os "grandes espíritos", saber da real origem de sua força: "energia

\footnotetext{
${ }^{80}$ Cf. Idem.

${ }^{81}$ Idem. $\$ 461$.

${ }^{82}$ Sobre a veneração do gênio como "espírito sobre-humano", Cf. Ibidem. Aurora. $\$ 548$.
} 
incessante, dedicação resoluta a certos fins, grande coragem pessoal e a sorte de ter uma educação com os melhores métodos, modelos e mestres" $" 83$.

O foco central de todas essas críticas ao gênio, feitas no período intermediário da filosofia nietzschiana, é retirar todo espírito criador do plano metafísico, desmistificar sua obra e torná-lo, por assim dizer, um simples mortal ${ }^{84}$. Isso fica evidente no aforismo $O$ porta-voz dos deuses em Opiniões e sentenças diversas, onde o filósofo argumenta que o poeta exprime as opiniões mais elevadas de um povo. Graças aos seus recursos artísticos, aquilo que enuncia passa a ser visto como algo prodigioso e o próprio poeta como um mensageiro divino. Conquanto, na nebulosidade do processo de criação, ele se esquece de onde realmente vem sua sabedoria espiritual: “da mãe, do pai, de mestres e livros de toda espécie, da rua e, particularmente, dos sacerdotes"85. A iluminação divina é, portanto, a "sabedoria popular misturada com tolice popular" Acontece que os artistas, segundo Nietzsche, em épocas mais ingênuas, se convencem de que um deus fala através deles; não abrem mão do fantástico, do mítico, do incerto, do simbólico e de algo miraculoso na genialidade como os pressupostos mais eficazes de sua arte. Isso, porque, não querem ser privados de atribuir significativas interpretações à vida. Eles consideram seu modo de criar mais importante do que a devoção científica à verdade ${ }^{87}$.

De acordo com a avaliação nietzschiana, os artistas têm interesse em que se acredite nas inspirações divinas, nas intuições repentinas [die plötzlichen Eingebungen], como se a ideia de uma obra de arte, ou o pensamento fundamental de um fílósofo, simplesmente surgisse como um raio de graça ${ }^{88}$. A crença em fundamentos metafísicos para a arte é um benefício para o artista, porque ele poderá emprestar significados agradáveis à vida. O gênio, entendido como aquele

\footnotetext{
${ }^{83}$ Cf. Ibidem. Humano, demasiado humano. "Perigo e benefício do culto ao gênio", §164.

${ }^{84} \mathrm{Em}$ outro aforismo de Humano, demasiado humano o filósofo ilustra com duas metáforas o caráter imanente da origem do gênio, não sem antes enfatizar que espera o entendimento da genialidade sem nenhum ressaibo mitológico ou religioso. A primeira metáfora trás a imagem da engenhosidade de um prisioneiro que busca meios para se libertar. A segunda metáfora é de alguém que se perdeu completamente ao andar pela floresta e se esforça por achar uma saída, às vezes descobre um caminho que ninguém conhece. Com essas imagens, além de desvinculá-lo de pressupostos metafísicos, Nietzsche demonstra que a origem do gênio é a mesma que os espíritos livres. Cf. Idem. §231.

${ }^{85}$ Ibidem. Humano, demasiado humano II. "Opiniões e sentenças diversas", $\$ 176$.

${ }^{86}$ Idem.

${ }^{87} \mathrm{Cf}$. Ibidem. Humano, demasiado humano. $\$ 146$.

${ }^{88}$ Idem. $\$ 155$.
} 
que é capaz de captar, através de um entusiasmo extraordinário, a realidade "emsi" das coisas, conseguirá outorgar ao mundo e à ação a maior profundidade e significação possível. Todavia, Nietzsche passou a rejeitar veementemente qualquer elo metafísico, místico, transcendente entre o gênio e sua criação. O filósofo tornou-se combatente inclusive da ideia de "dom" e "talentos inatos" todos "os grandes criadores foram grandes trabalhadores, incansáveis, não apenas no inventar, mas também no rejeitar, eleger, remodelar e ordenar" ${ }^{\text {"90 }}$. Dessa forma, até mesmo a improvisação artística está submetida à memória imitativa e ao empenho, não há nela nada de fantástico; as mentes talentosas estão cheias de lembranças de todas as coisas boas possíveis, enquanto os cérebros originais, que criam a partir apenas de si mesmos, estão sujeitos a produzir algo vazio e insípido $^{91}$.

É nítido o posicionamento positivista de Nietzsche nesse momento de sua obra. Para ele, quanto mais delicado é o sentimento do homem, quanto mais profundo é seu pensamento, quanto mais elevada é a sua autoestima e "quanto mais ele aparece como gênio entre os animais", tanto mais perto chega do real conhecimento do mundo. Porém, diferentemente do que a humanidade habituouse a pensar, isso não se faz com religião e arte, mas com ciência. As artes e as religiões são apenas uma forma de "floração do mundo", elas não podem, em absoluto, nos fazer entender a raiz das coisas, pelo contrário, elas apenas nos deixam embriagados pelo aroma das flores; isto é, elas nos inebriam prazerosamente com a ilusão de que é possível conhecer a totalidade do mundo como coisa-em- $\mathrm{si}^{92}$. A arte, familiarizada às explicações metafísicas, está preocupada em conjecturar sobre a essência por trás da realidade, isso pode até

\footnotetext{
${ }^{89}$ Para o filósofo, se torna grande não por dom, mas pelo esforço da repetição, tal qual o artesão, que aprende a construir perfeitamente as partes antes de ousar fazer um grande todo. Cf. Idem. "A seriedade do ofício", $\$ 163$.

${ }^{90}$ Nietzsche nos exemplifica com "Beethoven, que ao poucos juntou as mais esplêndidas melodias e, de certo modo, as retirou de múltiplos esboços". Idem. \$155.

${ }^{91}$ Cf. Idem. "O gênio e o nada", § 165.

92 "Estas são, é verdade uma floração do mundo, mas não se acham mais próximas da raiz do mundo do que da haste (...). O erro tornou o homem profundo, delicado e inventivo a ponto de fazer brotar as religiões e as artes. O puro conhecimento teria sido incapaz disso. Quem nos desvendasse a essência do mundo nos causaria a todos a mais incômoda desilusão. Não é o mundo como coisa em si, mas o mundo como representação (como erro) que é tão rico em significado, tão profundo, maravilhoso, portador de felicidade e infelicidade. Essa conclusão leva a uma filosofia da: que, alias, pode se unir tão bem a uma afirmação prática do mundo quanto ao seu oposto". Idem. "Embriagado pelo aroma das flores", § 29.
} 
proporcionar um deleite e conforto ${ }^{93}$. No entanto, o que é valorizado por Nietzsche é a ciência que se preocupa, tão somente, com a "representação", como o vir-a-ser repleto de significado. Uma ciência que pode ser chamada de "química das ideias e sensações" ${ }^{94}$, pois está encarregada de todas as sensações que experimentamos.

Por esse ângulo, a cultura superior é aquela marcada pela valorização de verdades simples e despretensiosas, obtidas com métodos rigorosos, frente aos erros que ofuscam e consolam, iguais aos cometidos pelos homens da metafísica e da arte. Em contraste com o que defendia em seus escritos de juventude, Nietzsche prevê a chegada de um período em que os espíritos superiores da ciência predominarão. No início dessa nova era científica, os adoradores da arte, bela ou sublime, vão zombar do pensamento rigoroso. Nota-se que o filósofo, em completa oposição às antigas formulações, agora considera a "ocupação séria com o simbólico" o distintivo de uma cultura inferior. Além disso, ele pressente que a arte tende a ser intelectualizada ${ }^{95}$. Apesar dessas considerações fortemente positivistas, é preciso dizer que Nietzsche conservará, na fase intermediária de sua produção, questões que são verdadeiros emblemas de toda sua filosofia, por exemplo, a crítica à fé na linguagem e no conceito como aeternae veritates. Ele entende que o homem da linguagem imaginou, não apenas denominar as coisas, porém exprimir com as palavras o supremo saber sobre coisas ${ }^{96}$. Essa apreciação sobre a linguagem engatilha outro tema que também é insígnia de sua filosofia: a crítica à lógica baseada em pressupostos sem nenhuma correspondência com o mundo real.

Apesar da valorização da ciência frente à arte, há vários aforismos onde Nietzsche denuncia a supervalorização da lógica na tradição ocidental. Ele afirma que uma das coisas que pode levar um pensador ao desespero é o conhecimento de que o ilógico é necessário e que dele surge muita coisa boa. Apenas os homens demasiadamente ingênuos pensam que a natureza humana possa se converter em

\footnotetext{
${ }^{93}$ Cf. Idem. $\$ 17$.

${ }^{94}$ [Chemie der Vorstellungen und Empfindungen]. Cf. Idem. §1.

${ }^{95}$ Idem. §3.

96 "de fato a linguagem é a primeira etapa no esforço da ciência. Da crença na verdade encontrada fluíram, aqui também, a mais poderosa fontes de energia. Muito depois - somente agora - os homens começam a ver que, em sua crença na linguagem, propagaram um erro monstruoso. Felizmente é tarde demais para que isso faça recuar o desenvolvimento da razão, que repousa nessa crença". Idem. §11.
} 
algo puramente lógico. Se essa conversão fosse realmente possível, muito do humano se perderia. Assim sendo, mesmo o homem mais racional precisa, de tempo em tempo, da sua ilógica relação fundamental com as coisas $^{97}$. O problema do logicismo exacerbado é que ele se tornou, ao longo dos séculos, o fundamento da metafísica: foi a partir dos princípios silogísticos que se deu crédito à cognoscibilidade de cada objeto em si, em sua própria essência, como um objeto idêntico a si mesmo, portanto, existente por si mesmo e, no fundo, sempre igual e imutável $^{98}$. Para Nietzsche, toda coisa em si mesma é digna de uma gargalhada homérica ${ }^{99}$.Assim sendo, a metafísica como ciência do "em si", que durante um longo tempo foi considerada o saber das verdades fundamentais, não é outra coisa senão a ciência dos erros fundamentais do homem.

Sabendo desses pormenores da reviravolta no pensamento nietzschiano, resta-nos elucidar qual o lugar reservado à música. Como já sabemos, antes o filósofo a considerava como a obra de arte superior, elevada hierarquicamente em relação às demais formas de criação artística, justamente por sua capacidade de comunicar a essência do mundo, logo, era concebida como uma linguagem universal. Agora, desvencilhado de qualquer resquício estético-metafísico, Nietzsche vai destituir a arte dionisíaca de toda sua majestade. Afastar-se de Wagner e Schopenhauer implica, devido àquilo que esses nomes representam na história da arte, o distanciamento da música, ao menos de uma concepção ontológico-musical. Nas publicações que compreendem a fase intermediária, podemos encontrar diversos aforismos que repensam o valor da música. $\mathrm{Na}$ maioria deles há uma crítica velada às obras wagnerianas, em outros, encontramos uma crítica explícita ao compositor. No entanto, o ponto é que, da mesma forma em que esvaziou o cálice criticando a embriaguez, silenciou Dioniso e congelou o gênio, Nietszche irá calar as musas por um determinado tempo.

Os parágrafos a seguir, por terem como tema central a música, abrirão nosso segundo estásimo. Nele iremos mostrar, em linhas gerais, qual o significado desse emudecimento.

\footnotetext{
${ }^{97}$ Cf. Idem. $\$ 31$.

${ }^{98}$ Cf. Idem. $\$ 18$.

${ }^{99}$ Cf. Idem. §16.
} 


\section{6}

\section{¿TÁIIMON $\triangle E^{\prime} Y T E P O N$}

6.1 .

A re-significação da música

É perceptível na seção "Da alma dos artistas e escritores" o novo tratamento conferido à música. No aforismo 215, Nietzsche assevera que essa arte, em si, não é tão significativa para o nosso mundo interior, nem tão profundamente tocante a ponto de ser considerada uma linguagem que comunica imediatamente os sentimentos. Nós só acreditamos que ela é capaz de falar diretamente ao nosso íntimo e, até mesmo, que dele parta, devido ao simbolismo - presente nos movimentos rítmicos e nas intensidades tonais - adquirido do seu parentesco ancestral com a poesia. Há, notoriamente, uma inversão das considerações estéticas de $O$ Nascimento da tragédia: a poesia, antes pensada como fruto da música, agora é pintada como a responsável pela deturpação presente no drama musical. Depois que as duas estiveram unidas em uma longa evolução, a forma musical se entreteceu totalmente com fios de conceitos e sentimento. A "música absoluta", no seu soar medido e variamente acentuado, já causa prazer. Por isso, ela deve se desvencilhar das amarras das palavras e de todo o simbolismo linguístico tão expressivo na ópera, no Lied e nas centenas de tentativas daquilo que Nietzsche chama de "pintura tonal", para assim, se reencontrar o estado cru da música ${ }^{1}$.

É fundamental ressaltar que nessa nova abordagem a música não fala da "vontade" ou da coisa-em-si. Conferir a ela esse atributo metafísico é tarefa exclusiva do intelecto, que havia traduzido toda a "esfera da vida interior para o simbolismo musical" ", foi um processo cognitivo que introduziu uma significação no som, não há, portanto, nenhum fundo ontológico na criação ou na audição musical. Do mesmo modo, a música não é uma linguagem universal, tal qual defendia Schopenhauer e o jovem Nietzsche schopenhauriano, pelo contrário, agora ela é vista tão somente como um fruto da cultura, logo, está limitada à determinada época e lugar, assim como às condições políticas e sociais

\footnotetext{
${ }^{1}$ Cf. Idem. $\$ 215$.

${ }^{2}$ Idem.
} 
específicas. No aforismo A música como fruto tardio da cultura, ela é pintada como um extrato de determinado solo cultural, a última dentre todas as artes a florescer, reunindo em si as marcas de um tempo; por isso, "ela soa no interior de um mundo novo e assombrado, como a linguagem de uma era desaparecida, vindo tarde demais" ". Apenas Haendel, exemplifica Nietzsche, ressoou o melhor da alma de Lutero; Apenas Mozart resgatou a época de Luiz XIV; Apenas na música de Beethoven e Rossini o século XVIII cantou derradeiramente ${ }^{4}$.

Com tal argumentação o filósofo pretende demonstrar que a música não é uma linguagem universal e supratemporal que comunica a essência que transcende as gerações. Todavia, ela corresponde a uma "medida de sensibilidade, calor e tempo que uma cultura bem determinada, delimitada no tempo e no espaço traz em si como lei interior" ". Uma música moderna, por exemplo, seria inacessível aos antigos. É claro que essa análise tem como alvo a obra wagneriana. O filósofo postula que a música alemã de sua época, ou seja, Wagner, por mais que ansiasse dominar, não seria mais compreendida em um tempo vindouro. Nietzsche imagina que a cultura da qual surgiu essa música - cujo solo fecundante é o catolicismo e o nacionalismo - não seja mais compreendida em um futuro próximo. É da natureza da arte das musas tornar-se mais precocemente insípida do que as demais artes plásticas, sem contar o pensamento que, por sua vez, se demonstra mais resistente e durável. Apesar de estar fazendo uma crítica à decadência de sua época, a avaliação nietzschiana, transportada à cultura popular, mostra-se verdadeiramente correta, os estilos musicais, ao longo dos séculos, ao menos para as massas, tem um curto prazo de validade.

Além disso, o poder de comunicabilidade da música haveria se desenvolvido da mesma forma que a linguagem convencional. Para Nietzsche, mais antiga que todas os modos de linguagem é a imitação dos gestos involuntários (tal como o bocejo provoca em um observador a imitação involuntária desse gesto). Cada imitação de gesto reconduzia o imitador ao sentimento do rosto ou do corpo do imitado. Assim começamos a nos compreender, basta lembrarmo-nos de como o bebê compreende a sua mãe. Tão

\footnotetext{
${ }^{3}$ Ibidem. Humano, demasiado humano II. "Opiniões e sentenças diversas", §171.

${ }^{4}$ Cf. Idem.

${ }^{5}$ Idem.
} 
logo as pessoas se entenderam pelos gestos, nasceu um simbolismo gestual, isto é, passamos a produzir um som acompanhado de um gesto - que se juntavam simbolicamente - até, mais tarde, nos tornarmos capazes de nos comunicar apenas pelo som. O mesmo teria acontecido com a música dramática: enquanto, em um primeiro momento, sem dança, sem gestos explicativos a música não passava de um ruído vazio, após um longo convívio entre o som e os movimentos, o ouvido foi educado para imediatamente interpretar as figuras sonoras e, por fim, chegar a uma rápida compreensão, já sem o auxílio do visível. A "música absoluta" seria, justamente, aquela em que tudo é logo compreendido simbolicamente, sem qualquer auxílio ${ }^{6}$.

Com essa elaboração, o filósofo quer destituir definitivamente a música de qualquer categoria metafísica. Tudo pode ser explicado positivamente, seja pela fisiologia, pela ciência histórica ou pela ciência física. A arte musical diz tão somente ao ouvido e, portanto, passa a ser concebida, nessa perspectiva, depreciativamente: Nietzsche chega, até mesmo, a escrever contra o cultivo da música, sugerindo que a educação artística das crianças deva priorizar a visão, mediante a pintura, o esboço de paisagens, de pessoas e eventos; isso traria o benefício de tornar o olho agudo, calmo e perseverante na observação de situações. Já o cultivo artístico da audição não resultaria em uma vantagem semelhante. Por isso, as escolas primárias deveriam dar preferência à arte da visão frente àquela do ouvido ${ }^{7}$. Ainda sobre isso, em um aforismo de Aurora, o ouvido é considerado o órgão do medo, desenvolvido na noite, na penumbra das cavernas e nos bosques sombrios, durante a época mais longa da humanidade, daí o caráter da música: uma arte da noite e da penumbra ${ }^{8}$. Assim como o ouvido não é tão necessário no claro, a música moderna não é necessária para aqueles que têm sua vida plena. Ela seria uma necessidade artística de segunda ordem, uma forma de inebriar os descontentes e afastar o tédio e mal-estar por alguns instantes ${ }^{9}$.

Interessante que ao analisar a relação de seus contemporâneos com a música, Nietzsche percebe que o povo diz possuir uma ânsia pela arte, mas, na

\footnotetext{
${ }^{6}$ Cf. Ibidem. Humano, demasiado humano. \$216.

7 Aforismo intitulado Contra o cultivo da música. Ibidem. Humano, demasiado humano II. "Opiniões e sentenças diversas”, §213.

${ }^{8}$ Ibidem. Aurora. $\$ 250$.

${ }^{9}$ Ibidem. Humano, demasiado humano II. “Opiniões e sentenças diversas”, $§ 169$.
} 
verdade, é só um pouco e de satisfação barata, basta apenas um refugo de arte para que eles se contentem. Tal constatação o leva a escrever, em Opiniões e sentenças diversas, o seguinte: "Considere-se, por exemplo, que melodias e canções alegram atualmente as mais vigorosas, incorruptas, ingênuas camadas da nossa população, (...) não é amada e mesmo acarinhada a pior música que nos dias de hoje se produz?"10. Por isso, quem afirma ter uma carência profunda e insaciável de arte, está mentindo ou delirando. Em geral, são os "descontentes mais refinados", que por si só não são capazes de alcançar alegria verdadeira, o que hoje em dia poderíamos chamar de classe média - o homem culto que não se libertou dos consolos religiosos, o financeiramente privilegiado que se acha nobre demais para atividades modestas, os jovens incapazes de criar deveres satisfatórios para si, as mulheres solitárias com problemas no matrimônio, os eruditos e trabalhadores que nunca encontram tempo livre e os artistas incompletos - que são os necessitados de arte. E o que desejam propriamente da arte? Nietzsche responde:

Ela deve lhes afastar, durante horas ou instantes, o mal-estar, o tédio, a consciência meio ruim, e, se possível, reinterpretar em grande escala o erro de sua vida e de seu caráter, vendo-o como erro no destino do mundo - muito diferentemente dos gregos, que sentiam na sua arte o emanar e transbordar de sua própria saúde e bemestar e que amavam ver sua perfeição uma vez mais fora de si mesmos: - eram conduzidos à arte pela fruição de si, e estes nossos contemporâneos, pela aversão a $\mathrm{si}^{11}$.

Ao ler o aforismo acima, escrito para o que se tornou o segundo volume de Humano, demasiado humano, portanto em meados de 1879, é impossível não se reportar automaticamente aos nossos dias e à relação de nossos contemporâneos com a arte, conferindo assim, uma atualidade a Nietzsche. Hoje é frívola, senão hipócrita, a necessidade artística do povo. Essa situação explicita-nos uma sociedade culturalmente doente: isso porque, para a maioria, a única forma de arte acessível é aquela oferecida como mercadoria, como um produto a ser comprado. Intrínseco a esse problema, as pessoas, como em um fenômeno global, tendem a

\footnotetext{
${ }^{10}$ Idem.

${ }^{11}$ Idem.
} 
se contentar com o "lixo cultural" rotulado de arte. Para elas, a única coisa que está em jogo é o mero entretenimento, a hedônica busca por satisfação imediata e a desesperada tentativa de fuga, mesmo que momentaneamente, do "mal do nosso século", o tédio. Somado a isso, existe um sentimento de imprescindibilidade em debater e julgar moralmente as obras de arte, porém, baseado apenas na superficialidade de ideologias e pré-conceitos morais, em outras palavras, há uma embriaguez do discurso moral e político - sobretudo da classe média, ou dos "descontentes mais refinados", para utilizar um termo nietzschiano - que acaba recobrindo o âmbito artístico na forma de uma pseudo-avaliação das artes.

Além disso, há outro aspecto da crítica à arte que deve ser mencionado: em alguns textos - sempre pensando em Wagner - Nietzsche alude a um aspecto fisiologicamente perigoso na musicalidade: ela pode, por exemplo, cativar com toda sua volúpia e grandiosidade, tornando até mesmo as pessoas mais moderadas, intemperantes. Contudo, quando o indivíduo submete-se continuamente e repetidamente aos exageros musicais, corre o sério risco de ter um abalo e um solapamento de sua saúde espiritual ${ }^{12}$. O risco de uma falência da saúde é igualmente perigoso se alguém, após ser privado por longo tempo da música, é novamente entorpecido por ela. As consequências dessa privação interrompida é "o sentimento, ao mesmo tempo, de amargura e ferimento, saciedade e nostalgia, e força a bebericar", o enfraquecimento das vistas, como se a luz perdesse a claridade, em resumo, uma sensação de desfalecimento e a “impressão de que a música ressoa como numa prisão"13. A música pode, portanto, debilitar a saúde. Ao descrever esses efeitos fisiológicos, Nietzsche está se referindo ao próprio colapso nervoso que coincidiu com o afastamento de Wagner. Ao menos, é isso que ele deixa transparecer em uma carta à amiga Malwida, quando diz como a "música desesperadora" o afetou profundamente ${ }^{14}$.

Todo ataque à arte musical é resposta a uma necessidade de reformulação de pensamento. Quando se decepciona com Wagner - eis aqui outro símbolo e não

\footnotetext{
${ }^{12}$ Cf. Idem. $\$ 159$.

${ }^{13}$ Cf. Idem. "O Andarilho e sua sombra", §154.

14 "Minhas reflexões e meus escritos, sempre problemáticos, até agora sempre me fazem adoecer; enquanto eu era um verdadeiro erudito, tive saúde. Mas então chegou aquela música desesperadora [nervenzerrüttende Musik] e a filosofia metafísica e a preocupação com mil coisas que não me interessavam". Carta a Malwida von Meysenbug de 1 de julho de 1877. (O adjetivo nervenzerrüttende carrega a ideia de irritação nervosa).
} 
uma pessoa - Nietzsche procurou se afastar de tudo o que o compositor representava, então congelou o gênio, a embriaguez e silenciou as musas. Entretanto, quando critica esses elementos, que antes eram centrais em sua filosofia, seu principal objetivo é desvencilhar seu pensamento de qualquer base metafísica $^{15}$. Ele deveria eliminar todo elo que ainda o ligasse às formulações schopenhaurianas e wagnerianas. O foco era a construção de um modo de pensar autêntico. Para isso, foi preciso se distanciar dos concertos. A música ainda era uma ponte que, invariavelmente, o levava às ideias do passado. Por um tempo Nietzsche viveu afastado dela ${ }^{16}$, mas foi só por um tempo: ele encontrará em outros compositores, sobretudo em Bizet, o deleite estético. Em suas obras tardias a música reassumirá o seu protagonismo, principalmente, em Assim falou Zaratustra. Aliás, não é somente as musas que voltam a cantar, a embriaguez e o próprio gênio reassumirão um importante papel na estética nietzschiana. Também Dioniso - como na lenda do deus menino que, depois de dilacerado, renasce do próprio coraçãozinho - ressurgirá elevado na obra de Nietzsche, agora na forma do pessimismo dionisíaco e do gênio do coração.

\footnotetext{
15 "Quando escrever suas cartas sobre música utilize o menos possível expressões metafísicas schopenhaurianas; eu acredito - Perdão! Creio que sei - que é falsa, e que todos os escritos que estão impressos com ela serão incompreensíveis" Carta a Carl Fuchs de 29 de julho de 1877.

16 "Quanto a mim, vivo bastante distante da música em geral - assim deve ser". Carta ao amigo Gustav Krug en Bonn de 6 de janeiro de 1879.
} 


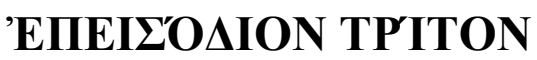

\section{1.}

O pessimismo dionisíaco:

As menções a Dioniso ressurgem na obra nietzschiana de modo efetivo, isto é, na condição de um termo que reúne em si a significação de um pensamento filosófico - ou se preferirem, como um "conceito" - a partir de 1886, na obra Além do bem e do mal, na forma do "Gênio do coração" e, em 1887, no "Livro V" adicionado à obra A Gaia ciência, na forma do "pessimismo dionisíaco"1. Esses dois momentos podem ser considerados como as "portas de (re)entrada" do deus no pensamento nietzschiano. A partir de então, o filósofo quebra definitivamente o longo silêncio em relação ao dionisíaco ${ }^{2}$, e o reintroduz como o elo central que irá anelar os principais temas de sua filosofia madura. No entanto, devemos reiterar que não se trata aqui do mesmo Dioniso formulado no período de $O$ Nascimento da tragédia, entretanto, de um novo símbolo, transmutado, ou seja, despido de qualquer roupagem metafísica. Ainda se conservarão alguns traços correspondentes ao entendimento estético-afirmativo de outrora, por exemplo, o termo ainda equivalerá à loucura, ao prazer na destruição, à embriaguez artística, todavia, não em oposição às formas e à imagem - Nietzsche abandonará por completo a dicotomia "apolíneo-dionisíaca". Agora, ele diz tão somente ao corpo, à abundância de vida. $\mathrm{O}$ riso será a sua categoria frente a qualquer realidade alheia a esta.

\footnotetext{
${ }^{1}$ Antes dessa reaparição, o termo Dioniso e sua substantivação, o dionisíaco, aparecem algumas vezes nos Fragmentos póstumos a partir de 1880, mas sem uma importância significativa, geralmente fazem apenas referência ao período de $O$ Nascimento da tragédia; nesse caso, podemos anotar, por exemplo, os fragmentos 4[225] e 24[101] de 1880. Já em 1883, Dionysos aparece em uma prematura associação à obra Assim falou Zaratustra, assim como no fragmento 13[1]. A contar 1884, os termos voltam a ter uma relevância maior, eles apresentam-se como preparação para Além do bem e do $\mathrm{mal}$, inaugurando, portanto, uma nova fase do pensamento nietzschiano. Isso pode ser conferido nos fragmentos 25[95] e 26 [258] de 1884; e nos fragmentos 34[17] e 34[176] de 1885 .

${ }^{2}$ É exatamente isso que Nietzsche diz em uma carta ao amigo, o músico Heinrich Köselitz em 22 de março de 1884: "Nas últimas páginas haverá uma surpresa. Somente o diabo sabe! Depois de ter quebrado, de tal maneira, o meu silêncio, sou obrigado a fazer "algo mais", a formular algum tipo de "filosofia do futuro" - com a inclusão de "danças dionisíacas", "livro-tolos" e outras diabruras. Pois tem que se continuar vivendo!!! O que você acha?".
} 
Todos esses significados já estão contidos na ideia do "pessimismo dionisíaco", desenvolvida por Nietzsche no parágrafo 370 de A Gaia ciência, intitulado "O que é o romantismo?". A pergunta título antecipa-nos que o tema central do aforismo não é o dionisíaco, mas se for, então será em comparação à definição encontrada sobre o que é romantismo. O ponto de partida do filósofo para chegar a essa definição, para não contrariar seus preceitos, não são a explicitação lógica e exegética do conceito, porém, suas próprias experiências e vivências pessoais, ou melhor, os erros e superestimações que lançou, quando jovem, à modernidade. O equívoco nietzschiano foi compreender "o pessimismo do século XIX como sintoma de uma elevada força de pensamento, de mais ousada valentia, de mais vitoriosa plenitude de vida, do que caracterizara o século XVIII, a era de Hume, Kant, Condillac e os sensualistas"3. Assim, considerou a opulência da cultura alemã como o signo de uma cultura trágica. Do mesmo modo, interpretou a música alemã como se exprimisse uma potência dionisíaca, acreditou "ouvir o terremoto com que uma força primordial, há muito represada, finalmente se desafoga". Contudo, reconhece que aquilo que pensava ser trágico no pessimismo filosófico, e dionisíaco na música alemã, constituía, na verdade, o seu romantismo ${ }^{4}$.

O romantismo como movimento histórico é, grosso modo, um momento criativo da Europa que surge em contraste ao iluminismo, que por sua vez, é entendido como o apogeu das luzes da razão, que desfaz qualquer obscuridade intelectual, a partir da sistematização da vida humana, por meio de conceitos e sistemas que se pretendiam claros e válidos universalmente. Em oposição a isso, o romantismo baseou-se em insondáveis mistérios do espírito humano e da natureza; o absoluto, o infinito e o ilimitado eram parte de suas indagações. Em geral, tinha como principal tema os sentimentos, sobretudo, a dor, o dilaceramento

\footnotetext{
${ }^{3}$ NIETZSCHE. A Gaia ciência. $\$ 370$.

${ }^{4} \mathrm{Em}$ um fragmento que prepara o $\$ 370$, Nietzsche avalia: "Aplicação errada no presente: interpretei o pessimismo como resultado de força e da abundância de vida [Kraft und Lebensfülle], que podem dar-se ao luxo do trágico. Da mesma forma, interpretei a música alemã como expressando superabundância e originalidade dionisíacas, a saber:

1) Eu superestimei o Ser [Wessen] alemão;

2) Eu não entendi as fontes da melancolia [Verdüsterung] moderna;

3) Eu não tinha a compreensão histórico-cultural da origem da música moderna e do seu essencial romantismo.

Além desta aplicação indevida, o problema persiste: como seria uma música que não tivesse origem romântica, mas sim dionisíaca?”. Ibidem. Fragmento póstumo de 1885, 2[111].
} 
e a solidão, podendo, assim, ser considerado como uma forma de "emocionalismo exagerado". Porém, sem deixar de se preocupar com o pensamento: o romantismo, na sua origem, é a aproximação do pensamento filosófico à arte. Além disso, os românticos fizeram da ironia, da alegoria, dos paradoxos e dos fragmentos o seu modo de expressão, era a forma com que evidenciavam, de dentro da própria linguagem, sua falta de completude ${ }^{5}$. Como podemos notar, todas essas características são muito próximas à filosofia nietzschiana de juventude, e, em alguns aspectos, à sua filosofia mais tardia também.

Apesar das proximidades, Nietzsche será extremamente crítico do romantismo, principalmente daquilo que reconhece como a influência romântica em seu próprio pensamento. No entanto, o alvo de suas críticas não é direcionado - ao menos não no aforismo que nos toma a atenção agora - aos diversos poetas, artistas, compositores e filósofos pertencentes a este período, mas, exclusivamente à obra wagneriana e ao pensamento schopenhauriano. Para Nietzsche, não é importante mencionar os demais membros do romantismo, porque sua intenção é demonstrar duas formas, em si contraditórias, de se pensar a vida. Então ele reinterpreta, a seu modo, o conceito Romantik, desvinculando-o parcialmente daquilo que foi o movimento histórico e, com isso, destaca Wagner e Schopenhauer como os maiores exemplos do "pessimismo romântico", portanto, antípodas do "pessimismo dionisíaco". Essa primeira forma de pessimismo, corresponde a uma postura de fraqueza e doença; enquanto a segunda, de força e saúde. Nesse sentido, o romantismo é interpretado fisiologicamente. A fórmula nietzschiana é aparentemente simples: "a arte é consequência da insatisfação com o real? Ou uma expressão de agradecimento pela felicidade gozada? No primeiro caso, romantismo; no segundo, auréola de glória e ditirambo (em suma, arte apoteótica)"6.

Se a arte é consequência de uma insatisfação consigo mesmo ou com a vida, então ela pressupõe a fraqueza. Ao contrário, se ela é expressão de júbilo, mesmo diante das intempéries da vida que luta incessantemente, então ela presume a vitalidade. Porém, para ambos os casos Nietzsche prevê que haja sofrimento e

\footnotetext{
${ }^{5}$ Sobre as características do romantismo e sua relação com a arte e a filosofia moderna, Cf. ANDRADE, Pedro Duarte. Estio do tempo. Romantismo e estética moderna.

${ }^{6}$ Ibidem. Fragmento póstumo de 1886, 2[114].
} 
sofredores, de modo que toda arte, assim como toda filosofia possa ser vista como um paliativo. Mas como há tanto os tipos fracos como os fortes, também existem "os que sofrem de abundância da vida, que querem uma arte dionisíaca e também uma compreensão trágica da vida" e, em oposição a estes, "os que sofrem de empobrecimento da vida, que buscam silêncio, quietude, mar liso, redenção de si mediante a arte e o conhecimento, ou a embriaguez, o entorpecimento, a convulsão, a loucura"7. Os indivíduos fracos necessitam sempre de consolo para o seu sofrimento. Dicotomicamente, o homem do pessimismo dionisíaco, rico em saúde, não precisa de redenção, ele suporta com alegria todo sofrimento e contradições inerentes ao fluxo da vida. A diferença entre essas duas tipologias são descritas da seguinte forma no parágrafo 370 de A Gaia ciência:

O mais rico em plenitude de vida, o deus e homem dionisíaco, pode permitir-se não só a visão do terrível e discutível, mas mesmo o ato terrível e todo luxo de destruição, decomposição, negação; nele o mal, sem sentido e feio parece como que permitido, em virtude de um excedente de forças geradoras, fertilizadoras, capaz de transformar todo deserto em exuberante pomar. Inversamente, o que mais sofre, o mais pobre da vida necessitaria ao máximo de brandura, paz e bondade, tanto no pensar quanto no agir, e, se possível, de um deus que é propriamente um deus para doentes, um "salvador"; e igualmente da lógica, da compreensibilidade conceitual da existência - pois a lógica tranquiliza, dá confiança - em suma, de uma certa estreiteza cálida que afasta o medo, um encerrar-se em horizontes otimistas ${ }^{8}$.

Foi preciso passar por um processo lento e gradual de aprendizagem para que Nietzsche pudesse perceber, com perspicácia, a diferença entre os dois tipos de sofredores e, consequentemente, reconhecer o erro cometido em confundir o romantismo de seus antigos mestres com a força trágica. $\mathrm{O}$ aprendizado tornou seu olhar mais agudo para aquilo que denomina de "difícil e insidiosa inferência regressiva", isto é, "inferência que vai da obra ao autor, do ato ao agente, do ideal àquele que dele necessita, de todo modo de pensar e valorar à necessidade que por trás dele comanda" ${ }^{9}$. Isso significa que todos os valores das produções culturais correspondem aos anseios e às necessidades de seus criadores. Todavia, tal inferência regressiva não pode ser entendida como uma simples decomposição lógico-gramatical, onde se postula um sujeito criador como a causa subjetiva de sua obra. Antes disso, o anseio que se faz criador tem como fundo a força ou a fraqueza, a saúde ou a doença, logo, o sujeito da obra nada mais é do que o seu

\footnotetext{
${ }^{7}$ Ibidem. A Gaia ciência. $\$ 370$.

${ }^{8}$ Idem.

${ }^{9}$ Idem.
} 
corpo. O modo de avaliação da nova estética nietzschiana é, então, exclusivamente fisiológico; por isso ele se questiona em cada caso: "foi a fome ou a abundância que aí se fez criadora?" 10 .

Interessante que Nietzsche, em suas paradoxais imagens, revela-nos que tornou os seus olhos agudos, perspicazes para avaliar a cultura justamente na doença, isto é, no período em que sua grave enfermidade causou-lhe muitas dores nos olhos e inclusive a cegueira: paradoxalmente, a impossibilidade de enxergar desenvolveu sua capacidade de ver, a privação fez de sua visão mais precisa. No prólogo de A Gaia ciência, escrito na mesma época do "Livro V", o filósofo explica-nos que, com a inquietação de um psicólogo, levou todas as curiosidades científicas para a doença, então percebeu que em alguns homens são as deficiências que filosofam, e em outros as riquezas e forças. No primeiro caso, os doentes precisam da sua filosofia como apoio, redenção, medicamento, alheamento de si; no segundo, ela é apenas uma forma de exteriorizar o prazer e a gratidão consigo mesmo, nas palavras do filósofo, "um formoso luxo, no melhor dos casos a volúpia de uma triunfante gratidão, que afinal tem de se inscrever, com maiúsculas cósmicas, no firmamento dos conceitos" ${ }^{\prime 1}$. Para Nietzsche, o pensamento predominante na história da filosofia seria aquele onde a pressão da doença se faz criadora, portanto o pensamento que busca sossego, brandura, consolo $^{12}$.

Tais considerações ratificam a perspectiva fisiológica do pensamento nietzschiano, o corpo é a verdadeira fonte para o ato criador. O filósofo está tão seguro de suas impressões que questiona se a filosofia até então não teria sido apenas uma má-compreensão do corpo, fundada no "inconsciente disfarce de necessidades fisiológicas sob o manto da objetividade", tão visíveis nas "insânias da metafísica". O fillosofar não teria, portanto, suas indagações voltadas à verdade, mas sim à saúde e à vida que cresce. No entanto, a doença não deve ser completamente ignorada. A instabilidade da saúde também traz os seus benefícios; ela ocasiona, por exemplo, o aprofundamento de si, ensinando-nos

\footnotetext{
${ }^{10}$ Idem.

${ }^{11}$ Idem. "Prólogo", §2.

12 "Toda filosofia que põe a paz acima da guerra, toda ética que apreende negativamente o conceito de felicidade, toda metafísica e física que conhece um finale, um estado final de qualquer espécie, todo anseio predominantemente estético ou religioso por um Além, Ao-lado, Acima, Fora, permitem perguntar se não foi a doença que inspirou o filósofo". Idem.
} 
como interrogar e dominar a nós mesmos. A doença e o sofrimento colocariam a própria vida em forma de pensamento. Nesse entendimento, “Apenas a grande dor, a lenta e prolongada dor, aquela que não tem pressa, na qual somos queimados com madeira verde, por assim dizer, obriga a nós filósofos a alcançar profundidade extrema"13. A ideia não é que a dor possa proporcionar o aperfeiçoamento da pessoa, mas sim - através de experimentações corporais intensas, que exigem o exercício de autodomínio - um aprofundamento de si. Por isso, o corpo e a dor são mais primordiais aos artistas e filósofos do que a consciência entendida como mera abstração:

\begin{abstract}
Não somos batráquios pensantes, não somos aparelhos de objetivar e registrar, de entranhas congeladas - temos de continuamente parir nossos pensamentos em meio a nossa dor, dando-lhes maternalmente todo o sangue, coração, fogo, prazer, paixão, tormento, consciência, destino e fatalidade que há em nós. Viver - isto significa, para nós, transformar continuamente em luz e flama tudo o que somos, e também tudo o que nos atinge; não podemos agir de outro modo ${ }^{14}$.
\end{abstract}

Desse modo, a convalescência de Nietzsche é um exemplo prático de sua fisiologia estética: por mais que sua fragilidade física o fizesse sofrer todos os tipos de moléstias - aflição nos olhos, persistentes crises de enxaqueca acompanhadas de enjoo e vômito, uma verdadeira "tirania da dor" e o "radical isolamento" - o que define sua natureza é uma imprescindível força e um enorme anseio por recuperação, marcas definitivas de saúde. Dessa forma, se consideramos a obra nietzschiana sob o crivo de sua própria avaliação, então podemos dizer que ali foi a abundância que se fez criadora. Essa reflexão se faz muito pertinente nos dias atuais, visto que vivemos em época onde nenhum tipo de sofrimento é aceito. A sociedade e a cultura contemporânea se estruturaram de tal forma que não concede mais espaço à verdadeira experimentação da dor, da solidão e do sofrimento. Existe um sem-número de subterfúgios que anestesiam imediatamente qualquer desconforto, físico ou emocional. Podemos dizer, seguramente, que hoje não há mais lugar para a decepção. Isso é extremamente problemático, porque o resultado é o surgimento de um indivíduo invariavelmente fraco, doente nos diversos aspectos da vida, e, por consequência, criador e

\footnotetext{
${ }^{13}$ Idem. "Prólogo", §3.

${ }^{14}$ Idem.
} 
apreciador de uma arte vazia, insalubre, que ocasiona, como em um círculo vicioso, a manutenção da enfermidade cultural.

Não obstante, no que diz respeito à relação entre a dor, o sofrimento e o criar, lembremo-nos de que existem dois tipos de sofredores, os que sofrem de abundância da vida e os que sofrem de empobrecimento da vida. Os primeiros seriam os raros que são capazes de fazer da doença e da dor uma necessidade, ou seja, aqueles que converteriam o sofrimento, o terrível, a falta de sentido em um leque de possibilidades para dar à vida, graças às suas "forças fertilizadoras", novos impulsos e significados. A energia geradora desse tipo é tão abundante que ele acaba por assegurar sentido aos demais. $\mathrm{O}$ seu olhar duro para a vida permite que eles enxerguem alternativas, mas não ilusões que sirvam de consolo e de anestesia do sofrer. Por outro lado, os sofredores de empobrecimento da vida anseiam justamente por ilusão, redenção, querem se afastar, a todo custo, das tensões e dos medos, projetam somente "encerrar-se em horizontes otimistas". Entretanto, de acordo com Nietzsche, o consolo almejado por esse tipo mais fraco pode ser do "silêncio, quietude, mar liso", através da "arte e do conhecimento", ou, através da "embriaguez, o entorpecimento, a convulsão, a loucura". O romantismo é entendido como a necessidade simultânea de tranquilidade e embriaguez. Essa era a característica do romantismo que unia as obras de Wagner e Schopenhauer ${ }^{15}$.

Partindo dessas especulações, Nietzsche colocará na mesma esteira a religião cristã, o conhecimento lógico e a filosofia epicurista. Todos os três, aparentemente distintos entre si, se aproximam na medida em que respondem à necessidade de um horizonte otimista, ou seja, asseguram aos fracos e temerosos a ilusão de um porto seguro. A religião garante aos fiéis a ideia de proteção miraculosa, inventa um sentido para a existência, pois confere ao ser, que vive em um universo infinito, a certeza de ser eleito de Deus, que é propriamente um deus para doentes, um "salvador" que redime até da finitude com a promessa da vida eterna. A lógica funciona da mesma forma, uma vez que proporciona a "compreensibilidade conceitual da existência", segundo Nietzsche, ela tranquiliza,

\footnotetext{
${ }^{15}$ Apesar de Schopenhauer aludir mais para o refúgio na tranquilidade do conhecimento, também encontrava consolo no êxtase estético. Do mesmo modo, Wagner apontou mais para a embriaguez e loucura da música, mas também encontrou redenção no apaziguamento do conhecimento.
} 
dá confiança, de modo que nós poderíamos acrescentar aqui a inabalável fé nas ciências. Epicuro, apesar de ter combatido o cristianismo ${ }^{16}$, era considerado por Nietzsche um decadente. O medo da dor, mesmo da mais ínfima dor, fez com que a filosofia de seu jardim tivesse como base a supressão dos sentimentos, a $\dot{\alpha} \tau \alpha \rho \alpha \xi \xi i \alpha$, isto é, o nada ${ }^{17}$. Isso representa os mesmos fundamentos da religião cristã: a tentativa de se redimir de todo o sofrimento ${ }^{18}$. A redenção de Epicuro não foi outra coisa senão fazer com que a dor cessasse, essa é a felicidade de um sofredor bem doente ${ }^{19}$.

Assim sendo, Nietzsche entende que Epicuro é o "oposto de um pessimista dionisíaco, assim como o cristão, que na realidade é somente uma espécie de Epicuro e, como este, essencialmente um romântico" ${ }^{20}$. Ora, ambos são pessimistas românticos, porque, de acordo com a inferência regressiva, é a fome que se faz criadora. Contudo, ainda no parágrafo 370, será apresentado outro modo de distinção que permitirá a nosso filósofo mais uma possibilidade de avaliar as necessidades criadoras. Trata-se de atentar se a causa da criação é o desejo de "eternizar, de fixar, de Ser, ou o desejo de destruição, de mudança, de novo, de futuro, de vir-a-ser". Nota-se que Nietzsche recorre à história da filosofia, e traz para a sua análise estética o embate cosmológico entre Devir e Ser. Na tradição, o Devir refere-se à visão de mundo, difundida emblematicamente por Heráclito, de que tudo está condicionado à constante mudança. Já na perspectiva do Ser, geralmente associada a Parmênides, o movimento e as transformações são ilusões, pois o Ser é, por definição, imutável. Destarte, o impulso criador basear-se-á ou no desejo de que tudo se mantenha da mesma forma, ou no anseio de que tudo deva ser alterado.

\footnotetext{
16 "Leia-se Lucrécio para entender contra o que Epicuro fez guerra - não contra o paganismo, mas contra o "cristianismo", isto é, a corrupção das almas através dos conceitos de culpa, punição e imortalidade. - Combateu os cultos subterrâneos, todo o cristianismo latente - naquele tempo negar a imortalidade já era uma verdadeira salvação. - E Epicuro havia triunfado, todo intelecto respeitável em Roma era epicurista". Ibidem. O Anticristo. §58.

${ }^{17}$ Entretanto, assim como no caso da "redenção", (...) expressa-se uma apreciação igual à do lúcido, frio, helenicamente frio, porém sofredor Epicuro: o hipnótico sentimento do nada, o repouso do mais profundo sono, ausência de sofrimento, em suma - para os sofredores profundamente desgraçados é lícito exagerar nisso bem supremo, o valor entre os valores, isto tem de ser considerado positivo por eles, sentido como o positivo mesmo. (segundo a mesma lógica do sentimento, em todas as religiões pessimistas chama-se ao nada Deus). Ibidem. A Genealogia da moral. "Terceira dissertação", $\$ 17$.

${ }^{18} \mathrm{Cf}$. Ibidem. O Anticristo. $\$ 30$.

${ }^{19}$ Ibidem. Fragmento póstumo de 1884, 25[17].

${ }^{20}$ Ibidem. A Gaia ciência. $\$ 370$.
} 
No entanto, é imprescindível destacar que, tanto o desejo de transformação, destruição e devir, quanto a vontade de eternizar, de que tudo permaneça tal como é, só podem ser fisiologicamente avaliados quando o anseio é cruzado com a necessidade. Isso quer dizer que a ânsia por devir, por vicissitude e desmantelamento pode ser tanto uma necessidade de fraqueza, de fome, quanto de força e abundância. Igualmente, o desejo por conservação, por manutenção pode ser motivado pela doença ou pela saúde. Desse modo, quando a aspiração por novidade, por destruição e mudança é expressão de energia superabundante, como diz Nietzsche, "prenhe de futuro", o resultado é a produção de uma obra apoteótica, que pode ser chamada de dionisíaca. Por outro lado, a exigência de destruição também pode provir do ódio do frustrado, daquele que se sente mal favorecido, que tem urgência em destruir porque tudo lhe irrita e lhe revolta, inclusive toda a existência. $\mathrm{O}$ filósofo, de forma excessivamente crítica, compara esse tipo rancoroso e destruidor com os anarquistas europeus do século XIX.

Da mesma maneira, a ânsia por fixar e eternizar exige uma dupla interpretação. Ela pode vir da saúde, da gratidão e do amor e, então, será sempre uma arte apoteótica, tal como a límpida e amável poesia do persa Hafiz; como em Goethe, "vertendo uma homérica luz e glória sobre todas as coisas"; como Rafael, que demonstrava agradecimento pela existência onde não se expressava de modo especificamente cristão, e Rubens, tal como ilustra Nietzsche em um fragmento $^{21}$. Entretanto, a vontade de Ser, de conservar também pode ser exigência de um grande sofredor, de "um torturado, que gostaria de dar ao que tem de mais pessoal, singular e estreito, à autêntica idiossincrasia do seu sofrer o cunho de obrigatória lei e coação", esse tipo faz de sua obra um modo de vingança contra tudo. É o caso da filosofia schopenhauriana e da música wagneriana, os maiores exemplos de pessimismo romântico, aquilo que Nietzsche considerava o último grande acontecimento do destino de sua cultura. A fraqueza e a debilidade nervosa dos pessimistas românticos os constrangiam a querer fixar e eternizar, sobretudo, o passado. Por isso, representam uma forma de decadência mórbida: estão muito à frente, muito atrasados e completamente infecundos ${ }^{22}$. Essa aspiração pelo antigo

\footnotetext{
${ }^{21}$ Cf. Fragmento póstumo de 1885 2[114].

22 "Das Wesen der Romantik gieng mir auf: der Mangel einer fruchtbaren Art von Menschen ist da zeugend geworden". [A essência do romantismo me impressionou: nele a falta de um tipo fecundo de homem tornou-se produtivo]. Fragmento póstumo de 1885, 2[113].
} 
e pela nostalgia melancólica testemunha a insatisfação consigo mesmo dos românticos ${ }^{23}$.

No entanto, em contraposição ao pessimismo romântico - cujo desejo é o infrutífero regresso nostálgico ao passado - Nietzsche exorta para um pessimismo do futuro, que ele pressente chegar: "ele virá! já o vejo vindo!". Esse pessimismo é bastante diferente daquele. O filósofo reconhece que essa nova forma de criar e filosofar pertence a si mesmo, o considera de tal modo inseparável de si, que se vale das expressões latinas proprium e ipsissimum para enfatizar que se trata de sua quintessência. Não obstante, para entendermos qual é o sentido mesmo desse pessimismo vindouro, devemos destacar que, em outros momentos de sua obra, Nietzsche julga que o clássico é a antítese do romântico. Em $O$ Andarilho e sua sombra, por exemplo, demonstra essa relação antitética quando atribui ao clássico o adjetivo "força" e ao romântico, "fraqueza" 24 . A oposição entre os termos é enfatizada ainda em um fragmento póstumo onde o romantismo é pensado como “inimizade contra o gosto clássico, o simples, o rigoroso, o grande estilo" ${ }^{25}$. Já em outro fragmento de 1888, que retoma ideias de $O$ Nascimento da tragédia, é ressaltada a dicotomia entre o clássico e o romântico, mas agora no que se refere a duas formas antagônicas de pessimismo:

\begin{abstract}
Uma nova concepção de arte, como o grande estimulante da vida, como o que incita a viver e, igualmente, sua concepção de pessimismo, de um pessimismo da força de um pessimismo clássico: o termo clássico é usado aqui não no sentido de uma delimitação histórica, mas sim psicológica. A antítese do pessimismo clássico é o pessimismo romântico: esse no qual se formula em conceitos e valorações a debilidade, fadiga e a decadence da raça, o pessimismo de Schopenhauer, por exemplo, como o de A. de Vigny, o de Dostoievsky, o de Leopardi, o de Pascal, o de todas as grandes religiões niilistas (brahmanismo, budismo, cristianismo - eles podem ser chamados niilistas, porque todos eles glorificam o conceito antitético da vida, o nada, como meta, como o bem supremo, como "Deus") $)^{26}$.
\end{abstract}

O clássico não seria, então, uma delimitação histórica, mas uma espontaneidade psicológica, caracterizada pela força que permite ao forte lançarse à vida mesmo diante de todas as consequências perigosas. A força do clássico

\footnotetext{
${ }^{23}$ Cf. Fragmento póstumo de 1888, 5[97].

24 "Clássico e romântico. - Tanto os espíritos de tendência clássica como os românicos - duas categorias que sempre existirão - entretêm uma visão do futuro: mas os primeiros a partir da força de seu tempo, os outros a partir da fraqueza deste". Ibidem. Humano, demasiado humano II. O Andarilho e sua sombra. $\$ 217$.

25 "Romantik: die Feindschaft (...) gegen den klassischen Geschmack, den einfachen, den strengen, den großen Stil". Ibidem. Fragmento póstumo de 1888, 14[7].

${ }^{26}$ Ibidem. Fragmento póstumo de 1888, 14[25].
} 
consistiria na capacidade de renúncia constante dos impulsos românticos que exigem consolo e redenção. No entanto, na conclusão do parágrafo 370 de A Gaia ciência, quando exorta para o pessimismo futuro, Nietzsche assevera que o termo "clássico" teria se tornado muito gasto, de modo que passou a repugnar os seus ouvidos. A palavra teria se convertido em um conceito, e como tal, tornou-se redonda e indistinta. "Clássico", portanto, perdeu a eficácia de comunicar a visão de um pensamento vindouro, distinguido por sua potência restauradora. A sentença deixou de servir aos interesses nietzschianos, porque, por corresponder a um conceito convencional, imprimiria um caráter rígido a um modelo de pensamento que não admite engessamento, além disso, a novidade que é anunciada não aceitaria a carga de preconceitos que um nome carrega durante o seu longo uso histórico-conceitual. Dessa forma, Nietzsche recorrerá aos seus símbolos e chamará de "pessimismo dionisíaco" a filosofia futura, que no fundo, é fruto de suas entranhas e escrita com seu próprio sangue.

Apesar de considerar um por vir, o filósofo não deixa de nos dar pistas sobre o sentido do pessimismo dionisíaco. De saída, sabemos que ele é pensado em contravenção ao pessimismo romântico, logo, seria um modo de filosofar entenda-se aqui filosofar como uma atividade intrínseca ao viver, portanto ligada à arte e às mais diversas formas de vivências - cujo motor é a superabundância de vida e a saúde do corpo. O dionisíaco, nesse sentido, encontraria a volúpia na destruição, na novidade, no vir-a-ser, na mesma medida em que gozaria no eternizar e na conservação. O pessimismo dionisíaco é afirmativo par excellence, tudo que é áspero, vertiginoso, perigoso, caótico e sem sentido - pois a falta de sentido, às vezes, irrompe até mesmo os mais potentes criadores - é afirmado. A afirmação dionisíaca joga também com a embriaguez e com a loucura, até então consideradas marcas da decadência romântica. Isso é possível, porque o dionisíaco abarca inclusive os seus contrários. Por ser uma maneira superabundante de criação, não permite excluir nada - isso seria uma característica do "clássico", não do dionisíaco - o que nos leva a pensar que nem mesmo a "doença", a "fraqueza" e o "empobrecimento" são negados ou 
suprimidos, mas sim, admitidos para então serem convertidos em potência criadora $^{27}$.

O pessimismo dionisíaco, entendido como visão de mundo, promoveria um saber que nunca é acabado, um filosofar que não se estabiliza ${ }^{28}$, mas que se atualiza constantemente, isso, porque tem como origem vivências incessantes e contraditórias, e depois se direciona interpretativamente a elas. Outra especificidade desse novo pessimismo é "o prazer de agarrar pelos chifres os problemas da existência" ${ }^{29}$, ou seja, uma busca voluntária dos aspectos terríveis e questionáveis da vida, fazendo, assim, eclodir a pergunta: “Quanto de 'verdade' suporta e ousa um espírito"? ${ }^{30}$. Tal questionamento funciona como um medidor de forças, ele constrange os mais fracos ao fortalecimento. Nesse sentido, o dionisíaco cumpriria um papel transformador, ele tende a promover uma inversão: tornar os aspectos da existência anteriormente negados, não só necessários, porém, desejáveis em si mesmos. No entanto, quando se afirma esses aspectos sombrios do existir, não se faz com o peso de um imperativo ético, antes disso, a marca do dionisíaco é a leveza, como diz Nietzsche: "A vida tornou-se-me leve, a mais leve, quando exigiu de mim o mais pesado" 31 . Agora, tudo que se faz dionisiacamente, se faz como em um jogo ${ }^{32}$, com a jovialidade de uma brincadeira, as coisas mais sérias são encaradas como na comédia, o riso é a única arma de Dioniso ${ }^{33}$.

Nietzsche disse pouco sobre o seu pessimismo dionisíaco, todavia, nas poucas linhas em que se dedica a ele, dá-nos indícios suficientes para entendermos qual será a significação do "dionisíaco" em sua filosofia mais tardia.

\footnotetext{
27 "Em última análise, uma questão de força: um artista extremamente rico e de vontade poderosa poderia girar completamente toda essa arte romântica até o anti-romantico ou - para usar minha fórmula - até o dionisíaco, do mesmo modo do que nas mãos do mais forte, todo tipo de pessimismo e niilismo se converte simplesmente em um martelo e em mais um instrumento com o qual se adiciona um novo par de asas". Ibidem. Fragmento póstumo de 1885, 2[101].

${ }^{28}$ Cf. STEGMAIER, W. Geist. Hegel, Nietzsche und die Gegenwart. Apud. Estudos Nietzsche, Curitiba, v. 1, n. 1, p. 35-60, jan./jun. 2010.

${ }^{29}$ É exatamente assim que Nietzsche descreve a sua invenção, o pessimismo dionisíaco, ao amigo Carl Funchs em uma carta de 29 de julho de 1888: "noch als Erfinder einer neuen Art Pessimismus (eines dionysischen, aus der Stärke geborenen, der sich das Vergnügen macht, das Problem des Daseins an seinen Hörnern zu packen". [nem como descobridor de um novo tipo de pessimismo (de um pessimismo dionisíaco, nascido da força, que dá prazer de agarrar por seus chifres o problema da existência)].

${ }^{30}$ NIETZSCHE. Fragmento póstumo de 1887, 10[3].

${ }^{31}$ Ibidem. Ecce homo. "Por que sou tão inteligente", $\$ 10$.

32 "Não conheço outro modo de lidar com grandes tarefas senão o jogo [Spiel]". Idem.

${ }^{33}$ Cf. Ibidem. Para a genealogia da moral. "Prólogo", §7.
} 
Tais indícios revela-nos que o termo ressurge desvinculado da conotação que possuía no período de $O$ Nascimento da tragédia. Antes compreendido como uma pulsão metafísica, agora é o verdadeiro símbolo de combate as doutrinas transcendentes. Eis aí o elemento mais importante de sua transmutação: o dionisíaco passa a denotar uma força imanente, que só pode ser interpretada fisiologicamente. Além disso, outros termos relacionados a Dioniso, que na fase intermediária do pensamento nietzschiano foram criticados ou suprimidos, tais como, a embriaguez, a música, o gênio, a loucura, são reformulados e reaparecem em plena associação aos temas que a divindade simbolizará. Dentre esses temas, podemos destacar o jogo cósmico, ou seja, a transitoriedade das coisas interpretada como uma prazerosa força geradora e destruidora, em constante criação ${ }^{34}$. A partir desse prisma dionisíaco, que abraça os contrários - excesso e equilíbrio; prazer e dor; grito e riso; o Sim no horror -, Nietzsche pensará a arte, a vida e o mundo. Como veremos é sobre isso que versa o poético e, portanto, misterioso aforismo $O$ gênio do coração.

\section{2.}

\section{O "gênio do coração"}

Após o longo período de silêncio, a voz de Dioniso ressurge, na obra publicada de Nietzsche, no parágrafo 295, o penúltimo de Além do bem e do mal. É a primeira vez, depois de ser revestido pela máscara da ausência, que o nome da divindade aparece como símbolo que comunica a profusão do pensamento nietzschiano. O que caracteriza o seu reaparecimento é a metamorfose: o deus deixa de corresponder à dissolução do indivíduo no caos primitivo, para agora recobrir de sentido o íntimo humano. A sua efígie passa a ser, então, a do "grande oculto, o deus-tentador e aliciador de consciências"35, cuja voz - "que sabe descer ao submundo de cada alma" - o filósofo chama de "gênio do coração". Interpretar a miríade de significados do aforismo 295 e entender a relevância do "gênio do coração" no corpus nietzschiano será a parte mais difícil deste trabalho. Isso, porque, o modo como Nietzsche ali se expressa, leva às últimas

\footnotetext{
${ }^{34}$ Cf. Fragmento póstumo de 1885, 2[106].

${ }^{35}$ NIETZSCHE. Além do bem e do mal. \$295.
} 
consequências o estilo aforístico: nada é explicitado, pelo contrário, há mais velamento do que esclarecimento, tudo se diz de forma dramática, com hipérbole e tensão. Dioniso reassume, portanto, o seu lugar de crítico da linguagem tradicional - esse será mais um entre os seus propósitos -, e quando denuncia os limites desta, podemos dizer que o faz com um estilo bem próprio - o ditirambo.

Desse modo, o "gênio do coração" não se deixa entender através da fala, da linguagem estruturada em signos representacionais: ele "não diz palavra [nicht ein Wort sagt], não lança olhar em que não haja ideia e oceano de sedução, de cuja maestria faz parte o saber parecer - e não aquilo que é”. Não está em jogo, portanto, a comunicação do Ser que é categorizado através de termos rígidos, mas sim as sensações que, em uma onda violenta, atravessam o indivíduo, seduzindo-o para que as experimente cada vez mais intensamente. Contudo, para fazer jus à sua crítica e minimizar, ao máximo quanto possível, a antinomia de expressar por meio da linguagem um "conceito" que não pode ser esgotado, nem fixado, que incorpora a contradição e, consequentemente, extrapola os domínios da linguagem, Nietzsche repensa o texto aforístico e, então, elabora uma estrutura estilística, próxima à poesia, onde uma construção em elipse de orações subordinadas, com apêndices intermináveis promove um discurso que se expande além das barreiras sintáticas. O resultado foi um aforismo único, cuja leitura provoca, inicialmente, um acúmulo de tensão que aumenta e diminui ciclicamente, mas, devido à falta de uma conclusão redentora, não se permite descarregar por completo, há apenas um alívio parcial com a repetição da oração principal - "o gênio do coração":

(...) o gênio do coração, que a tudo estridente e autocomplacente faz calar e ensina a ouvir, que alisa as almas ásperas e lhes dá no novo anseio a saborear - estenderse imóveis como espelho d'água, para que nelas se espelhe o profundo céu -; $o$ gênio do coração, que à mão rude e arrebatada ensina a hesitar e a aprender com maior graça, que advinha o tesouro oculto e esquecido, a gota de bondade e doce espiritualidade sob o espesso e opaco gelo, e é um mágico imã para todo grão de ouro que por muito jazeu sepulto na prisão de lama e areia; o gênio do coração, de cujo toque cada um fica mais rico, não agraciado e surpreso, não redimido e oprimido por um bem alheio, porém mais rico de si mesmo, mais novo do que nunca, partido, por um vento brando acariciado e sondado, mais inseguro talvez, mais grácil frágil fraco, porém cheio de esperanças ainda sem nome, cheio de uma nova vontade e energia, nova relutância e apatia... 36

\footnotetext{
${ }^{36}$ Idem. (Grifo nosso).
} 
A inserção da exclamação "o gênio do coração" divide a narrativa em espécies de "grupos rítmicos". A alternância entre esses grupos, ou seja, a passagem pelas breves pausas, ocasionadas pela flutuação da sentença título, funciona como um efeito-gangorra para a tensão. Entretanto, com o acréscimo de abordagens sempre novas, sem nenhuma previsão de conclusão, em um artifício retórico admirável, o movimento aumenta e a tensão chega ao cume, despertando a sensação de se perder completamente, estar sem fundamentos ou referências como naquela imagem de quem entra na água e, de repente, percebe-se sem fundo e à mercê do ir e vir das marés ${ }^{37}$-, para, então, ser aliviado pela interrupção do locutor, que faz daquele que lê o seu interlocutor, anunciando, finalmente, a identidade de quem vinha falando - o deus Dioniso. Essa interrupção marca a primeira mudança de mote no aforismo que, por sua vez, pode ser dividido em três períodos distintos: um monólogo inicial, um diálogo com o leitor e, por fim, um diálogo entre Nietzsche e a própria divindade. As partes são estruturalmente diferentes, mas, apesar do nítido contraste, no fundo, são impressionantemente coesas.

\begin{abstract}
... mas que faço, meus amigos? De quem lhes falo? Distraí-me a ponto de sequer lhes dizer o seu nome? A menos que já tenham adivinhado que é esse deus e espírito problemático, que de tal modo deseja ser louvado. Como sucede a todo aquele que desde criança esteve a caminho e fora de casa, também a mim me sobressaltaram espíritos raros e bem poucos inofensivos, sobretudo e quase sempre esse do qual venho falando, ninguém menos do que o deus Dioniso, esse grande ambíguo deustentador, a quem certa vez, como sabem, em todo sigilo e reverência ofereci meu primogênito - tendo sido o último a lhe ofertar um sacrifício, ao que parece: pois não encontrei ninguém que compreendesse então o que eu fazia. Nesse meio tempo aprendi mais, e até demais, sobre a filosofia desse deus, de boca em boca, como disse - eu, o derradeiro iniciado e último discípulo do deus Dioniso: e talvez eu pudesse enfim, caros amigos, lhes dar de provar um pouco dessa filosofia, tanto quanto me é permitido? A meia voz, como é justo: pois ela inclui coisa nova, secreta, estranha, singular, inquietante. Já o fato de Dioniso ser filósofo, e também os deuses filosofarem, portanto, parece-me uma novidade um tanto insidiosa, que justamente entre os filósofos despertaria suspeita - mas vocês, caros amigos, provavelmente lhe oporão menor resistência, ao menos que ela chegue tarde e no momento inoportuno: pois hoje em dia, segundo me consta, vocês não gostam de acreditar em Deus ou em deuses. E talvez eu não tenha de ir, na franqueza do que falo, mais longe do que seria grato aos hábitos severos de seus ouvidos?(...) ${ }^{38}$
\end{abstract}

Em termos estilísticos, o texto é uma adequação linguística que permite falar com maior coerência de Dioniso. Aliás, podemos dizer, sem exagero, que o

\footnotetext{
${ }^{37}$ Cf. Ibidem. Humano, demasiado humano II. "Opiniões e sentenças diversas”, §134.

${ }^{38}$ Idem.
} 
formato multiforme, ambíguo, obscuro, tenso e sereno do parágrafo é o reflexo da própria força dionisíaca na forma de linguagem. Sem contar que os efeitos artísticos suscitados na leitura denunciam a compreensão do novo Dioniso em contraste com a antiga: se antes era Apolo o responsável pela serenidade e pela proteção da imagem contra a tensão dionisíaca, agora Dioniso e seu par dicotômico se tornam um só, a divindade assume o duplo caráter de proporcionar a tensão trágica e, também, o alívio, como se, paradoxalmente, protegesse-nos de se afogar na tensão que ele mesmo proporciona. Dioniso funde-se a Apolo até mesmo no que se refere à oposição Ser e Aparência: como vimos acima, sua maestria é o "saber parecer", ele joga, portanto, com a aparência; todavia, ele também é quem "sabe descer ao submundo de cada alma", ele é o "apanhador de ratos da consciência" [Rattenfänger der Gewissen], como o "Pied Piper", o tocador de flauta de Hamelin que seduz ratos e crianças. Isso significa que ele perscruta o íntimo, o Ser de cada um. No entanto, Ser aqui não é antitético - como na metafísica - ao corpo e às intensidades instintivas.

Ainda no que concerne à estilística, consideramos importante salientar a comparação feita por Thönges ${ }^{39}$ entre o aforismo 295 e "a canção do sim e do amém" de Assim falou Zaratustra, porém, destacando como ponto de mediação entre esses escritos nietzschianos a "carta do dia 10 de maio" do jovem Werther. As três passagens estabelecem entre si uma relação, ora de aproximação, outrora de distanciamento. Elas se aproximam no que diz respeito à forma, ou seja, apesar de cada um preservar o seu estilo próprio, se valem de determinados recursos linguísticos e de certas imagens que acabam por estabelecer um traço de parentesco. Por exemplo, em todos eles há um acúmulo de sentenças que impelem para uma conclusão redentora, mas que, por sua vez, adia constantemente a sua chegada, dando lugar a mais sentenças; ademais, os três recorrem a imagens que exprimem claramente um movimento, ou de ascensão ou de descensão. Conquanto, quando o foco direciona-se aos anseios dos respectivos personagens e, consequentemente, para aquilo que eles representam a comparação entre os textos só pode ser feita por contrastes.

\footnotetext{
${ }^{39}$ THÖNGES, Bernd. Das Genie des Herzens. Uber das Verhältnis von aphoristischem Stil und dionysischer Philosophie in Nietzsches Werken. p. 17 - 29.
} 
No texto de Goethe, por exemplo, o soerguimento da emoção tem início na alegria radiante e na tomada de ar no cume, mas depois, como em um contramovimento, na cadência da descida. A carta exprime um movimento de descensão, nitidamente perceptível nas linhas finais com a seguinte confissão do personagem: "Meu amigo! Mas vou ao chão ante isso, sucumbo ante o poder e a majestade dessas aparições" ${ }^{\prime 4}$. Para Thönges, Werther sucumbe à natureza panteísta, precisamente porque impõe a si a necessidade de uma expansão entusiástica. Ele formula a renúncia do seu próprio "eu” para transformar sua alma no espelho meramente passivo do Deus infinito ${ }^{41}$. Assim sendo, a vida se esvai e se destrói, pois o infinito, de acordo com a posição do jovem Goethe, não pode ser apreendido apenas pelo fato do homem se doar a ele. Por outro lado, em contraste com a carta de Werther, as “canções de sim e amém” em Assim falou Zaratustra, ocorrem nas alturas alcançadas através do movimento de ascensão proporcionado pelo próprio cântico: "Se algum dia estendi céus serenos sobre mim, e com asas próprias voei em céus próprios: se nadei brincando em profundas distâncias de luz, e veio a sabedoria de pássaro de minha liberdade,42.

Outro contraste é que o hino de Zaratustra - em oposição ao amor cósmico, ou seja, à necessidade de expansão entusiástica e o desejo de infinito de Werther exalta o amor pela eternidade. Nos chama a atenção que, em ambos os casos, a ânsia dos personagens é ilustrada pela metáfora do sentimento do amante para a mulher: o amor ao infinito de Werther: “Ah, meu amigo, quando o mundo infinito começa a despontar assim ante meus olhos e o céu se reflete todo ele em minha alma, como a imagem de uma amada..."43; e o amor à eternidade de Zaratustra: "Jamais encontrei a mulher da qual desejaria filhos, a não ser esta mulher a quem amo: pois eu te amo, ó eternidade!"44 . Entretanto, a diferença marcante entre eles é que, no caso do protagonista de Goethe, o infinito só pode ser atingido pela supressão da vida, pela auto entrega à totalidade, conhecida como o "abraço cósmico"; no segundo, o anseio ardente pela eternidade só pode ser compreendido

\footnotetext{
${ }^{40}$ GOETHE. J. W. von. O Sofrimento do jovem Werther. "10 de maio", p.8. Completo no [Apêndice $\alpha$ ]

${ }^{41}$ Cf. THÖNGES, Bernd. Op. Cit. p. 19 e 20.

${ }^{42}$ NIETZSCHE. Assim falou Zaratustra. "Os sete selos", §7.

${ }^{43}$ GOETHE, J. W. von. Op. Cit. p. 9.

${ }^{44}$ NIETZSCHE. Op. Cit. $\$ 1$ - $\$ 7$.
} 
como uma afirmação da vida mesma, e o desejo de que o instante vivido se repita eternamente no que é chamado de "nupcial anel dos anéis - o anel do retorno"45.

Estilisticamente o aforismo "o gênio do coração" assemelha-se à construção elíptica da carta de Werther e do "canto do sim e do amém". Em relação ao primeiro a aproximação pode ser estreitada ainda mais pela comum inserção de um interlocutor, o amigo [mein Freund]; já em relação ao texto de Assim falou Zaratustra, a constante repetição de sentenças que aliviam parcialmente a tensão pode ser destacada como mais um elo de afinidade. Além disso, o "gênio do coração" também percorre um movimento, porém, sua direção é ambivalente: há tanto a descida como a ascendência. Todavia, é mister dizer que toda semelhança só pode ser considerada superficialmente. Em uma perspectiva mais profunda, nota-se que o parágrafo 295 mantém-se equidistante da enfática autoafirmação presente na imagem do "anel dos anéis" de Zaratustra, e do "resignado silêncio de Werther" ${ }^{\natural 6}$. O modo como o filósofo interrompe a escalada emocional aqui é único: ele alterna entre diferentes períodos, como se fossem "sub-estilos" dentro do mesmo texto: passa de um monólogo em antífona para uma saudação dialógica e, enfim, para um diálogo entre autor e personagem ${ }^{47}$. No final, o próprio Nietzsche fala como autor de seus escritos. Ele nos ensina que o "gênio do coração" é o deus Dioniso e se refere a si como o seu "derradeiro iniciado".

Quando se refere a si mesmo como o derradeiro discípulo do deus Dioniso, Nietzsche quer dizer que foi o último a converter os preceitos de uma divindade, pertencente a uma religião há muito esquecida, em um símbolo que permite expressar sua interpretação da vida. No entanto, se um dos principais preceitos desse antigo nume é a oscilação entre a ausência e a presença, então, o que o símbolo exprime também oscila entre a revelação e o ocultamento. Isso significa que a vida, segundo o filósofo, nunca se deixa apreender totalmente, pois não há compreensão absoluta e nem verdades simples $^{48}$, apenas perspectivas. Para explicar a existência é necessário, portanto, um conceito que se adeque a esse trânsito inconstante das coisas. Essa marca de Dioniso como um "conceito

\footnotetext{
${ }^{45}$ Idem.

46 "das resignative Verstummen Werthers einzumünden". THÖNGES, Bernd. Op. Cit. p. 20.

${ }^{47}$ Um personagem conceitual? Cf. DELEUZE, Gilles e GUATTARI, Félix. O que é a Filosofia? p. $51-78$.

48 “"'Toda verdade é simples." - não é isso uma dupla mentira? -". Ibidem. Crepúsculos dos ídolos. "Máximas e flechas", $\S 4$.
} 
impreciso" está escondida na parte inicial do aforismo 295, ali a forma e o conteúdo aludem a essa ambivalência: negando a predicação imediata, bem como negando o seu nome diretamente, Nietzsche obriga a compreensão do termo em meio à ambiguidade e atributos opostos. Contudo, devemos deixar claro que o texto em questão não fala exclusivamente das peculiaridades de Dioniso como sentença, como a efígie de uma linguagem não tradicional, o aforismo gira em torno de questões filosóficas profundas e remete à visão de mundo que o deus significará.

Dessa forma, o "gênio do coração" descrito como "tentador", "aliciador", “educador”, “destruidor”, “criador” não apenas revela as nuances do pensamento nietzschiano sobre a vida, a cognição, a arte, a verdade como também a íntima relação que eles estabelecem entre si. Assim sendo, depois dessas considerações sobre o estilo do aforismo, cabe-nos agora interpretar os significados profundos dessa relação a partir do aforismo 295 e, com isso, entender qual é o sentido mesmo do segundo Dioniso - e segundo do dionisíaco - na obra tardia de Nietzsche.

\subsection{1. O "gênio do coração" como espelho d'água e ternura:}

Se umas das principais características do "gênio do coração" é a ambiguidade e a contradição, então, podemos concluir que ele não exclui o antigo Dioniso. Da mesma forma em que o dionisíaco do trabalho inicial de Nietzsche não poderia ser pensado sem o seu oposto, o apolíneo, agora, o novo símbolo nietzschiano, incorporado a Apolo, não pode ser pensado sem os atributos que lhe eram intrínsecos nas formulações de juventude. O novo Dioniso, renascido e transmutado ainda mantém suas insígnias: ele continua a ser o deus da embriaguez, da desmesura, do caos, do horror, da destruição, do dilaceramento, da música, etc. Entretanto, também passa a ser o símbolo de serenidade, de calma, de jovialidade e, sobretudo, de ternura. Por isso seu epítome, no aforismo 295, poderia ser aquele que a "tudo estridente e autocomplacente faz calar e ensina a ouvir, que alisa as almas ásperas e lhes dá no novo anseio a saborear-estender- 
se imóveis como espelho d'água, para que nelas se espelhe o profundo céu". Além do mais, o toque do "gênio do coração" torna tudo "mais novo do que nunca, partido, por um vento brando acariciado e sondado, mais inseguro talvez, mais grácil [zärtlicher] frágil fraco, porém cheio de esperanças ainda sem nome”.

O deus que conhece o dilaceramento e a dor mais terrível, esse deus que enlouquece ferozmente e que arrepia de pavor aquele com quem defronta, também é a divindade grácil, que acalma com bondade. A ternura será, na obra madura de Nietzsche, um dos mais importantes desígnios dionisíacos. Essa ideia é confirmada no $\$ 7$ do capítulo dedicado à Assim falou Zaratustra em Ecce homo, onde o ditirambo - que é a linguagem própria de Dioniso, e o modo eleito como propício para falar consigo mesmo - exprime com uma delicadeza divina, atribuindo significado reconfortante a tudo ${ }^{49}$. Apesar de o aforismo 295 aproximar a ternura à insegurança, à fraqueza e à fragilidade, ele também a vincula a uma fonte de esperança futura, que ainda não tem nome; essa expectativa tranquilizadora não é outra coisa senão o anúncio velado da vontade de poder, logo, a ternura dionisíaca está ligada ao por vir potente, ou seja, ao terno caminho necessário para "avançar", “conquistar" e "superar". Nesse sentido, a ternura como categoria filosófica nietzschiana não pode ser vista como sinônimo de omissão ou resignação, longe disso, ela é ativa, uma das condições para a ação criativa.

A ternura também é a principal característica do personagem Zaratustra. Sabemos pelos inúmeros testemunhos de Nietzsche, principalmente em Ecce homo, que o dionisíaco, em Um livro para todos e para ninguém, tornou-se ato supremo $^{50}$. Dioniso e Zaratustra compartilham do mesmo sofrimento ${ }^{51}$, podemos dizer que tudo o que o filósofo costumava pensar pelo símbolo Dioniso, foi expresso pela boca de seu protagonista ${ }^{52}$. Por consequência, Zaratustra assume a

\footnotetext{
49 "Que linguagem falará um tal espírito, ao falar só consigo mesmo? A linguagem do ditirambo. Eu sou o inventor do ditirambo. Ouça-se como Zaratustra fala consigo mesmo antes do nascer do sol: uma tal felicidade esmeralda, uma tal delicadeza divina [göttliche Zärtlichkeit] não tinha voz antes de mim". Ibidem. Ecce homo. "Assim falou Zaratustra", §7.

${ }^{50}$ Nosso próximo Estásimo tratará da relação de Assim falou Zaratustra com a linguagem musical e, consequentemente, com o dionisíaco.

${ }^{51}$ Cf. Ibidem. Ecce homo. "Assim falou Zaratustra", §8.

${ }^{52} \mathrm{O}$ próprio autor confirma isso no rascunho de uma carta, que pretendia enviar para irmã, de 20 de Maio de 1885: "O que eu costumava pensar sob o símbolo de Dionísio, que agora estou preparando lentamente pela boca de meu $\mathrm{Z}<$ aratustra〉, é do tipo mais perigoso (...)". [Was ich mir
} 
prerrogativa da ternura. Isso é explícito em várias passagens da obra e em diversos fragmentos póstumos. Em um desses fragmentos, a brandura e a bondade por tudo que é vivo é considerado o grande perigo de Zaratustra, cuja única proteção é a "vontade criativa" pessoas mais susceptíveis a serem feridas e, por isso, mais vulneráveis aos riscos da resignação e do niilismo, porém, ao mesmo tempo, fornece as condições de superar todo e qualquer tipo de negação através da amabilidade, isto é, da capacidade de amar. Para Nietzsche, "se um dia não conseguir suportar a vida, deve tratar de amá-la - esse é a artimanha do mais sábio",54. Existe, portanto, sabedoria na ternura que, por sua vez, está ligada à força criadora, que impele a criar.

Por outro lado, "Todos os criadores devem ser duros martelos" fragmento de 1883. Ora, se na ternura há uma força criadora, então, nela também existe um aspecto de dureza. A ternura não é acompanhada de indiferença, de passividade, pelo contrário, ela é tenaz, acompanhada pela força-de-vontade, pela coragem e, sim, pela agressividade e pela firmeza. A rigidez é necessária para que o homem terno supere as incertezas da vida. Nietzsche não entende, portanto, ao menos nesse momento de sua obra, a ternura como dicotômica à dureza. Essa relação é ilustrada em Assim falou Zaratustra, quando o personagem, profundamente abalado e temoroso pelo seu "mais abismal pensamento", se compara ao amante que, desconfiado do sorriso aveludado demais, afasta de si a bem-amada, "ainda carinhoso em sua dureza"56. É impreterível a robustez para suportar o pensamento terrível da inexorabilidade das coisas, da mesma forma que a brandura é necessária para superação afirmativa desse pensamento. Além de tudo, não podemos deixar de mencionar a imagem do professor que - como

\footnotetext{
früher unter dem Symbol des Dionysos gedacht habe, wasich jetzt langsam durch den Mund meines $Z<$ arathustra $>$ vorbereite, sindDinge der gefährlichsten Art (...)].

53 "Sua ternura por tudo vivo é seu perigo, ó Zaratustra! E ai de você, se você não tivesse vontade criativa!" [Deine Zärtlichkeit zu allem Lebenden ist deine Gefahr, oh Zarathustra! Und wehe dir, wenn du keinen schaffenden Willen hättest!'] Ibidem. Fragmento póstumo de 1883, 17[15]. (Grifo nosso).

54 "Und wenn du das Leben einst nicht aushalten kannst, mußt du suchen, es lieb zu gewinnensolches nämlich war immer der Kunstgriff der Weisesten". Fragmento póstumo de 1883, 17[1].

${ }^{55}$ Ibidem. Fragmento póstumo de 1883, 17[15].

${ }^{56} \mathrm{Cf}$. Ibidem. Assim falou Zaratustra. "A bem-aventurança involuntária". Nietzsche fez a seguinte anotação preparatória dessa passagem: "Evocação do pensamento mais terrível e abissal. A natureza predestinada - Hino. Bem-aventurança contra a vontade (como uma pessoa afasta de si a amada, mas é terno em sua dureza)". Fragmento póstumo de 1883, 20[8].
} 
veremos, será outro importante retrato de "Dioniso-gênio do coração" - é severo, duro, muitas vezes inflexível, signos de sua responsabilidade pedagógica em trans-formar, conquanto, sem eximir-se da amabilidade, do carinho e da doçura ${ }^{57}$.

A ternura é fundamental para todos os importantes temas de Assim falou Zaratustra. Ela acompanha, por exemplo, aquele que se recupera do impacto da "morte de Deus": isso fica claro quando Zaratustra não se irrita com o convalescente que finta ternamente [zärtlich] para a sua ilusão e à meia-noite se esgueira em torno do sepulcro onde jaz o seu deus ${ }^{58}$; ainda que suas lágrimas sejam sinais de um corpo doente, a ternura é o primeiro sintoma de recuperação, de amabilidade para um mundo onde agora, sem o amparo deífico, tudo aparece como novas possibilidades. Não obstante, outro tema relacionado à ternura é a radical formulação do eterno retorno. Apesar de Nietzsche omitir qualquer menção direta que vincule uma coisa à outra, não podemos deixar de estabelecer uma conexão entre uma docilidade e a alegre aceitação ao pensamento de que tudo retorne eternamente. Corrobora a nossa perspectiva um comentário, feito em Ecce homo, de uma passagem do capítulo "De velhas e novas tábuas" que claramente alude ao eterno retorno ${ }^{59}$. Nesse comentário, Nietzsche explicita que o vir-a-ser entendido como eterno círculo é a ideia mesma de Dioniso, e acrescenta o seguinte sobre a psicologia do tipo Zaratustra como oposto de um espírito de negação:

(...) como o espírito portador do mais pesado destino, de uma fatalidade de tarefa, pode, no entanto, ser o mais além e mais leve [der leichteste] - Zaratustra é um dançarino - : como aquele que tem a mais dura e terrível percepção da realidade, que pensou o "mais abismal pensamento", não encontra nisso, entretanto, objeção alguma ao existir, sequer ao seu eterno retorno - antes uma razão a mais para ser ele mesmo o eterno Sim a todas as coisas, "o imenso ilimitado Sim e Amém"... "A todos os abismos levo a bênção do meu Sim"... Mas esta é a ideia do Dionísio mais uma vez ${ }^{60}$.

\footnotetext{
${ }^{57}$ Essa ideia é ilustrada também ao se referir a seus livros: diz que "é preciso conquistá-los com os dedos mais ternos, e com os punhos mais bravos". Ibidem. Ecce homo. "Por que escrevo livros tão bons". $\$ 3$.

${ }^{58}$ Cf. Ibidem. Assim falou Zaratustra. "Dos transmundanos".

${ }^{59}$ Eis a passagem citada e comentada por Nietzsche: "a alma que possui a mais longa escala e mais fundo pode descer, a alma mais extensa, que mais longe pode correr e errar e vagar dentro de si, a mais necessária, que com prazer se lança no acaso, a alma que é, e mergulha no vir a ser, a que tem, e quer mergulhar no querer e desejar, a que foge de si mesma, que a si mesma alcança nos círculos mais amplos, a alma mais sábia, à qual fala mais docemente [süssesten] a tolice, a que mais ama a si mesma, na qual todas as coisas têm sua corrente e contracorrente, seu fluxo e refluxo". Ibidem. Ecce homo. "Assim falou Zaratustra", §6. (grifo nosso).

${ }^{60}$ Idem. (Grifo nosso).
} 
Zaratustra aceita o mais pesado destino, ou seja, a fatalidade do eterno retorno com a leveza de seu espírito, com a delicadeza de um bailarino. Bailar, neste caso, é o símbolo máximo de afirmação imanente; é ter, portanto, os pés no chão e sujá-los de terra com movimentos graciosos. De nenhuma outra forma se demonstra o amor pela vida como na ternura de uma dança. Mas, assim como viver é repleto de perigos e desafios, dançar também é: constantemente existe a ameaça de se escorregar, cair. $\mathrm{Na}$ vida e no bailar é preciso correr riscos, se lançar; por isso o "gelo liso é paraíso para quem sabe dançar" ${ }^{61}$. Contudo, outra questão, essencialmente dionisíaca, que atravessa Assim falou Zaratustra e está em plena associação com a ternura, é a investigação sobre a natureza mesma da solidão. Tal tema é tão importante para Nietzsche, que ele chega a se considerar como "a solidão na forma de ser humano" 62 . É claro que o filósofo não a compreende como o mero "estar só", muito menos como algo negativo à existência. A solidão está anelada a todas as grandes questões de sua filosofia e, por isso, possui um parentesco indistinguível das significações do segundo Dioniso. Tal qual o deus, ela é pressuposto supremo de uma vida afirmativa, porém, igualmente a ele, é ambígua e contraditória, ou seja, ela é, ao mesmo tempo, asfixiante e fonte de revigoramento.

Esse caráter ambivalente da solidão se justifica, porque ela demanda muita energia, a ponto de ser corrosiva ${ }^{63}$. Por isso, as metáforas nietzschianas sobre o tema envolvem, geralmente, o gelo dos cumes e a exigência de pulmões fortes para se respirar nas alturas ${ }^{64}$. Por outro lado, são, precisamente, o silêncio e

\footnotetext{
${ }^{61}$ Ibidem. A Gaia ciência. "Brincadeira, astúcia e vingança". §13.

62 "ich bin die Einsamkeit als Mensch..." Ibidem. Fragmento póstumo de 1888, 25[7]. (A solidão será novamente abordada na seção 8.1. deste trabalho).

${ }^{63}$ Nietzsche escreve sobre isso em um fragmento que planejava como complemento a Humano, demasiado humano: "Enquanto isso, eu aprendi o que poucos até agora aprenderam, a suportar a solidão, "a compreender a solidão" -: e entre os sintomas essenciais de um "espírito livre" eu colocaria que ele prefere andar sozinho, voar sozinho e se algum dia tiver com as pernas doentes, se rastejar sozinho. A solidão se não cura, então mata: isso é verdade; a solidão é parte de uma arte médica terrível e perigosa. Mas é certo que quando ela cura, faz do homem mais saudável e mais soberano do que qualquer outro homem que viva em companhia, que uma árvore em sua floresta: a solidão põe definitivamente a prova, mais do que todas as outras doenças, se algum nascido está verdadeiramente predestinado à vida - ou à morte, como a grande maioria. Em suma, só a partir da solidão eu aprendi até o fim os conceitos relacionados de "espírito livre" e de "saúde"'. Fragmento póstumo de 1885, 40[59].

64 "Quem sabe respirar o ar de meus escritos sabe que é um ar das alturas, um a r forte. É preciso ser feito para ele, senão há o perigo nada pequeno de se resfriar. O gelo está próximo, a solidão é
} 
quietude dos ermos picos as condições para a criatividade, o reencontro de si, o fortalecimento e, sobretudo, para a saúde do corpo e espírito ${ }^{65}$. Essa dupla face também diz respeito à ternura: a experimentação da solidão oscila entre o desconforto e o pesar, a doçura e a leveza. Nietzsche observa sobre essa ambivalência em vários momentos de sua obra, sobretudo, nas descrições das idas e vindas de Zaratustra. Dentre essas descrições a que melhor ilustra tal natureza dura e terna - está no capítulo "O regresso", onde a solidão é pintada como uma mãe: "agora apenas me ameaça com o dedo como fazem as mães, agora sorri para mim como sorriem as mães". A mãe é dura, repreende e castiga, porém, abraça e sorri ternamente. A solidão, assim como as mães, deve ser considerada um porto-seguro, o lugar de se reestabelecer do convívio desgastante com a multidão ${ }^{66}$. Para isso Zaratustra sempre volta à sua caverna, ali encontra sua pátria: “Ó solidão! Solidão, pátria minha! Quão terna [zärtlich] e bemaventurada me fala a tua voz!"67.

Não obstante, o aspecto sereno e terno da solidão só podem ser concebidos juntamente com o silêncio. Nesse ponto, identificamos uma das mais radicais mutações de Dioniso no pensamento de Nietzsche, talvez a única que seja revelada de forma explícita no aforismo 295: o "gênio do coração" deixa de ser aquele deus da dissonância musical, do urro feminino e do alarido enfeitiçado pelo vinho, para, então, ser quem "a tudo estridente e autocomplacente faz calar e ensina a ouvir". Não é de se estranhar que Nietzsche, devido a sua doença, que lhe causava terríveis dores de cabeça, viajasse constantemente em busca de quietude para convalescer ${ }^{68}$. Com isso, fez do silêncio uma de suas categorias

monstruosa - mas quão tranquilas banham-se as coisas na luz! Com que liberdade se respira!". Ibidem. Ecce homo. "Prólogo", §3.

65 "Mas tenho necessidade de solidão, quer dizer, recuperação, retorno a mim, respiração de ar livre, leve, alegre... Todo o meu Zaratustra é um ditirambo à solidão, ou, se fui compreendido, à pureza". Idem. "Por que sou tão sábio", §8.

66 “Objeção é também sofrer da solidão — sempre sofri somente da "multidão"'. Idem. "Por que sou tão inteligente”, §10.

${ }^{67}$ Ibidem. Assim falou Zaratustra. "O regresso".

${ }^{68}$ Isso Nietzsche testemunha em uma carta ao amigo Heinrich Köselitz de 26 de abril de 1887: "Querido amigo: Desculpe-me, mas nada vem de minha viagem a Veneza. Mas, tudo está protestando, a começar pelos olhos e a cabeça: quatro vezes nos últimos dias, meus abomináveis ataques; uma horrível melancolia e irritabilidade; uma profunda necessidade de silêncio [Stille]... Ocorreu-me que não sou digno de ver coisas tão belas (e ouvir!), perdoe-me de novo!”. 
filosóficas, a ponto de considerá-lo como algo instintivamente seu ${ }^{69}$. O silêncio anda de mãos dadas com a solidão, ele é a condição para a ternura desta. Além disso, é indispensável para se gerar um grande pensamento e, depois, para ruminálo, para entendê-lo e, no caso de um pensamento radical, para aceitá-lo ${ }^{70}$. Foi assim com Zaratustra, ele precisou mergulhar na quietude e na solidão para assimilar o seu pensamento abissal. Todavia, o silêncio, tal qual todo pressuposto dionisíaco, é ambíguo, ele pode ser experimentado como bem-aventurança ${ }^{71}$, mas também, como uma agonia sufocante ${ }^{72}$. É preciso ser forte para fazer do silêncio afável.

Na obra Assim falou Zaratustra, o silêncio ganha contornos de um verdadeiro problema filosófico. Ele é considerado como a fonte de um pensamento abissal e, por conseguinte, indispensável para o seu amadurecimento. Por isso, ele é ambíguo: dele surge a ideia, e dele precisamos para compreender todos os desdobramentos dessa ideia. Nesse meio termo, o silêncio é sufocante, até mesmo doloroso, pois estamos em um processo criativo intenso, que exige o desprendimento de muita energia. Veja como Zaratustra fala dessa situação: “ $A h$, pensamento abismal que é meu pensamento! Quando acharei a força para ouvirte cavar e não mais tremer? Até à garganta me vêm as batidas do coração, quando te ouço cavar! Mesmo teu silêncio me quer sufocar, ó abismal silencioso!" 73 . Por outro lado, quando se adquire força suficiente para suportá-lo e, consequentemente, para entendê-lo - em companhia da solidão - como a cláusula magma do criar, ele passa a ser experimentado ternamente. No movimento criativo - em alegoria ao processo do parto, onde a mulher dá à luz uma nova vida passando de um estágio de dor a outro de ternura - o silêncio desloca-se da condição de perturbador à de afabilidade. A metáfora nietzschiana

\footnotetext{
${ }^{69}$ Nietzsche escreve em uma versão não publicada de Ecce homo: "O silêncio é em mim tão instintivo como nos senhores filósofos a garrulice". Cf. Ibidem. Ecce homo. "Por que escrevo tão bons livros", nota " 36 ".

70 "É este o novo silêncio que aprendi: seu barulho a meu redor estende um manto sobre meus pensamentos". Ibidem. Assim falou Zaratustra. "Da virtude que apequena", §2.

71 "Oh, venturoso silêncio ao meu redor! Oh, puros odores ao meu redor! Oh, como este silêncio extrai ar puro do peito profundo! Oh, como escuta este venturoso silêncio!" Idem. "O Regresso".

${ }^{72}$ Por exemplo, Nietzsche diz que o silêncio oprime, sufoca e, também, atribui a ele os adjetivos de horrível, pérfido, veja: "Uma outra coisa é o horrível silêncio que se ouve em torno". Ibidem. Ecce homo. "Assim falou Zaratustra", §5. "e eu caminhava sozinho naquele pérfido silêncio". Assim falou Zaratustra. "O Adivinho".

${ }^{73}$ Ibidem. Assim falou Zaratustra. "Da bem-aventurança involuntária".
} 
para essa silente ternura criadora não poderia ser outra senão a luminosidade: “ $O$ solidão dos dadivosos! Ó silêncio dos luminosos!",74

A quietude que resplandece em ternura é o que almeja o "gênio do coração" quando "alisa as almas ásperas e lhes dá no novo anseio a saborear-estender-se imóveis como espelho d'água, para que nelas se espelhe o profundo céu". Alisar as asperezas não significa outra coisa senão tornar terno, afetuoso, brando. Dioniso detém as almas para deitarem e ficarem imóveis, tácitas, fazendo-as - em outro movimento de ascensão - espelharem as profundidades do firmamento. O que a alma captura como espelho liso e calmo é, precisamente, os recantos recônditos de nosso $\mathrm{Ser}^{75}$. Não fazemos aqui nenhuma referência ontológicometafísica, (ou religiosa) à subjetividade e ao espírito como dicotômicos ao corpo, mas, tão-somente, ao calar dos rumorosos afazeres cotidianos para, então, atentar aos íntimos pensamentos que nos constitui, entretanto, que só podem ser apreciados no silêncio. Desaprendemos a escutar nossos ternos pensamentos, pois, na cotidianidade estrondosa em que vivemos se fez impossível um momento de silente introspecção. Por isso, a Vida admoesta Zaratustra: "Não estales o chicote dessa maneira terrível! Bem sabes que o barulho mata os pensamentos - e agora me vêm pensamentos tão ternos" "76 " o "gênio do coração" nos constrange ao silêncio e nos ensina a tê-lo ternamente para, que assim, possamos ouvir a nós mesmos.

Sem embargo, vale dizer que uma sociedade doente [como a nossa] não suporta a quietude, sua marca é a tagarelice e o burburinho, tudo é motivo para o estardalhaço, igual às moscas do mercado de Assim falou Zaratustra ${ }^{77}$. O silêncio

\footnotetext{
${ }_{75}^{74}$ Idem. "O canto noturno"; também em, Ecce homo. "Assim falou Zaratustra", §7.

${ }^{75}$ Em Opiniões e sentenças diversas, Nietzsche escreve o seguinte sobre a poesia de Goethe: "um céu luminoso refletindo-se nos rostos e eventos: o saber e a arte convergindo numa nova unidade: o espírito coabitando sem presunção e ciúme com sua irmã, a alma, e extraindo da oposição a graça da seriedade, não a impaciência da discórdia: - tudo isso seria o abrangente, o geral, o fundo dourado sobre o qual as sutis diferenças dos ideais encarnados constituiriam o quadro mesmo, o da sempre maior elevação humana". Aqui, em harmonia com a metáfora do céu espalhado na alma do aforismo 295, Nietzsche demonstra o impulso goethiano de reconhecer o incondicionado no condicionado, e também a possibilidade de escrutar as profundidades do Ser através da arte. Ibidem. Humano demasiado humano II. "Opiniões e sentenças diversas", §99.

${ }^{76}$ Ibidem. Assim falou Zaratustra. "O Outro canto da dança", §2.

77 "Foge para a tua solidão, meu amigo! Vejo-te atordoado pelo barulho dos grandes homens e picado pelos ferrões dos pequenos. A floresta e o rochedo sabem calar-se dignamente contigo. Volta a semelhar-te à árvore que amas, a de amplos galhos: atenta e silenciosa pende ela sobre o mar. Onde cessa a solidão, ali começa o mercado; e onde começa o mercado, ali também começa o barulho dos grandes atores e o zumbido das moscas venenosas. Idem. "Das Moscas do mercado".
} 
causa mal-estar nas pessoas enfraquecidas ${ }^{78}$. Para uma imediata confirmação disso, basta observar nossas crianças e jovens que, de modo geral, não se admitem nem ao menos um instante de experimentação silenciosa. Eles têm às mãos, ou melhor, aos ouvidos toda sorte de subterfúgios para escapar do remanso. Para que a taciturna calmaria seja encarada como terna e aprazível é preciso de força, adquirida somente através de uma educação dionisíaca. Por mais contraditório que pareça, o antigo deus do frenesi educa agora para a quietação. No entanto, ainda que Nietzsche tenha colocado o silêncio como virtude dos fortes, não significa que tenha renegado completamente à música; pelo contrário, a arte musical continuará a ser emblema de seu Dioniso. Porém, como se pode deduzir, a música valorizada agora é aquela cuja principal característica é a ternura. Desde o período de Humano, demasiado humano essa reformulação já era feita; as extasiantes obras, iguais as de Wagner, são rebaixadas em nome de composições mais suaves, baseadas no princípio da serenidade e da ternura, tais como as melodias de Mozart.

Em Andarilho e sua sombra, por exemplo, Nietzsche contrasta Mozart com o que ele chama de "música de hoje", a "música moderníssima, com seus pulmões fortes e nervos fracos"79. A principal característica desses compositores era acreditar que o mandamento supremo da apresentação musical é dar a cada peça o maior alto-relevo possível, fazendo-a falar a linguagem dramática a todo custo. Mas, se aplicássemos essa fórmula à música de Mozart, então cometeríamos um verdadeiro pecado contra o espírito, "o sereno, o ensolarado e o terno [zärtlichen]", cuja seriedade é afável e não terrível ${ }^{80}$. Em contraposição à “música de hoje", Nietzsche elogia o artista do futuro, que fala a linguagem de Rossini e Mozart como sua língua materna, tal linguagem seria, justamente, a da música terna, demasiada doce, que desperta um sorriso frente ao vulgar ${ }^{81}$. Já em uma anotação de 1886 - que preparava o capítulo "Sobre a fisiologia da obra de arte" do livro nunca terminado, Der Wille zur Macht ${ }^{82}$ - o filósofo esclarece que não é suficientemente feliz e sadio para a música romântica, inclusive a de Beethoven, a

\footnotetext{
${ }^{78}$ Vale lembrar que os discípulos de Zaratustra se irritam com o silenciar do mestre. Da mesma forma, as pessoas comuns de hoje em dia se incomodam com os silenciosos, eles são estranhos à norma.

${ }^{79}$ NIETZSCHE. Humano, demasiado humano II. "O Andarilho e sua sombra", §166.

${ }^{80}$ Cf. Idem. §165; também em: Nietzsche contra Wagner. "Wagner como perigo", §2.

${ }^{81} \mathrm{Cf}$. Ibidem. Fragmento póstumo de 1886, 7[22].

${ }^{82}$ Cf. Idem. 1888, 18[17].
} 
quem tachava como o primeiro romântico. Prefere, então, a música de Mozart "a flor do barroco alemão" ${ }^{\text {"83 }}$ - que expressa sentimentos tão germânicos: a "candura ingênua, a ternura melancólica, o contemplativo, os sorrisos vagos, a timidez do amor" ${ }^{\prime \prime 4}$.

A inclinação de Nietzsche para uma música, cuja principal característica consiste na ternura, é, antes de qualquer coisa, uma questão fisiológica. Ele nos explica abertamente que tem necessidade de uma música que o faça esquecer o sofrimento $^{85}$. A princípio, essa afirmação cria um mal estar, pois parece aludir à arte como consolo, contrariando, portanto, toda elaboração elogiosa à dor e ao sofrimento do pessimismo dionisíaco; porém, o filósofo imediatamente nos esclarece que isso faz parte de seu ponto de vista fisiológico da arte, a partir do qual concebe a boa música como aquela que faz a vida animal se sentir divinizada, festejada; que incita ao desejo de dançar através de "ousados e audaciosos ritmos exuberantes"; que alivia a vida com "delicadas [zärtliche] e suaves harmonias douradas ${ }^{\prime 86}$. Essa perspectiva estético-fisiológica, que avalia a arte pelo crivo do corpo, do estômago, foi mais bem explorada no aforismo - já estudado por nós anteriormente ${ }^{87}$ - "Fala o cínico" de A Gaia ciência: nele, Nietzsche faz questão de declarar que todas as suas objeções à música de Wagner são fisiológicas, contra ela protestam os seus órgãos e vísceras. Em oposição a isso, o seu corpo inteiro deseja da música "alívio: como se todas as funções anímicas fossem aceleradas por ritmos leves", como se a vida fosse "dourada por boas ternas, áureas harmonias" ${ }^{\prime 9}$.

A partir dessa perspectiva estético-fisiológica, podemos concluir que a ternura está intimamente ligada ao corpo e, por consequência, pertence a um tipo saudável, em cuja benevolência se expresse toda a sua vitalidade. Além disso, em

\footnotetext{
${ }^{83}$ Idem. 1885, 1[180].

84 "Mozart - ganz deutsche Gefühle ausdrückend, la candeur naïve, la tendresse mélancholique, contemplative, les vagues sourires, les timidités de l'amour". Idem. 1886, 7[7].

85 "Was ich nöthig habe, ist Musik, bei der man das Leiden vergiß". Idem.

${ }^{86}$ Idem.

${ }^{87}$ Cf. nota 17 do tomo 4.2 .

${ }^{88}$ Ainda sobre a música terna: "Direi ainda uma palavra para os ouvidos mais seletos: o que espero realmente da música. Que seja alegre e profunda como uma tarde de outubro. Que seja singular, travessa, terna, uma doce mulherzinha de baixeza e encanto...". NIETZSCHE. Ecce homo. "Por que sou tão inteligente". §7.

${ }^{89}$ NIETZSCHE. A Gaia ciência. §368; e também em Nietzsche contra Wagner, "No que faço objeções".
} 
$O$ Anticristo, Nietzsche defende que quando o homem saudável, excepcional [Ausnahme-Mensch] trata o medíocre [Mittelmässigen] com mais delicadeza que a si próprio ou os seus iguais, não o faz como sinal de sua bondade de coração, mas como um dever ${ }^{90}$. Conquanto, é importante dizer que, na obra nietzschiana, a ternura e a amabilidade são completamente desvinculadas da compaixão; elas são vistas, a partir do prisma de suas origens, como contraditórias: enquanto as primeiras são virtudes fortes, demonstram saúde, a compaixão é considerada "em si como fraqueza, como caso especial da incapacidade de resistência aos estímulos", e, exatamente por esse motivo, "passa por virtude apenas pelos décadents" $"$. Assim sendo, na medida em que a ternura é um pressuposto de atividade, a compaixão é de passividade; do mesmo modo em que aquela é ativa, esta é reativa. Por essa razão, Nietzsche, em Ecce homo, coloca a superação da compaixão entre as virtudes nobres ${ }^{92}$.

Chegando a esta etapa de nosso trabalho, depois de ter investigado cuidadosamente uma grande variedade de temas da filosofia nietzschiana, acostumamo-nos a nos manter sempre em alerta com as constantes voltas e reviravoltas de perspectivas do filósofo sobre um mesmo tema. Isso não é diferente com a acepção da "ternura": o que apresentamos até aqui não é definitivo. Existem momentos em que Nietzsche atribui a ela uma conotação pejorativa e a desloca para o lado da fraqueza. Em um fragmento de 1885, por exemplo, o filósofo associa a afabilidade à fragilidade quando diz que o desejo do povo de "ser duro, fatalista, destruidor de ilusões - é o desejo das pessoas mais frágeis e mais afáveis [schwacher und zärtlicher]" "93. Já em uma anotação do outono de 1887, ao fazer uma crítica ao Novo testamento cristão, concebe como a virtude mais humilde de todas aquela que reconhece a "ovelha de rebanho como ideal", essa seria "uma espécie de virtude pequena, terna, benevolente, serviçal, entusiasta e satisfeita"94. No entanto, apesar dessa mudança de ideia, o que queremos ressaltar é a ternura como um dos importantes elementos que Dioniso passou a representar. Desse modo, as duras e inequívocas verdades da filosofia

\footnotetext{
${ }^{90}$ Cf. Ibidem. O Anticristo. $\$ 57$.

${ }^{91}$ Ibidem. Ecce homo. "Por que sou tão sábio", §4.

${ }^{92}$ Idem.

${ }^{93}$ Cf. Ibidem. Fragmento póstumo de 1885, 1[220].

${ }^{94}$ Dificulta nossa tradução/compreensão o fato de Nietzsche não separar as virtudes por vírgulas: "eine kleine zärtliche wohlwollende hülfreiche und schwärmerisch-vergnügte Art Tugend". Ibidem. Fragmento póstumo de 1887, 10[73].
} 
dionisíaca se dissolvem agora em imagens, som, tato e gesto ternos. Nisso consistirá os seus ensinamentos e sua sedução.

A ternura abre caminho, portanto, para outros dois aspectos de fundamental importância para compreendermos a significação do novo Dioniso: o "gênio do coração" é um professor e um aliciador. Essa trindade de atributos - terno, educador e sedutor - não esgotam as possibilidades de interpretação do aforismo 295 de Além do bem e do mal, porém, nos fornecem uma ampla visão sobre o sentido filosófico da divindade no referido texto e, por conseguinte, na obra tardia de Nietzsche. Em virtude disso, o assunto de nossa próxima seção será, precisamente, investigar o significado dos símbolos "deus-tentador" e "deuseducador".

\subsection{2.}

\section{O "gênio do coração" como sedutor e educador:}

No aforismo 295 de Além do bem e do mal, um dos adjetivos atribuídos a Dioniso que mais chama a atenção é o "sedutor" [Verführer], qualidade que deve ser compreendida em correspondência com o termo "deus-tentador" [VersucherGott]. A imagem que Nietzsche escolhe para acentuar o caráter aliciador do "gênio do coração" é no mínimo curiosa: o "apanhador de ratos" [Rattenfänger], uma referência ao flautista forasteiro que, segundo a lenda, teria livrado a cidade de Hamelin de uma infestação de ratos, isso com a proeza de encantar os repugnantes animais que seguiram a melodia de seu instrumento até se afogarem no rio. O Rattenfänger da história, como vingança por não ter recebido o pagamento acordado, também enfeitiça com sua música as crianças que, seduzidas pelo som da flauta, o seguiram para nunca mais serem encontradas. Com essa alegoria o filósofo ressalta o caráter sedutor do "gênio do coração"; ele é um aliciador de consciências que destrói o próprio sujeito cognitivo, ou seja, assim como os ratos encantados perderam o discernimento, Dioniso como deus-tentador é responsável por desmantelar os velhos fundamentos cognoscentes - tais como os metafísicos, morais e religiosos - e nos afogar com suas novas verdades. 
Como sedutor, "o gênio do coração" domina a arte de trazer para fora do bastião da "consciência", com chamarizes próprios, determinados preceitos responsáveis por estruturar cognitivamente um modelo de realidade que, há muito tempo, foi consagrado como verdade inquestionável. No processo de sedução, essas antigas estruturas são alienadas da consciência e destruídas por uma nova visão de mundo dionisíaca. A sedução é entendida, então, como um deslumbramento vertiginoso, um irremissível encanto e indomável atração por algum objeto/ideal detentor de um fascínio poderoso, capaz de atribuir significado às coisas. Impossível não pensar como exemplo a fascinação causada pela pessoa amada, cujo simples pensamento de sua ausência faria tudo perder o sentido ${ }^{95}$. Entretanto, o problema é que, para Nietzsche, os antigos modelos estruturantes da realidade, sejam os de ordem cognitiva ou os de ordem moral, também são formas de sedução, tal qual a verdade dionisíaca. Isso, porém, não significa que Dioniso seduza para um modelo verdadeiro frente a um falso. Nietzsche abandona a utilização dos valores "verdade" e "falsidade" 96 ; a diferença, portanto, entre o aliciamento do deus-tentador e dos antigos ideais é que estes últimos são decadentes, resultam na manutenção da fraqueza, ao passo que o primeiro na dinamização da força.

Partindo dessa análise, podemos dizer que Nietzsche identifica como formas decadentes de sedução todos os ideais que buscam valor fora da vida mesma e que, por sua vez, fundamentaram a cultura ocidental, tornando-a degenerada. Uma rápida pesquisa do emprego que o filósofo faz, em seus cadernos de anotações, da sentença "Verführer", comprova essa ideia: ele considerava, por exemplo, que "as palavras são a sedução dos filósofos e a linguagem a teia em que eles se

\footnotetext{
${ }^{95}$ Vale lembrar que Nietzsche alude à mulher como símbolo da vida sedutora (Cf. Fragmento póstumo de 1883, 13[1]; A Gaia ciência, §338) e no Fragmento póstumo de 1886, 1[101] compara a mulher e a criança à virtude mais sedutora. Já no fragmento de 1887 6[21] compara os ideais a belos olhos e seio inchados ao passo que no fragmento 10[68] do mesmo ano diz que dessas características femininas o homem forte não se deixa seduzir.

${ }^{96}$ Isso é demonstrado claramente no seguinte fragmento: "Nós, imoralistas [Wir Immoralisten] somos hoje o único poder que não precisa de aliados para vencer, então somos de longe os mais fortes entre os fortes. Nós nem sequer precisamos de uma mentira: que outro poder poderia renunciar a ela? Uma forte sedução luta por nós, talvez a mais forte que existe - a sedução da verdade... da verdade? Quem colocou essa palavra na minha boca? Mas eu a retiro novamente; desprezo a orgulhosa palavra: não, não precisamos dela, chegaremos ao poder e à vitória sem a verdade. A magia que luta por nós, o olho de Vênus, que encanta e cega nossos oponentes, é a magia do extremo, a sedução que exerce o máximo [die alles Äußerste übt]: somos imoralistas somos o derradeiro limite [Äußersten]...”. NIETZSCHE. Fragmento póstumo de 1887, 10[94].
} 
contorcem"97; que a vaidade pelo "conhecimento em si" promove a sedução pelo número, pela lógica e pelas leis ${ }^{98}$; que a superstição criada pelos judeus converteu-se em uma vantajosa sedução ${ }^{99}$; nesses termos, a moral só pode ser vista como meio de sedução ${ }^{100}$; o Novo testamento com suas virtudes gregárias são o melhor livro de $\operatorname{sedução~}^{101}$; a inteligência do apóstolo Paulo e o poder do cristianismo também são considerados formas de sedução ${ }^{102}$; aliás, Nietzsche considera o "cristianismo como a mentira mais fatal que seduziu até agora, como a maior mentira ímpia"103; o filósofo ainda reconhece um poder de sedução nos ideais emasculados [Menschheits-Ideals] ${ }^{104}$; como não poderia deixar de ser, Richard Wagner também é considerado um sedutor ${ }^{105}$; enfim, "seduzem todos os decadentes: “a cruz”, “o amor”, “o santo”, a pureza, no fundo, apenas pessoas e conceitos mortais e perigosos" $" 106$.

Além disso, a "afirmação de que a verdade existe e que ela acaba com a ignorância e com o erro é uma das maiores seduções que existem"107. Dentre todas as formas decadentes de deslumbramento, esta última é a mais devastadora, porque, só através dela todas as demais são possíveis. Segundo o filósofo, a sedução da humanidade "sob o manto da intenção mais santa, o uso criminoso que até agora tem sido feito da palavra "verdade""108, isto é, a perversidade feita - pela ciência, filosofia e religião - com o encantamento redentor da noção de veracidade absoluta, causado nas pessoas fracas, corresponde a uma história maligna e funesta, "a história do crime mais persistente, da sedução mais nefasta, do envenenamento mais deliberado, o acontecimento propriamente negro da humanidade, sob cuja influência, os mais profundos instintos da vida foram

\footnotetext{
97 "Die Verführer der Philosophen sind die Worte, sie zappeln in den Netzen der Sprache". Ibidem. Fragmento póstumo de 1875, 6[39].

${ }^{98}$ Cf. Idem. 1886, 5[14].

${ }^{99}$ Cf. Idem. 1887, 9[50].

${ }^{100}$ Cf. Idem. 1887, 9[124].

${ }^{101}$ Cf. Idem. 1887, 10[73] e 10[75].

${ }^{102}$ Cf. Idem. 1887, 10[188] e 10[189].

103 "Ich betrachte das Christenthum als die verhängnißvollste Lüge der Verführung, die es bisher gegeben hat, als die große unheilige Lüge". Idem. 1887, 10[191].

${ }^{104}$ Cf. Idem. 1887, 10[157], §1.

${ }^{105}$ Cf. Idem. 1888, 14[165]. (Correspondente ao $\$ 6$ de O Caso Wagner).

${ }^{106}$ Cf. Idem. 1888, 23[4].

107 "Die Behauptung, daß die Wahrheit da sei und daß es ein Ende habe mit der Unwissenheit und dem Irrthum, ist eine der größten Verführungen, die es giebt”. Idem. 1888, 15[46]

${ }^{108}$ Idem. 1888, 15[43].
} 
difamados e questionados" "109. Há atração e açúcar demais na "verdade", porque ela fundamenta uma existência segura e redentoramente calculável. $\mathrm{O}$ fascínio pela certeza irrefutável se escamoteou, ao longo da tradição, na inabalável crença nas categorias: "finalidade", que postula a todo acontecimento uma causa e, portanto, um "sentido"; "unidade", que credita a todas as esferas da existência a possibilidade de serem organizadas e sistematizadas, logo, de serem objetos do conhecimento humano; "ser", que garante um fundo ontológico, uma essência e, assim, perenidade às coisas, inclusive ao homem. Todas essas categorias são quimeras criadas por necessidades psicológicas ${ }^{110}$.

O "gênio do coração" vem para desmantelar todas essas formas degeneradas de deslumbre. O seu sucesso ocorre, porque, ele é um sedutor mais ardiloso, o "grande ambíguo deus-tentador", cujos chamarizes de sedução oscilam entre uma desconcertante filosofia, uma arte transformadora e, até mesmo, o processo que vai da doença à convalescência. O fascínio dionisíaco não é, então, fazer brilhar uma nova doutrina, todavia, através desses artifícios, revelar que toda "verdade" é apenas superfície, um véu que encobre profundos e inacessíveis abismos. Aí está o mais forte encanto da vida, aquilo que é identificado, em $A$ Gaia ciência, como o seu aspecto feminino ${ }^{111}$. Dioniso alicia para a sabedoria, já praticada pelos gregos, de permanecer na superfície, na pele, alegrar-se na aparência $^{112}$. Contudo, para se atingir esse estágio de ternura, é preciso antes superar os tormentos e a vontade de negação causados pela ausência de sentido que, no seu turno, advém quando os antigos valores supremos "desvalorizam-se" e quando falta as respostas aos "por quês?",113. Eis a ambiguidade do deus tentador: é bom para com o homem, o seduz para torná-lo mais forte e mais belo, embora, também é mal para com ele, almeja destruí-lo. O aspecto benevolente da sedução dionisíaca é evidente no período final do aforismo 295, onde o deusfilósofo, em uma espécie de diálogo com Nietzsche, o seu "último discípulo e iniciado", confessa o seguinte:

\footnotetext{
${ }^{109}$ Idem.

${ }^{110}$ A eventual descredibilidade dessas categorias é, para Nietzsche, a causa dos três estados psicológicos de niilismo. Cf. Idem. 1888, 11[99].

111 "há sobre ela, entretecida de ouro, um véu de belas possibilidades, cheio de promessa, resistência, pudor, desdém, compaixão, sedução - Sim! A Vida é uma mulher!”. Ibidem. A Gaia ciência. \$339. Cf. a citação completa na nota 160 da seção 2.6.

${ }^{112}$ Cf. Idem. "Prologo", §4.

${ }^{113}$ Cf. Ibidem. Fragmento póstumo de 1887, 9[35].
} 
"Eventualmente posso amar o ser humano" - aludindo a Ariadne, que estava presente -: “ele é para mim um animal agradável, valente, inventivo, que não tem igual sobre a terra, em todo labirinto ele é capaz de se achar. Sou bom para com ele: com frequência medito em como fazê-lo avançar e torna-lo mais forte, mais malvado e profundo". - "Mais forte, mais malvado e profundo?", perguntei aterrorizado. "Sim", confirmou ele, "mais forte, mais malvado e profundo, e também mais bonito" - e ao dizê-lo sorriu o deus tentador seu sorriso alciônico, como se tivesse dito uma encantadora gentileza. Igualmente se nota: a essa divindade não falta somente pudor -; e há bons motivos para supor que alguma coisa os deuses poderiam aprender conosco. Nós, homens, somos - mais humanos...

Vamos nos concentrar agora no aspecto benevolente da sedução dionisíaca para, em seguida, voltarmos a nossa atenção para o seu caráter atroz, destruidor. Ao dizer que "eventualmente ama o ser humano", que "é bom para com ele" e que medita em como "torná-lo mais forte, mais malvado e mais belo", o deus-tentador revela os propósitos e efeitos de sua sedução: ele pretende elevar os homens, fazer daquilo que eles têm de mais peculiar, divino. Com isso, também os transformam em sedutores; ora, na medida em que se tornam mais bonitos e mais profundos, ficam igualmente mais atraentes. É importante ressaltar que imagem de "profundidade", na linguagem do nosso aforismo, está associada ao "descer no submundo de cada alma" ou ao "espelhar o céu profundo", como demonstramos anteriormente, metáforas ao processo de escrutar a si mesmo, ou melhor, de aproximação de si. Nesse sentido, o "gênio do coração" encanta o homem para se acercar de si mesmo. Isso é necessário, porque, o deslumbramento decadente, reativo, da verdade metafísica, lógica ou religiosa, por assim dizer, o afastou daquilo que ele é realmente. "Dioniso" é, nesses termos, o modo como Nietzsche traduz a força incidental que constrange o ser humano a retornar para si. Força esta que se manifesta, por exemplo, na volúpia da criação ou contemplação $\operatorname{artística~}^{114}$.

É indispensável entender que o mencionado "retorno a si” não faz referência ao "eu", ao sujeito cartesiano, longe disso, Dioniso seduz justamente para a dissolução das supostas verdades assentadas na oposição metafísica "sujeito e objeto". Aprofundar-se em busca de si não significa, portanto, ir ao encontro da segurança proporcionada pelo cogito fundante de realidades indubitáveis, ao contrário, é afundar-se em labirinto. A falta de um caminho pré-definido - ou de

\footnotetext{
${ }^{114}$ Nietzsche fala no $\$ 225$ de Além do bem e do mal em "energias criadoras” [gestaltende Kräfte].
} 
um $\mu \varepsilon \theta^{\prime} o ́ \delta o ́ \varsigma$ seguro, para fazer uma brincadeira etimológica - é, precisamente, o que o deus-filósofo ama no homem. A ausência de fundamento o impele a ser um animal inventivo, sobretudo, valente [tapferes], pois, mesmo quando os valores supremos dissolvem-se e só lhe resta a falta de sentido, a escuridão de um labirinto, sem o fio condutor da razão, da lógica, da religião e suas respectivas certezas absolutas, o homem dá um jeito de se encontrar. Mesmo que para isso tenha que criar asas e queimar seus lábios com brasas celestes! Destarte, chamanos a atenção que, no aforismo 295, quando Dioniso diz amar os humanos, alude para Ariadne que, na cena imaginada por Nietzsche, também estava presente ${ }^{115}$. Ainda que sua presença no texto passe quase despercebida, sua significação simbólica é tão importante quanto à do deus: ela representa todo um tipo que suporta a sedução dionisíaca com valentia e graça.

Enquanto o "gênio do coração" simboliza aquela força, difícil de comunicar pela linguagem tradicional, que atravessa o indivíduo, fazendo-o reconhecer que as "verdades absolutas" de outrora não passam de deslumbres enfraquecedores e valores decadentes, Ariadne simboliza um modelo de pessoa saudável, cuja força transbordante permite ser transpassada pela sabedoria dionisíaca com ternura e júbilo. Lembremo-nos que nos mitos antigos, Ariadne é quem auxilia Teseu a escapar do labirinto com um fio de lã. No entanto, é seduzida por Dioniso e divinizada por ele ${ }^{116}$. Nesse sentido, Ariadne representava a atração pela lógica, pela razão, pela linguagem, contudo, depois de ser tocada pelo deus-tentador, passou a ser o símbolo máximo das profundidades labirínticas. Uma transformação que certamente Nietzsche reconhecia em si, ele também teria sido tocado por Dioniso e salvo dos fascínios da juventude. Mas, diferentemente do filósofo que teve de atravessar os dissabores do "isolamento doentio" e dos "desertos de experimentação"117, Ariadne retrata o aspecto benevolente da sedução dionisíaca: a relação entre o deus e sua amada, nas imagens nietzschianas, é sempre de gracejo, meiguice e de flerte, como neste fragmento:

\footnotetext{
115 "- und dabei spielte er auf Ariadne an, die zugegen war-" 
""Oh, Ariadne, tu mesma és o labirinto: não se consegue sair de ti" ..."Dionísio, você me lisonjeia, você é divino"..."

Ariadne não só suporta a sabedoria dionisíaca, como se alegra em ser labirinto, considera isso uma lisonjaria. Dessa forma, ela é o extremo oposto de um tipo que tem necessidade de valores reativos e, sobretudo, de certezas claras $e$ distintas. Esse tipo é Teseu, o modelo de homem da racionalidade exacerbada, cuja efígie de herói, entre outras coisas, representa a necessidade de estratagemas, ou seja, representa as pessoas que não se arriscam em hipótese alguma, que precisam calcular todos os aspectos da vida para planejar o próximo passo; ser herói, também quer dizer que todas as suas ações passam pelo crivo da moralidade, o ideal de "bem" é o lume e fio-guia de seu caminho ${ }^{119}$. O tipo Teseu não suporta a imprevisibilidade do labirinto, porém, é incapaz de escapar dele sem o auxílio da linha condutora de Ariadne, geralmente, associado à metafísica, ao cientificismo, às superstições religiosas e às outras formas de seduções degeneradas; isso quer dizer que suas forças criadoras são suprimidas quase que por completo. Ademais, o inimigo de Teseu é o touro, a maior representação dos nossos instintos animalescos, do nosso aspecto irracional e daquilo que Nietzsche considera divino em nós, o nosso corpo.

A figura de Ariadne e a de Teseu são antípodas, até mesmo, no que concerne aos instintos: se por um lado o herói é o aniquilador do touro, então, pelo outro lado, o cordão de Ariadne - já divinizada por Dioniso - é o fio condutor corporal. Ao menos é isso que o filósofo escreve no curioso final de um texto sobre "moral e fisiologia" de 1885. Essa nota faz uma reflexão sobre a maneira que a consciência foi valorizada, historicamente, como o "estágio mais avançado da evolução orgânica", ao passo que o corpo, da qual ela é mero instrumento, foi desvalorizado. $\mathrm{O}$ fragmento foi escrito com uma linguagem definidamente mais dissertativa do que aforística, assim, muito próxima do estilo e do conteúdo de Genealogia da moral. Entretanto, o que nos chama a atenção é

\footnotetext{
118 “,Oh Ariadne, du selbst bist das Labyrinth: man kommt nicht aus dir wieder heraus“... / „Dionysos, du schmeichelst mir, du bist göttlich“...” Ibidem. Fragmento póstumo de 1887. $10[95]$.

${ }^{119}$ Sobre o aspecto moral do herói em Teseu, Nietzsche escreve: "—-Teseu tornou-se um absurdo, disse Ariadna, Teseu tornou-se virtuoso - Ciúme de Teseu em relação ao sonho de Ariadne. O herói que admira a si mesmo, que se torna um absurdo. A reclamação de Ariadne. Dionísio sem ciúmes: "O que eu amo em você, como poderia um Teseu amar?"”. Idem. 1887, 9[115].
} 
que, na conclusão do texto, Nietzsche muda o tom e imagina-se em um diálogo com a divina Ariadne, basicamente no mesmo formato de seu diálogo com Dioniso descrito na parte final do parágrafo 295. O encontro imagético teria ocorrido na primeira visita do filósofo a Naxos, ilha onde a donzela de Creta teria sido abandonada por Teseu e cortejada pelo nume. Nessa curta conversa, Ariadne se revela inteiramente instintiva, desdenha de toda a filosofia ocidental que reprimiu os instintos corpóreos em virtude da razão; assim sendo, o seu fio condutor não é outra coisa aqui senão o próprio corpo ${ }^{120}$ :

\begin{abstract}
Tagarelando de tal forma, sem se reprimir, eu me entreguei ao meu instinto pedagógico [Lehrtriebe], pois fui abençoado por ter alguém que pudesse ficar me ouvindo. Mas, neste momento, Ariadne não aguentava mais - a história aconteceu na minha primeira visita a Naxos -: "mas meu senhor, disse ela, você fala um alemão de porcos [Schweinedeutsch]!" - "Alemão, eu respondi alegremente, simplesmente alemão! Deixe o porco para lá, minha deusa! Eles subestimam a dificuldade de dizer coisas boas em alemão!" - "Coisas boas! exclamou Ariadne horrorizada: mas isso era apenas positivismo [Positivismus]! Filosofia de focinho [Rüssel-Philosophie]! Miscelânea e estrume concetual a partir de cem filosofias! Para onde isso leva!" - e ela impacientemente brincou com o famoso fio que uma vez conduziu Teseu através do labirinto. - Então veio à tona que Ariadne levava, em sua educação filosófica, o atraso de dois milênios ${ }^{121}$.
\end{abstract}

Além de instintiva, Ariadne se revela sarcástica. Seu modo de falar é irônico, repleto de metáforas que remetem ao animalesco. A linguagem depurada, lógica, que fundamentou a racionalidade ocidental e, consequentemente, a filosofia alemã, ela não compreende; e mais do que isso, ela a despreza de tal forma, que chega a compará-la a uma miscelânea conceitual e ao "estrume de porco". Nota-se, então, que sua educação filosófica não acompanhou os dois milênios de depreciação dos instintos. Os seus ouvidos, de fato, não estão preparados para escutar todo esse tipo de positivismo e os infindáveis discursos metafísicos que foram se sobrepondo, um aos outros, ao longo da tradição. Talvez, por isso que Dioniso/Nietzsche considere as suas orelhas graciosamente

\footnotetext{
${ }^{120}$ Imediatamente antes do trecho citado, Nietzsche assevera que "seguindo o fio condutor do corpo [Leitfaden des Leibes] descobrimos que nossa vida é possível graças a interação de muitas inteligências". Ibidem. 1885, 37[4].

${ }^{121}$ Idem. (A parte final desse fragmento póstumo coroa um texto escrito, com um estilo dissertativo e mais tradicional, sobre a importância do corpo para a vida. A leitura dessa parte, tanto em separado, quanto em correspondência com a primeira parte, possui uma dupla interpretação: o diálogo pode ser tanto entre Dioniso e Ariadna, como entre Nietzsche e Ariadne. No entanto, em ambos os casos o sentido permanece o mesmo).
} 
pequenas $?^{122}$ Não obstante, tais considerações nos leva a concluir que o seu "famoso fio, que uma vez conduziu Teseu através do labirinto" era realmente o corpo. Nessa ocasião tentou mostrar ao herói a importância de se guiar pelos instintos. Mas, com isso, Teseu se perdeu! Essa desventura o filósofo demonstrou na seguinte anotação de 1887, a qual pretendia transformar em uma "peça satírica", baseada no triangulo amoroso desses personagens:

\begin{abstract}
“Ariadne, disse Dioniso, você é um labirinto: Teseu se perdeu em ti, ele já não tem mais o fio; de que adiantou ele não ter sido devorado pelo Minotauro? O que o devora agora é pior que o Minotauro." "Você me lisonjeia", respondeu Ariadne, "mas estou cansada de minha compaixão, todos os heróis devem ser destruídos por mim: este é meu último amor por Teseu: eu o destruirei" $" 123$.
\end{abstract}

Neste fragmento, vemos Ariadne também como sedutora: ela fascina Teseu de tal forma que, então, ele não consegue mais se desvencilhar de seus inextricáveis caminhos. Porém, essa fascinação, como se pode notar, não é mais aquela benevolente da qual falávamos, mas uma sedução cruel e destruidora. Ao invés de ternura e júbilo, o seu processo envolve maldade, desolação e toda sorte de aflição. Essa parece ser a situação de Teseu na citação acima, algo de muito terrível o devora, aliás, algo pior que do que o Minotauro. O que o devora é a própria Ariadne e, por consequência, o próprio labirinto em que se viu imerso, para o qual foi seduzido, e sem possibilidade de escape, uma vez que já não há mais o fio. O labirinto o consome, o destrói, a imagem que pode ser pintada é de Teseu submerso em treva labiríntica, consternado, em desespero por ter se aniquilado todas as suas verdades que fundavam a sua existência. Contudo, apesar do quadro desolador, o resultado esperado, tal e qual no caso da sedução benevolente, é a vitalidade, o excesso de força, a jovialidade e, acima de tudo, a capacitação para criar, mesmo nos tenebrosos labirintos abismais da existência. Enquanto no aforismo 295 destaca-se o caráter terno da sedução dionisíaca, os seu

\footnotetext{
${ }^{122}$ Nietzsche escreve sobre a orelha da donzela em outra cena de meigo flerte: “"'Ó divino Dioniso, por que me puxas as orelhas?", perguntou Ariadne a seu filosófico amante, num daqueles celebre diálogos em Naxos. "Acho um certo humor nas tuas orelhas, Ariadna: por que não são elas ainda mais cumpridas?"”. Ibidem. Crepúsculo dos ídolos. "Incursões de um extemporâneo", §19. Cf. também, Fragmento póstumo de 1888, 16[40], §2.

${ }_{123}$ “"'Ariadne, sagte Dionysos, du bist ein Labyrinth: Theseus hat sich in dich verirrt, er hat keinen Faden mehr; was nützt es ihm nun, daß er nicht vom Minotauros gefressen wurde? Was ihn frißt, ist schlimmer als ein Minotauros". Du schmeichelst mir, antwortete Ariadne, aber ich bin meines Mitleidens müde, an mir sollen alle Helden zu Grunde gehen: Das ist meine letzte Liebe zu Theseus: "ich richte ihn zu Grunde"”' Ibidem. Fragmento póstumo de 1887, 9[115], §3. (grifo nosso)
} 
aspecto atroz e destruidor é mais bem ilustrado nas anotações não publicadas, tais como:

\begin{abstract}
"Parece-me que está tramando algo maléfico: levar os homens à destruição?" disse uma vez ao deus Dioniso - "Talvez, respondeu o deus, mas de tal forma que resulte algo para ele". - "O que então? Perguntei curiosamente. Quem então? Deverias perguntar". Assim falou Dioniso e em seguida permaneceu em silêncio de um jeito que lhe é tão próprio, ou seja, tentador [versucherisch]. Deveria tê-lo visto! - Era primavera, e todas as árvores se transbordavam em jovem seiva ${ }^{124}$.
\end{abstract}

No aforismo 295, o "gênio do coração" é benigno para o homem, medita em como torná-lo, entre outras coisas, mais belo; por outro lado, no fragmento supracitado, Nietzsche-personagem desconfia de que o deus planeja algo de surpreendentemente maléfico: arruinar os homens! Ao ser indagado sobre o perverso plano de destruição, Dioniso assente de um jeito tão próprio, maliciosamente. Todavia, ele faz questão de exclamar que não pretende aniquilar por completo o ser humano, conquanto, de uma forma tal, que ele ainda tenha possibilidade de se reestabelecer, dessa vez mais forte, mais duro e, além disso, que possa resultar algo dele, para ele, isto é, que possa se fazer criador de si mesmo. Aí está o significado da repreensão que Dioniso faz à interrogação de Nietzsche: não se deve perguntar "o que resulta desse processo?", mas sim, "quem resultará?". O produto da sedutora destruição dionisíaca é, portanto, um “quem", um novo homem. Sem dúvida, Nietzsche tinha em mente o übermensch, todavia, pensava também em um tipo real, possível, cuja principal marca é a transvaloração de todos os valores. Assim sendo, o homem é como o vaso de barro que, nas mãos do oleiro, é quebrado e aperfeiçoado. No entanto, ele é, ao mesmo tempo, a matéria e o artesão, abismalmente dividido em criatura e criador, caos e ordem pictórica e, como veremos no aforismo abaixo, tem como “causa motriz" de intersecção as intempéries do existir:

124 “"'Du scheinst mir Schlimmes im Schilde zu führen, man möchte glauben, du wolltest den Menschen zu Grunde richten?" - sagte ich einmal zu dem Gotte Dionysos. "Vielleicht, antwortete der Gott, aber so, daß dabei Etwas für ihn heraus kommt." - "Was denn? fragte ich neugierig. - Wer denn? solltest du fragen." Also sprach Dionysos und schwieg darauf in der Art, die ihm eigen ist, nämlich versucherisch. Ihr hättet ihn dabei sehen sollen! — Es war Frühling, und alles Holz stand in jungem Safte". Idem. 1886, 4[4]. O mesmo texto, apenas com algumas sutis diferenças, pode ser lido no fragmento de 1885, 2[25]. (grifo nosso). 
A disciplina do sofrer, do grande sofrer - não sabem vocês que até agora foi essa disciplina que criou toda a excelência humana? A tensão da alma na infelicidade, que lhe cultiva a força, seu tremor ao contemplar a grande ruína, sua inventividade e valentia no suportar, persistir, interpretar, utilizar a desventura, e o que então lhe foi dado de mistério, profundidade, espírito, máscara, astúcia, grandeza - não lhe foi dado em meio ao sofrimento? No homem estão unidos criador e criatura: no homem há matéria, fragmento, abundância, lodo, argila, absurdo, caos; mas no homem há também criador, escultor, dureza de martelo, deus-espectador e sétimo dia - vocês entendem esta oposição? E sua compaixão diz respeito à 'criatura no homem', ao que tem que ser formado, quebrado, rompido, forjado, queimado, incandescidos, purificado - ao que necessariamente tem de sofrer e deve sofrer? ${ }^{125}$

O parágrafo de Além do bem e do mal é muito ilustrativo e resume com clareza a questão da sedução destruidora de Dioniso. Sem as intempéries, sem a dor e a ruína o homem não é capaz de se fazer criador e criatura em uma só pessoa. Esquivando-se do sofrimento, ou é exclusivamente criador, então cria valores para consertar o mundo e os demais, mas incapaz de se moldar; ou então é apenas criatura, moldada pelos ideais consagrados pela tradição. É necessário ser quebrado, padecer em profundos labirintos para se tornar, concomitantemente, artista e Obra-de-arte. Nesses termos, o "gênio do coração" tem o poder de nos fazer mais fortes, mais belos e mais profundos, precisamente, por nos destruir e nos fazer afligir. Não há exagero em dizer que entre as mais terríveis aflições se destacam os próprios ensinamentos dionisíacos. Esse deus-tentador, como diz Nietzsche, "nos faz suar na cama"126. Não obstante, o significado mesmo de toda essa sedução e mortificação de que tanto falamos é a concepção do caráter geral do mundo, cujo termo mais apropriado para designá-la é - "Dioniso". Esse mundo dionisíaco é caracterizado pelo "caos por toda eternidade" 127 e, por consequência, é um mundo onde todos os valores se nulificam e os ideais perdem o poder de encantar.

O mundo que Nietzsche chama de dionisíaco é um mundo sem propósito e sem finalidade, de acordo com suas próprias palavras: "uma enormidade de forças, sem princípio e sem fim, uma grandiosa e férrea força que não aumenta e nem diminui, que não se consome, mas apenas se transforma" ${ }^{" 128}$. O indivíduo que

\footnotetext{
${ }^{125}$ Ibidem. Além do bem e do mal. §225.

${ }^{126}$. Ibidem. Fragmento Póstumo de 1885, 34[181]. [Apêndice $\beta$ ]

127 “O caráter geral do mundo, no entanto, é caos por toda a eternidade, não no sentido de ausência de necessidade, mas de ausência de ordem, divisão, forma, beleza, sabedoria e como quer que se chamem nossos antropomorfismos estéticos". Ibidem. A Gaia ciência. §109.

${ }^{128}$ Ibidem. Fragmento póstumo de 1885, 38[12].
} 
subitamente se percebe lançado nesse cosmos de devir eterno - que constantemente destrói e constrói a si próprio ${ }^{129}$ - é sufocado pela constatação de que todos os então princípios reguladores são apenas quimeras, meras ilusões criadas com a intenção de emprestar sentido à existência. Nesse momento, o deustentador é efetivamente um destruidor, porque não há "verdade" que resista à sua investida, todos os preceitos são demolidos, isto significa que o indivíduo, no momento em que é transpassado pela sabedoria dionisíaca, encontra-se sem nenhum fundamento científico, metafísico-filosófico, religioso e moral para a vida. Contudo, nesse exato momento, o sedutor-destruidor converte-se em educador, ou seja, o sufocante deslumbre por essa ácida interpretação da realidade, acompanhado pelo desencantamento dos velhos ideais, ocorre ao mesmo tempo em que o "gênio do coração" ensina a viver com sincera alegria, mesmo em meio ao nadificante caos. Sem o seu papel pedagógico, as pessoas tornar-se-iam niilistas.

O aspecto educativo do "gênio do coração" está intimamente ligado à ternura, lembrando que esta não é dicotômica à dureza. Assim sendo, o homem instruído pela sabedoria dionisíaca "olha para dentro de si como para um espaço sideral e traz vias lácteas em seu interior, sabe também como são irregulares todas as vias lácteas; elas conduzem ao caos e ao labirinto da existência" ${ }^{\text {"130; }}$ entretanto, isso não o perturba mais, pelo contrário, mantém-se sereno e predisposto ao criar. Educar-se dionisiacamente consiste, portanto, em tornar-se terno, todavia, também "mal”, ou seja, forte o suficiente para resistir, ante ao caos, à "vontade de negação" e à "vontade de verdade a todo custo". "Um homem labiríntico", diz Nietzsche, "nunca procura a verdade, mas tão somente sua Ariadne"131. Isso é confirmado em outro texto de 1886 - preparado para ser o epílogo de Humano, demasiado humano - onde nosso filósofo traz à cena os "espíritos livres" para ressaltar que as únicas verdades que aceita para si são aquelas que façam os pés dançar ${ }^{132}$. A dança, como dito anteriormente, é o maior

\footnotetext{
129 "diese meine dionysische Welt des Ewig-sich-selber-Schaffens, des Ewig-sich-selberZerstörens". Idem. (Aprofundaremos nesse tema na seção subsequente).

${ }^{130}$ Ibidem. A Gaia ciência. $\$ 322$.

${ }^{131}$ Idem. 1883 4[55].

132 “Ainda que digas verdades: com essas verdades não há pés que possam dançar, portanto estão longe de ser verdades para nós! Ecce nostrum veritatis sigillum! [Eis aqui nosso selo da verdade!]”. Idem. 1886, 4[9]. [Apêndice 7 ]. O mesmo texto, com poucas alterações já havia sido escrito em um caderno do verão de 1885 , Cf. 40[59], §3.
} 
signo de amor incondicional à vida, mesmo diante do terrível; por consequência, dançar passa a ser signo de coragem, de resistência com serenidade, ternura e, sobretudo, de alegria.

Não podemos falar em uma educação dionisíaca sem mencionar a alegria e, por consequência, o riso. De fato, o júbilo e a gargalhada são categorias indissociáveis do segundo Dioniso. No aforismo 295, por exemplo, o "gênio do coração" ao dizer que pretende educar o homem para ser "mais forte, mais malvado e profundo, e também mais bonito" sorri com seu "sorriso alciônico [halkyonischen Lächeln], como se tivesse dito uma encantadora gentileza". Para Nietzsche, o riso é, grosso modo, uma forma de elevação da potência, um modo afirmativo de se posicionar em relação ao mundo, em outras palavras, é uma maneira de valorar a realidade instintivamente. A risada é, nesse sentido, a exteriorização da ação valorativa. Isso é ilustrado em um fragmento de 1885 , onde o filósofo usa a gargalhada do deus-tentador para criticar os juízos sintéticos $a$ priori de $\mathrm{Kant}^{133}$. Além disso, a ternura do "sorriso de uma criança" é o que resulta de toda sorte de sofrimento e dificuldade que o tipo forte vivenciou e ainda carrega sobre $\mathrm{si}^{134}$. Zaratustra, umas das máscaras de Dioniso na obra nietzschiana exorta a todo o momento para o riso. Para o personagem, rir é a marca do criador $^{135}$. Contudo, quando não for resultado de uma força afirmativa, predisposta aos ensinamentos de Dioniso/Zaratustra, o riso torna-se uma categoria reativa, marca do ressentimento ${ }^{136}$.

\footnotetext{
133 “Como é que as mulheres dão à luz seus filhos vivos? Eu sempre achei que os pobres animais deveriam vir sufocados ao mundo devido a inferior constituição de suas forças de resistência. A porta é estreita e apertado é o caminho, como está escrito: ou como são possíveis filhos vivos a priori? - E enquanto assim questionava, eu acordei completamente do meu sono dogmático, dei um empurrãozinho na barriga do deus e perguntei, com a seriedade de um chinês de Königsberg: "Em suma: como são possíveis juízos sintéticos a priori?" - "Mediante uma faculdade para isso" respondeu o deus segurando o estômago [de tanto rir]". Idem. 1885, 34[183].

134 "Qual é a coisa mais difícil de fazer para o homem? Amar aqueles que nos desprezam; abandonar nossa causa quando se celebra a sua vitória, por causa da verdade e da reverência; estar doente e rejeitar o consolador; mergulhar em água fria e suja; fazer amizade com quem não sabe ouvir; apertar as mãos do fantasma, mesmo se isso nos apavora: - Tudo isso, dizia Zaratustra, eu fiz e levo comigo: e a tudo isso eu dou hoje por pouco - por um sorriso de uma criança". Idem. 1883, 5[1], §162. Cf. também: 1883, 4[96] e 4[112].

135 "Se algum dia eu ri a risada do raio criador, ao qual segue, resmungão mas obediente, o demorado trovão do ato" Ibidem. Assim falou Zaratustra". "Os Sete selos", §3.

${ }^{136}$ Quando Zaratustra desce aos homens do mercado para anunciar-lhes a sua boa nova, é recebido com escárnio por aqueles que não o compreendiam: "Plácida está minha alma, e clara como os montes na manhã. Mas eles acham que sou frio, e um zombador de terríveis pilhérias. E agora eles olham para mim e riem: e, ao rir, também me odeiam. Há gelo no seu riso". "Prólogo" Idem. §5
} 
Não obstante, descrever Dioniso como tentador e aliciador também é um meio de conservar o seu epítome de louco, a efígie de divindade que arrasta à demência. E o que é, precisamente, a loucura dionisíaca? Alegrar-se inabalavelmente, mesmo diante da revelação de um mundo sem propósito, sem segurança e sem verdades acalentadoras, porém um mundo que não é, em hipótese alguma, antitético à alegria. Enfatizamos aqui que loucura dionisíaca não é o mesmo que felicidade. As acepções de felicidade tendem a compreendê-la como um "além", um "depois", um "logo ali", ou seja, ela nunca é experimentada efetivamente, porque, é a promessa de um reino dos céus; a esperança de um sonho a se realizar; ou o fim da vida, tal como postula Aristóteles ${ }^{137}$. Além disso, a ideia de felicidade não admite coexistência com a tristeza, ou com a angústia: é uma incompatibilidade lógica admitir que esteja triste e feliz ao mesmo tempo. Por isso, a loucura dionisíaca é a alegria, a gaia ciência: ela é vivenciada no instante agora, nos atravessa mesmo nos momentos de imensa dor e tristeza basta pensar na devastação do espírito no momento mais lúgubre da vida, o luto, que, no entanto, pode ser atravessado por uma gloriosa alegria, quando, por exemplo, nos assalta uma terna lembrança daquele que partiu. Alegrar-se no caos e na dor, criar em meio aos abismos labirínticos da existência é a mais insana sedução - e ensinamento - de Dioniso.

Destarte, depois dessa exposição sobre o "gênio do coração", podemos afirmar com maior segurança, que os grandes assuntos da filosofia nietzschiana mais tardia estabelecem entre si uma conexão, claramente visível quando os tais temas são analisados pelo prisma do símbolo Dioniso. Pensando nisso, o nosso trabalho deve agora ocupar-se de investigar a relação entre os desígnios do "gênio do coração", até aqui apresentados, com a concepção cosmológica de Nietzsche, abertamente nomeada como "meu mundo dionisíaco", a saber, o mundo como vontade de poder [der Wille zur Macht]. No entanto, antes de falarmos especificamente sobre esse assunto, consideramos importante fazer mais uma observação a respeito do deus-tentador como educador: uma possível aproximação entre o "gênio do coração" e Sócrates.

${ }^{137}$ Cf. ARISTÓTELES. Ética a Nicômaco, X. 
Essa ideia foi defendida por Ernst Bertram e, $\log$ depois, por Walter Kaufmann e Pierre Hadot. Bertram, em Nietzsche. Versuch einer Mythologie (1918), defende que o "gênio dionisíaco-socrático do coração" seria a forma secreta de como o filósofo escreve psicologicamente de si. Isso estaria claro na citação parcial que Nietzsche faz do aforismo 295 no capítulo "Por que escrevo livros tão bons" de sua autobiografia. Na versão citada, é omitida qualquer menção ao nome de Dioniso, além do acréscimo de uma pequena introdução dizendo o seguinte: "Para dar uma ideia de mim como psicólogo, tomo um curioso fragmento de psicologia que aparece em Além do bem e do mal - proíbo, aliás, qualquer conjectura acerca de quem descrevo nesta passagem"138. Dessa forma, o "gênio do coração", seria uma autocitação em que "Nietzsche e Sócrates", "Dioniso e Zaratustra" são transformados em si, disfarçados um pelo outro, discretos um para o outro, entretanto, em cujo ponto de aproximação estaria a efígie do deus que busca discípulos, ou seja, a necessidade velada de Nietzsche em se tornar o gênio que transforma corações. Na análise de Bertram, o personagem Zaratustra seria o corolário da vontade de ser aquele grande educador socraticamente transformador ${ }^{139}$.

Hadot, na introdução que fez à edição francesa da obra de Bertram, ratifica essa ideia. Para ele, o que Nietzsche odeia em Sócrates é teórico, contudo, arde em nostalgia por aquilo que o símbolo socrático representa como "grande educador". O ideal pedagógico do Sócrates-platônico era envolvido na atmosfera do amor, tal e qual o de Zaratustra e de Dioniso, além disso, a misteriosa propedêutica do Banquete de Platão vem coincidir com os propósitos educativos expressos no hino "gênio do coração". O Enigmático aforismo 295 seria, portanto, o ponto em que Nietzsche cerziu uma conexão entre o aspecto pedagógico de sua filosofia dionisíaca e a imagem de educador que tanto admirava em Sócrates. Admiração que surgiu de seu próprio anseio em ser um grande educador. Ainda no que concerne a essa aproximação, Kaufmann é o outro

\footnotetext{
${ }^{138}$ Ibidem. Ecce homo. "Por que escrevo livros tão bons", §6.

139 "Zaratustra, essa mais poderosa utopia pedagógica que um socrático já terá erigido desde Platão; Zaratustra como o "mestre ideal", como a voz de Sócrates, que Nietzsche sonha ir além de Sócrates, como o mito do educador dionisíaco, o educador e criador do além-do-homem, como o mais gentil e o mais "malicioso de todos os pescadores dos homens: pois é ele quem sou eu tenho sido no fundo e desde o início a puxar, atrair, erguer, elevar, um puxador, preceptor e tratador, que um dia, não em vão, instou a si mesmo: 'Torna-te o que és!'(Zaratustra)'. BERTRAM, Ernst. Nietzsche: attempt at a mythology. p. 285 - 286. (a citação se refere ao capítulo "A Oferenda do mel" da IV parte de Assim falou Zaratustra).
} 
autor que vai buscar diversos elementos na obra de Nietzsche para comprovar a tese de uma forte admiração deste ao filósofo grego. Dentre esses elementos, podemos destacar que, em Ecce homo, o filósofo responde a pergunta "por que eu escrevo livros tão bons" de forma surpreendente: "Não existe espécie mais orgulhosa e mais refinada de livros - eles alcançam aqui e ali o mais elevado que se pode alcançar na Terra, o cinismo" ${ }^{140}$. O cinismo, diz Kaufmann, remonta à grande ironia que marca a sabedoria socrática ${ }^{141}$.

Kaufmann ainda anota que Nietzsche assume para si dois conceitos antes idealizados em Sócrates: "bufão" [Hanswurst] e "sátiro" [Satyr]. O primeiro, ele próprio atribui à imagem socrática em Crepúsculo dos ídolos ${ }^{142}$; o segundo é o termo com o qual Alcebíades platônico costumava referir-se ao mestre, difundindo sua imagem satírica ${ }^{143}$. Todavia, no $§ 2$ do Prólogo de Ecce homo, Nietzsche diz ser um sátiro e não um santo. No $\S 4$ do capítulo "Por que sou tão inteligente", ele elogia "aquela malícia divina sem a qual sou incapaz de imaginar o perfeito" e, com isso, evoca novamente a imagem do sátiro. Na mesma seção, diz de Shakespeare: "o que deve um homem ter sofrido, para necessitar de tal modo ser bufão!"; e, no $§ 1$ do capítulo final "Por que sou um destino", diz de si mesmo: "Eu não quero ser um santo, seria antes um bufão... Talvez eu seja um bufão...”. Esse modo coincidente de se referir a si e a Sócrates, somado ao fato de ter chamado o pensador grego, no parágrafo 340 de A Gaia ciência, de "Unhold

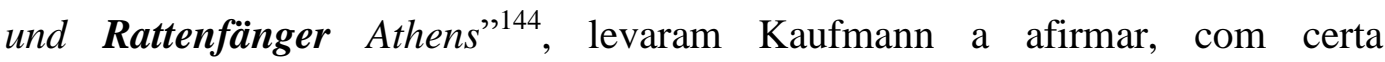
propriedade, que o "gênio do coração" citado em Ecce homo seria uma última demonstração do amor a Sócrates. Assim, todas as significações filosóficas de

\footnotetext{
${ }^{140}$ Cf. NIETZSCHE. Ecce homo "Por que escrevo tão bons livros", §3.

${ }^{141}$ Kaufmann recorda o $\$ 86$ de "Andarilho e sua sombra" para sustentar essa aproximação: "na jubilosa seriedade socrática e na sabedoria travessa que constitui o melhor estado da alma do homem". Para ele "Ecce homo vai além de qualquer livro anterior de Nietzsche ao tentar traduzir o cinismo do "grande irônico" em prosa". Cf. KAUFMANN, Walter A.. Nietzsche's Admiration for Socrates.

142 "O dialético é uma espécie de palhaço [Hanswurst]: as pessoas riem dele, não o levam a sério. - Sócrates foi o palhaço [Hanswurst] que se fez levar a sério: que aconteceu aí realmente?". NIETZSCHE. Crepúsculo dos ídolos. "O problema de Sócrates”, §5.

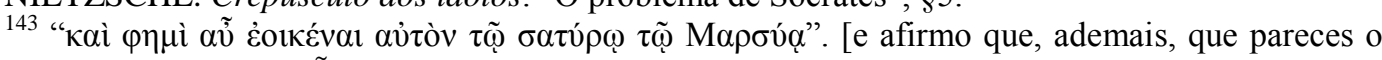

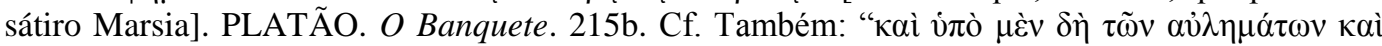

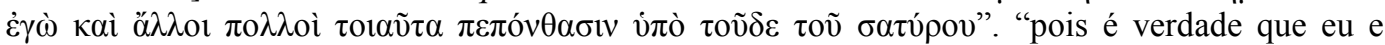
vários outros jovens experimentamos as odes da flauta deste sátiro". Idem. 216c.

144 "monstro e aliciador ateniense". Lembremos que Paulo Cesar de Souza traduz Rattenfänger, literalmente apanhador de ratos, referência ao flautista de Hamelin, como "aliciador".
} 
Dioniso teriam como fundo a imagem socrática apropriada e admirada por Nietzsche.

No entanto, apesar de reconhecermos que Sócrates é uma figura altamente ambígua na obra nietzschiana: ora severamente difamado, outrora considerado como sátiro, zombeteiro, flautista, sedutor e educador que faz os jovens tremerem e soluçarem $^{145}$, não podemos aceitar a interpretação de que Dioniso, enquanto o "gênio do coração", o meta-símbolo que agrega em si as principais ideias de Nietzsche, seja indissociável da imagem socrática. Essa recusa tem como base uma simples constatação: a efígie de Sócrates que se destaca nas diversas formulações nietzschianas é a do velho doente, que sofreu da vida e, como o fraco ressentido, se vingou da vida com suas últimas palavras ${ }^{146}$. Não podemos nos esquecer da gama de significados decadentes que podem ser extraídos do fato de ele expulsar as mulheres da prisão. Dessa forma, Sócrates seria antípoda do deus que educa para a alegria no sofrimento. Enquanto Sócrates é o filósofo da alma contra o corpo e, portanto, da essência, Dioniso é o deus-filósofo da aparência, “da seiva jovem”, ou seja, da vontade de poder ${ }^{147}$.

\subsection{3. \\ O "gênio do coração" como filósofo:}

Uma das imagens mais intrigantes do aforismo 295 é a revelação do "fato de Dioniso ser filósofo, e também os deuses filosofarem". Essa é a novidade que Nietzsche conta aos seus "amigos" interlocutores. Ele confessa, então, que aprendeu até demais sobre a filosofia desse deus, de quem se considera o "derradeiro iniciado e último discípulo". Agora, essa filosofia não deve mais permanecer um conhecimento secreto, deve ser anunciada, porém, é preciso que seja a meia voz, "pois ela inclui coisa nova, secreta, estranha, singular, inquietante". Destarte, a descrição aforística do "gênio do coração" como deusfilósofo significa que existe uma verdade de mundo dionisíaca, ou seja, existe uma compreensão da realidade que só pode ser exprimida levando-se em conta o

\footnotetext{
${ }^{145}$ Cf. NIETZSCHE. A Gaia ciência. $\$ 340$.

${ }^{146} \mathrm{Cf}$. Idem.

${ }^{147} \mathrm{Cf}$. Ibidem. Fragmento póstumo de 1885, 41[9]. [Apêndice $\delta$ ]
} 
símbolo Dioniso. A grande diferença entre este modo de se fazer filosofia e todos os demais é que aqui se concebe e se expressa uma verdade, entretanto, não por meio de uma linguagem sistemática ou conceitos que se pretendem totalizantes, que almejem esgotar todas as possibilidades interpretativas. Nietzsche faz questão de realçar essa questão linguística no aforismo, diz que o "deus em questão foi além, muito além em diálogos assim, e estava sempre muitos passos à minha frente", se referindo à antiga forma sistemática com a qual escrevia sobre a filosofia dionisíaca, e depois completa:

\begin{abstract}
Sim, se me fosse permitido lhe aplicar, conforme o costume humano, belos e solenes títulos [Tugendnamen] de pompa e virtude, eu celebraria sua coragem de explorador e descobridor, sua impetuosa honestidade, veracidade e amor à sabedora. No entanto, um deus como este não sabe o que fazer dessas pomposas ninharias. "Guarde isso", ele diria, "para você e seus iguais, e todos aqueles que o necessita! Eu - não tenho motivo para cobrir minha nudez!” - Já se percebe: a essa espécie de filósofos e divindades talvez falte pudor ${ }^{148}$.
\end{abstract}

Na filosofia de Dioniso, a tendência em aplicar "solenes nomes" e cunhar sofisticados termos - tal como os intelectuais da tradição se habituaram a fazer - é vista apenas como um costume hipócrita [heuchlerische] ${ }^{149}$ de utilizar palavras para encobrir, maquiar a realidade, sob o pretexto de explicitá-la. Isso ocorre porque os filósofos, ou os cientistas, acreditam ter realmente explorado e descoberto o fundo último do mundo, e que as sentenças, por eles inventadas, nos traduzem a veracidade inalterável das coisas. Por outro lado, os nomes são, na filosofia dionisíaca, apenas "pomposas ninharias" que dissimulam a realidade na medida em que pretendem desnudá-la. Nesse ponto de vista, a falta de pudor de Dioniso pode ser interpretada como a forma com a qual se relaciona com a verdade: sem a vestimenta conceitual, sem o intermédio da linguagem tradicional e sua "ilusão de completo desvelamento". Assim sendo, a nudez do deus se assemelha ao ato despudorado de Baubo que, ao despir-se, mais esconde do que revela. Não é em vão que Nietzsche, no Prólogo de 1886 de A Gaia ciência, escolhe "Baubo" como o nome grego para a verdade ${ }^{150}$. Para a filosofia dionisíaca - como não há "coisa-em-si", "realidade em si", "significado em si” dos quais

\footnotetext{
148 NIETZSCHE. Além do bem e do mal. \$295.

${ }^{149}$ Cf. Ibidem. Fragmentos póstumos de 1885 34[181] e 41[9].

${ }^{150}$ Cf. também: Nietzsche contra Wagner. "Epílogo", §2.
} 
deveríamos examinar o "em si"151 - a verdade só pode ser analisada do ponto de vista da manifestação e da aparência.

Devido à soberania da tradição metafísica, baseada na lógica platônicodualista do ser, o termo "aparência" carrega sobre si uma carga históricosemântica que Nietzsche precisa desmantelar. De saída, para o filósofo, o termo não corresponde ao oposto de alguma essência, mas é "aquilo mesmo que atua e vive, que na zombaria de si mesmo chega ao ponto de me fazer sentir que tudo aqui é aparência, fogo-fátuo, dança de espíritos e nada mais" "152. A aparência é, portanto, a verdade e a única realidade das coisas, não há contraposição entre uma e outra. A "aparência" é aquilo que pode ser caracterizada, relativamente muito bem, com todos os predicados existentes, inclusive com os predicados opostos. No entanto, com a palavra, diz o filósofo em um fragmento, não se expressa nada mais do que sua inacessibilidade para os procedimentos e distinções lógicas, ou seja, a relação entre "aparência" e "verdade lógica" só é possível em um mundo imaginário. Assim sendo, o entendimento que se faz de aparente-realidade se opõe ao "mundo de verdade" imaginativo ${ }^{153}$. Pensando nisso, Nietzsche procura um nome que possa designar essa realidade com honestidade, não a partir de sua natureza inatingível, mas de dentro, então a chama de vontade de potência ${ }^{154}$. O texto que melhor ilustra essa compreensão dionisíaca é a famosa anotação de 1885:

\begin{abstract}
E vocês sabem o que é para mim "o mundo"? Devo lhes mostrar em meu espelho? Este mundo: uma enormidade de força, sem começo e sem fim, uma grandeza como a do ferro, de força que não se torna maior e nem diminui, que não se consome, mas apenas se transforma, como um todo, invariavelmente grande, uma economia sem despesas e perdas, mas igualmente sem crescimento, sem receita, envolta pelo "nada" como suas fronteiras, nada que se dissipe, nada infinito estendido, mas como uma força determinada, em um espaço determinado, que em algum lugar seria "vazio", mas que se mostra como força em toda parte, como um jogo de forças e ondas de força, ao mesmo tempo um e "muitos", crescendo aqui e, ao mesmo tempo, diminuindo lá, em um mar de forças que se precipitam em si mesmas e se afluem
\end{abstract}

\footnotetext{
${ }^{151}$ Uma "coisa-em-si", algo tão equivocado como um "sentido-em-si", um "significado em si". Não existe "um fato em si" [Thatbestand an sich], mas deve sempre introduzir-se primeiro um significado para que possa haver fato [Thatbestand]. / O "o que é isto?" é uma posição de sentido vista de outra coisa. A "essência", a "entidade" é algo de perspectiva e já pressupõe multiplicidade. Na base está sempre "o que é isso para mim?" (para nós, para tudo que vive, etc.) / Uma coisa estaria designada se a respeito dela todos os seres perguntassem e respondessem "o que é isto?" Supondo que falte um único ser, com suas relações e perspectivas próprias sobre todas as coisas: e a coisa ainda não é "definida". Ibidem. Fragmentos póstumos de 1885 2[149].

${ }^{152}$ Ibidem. A Gaia ciência. §54.

${ }^{153}$ Ibidem. Fragmento póstumo de 1885, 40[53].

${ }^{154}$ Idem.
} 
para o interior de si mesmas, eternamente se alterando, eternamente correndo de volta, com tremendos anos do retorno, com o fluxo e refluxo de suas configurações [Gestaltungen], do mais simples ao mais múltiplo, do mais quieto, o mais rígido, do mais frio em direção ao mais ardente, mais selvagem, mais contraditório em relação a si mesmo, e depois novamente retornando ao simples a partir da plenitude, a partir do jogo de contradições de volta para a alegria da harmonia, afirmando a si mesma ainda nessa igualdade de suas trilhas e anos, abençoando a si mesmo como ao que deve eternamente retornar, como um devir, que nunca encontra saciedade, desgosto, não conhece nenhum e cansaço -: este meu mundo dionisíaco do eterno-criar-a-simesmo, do eternamente-destruir-a-si-mesmo, este mundo-misterioso da dupla volúpia, esse meu para além do bem e do mal, sem meta, a menos que a meta seja a felicidade do círculo, sem vontade, a menos que o anel tenha para si mesmo uma boa vontade - vocês querem um nome para este mundo? Uma solução para todos os seus enigmas? Uma luz também para vocês, os mais escondidos, fortes, intrépidos e amigos da meia-noite? - Esse mundo é a vontade de poder - e nada mais! E também vocês são essa vontade de poder - e nada mais! ${ }^{155}$

Dioniso como deus-filósofo é o responsável por revelar a compreensão da realidade-aparente enquanto vontade de poder. Chama-nos a atenção que o fragmento supracitado, igual ao período inicial do aforismo "o gênio do coração", é construído em uma estrutura elíptica, onde os arcos semânticos se repetem sucessivamente, sem uma previsão de conclusão redentora, gerando, com isso, certa tensão no leitor. Existe ainda outra semelhança entre os textos: tanto em um como no outro, Nietzsche toma o leitor como seu interlocutor. Há uma impessoalidade no texto, o filósofo utiliza dos Personalpronomen "Ihr" e "auch" para indicar que está falando com um "vocês", ou seja, com alguém próximo. A filosofia dionisíaca é revelada, portanto, para esses "amigos" de ouvidos sensíveis, por isso ela deve ser anunciada a meia voz. Também é devido à exigência desses ouvidos que Nietzsche sente a necessidade de empregar um nome: "vocês querem um nome para este mundo?", inquere aos interlocutores, reconhecendo que o termo, o conceito é para eles uma espécie de luz e a única solução para enigmas. Não obstante, cunhar um nome - vontade de poder - não significa aqui um contrassenso com o que foi dito anteriormente, isto é, fazer uma análise lógico-sistemática do mundo, todavia, é promover uma leitura da realidade-aparente "desde dentro", a partir de sua estrutura interna, o que só é possível corporalmente.

Nesse sentido, a vontade de poder é a proposta nietzschiana de que o corpo é o instrumento que traduz a vida ao indivíduo, ou seja, o corpo é meio pelo qual

\footnotetext{
${ }^{155}$ Idem. 1885, 38[12].
} 
ele pode ter uma experiência direta da realidade. Isso é defendido no parágrafo 36 de Além do bem e do mal, onde é feita a suposição de que nada é dado como real exceto nosso mundo de desejos e paixões, e que a única realidade a que podemos ter acesso é a dos nossos impulsos, uma vez que o pensamento é apenas a relação desses impulsos entre si. O corpo é considerado, portanto, como o único meio de compreensão da vida. Desse modo, podemos perguntar hipoteticamente se esses dados corporais bastariam para compreendermos também o chamado "mundo mecânico", "material"? Nietzsche deixa claro que não está falando do mundo como aparente-ilusão, ou representação, no sentido dos antigos filósofos, mas "como da mesma ordem de realidade de nossos afetos, - como uma forma mais primitiva do mundo dos afetos, na qual ainda esteja encerrado em poderosa unidade tudo o que então se ramifica e se configura no processo orgânico"156. A questão aqui é se existe uma espécie de vida instintiva, na qual todas as funções orgânicas estão interligadas como uma forma prévia de vida. Aceitando essa hipótese, o próximo passo é estender a interpretação do mundo orgânico ao inorgânico.

A partir de um procedimento analógico, Nietzsche pretende compreender toda a realidade com base na experimentação da vida através do próprio corpo. Sua hipótese é a seguinte: se reconhecemos a vontade ${ }^{157}$ como atuante, se acreditamos na causalidade da vontade, então, podemos entender essa causalidade da vontade como única. Por conseguinte, uma vez que a "vontade" não atua sobre a matéria (na ação do nervo, por exemplo), em todos os fenômenos em que se reconhece um efeito [Wirkung], deve-se imaginar que uma vontade atuou sobre outra vontade. Desse modo, em todo acontecimento mecânico que sobre ele atue uma força, se trataria justamente da força de uma vontade, ou seja, o acontecimento deveria ser compreendido como o efeito dessa vontade. Aceitando essa hipótese - de que uma única força existente teria a mesma natureza do querer - então, não se poderia mais continuar interpretando os acontecimentos como efeito de forças neutras que buscam equilíbrio, tal como defende a mecânica moderna. Porém, como efeito de uma força que nunca se equilibra totalmente,

\footnotetext{
${ }^{156}$ Ibidem. Além do bem e do mal. \$36.

${ }^{157}$ Para Nietzsche vontade não é entendida como uma unidade causal. O homem todo é pluralidade de afetos, a vontade seria o afeto dominante: "Querer, isso é, mandar: mandar é um determinado afeto (este afeto é uma súbita explosão de força)". Fragmento póstumo de 1884, 25[436].
} 
uma força que nunca cessa, que é caracterizada como poder, ou seja, como um afeto segundo o modelo do querer - a vontade de poder. Isso seria, para Nietzsche, o "mundo visto de dentro, definido e designado conforme o seu caráter inteligível" $" 158$.

Em um primeiro olhar, toda essa elaboração nietzschiana nos faz lembrar de Schopenhauer, principalmente devido à palavra escolhida - Wille; se a concepção de que o mundo é vontade de poder e nada mais tem, de alguma forma, raízes no pensamento schopenhauriano, então não podemos dizer; a única coisa que podemos afirmar é que Nietzsche enfatiza a completa distinção e ausência de qualquer paralelo entre ambas as filosofias da vontade. A diferença radical é que, enquanto em Schopenhauer a vontade é o "em-si" do mundo, a essência primordial que se objetiva na representação aparente, para Nietzsche, como já sabemos, não existe a diferença entre aparência e realidade, qualquer forma de coisa-em-si foi derradeiramente abolida. Além disso, o filósofo de Zaratustra considera o conceito de Schopenhauer uma "mera palavra vazia"159, pois a vontade não é uma realidade unitária como este defendia. Sua unidade é só um nome que encobre uma multiplicidade de forças complexas ${ }^{160}$. Apesar de geralmente se empregar o termo [Kraft] no singular, seu entendimento deve sempre ser plural: "as forças", porque elas sempre ocorrem em enfrentamento. O mundo é, então, uma constante luta entre uma pluralidade de forças. Entretanto, ainda que as diferenças sejam acentuadas por Nietzsche, devemos observar que há uma semelhança que foi completamente ignorada por ele: o aspecto imanente da filosofia schopenhauriana, isto é, o entendimento de que o corpo é o único veículo de "acesso" à vontade.

Vimos anteriormente que o corpo é pensado por Schopenhauer de duas formas distintas: por um lado é visto como todos os demais objetos da intuição, isto é, apenas como uma representação do sujeito que conhece; por outro lado, o corpo também é concebido como a própria manifestação da vontade, através do qual podemos conhecer a essência das coisas ${ }^{161}$. Contudo, Schopenhauer defende,

\footnotetext{
158 Idem.

${ }^{159}$ Cf. Ibidem. Fragmento póstumo de 1888, 14[121].

${ }^{160}$ Cf. Ibidem. Além do bem e do mal. $\$ 19$.

161 "Nós temos agora, portanto, a respeito da essência e atividade do nosso próprio corpo, um duplo conhecimento muito significativo, e que nos é dado de modos completamente diferentes;
} 
no "livro terceiro" de sua grande obra, que uma apreensão objetiva e correta das coisas só é possível quando são consideradas durante o completo silêncio da vontade; por consequência, todo afeto e toda paixão são vistos como empecilhos para conhecimento objetivo. Os sentimentos, os interesses e inclinações distorcem a percepção das coisas. Nesse sentido, para conhecer em grau máximo seria necessário estar desvinculado dos princípios da razão, de modo que "o puro sujeito do conhecimento é aquele isento de vontade e alheio à dor e ao tempo" ${ }^{\text {"162, }}$ em outras palavras, livre das afecções corporais. Assim sendo, podemos dizer que tal formulação do conhecimento puro e objetivo, com um fundo notoriamente kantiano, é o extremo oposto da concepção da vontade de potência. A concepção nietzschiana é um verdadeiro contra-modelo, cuja base é a valorização dos afetos.

No $\$ 12$ de Genealogia da moral, é apresentado esse seu contra-modelo de maneira explícita. No final desse texto, Nietzsche faz questão de citar Schopenhauer para demonstrar que a ideia de um conhecimento puro, sem a intervenção dos afetos não passa de uma "fábula conceitual que estabelece um "puro sujeito do conhecimento, isento de vontade, alheio à dor e ao tempo". Para ele devemos nos guardar dos "tentáculos de conceitos contraditórios como "razão pura", "espiritualidade absoluta", "conhecimento em si"",163. Com isso, Nietzsche esclarece seu perspectivismo: só existe o modo perspectivo de conhecer, tudo são interpretações e perspectivas afetivas. Destarte, quanto mais afetos falam sobre determinada coisa, mais completo será o nosso "conceito" da coisa. Por outro lado, acaso conseguíssemos suspender todos os afetos, sem exceção, então, estaríamos castrando nosso intelecto. O conhecimento não é, portanto, de uma natureza não-afetiva, porém, é o resultado de um acordo, um contrato, um tratado de paz entre múltiplos afetos que se enfrentam, se contrapõem, se afrontam, em uma batalha onde cada um deles exige a afirmação de seu próprio ponto de vista, mas depois de exaustiva guerra apaziguam-se e encontram um meio termo ${ }^{164}$. Essa é a ideia mesma da vontade de poder, o mundo visto "de dentro".

vamos nos servir dele como uma chave, para penetrar até as essências de todos os fenômenos da natureza". SCHOPENHAUER. O Mundo como vontade e representação. §19. p. 114. (trad. Sá Correia).

162 "sondern er ist reines, willenloses, schmerzloses, zeitloses Subjekt der Erkenntni $\beta$ ". Idem. §34.

${ }^{163}$ Ibidem. Genealogia da moral. "Terceira dissertação", §12.

${ }^{164}$ Cf. Ibidem. A Gaia ciência. \$333. 
A vontade de poder é pensada, então, como uma constante luta entre forças desiguais, capazes de avaliarem-se reciprocamente. Este conflito não almeja a eliminação da força oposta, mas sim o seu domínio, assimilação e a contínua superação de si. Na medida em que acontece o combate entre essas forças, por haver uma imposição de um sentido às outras forças por parte da dominante, isso em função do jogo de dominação próprio dos afetos em luta, implica que ocorra o constante exercício da interpretação. Desse modo, o conceito de poder deve ser entendido como luta entre uma pluralidade de forças, todavia, deve-se saber que nessa luta há pausas, momento no qual elas são capazes de se coordenar, de estabelecer relações de organização e hierarquias temporárias. Cada uma dessas pulsões, ou forças, procura poder para si. Como diz Nietzsche: “Cada pulsão é uma espécie de ânsia de domínio, cada uma tem sua perspectiva, que deseja impor como norma a todos os demais impulsos" $" 165$. No entanto, é importante destacar que o filósofo entende o poder de cada pulsão de modo relacional, ou seja, uma vontade de poder sempre está em relação com outra.

Não obstante, deve-se enfatizar que Nietzsche pensa a vontade de poder de maneira global, isto é, ela abarca desde as forças cosmológicas que constituem o mundo, até as formas de existência, inclusive nossa constituição psicofisiológica e sua relação com os valores morais. No que diz respeito à nossa psicofisiologia, as pulsões que nos constituem, enquanto estão em relação umas com as outras, acabam por estabelecer percepções, interpretações e perspectivas. No momento em que a pulsão percebe ou interpreta ela é também um afeto $[A f f e k t]^{166}$. Quando uma pulsão percepciona, por exemplo, ela é afetada pelo objeto da percepção, seja outra pulsão, a realidade, ou ela mesma. Porém, isso não quer dizer que as pulsões e os afetos são todos conscientes, apenas aqueles que assumem a condição de pensamentos, anseios e sentimentos tornam-se conscientes. De outro lado, toda forma de consciência está em correspondência com pulsões e afetos inconscientes. Por conseguinte, nota-se que, para Nietzsche, a vontade de poder constituiria, de certa forma, a subjetividade do indivíduo.

\footnotetext{
165 "Jeder Trieb ist eine Art Herrschsucht, jeder hat seine Perspektive, welche er als Norm allen übrigen Trieben aufzwingen möchte". Ibidem. Fragmento póstumo de 1886, 7[60]. (Grifo nosso).

166 "Não se deve perguntar: "Quem interpreta?" Mas o que é o próprio interpretar, enquanto uma forma da vontade de poder, tem existência (mas não como um "ser", mas como um processo, um devir) como um afeto". [Man darf nicht fragen: „,wer interpretirt denn?" sondern das Interpretiren selbst, als eine Form des Willens zur Macht, hat Dasein (aber nicht als ein „Sein“, sondern als ein Prozeß, ein Werden) als ein Affekt.]. Idem. 1885, 2[151].
} 
Nessa perspectiva, a vontade de poder levaria a cabo a crítica nietzschiana ao subjetivismo metafísico, pois ela nega a existência de uma unidade subjetiva, dissolve o "sintético conceito do "eu",167, ou seja, o "ego" cartesiano que é sujeito e a causa do efeito pensamento. De acordo com essa proposta, o sujeito só é uma unidade, uma pessoa una, no momento em que ocorre uma temporária organização e acordo entre a multiplicidade de pulsões e afetos. Devemos conceber, segundo Nietzsche, que a subjetividade é o corpo que, por sua vez, é construído como uma estrutura social de "sub-vontades" ou "sub-almas" 168 . Dessa forma, diz o filósofo, "toda unidade só é unidade enquanto organização e jogo de conjunto, de maneira igual à unidade das comunidades humanas, ou seja, oposta à

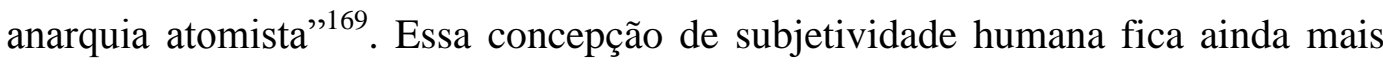
evidente no famoso parágrafo 333 de A Gaia ciência, onde o a consciência é descrita como "as últimas cenas e ajuste de contas de um longo processo", no qual impulsos com visões unilaterais lutam por sua supremacia. $\mathrm{O}$ que durante muito tempo foi tido como "pensamento absoluto", na verdade, diz Nietzsche, ocorre, em sua maior parte, de maneira inconsciente e não sentida por nós.

O conhecimento e o pensar consciente são, nesse sentido, o apaziguamento de impulsos e afetos que antes de virem à consciência batalhavam violentamente entre si, no escuro inconsciente do corpo. Talvez a exaustão de todos os pensadores, questiona o filósofo, possa ter sua origem nesse campo de batalha. Dito isto, vale ressaltar que a vontade tem essa mesma origem que o pensamento. Quando afirmamos, por exemplo, que alguém tem uma vontade - o que é o mesmo que dizer que a pessoa é uma vontade - entendemos esse querer como a organização provisória resultante de uma intensa e oculta disputa de vontades. No entanto, de acordo de como essas pulsões se relacionam entre si, o resultado pode ser uma "vontade forte" ou uma "vontade fraca". Isso não significa que existam vontades fortes ou fracas, nada disso; a força e a debilidade são consequências da forma como elas se organizam. Quando há uma anarquia das pulsões, o resultado é uma "vontade fraca", por outro lado, quando há uma coordenação das mesmas, baixo ao predomínio de só uma pulsão, o efeito é uma "vontade forte". Essa diferença é ilustrada da seguinte forma: no primeiro caso, ocorre a "oscilação

\footnotetext{
${ }^{167}$ Ibidem. Além do bem e do mal. §19.

${ }^{168} \mathrm{Cf}$. Idem.

${ }^{169}$ Ibidem. Fragmento póstumo de 1886, 2[87].
} 
constante e a falta de centro de gravidade; no segundo, a precisão e a claridade da direção" ${ }^{170}$.

Tal imagem pode ser pensada claramente no aspecto sócio-político, isto é, todas as relações interpessoais são, no fundo, relações entre vontades, onde o poder é o modo como as pessoas afetam umas às outras. O poder é, precisamente, o que transcorre no jogo entre diversas vontades. Assim sendo, uma sociedade, uma política, ou um grupo que tenha a vontade caracterizada como "forte", é aquela cuja multiplicidade subjetiva é conduzida hierarquicamente por uma vontade dominante. A mesma coisa ocorre no plano psicofisiológico, quando há uma anarquia dos instintos e afetos o resultado é um corpo doente e um espírito décadent ${ }^{171}$. Conquanto, antes que adentremos no terreno polêmico da vontade de poder na esfera política, devemos enfatizar que o resultado do conflito entre as vontades é sempre provisório. A vontade de poder é sempre uma vontade de dominação e imposição, porém, a dominação nunca é perene, não é possível uma imposição absoluta ${ }^{172}$. Por isso, não podemos pensar, nestes termos, uma forma de controle social que não envolva a oscilação de pontos de vistas dominantes a partir de relações intersubjetivas, pois, como esclarece Nietzsche: "a vontade de poder só pode se exteriorizar ante resistências; sempre busca o que resiste a ela"173.

Feitas essas considerações introdutórias, devemos salientar que a vontade de poder é de fundamental importância para compreensão da filosofia madura de Nietzsche como um todo. Esse conceito possui inúmeros desdobramentos na sua obra, por isso, existe uma infinidade de pesquisadores e comentadores que se dedicaram exaustivamente em esclarecer as infindáveis problematizações que

\footnotetext{
${ }^{170}$ Ibidem. Fragmento póstumo de 1888, 14[219]

${ }^{171}$ Nietzsche escreve sobre a anarquia dos instintos como décadence em Sócrates no fragmento de $1888,14[92]$.

${ }^{172}$ Interessante como o professor João Constâncio demonstra essa transitoriedade aludindo para a dialética do senhor e do escravo descrita em Genealogia da moral: "O que Nietzsche descreve aqui é como o escravo é afetado pela opressão do senhor, e de tal forma que o ódio de sua impotência - seu ressentimento - acaba por criar novos valores (ou seja, uma nova postura intersubjetiva), de tal forma que, no final, esses valores afetam e derrotam o senhor por incutirem má consciência na sua relação intersubjetiva com o escravo". CONSTÂNCIO, João. "Lutas por reconhecimento e vontade de poder: uma afinidade entre Hegel e Nietzsche?". In. Cadernos Nietzsche, 36, 2016. p 118.

173 "Der Wille zur Macht kann sich nur an Widerständen äußern; er sucht also nach dem, was ihm widersteht". Idem. 1887, 9[151].
} 
surgem dessa questão ${ }^{174}$; portanto, teríamos ainda muito que explorar e dizer sobre o tema, mas nosso tempo é curto e nosso objetivo é claro: demonstrar que a filosofia do "deus-filósofo", Dioniso-gênio do coração, não é outra senão a vontade de poder. Dissemos diversas vezes ao longo deste trabalho que o dionisíaco anela os principais assuntos da filosofia de Nietzsche, isto é, as grandes questões de sua obra estão admiravelmente conectadas. Todavia, quando esses temas são analisados através do prisma dionisíaco, o elo entre eles torna-se ainda mais nítido, principalmente, quando tomamos a vontade de poder como a essência da filosofia dionisíaca. Isso ocorre, porque este projeto foi imaginado pelo filósofo como a coroação e síntese de todo o seu pensamento. Desse modo, podese compreender a última filosofia nietzschiana como uma teia, cuja base conceitual é a ideia da vontade de poder e cujo nome apropriado para designá-la é filosofia dionisíaca.

Em termos de produção bibliográfica, os planos de Nietzsche era escrever uma grande obra dividida em quatro livros com títulos diferentes, com a ideia de redigir um volume por ano ${ }^{175}$. O primeiro deles seria dedicado ao diagnóstico da época e do processo civilizatório, centrado na ideia de niilismo; o segundo iria ter como tema a crítica dos valores tradicionais; o terceiro versaria sobre uma nova forma de valorização, a saber, a vontade de poder; o quarto se dedicaria à ideia do eterno retorno ${ }^{176}$. Com isso, podemos observar que Nietzsche buscava exprimir com maior evidência a unidade de seu pensamento ${ }^{177}$. No entanto, entre 26 de agosto e 3 de setembro de 1888, o filósofo abandonou o projeto "A vontade de poder" para, então, dedicar-se a um novo projeto de obra capital - que também será abandonado - igualmente dividida em quatro volumes, chamada Transvaloração de todos os valores ${ }^{178}$, cujo primeiro capítulo seria formado por

\footnotetext{
${ }^{174} \mathrm{Cf}$. [Apêndice $\varepsilon$ ]

175 Sobre esse projeto Nietzsche escreve de Sils-Maria à irmã em Assunção: "Minha saúde melhorou consideravelmente, segundo o julgamento de todos que me viram de novo: sinais disso estou sendo rude. Apenas os olhos regrediram - porque olhei demais. Para os próximos 4 anos, está anunciada a preparação de uma obra capital [Hauptwerk] de quatro volumes; O título já é assustador: “A vontade de poder. Tentativa de transvalorização de todos os valores”. Para isso, tenho tudo necessário: saúde, solidão, bom humor, talvez uma mulher”. Carta de 2 de setembro de 1886, a Bernhard e Elisabeth Förster.

${ }^{176}$ Os planos de Nietzsche para cada capítulo podem ser checados nos fragmentos póstumos de 1888 12[2] e $18[17]$.

${ }^{177}$ Isso pode ser observado na carta ao amigo Franz Overbeck de 7 de abril de 1884. [Apêndice $\zeta$ ]

178 Nietzsche escreve em diversas cartas a importância conferida ao projeto Transvaloração de todos os valores. Cf., por exemplo, carta a Reinhart von Seydlitz de 12 de febrero de 1888; a Franz
} 
parte do escrito publicado postumamente como O Anticristo ${ }^{179}$. Apesar de ter abandonado os planos de composição e publicação, a ideia do mundo como vontade de poder manteve-se, isso fica claro em Crepúsculo dos ídolos, sua última obra publicada em vida, escrita com o material acumulado desde 1885 para compor o antigo projeto.

Não obstante, devemos dizer que somente em uma única anotação de 1885 , Nietzsche alude para a relação entre a "filosofia de Dioniso" e a vontade de poder. Nesse texto, o aspecto dionisíaco é, precisamente, o reconhecimento do "sumo deleite da existência" no criar e transformar, tanto os homens quanto as coisas, e na "moral" vista como interpretação, ou seja, como um meio de dar à vontade dominante força e flexibilidade para formar a humanidade ${ }^{180}$. Chama-nos atenção que no início dessa anotação, após esclarecer que a moral e as religiões são o principal meio pelo qual se pode modelar do homem à maneira que um queira pressupondo que se tenha um excedente de forças criativas para impor, por um longo tempo, legislações e costumes - Nietzsche diz que refletiu sobre os meios de fazer o homem mais "forte e mais profundo", então compreendeu que não é através da moral do instinto gregário, habitual na Europa moderna, que só almeja o bem-estar, segurança e felicidade, todavia, "a planta homem cresce com mais vigor e mais belamente" onde seu espírito inventivo é desafiado por uma pressão e coerção prolongada, e, consequentemente, pela dureza, crueldade, discrição, desconforto, desigualdade de direitos, guerra, choque de todos os tipos, enfim, por uma moral invertida, com propósitos em oposição aos ideais gregários.

Essa anotação de 1885 é importante para nossa argumentação, porque, além de explicar a relação da vontade de poder com a moral, o texto é construído em

Overbeck de 13 de fevereiro de 1888; a Malwida von Meysenbug de 4 de outubro de 1888; a Franz Overbeck de 18 de outubro de 1888; [Apêndice $\eta$ ] e o prólogo que havia rascunhado para essa obra no fragmento póstumo de 1888, 19[7].

${ }^{179}$ Para o novo plano literário Nietzsche pensou em seis diferentes projetos, que podemos observar nos seguintes fragmentos: 11[416], 19[8], 22[14], 22[24], 23[8] e 23[13]. Praticamente todos eles foram divididos em quatro livros, dos quais o primeiro é sempre $O$ Anticristo.

180 “(...) Todo este modo de pensar eu chamei para mim mesmo de filosofia de Dioniso: uma consideração que reconhece no criar e transformar, tanto do homem quanto das coisas, o sumo deleite da existência, e na "moral" vista unicamente como um meio para dar à vontade dominante uma força e flexibilidade conforme as quais se possam ser formada a humanidade. Eu observo em que medida as religiões e os sistemas educativos acumulam e transmitem força; e nada me parece mais essencial que estudar as leis da criação, para não perder de novo maior quantidade de força, mediante uniões e modos de vida pouco convenientes". NIETZSCHE. Fragmento póstumo de $1885,34[176]$. 
certa similitude com o parágrafo 295 de Além do bem e do mal. Enquanto nesse texto Nietzsche avalia a moral europeia depois de refletir os meios de fazer o homem mais forte e profundo; Dioniso-gênio do coração também medita em como tornar o homem mais "forte, malvado e profundo". Outro ponto de conexão entre os textos é o destaque concedido ao caráter criativo do ser humano: aqui, é levado em consideração o "espírito inventivo" [Verstellungsgeist], a capacidade de se ajustar, de se reinventar diante da pressão; já no aforismo 295, é o caráter inovador [erfinderisches], a capacidade de se encontrar em qualquer labirinto que é exaltado. Além disso, a sedução e a educação são outros elementos em comum nos dois textos: no fragmento de 1885 , por exemplo, Nietzsche ressalta a sedução que a moral da Antiguidade provoca nas almas mais fortes ${ }^{181}$; e ao observar como as religiões e os sistemas educativos acumulam e transmitem força, conclui que "nada me parece mais essencial do que estudar as leis da criação [Gesetze der Züchtung], a fim de não perder novamente grande quantidade de força, através de conexões e modos de vida inadequados" ${ }^{, 182}$.

Sabendo disso, podemos dizer que Dioniso é, na filosofia madura de Nietzsche, outro nome para vontade de poder. A divindade diz respeito ao prazer e ao desprazer intrínsecos à busca pelo poder ${ }^{183}$. Isso não significa que a vontade de poder almeje o deleite e faça dele sua motivação, mas, por outro lado, o prazer advém quando se atinge, depois de dolorosa luta, aquilo que realmente se anseia o poder ${ }^{184}$. No entanto, é importante dizer que a perspectiva nietzschiana não é um "biologismo" no sentido positivo do termo, porém uma compreensão genealógica do poder, isto é, uma reflexão fisiológica do prazer e da dor que acompanham a atividade de crescimento e declínio da força que, no que lhe concerne, se manifesta no corpo como instintos, desejos, paixões e afetos. Nesse ponto, a fisiologia nietzschiana entende o corpo como o instrumento de interpretação da vontade de poder e, consequentemente, como dispositivo de criação artística. Em

\footnotetext{
181 “(...) porque o mundo antigo prevalecia uma moral diferente da atual, e de fato o homem era, então, sob o feitiço de sua moralidade, mais perverso [böser] e profundo: a sedução da Antiguidade é exercida sobre as almas mais fortes, é provavelmente a mais sutil e imperceptível de todas as seduções". Idem.

${ }^{182}$ Idem.

${ }^{183}$ Cf. Idem. 1887, 14[82].

184 “O prazer é apenas um sintoma do sentimento do poder alcançado, uma consciência de diferença (...). O prazer acompanha, não impõe movimento..." [Lust ist nur ein Symptom vom Gefühl der erreichten Macht, eine Differenz-Bewußtheit (...). Lust begleitet, Lust bewegt nicht...]. Idem. 1887, 14[121]. Cf. também: 14[129], 14[173].
} 
outras palavras, a vontade de poder é concebida, no seu perpétuo jogo de forças que movimenta o devir, como a "atividade artística originária [Ur-kunstler]"185 que, por seu turno, é traduzida em estados corporais criativos. Esse é o significado máximo de Dioniso na última filosofia nietzschiana, a tradução feita pelo corpo da vida - isto é, do caos de forças diversamente qualificadas e quantificadas, que se enfrentam sem cessar, sem outro objetivo que não o predomínio e o máximo de poder - em arte.

A luta das forças entre si é, então, o que promove a criação. As formas artísticas são a manifestação da unidade atingida pela vitória de uma força sobre suas oponentes, as quais se submetem temporariamente à soberania da vencedora. A obra de arte dionisíaca é, portanto, a interpretação e a prefiguração dessa pacífica unidade, mas também do próprio caos e das batalhas ocultas que antecedem à hegemonia. Entretanto, como a supremacia é sempre provisória, o processo de criação artística envolve eterno ciclo de destruição e reconstrução. É dessa maneira que a obra de arte prefigura o mundo a partir "de dentro", isto é, "dando sem cessar rosto às coisas, criando e destruindo sem outra finalidade senão exercitar espontaneamente seu próprio dinamismo interno" ${ }^{\text {"186 }}$. Se aqui está o sentido cardeal do segundo Dioniso, também é aqui, nessas considerações artístico-fisiológicas, que encontramos a ressignificação da embriaguez. A sensação inebriante, no âmbito artístico, corresponde, efetivamente, a um mais de força ${ }^{187}$. No entanto, esse será o tema posteriormente explorado.

Por fim, não podemos deixar de mencionar o papel que o símbolo Dioniso exerce como o criador de sentido para a vida. Isso se justifica, porque depois da hipótese da vontade de poder, todas as dimensões da realidade - a natureza, a sociedade, o indivíduo, a história, etc. - perderam definitivamente o sentido, isso quer dizer que nada mais pode ser valorado como "em si”. Agora tudo é apenas energia, um "quantum de força" $" 188$ e o jogo de vontades que, incessantemente, se confrontam entre si, resultando na produção de interpretações e perspectivas. Desse modo, todo sentido é proposto ou imposto por uma vontade de poder.

\footnotetext{
${ }^{185}$ Cf. MECA, Diego Sanchez. Nietzsche la experiencia dionisíaca del mundo. p. 129.

186 Idem. 130.

187 "Das Rauschgefühl, thatsächlich einem Mehr von Kraft entsprechend". NIETZSCHE. Fragmento póstumo de 1888, 14[117].

${ }^{188}$ Cf. Ibidem. A Gaia ciência, §360; Fragmentos póstumos de 1886, 2[146]; 1887, 10[53]; $10[118] ; 1888,14[121]$;
} 
Contudo, esse é o propósito mesmo da sabedoria dionisíaca, isto é, interpretar constantemente e criar incessantemente, inclusive novos sentidos, o que significa fazer da vida uma obra de arte, criar artisticamente sentidos para a existência. Assim sendo, o dionisíaco, do terceiro período, é visto por Nietzsche como uma espécie de "luxo, também uma forma de valentia em enfrentar tudo que é terrífico; uma simpatia pelo horrível e problemático, ou seja, o dionisíaco na vontade, no espírito e no gosto" $" 189$.

Pois bem, depois de todos esses apontamentos sobre o ressurgimento de Dioniso na obra nietzschiana como o "gênio do coração", caminhamos para nossa próxima seção que examinará brevemente a relação do dionisíaco com a obra na qual, segundo Nietzsche, o dionisíaco "se tornou ato supremo" - Assim falou Zaratustra. No entanto, consideramos imprescindível que aqui ainda se faça outra indagação: Quem são esses amigos de Nietzsche? Para quais ouvintes com "hábitos estritos" [strengen Gewohnheiten] ${ }^{190}$, que não acreditam em Deus ou nos deuses, o filósofo confessa, em amistoso diálogo, os segredos de sua filosofia? No prefácio de Humano, demasiado humano, escrito em 1886, mesmo período do aforismo o "gênio do coração"191, os interlocutores são os espíritos livres, fantasmas companheiros, inventados para compensar a ausência de amigos. Todavia, não devemos deixar de mencionar os amigos reais, como Overbeck, Rohde, Burckhardt, e o círculo em torno de Malwida von Meysenbug, a quem Nietzsche "exigia" a atenção para a sua filosofia. No entanto, apesar disso, os testemunhos de suas cartas e, sobretudo o diálogo com seus próprios pensamentos no aforismo imediatamente seguinte ao $\$ 295^{192}$, nos esclarecem que a solidão é a verdadeira matéria prima de suas formulações, e seu pensamento é invariavelmente fruto da espera solitária. Isso pode ser comprovado nas seguintes correspondências:

\footnotetext{
189 "Ein Luxus gleichsam; eine Form der Tapferkeit ebenfalls, welche sich dem Furchtbaren entgegenstellt; eine Sympathie für das Schreckliche und Fragwürdige, weil man, unter Anderem, schrecklich und fragwürdig ist: das Dionysische in Wille, Geist, Geschmack”. Idem. 1887, $11[228]$.

${ }^{190}$ Cf. Além do bem e do mal. \$295.

${ }^{191}$ Que, aliás, foi planejado inicialmente para ser parte desse prefácio.

${ }^{192}$ NIETZSCHE. Op Cit. §296. [Apêndice $\theta$ ]
} 
Apesar de tudo, não me tornei mais rico em amizades: a vida me apresenta cada vez mais o dever com a terrível condição de sua realização solitária. É difícil ter empatia comigo; Agora quase dou por certo que, mesmo entre os conhecidos, seja grosseiramente mal compreendido, e agradeço por toda sutileza na interpretação, inclusive pela boa vontade de sutileza. Eu sou um asno, sem dúvida ${ }^{193}$.

A propósito, você sabe que Nice é o meu lugar de trabalho e solidão, como SilsMaria, e que eu só uso a sociedade para poder, a meu modo, estar solitário (quero dizer, ficar longe por horas, descansar) ${ }^{194}$.

Talvez também ajude a projetar algumas luzes iluminadoras em meu Zaratustra, que é, portanto, um livro incompreensível, porque remonta a todos os tipos de vivencias que não compartilho com ninguém. Se eu pudesse te dar uma noção do meu sentimento de solidão! Nem entre os vivos e tão pouco entre os mortos, tenho alguém com quem me sinta próximo. Isso é indescritivelmente horrível; e somente a prática de suportar esse sentimento e seu desenvolvimento gradual desde a infância, torna compreensível para mim que eu ainda não tenha sucumbido por causa da solidão. Além disso, a tarefa pela qual vivo está claramente diante de mim - como um factum de indescritível tristeza, mas transfigurado pela consciência de que há grandeza nela, a grandeza de uma tarefa jamais estabelecida a um mortal ${ }^{195}$.

Um animal se esconde em sua caverna quando está enfermo; o mesmo acontece com le bête philosophe [a besta filósofo]. Raramente me vem uma voz amiga. Eu estou sozinho agora, absurdamente só; e na minha luta inexorável e subterrânea contra tudo o que até agora tem sido venerado e amado pelos homens (minha fórmula para isso é a "Transvaloração de todos os valores") uma parte de mim mesmo, de maneira inadvertida, se converteu em uma caverna - algo oculto que já não mais encontra, ainda que assobiem para encontra-lo. Mas não vai se vai busca-lo... ${ }^{196}$

Estas são apenas algumas das muitas cartas em que o filósofo declara abertamente a sua solidão. Elas dão a dimensão da natureza solitária de Nietzsche que, por sua vez, sempre descreve seu isolamento de forma ambígua: como um sofrimento terrível e, ao mesmo tempo, como a fonte de toda a energia criativa que exige os seus pensamentos. Assim falou Zaratustra é de todas as suas obras a que mais se dedica ao tema da solidão. É nesse livro também que pela primeira vez é mencionada a hipótese da vontade de poder. Desse modo, "Um livro para todos e para ninguém" é indissociável da filosofia dionisíaca. Em Ecce homo essa aproximação é enfatizada várias vezes, assim sendo, podemos dizer que a obra apresenta uma espécie de tríade com os nomes Zaratustra-Dioniso-Nietzsche.

\footnotetext{
${ }^{193}$ Carta a Erwin Rohde de 23 de fevereiro de 1886.

${ }^{194}$ Rascunho da carta a Paul Lanzky do começo de agosto de 1886.

${ }^{195}$ Carta a Franz Overbeck de 5 de agosto de 1886.

${ }^{196}$ Carta a Reinhart von Seydlitz de 12 de fevereiro de 1888.
} 
Além disso, a linguagem ali foi elaborada como uma forma próxima a do ditirambo, ou seja, poética e, segundo o autor, musical. Pensado nisso, nosso próximo estásimo apresentará, de forma sucinta, o estilo de Assim falou Zaratustra a fim de demonstrar o vínculo existente entre os "cantos" de seu protagonista e a filosofia dionisíaca tardia. 


\section{8}

\section{হTÁIIMON TP'ITON}

\section{1.}

\section{Zaratustra e o filosofar ditirâmbico:}

Assim falou Zaratustra ocupa lugar de destaque na obra de Nietzsche. Esta afirmação torna-se possível ao atermo-nos apenas às palavras do próprio filósofo, não são poucas as referências em fragmentos póstumos, cartas e, até mesmo, nas edições pósteras de seus livros publicados em vida a respeito sobre a posição de destaque que o livro de 1883/85 desempenha para o autor. Uma destas menções é a carta endereçada ao pianista e musicólogo Carl Funchs, datada de 18 de julho de 1888 que contém as seguintes ponderações:

\footnotetext{
Eu dei aos homens o livro mais profundo que eles já tiveram, meu Zaratustra: um livro que confere uma tal distinção que quem pode dizer "Eu entendi seis sentenças dele, isto é, vivi através delas" pertence a uma ordem superior de mortais. - Mas como alguém poderia reparar nisto! Pagar por isto! É quase corromper o caráter de alguém! O abismo se tornou muito profundo. Desde então, o que faço nada mais é que bufonarias para permanecer mestre de uma intolerável tensão e fragilidade. Isto cá entre nós. $\mathrm{O}$ resto é silêncio.
}

Indiferente se Nietzsche olha para seu Zaratustra com certa megalomania, o que se mostra evidente é a profundidade que reconhece em cada linha, por isso "um livro para todos e para ninguém"; não é possível imaginar outro subtítulo para o escrito que exige do seu leitor mais que atenção, porém um mergulho abissal às vivências transformadoras. É impossível, segundo suas pretensões, entender o canto da personagem - que se coloca como sombra do próprio filósofo - e manter-se o mesmo: "Disseram-me que é impossível pôr de lado um livro meu - que eu perturbo inclusive o repouso noturno", assegura o filósofo no capítulo "Porque escrevo tão bons livros" de Ecce homol.

Nessa característica encontra-se a profundidade da composição capital nietzschiana: a obrigação de experimentar transformações, e para isso, viver e compreender o que ali se anuncia. Nesse sentido, a obra possui a mesma característica educativa de Dioniso: a pedagogia, em ambos os contextos, consiste

\footnotetext{
${ }^{1}$ NIETZSCHE. Ecce homo - "Porque escrevo livros tão bons", §3.
} 
na exigência de tornar-se forte. Esta tarefa trans-formadora é árdua, é preciso que se tenha o merecimento para prová-la, principalmente se considerarmos a estilística adotada. "Do meu Zaratustra, opino que é, talvez, a obra mais profunda existente em língua alemã, e também a mais perfeita quanto ao idioma", é o que diz ao professor Karl Knortz em uma carta de junho de 1888, na qual realça a preocupação que teve com a linguagem.

Como sabemos, não é na forma de um sistema que Nietzsche exprime aqui o seu pensamento, todavia por meio de um estilo poético, o que pode ser chamado de uma "prosa musical e artística". Sobre a importância desse estilo para a língua alemã, Nietzsche faz várias considerações em Ecce homo que são altamente significativas para pensar e situar Assim falou Zaratustra como obra à parte e "mais profunda em língua alemã", como também para vinculá-la à filosofia dionisíaca. Destas considerações destacamos um trecho do capítulo "Porque escrevo tão bons livros":

\begin{abstract}
Direi ao mesmo tempo algo geral sobre a minha arte do estilo. Comunicar um estado, uma tensão interna de páthos por meio de signos - eis o sentido de todo estilo; (...) Sempre pressupondo que haja ouvidos - que haja aqueles dignos de um tal páthos, que não faltem aqueles com os quais é possível comunicar-se - meu Zaratustra, por exemplo procura ainda agora por eles - ah, ele ainda terá muito a procurar! - É preciso ter o merecimento para prová-lo... E até lá não haverá quem compreenda a arte que foi esbanjada: jamais alguém pôde esbanjar tantos meios artísticos novos, inauditos, só então e para isso criados. Que tal coisa fosse possível em língua alemã, era algo a ser provado. (...) Antes de mim não se sabia o que pode ser feito com a língua alemã - o que pode ser feito com a língua ${ }^{2}$.
\end{abstract}

Nietzsche faz uso de uma arte de estilo [Kunst des Stils] que é rodeada de ritmo e lirismo: para ele, a arte do grande ritmo, do grande estilo dos períodos que expressam o fluir das paixões sublimes ${ }^{3}$. Assim sendo, toda a obra Zaratustra pode ser considerada música. Por isso, o renascimento da arte de ouvir é uma condição prévia para as suas profundidades. A linguagem que fala é a linguagem do ditirambo, dos cantos de Dioniso, aliás, o dionisíaco ali se torna ato supremo ${ }^{4}$. Ditirambo eram as antigas formas líricas, ou melhor, de coro lírico, diretamente ligado aos cultos a Dioniso. Tratava-se de poemas entusiásticos inspirados pela embriaguez, sempre com a música em primeiro plano.

\footnotetext{
${ }^{2}$ NIETZSCHE. Ecce homo - "Porque escrevo livros tão bons", §4.

${ }^{3}$ Idem

${ }^{4}$ Idem - "Assim falou Zaratustra”, §6.
} 
Quando em sua autobiografia, nas reflexões a respeito de Zaratustra, Nietzsche coloca-se como inventor do ditirambo ${ }^{5}$ está, na verdade, salientando que a escrita de seu livro carrega a sabedoria dionisíaca. Isto significa que Nietzsche não abandona completamente sua concepção de tragédia formulada em juventude. Assim falou Zaratustra apresenta-se como aprimoramento de seu pensamento apresentado em $O$ Nascimento da tragédia. E este aperfeiçoamento encontra-se principalmente, e de forma mais evidente, na estilística poética. Assim sendo, no que diz respeito à diferença entre o modo como expõe suas primeiras indagações e à musicalidade das palavras o autor nos deixa uma queixa, escrevendo no prefácio de "Tentativa de autocrítica" como deveria realmente ter se expressado outrora:

É que uma "alma nova", como ela era, deveria ter cantado, e não falado! Que lástima que aquilo que eu tinha a dizer eu não me atrevi a dizê-lo como poeta: talvez fosse capaz de fazê-lo ${ }^{6}$

Nietzsche reconhece o valor de sua obra inaugural, mas percebe também as falhas que nela se encontram: o que tinha para ser dito, poderia ser expresso de maneira artístico-musical. Desta forma, o dionisíaco há muito tempo apresentado renasce também na figura de seu personagem dançarino, que carrega em si o páthos trágico, a saber: Zaratustra é afirmativo, o oposto de qualquer pessimismo, aquele que diz $\operatorname{Sim}$ sem quaisquer reservas, no qual a música exerce função primordial. "Zaratustra pertence à rubrica das 'sinfonias", diz em uma carta a Peter Gast ${ }^{7}$. Mas o que significa dizer que Assim falou Zaratustra foi escrito com a pena que dança ao som de uma música ou uma sinfonia, ou seja, qual o significado de afirmar que sua obra "mais importante" é na verdade canto e poesia ditirâmbica? Não há dúvida de que falamos de uma obra filosófica e, consequentemente, de um filósofo. A linguagem artística então adotada leva a cabo a proposta, inicialmente composta em $O$ Nascimento da tragédia, de expressar um pensamento - filosófico - de maneira menos conceitual e

\footnotetext{
5 “Que linguagem falará um espírito, ao falar só consigo mesmo? A linguagem do ditirambo. Eu sou o inventor do ditirambo. Ouça-se como Zaratustra fala consigo mesmo antes do nascer do sol: uma tal felicidade esmeralda, uma tal delicadeza divina não tinha voz antes de mim. Mesmo a mais finda melancolia de Dioniso se torna ditirambo". Idem, §7.

${ }^{6}$ NIETZSCHE. $O$ Nascimento da tragédia - "Tentativa de autocrítica", §3.

7 "A que rubrica pertence, com efeito, esse Zaratustra? Creio que é quase à das 'sinfonias". Carta a Peter Gast de abril de 1883.
} 
sistemática. Sendo assim, a experiência de inspiração para a composição de Zaratustra é a mesma dos poetas, aquela que proporciona o "retorno da linguagem à natureza da imagem". Esta experiência é descrita em Ecce homo dessa forma:

\begin{abstract}
Alguém, no final do século XIX, tem nítida noção daquilo que os poetas de épocas fortes chamavam inspiração? Se não eu descreverei. (...) A noção de revelação, no sentido de que subitamente, com inefável certeza e sutileza, algo se torna visível, audível, algo que comove e transtorna no mais fundo, descreve simplesmente o estado de fato. Ouve-se, não se procura; toma-se, não se pergunta quem dá; um pensamento reluz como relâmpago, com necessidade, sem hesitação na forma - jamais tive opção. Um êxtase cuja tremenda tensão desata-se por vezes em torrentes de lágrimas; (...) Tudo ocorre de modo sumamente involuntário, mas como que em um turbilhão de sensação de liberdade, de incondicionalidade, de poder, de divindade... A involuntariedade da imagem, do símbolo, é o mais notável; já não se tem noção do que é imagem, do que é símbolo, tudo se oferece como a mais próxima, mais correta, mais simples expressão. Parece realmente, para lembrar uma palavra de Zaratustra, como se as coisas mesmas se acercassem e se oferecessem como símbolo (...) Esta é minha experiência de inspiração ${ }^{8}$.
\end{abstract}

A noção desta 'experiência de inspiração', que culmina na criação de Assim falou Zaratustra, assemelha-se à forma de composição dos poetas líricos exposta em $O$ Nascimento da tragédia ${ }^{9}$, no entanto, mais do que apontar Nietzsche como um artista-filósofo, devemos salientar que sua obra surge enquanto censura às filosofias construídas como tratados e sistemas. Existem vários fragmentos tardios que ressaltam esta crítica à escrita sistemática: "Desconfiamos de todos os homens de sistema, os evitamos cuidadosamente - a vontade de sistema é, ao menos para nós, algo que compromete uma falta de probidade" ${ }^{\text {10 }}$. Na escrita nietzschiana, a contar de suas primeiras publicações, sempre é privilegiada uma linguagem alegórica, mais ligada às experimentações corporais, frente a uma linguagem lógica e gramatical presente nos grandes ensaios. O aforismo do "gênio do coração" e a experiência que sua leitura imersiva nos proporciona é um bom exemplo disto.

Deste modo, diferentemente dos princípios lógicos aristotélicos, as contradições e os paradoxos são mais que permitidos, são privilegiados: os opostos se fundem em uma nova unidade, originando uma dimensão poética -

\footnotetext{
${ }^{8}$ Ibidem. Ecce homo - "Assim falou Zaratustra", §3.

9 "o gênio lírico sente nascer dentro de si, sob a influência mística da renúncia à individualidade e do estado de identificação, um mundo de imagens e símbolos (...) Imaginemos agora o artista no momento em que se percebe existente em meio a essas imagens, em que não é agente evocador, mas simples paciente, envolvido em um tumulto de paixões e aspirações subjetivas." Ibidem. $O$ Nascimento da tragédia, §5.

${ }^{10}$ Ibidem. Fragmento póstumo, primavera de 1888, 15[118].
} 
antes presentes nos mitos - que nos impõe o labor de interpretar o que ali se diz com as entranhas! Exige-se acima de tudo: "pôr-se de lado, dar-se tempo, ficar silencioso, ficar lento" " um silêncio que é característico ao "segundo Dioniso" - não uma decodificação puramente hermenêutica e racional. O gênero de Zaratustra leva às últimas consequências esta proposta; para seu autor, há contradição em praticamente cada sentença, tal como demonstra o seguinte excerto de Ecce homo: "As mais baixas e as mais elevadas forças da natureza humana, o mais doce, o mais terrivel flui de uma nascente com certeza perene ${ }^{„ 12}$. E o que significa esta antítese? "A sentença fremente de paixão; a eloquência tornada música; (...) A mais poderosa energia para o símbolo até aqui existente é pobre brincadeira, frente ao retorno da linguagem à natureza mesma da imagem" $"$.

A singularidade presente nas sentenças vibrantes, veementes e carregadas de paixão mostra-nos uma transposição da linguagem conceitual tradicional à linguagem poética e, até mesmo, musical; a música é considerada como a força máxima de expressão. A obra capital de Nietzsche concretiza-se como a mais livre de suas publicações, sendo então, o marco de amadurecimento e afastamento definitivo da metafísica presente em seu pensamento de juventude. Desse modo, é marco também de superação de Wagner e Schopenhauer. Entretanto, a ideia de superioridade da música - deles herdada - torna-se suprema em Assim falou Zaratustra. Tal ideia é demonstrada neste fragmento de 1887: "Comparada à música, toda comunicação por palavras é vergonhosa; as palavras diluem e brutalizam; as palavras despersonalizam; as palavras tornam o incomum comum" ${ }^{\prime 4}$. Interessante que essa ideia é muito parecida àquelas desenvolvidas no período de juventude. O ressurgimento de Dioniso na obra de Nietzsche marca também a reformulação da música como forma de linguagem.

Asssim sendo, entendemos que o estilo apresentado é o aprimoramento máximo do pensamento já exposto em momentos anteriores, mais precisamente, aquele que reflete a oposição entre o conceito e a música, construído como interpretação do modo como Richard Wagner conduzia suas obras, isto é, sempre

\footnotetext{
${ }^{11}$ Cf. Ibidem. Aurora - "Prólogo", §5.

${ }^{12}$ Ibidem. Ecce homo - "Assim falou Zaratustra", §6.

${ }^{13}$ Idem.

14 "Im Verhältniß zur Musik ist alle Mittheilung durch Worte von schamloser Art; das Wort verdünnt und verdummt; das Wort entpersönlicht; das Wort macht das Ungemeine gemein. Ibidem". Fragmento póstumo, outono de 1887, 10[60].
} 
destacando o poder dramático com que fala a música através do mito. A linguagem mítica exprime, portanto, uma representação do mundo não por uma linguagem conceitual, mas através de fatos e imagens que evocavam diversos sentimentos; é exatamente esta linguagem do mito, primitiva, em seu estado de origem que, segundo a Quarta consideração extemporânea, Wagner reintroduz no mundo sob a égide da música, sendo então a esperança de um futuro dionisíaco.

Porém, para nosso filósofo, ao descrever a música dionisíaca na arte wagneriana, na verdade estava descrevendo suas próprias intuições e em nada tinha a ver, em absoluto, com Wagner. Isso ele confirma em Ecce homo quando diz que em Richard Wagner em Bayreuth "pode-se tranquilamente colocar o meu nome ou o nome de 'Zaratustra' onde no texto há o nome de Wagner. Toda a imagem do artista ditirâmbico é a imagem do poeta preexistente do Zaratustra" ${ }^{\text {"15 }}$. Portanto, a arte suprema de dizer Sim à vida, à tragédia afirmadora e transfiguradora só é possível pelo caráter arrebatador da embriaguez dionisíaca. No entanto, como veremos na próxima seção, o entorpecimento estético terá outra significação: ainda afirmativa, contudo intimamente ligada à vontade de poder.

Não obstante, é mister salientar que a crítica nietzschiana ao conceito e à lógica tradicional não é unilateral. Isto é, por mais que o filósofo desenvolva um estilo bastante pessoal, repleto de imagens e símbolos, ele não abandona à lógica; caso o fizesse, seria impossível se comunicar. A crítica de Nietzsche está mais ligada à tentativa de desmantelar a metafísica e sua tendência em demonstrar verdades absolutas do que qualquer outra coisa. Dessa forma, seu estilo em Assim falou Zaratustra e em alguns dos seus mais belos aforismos, mais do que um abandono quimérico da lógica e do conceito, é uma linguagem da experimentação: o que se faz ali são experiências com o próprio pensamento, traquejos linguísticos de que resultaram 'conceitos diferentes' daqueles que, até então, eram comum na filosofia. Quando olhamos para seus inúmeros cadernos de anotações comprovamos como seu(s) estilo(s) se constrói a partir de experimentos com o pensamento e múltiplas tentativas com a escrita: existem, por exemplo, ao menos oito fragmentos de estilos diversificados que preparam ou reelaboram o aforismo "gênio do coração". Os cânticos de Zaratutra e os aforismos

\footnotetext{
${ }^{15}$ Ibidem. Ecce homo - "O Nascimento da tragédia”, §4.
} 
ditirâmbicos exprimem, portanto, 'conceitos', não cristalizados e definitivos, de uma filosofia que está sempre em movimento.

Outra perspectiva importante a respeito do estilo nietzschiano - e que está em plena conexão com o segundo Dioniso - é o caráter solitário de sua linguegm. Sua escrita nasce da solidão e volta-se a ela. Como dito, é um livro para todos, porque todos podem ter acesso e lê-lo, mas também é um livro para ninguém, como indica seu subtítulo, pois Nietzsche não o escreve para o rebanho e às massas; "não me compreendem, não sou a boca para esses ouvidos"16 diz Zaratustra após tentar falar à multidão na praça do mercado e não ser compreendido por ela. Essa distância presente entre os homens comuns do mercado, os homens de instinto gregário e o que professa a personagem dá-se, porque a obra nasce da solidão e a tem como condição para o seu entendimento. Neste sentido, quando concebemos Assim falou Zaratustra em tons musicais, ou melhor, quando entendemos que Zaratustra é ditirâmbico, devemos encarar que "Todo Zaratustra é um ditirambo à solidão", cada linha e cada palavra evoca a solidão. Esse sentimento estabelece-se como pilar e fundamento de todo a obra.

A partir do exame de Ecce homo, a obra autobiográfica segundo a qual Nietzsche elucida pela primeira vez Assim falou Zaratustra $^{17}$, podemos indicar o papel importante que ocupa a solidão na escrita nietzschiana; são vários os textos que associam seu pensamento às alturas e, consequentemente, a uma forma de isolamento. Já nas primeiras páginas, o prólogo reflete sobre seus escritos do seguinte modo:

Quem sabe respirar o ar de meus escritos sabe que é um ar das alturas, um ar forte. É preciso ser feito para ele, senão há o perigo nada pequeno de se resfriar. O gelo está próximo, a solidão é monstruosa - mas quão tranquilas banham-se as coisas na luz! Com que liberdade se respira! Quantas coisas sentem-se abaixo de si! - filosofia, tal como até agora entendi e vivi, é a vida voluntária e dos cumes ${ }^{18}$.

A efígie que Nietzsche nos traz acima, altamente imagética e ilustrativa, revela que sua filosofia é uma tarefa das alturas, ou seja, trata-se de uma atividade

\footnotetext{
${ }^{16}$ Ibidem. Assim falou Zaratustra. "Prólogo"§5.

${ }^{17}$ Ecce homo elucidará, pela primeira vez, o meu Zaratustra, o primeiro livro de todos os milênios, a Bíblia do futuro, a manifestação suprema do gênio humano, no qual o destino da humanidade está contido. Carta enviada a Deussen, em 26 de Novembro de1888.

${ }^{18}$ Ibidem. Ecce homo - "Prólogo", §3.
} 
que exige um distanciamento das multidões e de tudo que se estabelece enquanto vulgar e comum; há, portanto, a necessidade de isolamento e do reencontro consigo, a solidão impõe-se como condição prévia de "como alguém se torna o que é”. Neste sentido, tal sentimento é a premissa para construção do pensamento que se erige como o retorno a si mesmo; é exatamente este retorno solitário a "si mesmo" que o filósofo reconhece como sendo a característica primordial de sua filosofia. No entanto, para tal tarefa, para atingir o ar puro e gélido dos cumes é preciso ter pulmões fortes, isto porque a solidão apresenta-se de forma ambígua: ao mesmo tempo em que se posiciona como método para a tranquilidade, para a luz e para a liberdade, posiciona-se também como caminho ao sofrimento no gelo, alusão a algo que se deve dolorosamente suportar. A solidão é desejável, que se busca voluntariamente, mas também o que proporciona as intempéries do recolhimento nos picos.

Dado o paradoxo, reconhecemos um duplo caráter na compreensão da solidão nietzschiana: por um lado é algo que devemos escolher, pois é restauradora e revigorante, é exatamente nela que se restabelece dos degenerativos convívios humanos, servindo, então, como preventiva contra o contágio de ideais impuros e tolos ${ }^{19}$, assim tornada fonte de renovação e força para construção do próprio pensamento puro e livre; por outro lado, e contraditoriamente, a solidão é ameaçadora e asfixiante ${ }^{20}$, visto que demanda uma enorme energia para se desvencilhar e se proteger do que não pertence a si. A cena pouco acolhedora do "gelo", que a imagem da solidão evoca, indica o seu caráter doloroso, deacordo com as palavras de Nietzsche "cada conquista é consequência da coragem, da dureza consigo, da limpeza consigo" ${ }^{21}$. Viver uma filosofia que se edifica na solidão solicita duros exercícios, porém encontra o seu sentido profilático.

Por possuir seu lado aflitivo a solidão também denota uma característica seletiva: o ar que se respira nos cumes é forte, "é preciso ser feito para ele", somente os fortes suportam os perigos das andanças solitárias pelo que foi proibido e moralizado. Os homens de instinto gregário entendem a solidão como

\footnotetext{
19 "Mas tenho necessidade de solidão, quer dizer, recuperação, retorno a mim, respiração de ar livre, leve, alegre... Todo meu Zaratustra é um ditirambo à solidão, ou, se fui compreendido, à pureza... Felizmente não à pura tolice - o nojo do homem, da "gentalha", sempre foi meu maior perigo..." NIETZSCHE. Ecce homo - "Porque sou tão inteligente", §8.

${ }^{20}$ A solidão o cerca e o abraça, sempre mais ameaçadora, asfixiante, opressiva, terrível deusa e selvagem mãe das paixões. Ibidem. Humano, demasiado humano. - "Prólogo", §3.

${ }^{21}$ Ibidem. Ecce homo - "Prólogo", §3.
} 
algo a ser evitado a qualquer custo, não compreendem e não dão conta da solidão; são eles os homens do mercado descritos na seção "Das moscas do mercado" na primeira parte de Assim falou Zaratustra: "onde cessa a solidão, ali começa o mercado; onde começa o mercado, ali também começa o barulho dos grandes atores e o zumbido das moscas venenosas". A mesma seção termina acintosamente com as seguintes palavras: "Foge, meu amigo, para tua solidão e para onde o ar é rude e forte! Não é tua sina espantar moscas"22. O homem solitário distancia-se das "moscas venenosas do mercado", livra-se da moral vulgar das massas, vê seus antípodas abaixo de si. O isolamento criador é, no olhar de Nietzsche, para poucos, o rigor que se faz necessário na solidão a tornam classificatória, fazendo com que as pessoas comuns distorçam seu real significado atribuindo à natureza humana o comportamento do rebanho.

Os fortes que se submetem ao risco de "se resfriar" e vencem os obstáculos do ambiente inóspito das alturas, têm a solidão como prerrogativa de saúde, recuperação e, sobretudo, retorno a si. Sendo assim, ela é prerrogativa de um dionisíaco retorno à própria força criadora. A energia para o absoluto isolamento está ligada ao ruminar, ao criar e ao amadurecer das íntimas ideias sem o risco de contágio com a "gentalha". Dessa forma, esse sentimento está em plena associação com a embriaguez. Não seria um equívoco em afirmar que a solidão proporciona um entorpecimento. Contudo, essa intoxicação dos solitários não é aquela mesma defendida no período do Nascimento da tragédia que fundia a multiplicidade de seres em um. Agora a embriaguez dionisíaca diz respeito a um estado de elevação de força que, por sua vez, é impreterível para a criação e contemplação artística. Trata-se de uma experiência fiosiológica, mas com o fundo indissociável da experimentação solitária de si. Sendo assim, a próxima etepa de nosso trabalho ocupar-se-á de evidenciar a reformulação que Nietzsche faz da embriaguez e sua íntima ligação com o "segundo Dioniso".

\footnotetext{
${ }^{22}$ NIETZSCHE. Assim falou Zaratustra - "Das moscas do mercado". p. 51 e 54.
} 


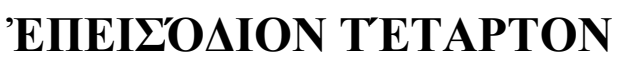

\section{1. O último brinde: a arte como embriaguez:}

Em Ecce homo, a relação de Zaratustra com o dionisíaco é ainda mais evidente. Nietzsche, em sua autobiografia, nos esclarece que seu personagem é, em sua obra, mais umas das muitas máscaras de Dioniso. Ambos os nomes são formas que o filósofo encontrou para melhor exprimir seus pensamentos mais profundos. Desse modo, Zaratustra-Dioniso está em íntima correspondência com a vontade de poder: o protagonista de "Um Livro para todos e para ninguém", por exemplo, foi o primeiro a anunciá-la, enquanto Dioniso, em suas múltiplas significações filosóficas, no fundo, acaba sempre remetendo a ela. Não obstante, dentre todas essas significações de Dioniso na última fase nietzschiana, aquela que mais se aproxima das formulações do período de $O$ Nascimento da tragédia é a concepção do dionisíaco como "a suprema experiência artística" e, por conseguinte, da arte como uma figura insigne da vontade de poder, ou seja, a arte entendida como o meio pelo qual se pode imergir, fisiologicamente, na realidade mesma das coisas. Nessa perspectiva, o dionisíaco se aproxima novamente da embriaguez [Rausch]. Nietzsche, para sua definitiva posição estética, reavalia mais uma vez o significado da intoxicação inebriante e atribui a ela o significado de um estado fisiológico fundamental para criação artística.

O dionisíaco é, na última filosofia de Nietzsche, sobretudo, uma experiência de criação artística. Dioniso é vontade de poder que se traduz em estados corporais criativos! Isso se explica da seguinte forma: a vontade de poder é um caos de forças diversamente qualificadas e quantificadas que lutam constantemente entre si, com o único objetivo de exercer o predomínio e o poder. Assim sendo, o devir do mundo está orientado pela busca de expansão e supremacia de uma força sobre as demais. Este impulso interior é o que Nietzsche considera como a constrição interna que se apodera do artista e o obriga a criar. Os estados estéticos são, portanto, fisiológicos. O corpo, instrumento que melhor caracteriza a vontade de poder na forma de um campo de batalha de afetos, vontades e paixões que se enfrentam violentamente por predominância, é 
constrangido a dar forma a esse caos, o que é, justamente, a atividade de criação artística. $\mathrm{O}$ ato de subjugar o caos é, então, a melhor caracterização do último dionisíaco. O corpo, em seu regime estético é descrito, por Nietzsche, como em um estado de extrema agudeza, excitabilidade e vivacidade dos sentidos, onde a confusão de afetos e forças é vista como formas precisas e, por isso, podem ser comunicadas claramente. Todavia, todo esse processo é, para o filósofo, concomitante à embriaguez ${ }^{1}$.

Nesse sentido, a sensação inebriante é concebida como o sentimento que acompanha o aumento excessivo de força; a embriaguez corresponde a uma superabundância, uma intensificação de força. A arte, por sua vez, em um processo cíclico, resulta e produz essa intensificação. Sobre isso Nietzsche escreve que "o embelezamento é uma consequência necessária do aumento de força. O embelezamento é expressão de uma vontade vitoriosa, de uma melhor condição de uma harmonização dos desejos violentos, de uma posição de um peso perpendicular infalivel" ${ }^{\prime 2}$. O belo como produto artístico é resultado da hegemonia de uma força, dessa forma, completa o filósofo: "o estado de prazer que se chama embriaguez é, exatamente, um elevado sentimento de poder...”3. O artista, portanto, tem a sensação de espaço e tempo alterada ${ }^{4}$, por isso, ele não deve ver nada como é, porém, mais pleno, mais simples e mais forte de como realmente é. A arte é mimética, mas apenas do "mundo de dentro", do jogo das forças; todavia, para isso é necessário que o artista tenha o corpo resistente, uma espécie de “juventude e eterna primavera corporal”, o que para Nietzsche não é outra coisa senão uma embriaguez artística habitual. Nessa análise, a embriaguez como um mais de força é indispensável para a atividade estética, tal como demonstra a seguinte aforismo:

Sobre a psicologia do artista. - Para haver arte, para haver alguma atividade e contemplação estética, é indispensável uma precondição fisiológica: a embriaguez. A suscetibilidade de toda a máquina tem de ser primeiramente intensificada pela embriaguez: antes não se chega a nenhuma arte. Todos os tipos de embriaguez têm força para isso, por mais diversamente ocasionados que sejam; sobretudo a embriaguez da excitação sexual, a mais antiga e primordial forma de embriaguez. Assim também a embriaguez que sucede todos os grandes desejos, todos os afetos poderosos; a embriaguez da festa, da competição,

\footnotetext{
${ }^{1}$ Cf. MECA, Diego Sanchez. Op. Cit. p. $323-324$.

${ }^{2}$ NIETZSCHE. Fragmento póstumo de 1888, 14[117].

3 “der Lustzustand, den man Rausch nennt, ist exakt ein hohes Macht gefühl...”. Idem

${ }^{4}$ Sobre a embriaguez como alteração, ou "melhor precisão do sentimento do espaço e tempo" Cf. Idem e também 14[46].
} 
do ato de bravura, da vitória, de todo movimento extremo; a embriaguez da crueldade; a embriaguez na destruição; a embriaguez sob certos influxos meteorológicos, por exemplo, a embriaguez primaveril; ou sob a influência de narcóticos; a embriaguez da vontade, por fim, de uma vontade carregada e avolumada. - O essencial na embriaguez é o sentimento de acréscimo da energia e de plenitude. A partir desse sentimento o indivíduo [se] dá às coisas, força-as a tomar de nós, violenta-as - este processo se chama idealizar. Livremonos aqui de um preconceito: idealizar não consiste, como ordinariamente se crê, em subtrair ou descontar o pequeno, o secundário. Decisivo é, isto sim, ressaltar enormemente os traços principais, de modo que os outros desapareçam ${ }^{5}$.

Esse texto de Crepúsculo dos ídolos diz claramente que a embriaguez é fundamental não só para a criação, como para contemplação estética. Chama-nos a atenção que o título do aforismo refere-se à psicologia do artista, isso, porque não podemos falar do corpo sem o aparato psicológico, da mesma forma que não podemos falar da mente ignorando o corpo. Para Nietzsche, a psicologia é sempre uma fisiologia e a fisiologia é sempre uma psicologia. Além disso, é importante ressaltar que a embriaguez aqui não desempenha o mesmo sentido do "fenômeno fisiológico" em oposição ao sonho apolíneo de O Nascimento da tragédia, mas, como bem observou Heidegger, “a embriaguez é o estado estético pura e simplesmente fundamental"6. É claro que Nietzsche abandonou as posições metafísicas de antigamente, porém, nos últimos escritos o apolíneo e o dionisíaco enquanto fenômenos fisiológicos são resgatados para que se possa repensar a arte. No entanto, a embriaguez, agora, abarca também o apolíneo, tal como demonstra o filósofo em um fragmento de 1888: "Na embriaguez dionisíaca há sexualidade e volúpia: nenhuma delas falta no apolíneo"7 . Com isso, Nietzsche quer dizer que também existe uma embriaguez na imagem, uma intoxicação no sonho, como podemos observar no parágrafo de Crepúsculo dos ídolos:

Que significam os conceitos opostos que introduzi na estética, apolíneo e dionisíaco, os dois entendidos como espécies de embriaguez? - A embriaguez apolínea mantém, sobretudo, o olhar excitado, de modo que ele adquire a força da visão. O pintor, o escultor, o poeta épico são visionários par excellence. Já no estado dionisíaco, todo o sistema afetivo é excitado e intensificado: de modo que ele descarrega de uma vez todos os seus meios de expressão e, ao mesmo tempo, põe para fora a força de representação, imitação, transfiguração, transformação, toda espécie de mímica e atuação ${ }^{8}$.

\footnotetext{
${ }^{5}$ Ibidem. Crepúsculo dos ídolos. "Incusões de um extemporâneo", §8.

${ }^{6}$ HEIDEGGER, Martin. Nietzsche. "Vontade de poder como arte", p. 79.

7 "Im dionysischen Rausche ist die Geschlechtlichkeit und die Wollust: sie fehlt nicht im apollinischen". NIETZSCHE. Fragmento póstumo de 1888, 14[36].

${ }^{8}$ Ibidem. Crepúsculo dos ídolos, "Incusões de um extemporâneo", §10.
} 
Nesse parágrafo Nietzsche nos dá uma definição prévia sobre o sentido mesmo da embriaguez: ela é a excitação e intensificação do sistema afetivo. Enquanto a ebriedade apolínea é a excitação da visão, a dionisíaca é de todo o sistema afetivo, ela provoca uma descarga de todos os meios de expressão. A embriaguez dionisíaca é um estímulo psicofisiológico que torna impossível não reagir: "para o homem dionisíaco é impossível não atender alguma sugestão, ele não ignora nenhum indício de afeto, possui instinto para compreensão $e$ adivinhação no grau mais elevado" "9. Além disso, nesse aforismo, Nietzsche aproxima novamente a música ao dionisíaco, diz que ela é igualmente uma "excitação e descarga geral dos afetos", mas considera que a música não dá conta de abranger um mundo de expressão afetiva vastamente mais pleno, ela é um "mero residuum do histrionismo dionisíaco". No estado dionisíaco original, o homem imita e representa com o corpo tudo o que sente. Contudo, há uma caraterística que abrange tanto a embriaguez dionisíaca quanto a apolínea, isto é, o estado em que "enriquecemos todas as coisas com nossa própria plenitude: o que enxergamos, o que queremos, enxergamos avolumado, comprimido, forte, sobrecarregado de energia"10.

O essencial na embriaguez é, então, o sentimento de elevação de força e de plenitude. Ela é o sentimento que nos convida a criar e promete prazer no ato criativo. "Nesse estado", diz Nietzsche, "o ser humano transforma as coisas até espelharem seu poder - até serem reflexos de sua perfeição. Esse ter de transformar no que é perfeito é - arte" ${ }^{\text {11 }}$. Em uma perspectiva que lembra muito o ideal grego de beleza artística pensado por Winckelmann ${ }^{12}$, Nietzsche afirma que na arte o ser humano é capaz de fruir a si mesmo enquanto perfeição, ele transforma em prazer em si, até mesmo o que ele não é; nisso consiste o idealizar. Atentemo-nos que o termo aqui não possui nenhuma conotação metafísica, antes disso, significa fazer-se partícipe das coisas, atribuindo "beleza" e "perfeição" a elas ${ }^{13}$. Idealizar é "ver mais plenamente, mais simplesmente, mais intensamente, o

\footnotetext{
${ }^{9}$ Idem.

${ }^{10}$ Idem. $\$ 9$.

${ }^{11}$ Idem.

${ }^{12}$ Cf. "O Re-descobrimento da Grécia", no Párado deste trabalho.

13 "1. A embriaguez: o aumento de sentimento de poder; a íntima necessidade de fazer das coisas um reflexo da própria plenitude e da própria perfeição -". [1. der Rausch: das erhöhte Machtgefühl; die innere Nöthigung, aus den Dingen einen Reflex der eigenen Fülle und Vollkommenheit zu machen -] Ibidem. Fragmento póstumo de 1888, 14[170]
} 
que é intrínseco ao criar” e, portanto, é uma atividade só possível mediante a embriaguez. Nesse sentido, Heidegger observa que o essencial do sentimento inebriante é a maneira como nos encontramos junto a nós mesmos e aí, ao mesmo tempo, junto às coisas, junto aos entes que nós mesmos não somos. "Sentir-se", nesse caso, implica a inserção, de antemão, do nosso corpo na totalidade da existência $^{14}$. O estado corporal ditará como significamos o mundo, assim, a embriaguez é o estado corporal em que significamos artisticamente as coisas.

Ainda de acordo com a interpretação heideggeriana, Nietzsche teria acentuado dois aspectos na embriaguez: o "sentimento de elevação da força" e o "sentimento de plenitude" como a capacidade de se lançar para além de si, possibilitando com isso uma relação com os entes, na qual o ente é experimentado como mais plenamente rico, mais transparente e mais essencial; em outras palavras, a embriaguez permite-nos uma interação com os demais entes e com nós mesmos, de tal modo que há a possibilidade de uma elevação de força, não no sentido de acréscimo objetivo de mais uma força, porém, no que diz respeito ao nosso modo de ser no mundo, isto é, a elevação da capacidade de fazer e ver, de aprender, de interpelar discursivamente, de comunicar e deixar-se levar. Do mesmo modo, o sentimento de plenitude, segundo Heidegger, também não diz respeito ao acúmulo objetivo de processos internos, mas, antes de tudo, "àquele ser afinado que se deixa determinar de um modo tal que nada lhe é estranho e nada lhe é demasiado, que ele está de chofre aberto para tudo e pronto para tudo: a maior audácia e o supremo risco" ${ }^{\prime 16}$. Assim sendo, a embriaguez tem a mesma conotação da afirmação dionisíaca: é um sentimento afirmativo que nos impele a desejar e amar a vida como criadores.

Nietzsche evidencia a embriaguez como esse sentimento estético-afirmativo fundamental, justamente, quando nos faz imaginar um estado oposto ao inebriante, isto é, o estado de sobriedade que, por consequência, pertence a uma específica natureza antiartística do instinto. Esse modo de ser é concebido, em Crepúsculo dos ídolos, como pertencente àquele que empobrece, dilui, debilita

\footnotetext{
${ }^{14}$ Cf. HEIDEGGER, Martin. Op. Cit. p. 80 e 81.

${ }^{15} \mathrm{Cf}$. NITZSCHE. Fragmento póstumo de 1888, 19[7], §3.

${ }^{16}$ HEIDEGGER, Martin. Op Cit. p. 82.
} 
todas as coisas. Esses "antiartistas" são descritos como famintos da vida: "necessariamente têm de tomar as coisas, consumi-las, fazê-las mais magras"17. O filósofo está se referindo aqui às pessoas cansadas, extenuadas, ressequidas, empobrecidas, "sob o olhar dos quais a vida sofre". A melhor ilustração históricosocial desse tipo é, para Nietzsche, o genuíno cristão, cuja natureza é invariavelmente antiartística. Um dos exemplos seria Pascal, que representaria uma espécie de idiossincrasia moral ${ }^{18}$. Enfim, “o sóbrio, (por exemplo: um erudito) não pode receber absolutamente nada da arte, porque não possui a força artística primordial"" essencialmente, afirmação, bênção, divinização da existência..."20. Com esse contraste, Nietzsche retoma a distinção entre saúde e doença, e força e debilidade.

Pensando nisso, o homem criador pertence a um tipo mais forte. Nietzsche considera que "o que para nós já é nocivo, o que em nós é doentio, no artista é apenas natureza" ${ }^{\prime 21}$, ou seja, a matéria bruta para ser convertida em arte. O belo é, nesse sentido, a exteriorização da superabundância do artista e, por consequência disso, toda arte é produtora de um efeito tônico, ela aumenta a força, inflama o prazer" $^{22}$, enfim, o "efeito das obras artísticas é suscitar o estado criador, a embriaguez"23. A embriaguez é, portanto, epidêmica, isto é, ela desperta em quem goza das obras o estado inebriante-criador. Apesar de Nietzsche não ter dito isso claramente, podemos falar de um aspecto educativo - tipicamente dionisíaco - na arte: ela constrangeria àquele que a contempla a experimentar da embriaguez criativa, possibilitando pedagogicamente, ao espectador, o sentimento de plenitude e o sentimento de elevação da força. Entretanto, também existe, em contraposição à força artística, o feio, o que está excluído da arte. Se por um lado o belo artístico é o símbolo da força criativa, então, por outro lado, o feio é o empobrecimento de vida, a impotência, a decomposição, a putrefação. O feio produz um efeito depressivo, ele remove a força e, por isso, oprime ${ }^{24}$. Nietzsche,

\footnotetext{
${ }^{17}$ NIETZSCHE. Crepúsculo dos ídolos. "Incusões de um extemporâneo", §9.

${ }^{18}$ Sobre o pessimismo e idiossincrasia moral de Pascal Cf. Ibidem. Fragmento póstumo de 1887, 9[182]; 10[121]; 11[55]; 11[228]; 11[408].

${ }^{19}$ Idem. 1887, 9[102].

${ }^{20}$ Idem. 1888, 14[47].

${ }^{21}$ Idem.

${ }^{22}$ Cf. Idem. 1888, 14[119].

${ }^{23}$ Idem. 1888, 14[47].

${ }^{24}$ Nota-se aqui um completo afastamento do filósofo de uma "estética negativa": o grotesco agora é visto como contrário a qualquer tipo de deleite. Cf. Fragmento póstumo. 14[119].
} 
em Crepúsculo dos ídolos, escreve que "nada é feio, exceto o ser humano que se degenera" e, em seguida, completa:

\begin{abstract}
Fisiologicamente, tudo o que é feio debilita e aflige o ser humano. Recorda-lhe declínio, perigo, impotência; faz com que realmente perca energia. (...) Seu sentimento de poder, sua vontade de poder, sua coragem, seu orgulho - tudo isso cai com o feio, aumenta com o belo... (...) O feio é entendido como sinal e sintoma de degenerescência: aquilo que recorda minimamente a degenerescência produz em nós o juízo de "feio". Todo indício de esgotamento, de idade, de peso, de cansaço, toda espécie de falta de liberdade, como a convulsão, como a paralisia, sobretudo o cheiro, a cor, a forma da dissolução, da decomposição, ainda que na extrema rarefação de símbolo - tudo provoca a mesma reação, o juízo de valor "feio". Um ódio irrompe: o que odeia aí o ser humano? Não há dúvida: o declínio de seu tipo. Ele odeia a partir do mais profundo instinto da espécie: nesse ódio há arrepio, cautela, profundidade, longividência — é o mais profundo ódio que existe. Por causa dele a arte é profunda... ${ }^{25}$
\end{abstract}

A arte, diz o filósofo, "é o grande estimulante da vida, uma embriaguez no viver, uma vontade de viver" ${ }^{, 6}$. A partir dessa premissa, o feio, por trazer à memoria a decadência, o perigo e a impotência, logicamente não teria lugar na arte. No entanto, em uma anotação de 1887, Nietzsche concede à fealdade um restritivo valor estético. Ele explica que "o impulso sexual, a embriaguez, a comida, a primavera, a vitória sobre o inimigo, o escárnio, a bravura, a crueldade, o êxtase do sentimento religioso" são estados em que atribuímos transfiguração e plenitude às coisas, até que elas reflitam nossa própria plenitude e entusiasmo pela vida. Destes estados, o "impulso sexual, a embriaguez e a crueldade pertencem à alegria festiva mais antiga dos homens e são igualmente preponderantes no artista original [anfänglichen]”. Dessa forma, a arte nos lembra da condição de vigor animal; de um lado, ela é "um excedente e um fluxo de florescimento da corporeidade no mundo das imagens e dos desejos; de outro lado, uma excitação das funções animais mediante imagens e desejos da vida intensificada" ${ }^{27}$, isso corresponde a uma elevação do sentimento de vida e um estimulante desse sentimento. Assim sendo, se feio comunica algo da energia vitoriosa do artista que alcançou vitória sobre o terrível, ou se o feio estimula levemente em nós o prazer

\footnotetext{
${ }^{25}$ Ibidem. Crepúsculo dos ídolos. "Incusões de um extemporâneo", §20.

${ }^{26}$ Ibidem. Fragmento póstumo de 1888, 15[10].

27 "Die Kunst erinnert uns an Zustände des animalischen vigor; sie ist einmal ein Überschuß und Ausströmen von blühender Leiblichkeit in die Welt der Bilder und Wünsche; andererseits eine Anregung der animalischen Funktionen durch Bilder und Wünsche des gesteigerten Lebens; eine Erhöhung des Lebensgefühls, ein Stimulans desselben”. Idem. 1887, 9[102]
} 
da crueldade, mesmo se for o prazer em ser cruel contra si mesmo, então, ele assume um caráter estético ${ }^{28}$.

Não obstante, Nietzsche publicou poucas linhas sobre o lugar que a intoxicação inebriante ocupa na sua definitiva estética, a fisiologia da arte. Além disso, suas diversas anotações sobre o tema, postumamente publicadas, condizem mais com projetos de escrita do que a um pensamento desenvolvido propriamente dito. Ainda assim é perfeitamente possível fazer um diagnóstico do "metasignificado" desempenhado ali pela embriaguez artística: apesar da complexidade do tema, se ignorarmos os inúmeros desdobramentos, conexões e problematizações possíveis, então, a lógica nietzschiana torna-se simples: o essencial da arte é, em última instância, a plenificação da existência, a produção de perfeição e plenitude. Isso é de tal e tal modo que a formulação "arte pessimista" é considerada um contradictio $^{29}$. Por conseguinte, a embriaguez corresponde ao estado fisiológico que é precondição para toda atividade artística, mas também é, ao mesmo tempo, efeito da obra de arte. Nietzsche explica isso dizendo que o artista ama, pouco a pouco, os meios nos quais o estado inebriante se dá a conhecer - "a extrema delicadeza e a magnificência das cores, a clareza das linhas, a nuance do tom ${ }^{\prime 30}$. Todas essas nuances, à medida que elas evocam as extremas intensificações de força que a embriaguez produz, despertam de volta a sensação de embriaguez.

Sabendo disso, podemos dizer que Nietzsche conservou determinados elementos de sua estética do período da metafísica do artista, a saber, em ambos os momentos a arte e a embriaguez são afirmativas, ou seja, promovem uma intensificação da alegria de viver. Todavia, as semelhanças não podem ir muito além. Se antes o belo dizia respeito apenas à arte apolínea, à forma, agora, o belo e a embriaguez dionisíaca são indissociáveis. Como bem observou Heidegger, "a embriaguez é a determinação fundamental; o belo o determinante" ${ }^{\text {31 }}$. Outra diferença que se deve destacar é que a embriaguez não é mais o estado frenético, aniquilador da forma e puramente extático que qualificava o dilaceramento trágico e a música de Wagner; o termo "não designa, aqui, o mero caos espumante e

\footnotetext{
${ }^{28}$ Cf. Idem.

${ }^{29}$ Idem. 1888, 14[47].

${ }^{30}$ Idem.

${ }^{31}$ HEIDEGGER, Martin. Op. Cit. p. 100.
} 
confusamente borbulhante, a beberronia do simples deixar-se levar e do movimento cambaleante" ${ }^{, 32}$. A intoxicação inebriante passou a designar o oposto à arte romântica, principalmente daquele sentido atribuído à obra wagneriana. Embriaguez significa, portanto, "a conquista mais clara e distinta da forma",33. Nessa perspectiva, existe também um aspecto de serenidade na embriaguez, muito próxima à ternura do "gênio do coração"; ela pode ser pensada como um inebriante deleite na calmaria, no apaziguamento da violência conflitiva dos afetos e paixões, o que é análogo ao prazer da força transfiguradora do amor paradoxalmente uma serenidade na turbulência.

Para finalizar, devemos enfatizar, a título de síntese, que, para Nietzsche, as imagens realçadas da vida triunfante e de sua força transfiguradora concedem às coisas certa perfeição. Quando se evidencia a beleza e perfeição, o mundo da sensibilidade e a embriaguez entrelaçam-se e são estimulados; o "belo" promove, portanto, uma excitação inebriante dos sentidos. É assim que acontece o estímulo dos artistas, eles são embriagados pela beleza e perfeição das coisas e, então, são coagidos a criar. Por outro lado, o belo tem o efeito de aquecer o sentimento de prazer, algo símile à força transfiguradora do "amor" ${ }^{34}$. Interessante que nessa concepção nietzschiana existe uma embriaguez no amor. Aliás, podemos compreender melhor a força transfiguradora da embriaguez artística, através de uma metáfora com o efeito inebriante desse sentimento. Em um fragmento de 1888, Nietzsche faz essa relação metafórica e explica que a embriaguez do amor "subjuga a tal ponto a realidade, que na consciência do amante a causa é apagada e aparece algo diferente em seu lugar-um tremor e um resplandecer de todos os espelhos sedutores de Circe..."35 . Isso não importa se o amor é a Deus, o amor altruísta, dos amantes, pois todos eles permanecem idênticos em sua raiz, ou

\footnotetext{
${ }^{32}$ Idem. p. 97.

${ }^{33}$ Idem. (Importante salientar que, tal com observou Heidegger, forma na última estética nietzschiana não ao elemento "formal", isto é, aquilo que carece de conteúdo e que, quanto ao conteúdo apenas se mostra como os limites que o contornam, mas sem a capacidade de influencialo. Para Nietzsche forma e conteúdo se coincidem e se confundem, sobre isso ele escreve: "Se é artista de verdade quando sente o que todos os não artistas chamam de "forma" como conteúdo, como "a coisa em si". Claro, isso significa que se pertence a um mundo invertido[verkehrte Welt]: pois doravante, o conteúdo torna-se algo meramente formal, - incluindo nossas vidas. NIETZSCHE. Fragmento póstumo de 1887, 11[3]; Cf. também 9[144] e 2[66].

${ }^{34}$ Cf. NIETZSCHE. Fragmento póstumo de 1887, 9[6].

${ }^{35}$ Idem. 1888, 14[120].
} 
seja, uma febre que tem razões para transfigurar-se e que se sente bem em iludir a si mesmo.

Sendo assim, "quando se ama", diz o filósofo, "sempre se mente bem, diante de si e sobre si mesmo: se vê com a aparência transfigurada, mais forte, mais rico, mais perfeito e, de fato, está mais perfeito..."36. Isso é o mesmo que acontece com a arte. Como vimos, em sua função orgânica [organische Funktion], fisiológica, encontramo-la inserida no mais angelical instinto da vida, isto é, como a grande estimulante da vida. A arte é, nessa perspectiva, como o amor, "uma sublime conveniência, mesmo quando mente". No entanto, para Nietzsche, a força da arte e do amor não se resume a mentir; a arte, por exemplo, "faz mais do que meramente imaginar, ela desloca os valores". O homem também é mais valioso inebriado pelo amor. Assim como nos animais nesse estado exteriorizam novos materiais, pigmentos, cores e formas, sobretudo novos movimentos, novos ritmos, novos sons atrativos e seduções, no amante aflora o espírito aventureiro, a ousadia para o perigo, como diz Nietzsche: "nesse idiota da felicidade, crescem asas $e$ novas capacidades, e, mesmo para a arte, as portas abrem-se para ele ${ }^{\# 3}$. Desse modo, a embriaguez do amor é a grande inspiração de todas as artes ${ }^{38}$; além disso, a embriaguez do amor tem outro vínculo com o entorpecimento artístico - tão intrínseco que é impraticável distinguir um do outro: o embelezamento do mundo, a intensificação do prazer de viver e a divinização da existência ${ }^{39}$.

Sabendo dessa particularidade da intoxicação inebriante que aproxima o amor à arte, torna-se impossível não fazermos aqui uma conexão com o amor fati. Em 1881, Nietzsche formula o que seria a base de sua moralidade: "amar o que é necessário", amar o destino ${ }^{40}$. O filósofo fez desse "imperativo" a razão, a garantia de doçura para o resto de sua vida ${ }^{41}$. Poderíamos dizer, com certa segurança, que o amor fati é o epílogo de toda filosofia nietzschiana e, por

\footnotetext{
${ }^{36}$ Idem.

37 Idem.

38 "Descontemos da lírica, em som e palavra, a sugestão daquela febre intestinal: o que resta da lírica e da música?... talvez l'art pour l'art: o virtuosístico grasnar de rãs frias, que desesperam em seu brejo... Quem criou tudo o mais foi o amor...". Idem.

${ }^{39}$ Chama-nos a atenção que, para o filósofo, o poder que tem a embriaguez do amor é estritamente fisiológico, chega até mesmo a alterar a constituição do corpo, aumentando a sua força quando ocorre a aproximação dos sexos como, por exemplo, em uma dança. Nietzsche escreve sobre isso em uma singular anotação. Idem. 1888, 17[5]. [Apêndice $\alpha$ ].

40 "Liebe das, was nothwendig ist". Idem. 1881, 15[20].

${ }^{41}$ Cf. Ibidem. A Gaia ciência. §276.
} 
consequência, a síntese de todos os significados de Dioniso. Desse modo, outra máscara desse deus seria o amor, ou seja, amar com intensa alegria tudo o que a vida tem a oferecer; trata-se, portanto, do amor incondicional que permite dizer sorridentemente - Sim. É claro que essa afirmação levanta vários questionamentos, todavia, Nietzsche não titubeia em postular isso como a efígie da sua filosofia, que, por sua vez, é entendida como experimentação, como vivência. Dentre os muitos escritos, publicados ou não, que versam sobre a afirmação dionisíaca, podemos destacar a seguinte anotação de 1888:

\begin{abstract}
Uma filosofia-experimental assim, tal como a vivo, antecipa como ensaio as possibilidades do niilismo radical: sem que com isso fosse dito que ela permanecesse em uma negação, em um não, em uma negação e vontade de não. Em vez disso, ela quer ir até o reverso inverso - até um dionisíaco dizer sim ao mundo tal como ele é, sem subtrações, exceções e seleções - ela quer o círculo eterno- as mesmas coisas, a mesma lógica ilógica de todo nó. O estado mais supremo que um filósofo pode alcançar: permanecer dionisíaco em relação à existência -: minha fórmula para tanto é amor fati ${ }^{42}$
\end{abstract}

Permanecer dionisíaco em relação à existência, ter uma atitude dionisíaca em relação à existência não é, como possa se pensar, uma submissão à fatalidade, ou seja, apenas suportar passivamente o necessário, menos ainda uma atitude de falseamento, ou de enfretamento odioso, porém é amar e se lançar no jogo que a vida é. Por consequência, é ter uma predisposição para correr todos os riscos do existir, sem sucumbir ao ressentimento ou ao niilismo, mesmo diante das terríveis dores, do sofrimento e da certeza da finitude que inevitavelmente acometerão a todo e qualquer ser existente. Sobre isso, Nietzsche diz, com sua linguagem tipicamente hiperbólica, que a filosofia [dionisíaca], tal como a entendeu e a viveu "é a busca voluntária inclusive das faces mais malditas e infames da existência. A partir da longa experiência que me proporcionou esse caminhar pelo gelo e pelo deserto, aprendi a considerar de outra maneira tudo o que foi filosofado até agora" ${ }^{43}$. Esse modo de filosofar-viver, que pode ser comparado a uma vocação para sofrer, permitiu ao filósofo fazer uma espécie de mapeamento da cultura e entender a psicologia por trás de cada valor. Desse modo pode transvalorar os ideais que atuam contra a vida.

\footnotetext{
${ }^{42}$ Idem. $1888,16[32]$.

${ }^{43}$ Idem.
} 
Não obstante, o ponto nevrálgico aqui é a finitude. A experimentação indireta da morte a partir do falecimento do ente próximo e a certeza incontornável de ser finito, lançado no mundo do devir eterno, podem fazer da vida algo irremediavelmente triste e sem sentido. Os "valores supremos" da tradição metafísica são, em última análise, uma tentativa de contornar o problema psicológico da iminente constatação da finitude. Assim sendo, os valores funcionam como uma espécie de placebo para as piscologias fracas que não suportam a tristeza, a angústia, o medo e a dor inerentes à inexorável nulidade de si. Por outro lado, o tipo que reconhece os fundamentos meramente psicológicos desses valores, ao mesmo tempo em que aceita o fato de que a pessoa que mais ama, assim como si mesmo deixarão de existir e, ainda assim, ama a vida em sua integridade, diz o jubiloso sim a ela é, deveras, um tipo dionisíaco. A fórmula nietzschiana que resume todos os significados de Dioniso é simples: “O dizer Sim à vida, mesmo em seus problemas mais duros e estranhos; a vontade de vida, alegrando-se da própria inesgotabilidade no sacrifício de seus mais elevados tipos - a isso chamei dionisíaco" ${ }^{44}$. A fórmula é simples, sua aplicação é complexa! Não seria uma loucura ser em si mesmo o eterno prazer do vir-a-ser e, com isso, o prazer no destruir? Ou seria a mais sublime sabedoria?

Para o pensador, que se declara último discípulo do "filósofo Dioniso", essa pergunta não faz sentido: loucura e sabedoria se confundem, vida e morte são indistinguíveis - jubilemo-nos!

\footnotetext{
${ }^{44}$ NIETZSCHE. Crepúsculo dos ídolos. "O que devo aos antigos”, §5. Também em Ecce homo, "O Nascimento da tragédia", §3.
} 


\section{'E $\Xi O \Delta O \Sigma$}

O coro entra em cena pela derradeira vez. O corifeu prepara-se para entoar seus últimos versos. Escutemos as lamentações de sua ode final: “Ai, ai! Óh, Erínias negras, deusas da morte, sois o destino inexorável de toda raça humana, assim destruístes a linhagem de Édipo, não se pode, deveras, fugir de vosso poder! ${ }^{1}$ Nada vale, aos olhos divinos, a existência dos frágeis mortais. Não há, para o ser humano, felicidade que não seja passageira ilusão. A sina do mísero Édipo é a prova, é impossível para qualquer homem ser feliz! ${ }^{2}$ Esta dor é comum a todos os cidadãos, ela sempre fere inesperadamente. Torrentes de lágrimas e perenes lamentos, por toda parte, se espalharão"3.

Ainda há pouco, o menino prostrou-se e acariciou ternamente os flancos de seu progenitor morto. É verdade que as veias, ainda quentes, jorravam o escuro sangue, mas isso não impediu que o infante Eurísaques se agarrasse e se mantesse unido, como suplicante, protetor e protegido, ao corpo inanimado de seu pai ${ }^{4}$.

Não foi também ainda agora que ouvimos as trombetas gregas tocarem, ditando a lenta marcha das mulheres troianas em direção às naus que as levariam para o cativeiro? Sim! Ainda se ouve o eco das trombetas soando concomitante ao estrondo de Pérgamo desfazendo-se em ruínas. Isso apenas alguns instantes depois de Taltíbio arrastar como espólio o gigantesco escudo de Heitor, antes ostensiva insígnia de glória, agora lúgubre féretro para o cadáver do tenro Astíanax, o último herdeiro de Ílion ${ }^{5}$.

Estes sinais indicam que chegamos ao " $E \xi$ o $\delta o \sigma$ de nossa peça. O deus $e x$ machina aqui, como já se sabe, é Dioniso. Conquanto, ele não é nenhuma divindade redentora, não está aqui para solucionar desenlaces, não livrará nenhum herói do dilaceramento, tão pouco eximirá as personagens das intempéries. Pelo contrário, ele exige a experimentação dos terríveis sofrimentos de forma mais

\footnotetext{
${ }^{1}$ Cf. ÉSQUILO. Sete contra Tebas. Versos 1059 a 1063.

${ }^{2}$ Cf. SÓFOCLES. Édipo Rei. Versos 1188 a 1195.

${ }^{3}$ Cf. EURÍPIDES. Hipólito. Versos 1462 a 1466.

${ }^{4}$ Cf. SÓFOCLES. Ajax. Versos 1400 a 1420.

${ }^{5}$ Cf. EURÍPIDES. As troianas. Versos 1315 a 1332
} 
intensa. Com isso, esse deus pretende tornar-nos mais fortes, mais corajosos e, talvez, mais sábios. A força, para amar o destino, amar o que é necessário; a coragem, para dançar e saltitar à beira dos abismos, também para atravessar desertos, escalar montanhas, explorar o desconhecido e para desejar, como a uma amante, a solidão; e, por fim, a sabedoria para tornar-nos criadores, para, como artistas, criar sentido e transvalorar antigas tábuas.

Após chegar ao final desta caminhada - cujo objetivo central foi fazer um mapeamento dos símbolos Dioniso e dionisíaco na obra de Nietzsche - chegamos a uma única conclusão concreta: tal tarefa foi apenas parcialmente cumprida.

Existem ainda, no pensamento de Nietzsche, muitos assuntos a respeito destes símbolos que não foram aqui abordados e outros que foram apenas superficialmente mencionados. Como demonstramos, o dionisíaco possui, no corpus nietzschiano, uma "meta-significação" que anela todos os grandes temas de sua filosofia.

Dentre esses temas diretamente ligados a Dioniso, mas que não foram aprofundados aqui está a doutrina do eterno retorno ${ }^{6}$. Esta se conecta ao dionisíaco tanto na sua interpretação ético-psicológica-afirmativa que, como o mais pesado dos pesos, constrange o indivíduo a viver afirmativamente cada instante como se esse fosse eterno, aceitando o que a vida tem a oferecer; quanto na sua interpretação cosmológica que, grosso modo, diz respeito ao perpétuo e cíclico jogo de forças da vontade de poder.

Outro assunto que merecia melhor atenção por ser indissociável da sabedoria dionisíaca é a morte de Deus. O aspecto dionisíaco desse tema é, precisamente, sua íntima relação com as seguintes questões: a transvaloração de todos os valores degenerativos, o desmantelamento da ideia de verdade absoluta, a crítica ao racionalismo e cientificismo da modernidade, a possibilidade de viver alegremente em um universo caótico, do eterno devir sem propósito, sem uma entidade metafísica reguladora.

\footnotetext{
${ }^{6}$ No fragmento póstumo de 19[8] de 1888, Nietzsche ao planejar os quatro capítulos de sua obra Transvaloração de todos os valores, projeta como o quarto Livro "Dioniso. Filosofia do eterno retorno".
} 
Além disso, a constatação da morte de Deus é, para Nietzsche, um dos grandes perigos da cultura, porque ela engendra o risco de sucumbir ao pior dos niilismos, isto é, depois que foram diluídas as referencias máximas que, até então, deram sentido e sustentação ao projeto cultural do Ocidente, fez-se presente o iminente risco de ser implantado um modo negador de existir, logo, um modo diametralmente oposto ao Sim dionisíaco.

É importante dizer que a existência ou inexistência de Deus não é, de fato, um problema filosófico que interessa a Nietsche. A fé religiosa é, para nosso filósofo, uma questão de foro íntimo. Afirmar o ateísmo seria, portanto, apenas uma inversão de credo, o mesmo que professar uma verdade absoluta invertida. Sua preocupação é, na verdade, com a degeneração da cultura; sua guerra é com aos valores decadentes que orientam a conduta, cuja raiz não é outra senão a duplificação do mundo iniciada por Platão.

Por outro lado, o aspecto afirmativo do dionisíaco é tão emblemático que Nietzsche, nos últimos escritos, escolhe uma imagem peculiar para designar a sua filosofia: Dioniso contra o 'crucificado'. É exatamente com esse epítome que o filósofo encerra sua autobiografia ${ }^{7}$.

Além da aparição em Ecce homo, o filósofo menciona a expressão "Dioniso contra o "crucificado" apenas em outras duas anotações de 1888. Nelas ele nos explica que o homem religioso típico é, seguramente, uma forma de decadência. No entanto, Nietzsche postula que existe um tipo de religião diferente, uma espécie de antítese daquelas que professam valores decadentes, isto é, as religiões pagãs. Nessa análise, os cultos pagãos são uma forma de ação de graças e uma divinização da vida. No melhor exemplo de paganismo haveria a apologia de um espírito extasiado-transbordante, igual a um tipo que absorve em si as dubiedades e contradições da existência. Essas características são, precisamente, o que Nietzsche diz ter reconhecido na religião grega de Dioniso ${ }^{8}$.

\footnotetext{
7 “ - Hat man mich verstanden? - Dionysos gegen den Gekreuzigten...” [Será que eu fui compreendido? - Dioniso contra o crucificado]. NIETZSCHE. Ecce homo. "Por que eu sou um destino", $\S 9$.

${ }^{8}$ Cf. Ibidem. Fragmento póstumo de 1888, 14, [89]. Além desse fragmento, a expressão pode ser encontrada no $14[137]$.
} 
Pensando nisso, a antítese "Dioniso contra o 'crucificado" não se refere à diferença de martírio das divindades, mas à fecundidade em relação à vida. Enquanto no símbolo de Dioniso o tormento, a destruição, a vontade de aniquilamento são condicionados pelo fluxo da vida - a sua eterna fertilidade e o seu eterno retorno; no segundo caso, o sofrimento, o "Crucificado como o inocente", vale como objeção contra esta vida, não passa de uma fórmula de condenação da vida. A diferença fundamental estre esses símbolos religiosos é, portanto, a forma como entendem o sofrimento: há o modo cristão de sofrer e o modo trágico, o que é explicado por Nietzsche da seguinte forma:

O ser humano trágico afirma inclusive o sofrimento mais áspero: é forte, pleno, divinizante o bastante para tanto. - $\mathrm{O}$ cristão nega até a sorte mais feliz sobre a Terra: é fraco, pobre, deserdado o bastante para sofrer de toda forma na vida... "o Deus na cruz" é uma maldição contra a vida, um dedo indicador para libertar-se dela; - o Dioniso despedaçado é uma promessa para a vida: saindo da destruição, ele voltará sempre ao lar, renascido ${ }^{9}$.

Além disso, nós podemos observar que a imagem de crucificação é um emblema de violência contra o corpo: a crucificação possui uma conotação explícita de repressão dos instintos corporais. A cruz é, nessa leitura, uma mensagem estritamente ressentida em relação ao corpo que, por sua vez, foi absorvida pelos dogmas morais do cristianismo. Isso explica, por exemplo, a origem da palavra mortificação no seu sentido religioso: é a morte da carne, o ascetismo no seu grau mais elevado.

Não obstante, averigua-se, aqui, a grande dificuldade que é "esgotar" todas as múltiplas acepções do dionisíaco na obra nietzschiana. Até mesmo o próprio filósofo, às vezes, parece perder-se na vasta significação que o símbolo desempenha ao longo de sua obra. Isso é perceptível na forma como fala de seu Dioniso em Crepúsculo dos ídolos: em "incursões de um extemporâneo", §10, como vimos anteriormente, ao falar dos conceitos opostos que introduziu na estética, descaracteriza-os de seu sentido originário ao atribuir uma forma de embriaguez ao fenômeno apolíneo; já em "O que devo aos antigos”, §4, ao refletir que levou a sério o fenômeno que leva o nome de Dioniso para compreender o "velho, ainda rico e até transbordante instinto helênico", diz que o conceito "é

\footnotetext{
${ }^{9}$ Idem.
} 
explicável apenas por um excesso de força", cingindo, então, o primeiro e o segundo Dioniso.

Nesse mesmo parágrafo da sua última obra publicada, ao referir-se às antigas formulações de $O$ Nascimento da tragédia, trata o termo com as conotações psicofisiológicas de seu pensamento maduro. Inclusive vincula os mistérios dionisíacos, nos quais "se expressa o fato fundamental do instinto helênico - sua 'vontade de vida",, ao desejo de vida eterna; em outras palavras, Nietzsche vincula a "psicologia do estado dionisíaco" ao eterno retorno da vida, ao "triunfante Sim à vida". A diferença aqui é que o elo entre o dionisíaco grego e a afirmação existencial não ocorre mais mediante o consolo metafísico frente ao dilaceramento individual e a união primaveril com o ser original, mas, por outro lado, mediante os mistérios da sexualidade. Isso significa que Nietzsche faz, agora, uma leitura estritamente fisiológica do fenômeno dionisíaco grego e, por consequência, de seu primeiro Dioniso.

Sem dúvida, Nietzsche mescla aqui os dois "Dionisos": trata-se ainda do fenômeno orgiástico, da volúpia sexual no seio da religião primitiva. Entretanto, também com elementos do dionisíaco tardio, do mundo enquanto vontade de potência. Mundo este onde "todo vir-a-ser e crescer, tudo o que garante o futuro implica a dor... Para que haja o eterno prazer da criação, para que a vontade de vida afirme eternamente a si própria, tem de haver também eternamente a "dor da mulher que pare”..."10. Para o filósofo tudo isso está significado no nome "Dioniso". "Não conheço simbolismo mais elevado" diz o filósofo, "que esse simbolismo grego"11.

Essa "mistura" que Nietzsche faz com o primeiro e o segundo Dioniso é, evidentemente, com a intenção de salvar as ideias de $O$ Nascimento da tragédia, as quais ele insistia em considerar como suas ideias mais originais.

Inclusive afirma, em Crepúsculo dos ídolos, que Jacob Burckhardt seria um dos únicos a ter reconhecido de imediato a seriedade de suas ideias inscritas em $O$ Nascimento da tragédia, por isso, o prestigiado filólogo teria acrescentado uma seção a respeito do fenômeno dionisíaco em sua obra magna sobre a cultura

\footnotetext{
${ }^{10}$ Ibidem. Crepúsculo dos ídolos. "O que devo aos antigos”, §4.

${ }^{11}$ Idem.
} 
grega $^{12}$. Além disso, a forma como se refere ao seu "primogênito" em Ecce homo e os diversos estudos que fez da primeira obra testemunham sobre essa intenção.

No entanto, demonstra-se aqui, além de tudo isso, a dificuldade, ou mesmo a impossibilidade, para nós pesquisadores que nos propomos à tarefa de esgotar a compreensão de um conceito tão volátil, isto é, de um símbolo filosófico que sofre diversas mutações, que não se prende aos princípios lógicos tradicionais, que admite a contradição - ele pode ser, por exemplo, um conceito que critica o conceito - e, apesar disso, conecta sistematicamente um pensamento rico, complexo, multiforme e multifásico que, por sua vez, exprime-se de forma nãosistemática (podemos até dizer que é expresso fragmentariamente) como o pensamento nietzschiano.

Essa mutabilidade do dionisíaco nietzschiano está em plena conexão com as características do próprio dionisismo histórico. Do mesmo modo em que o conceito de Nietzsche possui uma multiplicidade de significação, os mitos, ritos e cultos de Dioniso também possuem.

Acreditamos que para obter uma compreensão mais ampla das formulações nietzschianas deveríamos, então, entender o que Nietzsche encontrou quando, na juventude, teve os primeiros contatos com os mitos desse deus. Assim foi imprescindível reconstruir, mesmo que minimamente, alguns dos principais elementos filológicos do dionisismo helênico.

Dentre esses elementos, nota-se que foram destacados aqueles que, de alguma forma, tem relação com o dionisíaco nietzschiano. A ascendência oriental do culto dionisíaco, por exemplo, tem relevância fundamental para a argumentação de $O$ Nascimento da tragédia, a saber, a transformação de um rito bárbaro - repleto de práticas violentas, contrárias aos preceitos helênicos - na mais elevada forma de uma manifestação artística.

Nietzsche não teve acesso às traduções das plaquetas micênicas e minoicas que demonstraram a presença do culto dionisíaco no passado mais arcaico da Grécia. Por isso, ele defende a proveniência bárbara de Dioniso, que invade epidemicamente as fronteiras helênicas. Todavia, é nesse aspecto irruptivo e

\footnotetext{
${ }^{12}$ Cf. Idem.
} 
epidêmico que encontramos a chave interpretativa que permite pensar o dionisíaco como um fenômeno sem origem pré-definida, isto é, a energia do orgiástico, a volúpia narcótica acentuada pela dissonância frenética, marcas irrestritas do culto a Dioniso que fazem parte de qualquer cultura primitiva. Desse modo, poderíamos encontrar os princípios do dionisismo, com certas variações mítico-ritualísticas, em todos os lugares e tempos.

Contudo, no período de elaboração de $A$ Visão dionisíaca de mundo, o mais fundamental para Nietzsche no dionisismo histórico é o efeito da intoxicação inebriante aflorado nos participantes das celebrações extáticas. Nesse efeito, ele encontra a metáfora perfeita para desvendar os enigmas do mundo.

Nesse momento é que Nietzsche encontra na mitologia grega os símbolos Apolo e Dioniso para expressar, a seu modo, a oposição metafísica entre aparência e essência, antes interpretadas por Kant como fenômeno e númeno, e por Schopenhauer como representação e vontade.

Assim sendo, o filósofo une três paixões: a filologia, ou seja, o mágico universo literário dos gregos antigos, a apreciação estética, principalmente musical, e a filosofia, sobretudo, a kantiana e a schopenhauriana.

Como sabemos, Apolo e Dioniso, embasados nos elementos característicos de seus mitos representam, no domínio das artes, a oposição de estilos artísticos que vivem em luta um com o outro, e somente no florescimento da cultura grega, encontraram-se fundidos na forma de arte da tragédia grega.

Existem, nessa perspectiva, dois estados nos quais a arte irrompe no homem como um impulso [Triebe] da natureza, impondo-se queira ele ou não: de um lado o apolíneo como criador de formas, de outro o dionisíaco como criador se sons. O primeiro como coação para a visão, o segundo como coação para o orgiástico, cuja porta de entrada é a audição. Ambos os estados também estão presentes na vida fisiológica, apesar de mais atenuados, com os sentimentos de delícia pela existência, o sonho e a embriaguez respectivamente.

Do mesmo modo como expressam o contínuo desenvolvimento da arte, esses símbolos descrevem também, como um processo análogo ao artístico, o próprio vir-a-ser do mundo. Desse modo, o apolíneo e o dionisíaco designariam 
vários aspectos da existência: as artes, a religião, a fisiologia, a cosmologia e, até mesmo, a linguagem. Essa abrangência pode ser mais bem visualizada na seguinte tabela:

\begin{tabular}{lll} 
& Apolo & Dioniso \\
\hline Ontologia: & $\begin{array}{l}\text { Princípio de individuação (impulso } \\
\text { que constrange o ser originário a } \\
\text { dar forma as coisa na aparência). }\end{array}$ & $\begin{array}{l}\text { Rompimento do principio de } \\
\text { individuação (prazer extático em } \\
\text { aniquilar as forma, promovendo o } \\
\text { retorno ao Uno primordial). }\end{array}$ \\
\hline Fisiologia: & Sonho & Embriaguez \\
\hline Arte: & Artes plásticas / Música dórica & Música / Poesia lírica \\
\hline Religião: & Mito homérico $^{\text {Culto dionisíaco }}$ \\
\hline Linguagem: & Conceito $^{13}$ & Símbolo / Metáfora
\end{tabular}

No que diz respeito à ontologia, o apolíneo seria uma pausa no Unoprimordial, o todo da realidade que se manifesta no surgimento dos indivíduos no espaço e tempo. O apolíneo é, então, uma espécie de fragmentação originária. Ele nos concede o poder, ou a faculdade, de nos libertar da imersão do turbilhão caótico da existência essencial. Mesmo que por um tempo determinado, o indivíduo apolíneo é liberto da agitação selvagem e pode contemplar a multiplicidade que o cerca.

Mas durante essa pausa do Uno é inevitável uma solidão ontológica, porque o "sonhador" reconhece-se como indivíduo irreconciliavelmente separado. Há igualmente uma solidão do espectador do sonho individual; o sonho é sempre solitário, pois é exclusivo do indivíduo que sonha; os contornos do sonho isolam, sufocam, são limites que não podem ser ultrapassados.

Por outro lado, o dionisíaco é eliminação desses contornos que, por consequência, ocasiona a suspensão do próprio indivíduo. A intoxicação dionisíaca promove, portanto, uma interrupção da fragmentação apolínea. Aquilo que nos distingue como seres individuais, o princípio separador é superado. No

\footnotetext{
13 "Esse caráter antitético entre o dionisíaco e apolíneo no interior da alma grega é um dos grandes enigmas pelo qual Nietzsche sentiu-se atraído diante da essência grega. No fundo, Nietzsche se esforçou para desvendar por que justamente o apolinismo grego haveria de medrar a partir de um subsolo dionisíaco: o grego dionisíaco tinha necessidade de tornar-se apolíneo: isto é, tinha necessidade de quebrar a sua vontade de monstruoso, múltiplo, incerto e horrível com uma vontade de medida, simplicidade, ordenamento pela regra e pelo conceito". Ibidem. Fragmento póstumo de 1888, 14[14].
} 
entanto, no momento mesmo da fratura na pluralidade somos acometidos por um prazer primaveril, uma alegre e festiva união dos homens entre si e dos homens com a natureza. Dioniso é, nesse sentido, a força do pleno esquecimento de si, do esquecimento da identidade individual.

Se o apolíneo viabiliza uma liberdade, então, o dionisíaco rompe com ela: perdemos o controle e nos excedemos em relação a todas as coisas. $\mathrm{Na}$ embriaguez dionisíaca já não somos espectadores, todavia, somos protagonistas de tudo o que ocorre; somos arrastados e nos tornamos centro do que está acontecendo, experimentamos a totalidade da existência em nós.

Esse efeito inebriante só é possível mediante a música. Um ouvido dionisíaco se faz penetrar no que escuta. Ouvir, nesse caso, é mergulhar na realidade sonora e tornar-se parte dela. Além disso, a experiência musical dionisíaca, diferentemente da estaticidade da imagem apolínea, é movimento. A corrente sonora nos convoca ao seu movimento, constrange nosso corpo à dança.

É importante dizer que ambos os estados estéticos são responsáveis por gerar tanto prazer e de desprazer: no que concerne ao apolíneo, o prazer está ligado à imagem, à beleza da forma, à serenidade e à segurança da individuação; quanto ao desprazer, está ligado à angústia da individuação. Já no que diz respeito ao dionisíaco, existe o prazer extático-orgiástico, mas também o desprazer da perda da identidade, da dissolução e o desgosto pelo desaparecimento.

O apolíneo e o dionisíaco estão sempre em luta, não há hegemonia das forças, apenas reconciliações periódicas. A tragédia grega nasce justamente de uma trégua entre esses impulsos. O período histórico, artístico-literário marcado pelo advento do teatro trágico foi, segundo Nietzsche, o marco de maior intensidade cultural, ou seja, o momento em que se produziu o melhor da cultura ocidental.

Dois aspectos são fundamentais na formulação nietzschiana sobre a tragédia ática: primeiro, a interpretação - contracorrente em relação às interpretações aceitas na época - de que a serenidade não era o que melhor definia a Grécia. Para Nietzsche, todo aspecto apolíneo era apenas um véu que encobria um passado assustador; segundo, a tragédia representa um modo de existir incondicionalmente 
afirmativo. A então cultura, denominada de trágica, caracteriza-se por uma alegria inabalável por viver. Ainda que o terrível, o doloroso e o inexorável fim estejam logo ali, a vida é desejada e amada intensamente.

Esse desejo radiante pela existência só tem sua justificação mediante a arte. "Somente como fenômeno estético podem a existência e o mundo ser justificado eternamente". Isso, porque o próprio devir, assim como o próprio ser humano são obras de arte, isto é, o processo do vir-a-ser é entendido como uma manifestação artística original. Sem contar que a arte permite o ato criativo e assim possibilita criar novos sentidos.

Nesse ponto chegamos à essência do trágico: no conteúdo das tragédias os protagonistas se viam em situações nas quais a sua vontade, suas habilidades, sua força e perspicácia eram completamente insignificantes frente aos caprichos dos deuses e da Tó $\chi \eta$. Os heróis se encontravam, portanto, em um ambiente de total falta de sentido. Suas vidas e ações perdiam inteiramente o significado, uma vez que seus planos eram indiferentes frente aos imprevisíveis desígnios divinos. Não nos faltam exemplos no corpus das tragédias que sobreviveram.

A partir desse contexto, trágico referia-se à inexorável ausência de sentido. Contudo, na perspectiva nietzschiana, a postura de afirmar a vida, bendizê-la em júbilo, sem a necessidade de nenhum consolo outro que não a arte é precisamente o que chamou de sabedoria trágica.

Sabendo disso, podemos dizer que a filosofia nietzschiana é, acima de tudo, trágica. Esse é o sentido último de Dioniso em toda sua obra. Apesar de todas as reviravoltas, idas e vindas ao longo de sua produção intelectual, existe uma unidade, um fio de Ariadne que conecta harmoniosamente, para além das contradições, todas as obras de Nietzsche.

Para perceber esse sutil encaixe entre os escritos, é preciso de um olhar panorâmico, de distanciamento e, sobretudo, de tempo para digeri-los. Essas foram as condições que Nietzsche impôs a si mesmo para entender suas próprias obras, e só a partir de então enxergar o traço comum entre elas. Ao menos é isso que ele testemunha em uma carta de 1888: 
Muito curioso! Desde 4 semanas eu entendo meus próprios escritos, - e ainda mais, eu os aprecio. Com toda sinceridade, nunca soube o que eles significavam; eu mentiria se quisesse dizer, exceto Zaratustra, que eles haviam me impressionado. É como a mãe com seu filho: ela pode amá-lo, mas em perfeita ignorância sobre o que a criança realmente é. - Agora tenho a absoluta convicção de que tudo está bem desde o começo - Tudo é uma unidade e almeja a mesma unidade. Reli anteontem o "Nascimento" [da tragédia]: nele há algo indescritível, profundo, terno, feliz... ${ }^{14}$

Ao olhar para seus escritos, depois do distanciamento e do tempo necessário, Nietzsche reconhece todos como "Um", e mais do que isso, eles aspiram o mesmo fim. Essa unidade não é outra coisa senão o pensamento trágico: o reconhecimento da completa nulidade dos "valores supremos", o pressentimento do sofrimento próximo, a certeza da finitude e o jubiloso Sim, ao passo que a finalidade comum a todas as obras é o projeto de educação dionisíaca.

Sob todas as muitas máscaras de Dioniso ao longo de toda produção nietzschiana podemos encontrar, no fundo sem fundo, a imperiosidade da afirmação trágica, a entrega voluntariosa à existência, ou seja, amor fati.

Nesse sentido, defendemos a difícil tese de que todos os movimentos na obra nietzschiana compõem, em seu todo, uma filosofia trágica per excellence; isso quer dizer que o itinerário de produção intelectual nietzschiano - marcado em um primeiro momento pela admiração e amor intenso às ideias de Wagner e Schopenhauer, seguido de uma crise, ou seja, da violenta ruptura com seus “mestres" e, por fim, uma nova reformulação intelectual que resgata e reestrutura antigos preceitos até então "congelados" - analisado agora pode ser considerado um empreendimento trágico.

Não queremos dizer que Nietzsche premeditou cada mudança em seu pensamento, como se tivesse antecipadamente o projeto de construir uma filosofia trágica. No entanto, a forma como ele caba lidando com o "todo" de sua obra é, sem dúvida, verossímil à sua proposta trágica. A desilusão com Wagner e Schopenhauer, o assalto de desesperança em relação a tudo que alicerçava sua

\footnotetext{
14 "Sehr curios! Ich verstehe seit 4 Wochen meine eignen Schriften, — mehr noch, ich schätze sie. Allen Ernstes, ich habe nie gewußt, was sie bedeuten; ich würde lügen, wenn ich sagen wollte, den Zarathustra ausgenommen, daß sie mir imponirt hätten. Es ist die Mutter mit ihrem Kinde: sie liebt es vielleicht, aber in vollkommner Stupidität darüber, was das Kind ist. - Jetzt habe ich die absolute Überzeugung, daß Alles wohlgerathen ist, von Anfang an, - Alles Eins ist und Eins will. Ich las vorgestern die „Geburt“: etwas Unbeschreibliches, tief, zart, glücklich...” Carta ao amigo Heinrich Köselitz [Peter Gast] de 22 de dezembro de 1888.
} 
visão de vida e sua fé no mundo foi, em última instância, o que fecundou seu pensamento.

O "peripético" afastamento de Wagner e Schopenhauer, descrito nos prefácios de 1886, como um período de crise, de deserto, solidão e convalescência revela uma verdadeira anagnórise de Nietzsche-personagem-de-si, imprescindível para construção de sua filosofia, cuja principal característica é, de fato, uma contínua experimentação de pensamentos, um ininterrupto jogo de interpretação e reinterpretação das coisas.

Pensando nisso, os textos aforísticos - inclusive dos inúmeros cadernos de anotação e, até mesmo as cartas - são etapas preliminares a caminho da autodescoberta que estrategicamente nunca se concretiza. Os aforismos são, portanto, desvios necessários, atrasos, rotundas dos quais lentamente se chega à filosofia de Dioniso.

Assim sendo, fica claro que Dioniso estava escondido desde o início por trás do véu da forma aforística. Tal e qual no parágrafo do "gênio do coração" - que só nos permite conhecer o nome do deus-filósofo no segundo período, quando o discurso de descrições sem fim é quebrado - Nietzsche esconde Dioniso na sua obra até chegar o momento de revelá-lo; isto é, o aforismo 295 corresponde a um microcosmo da obra nietzschiana no que se refere ao dionisíaco. Ele está presente desde o início, mas só é desvelado no momento oportuno.

Tudo não passou de mais uma travessura desse deus menino? Oscilar entre as máscaras da presença e da ausência? Dioniso, silenciado, na verdade estava a todo o momento presente no pensamento nietzschiano. Talvez oculto nas entrelinhas de algum aforismo? Ou - para usar uma metáfora mais próxima ao título do nosso trabalho - estava como a lagarta escondida em seu casulo de seda, esperando as asas coloridas para ressurgir à luz! Dioniso, símbolo-conceitual, estava abstruso na própria forma aforística que lhe é própria, esperando a maturidade para ressurgir - transmutado.

O fato é que o conceito Dioniso/dionisíaco de O Nascimento da tragédia não se encaixava no pensamento pós Humano, demasiado humano, contudo, ele era muito caro para o filósofo. A máscara do silêncio, a sua completa ausência no 
período intermediário de produção nietzschiana, o conceito passava por uma reformulação silente.

Afirmar que houve uma "transmutação de Dioniso" significa, portanto, que ocorreu uma reestrutaração de seu plano simbólico-conceitual, entretanto, como se sabe, muitos elementos de sua significação original mantiveram-se. Essas diferenças podem ser mais bem visualizadas na tabela abaixo. Porém, deve-se ter em mente que o que se pretende com essa tabela é apenas matizar algumas nuances para excitar nossa reflexão, uma vez que apontar todas as diferenças e semelhanças é , como dissemos anteriormente, uma empreita muito difícil:

Primeiro Dioniso

\begin{tabular}{|c|c|c|}
\hline Natureza: & Um impulso [Triebe] da natureza. & $\begin{array}{l}\text { Uma Força da natureza } \\
\text { [Naturgewalten] }^{15}\end{array}$ \\
\hline Cosmologia: & $\begin{array}{l}\text { Um ímpeto de unidade, de } \\
\text { aniquilação da individuação para } \\
\text { retorno ao Uno-primordial. }\end{array}$ & $\begin{array}{l}\text { Mundo do eterno-criar-a-si-mesmo } \\
\text { e do eternamente-destruir-a-si- } \\
\text { mesmo }^{16}\end{array}$ \\
\hline Fisiologia: & $\begin{array}{l}\text { Impulso metafísico que se } \\
\text { manifesta corporalmente como } \\
\text { voluptuosa embriaguez artística. }\end{array}$ & $\begin{array}{l}\text { Forças, afetos e paixões que lutam } \\
\text { incessantemente entre si por } \\
\text { supremacia e poder. }\end{array}$ \\
\hline Embriaguez: & $\begin{array}{l}\text { Prazer no caos desforme e na } \\
\text { dissonância. }\end{array}$ & Prazer no criar formas belas. \\
\hline Arte: & $\begin{array}{l}\text { Música, poesia lírica e tragédia } \\
\text { grega. }\end{array}$ & Todas as formas artísticas. \\
\hline Belo: & $\begin{array}{l}\text { Destruição da aparência e da } \\
\text { forma, portanto do belo }{ }^{17} \text {; prazer } \\
\text { no grotesco e terrível (sublime). }\end{array}$ & Prazer no embelezamento. \\
\hline
\end{tabular}

Visão de mundo: $\quad$ Trágico-afirmativa.

Trágico-afirmativa.

Incontáveis são as máscaras da divindade há muito cultuada com tambores e urros, vinho e sangue. Inúmeros são os significados de Dioniso na filosofia de Nietzsche. Isso reflete a psicologia de quem se considera todos os nomes da história. Isto é, de um tipo que constantemente reinventa a si próprio. Desse modo, das inúmeras designações da divindade que foram feitas ao longo dos

\footnotetext{
${ }^{15}$ Cf. Ibidem. Fragmento póstumo 1888, 14[14].

${ }^{16} \mathrm{Cf}$. Idem, 1886, 38[12].

${ }^{17}$ Cf. Idem, 1886, 2[110].
} 
milênios, àquela que mais se aproxima às multiformes formulações nietzschianas é a seguinte:

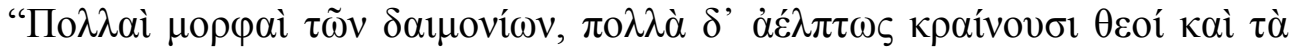

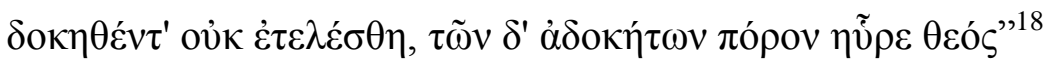

Tolóv $\delta^{\prime} \dot{\alpha} \pi \varepsilon ́ \beta \eta \tau o ́ \delta \varepsilon \pi \rho \tilde{\alpha} \gamma \mu \alpha$.

${ }^{18}$ Ver nota 1. da Seção 1.1. 


\title{
Referências bibliográficas:
}

\author{
TEXTOS ANTIGOS:
}

\section{Nota explicativa 1:}

Para as citações em língua grega antiga, utilizamos, na maioria dos casos, as fontes contidas em Perseus Digital Library Project vinculado à Tufts University, disponíveis no site: "http://www.perseus.tufts.edu".

AESCHYLUS. Aeschylus. Translation by Herbert Weir Smyth, Ph. D. in two volumes. Cambridge. Cambridge, Mass., Harvard University Press; London, William Heinemann, Ltd. 1926. (Disponível em http://www.perseus.tufts.edu).

APOLLODORUS. The Library, Translation by Sir James George Frazer, F.B.A., F.R.S. (2 Volumes). Cambridge, MA, Harvard University Press; London, William Heinemann Ltd. 1921. (Disponível em http://www.perseus.tufts.edu).

ARISTOFANES. Aristophanes Comoediae. Ed. F.W. Hall and W.M. Geldart. Oxford: Clarendon Press, 1907. (Disponível em http://www.perseus.tufts.edu).

Rãs. Trad. e notas Maria de Fátima Silva. Coimbra e São

Paulo: Imprensa Universidade de Coimbra e Annablume Editora, 2014.

ARISTÓTELES. Metafísica vols. I, II, III. Trad. Marcelo Perine. São Paulo: Edições Loyola, 2002.

Poética. Edição bilíngue. Trad. Paulo Pinheiro. : São Paulo: Editora 34, 2015.

CALLIMACHUS. Works. A.W. Mair. London: William Heinemann; New York: G.P. Putnam's Sons. 1921. (Disponível em http://www.perseus.tufts.edu).

DIÓGENES, Laércio. Vidas e doutrinas dos filósofos ilustres. Trad. Mario da Gama Kury. 2ª Ed. Brasília: Editora UnB, 2008.

EURÍPIDES. Bacantes. Trad. Eudoro de Souza. São Paulo: Hedra, 2010.

Euripidis Fabulae. (3 Vol.). Gilbert Murray. Oxford: Clarendon Press, 1913. (Disponível em http://www.perseus.tufts.edu).

. Ifigênia em Áulis; As Fenícias; As Bacantes. Trad. Mário da Gama Kury. Jorge Zahar: Rio de Janeiro, 1997.

Edições 70, 2000.

Os Heraclidas. Trad. Cláudia Raquel Cravo da Silva. Lisboa:

Delphi Complete Works of Euripides. Introduction to Euripides by Arthur S. Way. Trad. by Thomas W. Lumb. United Kingdom: Delphi Classics, 2003.

ÉSQUILO. Oréstia [Agamêmnon, Coéforas, Eumênides] Trad. de Mário da Gama Kury. Rio de Janeiro: Jorge Zahar, 2003. 
HESÍODO. Teogonia. A origem dos deuses. Estudo e trad. de Jaa Torrano. São Paulo: lluninueas, 1991.

The Homeric Hymns and Homerica with an English Translation by Hugh G. Evelyn-White. Harvard University Press; London, William Heinemann Ltd. 1914. (Disponível em http://www.perseus.tufts.edu).

HERÁCLITO. Fragmentos contextualizados. Edição bilíngue. Trad. Alexandre Costa. São Paulo: Odysseus, 2012.

HOMERO. Ilíada. Trad. Carlos Alberto Nunes. Rio de Janeiro: Nova Fronteira, 2015.

Homeri Opera (5 vol.). Oxford: Oxford University Press, 1920. (Disponível em http://www.perseus.tufts.edu).

Odisseia. Telemaquia - Regresso - Ítaca. Trad. Donaldo Schüler. São Paulo: L\&PM Editores, 2011.

The Odyssey (2 vol.). Trad. A.T. Murray. London: William Heinemann, Ltd. 1919. (Disponível em http://www.perseus.tufts.edu).

LAÊRTIOS, Diógenes. Vidas e Doutrinas dos Filósofos llustres. Trad. Mario da Gama Kury. Brasília: UnB, 2008.

Harvard University Press. 1972. (Disponível em http://www.perseus.tufts.edu).

PANÓPOLIS, Nono de. Dionisíacas. (4 Volumes). Trad. David Hernandes de La Fuente. Madrid: Gredos, 1995-2008.

Dionysiaca. (3 Vols.). Ed. W.H.D. Rouse. Harvard University Press; London: William Heinemann, Ltd. 1940-1942. (Disponível em http://www.perseus.tufts.edu).

PAUSÂNIAS. Description of the Greece. Bilingual version. Trad. W. H. S. Jones. United Kingdom: Delphi Classics, 2014.

Bibliotheca Historica, Books XVIII-XX. Immanel Bekker. Ludwig Dindorf. Friedrich Vogel. Leipzig: aedibus B. G. Teubneri, 19031906. (Disponível em http://www.perseus.tufts.edu).

PLATÃO. O Banquete. Edição Bilingue. Trad. José Cavalcante de Souza. São Paulo: Editora 34, 2016.

USP, 2010.

Crátilo. Trad. Luciano Ferreira de Souza. São Paulo: Editora Íon. Edição Bilingue. Trad. Victor Jabouille. Lisboa: Editorial Inquérito Ltda, 1988.

Menon. Edição Bilingue. Trad. Maura Inglésias. Rio de Janeiro: Editora Puc-Rio e Edições Loyola, 2001.

PLUTARCO. De Iside et Osiride in Moralia. Trand Frank Cole Babbitt. Cambridge, MA. Harvard University Press. London. William Heinemann Ltd. 1936. (Disponível em http://www.perseus.tufts.edu). 
. De Pythiae oraculis in Moralia. Trad. Gregorius N.

Bernardakis. Teubner: Leipzig. 1891. (Disponível em http://www.perseus.tufts.edu).

. Theseus in Plutarch's Lives. Trad. Bernadotte Perrin. Cambridge, MA. Harvard University Press. London: William Heinemann Ltd. 1914. (Disponível em http://www.perseus.tufts.edu).

SíCULO, Diodoro. Bibliotheca Historica, Books I-V. Immanel Bekker. Ludwig Dindorf. Friedrich Vogel. Leipzig: aedibus B. G. Teubneri, 18881890. (Disponível em http://www.perseus.tufts.edu).

SÓFOCLES. Édipo Rei. Trad. Mário da Gama Kury. Rio de Janeiro: Clássicos Zahar, 2010.

Oedipus the king. Oedipus at Colonus. Antigone. Trad. F.

Storr. The Loeb classical library, 20. Francis Storr. London; New York: William Heinemann Ltd.; The Macmillan Company. 1912. (Disponível em http://www.perseus.tufts.edu).

TUCÍDIDES. História da guerra do Peloponeso. Trad. Mário da Gama Kury. Brasília: Editora Universidade de Brasília, 4ํㅡㄹ., 2001.

\section{TEXTOS DE NIETZSCHE}

Nota explicativa 2:

As citações de Nietzsche feitas no original em alemão foram retiradas da versão organizada por Giorgio Colli e Mazzimo Montinari: Sämtliche Werke. Kritische Studienausgabe.

NIETZSCHE, Friedrich Wilhelm. A Filosofia na Idade Trágica dos Gregos. Trad. Maria Inês Madeira de Andrade. Lisboa e Rio de Janeiro: Elfos Editora e Edições 70, 1995.

A Gaia ciência. Trad. Paulo César de Souza. São Paulo: Companhia das Letras, 2001.

Acerca da verdade e mentira no sentido extramoral. Trad. Helga Hoock Qaudrado. Lisboa: Relogio D’Agua, 1997.

Assim falou Zaratustra: um Livro para Todos e para Ninguém. Trad. Paulo César de Souza. São Paulo: Companhia das Letras, 2011.

Aurora: reflexões sobre os preconceitos morais. Trad. Paulo César de Souza. São Paulo: Companhia das Letras, 2004.

A Visão dionisíaca do mundo e outros textos de juventude. Trad. Marcos Sinesio Pereira Fernandes, Marica Cristina dos Santos Souza. São Paulo: Martins Fontes, 2005.

Considerações Intempestivas I - David Strauss, Crente e Escritor. Trad. Lemos de Azevedo. Lisboa: Presença; São Paulo: Martins Fontes, 1979. 
Considerações Intempestivas II - Da Utilidade e dos Inconvenientes da História para a Vida. Trad. Lemos de Azevedo. Lisboa: Presença; São Paulo: Martins Fontes, 1979.

. Crepúsculo dos ídolos. Trad. Paulo César de Souza. São Paulo: Companhia das Letras, 2010.

Ecce homo: Como alguém se torna o que é. Trad. Paulo César de Souza. São Paulo: Companhia das Letras, 2008.

Escritos sobre Educação (Sobre o futuro dos nossos estabelecimentos de ensino / III Consideração Intempestiva Schopenhauer como Educador). Trad. Noéli Correia de Melo Sobrinho, 2ª Ed. Rio de Janeiro: PUC-Rio; São Paulo: Loyola, 2004.

Genealogia da moral: uma Polêmica. Trad. Paulo César de Souza. São Paulo: Companhia de Bolso, 2008.

Humano, demasiado humano: um livro para espíritos livres. Trad. Paulo César de Souza. São Paulo: Companhia das Letras, 2000.

Humano, demasiado humano II. Trad. Paulo César de Souza. São Paulo, Companhia das Letras: 2008.

O Caso Wagner: Um problema para Músicos \& Nietzsche contra Wagner: Dossiê de um Psicólogo. Trad. Paulo César de Souza. São Paulo: Companhia das Letras 1999.

O Anticristo e Ditirambos de Dioniso. Trad. Paulo César de Souza. São Paulo: Companhia das Letras, 2007.

Sämtliche Werke. Kritische Studienausgabe. (15 volume) Org. Giorgio Colli e Mazzimo Montinari. Gruyter \& Co.: Berlin; New Yorke, 1967-77.

Fragmentos póstumos. (4 volumes) Edición española dirigida por Diego Sánchez Meca Trad. Juan Luis Vermal e Joan B. Llinares. Madrid: Tecnos, 2006-2010.

Correspondência. (4 volumes). Edición dirigida por Luis Enrique de Santiago Guervós. Trad. Luis Enrique de Santiago Guervós. Madrid: Trotta, 2005-2012.

\section{TEXTOS COMPLEMENTARES}

ANDRADE, Pedro Duarte. Estio do tempo. Romantismo e estética moderna. Zahar: Rio de Janeiro, 2011.

BERNABÉ, Alberto e LUJÁN, Eugénio. Introducción al griego micénico: gramática, selección de texto y glosario. Saragoza: Monografias de filologia griega, 2006.

BARRENECHEA. Miguel-Angel de. Nietsche e o Corpo. Rio de Janeiro: 7 Letras, 2009. 
2014.

Nietzsche e a alegria do trágico. Rio de Janeiro: 7 Letras,

BAUDELAIRE. Richard Wagner e Tannhäuser em Paris. Trad. Plínio Augusto Coelho. São Paulo: Primeira linha, 1999.

BEISER, Frederick C.. The Fate of reason: German philosophy from Kant to Fichte. Massachusetts and London: Harvard University Press: Cambridge, 1987.

BERTRAM, Ernst. Nietzsche: attempt at a mythology. Trad. Robert E. Norton. Urbana and Chicago: University of Illinois Press, 2009.

BORGES. Jorge Luis. Obras completas. Buenos Aires: Emecé Editores, 1974.

BORNHEIM, Gerd. "Introdução à leitura de Winckelmann". In: WINCKELMANN, Johann Joachim. Reflexões sobre a Arte Antiga. Trad. Herbert Caro e Leonardo Tochtrop, $2^{\mathrm{a}}$ ed. Porto Alegre: Movimento, 1975.

BRANDÃO, Junito de Souza. Dicionário mítico-etimológico. Petrópolis: Vozes, 2014.

. Mitologia Grega (3 volumes.). Petrópolis: Vozes, 2015.

1992.

Teatro Grego: Origem e Evolução. São Paulo: Ars Poética

. Teatro Grego: Tragédia e Comédia. Petrópolis: Vozes, 1999.

CAVALCANTI, Anna Hartmann. Símbolo e alegoria. A gênese de concepção de linguagem em Nietzsche. São Paulo: Annablume 2005.

CAZNOK, Yara Borges; NETO, Alfredo Naffah. Ouvir Wagner, ecos nietzschianos. São Paulo: Musa Editora, 2000.

CHEVALIER, Jean; GHEERBRANT, Alain. Dicionnaire des symboles. Robert Paris: Laffont/Jupter, 1992.

CONSTÂNCIO, João. Arte e Niilismo. Nietzsche e o Enigma do Mundo. Lisboa: Edições Tinta-da-China, 2013.

. Nietzsche and Kantian Ethics (ed. with Tom Bailey). London: Bloomsbury, 2016.

Nietzsche and the Problem of Subjectivity (ed. with Maria João Branco and Bartholomew Ryan). Berlin/ Boston: Walter de Gruyter, 2015

CUNHA, Maria Helena Lisboa. Nietzsche espírito artístico. Londrina: Ed. CEFIL 2003.

DABDAB, J. A. Trabulsi. Dionisismo, poder e sociedade na Grécia até o fim da era clássica. Belo Horizonte: Editora UFMG, 2004.

DELEUZE, Gilles. A ilha deserta. Trad. Luiz B. L. Orlandi. São Paulo: lluminuras, 2006.

A filosofia crítica de Kant. Trad. Germiniano Franco. Lisboa: Edições 70, 1963.

. Nietzsche et la philosophie. Paris: PUF, 1973. 
. Os mistérios de Ariadne segundo Nietzsche. Trad. Peter Pál Pelbart. In: Cadernos Nietzsche, no 20, 2006.

DELEUZE, Gilles e GUATTARI, Félix. 0 que é a Filosofia? Trad. Maria Helena Rouanet e Bluma Villar. São Paulo: Editora 34, 2005.

DERRIDA, Jacques. Éperons Les Styles de Nietzsche. Bilingual edition. Chicago and London: The University of Chicago Press, 1979.

DESCARTES, René. Meditações metafísicas. Trad. Maria de Almeida Prado Galvão. São Paulo: Martins Fontes, 2000.

DÉTIENNE, Marcel. Dioniso a céu aberto. Trad. Carmem Cavalcanti. Rio de Janeiro: Jorge Zahar Editor, 1988.

DIAS, Rosa Maria; VANDERLEI, Sabina; BARROS, Tiago (organizadores). Leituras de Zaratustra. Rio de Janeiro: Mauad X FAPERJ, 2011.

DIAS, Rosa Maria. Nietzsche e a Música. São Paulo: Discurso editorial, 2005.

D'IORIO, Paulo. Nietzsche na Itália. A viagem que mudou os rumos da filosofia. Trad. Joana Angélica d'Avila Melo. Rio de Janeiro: Zahar, 2014.

FOUCAULT, Michel. Microfísica do Poder. Trad. Roberto Machado. Rio de Janeiro: Graal, 1984.

. Nietzsche, Freud e Marx. Trad. Jorge Lima Barreto. São Paulo: Princípio Editorial, 1997.

GOETHE, Johann Wolfgang von. In ECKERMANN, Johann Peter. "Conversations of Goethe. February 1826", Conversations of Goethe with Eckermann and Soret. 1st ed. Vol. 1. Cambridge: Cambridge University Press, 2011.

. O Sofrimento do jovem Werther. Trad. Marcelo Backs. Porto Alegre: L\&PM Pocket, 2001.

HADOT, Pierre. O Véu de Isis - Ensaio sobre a história da ideia de natureza. Trad. Mariana Sérvulo. São Paulo: Edições Loyola, 2006.

HEIDEGGER, Martin. Ensaios e conferências. Trad. Emmanuel Carneiro Leão, Gilvan Fogel, Marcia Sá Cavalcante Schuback. Petrópolis: Vozes, 2001

. Nietzsche. Trad. Marco Antônio Casanova. 2 ${ }^{\mathrm{a}}$ Ed. Rio de Janeiro: Forense Universitária, 2014.

Quem é o Zaratustra de Nietzsche? In: Ensaios e Conferências. Trad. Gilvan Fogel..Rio de Janeiro: Vozes, 2002. p. 87 110.

HÖLDERLIN, Friedrich. A Morte de Empédocles (Edição Bilíngüe). Trad. Maria Teresa Dias Furtado. Lisboa: Relógio D’Agua, 2001.

A Morte de Empédocles. Trad. Marise M. Curioni. São Paulo: lluminuras, 2008.

Grécia. In: Poesias completas. Trad. Federico Gorbea. Madrid: Ediciones 29, 1977. 
JAEGER, Werner. Paidéia: a formação do homem grego. Trad. Artur M. Parreira. São

Paulo: Martins Fontes, 1995.

KANT, Immanuel. Crítica da razão pura. Trad. Manuela Pinto Dos Santos e Alexandre Fradique Morujão. Lisboa: Edição da Fundação Calouste Gulbenkian, 2001. 70, 1990 . Crítica da razão prática. Trad. Artur Morão. Lisboa: Edições

Crítica da faculdade do juízo. Trad. Valério Rohden e Antônio Marques. Rio de Janeiro: Forense Universitária, 2002.

Prolegómenos a toda a metafísica futura que queira apresentar-se como ciência . Trad. Artur Morão. Lisboa: Edições 70, 1988.

KAUFMANN, Walter Arnold. "Nietzsche's Admiration for Socrates". In. Journal of the History of Ideas Vol. 9, N. 4, Octuber 1948. p. 472 - 491. (https://www.jstor.org/stable/2707219 em 31/07/2018).

KESSLER, Mathieu. L'esthétique de Nietzsche. Paris: PUF, 1998.

KLEIST, Heinrich von. An Abyss Deep Enough: Letters of Heinrich von Kleist, with a Selection of Essays and Anecdotes. Trad. e Org. Philip B. Miller. New York: E. P. Dutton, 1982.

KERÉNYI, Carl. A mitologia dos gregos. Vol. 1 A história dos deuses e do homem. Petrópolis: Vozes, 2016.

A mitologia dos gregos. Vol. 2 A história dos heróis.

Petrópolis: Vozes, 2015. . Arquétipos da religião grega. Petrópolis: Vozes, 2015.

. Dioniso: imagem arquetípica da vida indestrutível. Trad. de Ordep Serra. São Paulo: Odysseus, 2002.

Georg, 1957.

La Réligion antique. Traduction de Yves Le Lay. Genève:

LATERZA, Moacyr. Nietzsche e 0 Nascimento da tragédia. In: Kriterion: Revista de filosofia. Belo Horizonte, 74 - 75, janeiro-dezembro/1985.

LEMOS, Fabiano. Soldados e Centauros: Educação, filosofia e messianismo no jovem Nietzsche. Rio de Janeiro: Mauad X e Faperj, 2015.

LEBRUN, Gérard. Quem era Dioniso. In: Kriterion: Revista de filosofia. Belo Horizonte, 74-75, janeiro-dezembro/1985.

MACHADO, Roberto. Nietzsche e a Polêmica do Nascimento da tragédia. Rio de Janeiro: Jorge Zahar Editor, 2005.

. Nietzsche e a verdade: Rio de Janeiro: Rocco, 1985.

O nascimento do trágico: de Schiller a Nietzsche. Rio de Janeiro: Jorge Zahar Editor, 2006.

Zaratustra, tragédia nietzschiana. Rio de Janeiro: Jorge Zahar Editor 1997. 
MAFFESOLI, Michel. A sombra de Dioniso - contribuição a uma sociologia da orgia. Trad. de Rogério de Almeida. São Paulo: Zouk, 2005.

MARTON, Scarlat. Nietzsche. São Paulo: Brasiliense, 1983.

MECA, Diego Sanchez. Nietzsche, la experiencia dionisíaca del mundo. Madrid: Tecnos, 2013.

MILLINGTON, Barry (org.). Wagner: um compêndio.Trad. SAMPAIO, Luiz Paulo; ALVES, Eduardo Francisco. Rio de Janeiro: Jorge Zahar Editor, 1995.

NILSSON, Martin Persson. Historia de la religión griega. Buenos Aires: Eudeba, 1963.

OTTO, Walter F. Dioniso mito y culto. Trad. Cristina García Ohlrich. Madri: Ediciones Siruelà, 2001.

. Teofania. O Espirito da religião dos gregos antigos. Trad. Ordep Trindade Serra. São Paulo: Odysseus Editora. 2006.

ROHDE, Erwin. Psyche: Seelencult und Unsterblichkeitsglaube der Griechen. Freiburg i. B. und Leipzig, 1894.

RUFINONI, Priscila R. Entre o sublime retórico e o sublime moderno: - Apolo de Winckelmann. Revista de filosofia moderna e contemporânea. V. 1, n. 2 Brasília: 2013.

SÁNCHEZ, Diego Mariño. Injertando a Dioniso: Las interpretaciones del dios, de nuestros días a la Antigüedad. Madrid: Siglo XXI de Spaña Editores, 2014.

SCHILLER, Friedrich. Teoria da tragédia. Trad. Flávio Meurer. São Paulo: EPU, 1992.

Textos sobre o belo, o sublime e o trágico. Trad. Tereza Rodrigues Cadete. Lisboa: Imprensa Nacional/Casa da Moeda, 1997.

SCHOPENHAUER, Arthur. O Mundo como vontade e representação. Trad. Jair Barbosa. São Paulo: Editora Unesp, 2005.

O Mundo como vontade e representação. Trad. M. F. Sá Correia. Rio de Janeiro: Contraponto, 2014.

TAVARES, Manuel; FERRO, Mário. Análise da obra 'A origem da Tragédia' de Nietzsche. Lisboa: Editora Presença, 1997.

THÖNGES, Bernd. Das Genie des Herzens. Über das Verhältnis von aphoristischem Stil und dionysischer. Stuttgart: $M \& P$ und J. B. Metzlersche, 1993.

VERNANT, Jean-Pierre. As Origens do Pensamento Grego. Trad. Ísis Borges B. da Fonseca. Rio de Janeiro: Difel 2002.

VERNANT, Jean-Pierre e VIDAL-NAQUET, Pierre. Mito e tragédia na Grécia antiga. Trad. Anna Lia de Almeida. São Paulo: Perspectiva, 2011.

VENTRIS, Michael e CHADWICK, John. Documents in Mycenaean Greek. Cambridge at the university press, 1973. 
WAGNER, Richard. Beethoven. Trad. Ana Hartmann Cavalcante.: Rio de Janeiro: Zahar, 2010.

WEBER, José Fernandes. Formação (Bildung), Educação e Experimentação em Nietzsche. Londrina: Eduel, 2011.

WINCKELMANN, Johann Joachim. Gedanken über die Nachahmung der griechischen Werke in der Malerei und Bildhauerkunst. Stuttgart: Reclam, 1986. Edição bilíngüe. Alerçon (Orne). Paris: Aubier, 1990.

"Reflexões sobre a imitação dos gregos". In: LICHTENSTEIN, Jacqueline (org.). A Pintura, textos essenciais, Vol. 4. O belo. São Paulo: Editora 34, 2014.

"Reflexões sobre a imitação das obras gregas em pintura e escultura". Apud LICHTENSTEIN, Jacqueline (org). A Pintura, textos essenciais, Vol. 11. As escolas e o problema do estilo. São Paulo: Editora 34, 2014. 


\section{Apêndice:}

\section{1. ПРОАОГОГ (Prólogo):}

\section{$\alpha$}

Carta a Wilhelm Pinder em Naumburg <Pforta novembro de $1858>$

Querido Wilhelm

A decisão que havia tomado há muito tempo finamente se cumpriu. Me perdoe se acaso tenha esperado muito tempo por uma carta minha. Porém, de agora em diante, creio que poderemos escrever um ao outro sem interrupções. Avise também Gustav. -

As festas de Natal já estão se aproximando. Você provavelmente não faz ideia o quanto estou ansioso desta vez. Infelizmente, somente podemos trocar nossos desejos de felicitações por escrito. Eu não gosto disso. - Se não me engano, você já escolheu um livro para ti (um manual de Simrock de AltoMédio Alemão) e me parece uma ótima escolha. De minha parte ainda não decidi nada; se for possível me escreva uma relação de obras que eu possa gostar. Você com certeza sabe quais podem ser. Atualmente estou muito bem em Pforta, mas me diga, o que estudaram este semestre? Sinto muito que não tenhamos conseguido ler nada de Homero. Já traduzimos por conta própria todas as declinações do texto de Jacob, e de agora até o início de dezembro temos que fazer toda as compilações e resumos da história original. Uma boa tarefa. $\mathrm{O}$ estudo da história, tanto grega quanto prussiana deve ser realizada com profundidade, portanto devemos estudá-las seriamente. É verdade que no Instituto de Naumburg nossa tarefa era mais fácil, porém tens que admitir que tínhamos muita liberdade por lá. Em certo aspecto, estou feliz que tenhamos saído de lá Por outra parte, você não imagina quantas vezes tenho desejo de estar em Naumburg, em tua casa: Ali ficava bem! Aquela época boa se passou e não devo pensar nisso para não me sentir triste. - - - -

Agora tenho que terminar. O tempo e o papel estão acabando. Espero que me escrevas logo. E, não se esqueças que escolhi como assinatura permanente: "Semper nostra manet amicitia!" [Nossa amizade permanecerá para sempre].

Seu amigo

F.W. Nietzsche

Ps: Muitas felicidades a seus queridos pais e seus irmãos, a Gustav e a todos os amigos da escola.
Letter An Wilhelm Pinder in Naumburg <Pforta, Anfang November 1858>

Lieber Wilhelm!

Endlich ist mein längst gefaßter Entschluß zur Ausführung gekommen. Verzeih, daß ich dich mit meinem Briefe so lange habe warten lassen. Nun, ich denke, von nun an wollen wir uns wechselsweiße und ununterbrochen schreiben. Sage dies auch Gustav. -

Schon rückt die goldene Weihnachtszeit näher heran. Du glaubst wohl nicht, wie sehr ich mich diesmal darauf freue. Leider können wir uns gegenseitig unsre Wünsche nur schriftlich mittheilen. Dies thut mir sehr leid. Wenn ich nicht irre, so hast du dir schon ein Buch gewählt (Simrocks mittelhochdeutsches Lesebuch) und ich halte deine Wahl für vortrefflich. Ich wünsche mir vorläufig noch nichts bestimmtes; habe doch die Güte und schreibe mir nächstens eine Anzahl von Werken nach meinem Geschmack. Du wirst ja schon wissen. - Bis jetzt befinde ich mich in Pforta ganz wohl; schreibe mir doch einmal, was ihr dies Semester in der Klasse leßt. Besonders leid thut mir, daß wir keinen Homer leßen. Im Jakobs haben wir schon alle Deklinationen privatim übersetzt und müssen bis zum ersten Dezember alle Fabeln und Anekdoten bis zur Naturgeschichte praepariren. Eine hübsche Arbeit! In der preußischen, wie in der griechischen Geschichte wird sehr gründlich verfahren und wir müssen ordentlich arbeiten. - Viel ungezwungener war man auf dem Gymnasium in Naumburg; das ist sicher. Aber etwas zu frei war es auch, das wirst du nicht leugnen. Sogar in mancher Beziehung bin ich froh, daß ich davon fort bin. Du glaubst aber wiederum nicht, wie oft ich wünsche, in Naumburg bei dir zu sein; es war doch gar zu gemüthlich. Die schöne Zeit ist nun vorüber und ich darf nicht daran denken, um nicht traurig zu werden. - _ _ -

Ich muß aber doch nun schließen. Zeit und Papier mahnen ans Ende. Ich hoffe, daß Du mir sehr bald schreibst. Vergiß ja nicht, was ich mir jetzt als stehende Unterschrift gewählt habe: Semper nostra manet amicitia!

Dein Freund F. W. Nietzsche.

N.B. Viele Grüße na Deine lieben Eltern und Geschwister, na Gustav und an alle Schulkammeraden. 
$\boldsymbol{\beta}$ (grifo nosso)

A Erwin Rohde, em Florença

Basileia, 3 de setembro de 1869.

Meu querido amigo,

As cartas são coisas terríveis: Gostaria de lhe dar algo melhor, mas ao final o que posso oferecer é apenas o efêmero, o acorde e não a melodia. Sempre que sento e me ponho a escrever me vem à mente as palavras de Hördelin (meu poeta preferido na época do instituto): "Quando se está amando dáse o melhor de si". E o que tens recebido em minhas últimas cartas, se me recordo bem? Negações, aborrecimentos, solidão, coisas pequenas. $\mathrm{E}$, Zeus e o céu puro de outono sabem o quanto tenho caminhado justamente num caminho positivo, quantas horas passei tendo ideias novas e exuberantes, verdadeiras iluminações - e sempre que vêm tais estágios e períodos de ânimo tumultuoso, lhe envio, embaixo de um céu azul, uma carta repleta de bons pensamentos e desejos com a esperança de que a conexão elétrica entre nossas almas (ou de acordo com Reichenbach, as Chamas Ódicas) lhe transmitam essas rápidas palavras.

(...)
Latter An Erwin Rohde in Florenz.

<Basel,> am 3ten Sept. 1869.

Mein lieber Freund,

es ist ein böses Ding mit Briefen: man möchte vom Besten geben, und man giebt schließlich das ganz Ephemere, den Akkord und nicht die ewige Melodie. Immer wenn ich mich zum Briefschreiben an Dich niedersetze fällt mir das Wort Hölderlin's (meines Lieblings aus der Gymnasialzeit) ein „denn liebend giebt der Sterbliche vom Besten!"“ Und was hast Du nun, wenn ich mich recht erinnre, in meinen letzten Briefen bekommen? Negationen, Verdrießlichkeiten, Einsamkeiten, Einzelheiten. Und, weiß es Zeus und der herbstlich reine Himmel, so kräftig trägt's mich gerade in dieser Zeit in's Positive, so manche üppige Stunde mit reicher Einsicht und wirklicher Veranschaulichung geht an mir vorbei - aber immer wenn solche Zeiten und schwellende Stimmungen kommen, werfe ich einen ganzen Brief mit guten Gedanken und Wünschen für Dich in den blauen Himmel, in der Hoffnung, daß der elektrische Draht zwischen unsern Seelen (oder, nach Reichenbach die odische Lohe) diese Schnellschrift zu Dir befördert.

(...)

Grifo Nosso $\gamma$

A Franziska Nietzsche em Naumburg

Leipzig, 31 janeiro de 1866

(...)

Estou muito bem, tenho amigos na nossa sociedade filológica, que nos reúne todas as quintas-feiras; Entre estes há pessoas muito agradáveis. Minha palestra sobre a escrita do Teógenes já ocorreu e despertou muito interesse. Na próxima quinta-feira ouviremos o Dr. Kinkel sobre o início da arte grega; nós conhecemos algo que está perto de nós.

(...)

Cheguei a um acordo com Gersdorff para que pudéssemos nos reunir uma tarde por semana para lermos juntos com ele o grego, e com Mushacke outra tarde a cada duas semanas para Schopenhauer. Este filósofo ocupa um lugar muito importante em minhas ideias e estudos, e meu respeito por ele aumenta de maneira inigualável. Também faço propaganda a favor dele, e nem paro de esfregá-lo no nariz de algumas pessoas como, por exemplo, o primo.

(...)
An Franziska Nietzsche in Naumburg

<Leipzig, 31. Januar 1866>

(...)

Mir geht es ganz wohl, ich habe Freude an unserm philologischen Verein, der uns alle Donnerstag zusammenführt; es sind sehr liebenswürdige Menschen darunter. Meinen Vortrag über die Theognideische Redaktion habe ich gehalten, und er hat viel Interesse erregt. Nächsten Donnerstag werden wir den Dr. Kinkel über die Anfänge griechischer Kunst hören; wir haben uns etwas näher kennen gelernt.

(...)

Mit Gersdorff habe ich jetzt allwöchentlich einen Abend verabredet, wo wir zusammen griechisch lesen; mit ihm und Mushacke alle vierzehn Tage einmal, wo geschopenhauert wird. Dieser Philosoph nimmt eine sehr bedeutende Stellung in meinen Gedanken und meinen Studien ein, und mein Respekt vor ihm nimmt unvergleichlich zu. Ich mache auch Propaganda für ihn und weise einzelne Menschen, wie z. B. den Vetter geradezu mit der Nase auf ihn hin.

(...) 


\begin{abstract}
A Erwin Rohde em Hamburgo
Naumburg, 3 de novembro de 1867

(...)

Estou bastante solitário em Naumburg, não tem nenhum filólogo e nenhum admirador de Schopenhauer em meu círculo de conhecidos, e ademais me reúno raramente com estes, porque o serviço quase não me deixa tempo livre. Portanto, tenho muitas vezes a necessidade de relembrar o passado, para suavizar assim o presente e fazê-lo digerível. Esta manhã enquanto caminhava, com o casaco impermeável através da noite escura, fria e úmida, ouvindo o uivo do vento entre as negras sombras das casas, falava a mim mesmo "um homem de bem tem que ser divertido, tem que ter bom humor, e pensava em nossa festa de despedida, em Saltarin Kleinpaul - de cuja existência não se sabe nada nem em Naumburg nem em Leipzig, mas não devemos se preocupar com isso - no rosto dionisíaco de Koch, em nosso monumento no curso do rio de Leipzig que nós batizamos com o nome de Nirvana e que por iniciativa minha leva as solenes

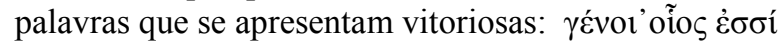
(...)
\end{abstract}

(...)

Ich bin in Naumburg ziemlich einsam; ich habe weder einen Philologen, noch einen Schopenhauerfreund im Kreise meiner Bekannten; und selbst diese kommen selten mit mir zusammen, weil der Dienst meine Zeit sehr beansprucht. Somit habe ich oft das Bedürfniß die Vergangenheit wiederzukäuen und die Gegenwart durch Beimischung jener Würze verdaulich zu machen. Als ich heute morgen im Regenmantel durch die schwarze kalte feuchte Nacht gieng, und der Wind unruhig um die dunklen Häusermassen blies, sang ich vor mich hin „ein Biedermann muß lustig, guter Dinge sein" und dachte an unsere närrische Abschiedsfeier, an den hüpfenden Kleinpaul - dessen Existenz augenblicklich in Naumburg und Leipzig unbekannt, aber deshalb nicht fraglich ist - an Kochs dionysisches Gesicht, an unser Gedenkmal am Ufer jenes Leipziger Stromes, das wir Nirwana tauften und das meinerseits die festlichen Worte, die sich siegreich erwiesen haben, trägt $\gamma \varepsilon$ ćvot'oĩo

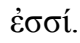
(...)

$\varepsilon$

\section{A Friedrich Ritschl em Leipzig}

Basileia, 30 Janeiro de 1872

Meu apreciado Senhor Conselheiro Particular

Espero que não tome como má a minha surpresa por não haver recebido nenhuma palavra sua sobre meu livro publicado recentemente e nem que se preocupe pela franqueza com que expresso minha surpresa. Pois, este livro tem algo de manifesto e a que menos ele convida é ao silêncio. Talvez o senhor se espante se te digo, meu querido mestre, que impressão suponho que meu livro causa em ti: espero que seja para você uma dessas promessas com que se encontra uma vez na vida, a saber, promessa para nossa ciência da Antiguidade, promessa para o ser alemão, ainda que tenha que perecer por ele um certo número de indivíduos. Bem, eu ao menos tenho percebido as consequências práticas de minhas opiniões e você adivinhará algo dele se lhe conto as conferências públicas que tenho ministrado aqui "Sobre o futuro de nossos centros de ensino". Me sinto bastante livre, creia você, de intenções e motivações pessoais, porque não busco nada para mim, apenas espero conseguir algo para os outros. O mais importante para mim é contribuir para a geração mais jovem de filólogos, e me sentiria frustrado em não conseguir. Pois bem, o seu silêncio causa em mim certa inquietude. Não que eu tenho alguma dúvida de sua simpatia por mim, disso já estou convencido de uma
An Friedrich Ritschl in Leipzig

Basel 30 Jan. 72.

Verehrtester Herr Geheimrath,

Sie werden mir mein Erstaunen nicht verargen, dass ich von Ihnen auch kein Wörtchen über mein jüngst erschienenes Buch zu hören bekomme, und hoffentlich auch meine Offenheit nicht, mit der ich Ihnen dies Erstaunen ausdrücke. Denn dieses Buch ist doch etwas von der Art eines Manifestes und fordert doch am wenigsten zum Schweigen auf. Vielleicht wundern Sie Sich, wenn ich Ihnen sage, welchen Eindruck ich etwa bei Ihnen, mein verehrter Lehrer, voraussetzte: ich dachte, wenn Ihnen irgend etwas Hoffnungsvolles in Ihrem Leben begegnet sei, so möchte es dieses Buch sein, hoffnungsvoll für unsere Altertumswissenschaft, hoffnungsvoll für das deutsche Wesen, wenn auch eine Anzahl Individuen daran zu Grunde gehen sollte. Denn die practische Consequenz meiner Ansichten werde ich wenigstens nicht schuldig bleiben, und Sie errathen etwas davon, wenn ich Ihnen mittheile, dass ich hier öffentliche Vorträge ,über die Zukunft unserer Bildungsanstalten" halte. Von persönlichen Absichten und Vorsichten fühle ich mich wie Sie mir glauben werden, so ziemlich frei, und weil ich nichts für mich suche, hoffe ich etwas für Andere $\mathrm{zu}$ leisten. Mir liegt vor allem daran, mich der jüngeren Generation der Philologen zu bemächtigen und ich hielte es für ein schmähliches Zeichen, wenn mir dies nicht gelänge. - Nun beunruhigt mich etwas Ihr Schweigen. 
vez por todas - mas por imaginar que por causa dessa simpatia deveria, de certo modo, se preocupar pessoalmente por mim. Escrevo para dissipar essas preocupações.

(...)
Nicht als ob ich einen Augenblick an Ihrer Teilnahme für mich gezweifelt hätte; von der bin ich ein für alle Mal überzeugt — wohl aber könnte ich mir gerade von dieser Theilnahme aus eine gleichsam persönliche Besorgniss um mich erklären. Diese zu zerstreuen schreibe ich Ihnen. (...)

\section{A Franziska e Elisabeth Nietzsche em Naumburg 24 de janeiro de 1872}

Minhas queridas mãe e irmã

Fiquei em silencio por mais tempo do que havia desejado. O novo ano me trouxe contratempos e as atividades são tantas que hoje devo fazer um registro formal para não perder o fio. Você recebeu, querida Lisbeth, o catalogo do Museu Rheinisches, enviado por Ritschl - nosso trabalho sobre pintura? O que eu fiz! E que algo assim apareça ao mesmo tempo que meu "Nascimento da tragédia" - que irônico e o quanto isso faz pensar.

A respeito do meu livro estão todos agitados, felizmente a maioria dos que ouço estão entusiasmados, outros irados. - Sim, há de ter um filho e um irmão se se escreve tais coisas - pois assim se merece o labor da escrita, pense, ter um irmão e um filho. É uma piada mas, como posso falar sério de certos acontecimentos que só podem ser compreendidos integralmente se com um choque.

\section{A Franziska und Elisabeth Nietzsche Basileia 24/01/1872}

Meine liebe Mutter und Schwester,

ich habe länger geschwiegen als ich wünschte. Das neue Jahr hat so mancherlei Abhaltungen und Thätigkeiten an mich herangebracht, daß ich heute förmlich ein Register machen muß, um nicht den Faden zu verlieren. Hast Du denn, liebe Lisbeth, das Register zum rheinischen Museum von Ritschl zugeschickt bekommen - unsre Hundearbeit von dazumalen? Was für Zeug habe ich doch schon gemacht! Und daß so etwas gerade zugleich mit meiner „Geburt der Trag.“ erscheinen muß — wie skurril und wie nachdenklich!

In Betreff meines Buches steht alles auf dem Kopf, glücklicherweise die meisten, von denen ich höre, vor Entzücken, andre vor Wuth. - Ja man muß einen Sohn und einen Bruder haben, die solche Sachen schreiben dann lohnt sich's, dächte ich, einen Bruder und einen Sohn zu haben. Nun, ich scherze - aber wie soll ich ernst von einem solchen Ereignisse reden, das durchaus nur mit Erschütterung begriffen werden kann!

\section{$\eta$}

A Wilhelm Vischer(-Bilfinger) em Basileia

Leipzig, Lessingstr., 22, 2. ${ }^{\circ}$ piso.

1 de fevereiro de 1869

Meu estimado senhor catedrático

Depois do que me foi comunicado hoje pelo senhor conselheiro particular Ritschel, não apenas é licito de minha parte, como necessário, me dirigir a você pessoalmente e lhe dar uma explicação franca sobre qual será meu comportamento caso seja nomeado, etc. Pois, para mim as condições e obrigações que este nomeamento comporta são tão conhecidas como oportunas, creio poder afirmar serenamente que não tenho nenhum motivo para recusar tal nomeação. Pois bem, desejo assegurar-lhe que me dedicarei à minha profissão com energias renovadas, com íntegra aplicação e com a melhor vontade e, sobretudo, meu

\section{An Wilhelm Vischer (-Bilfinger) in Basel \\ Leipzig, Lessingstr. 22, 2 Tr. am 1 Febr. 1869.}

Hochverehrtester Herr Professor,

nach dem, was mir heute Herr Geheimrath Ritschl mitgetheilt hat, ist es mir nicht nur erlaubt, sondern geboten, mich an Sie persönlich zu wenden und Ihnen eine unumwundene Erklärung darüber zu geben, wie ich mich im Falle einer Berufung usw. verhalten werde. Da mir alle dabei in Betracht kommenden Bedingungen und Verpflichtungen ebenso bekannt als erwünscht sind, so glaube ich getrosten Muthes aussprechen zu dürfen, daß ich eine eventuelle Berufung abzulehnen keinen Grund habe. Vielmehr bitte ich Sie, versichert zu sein, daß ich mit frischen Kräften, redlichem Fleiße und bestem Willen meinem Berufe leben werde, zumal es mein 
desejo mais sincero deve se justificar em certa medida pela extraordinária confiança com que você me honrou.

Nesse caso se puder exercer minha atividade desde os primeiros dias de maio na Universidade de Basiléia, seria para mim de um valor especial, conhecer seus desejos a respeito de minhas classes, pois para selecionar adequadamente minhas lições é necessário ter mais conhecimento das exigências e das condições relativas aquela Universidade do que posso ter neste momento. Provisoriamente, havia pensado ministrar lições particularmente sobre "E $\rho \gamma \alpha$ [Os Trabalhos $e$ os dias] de Hesíodo e palestras sobre as fontes da história da literatura grega. Estas minhas intenções se adequarão assim que possa ter conhecido o que desejas.

\section{Sou, com agradecida veneração, Seu \\ devoto}

Friedrich Nietzsche

Obs.: Devo acrescentar que minha promoção a doutor deverá ocorrer no mais tardar dentro de quatro semanas.

\section{[Anexo]}

$\mathrm{Eu}$, filho de um pastor rural protestante, nasci em $15 \mathrm{de}$ outubro de 1844 , no povoado de Röcken, na longínqua Merseburg, e ali transcorram os primeiros quatro anos de minha vida. Porém a morte prematura de meu pai nos obrigou a buscar um novo lugar, minha mãe escolheu Naumburg. Aqui, no instituto particular, fui preparado para o ensino diocesano do mesmo lugar, porém não frequentei durante muito tempo. Logo me apresentou a oportunidade de ser admitido na escola vizinha de Pforta. Aos alunos de Pforta se proporcionavam, desde o princípio, condições adequadas para estudar filologia. Neste centro são impostos-lhes de vez em quando tarefas especificamente filológicas, por exemplo, comentários sobre determinados textos de Sófocles e de Ésquilo. Assim, um mérito especial da escola de Pforta é que entre os alunos é boa educação ler e reler assiduamente autores gregos e latinos. Porém a maior sorte foi o fato de que tive excelentes professores de filologia, homens como Steinhart, Corssen, Loberstein, Keil, Peter, os quais me dedicaram uma parte de seus afetos.

Depois de uma estadia de seis anos, quando me havia despedido muito agradecido da escola de Pforta, como quem se despede de uma severa, porém bondosa tutora, marchei a Bonn. Ali, durante um certo tempo, meus estudos foram dirigidos à parte da filologia de Crítica aos Evangelhos e ao estudo das fontes do Novo Testamento. Além dessas incursões teológicas, fui ouvinte dos seminários de filologia e de arqueologia. Era um admirador, a distância, de Friedrih Ritschel. Deste modo me pareceu completamente natural deixar Bonn ao mesmo tempo que escolhi Leipzig como um herzlicher Wunsch sein muß, das ausgezeichnete Vertrauen, mit dem Sie mich geehrt haben, einigermaßen zu rechtfertigen.

Für den Fall nun, daß ich von Anfang Mai ab an der Universität Basel thätig sein dürfte, wäre es mir von besonderem Werthe, Ihre Wünsche betreffs meiner Vorlesungen zu kennen, da man, um Vorlesungen passend zu wählen, mit den Bedürfnissen und Zuständen der betreffenden Universität vertrauter sein muß als ich es gegenwärtig sein kann. Einstweilen hatte ich daran gedacht, über Hesiods "E $\rho \gamma \alpha$ priv. und über Quellenkunde der griechischen Literaturgeschichte publ. zu lesen. Doch corrigieren sich diese Absichten von selbst, so bald ich etwas Näheres über Ihre Wünsche in Erfahrung gebracht haben werde.

$$
\begin{gathered}
\text { Ich bin in dankbarer Verehrung } \\
\text { Ihr } \\
\text { ergebenster }
\end{gathered}
$$

Friedrich Nietzsche.

NB. Ich habe noch beizufügen, daß meine Promotion spätestens in vier Wochen erfolgt sein wird.

\section{[Beilage]}

Ich, der Sohn eines protestantischen Landgeistlichen, wurde am 15ten Oktober 1844 in dem Dorfe Röcken, unweit Merseburg, geboren und verlebte hier die ersten vier Jahre meines Lebens. Als aber der unzeitige Tod meines Vaters eine neue Heimat zu suchen nöthigte, war es Naumburg, auf das die Wahl meiner Mutter fiel. Hier bin ich in einem Privatinstitut für das Domgymnasium desselben Ortes vorgebildet worden, doch ohne diesem später dauernd anzugehören. Es bot sich nämlich bald eine Gelegenheit, in der benachbarten Schulpforte Aufnahme $\mathrm{zu}$ finden. Die Vorbedingungen $\mathrm{zu}$ einem Studium der Philologie werden einem Pförtner Schüler geradezu an die Hand gegeben. Es werden in dieser Anstalt mitunter spezifisch philologische Aufgaben gestellt zB. kritische Commentare über bestimmte sophokleische oder äschylische Chorgesänge. Dann ist es ein besondrer Vorzug der Schulpforte, daß unter den Schülern selbst eine angestrengte und mannichfache Lektüre griechischer und römischer Schriftsteller zum guten Ton gehört. Das Glücklichste aber war, daß ich gerade auf ausgezeichnete philologische Lehrer traf, auf Männer wie Steinhart, Corssen, Koberstein, Keil, Peter, die mir zum Theil auch ihre nähere Neigung schenkten:

Als ich nach einem sechsjährigen Aufenthalte der Schulpforte als einer strengen aber nützlichen Lehrmeisterin dankbar Lebewohl gesagt hatte, gieng ich nach Bonn. Hier richteten sich meine Studien eine Zeitlang auf die philologische Seite der Evangelienkritik und der neutestamentlichen Quellenforschung. Außer diesen theologischen Streifzügen war ich Zuhörer in den philologischen und archaeologischen Seminarien. Aus 


\begin{tabular}{|l|l|}
\hline $\begin{array}{l}\text { novo lugar de estudo. } \\
(\ldots)\end{array}$ & $\begin{array}{l}\text { der Ferne verehrte ich die Persönlichkeit Friedrich } \\
\text { Ritschl's. So fand ich es ganz natürlich zu gleicher Zeit } \\
\text { mit ihm Bonn zu verlassen und mir Leipzig als neue } \\
\text { akademische Heimat zu wählen. } \\
(\ldots)\end{array}$ \\
\hline
\end{tabular}

\title{
$\theta$
}

\begin{abstract}
Em meu mais profundo ser, ... eu pertenço à orientação histórica e à consideração histórica das coisas humanas, com uma tal determinação que a salvação do mundo jamais me pareceu encontrar-se num ou noutro dos sistemas filosóficos, que eu não posso nunca definir como "suicida" o desflorescimento natural de uma época ou de um fenômeno; que na individualização da vida não posso reconhecer uma regressão, nem crer que essas formas e potências de vida intelectual próprias de um povo dotado de qualidades excepcionais e em certa medida privilegiadas seriam critérios absolutos para todos os povos e para todos os tempos - assim como uma só religião não satisfaz, não satisfez, não satisfará jamais as diversas individualidades nacionais. - $\mathrm{O}$ senhor não pode impor a um "alexandrino" e a um erudito que condenem o conhecimento e que vejam somente na arte a força que modela o mundo, que o resgata e o liberta. (Carta de Ritschl a Nietzsche, 14 de fevereiro de 1872, KGB II/2, p.541. Apud. D'IORIO, Paolo. Nietzsche na Itália. p. 38.)
\end{abstract}

\section{$\boldsymbol{l}$}

A Malwida von Meysenbug em Florença

Basileia, 7 nov. 72

(...)

Para a terceira semana de novembro me foi anunciado uma magnífica visita de oito dias - aqui em Basiléia! A "Visita em si", Wagner com sua mulher. Estão de viagem para uma grande turnê, durante a qual querem passar por todos os grandes teatros da Alemanha e por ocasião também pelo famoso dentista da Basiléia, ao qual, portanto, estou muito agradecido. Conhece o novo escrito de Wagner "Sobre cantores e atores"? Por outro lado, asseguro que não conhece a apologia que o professor Rohde de Kiel tem escrito, tanto com a espada como com a pena, e com grande superioridade frente a seus adversários. Porque eu, com meu Nascimento da Tragédia, consegui me tornar o filólogo mais escandaloso da atualidade, e quem se compromete por mim comete uma autêntica temeridade, dado que todos estão em acordo em condenar-me. Porém a parte da polêmica, com a qual não queria importuná-la, o escrito de Rohde disse várias coisas justas sobre os fundamentos filológicos de meu livro, e, portanto, deverá ter algum interesse para você. Se pelo menos não temesse que com esta iniciativa generosa Rohde vai

\section{Latter An Malwida von Meysenbug in Florenz.} 7 Nov. 72.

(...)

Für die dritte Woche des November und zwar für 8 Tage ist mir ein herrlicher Besuch angekündigt - hier in Basel! Der „Besuch an sich“, Wagner mit Frau. Sie sind auf der großen Rundreise, auf der sie alle wesentlichen Theater Deutschlands berühren wollen, bei Gelegenheit aber auch den berühmten Basler Zahnarzt, dem ich also sehr viel Dank schulde! Die neueste Schrift Wagners „über Schauspieler und Sänger“ kennen Sie schon? Dagegen gewiß noch nicht die Apologie von Prof. Rohde in Kiel, die er, ebenso mit dem Schwert als der Feder, und mit großer Überlegenheit über seinen Gegner geschrieben hat. Ich habe es nämlich durch meine Geburt der Tragödie dazu gebracht der anstößigste Philologe des Tages zu sein, für den einzutreten ein wahres Wunderwerk der Kühnheit sein mag, da alles einmüthig ist über mich den Stab zu brechen. Abgesehn von der Polemik, mit der ich Sie nicht belästigen würde, enthält aber die Rohdesche Schrift vielerlei Gutes über die philologischen Fundamente meines Buches und wird dadurch bei Ihnen einige Theilnahme finden können. Wenn ich nur nicht fürchten müßte, daß der 
cair em um autêntico ninho de cobras venenosas e malvadas. Agora nós dois figuramos o Index!

No fundo, é apenas um mal-entendido; eu não escrevi para os filólogos, embora estes - se fossem capazes de lê-lo - também pudessem aprender com o meu livro um pouco de filologia pura. Agora se dirigem a mim exacerbados, e parece que pensam que eu cometi um crime, porque não os tive em conta, nem eles nem o seu modo de pensar. Também a obra de Rohde não terá êxito, porque nada pode encher esse abismo sem fim. Porém, eu continuo tranquilo em meu caminho e me resguardo em prestar atenção nessa repugnância que, de outra maneira, se me apresentaria espontânea a cada passo.

(...) großmüthige Schritt Rohdes ihn in ein wahres Nest von Mißgunst und Bosheit hineinführen wird! Jetzt sind wir Beide zusammen auf dem Index!

Im Grunde ist es ja eine Verwechslung; ich habe nicht für Philologen geschrieben, obwohl diese - wenn sie nur könnten - mancherlei selbst Rein-Philologisches aus meiner Schrift zu lernen vermöchten. Nun wenden sie sich erbittert an mich, und es scheint, sie meinen, ich habe ein Verbrechen begangen, weil ich nicht zuerst an sie und ihr Verständniß gedacht habe. Auch Rohde's That wird erfolglos bleiben, denn nichts vermag die ungeheure Kluft zu überbrücken. Nun ziehe ich ruhig weiter auf meiner Bahn und hüte mich den Ekel zu empfinden, zu dem man sonst auf Schritt und Tritt Veranlassung fände.

(...)

\section{$\kappa$}

A Friedrich Ritschl em Leipzig

Basileia, 6 abril 1872

(..)

Devo-lhe meu maior agradecimento pela bela e detalhada carta que me escreveu, sobre meu livro, ainda mais quando fui eu quem lhe havia provocado com pressão excessiva. É que desejava muito saber como havia reagido ante meu livro. Agora eu sei e estou mais tranquilo, mas não completamente. No entanto, não quero falar sobre ele. Mais adiante, quando publicar meu escrito Sobre o futuro de nossos estabelecimentos de ensino, ficará para o senhor mais claro e evidente o que quero. Entretanto, tenho o convencimentode que se deve passar várias décadas para que os filólogos possam entender um livro tão esotérico e científico no sentido mais elevado da palavra. Certamente, aparecerá tão logo uma segunda edição.

Envie boas lembraças e faça lhe chegar os melhores desejos a sua honorável esposa

de seu devoto

Friedrich Nietzsche
Latter An Friedrich Ritschl in Leipzig

Basel 6 April 1872

Für den schönen und ausführlichen Brief, den Sie mir über mein Buch geschrieben haben, bin ich Ihnen rechten Dank schuldig, um so mehr als ich ihn im Grunde durch ungebärdiges Drängen provozirt habe. Aber ich wollte durchaus wissen, wie Sie Sich zu meinem Buche verhalten würden. Nun weiß ich es und bin beruhigt: zwar nicht vollständig. Doch darüber will ich nicht schreiben. Später wird Ihnen das, was ich will, deutlicher und einleuchtender sein, wenn meine Schrift „über die Zukunft unserer Bildungsanstalten“ veröffentlicht sein wird. Inzwischen spreche ich die Überzeugung aus, $\mathrm{da}$ es für Philologen einige Jahrzehnte Zeit hat, ehe sie ein so esoterisches und im höchsten Sinne wissenschaftliches Buch verstehen können. Übrigens wird sehr bald eine zweite Auflage erscheinen.

Behalten Sie mich in gutem Angedenken und sagen Sie Ihrer verehrungswürdigen Frau Gemahlin das Beste von Ihrem

ergebenen

Friedrich Nietzsche

\section{$\lambda$}

\begin{tabular}{|l|l|}
\hline $\begin{array}{l}\text { A Erwin Rohde em Roma } \\
\text { Basileia, final de janeiro e } 15 \text { de fevereiro de } 1870 \\
\text { Meu querido amigo: }\end{array}$ & $\begin{array}{l}\text { An Erwin Rohde in Rom } \\
\text { <Basel, Ende Januar und 15. Februar 1870> } \\
\text { (...) }\end{array}$ \\
$\begin{array}{l}\text { Li ante um público misto uma palestra sobre "O Drama lieber Freund, } \\
\text { Mein }\end{array}$ & \begin{tabular}{l} 
Ich habe einen Vortrag vor gemischtem Publikum \\
\hline
\end{tabular}
\end{tabular}




\begin{tabular}{|c|c|}
\hline $\begin{array}{l}\text { Musical Antigo" e darei outra no dia } 1^{\circ} \text { de fevereiro } \\
\text { sobre "Sócrates e Tragédia". Meu amor pelo grego } \\
\text { cresce cada vez mais: não há melhor maneira de } \\
\text { abordar o grego do que a incansável perfeição pessoal. } \\
\text { O grau que alcancei agora é o da mais vergonhosa } \\
\text { confissão de minha ignorância. A existência do } \\
\text { filólogo, ocupado em um esforço crítico, mas a } \\
\text { milhares de quilômetros de distância dos gregos, torna- } \\
\text { se cada vez mais impossível para mim. Eu também } \\
\text { duvido que eu possa me tornar um verdadeiro filólogo. } \\
\text { (...) } \\
\text { Mas não quero ser provocado: realmente não tenho uma } \\
\text { ambição literária, não preciso me apegar a um modelo } \\
\text { predominante, porque não me esforço para posições } \\
\text { brilhantes e famosas. Pelo contráio, quero, quando } \\
\text { chegar o momento oportuno, me expressar de maneira } \\
\text { mais séria e franca possível. Agora, ciência, Arte e } \\
\text { filosofia crescem juntas de tal forma dentro de mim } \\
\text { que que pelo menos vou parir Centauros. } \\
\text { (...) }\end{array}$ & $\begin{array}{l}\text { gehalten über ,das antike Musikdrama“ und halte am } 1 \\
\text { Februar einen zweiten über, „Socrates und die Tragödie.“ } \\
\text { Ich gewinne immer mehr Liebe für das Hellenenthum: } \\
\text { man hat kein besseres Mittel sich ihm zu nähern als } \\
\text { durch unermüdliche Fortbildung seines eigenen } \\
\text { Persönchens. Der Grad, den ich jetzt erreicht habe, ist } \\
\text { das allerbeschämendste Eingeständniss meiner } \\
\text { Unwissenheit. Die Philologenexistenz in irgend einer } \\
\text { kritischen Bestrebung, aber Meilen abseits vom } \\
\text { Griechenthum wird mir immer unmöglicher. } \\
\text { (...) } \\
\text { Doch will ich mich nicht anfechten lassen: litterarischen } \\
\text { Ehrgeiz habe ich eigentlich gar nicht, an eine } \\
\text { herrschende Schablone mich anzuschliessen brauche ich } \\
\text { nicht, weil ich keine glänzenden und berühmten } \\
\text { Stellungen erstrebe. Dagegen will ich mich, wenn es } \\
\text { Zeit ist, so ernst und freimüthig äussern, wie nur } \\
\text { möglich. Wissenschaft Kunst und Philosophie wachsen } \\
\text { jetzt so sehr in mir zusammen, dass ich jedenfalls einmal } \\
\text { Centauren gebären werde. } \\
\text { (...) }\end{array}$ \\
\hline
\end{tabular}

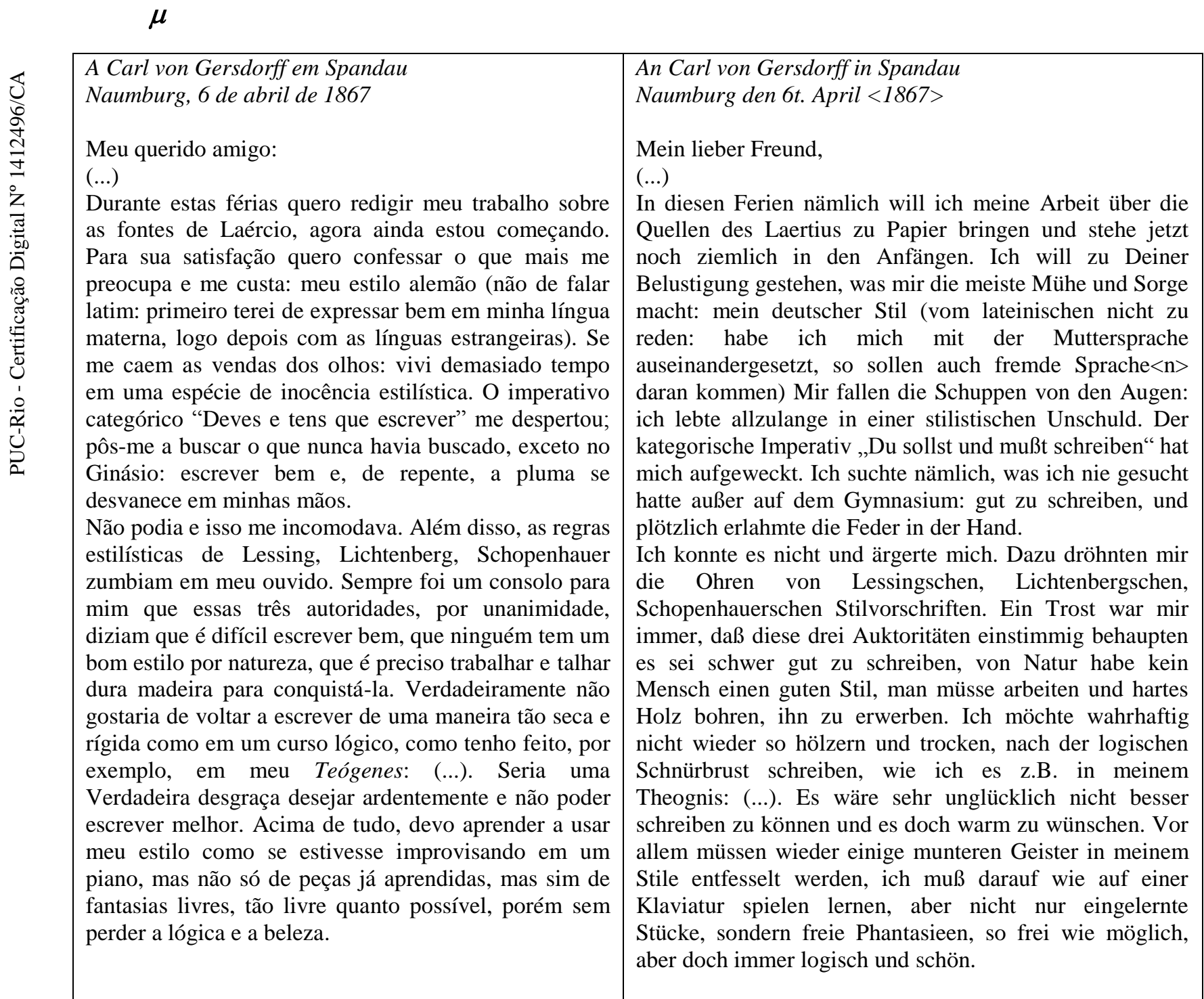


Em segundo lugar, outro desejo me atormenta. Um dos meus amigos mais antigos, Wilhelm Pinder, de Naumburg, está às portas de seu primeiro exame de direito; também conhecemos bem a angústia habitual de tais momentos. Mas o que mais estimo, o que me estimula a imitá-lo, não é tanto o exame em si, mas sua preparação. O fato de fazer todas as disciplinas de ciência em aproximadamente um semestre, e assim realmente alcançar uma idéia global delas, tem que ser útil e entusiasmar qualquer pessoa. É algo como se um oficial acostumado apenas a instruir sua companhia, de repente se percebesse em uma batalha, e que seus pequenos esforços podem produzir grandes resultados.

Bem, não podemos negar, de fato, que a maioria dos filólogos não tem essa visão global sublime da antiguidade, porque eles se aproximam demais do cenário e examinam apenas uma pequena mancha de óleo em vez de se maravilharem com as características grandiosas e audaciosas do toda a pintura e - o mais importante - desfrutar dele. Quando, pergunto, já tivemos esse gosto puro de nossos estudos da antiguidade, dos quais infelizmente falamos com muita frequência?

(...)
Zweitens beunruhigt mich ein andrer Wunsch. Einer meiner ältesten Freunde Wilhelm Pinder aus Naumburg steht jetzt dicht vor seinem ersten juristischen Examen; die wohlbekannten Ängste in solchen Zeitläuften kennen wir auch. Aber was mir gefällt, ja mich zur Nachahmung anstachelt, liegt nicht im Examen, sondern in der Vorbereitung dazu. Wie nützlich, ja wie erhebend muß es sein etwa in einem Semester alle Disciplinen seiner Wissenschaft an sich vorüber marschiren zu lassen und somit wirklich einmal eine Gesammtanschauung über dieselbe $\mathrm{zu}$ bekommen. Ist es nicht ebenso, als ob ein Offizier, stets nur gewöhnt seine Compagnie einzuexercieren, plötzlich in einer Schlacht zum Begriffe dessen kommt, was seine kleinen Bemühungen für große Früchte zeitigen können.

Denn wir wollen es nicht leugnen, jene erhebende Gesammtanschauung des Alterthums fehlt den meisten Philologen, weil sie sich zu nahe vor das Bild stellen und einen Oelfleck untersuchen anstatt die großen und kühnen Züge des ganzen Gemäldes zu bewundern und - was mehr ist - zu genießen. Wann, frage ich, haben wir doch einmal jenen reinen Genuß unsrer Alterthumsstudien, von dem wir leider oft genug reden.

(...)

\section{Basiléia, 10 de novembro de 1870 (dia de Lutero)}

Richard Wagner, em Tribschen

\section{Estimado Mestre}

Na primeira corrida deste novo semestre, que desta vez depois da minha longa ausência é particularmente violenta, nada mais reconfortante poderia me ocorrer do que o envio do seu "Beethoven". O quão importante tem sido conhecer a filosofia de sua música - o que, neste caso, significa a filosofia da música enquanto tal, eu poderia deixar claro para você em um ensaio que eu escrevi para mim neste verão "A visão dionisíaca do mundo". De fato, através desse estudo prévio pude compreender completamente, e com profundo prazer, a necessidade de sua argumentação, por muito distante que seja seu círculo de ideias, por muito surpreendente e assombroso que seja todo, e em particular a exposição da autentica realização de Beethoven. Porém temo que você pareça aos estéticos dos dias atuais, um tanto perambulante, soturno ao qual ocorrerá de ser desaconselhável, perigoso e sobretudo impossível seguí-lo. Nem mesmo a maior parte dos conhecedores da filosofia schopenhauriana estarão em situação de traduzir para si em conceitos e sentimentos a profunda harmonia entre os seus pensamento e do mestre. (...)

\section{An Richard Wagner in Tribschen}

Basel 10. Nov. am Luthertage. <1870>

Verehrtester Meister,

in dem ersten Anstürme des neuen Semesters, der diesmal, nach meiner langen Abwesenheit, besonders heftig ist, konnte mir nichts Erquicklicheres geschehen als die Übersendung Ihres „Beethoven“. Wie viel mir daran liegen musste, Ihre Philosophie der Musik - und das heisst doch wohl: die Philosophie der Musik kennen zu lernen, könnte ich Ihnen besonders an einem Aufsatze deutlich machen, den ich für mich in diesem Sommer schrieb, betitelt ,die dionysische Weltanschauung". In der That habe ich durch dies Vorstudium erreicht, dass ich die Notwendigkeit Ihrer Beweisführung vollständig und mit tiefstem Genüsse einsehe, so entlegen der Gedankenkreis, so überraschend und in Staunen versetzend alles und namentlich die Ausführung über Beethovens eigentliche That ist. Doch fürchte ich, dass Sie den Aesthetikern dieser Tage als ein Nachtwandler erscheinen werden, dem zu folgen nicht räthlich, ja gefährlich, vor allem unmöglich gelten muss. Selbst die Kenner Schopenhauerischer Philosophie werden der grössten Zahl nach ausser Stande sein, den tiefen Einklang zwischen Ihren Gedanken und denen ihres Meisters sich in Begriffe und Gefühle zu übersetzen. (...) 
A Gustav Krug em Naumburg
Pilatus, 4 de agosto de 1869
(...)

De novo passei os últimos dias na casa de meu venerado amigo Richard Wagner, que amavelmente me concedeu o direito ilimitado de realizar visitas frequentes e deve se enfadar comigo quando faço uma pausa de quatro semanas no uso desse direito. Compreenderás o que ganho com essa permissão: pois este homem, que até agora não há nenhum juízo que se tenha feito que o caracterize plenamente, mostra uma grandeza incondicional, perfeita em todas as suas qualidades, uma humanidade inatingivelmente nobre, uma profundidade e uma seriedade vital, que sempre tenho a sensação de estar ante a um dos seletos do século.

Ele também ficou muito feliz recentemente, tendo acabado de terminar o terceiro ato de seu Siegfried e passado, em um estado de força exuberante, a composição do Crepúsculo dos deuses. Tudo o que sei sobre Siegfried, de acordo com os primeiros esboços, é grandemente concebido, por exemplo, a luta de Siegfried com o "verme", o canto do pássaro, etc. Domingo de manhã, no meu lindo quarto com a vista mais livre sobre o lago dos Quatro Cantões, examinei minuciosamente alguns manuscritos que Wagner me confiou, singulares libretos de seu primeiro período parisiense, ensaios filosóficos e esboços teatrais, sobretudo uma profunda exposição dirigida ao "jovem amigo" o rei bárbaro, para ilustração dele mesmo acerca da ideia de Wagner "sobre o Estado e a Religião". Nunca foi falado a um rei de forma tão bela, nobre e profunda; uma pena que o jovem, tal como parece, tenha aprendido tão pouco com ele. (...)
An Gustav Krug in Naumburg

<Pilatus, 4. August 1869>

$(\ldots)$

Wieder habe ich einmal die letzten Tage bei meinem verehrten Freunde Richard Wagner verlebt, der mir in liebenswürdiger Weise das unumschränkte Recht häufiger Besuche ertheilt hat und mir böse ist, wenn ich einmal vier Wochen pausirt habe, von diesem Rechte Gebrauch zu machen. Du wirst mir nachfühlen, was ich mit dieser Erlaubniß gewonnen habe: denn dieser Mann, über den kein Urtheil bis jetzt gesprochen ist, das ihn völlig charakterisirte, zeigt eine so unbedingte makellose Größe in allen seinen Eigenschaften, eine solche Idealität seines Denkens und Wollens, eine solche unerreichbar edle und warmherzige Menschlichkeit, eine solche Tiefe des Lebensernstes, daß ich immer das Gefühl habe vor einem Auserwählten der Jahrhunderte zu stehen. Dazu war er jetzt gerade so glücklich, da er eben den dritten Akt seines "Siegfried" beendet hatte und im üppigsten Kraftgefühl eben an die Composition der „Götterdämmrung“" schreitet. Alles was ich nun aus dem „Siegfried“ kenne, nach dem ersten Entwürfe, ist großartig concipirt z.B. der Kampf Siegfrieds mit dem „Wurm“, das Vogellied usw. Am Sonntage Vormittag habe ich, in meiner reizenden Stube mit freistem Anblicke des Vierwaldstätter Sees und des Rigi, eine Anzahl Manuscripte durchmustert, die mir Wagner übergeben hatte, eigenthümliche Novellen aus seiner ersten Pariser Zeit, philosophische Aufsätze und Dramenentwürfe, vor allem aber ein tiefsinniges Exposé, gerichtet an den ,jungen Freund“ den baierischen König, zur Aufklärung desselben über Wagners Ansichten in „Staat und Religion“. Niemals ist schöner edler und tiefer zu einem König gesprochen worden; schade, daß der junge Mann, wie es scheint, so wenig davon gelernt hat. -

(...)

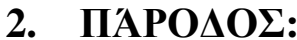

$\alpha$

"O culto desta deidade trácia, que diferenciava violentamente em todos os seus pontos dos cultos tributados aos deuses gregos, tal como os que conhecemos por Homero, e que, ao contrário, apresentava a maior afinidade com o povo frígio que, quase idêntico aos dos trácios, rendiam à sua deusa-mãe Cibele, um caráter totalmente orgiástico" (ROHDE, Erwin. Psyche: culto da alma e crença na imortalidade entre os gregos antigos)
"Der Cult dieser thrakischen Gottheit, in allen Punkten heftig abweichend von dem was wir etwa aus Homer als griechischen Götterdienst kennen, dagegen aufs nächste verwandt dem Culte, in welchem das, mit den Thrakern fast identische Volk der Phrygier seine Bergmutter Kybele verehrte, trug völlig orgiastischen Charakter" (ROHDE, Erwin. Psyche: Seelencult und Unsterblichkeitsglaube der Griechen. p. 301) 
"Os próprio gregos manifestavam com freqüência e de muitos modos que o berço do culto de Dionísio era a Trácia, diziam que esse culto se espalhou entre outras cidades trácias e floresceu principalmente no extremo sul dos muitos braços étnicos trácios e o mais conhecido dos helenos: o que povoava as terras situadas entre a foz do Hebro e a do Axio, na costa e nas montanhas que desciam daquele lado para o mar. $\mathrm{O}$ deus, a quem os gregos apelidaram de Dioniso, tinha, ao que parece, nomes diferentes entre as muitas tribos independentes dos trácios, entre os quais eram mais conhecido entre os gregos os nomes Sabos, Sabazios. Os gregos devem ter conhecido muito cedo, com certo espanto, a natureza e o culto deste deus, seja nas próprias terras da Trácia, atravessadas por eles em suas peregrinações, ao que mais tarde seria sua terra natal, e com a qual os antigos mantinham intenso contato e troca, seja no mesmo solo da Grécia, através do povo ou das tribos trácias, estabelecidos desde tempos imemoriais, em algumas regiões da Grécia central, na forma de lendas isoladas cujas premissas etnográficas davam certo os grandes historiadores dos séculos qurto e quinto da antiga era.
"Dass die Heimath des Dionysoscultes Thrakien war, sein Cult, wie bei anderen thrakischen Völkerschaften, so ins besondere blühte bei den, den Griechen am besten bekannten südlichsten der zahlreichen thrakischen Stämme, die von der Mündung des Hebros bis zu der des Axios an der Meeres-küste und in den darüber liegenden Berglandschaften wohnten, das haben die Griechen selbst oft und vielfach bezeugt. Der Gott, den die Griechen mit graecisirtem Namen Dionysos nannten, hatte, wie es scheint, bei den vielen gesonderten Stämmen der Thraker wechselnde Benennungen, unter denen Sabos, Sabazios, den Griechen die geläufigsten wurden. Wesen und Dienst des Gottes muss den Griechen früh bekannt und auffallend geworden sein, sei es nun in thrakischen Landen selbst, die sie, in ihre spätere Heimath wandernd, durchzogen haben müssen und mit denen sie seit alter Zeit in vielfachem Verkehr standen, sei es auf griechischem Boden, durch thrakische Stämme oder Haufen, denen in Urzeiten dauernde Sitze in manchen Gegenden Mittelgriechenlands zugeschrieben wurden in vereinzelten Sagen, deren ethnographische Voraussetzungen die grossen Geschichtsschreiber des fünften und vierten Jahrhunderts als thatsächlich begründet nahmen”. (Idem. 299 -300)

\section{$\gamma$}

"As cidades e estados da Grácia celebram seus festivais anuais, nas quais este deus é adorado como doador do embriagante sumo da videira, como tutor e protetor demoníaco da germinação e frutificação do reino vegetal e toda a natureza, como uma encarnação divina de plenitude da vida, como um modelo e protótipo da exaltada alegria de viver. A arte, como flor suprema de toda a coragem e altivez da vida, ganha na incomensurável intuição e inspiração do culto dionisíaco. A última cimeira da poesia grega, o drama, surge dos coros dos festivais dionisíacos"
"Städte und Staaten feiern ihm Jahresfeste, in denen er als Spender des begeisternden Trankes der Rebe, als dämonischer Schützer und Förderer alles Wachsthums und Gedeihens im Pflanzenreiche und der ganzen Natur, als göttliche Verkörperung des ganzen Umfanges und Reichthums natürlicher Lebensfülle, als Vorbild gesteigerter Lebensfreude gefeiert wird. Die Kunst, als höchste Blüthe alles Muthes und Uebermuthes zum Leben, gewinnt ins Unermessliche Anschauung und Anregung aus dem dionysischen Cult. Der letzte Gipfel griechischer Dichtung, das Drama, steigt aus den Chören dionysischer Feste empor" (Idem. p. 395)

\section{$\delta$}

"O que nos dizem da irresistibilidade e disseminação geral dos festivais de dança da padaria e sua excitação aponta para os fenômenos de tais epidemias religiosas, algumas das quais, mesmo em épocas posteriores, às vezes transbordaram países inteiros"
"Was uns von der Unwiderstehlichkeit und der allgemeinen Ausbreitung der bakchischen Tanzfeste und ihrer Aufregungen berichtet wird, lässt an die Erscheinungen solcher religiösen Epidemien denken, deren manche auch in neueren Zeiten bisweilen ganze Länder überfluthet hat”. (Idem. p. 330) Grifo nosso. 


\begin{abstract}
A Jacob Burckhardt em Basileia
Turin, 6 de janeiro de 1889

Querido Senhor Professor

Preferia finalmente de muito ser professor em Basileia do que Deus; mas não me atreveria levar tão longe o meu egoísmo privado até o ponto de omitir, por sua causa, a criação do mundo. Veja bem, devemos sacrificar-nos, independentemente da maneira e do lugar onde vivemos. Entretanto, reservei um pequeno quarto de estudante que se situa frente ao Palazzo Carignano ( - no qual nasci enquanto Vittorio Emanuele) e que, por outro lado, me permite ouvir, desde a minha mesa, a sumptuosa música que se faz debaixo de mim na Galeria Subalpina. Pago 25 fr. serviço incluído, ocupo-me eu mesmo do meu chá e de todas as compras, sofro com as minhas botas rasgadas e agradeço cada instante ao céu por este velho mundo para o qual os homens não foram suficientemente simples nem silenciosos. Como estou condenado a distrair a próxima eternidade com piadas de mau gosto, tenho aqui uma papelada que, para dizer a verdade, não é invejável, muito bela e nada cansativa. Os correios são a dois passos, é lá que ponho eu mesmo as cartas, para fazer o grande colunista do grande monde. Estou naturalmente em estreitas relações com o Figaro, e para que tenha uma ideia da minha inocuidade ouvi as minhas duas últimas piadas:
\end{abstract}

Não tome o caso Prado com excessiva severidade. Sou Prado, sou o pai de Prado, ouso dizer que sou também Lesseps... Queria dar aos meus parisienses, a quem amo, um novo conceito - o de um criminoso decente. Sou Chambige - também um criminoso honesto.

Segunda piada: eu saúdo os imortais. O Monsenhor Daudet pertence aos Quarenta.

Astu.

O que é desagradável e embaraçoso para a minha modéstia é que no fundo eu sou cada nome da história; mesmo com as crianças que pus no mundo, estou em examinar com uma certa desconfiança se todos os que vêm para o "Reino de Deus" vêm também de Deus.

(...)

Essa é a última carta de Nietzsche que se tem notícias.
An Jacob Burckhardt in Basel

<Turin,> Am 6 Januar 1889.

Lieber Herr Professor,

zuletzt wäre ich sehr viel lieber Basler Professor als Gott; aber ich habe es nicht gewagt, meinen PrivatEgoismus so weit $\mathrm{zu}$ treiben, um seinetwegen die Schaffung der Welt zu unterlassen. Sie sehen, man muß Opfer bringen, wie und wo man lebt. - Doch habe ich mir ein kleines Studenten-Zimmer reservirt, das dem Palazzo Carignano ( - in dem ich als Vittorio Emanuele geboren bin) gegenüber liegt und außerdem erlaubt, die prachtvolle Musik unter mir, in der Galleria Subalpina, von seinem Arbeitstisch aus zu hören. Ich zahle $25 \mathrm{fr}$. mit Bedienung, besorge mir meinen Thee und alle Einkäufe selbst, leide an zerrissenen Stiefeln und danke dem Himmel jeden Augenblick für die alte Welt, für die die Menschen nicht einfach und still genug gewesen sind. - Da ich verurtheilt bin, die nächste Ewigkeit durch schlechte Witze zu unterhalten, so habe ich hier eine Schreiberei, die eigentlich, nichts zu wünschen übrig läßt, sehr hübsch und ganz und gar nicht anstrengend. Die Post ist 5 Schritt weit, da stecke ich selber die Briefe hinein, um den großen Feuilletonisten der grande monde abzugeben. Ich stehe natürlich mit dem Figaro in näheren Beziehungen, und damit Sie einen Begriff bekommen, wie harmlos ich sein kann, so hören Sie meine ersten zwei schlechten Witze:

Nehmen Sie den Fall Prado nicht zu schwer. Ich bin Prado, ich bin auch der Vater Prado, ich wage zu sagen, daß ich auch Lesseps bin... Ich wollte meinen Parisern, die ich liebe, einen neuen Begriff geben - den eines anständigen Verbrechers. Ich bin auch Chambige auch ein anständiger Verbrecher.

Zweiter Witz. Ich grüße die Unsterblichen Monsieur Daudet gehört zu den quarante

Astu.

Was unangenehm ist und meiner Bescheidenheit zusetzt, ist, daß im Grunde jeder Name in der Geschichte ich bin; auch mit den Kindern, die ich in die Welt gesetzt habe, steht es so, daß ich mit einigem Mißtrauen erwäge, ob nicht Alle, die in das „Reich Gottes“ kommen, auch aus Gott kommen. (...)

(Grifo nosso) 


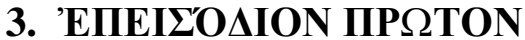

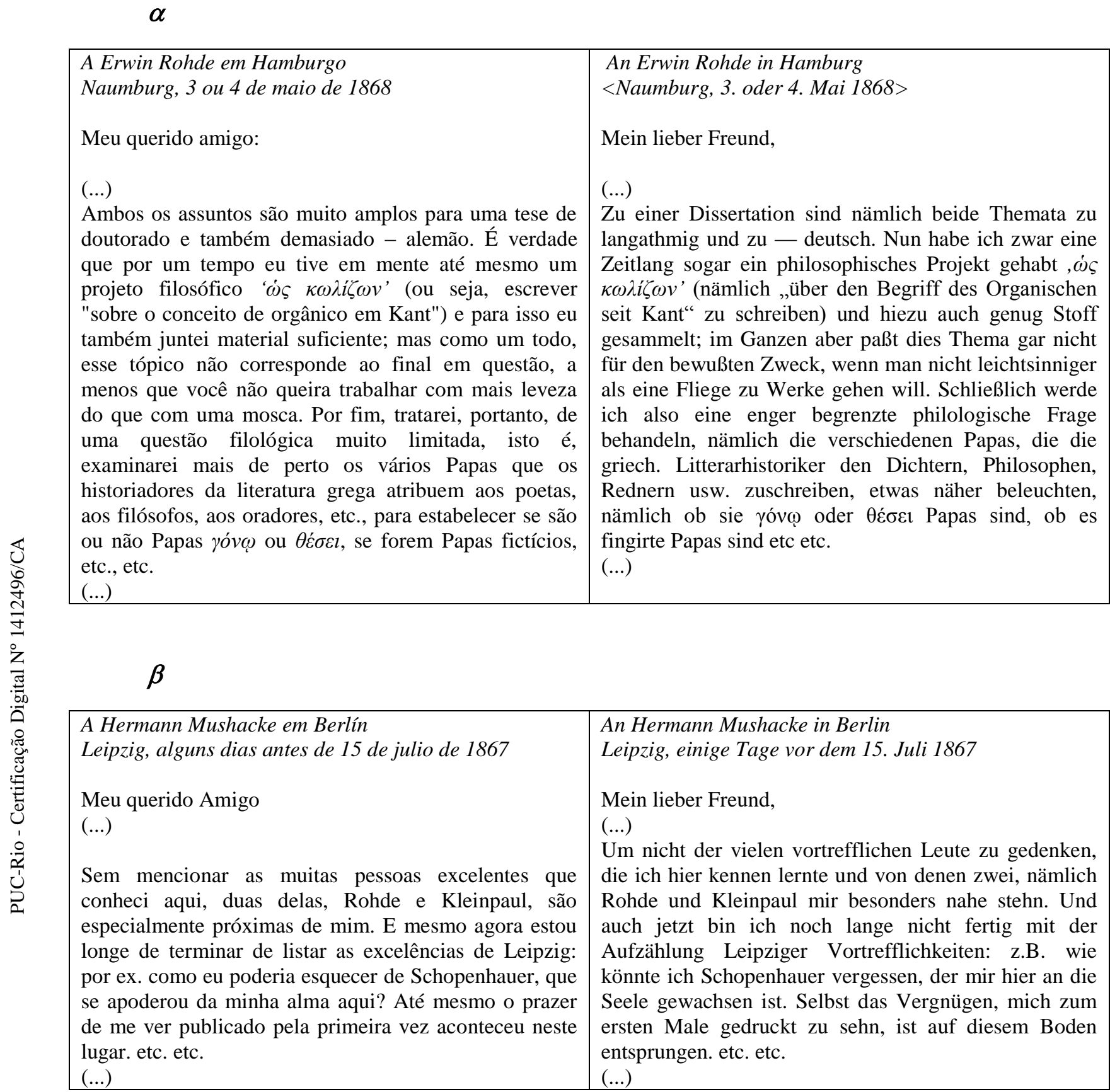

\section{$\gamma$}

A Carl von Gersdorff em Berlín

Naumburg 24 de novembro e 1 de dezembro de 1867

Meu querido amigo:

(...)

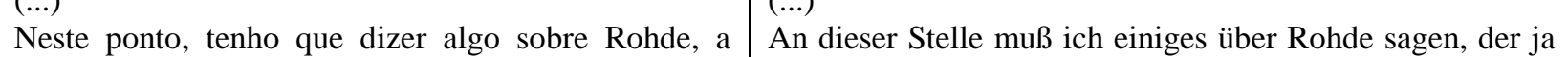

An Carl von Gersdorff in Berlin

Naumburg <24. November und> 1 Dez. 1867.

Mein lieber Freund,

(...) 
quem você conheceu há algum tempo. Nós dois estivemos quase todo o verão juntos e sentimos uma bela afinidade entre nós. É evidente que paira sobre essa amizade o gênio de quem Rohde me enviou uma foto há algumas semanas de Hamburgo: Schopenhauer. Imagino que você sentirá uma grande alegria pelo fato de que pessoas fortes e boas como Rohde, no melhor sentido da palavra, são cativadas por essa filosofia.

Já voltou a passar uma semana e é domingo, o único dia que posso cumprir meus deveres com as cartas. Mas, para retomar o discurso de onde o deixei há oito dias, vou contar outra influência de Schopenhauer. São dois trabalhos, um científico e um romance, ambos nascidos sob sua estrela. Talvez você já tenha ouvido falar sobre o livro que é intitulado Bahnsen, Contribución a la caracterología.

(...)

Em terceiro lugar, falarei a você sobre um evento com o qual Schopenhauer também está ligado em um contexto distante, embora ele não tenha sido a causa como afirmam os autoridades encarregadas. Trata-se do suicídio infeliz Kretzschmers na escola de Pforta. As razões são de fato desconhecidas ou são bem mantidas em segredo. Há algo de inexplicável no fato de que esse homem extraordinário e judicioso havia se casado há apenas três meses e, desse modo, também causou a infelicidade de uma jovem. Você sabe que ele também era um seguidor de Schopenhauer: e ainda a última vez que nós dois estivemos juntos em Almrich, falamos sobre a interpretação de Schopenhauer do suicídio.

(...)

Você compreenderá facilmente como essa transformação repentina foi surpreendente para mim, como foi violento afastar-me de minhas atividades habituais e de minha vida confortável. Apesar disso suporto esta mudança com espírito sereno e até sinto um certo prazer ante este golpe de destino. Agora sou muito grato ao nosso Schopenhauer, agora que tenho a oportunidade de praticar algo de $\ddot{\alpha} \sigma \kappa \eta \sigma \iota \varsigma$.

(...)

\section{A Carl von Gersdorff em Berlín}

Basileia, 11 de março de 1870

(...)

Para mim todo o melhor e mais belo está ligado aos nomes de Schopenhauer e Wagner, e estou orgulloso e feliz de meus amigos mais próximos concordarem com isso.

(...) auch Dir aus einer frühen Zeit her bekannt ist. Wir haben beide diesen Sommer fast immer zusammen gelebt und eine seltne Zusammengehörigkeit unter uns empfunden. Daß auch über diesem Freundschaftsbunde der Genius des Mannes schwebte, dessen Bild mir Rohde noch vor wenig Wochen aus Hamburg schickte, Schopenhauers, versteht sich von selbst. Du wirst, wie ich mir denke, darüber eine lebhafte Freude empfinden, daß gerade solche starke und gute Naturen, wie Rohde im besten Sinne ist, von jener Philosophie gepackt werden Wieder ist eine Woche vergangen, wieder ist es Sonntag, jetzt der einzige Tag, der mir zur Erfüllung meiner Briefpflichten übrig bleibt. Um aber ungefähr in dem Gedankenkreis zu bleiben, in dem ich mich vor 8 Tagen befand, erzähle ich Dir von anderem Einflusse Schopenhauers.

Da sind es zwei schriftstellerische Leistungen, eine wissenschaftliche und ein Roman, die unter diesem Gestirn geboren sind. Vielleicht hast $\mathrm{Du}$ schon von dem Buche gehört, das sich also betitelt „Bahnsen, Beiträge zur Charakterologie."

(...)

$\mathrm{Zu}$ dritt erzähle ich Dir von einem Ereigniß, mit dem Schopenhauer auch im fernen Zusammenhange steht, wenn er auch nicht, wie gutbesoldete Schulräthe behaupten, Ursache desselben ist. Es ist der unglückliche Selbstmord Kretzschmers in Schulpforte. Die Gründe sind thatsächlich nicht bekannt oder werden gut verschwiegen. Etwas Räthselhaftes liegt darin, daß der vortreffliche gewissenhafte Mensch sich ein Vierteljahr vorher noch verlobt hat und auf diese Weise noch ein junges Mädchen unglücklich macht. Daß er Anhänger Schopenhauers war, weißt Du: und noch das letzte Mal, als wir beide zusammen in Almrich waren, sprachen wir miteinander über Schopenhauers Auffassung des Selbstmordes.

(...)

Wie überraschend dieser Umschwung war, wie gewaltsam ich meinem gewöhnlichen Treiben und bequemen Dahinleben entfremdet wurde, wirst Du leicht nachfühlen. Trotzdem ertrage ich diese Veränderung gefaßten Muthes und empfinde sogar an diesem Streiche des Schicksals ein gewisses Behagen. Jetzt bin ich erst unserm Schopenhauer recht dankbar geworden, jetzt wo ich Gelegenheit habe, etwas $\ddot{\alpha} \sigma \kappa \eta \sigma \iota \varsigma$ zu treiben.

(...)

An Carl von Gersdorff in Berlin

<Basel, 11. März 1870>

(...)

Für mich knüpft sich alles Beste und Schönste an die Namen Schopenhauer und Wagner, und ich bin stolz und glücklich, hierin mit meinen nächsten Freunden gleichgestimmt zu sein

(...) 
$\delta$

A Carl von Gersdorff en Görlitz
7 de abril de 1866, Naumburg

(...)

De qualquer forma, não é possível ignorar que não compreendo completamente essa preocupação que me impus, que me distrai de mim (e de Schopenhauer - que muitas vezes chega a ser o mesmo), que por consequência me expõe ao julgamento do povo e até obriga-me a assumir a máscara de uma erudição que não tenho.

(...)

Minhas recreações, apesar de recreações raras, são três: meu Schopenhauer, a música de Schumann e, finalmente, as cominhadas solitários.

Ontem houve uma impressionante tempestade no céu, subi rapidamente para uma montanha próxima chamada "Leusch" (talvez você possa me interpretar essa palavra), e eu encontrei no topo uma cabana, um homem que sacrificou dois cabritos e seu filho. A tempestade descarregou violentamente com chuva de granizo; senti um entusiasmo inigualável e compreendi claramente que só podemos compreender a natureza quando somos forçados a nos refugiar nela de nossas preocupações e tormentos. Que era para mim o homem e seu desejo insaciável! O que foi para mim o eterno "tu deves", "não deves"! Quão distintos o raio, a tempestade, o granizo, poderes livres, sem ética! Quão felizes e quão poderosos eles são, pura Vontade, sem serem perturbados pelo intelecto!

Por outro lado, aprendi exemplos suficientes sobre como o intelecto é nebuloso com os seres humanos.

(...)

$* * *$

A Carl von Gersdorff, em campanha

Naumburg, final de agosto de 1866

(...)

Finalmente deve-se mencionar Schopenhauer de quem teho enorme simpatia.

(...)

A arte é livre, mesmo na esfera dos conceitos. Quem pretende refutar uma frase de Beethoven, e quem pretende reprovar algum erro a uma madonna de Rafael?

- Como você vê, mesmo neste ponto de vista crítico mais rigoroso sempre temos nosso Schopenhauer, além disso, ele se torna para nós quase algo mais. Se filosofia é arte, então Haym também deve se esconder diante de Schopenhauer; se a filosofia deve edificar, não conheço nenhum filósofo que edifique mais do que o nosso Schopenhauer.

(...)

Adieu, querido amigo,

seu F W. Nietzsche.
An Carl von Gersdorff in Görlitz

7 Apr. 1866. Naumburg.

(...)

$\mathrm{Zu}$ leugnen ist es übrigens nicht, daß ich mitunter kaum diese mir selbst aufgelegte Sorge verstehe, die mich von mir selbst abzieht, (dazu von Schopenhauer - was oftmals eins ist) mich in ihren Folgen dem Urtheile der Leute aussetzt und womöglich gar mich zur Maske einer Gelehrsamkeit zwingt, die ich nicht habe.

(...)

Drei Dinge sind meine Erholungen, aber seltne Erholungen, mein Schopenhauer, Schumannsche Musik, endlich einsame Spaziergänge.

Gestern stand ein stattliches Gewitter am Himmel, ich eilte auf einen benachbarten Berg, „Leusch“ genannt (vielleicht kannst Du mir dies Wort deuten) fand oben eine Hütte, einen Mann, der zwei Zicklein schlachtete, und seinen Jungen. Das Gewitter entlud sich höchst gewaltig mit Sturm und Hagel, ich empfand einen unvergleichlichen Aufschwung und ich erkannte recht, wie wir erst dann die Natur recht verstehen, wenn wir $\mathrm{zu}$ ihr aus unsern Sorgen und Bedrängnissen heraus flüchten müssen. Was war mir der Mensch und sein unruhiges Wollen! Was war mir das ewige „Du sollst“" „Du sollst nicht“! Wie anders der Blitz, der Sturm, der Hagel, freie Mächte, ohne Ethik! Wie glücklich, wie kräftig sind sie, reiner Wille, ohne Trübungen durch den Intellekt!

Dagegen habe ich Beispiele genug erfahren, wie trübe oftmals der Intellekt bei den Menschen ist.

(...)

\section{An Carl von Gersdorff im Feld}

<Naumburg, Ende August 1866>

(...)

Schließlich soll auch Schopenhauer noch erwähnt werden, an dem ich noch mit vollster Sympathie hänge. (...)

Die Kunst ist frei, auch auf dem Gebiet der Begriffe. Wer will einen Satz von Beethoven widerlegen, und wer will Raphaels Madonna eines Irrthums zeihen? $\mathrm{Du}$ siehst, selbst bei diesem strengsten kritischen Standpunkte bleibt uns unser Schopenhauer, ja er wird uns fast noch mehr. Wenn die Philosophie Kunst ist, dann mag auch Haym sich vor Schopenhauer verkriechen; wenn die Philosophie erbauen soll, dann kenne ich wenigstens keinen Philosophen, der mehr erbaut als unser Schopenhauer.

(...)

Adieu, lieber Freund,

Dein F W. Nietzsche. 


\begin{abstract}
A Hermann Mushacke em Berlín
Leipzig, 11 de julho de 1866

Querido amigo:

(...)

Mas o que eu mais quero é poder compartilhar pensamentos e experiências com você por um bom tempo: uma vez que Schopenhauer tirou as vendas do otimismo de nossos olhos, nosso olhar é mais aguçado. A vida é mais interessante, mesmo que perca a beleza.
\end{abstract}

(...)

Hoje envio calorosas felicitações pela sua saúde física e espiritual, pelos seus estudos e, finalmente, pela nossa amizade. Cumprimentos aos membros de sua venerada família da parte de seu

amigo

Friedr. Nietzsche

Elisenstr. 7, piso baixo.

Eu correspondi ansiosamente a Deussen, que lhe envia saudações de Tübingen. Ele é novamente o teólogo e, de fato, incorrigível (ou seja, apesar de Kant e Schopenhauer). Isso realmente me incomoda.

\section{An Hermann Mushacke in Berlin}

<Leipzig, 11. Juli 1866>

Lieber Freund,

(...)

Nichts wünschte ich aber mehr als wieder einmal längere Zeit persönlich mit Dir Gedanken und Erlebnisse austauschen zu können: denn seitdem Schopenhauer uns die Binde des Optimismus vom Auge genommen, sieht man schärfer. Das Leben ist interessanter, wenn auch häßlicher.

(...)

Heute bringe ich Dir meine warmen Glückwünsche für Dein körperliches und geistiges Wohl, für Dein Studium, endlich für unsre Freundschaft. Grüße Deine verehrten Angehörigen auf das Beste von Deinem

Freunde

Friedr. Nietzsche.

Elisenstr. 7. parterre.

Mit Deussen, der Dir seine Grüße aus Tübingen schickt, habe ich eifrig correspondirt. Er ist wieder theologus und zwar unverbesserlich (nämlich trotz Kant und Schopenhauer). Das thut mir geradezu wehe.

\section{$\zeta$}

A Carl von Gersdorff, dirigida a Núremberg

Leipzig, 15 de agosto de 1866

(...)

Caro amigo, é certamente puro egoísmo, mas você vai entender que eu especialmente te peça que volte a Leipzig. Existe alguém no mundo que eu possa conversar agora? Eu realmente não me importo com o número de pessoas que conheço; entre estes, há pessoas amáveis e inteligentes, das quais se destaca especialmente Kleinpaul. Mas o tempo em que eram feitas rapidamente amizades - palavra esta que significa muito mais - acabou para mim. Eu prefiro viver em uma certa solidão e escrever cartas para meus amigos verdadeiros em que peço que venham a Leipzig.

Eu também quero tentar influenciar Deussen por carta. Depois de nos escrever duas vezes, sua última carta continha a confissão de que "ele cometera loucura". Kant e Schopenhauer o ajudaram a enxergar com mais clareza. Quantos já não ajudaram! Apesar disso, ele quer levar seu jugo resignado até o fim. Na verdade, ele quer voltar para a filosofia depois de fazer seu exame de teologia.

(...)

\section{An Carl von Gersdorff, nach Nürnberg gerichtet Leipzig am 15 Aug. 1866.}

(...)

Lieber Freund, es ist zwar rein egoistisch, aber Du wirst es begreifen, wenn ich ganz besonders Dich bitte nach Leipzig wieder zu kommen. Mit wem in aller Welt soll ich mich jetzt aussprechen? Die Masse der Bekannten thuts wahrlich nicht; es sind viele liebenswürdige und verständige Menschen darunter, aus denen ich besonders Kleinpaul heraushebe. Aber die Zeit, wo man schnell Freundschaften — was doch viel mehr sagen will schließt, ist für mich vorüber. Lieber lebe ich da etwas einsam und schreibe Briefe an meine wirklichen Freunde, in denen ich sie bitte nach Leipzig zu kommen. Auch auf Deussen will ich noch versuchen brieflich einzuwirken. Nach dem wir uns zweimal geschrieben hatten, brachte sein letztes Schreiben das Bekenntniß, „er habe einen dummen Streich gemacht“. Kant und Schopenhauer haben ihm zu dieser Einsicht verholfen. Wie vielen haben sie nicht schon geholfen! Trotzdem will er sein Joch bescheiden zu Ende tragen; was ich gar nicht verstehe. Er will nämlich nach seinem ersten theologischen Examen zur Philologie zurückkehren. (...) 


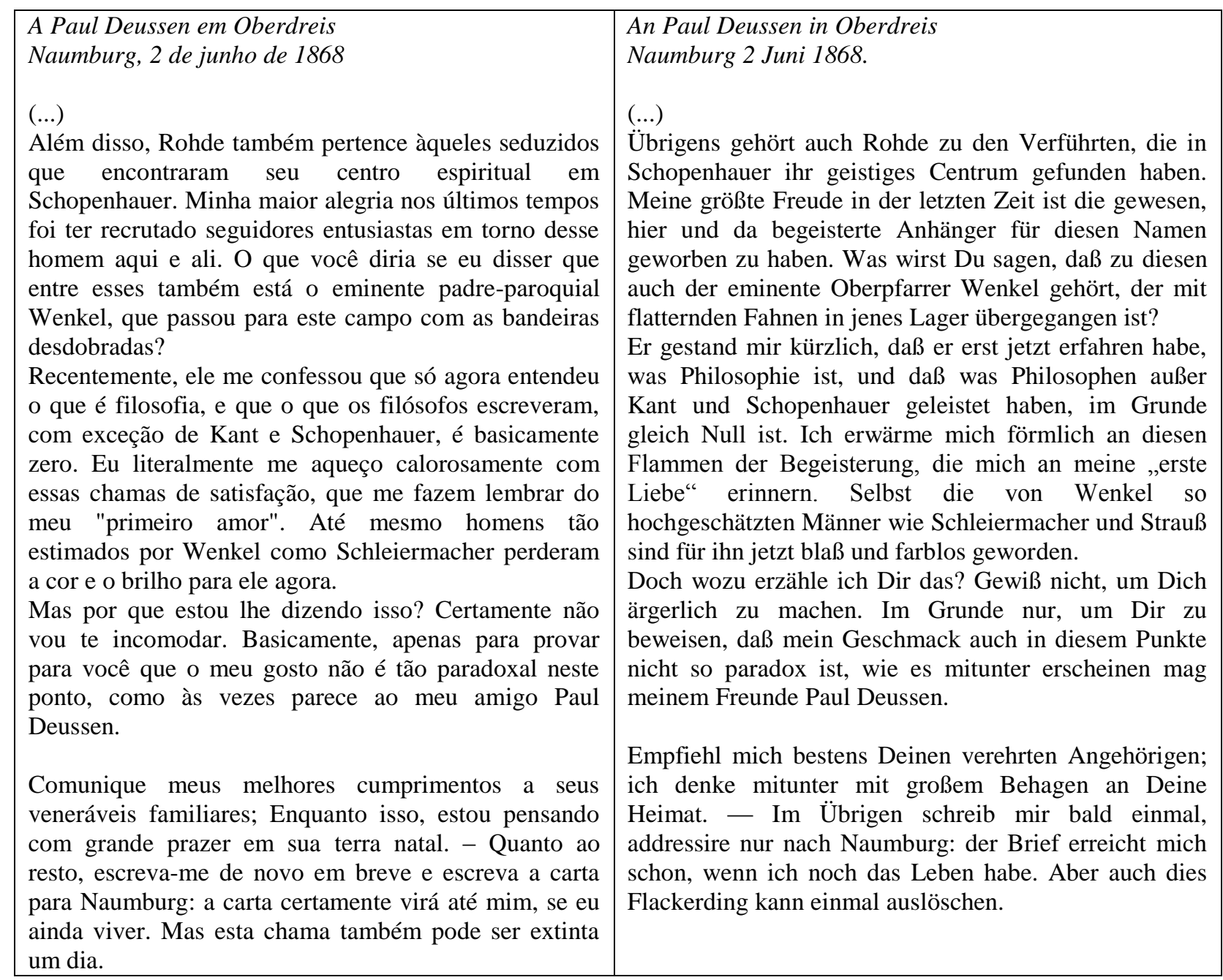

\section{$\theta$}

\begin{tabular}{l}
\hline A Erwin Rohde em Kiel \\
Naumburg, 6 de junho de 1868 \\
(...) \\
Se um destino favorável o tivesse permitido e você \\
também tivesse vindo durante este Pentecostes para o \\
tranquilo Naumburg, eu teria tido a alegria de poder \\
mostrar-lhe duas coisas novas e belas: um bom livro e \\
um novo amigo de Schopenhauer. \\
(...) \\
O novo amigo de Schopenhauer é o pastor episcopal \\
Wenkel, que você já conhece. Estou muito feliz com essa \\
transformação e conversão, e no ardente entusiasmo \\
desse homem, eu revivo a primeira embriaguez do "amor \\
juvenil", aqueles dias de outono em Leipzig, quando, \\
pela primeira vez, a melodia mágica de Schopenhauer \\
tocou profundamente meu coração. \\
O próprio Wenkel confessou-me que não entendera até \\
agora o que é filosofia, que só agora a vida começa a
\end{tabular}

An Erwin Rohde in Kiel

Naumburg, <6.> Juni. 〈1868>

Wenn ein günstiges Geschick es erlaubt hätte und $\mathrm{Du}$ auch dieses Pfingsten in dem stillen Naumburg eingekehrt wärest, so würde ich die Freude gehabt haben, Dir zwei neue und schöne Dinge zeigen zu können: ein gutes Buch und einen neuen Schopenhauerfreund.

(...)

Das Buch erstens heißt „die drei Pfade“ und ist von einem Engländer Herbert Grey geschrieben. Der neue Schopenhauerfreund ist der auch Dir bekannt gewordne Oberpfarrer Wenkel. Ich freue mich erstaunlich über diese Um- und Einkehr und erlebe in der Begeisterungsflamme dieses Mannes von neuem den ersten Rausch der ,jungen Liebe“, jene Leipziger Herbsttage, in denen zum ersten Male jene wundersame 
despertar para ele e que ele vagara anteriormente como num sonho. Ele disse agora que o trabalho dos filósofos, com exceção de Kant e Schopenhauer, não valeria nada. Até mesmo Schleiermacher e sua adorada [escola de teologia de] Tübinger pareciam agora lânguidos e pálidos. Ele também pendurou o retrato de Schopenhauer em sua sala de estudos. Suas conversas giram preferencialmente em torno dos problemas éticos: se você fosse a Naumburg, teria a satisfação de ouvir Schopenhauer do púlpito.

$\mathrm{O}$ que ainda tem um valor especial para mim é que Wenkel sente um profundo respeito pela personalidade, também moral, de Schopenhauer. Esse acréscimo à nossa congregação é realmente significativo, especialmente porque Wenkel tem a capacidade de despertar entusiasmo e, em toda parte, com a ânsia de um novo convertido direciona as pessoas para o homem cujo nome, quando ele ainda era um Saulo, desagradava profundo e intimamente. -

Hast Du gerade Beine? So hab ich bald keine? -
Schopenhauersche Musik mir das Herz im Tiefsten löste. Wenkel selbst gestand mir, daß er jetzt erst erfahren habe, was Philosophie sei, daß jetzt erst das Leben sich ihm zu erschließen anfange und daß er früher wie im Traume gewandelt sei. Was außer Kant und Schopenhauer die Philosophen geleistet hätten, das schätze er jetzt keinen Deut. Selbst Schleiermacher und seine geliebten Tübinger erscheinen ihm jetzt matt und farblos. Auch er hat jetzt das Bild Schopenhauers in seiner Studirstube aufgehängt. Seine Gespräche haben gar kein anderes und lieberes Objekt als ethische Probleme; wärst $\mathrm{Du}$ in Naumburg, so hättest $\mathrm{Du}$ das Vergnügen Schopenhauer von der Kanzel herab zu hören. Was mir noch besonders werth ist: Wenkel hat einen mächtigen Respekt vor der Persönlichkeit, auch vor der moralischen Sch.'s. Dieser Zuwachs zu unsrer Gemeine ist wirklich ein bedeutender, besonders da Wenkel die Fähigkeit hat Begeisterung zu wecken und überall jetzt mit dem Eifer eines Neubekehrten die Leute auf jenen Mann hinweist, dessen Name ihm selbst, als er noch ein Saulus war, gründlich und innerlich mißfiel. -

F N. Hast Du gerade Beine? -

So hab ich bald keine? -

\section{$\boldsymbol{l}$}

\section{A Wilhelm Vischer(-Bilfinger) em Basileia}

Basileia, provavelmente janeiro de 1871

Estimado Senhor e Conselheiro:

Para o projeto que lhe explicarei a seguir, preciso de maneira especial seu conselho benevolente e sua sincera simpatia, que você me mostrou tantas vezes. Como verá eu considerei seriamente o bem-estar da universidade e que seu real interesse me leva à seguinte exposição: meus médicos lhe dirão de que maneira estou doente de novo e que a causa desse estado insuportável é o trabalho excessivo.

(...)

Eu vivo em um conflito único, e é isso que me exaure $\mathrm{e}$ isso me consome, inclusive fisicamente. $\mathrm{Eu}$, por natureza, sinto fortemente compelido a examinar filosoficamente coisas como um todo unitário e para perseverar em um problema com continuidade sem ser molestado, com longas cadeias de pensamento, me sinto sempre atraído para lá e para cá e desviado de meu caminho pelas multiplas tarefas profissionais. A longo prazo, eu não suporto essa coexistência de instituto e universidade, porque sinto que a minha verdadeira tarefa, que, se necessário, deveria sacrificar tada profissão, minha tarefa filosófica, sofre com o fato de ser reduzida à ocupação marginal. Acho que essa descrição indica claramente o que me

\section{An Wilhelm Vischer(-Bilfinger) in Basel}

Basel, vermutlich Januar 1871

Verehrtester Herr Rathsherr,

für die nachfolgende Combination brauche ich in besonderem Maße Ihren wohlwollenden Rath und Ihre mir schon mehrfach bewährte wahre Theilnahme. Sie werden sehen, daß ich das Wohl der Universität ernsthaft in's Auge gefaßt habe, und daß deren wirkliches Interesse mich $\mathrm{zu}$ der folgenden, etwas ausführlichen Auseinandersetzung nöthigt.

(...)

Ich lebe hier in einem eigenthümlichen Konflikt, und der ist es, der mich so erschöpft und selbst körperlich aufreibt. Von Natur auf das Stärkste dazu gedrängt, etwas Einheitliches philosophisch durchzudenken und in langen Gedankenzügen andauernd und ungestört bei einem Problem zu verharren, fühle ich mich immer durch den täglichen mehrfachen Beruf und dessen Art hin und her geworfen und aus der Bahn abgelenkt. Dieses Nebeneinander von Pädagogium und Universität halte ich kaum auf die Länge aus, weil ich fühle, daß meine eigentliche Aufgabe, der ich im Nothfalle jeden Beruf opfern müßte, meine philosophische, dadurch leidet, ja zu einer Nebenthätigkeit erniedrigt wird. Ich glaube daß diese Schilderung auf das Schärfste das bezeichnet, was mich hier so aufreibt und mich zu keiner 
consome e o que não me deixa cumprir meu trabalho de forma serena e equilibrada, que, por outro lado, me esgota fisicamente e acaba gerando males como os atuais: se retornassem com frequência, me obrigariam, por razões puramente físicas, a abandonar a profissão filológica.

Nesse sentido, permito-me propor minha candidatura para a Cadeira de filosofia deixada livre pela partida de Teichmüller.

Quanto à minha legitimidade para ambicionar a cadeira de filosofia: na verdade, devo testemunhar a meu favor que acredito ter as habilidades e os conhecimentos necessários e até me sinto, em geral, mais empoderado para essa posição do que para uma posição filológica. Quem me conhece desde meus anos como estudante nunca duvidou da prevalência em mim de inclinações filosóficas; e também nos estudos filológicos fui atraído com preferência pelo que me pareceu mais significativo, seja pela história da filosofia, seja pelos problemas éticos e estéticos. Por outro lado, concordo inteiramente com o seu parecer, e acrescento a meu favor, que, dada a difícil situação atual da filosofia na universidade e os poucos candidatos verdadeiramente qualificados, tem mais direito quem possa demonstrar uma sólida formação filológica e despertar nos alunos o interesse por uma minuciosa interpretação de Aristóteles e Platão. Eu quero lembrar que acabei de anunciar dois cursos que são filosóficos por natureza neste sentido: "Os filósofos pré-platônicos com interpretação de fragmentos escolhidos" e "Sobre questões platônicas". Desde que estudei filologia, nunca me cansei de manter contato íntimo com a filosofia; então, meu principal interesse sempre foi orientado para questões filosóficas, como pode ser testemunhado por aqueles que lidaram comigo. Entre os colegas aqui, por exemplo, Overbeck poderia dar alguma informação sobre isso, de fora ninguém poderia fazer melhor do que o meu amigo Dr. Rohde, professor em Kiel. Na verdade, é preciso atribuir apenas ao azar que não fiz meus planos universitários em filosofia desde o início: ao azar sou privado de ser um professor de filosofia significativo e verdadeiramente estimulante: do qual certamente não se pode maravilhar com a atual constelação de filosofia. Filosofia na universidade. Certamente um dos meus mais vívidos desejos seria preenchido se eu pudesse também seguir aqui a vóz da minha natureza: e acho que posso esperar que, eliminando o conflito mencionado anteriormente, meu estado físico de saúde também seria muito mais estável. Muito em breve poderei me apresentar publicamente como qualificado para uma cadeira de filosofia: meus trabalhos publicados sobre Diógenes Laércio também podem ser válidos em qualquer caso para minhas aspirações histórico-filosóficas. Sempre me interessei por questões e investigações pedagógicas: ser capaz de ensinar lições sobre isso será uma alegria para gleichmäßig-heiteren Berufserfüllung kommen läßt, was andernseits meinen Körper erschöpft und bis zu solchen Leiden anwächst, wie die jetzigen sind: die, wenn sie öfter wiederkehren sollten, mich rein physisch zwingen würden, jeden philologischen Beruf aufzugeben.

In diesem Sinne erlaube ich mir, mich bei Ihnen um die durch Teichmüllers Weggang erledigte philosophische Professur zu bewerben.

Was meine persönliche Berechtigung, den philosophischen Lehrstuhl zu ambitionieren, betrifft: so muß ich allerdings mein eignes Zeugniß voranstellen, daß ich dazu Potenz und Kenntnisse zu besitzen glaube und mich sogar, Alles in Allem, für jenes Amt befähigter fühle als für ein rein philologisches. Wer mich von meinen Schul- und Studentenjahren kennt, ist nie über die Prävalenz der philosophischen Neigungen im Zweifel gewesen; und auch in den philologischen Studien hat mich vorzugsweise das angezogen, was entweder für die Geschichte der Philosophie oder für die ethischen und aesthetischen Probleme mir bedeutsam erschien. Sodann stimme ich völlig Ihrem Urtheile bei und mache es für mich geltend, daß bei der augenblicklichen etwas schwierigen Lage der Universitätsphilosophie und bei der geringen Zahl der wirklich geeigneten Bewerber derjenige einiges Anrecht mehr hat, der eine solide philologische Bildung aufzuweisen hat und bei den Studierenden die Theilnahme für eine sorgfältige Interpretation des Aristoteles und Plato wecken kann. Ich erinnere daran, daß ich bereits zwei Collegien angekündigt habe, die in diesem Sinne philosophischer Natur waren ,die vorplatonischen Philosophen mit Interpretation ausgewählter Fragmente“ und „über die platonische Frage." So lange ich Philologie studiere, bin ich nie müde geworden, mich mit der Philosophie in enger Berührung zu erhalten; ja meine Haupttheilnahme war immer auf Seiten der philosophischen Fragen, wie mir mancher bezeugen kann, der mit mir umgegangen ist. Von hiesigen Collegen möchte zB. Overbeck darüber einigen Aufschluß geben können, von Auswärtigen Keiner mehr als mein Freund Dr. Rohde Privatdozent in Kiel. Es ist eigentlich nur dem Zufall zuzuschreiben, daß ich nicht von vornherein für Philosophie meine Universitätspläne gemacht habe: dem Zufall, der mir einen bedeutenden und wahrhaft anregenden philosophischen Lehrer versagte: worüber man bei der jetzigen Constellation der philosophischen Zustände an Universitäten sich gewiß nicht wundern darf. Gewiß aber würde hierin einer meiner wärmsten Wünsche erfüllt, wenn ich auch hier der Stimme meiner Natur folgen dürfte: und ich glaube hoffen zu können, daß nach Beseitigung jenes vorhin erwähnten Conflikts auch mein körperliches Befinden ein bei weitem regelmäßigeres sein wird. Als befähigt für eine philosophische Lehrstelle werde ich mich bald genug öffentlich ausweisen können: meine gedruckten Arbeiten über Laert. Diog. sind jedenfalls auch für meine philosophisch-historischen Bestrebungen geltend zu machen. Für pädagogische Fragen und Untersuchungen habe ich immer Theilnahme 
mim. Entre os filósofos recentes, estudei Kant e Schopenhauer com uma predileção especial. Nos últimos dois anos, tenho certeza de que recebeu de mim a boa impressão de evitar impropriedade e escândalo e que posso diferenciar o que é apropriado e dizer aos alunos o que não é.

Se você permitir que eu explique o meu projeto na íntegra, penso que você encontraria em Rohde um sucessor muito apropriado para minha cátedra em filologia e o lugar no instituto. Rohde, a quem eu conheço perfeitamente há quatro anos, é a mais qualificado entre todos os jovens filólogos que conheci e uma jóia para a universidade que o conquistar; além disso, ele ainda está disponível, embora eu tenha ouvido que em Kiel eles estão planejando permanentemente mantê-lo através da fundação de uma nova cadeira extraordinária de filologia.

Eu não posso expressar o suficiente como aliviaria minha existência a proximidade do meu melhor amigo aqui em Basileia. Toda essa mudança poderia começar imediatamente com o início do novo semestre de verão, para que não houvesse lacuna na ocupação do instituto. De minha parte, eu estaria pronto para anunciar minhas lições de filosofia e começar minha nova posição dando uma aula inaugural no começo do semestre.

Não tenha medo, caro conselheiro, pela singularidade do projeto proposto e torná-lo digno de sua consideração

Invocando sua indulgência, seus conselhos e sua simpatia,

Eu permaneço seu com a lealdade mais respeitosa

Dr. Fr. Nietzsche

Prof. $o$. p. da clas. filol. gehabt: darüber lesen zu dürfen wird mir eine Freude sein. Von neueren Philosophen habe ich mit besonderer Vorliebe Kant und Schopenhauer studiert. Sie haben aus den letzten 2 Jahren gewiß von mir den guten Glauben gewonnen, daß ich das Unpassende und Anstößige zu vermeiden verstehe und daß ich unterscheiden könne, was sich im Vortrag vor Studierenden schickt, was nicht.

Wenn ich Ihnen nun meine Kombination völlig darstellen darf, so hatte ich geglaubt, daß Sie in Rohde einen überaus geeigneten Nachfolger für meine philologische Professur und Stelle am Pädagogium finden würden. R., mir seit 4 Jahren auf das Genaueste bekannt, ist von allen jüngeren Philologen, die mir vorgekommen sind, der allerbefähigste und für jede Universität, die ihn erwirbt, ein wahrer Schmuck; zudem ist er wirklich noch zu haben, während ich höre, daß man in Kiel damit umgeht, durch Gründung einer neuen philolog. außerordentl. Professur ihn dauernd dort festzuhalten. Ich kann nicht genug aussprechen, wie sehr mir das Dasein hier in Basel durch die Nähe meines besten Freundes erleichtert würde. - Die ganze Konversion der Dinge könnte sofort mit dem Beginn des neuen Sommersemesters beginnen, so daß also keinerlei Lücken in der Besetzung der Stellen eintrete. Ich meinerseits wäre sofort bereit, Ihnen die Ankündigung meiner philosoph. Vorlesungen zu machen und würde durch eine regelmäßige Antrittsvorlesung im Anfange des Sommers meine neue Stellung inaugurieren.

Lassen Sie sich, verehrtester Herr Rathsherr, von der Sonderbarkeit der vorgeschlagnen Combination nicht erschrecken und würdigen Sie dieselbe einer Erwägung.

Um Ihre Nachsicht, Ihren Rath, Ihre Theilnahme bittend

bin ich in hochachtungsvoller

Ergebenheit der Ihrige

Dr. Fr. Nietzsche

Prof. o. p. der klass. Philol.

\section{$\kappa$}

\section{A Erwin Rohde em Hamburgo}

Leipzig, 9 de novembro de 1868

(...)

Entramos em uma sala muito aconchegante do Brockhaus. Só estão presentes a família mais próxima, Richard e nós dois. Sou apresentado a Richard e lhe dirijo algumas palavras de admiração; ele quer saber exatamente como me familiarizei com sua música, ele renega veementemente todas as performances de suas óperas, com exceção das famosas de Munique, e faz piada dos diretores que, com tom suave, interpelam sua orquestra dizendo: "Senhores, agora apaixonadamente"
An Erwin Rohde in Hamburg

<Leipzig, 9. November 1868>

(...)

Wir kommen in dem sehr behaglichen Salon Brockhaus an: es ist niemand weiter vorhanden als die engste Familie, Richard und wir beide. Ich werde Richard vorgestellt und rede zu ihm einige Worte der Verehrung: er erkundigt sich sehr genau, wie ich mit seiner Musik vertraut geworden sei, schimpft entsetzlich auf alle Aufführungen seiner Opern, mit Ausnahme der berühmten Münchener und macht sich über die Kapellmeister lustig, welche ihrem Orchester im 
"Queridos, ainda um pouco mais apaixonadamente!". Wagner se diverte imitando o dialeto de Leipzig. Agora vou dizer-lhe brevemente o que nos ofereceu esta noite: emoções tão agradável e um sabor tão forte, que ainda estou embargado por eles, e não posso fazer nada melhor do que te falar, meu caro amigo, e anunciar "uma maravilhosa novidade". Antes e depois do jantar, Wagner tocava ao piano todas as passagens importantes de Masters cantores, imitando todas as vozes de maneira muito desinibida. Ele é um homem fabulosamente vivaz e ardente, ele fala muito rápido, é muito engraçado e consegue fazer uma reunião de natureza privada como essa inteiramente feliz. Enquanto isso, tive uma longa conversa com ele sobre Schopenhauer: Ah! Você entende que a alegria era para mim ouvi-lo falar sobre isso com um entusiasmo totalmente indescritível, ele admirava como Schopenhauer foi o único filósofo que compreendeu a essência da música; então ele quis saber qual era a atitude dos professores sobre esse filósofo, riu muito sobre o Congresso de Filosofia de Praga e falou sobre "os filósofos vassalos".

Depois ele leu parte de sua biografia, que está escrevendo agora, uma cena tão assustadora de sua vida como estudante em Leipzig, que ainda quando penso nisso não consigo parar de rir; ele escreve de uma maneira muito ágil e brilhante. No final, quando estávamos nos preparando para sair, ele apertou minha mão calorosamente e me convidou com grande bondade a visitá-lo para discutir música e filosofia. Ele também me encarregou de conhecer sua irmã, sua família e sua música: algo que eu aceitei solenemente. -

Contarei-lhe mais quando me dispuser, mais tarde, de mais objetividade.

Para hoje, uma despedida afeiçoada e os melhores desejos para a sua saúde.

FN.

(...) gemüthlichen Tone zurufen: „meine Herren, jetzt wird's leidenschaftlich“, „Meine Gutsten, noch ein bischen leidenschaftlicher!" W. imitirt sehr gern den Leipziger Dialekt. -

Nun will ich Dir in Kürze erzählen, was uns dieser Abend bot, wahrlich Genüße so eigenthümlich pikanter Art, daß ich auch heute noch nicht im alten Gleise bin, sondern eben nichts besseres thun kann, als mit Dir, mein theurer Freund, zu reden und „,wundersame Mär“ zu künden. Vor und nach Tisch spielte Wagner und zwar alle wichtigen Stellen der Meistersinger, indem er alle Stimmen imitirte und dabei sehr ausgelassen war. Es ist nämlich ein fabelhaft lebhafter und feuriger Mann, der sehr schnell spricht, sehr witzig ist und eine Gesellschaft dieser privatesten Art ganz heiter macht. Inzwischen hatte ich ein längeres Gespräch mit ihm über Schopenhauer: ach, und Du begreifst es, welcher Genuß es für mich war, ihn mit ganz unbeschreiblicher Wärme von ihm reden zu hören, was er ihm verdanke, wie er der einzige Philosoph sei, der das Wesen der Musik erkannt habe: dann erkundigte er sich, wie sich jetzt die Professoren $\mathrm{zu}$ ihm verhalten, lachte sehr über den Philosophencongreß in Prag und sprach ,von den philosophischen Dienstmännern.“

Nachher las er ein Stück aus seiner Biographie vor, die er jetzt schreibt, eine überaus ergötzliche Scene aus seinem Leipziger Studienleben, an die ich jetzt noch nicht ohne Gelächter denken kann; er schreibt übrigens außerordentlich gewandt und geistreich. - Am Schluß, als wir beide uns zum Fortgehen anschidtten, drückte er mir sehr warm die Hand und lud mich sehr freundlich ein, ihn zu besuchen, um Musik und Philosophie zu treiben, auch übertrug er mir, seine Schwester und seine Anverwandten mit seiner Musik bekannt zu machen: was ich denn feierlich übernommen habe. -

Mehr sollst Du hören, wenn ich diesem Abende etwas objektiver und ferner gegenüberstehe.

Heute ein herzliches Lebewohl und beste Wünsche für Deine Gesundheit.

FN.

(...) 
A Carl von Gersdorff

Leipzig, quarta-feira 16 de janeiro de 1867

Meu querido amigo,

também foi no início de janeiro, quando eu também estava ao lado de um leito de morte, a de um parente próximo, que depois da minha mãe e minha irmã tinha mais direito de meu amor e meu respeito; foi ela quem tinha participado fielmente dos acontecimentos da minha vida e com ela se foi toda uma parte do meu passado e da minha infância. Mas quando recebi sua carta, meu querido, meu pobre amigo tão golpeado, foi uma dor intensa, a diferença entre as duas mortes era muito grande; em um caso que chegou ao fim uma vida aproveitada com boas ações, e levado para a velhice com um corpo fraco: todos nós tínhamos a sensação de que as forças do corpo e do espírito tinham sido esgotadas e que a morte logo levaria nossa querida. Mas com o seu irmão, a quem sempre apreciei e admirei, o que perdemos!

Perdemos uma dessas nobres e raras naturezas romanas, e de que Roma, em seu auge, teria se sentido orgulhosa de modo que como teu irmão tem muito mais direito de estar orgulhoso.

Como é estranho que nosso tempo insignificante gere tais heróis! Mas você sabe o que os antigos pensavam sobre isso: "O favorito dos deuses morre logo".

(...)

Essa morte foi talvez a maior dor que poderia atingir você.

Bem, caro amigo, agora - pelo tom de sua carta - você experimentou em si mesmo o porquê nosso Schopenhauer exalta o sofrimento e as tribulações como um destino esplêndido, como $\delta \varepsilon v ́ \tau \varepsilon \rho o \varsigma ~ \pi \lambda$ oṽ , a a negação de Vontade.

Você experimentou e também percebeu o poder purificador da dor que se acalma e fortalece no interior. Estamos em uma época em que você mesmo pode provar quanto há de verdade na doutrina de Schopenhauer. Se o quarto livro do seu trabalho principal agora vai provocar uma impressão desagradável, deprimente e irritante se você não tem a força de sustentação para fazer deixar a dor mais extrema, para levá-lo àquele estado melancólico, mas feliz, que nos une também ao ouvirmos de uma música nobre, àquele estado em que alguém está despojado de seus restos mortais: então eu não quero ter nada a ver com essa filosofia. Só quem tem um coração cheio de dor pode e deve falar uma palavra decisiva sobre essas coisas: nós, imersos no fluxo de acontecimentos e da vida, e apenas ansiosos para essa negação da vontade como uma ilha das bem-aventuranças, não podemos julgar se o consolo de tal filosofia é suficiente também para o tempo de uma profunda desolação.

(...)
An Carl von Gersdorff in Spandau

Leipzig Mittwoch. <16. Januar 1867>

Mein lieber Freund,

es war ebenfalls in den ersten Tagen des Januars, wo auch ich in Naumburg an einem Sterbebette stand, an dem einer nahen Verwandten, die nächst Mutter und Schwester die nächsten Anrechte auf meine Liebe und Verehrung hatte, die treulich an meinem Lebenswege Antheil genommen hatte, und mit der ein ganzes Stück meiner Vergangenheit und vornehmlich meiner Kindheit von uns gewichen ist. Und doch, als ich Deinen Brief empfieng, mein lieber, armer, schwergetroffner Freund, ergriff mich ein viel heftigerer Schmerz: war doch auch der Unterschied der beiden Sterbefälle so groß. Dort war ein Leben vollbracht, mit guten Handlungen ausgenützt, mit schwachem Körper bis zum Alter getragen: wir hatten alle die Empfindung, daß die Kräfte des Körpers und Geistes verzehrt waren und daß der Tod nur für unsre Liebe zu früh komme. Aber was schied mit Deinem auch von mir stets bewunderten und verehrten Bruder.

Es schied von uns eine jener seltnen, edlen Römernaturen, auf die Rom in seiner besten Zeit stolz gewesen wäre, auf die Du als Bruder noch viel mehr Anrecht hast stolz zu sein. Denn wie selten bringt unsre erbärmliche Zeit solche Heldengestalten hervor. Aber Du weißt es ja, wie die Alten darüber denken: „der Götter Lieblinge sterben früh.“

(..)

Nun, lieber Freund, Du hast jetzt - das merke ich an dem Tone Deines Briefes - jetzt selbst an Dir erfahren, warum unser Schopenhauer das Leiden und die Trübsale als ein herrliches Geschick, als den $\delta \varepsilon v ́ \tau \varepsilon \rho \circ \varsigma \pi \lambda \circ \tilde{\text { c }}$ zur Verneinung des Willens preist. Du hast auch die läuternde, innerlich beruhigende und festigende Kraft des Schmerzes erfahren und empfunden. Es ist eine Zeit, in der Du selbst erproben kannst, was wahr ist an der Lehre Schopenhauers. Wenn das vierte Buch seines Hauptwerkes jetzt auf Dich einen häßlichen, trüben, lästigen Eindruck macht, wenn es nicht die Kraft hat, Dich zu erheben und Dich aus dem äußeren heftigen Schmerze hindurchzuführen zu jener wehmüthigen, aber glücklichen Stimmung, die uns auch beim Anhören edler Musik ergreift, zu jener Stimmung, in der man die irdischen Hüllen von sich abfallen sieht: dann mag auch ich nichts mehr mit dieser Philosophie zu thun haben. Der Schmerzerfüllte kann und darf allein über solche Dinge ein entscheidendes Wort sagen: wir anderen mitten im Strome der Dinge und des Lebens stehend, jene Verneinung des Willens nur ersehnend als ein glückseliges Eiland, wir können es nicht beurtheilen, ob der Trost solcher Philosophie auch für die Zeiten tiefer Trauer ausreicht.

(...) 


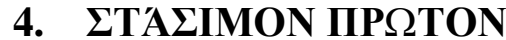

$\alpha$

\begin{abstract}
A Heinrich Köselitz in Veneza
Nice, de 6. Jan. 1888

(...)

$\mathrm{Na}$ quinta-feira passada fiz minha primeira visita a Monte Carlo para um concert classique (que também contou com a presença do Imperador do Brasil), somente a mais alta música francesa moderna: ou, para falar mais claramente, só Wagner de má qualidade. Eu não suporto esta música pitoresca sem ideias, sem forma, sem qualquer ingenuidade e nem verdade. Nervosa, brutal, insuportavelmente insistente e soberba - e tão maquiada!! Uma das peças era de tempestade no mar, outra era uma caçada selvagem, a terceira era um balé de Erínias (para a Oresteia de Ésquilo!!!)
\end{abstract}

Isso é décadence ...

Quando as escutava, pensei na música do meu maestro veneziano [Heinrich Köselitz] como uma felicidade perdida; outubro, ao seu lado, foi o único refrigério que tive este ano, por isso não posso ser grato o suficiente.
An Heinrich Köselitz in Venedig

Nizza, den 6. Jan. 1888

(...)

Vorigen Donnerstag habe ich meinen ersten Besuch in Monte Carlo gemacht, zu einem concert classique (welchem auch der Kaiser von Brasilien beiwohnte) Lauter modernste französische Musik: oder vielmehr, deutlicher zu reden, lauter schlechter Wagner. Ich halte diese pittoreske Musik ohne Ideen, ohne Form, ohne jedwede Naivetät und Wahrheit nicht mehr aus. Nervös, brutal, unausstehlich zudringlich und großthuerisch und so geschminkt!! Das Eine war eine Art Seesturm, das Andre eine wilde Jagd, das dritte ein ErinnyenBallet (zur Oresteia des Aeschylus!!!)

Dies ist décadence..

Dabei gedachte ich wie eines verlorenen Glückes der Musik meines Venediger maestro; der Oktober bei Ihnen war dies Jahr mein einziges Labsal, ich kann Ihnen nicht dankbar genug sein.

Do coração do seu amigo

Von Herzen Ihr Freund

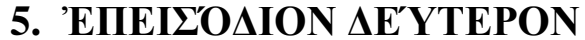

\section{$\alpha$}

A Reinhardt von Seydlitz em Berlim
Basilea 24 set. 1876
Querido e estimado senhor,
depois de uma carta assim, um testemunho
emocionante de sua alma e seu espírito, eu não posso
dizer nada: salvo apenas isto - mantenha contato,
vamos tentar não nos perder uma vez que nos
encontramos! Tenho diante de mim a linda certeza de
ter ganho outro amigo verdadeiro. Se você soubesse o
que isso significa para mim! Na verdade, estou
sempre à caça de homens, como um corsário, mas
não para vendê-los como escravos, mas para libertá-
las. Eu gostaria que passássemos uma temporada
juntos: dado que meus olhos (que estão sendo
tratados com uma cura atropina) me impedem de uma
comunicação epistolar, se algo assim é possível; coisa
que duvido.

A Reinhardt von Seydlitz em Berlim

Querido e estimado senhor,

depois de uma carta assim, um testemunho dizer nada: salvo apenas isto - mantenha contato, vamos tentar não nos perder uma vez que nos encontramos! Tenho diante de mim a linda certeza de que isso significa para mim! $\mathrm{Na}$ verdade, estou sempre à caça de homens, como um corsário, mas não para vendê-los como escravos, mas para libertájuntos: dado que meus olhos (que estão sendo

\section{An Reinhart von Seydlitz in Berlin}

Basel 24 Sept. 1876.

Lieber und werther Herr,

nach einem solchen Briefe, einem so ergreifenden Zeugnisse Ihrer Seele und Ihres Geistes kann ich nichts sagen: als allein dies - bleiben wir uns nahe, sehen wir zu dass wir uns nicht wieder verlieren, nachdem wir uns gefunden haben! Ich sehe die schöne Gewissheit vor mir, einen wahren Freund mehr zu gewinnen. Und wenn Sie wüssten, was dies für mich bedeutet! Bin ich doch immer auf Menschenraub aus, wie nur irgend ein Corsar; aber nicht um diese Menschen in der Sclaverei, sondern um mich mit ihnen in die Freiheit zu verkaufen.

Nun wünschte ich, dass wir eine Zeit einmal zusammen leben möchten: denn meine Augen (welche man noch dazu mit einer Atropinkur behandelt) verbieten mir eine briefliche Verständigung, selbst wenn eine solche möglich 
Em 01 de outubro parte o senhor até Davos, e eu, no mesmo dia, para a Itália, para recuperar minha saúde em Sorrento, onde irei morar com com a minha amiga mais querida, a senhorita von Meysenbug (Você conhece suas Memórias de uma idealista? Stuttgart, 1875) Um amigo e um aluno também me acompanham - temos uma casa para todos e também os mais altos interesses em comum: será uma espécie de monastério para espíritos livres. Do amigo mencionado eu não quero esconder que ele é o autor de um livro anônimo muito curioso, Observações Psicológicas (Berlin, Carl Duncker, 1875).

Por que eu te digo tudo isso? Você já adivinhou minha esperança secreta: - Estaremos em Sorrento por um ano aproximadamente, então eu vou voltar à Basileia, a menos que eu construa em outro lugar meu mosteiro, quero dizer "a escola de educadores" (onde eles se educam a si mesmo) com grande estilo.

Seu devoto de todo o coração Friedr. Nietzsche wäre; woran ich aber zweifle.

Sie gehen am 1 October nach Davos, und ich, am gleichen Tage, nach Italien, um in Sorrent meine Gesundheit wieder $\mathrm{zu}$ finden, im Zusammenleben mit meiner verehrten Freundin Fräulein von Meysenbug (kennen Sie deren „Memoiren einer Idealistin“? Stuttgart 1875) ebenfalls begleiten mich ein Freund und ein Schüler dahin - wir alle haben ein Haus zusammen und alle höheren Interessen überdies gemeinsam: es wird eine Art Kloster für freiere Geister. Von dem erwähnten Freunde will ich nicht verschweigen, dass er der Verfasser eines anonymen sehr merkwürdigen Buches ist ,psychologische Beobachtungen“ (Berlin Carl Duncker 1875)

Warum erzähle ich dies Ihnen? O Sie errathen meine stille Hoffnung: - wir bleiben ungefähr ein Jahr in Sorrent. Dann kehre ich nach Basel zurück, es sei denn dass ich irgendwo mein Kloster, ich meine ,die Schule der Erzieher" (wo diese sich selbst erziehen) in höherem Style aufbaue.

Von ganzem Herzen Ihnen ergeben Friedr. Nietzsche $\beta$

\section{A Carl Burckhardt em Basileia \\ Basileia, 2 de maio de 1879}

Ilustre Sr. Presidente:

O estado da minha saúde, razão pela qual já tive que me dirigir a um pedido em mais de uma ocasião, faz com que eu dê o último passo hoje e expresse o pedido para que me permita retirar-me do meu cargo de professor da Universidade. As dores de cabeça, que vêm aumentando até se tornarem extremas, as perdas crescentes de tempo que sofro por ataques entre dois até seis dias, a diminuição considerável da minha capacidade de enxergar, que foi recentemente verificada (pelo Senhor Professor Schiess), e que apenas me permite ler e escrever sem dor por vinte minutos - tudo isso em conjunto me obriga a admitir que não posso mais cumprir minhas obrigações acadêmicas e que a partir de agora não posso executá-las, depois que me permitem nos últimos anos várias irregularidades no cumprimento desses deveres, com grande pesar em cada ocasião. Seria em detrimento de nossa Universidade e dos estudos filológicos a ela atribuídos que eu continue desempenhando um papel para o qual não estou mais à altura da tarefa. Também não posso ter em breve melhoria na condição de minha cabeça, porque durante anos eu fiz tentativa após tentativa de acabar com essa enfermidade e poder regular minha vida de forma estrita, com renúncias de todos os tipos - em vão, como hoje, não tenho mais fé em poder suportar minha condição por mais tempo, devo confessar a mim mesmo. Então só resta expressar, com profundo pesar, o desejo de minha demissão em acordo com o $\$ 20877$ do estatuto da Universidade, junto com os

\section{An Carl Burckhardt in Basel}

Basel d. 2. Mai 1879.

\section{Hochgeachteter Herr Präsident!}

Der Zustand meiner Gesundheit, derentwegen ich schon mehrere Male mich mit einem Gesuche an Sie wenden musste, lässt mich heute den letzten Schritt thun und die Bitte aussprechen, aus meiner bisherigen Stellung als Lehrer an der Universität ausscheiden zu dürfen. Die inzwischen immer noch gewachsene äusserste Schmerzhaftigkeit meines Kopfes, die immer grösser gewordene Einbusse an Zeit, welche ich durch die zweibis sechstägigen Anfälle erleide, die von neuem (durch Hrn. Prof. Schiess) festgestellte erhebliche Abnahme meines Sehvermögens, welches mir kaum noch zwanzig Minuten erlaubt ohne Schmerzen $\mathrm{zu}$ lesen und $\mathrm{zu}$ schreiben - diess Alles zusammen drängt mich einzugestehen, dass ich meinen akademischen Pflichten nicht mehr genügen, ja ihnen überhaupt von nun an nicht nachkommen kann, nachdem ich schon in den letzten Jahren mir manche Unregelmässigkeit in der Erfüllung dieser Pflichten, jedes Mal zu meinem grossen Leidwesen nachsehen musste. Es würde zum Nachtheile unserer Universität und der philologischen Studien an ihr ausschlagen, wenn ich noch länger eine Stellung bekleiden müsste, der ich jetzt nicht mehr gewachsen bin; auch habe ich keine Aussicht mehr in kürzerer Zeit auf eine Besserung in dem chronisch gewordenen Zustande meines Kopfleidens rechnen zu dürfen, da ich nun seit Jahren Versuche über Versuche zu seiner Beseitigung gemacht und mein Leben auf das Strengste darnach geregelt habe, unter Entsagungen jeder Art - umsonst wie ich mir heute eingestehen muss, wo ich den Glauben nicht mehr habe meinen Leiden noch lange widerstehen zu können. So 
agradecimentos pelas muitas evidências da indulgência benevolente que a alta autoridade me deu desde o dia da minha nomeação até hoje.

Enquanto isso, peço-lhe, distinto Sr. Presidente, para interceder em nome de minha petição, eu sou e serei, com particular referência

o mais atencioso

Seu muito devotado

Dr. Friedrich Nietzsche Professor o. p.

(em ditado) bleibt mir nur übrig, unter Hinweis auf $\S 20$ des Universitätsgesetzes, mit tiefem Bedauern den Wunsch meiner Entlassung auszusprechen, zugleich mit dem Danke für die vielen Beweise wohlwollender Nachsicht, welche die hohe Behörde mir vom Tage meiner Berufung an bis heute gegeben hat.

Indem ich, hochgeachteter Herr Präsident, Sie bitte Fürsprecher meines Gesuchs zu sein, bin und verbleibe ich in vorzüglicher Verehrung

Ihr ganz ergebener Dr Friedrich Nietzsche Professor o. p.

(dictirt)

\section{$\gamma$}

A Richard e Cosima Wagner en Bayreuth (esboço)

Basileia, começo de 1878

\section{$\mathrm{R}<$ ichard $>\mathrm{W}<$ agner $>\mathrm{S}<$ ra. $>$}

Ao enviá-lo - confio meu segredo em suas mãos e o de seu nobre consorte, e suponho que a partir de agora também será seu segredo. Este livro é meu: eu trouxe à luz meus mais íntimos sentimentos sobre pessoas e coisas, e pela primeira vez eu delimitei os contornos de meu próprio pensamento. Em tempos cheios de paroxismos e tormentos, este livro foi meu consolo, aquele que não falhou, quando todos os outros o fizeram. Talvez eu ainda esteja vivo porque consegui escrevê-lo.

Era necessário escolher um pseudônimo, primeiro porque eu não eu não gostaria de interferência des meus escritos anteriores; e segundo, porque eu quero impedir com isso a ofensa pública e privar a dignidade da minha pessoa (já que minha saúde não suportaria isso) e, por fim, especialmente, porque eu queria possibilitar uma discussão objetiva, na qual meus amigos inteligentes também podessem participar, sem um sentimento de afeição atrapalhando como antes. Ninguém quer falar ou escrever contra o meu nome. Mas eu sei que nenhum deles têm os pontos de vista que este livro argumenta, no entanto, eu tenho muita curiosidade sobre contraargumentos que vão argumentar neste caso.

$\mathrm{Eu}$ me sinto como um oficial que assumiu um posto inimigo. Ferido sim - mas agora esta por cima e estende sua bandeira. Sentindo mais felicidade do que dor, muito mais, não importa o quão terrível seja o espetáculo aterrador.

Enquanto eu, como disse, não conheço ninguém que agora é companheiro do meu pensamento, tenho, no entanto, a ilusão de pensar não como indivíduo, mas como um coletivo - é uma sensação muito estranha de solidão e pluralidade. - Um arauto que está à frente e que não sabe ao certo se a cavalaria o segue ou se ela sequer existe.

\section{An Richard und Cosima Wagner in Bayreuth (Entwurf) <Basel, Anfang 1878>}

$\mathrm{R}<$ ichard $>\mathrm{W}<$ agner $>$ und $\mathrm{Fr}<\mathrm{au}>$

Indem ich — übersende, lege ich mein Geheimniß vertrauensvoll in Ihre und Ihrer edlen Gem<ahlin> Hände und nehme an daß es nunmehr auch Ihr Geh<eimnis> sei. Dies Buch ist von mir: ich habe meine innerste Empfind<ung> über menschliche Dinge darin ans Licht gebracht und zum ersten Male die Peripherie meines eigenen Denkens umlaufen. In Zeiten, welche voller Parox<ismus> und Qualen waren, war dies Buch mein Trostmittel, welches nicht versagte, wo alle anderen Trostm<ittel> versagten. Vielleicht lebe ich noch, weil ich seiner fähig war.

Es mußte <ein> Pseudon<ym> gewählt werden, einmal weil ich die Wirkung meiner früheren Schriften nicht stören mochte, sodann weil die öffentl<iche> und private Beschmutzung der Würde meiner Person damit verhindert werden soll (weil meine Gesundheit dergleichen nicht mehr aushält) endlich und namentlich, weil ich eine sachliche Diskussion möglich machen wollte, an der auch meine so intelligenten Freunde aller Art theilnehmen können, ohne daß ein Zartgefühl ihnen wie bisher dabei im Wege stand. Niemand will gegen meinen Namen schreiben und reden. Aber ich weiß keinen von ihnen, der die Ansichten dieses Buches hätte, bin aber sehr lernbegierig in Bezug auf die Gegengründe, welche in diesem Falle vorzubringen sind. Mir ist zu Muthe wie einem Offizier der eine Schanze gestürmt hat. Zwar verwundet - aber er ist oben und entrollt nun seine Fahne. Mehr Glück, viel mehr als Leid, so furchtbar das Schauspiel rings herum ist.

Obschon ich wie gesagt niemanden kenne, der jetzt noch mein Gesinnungsgenosse ist, habe ich doch die Einbildung, nicht als Individuum sondern als Collektivum gedacht zu haben - das sonderbarste Gefühl von Einsamkeit und Vielsamkeit. - Herold vorangeritten, <der> nicht genau weiss, ob die Ritterschaft ihm nachkommt oder ob sie noch existirt. 


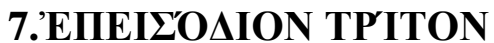

$\alpha$

O Sofrimento do jovem Werther-Goethe

10 de maio

Uma serenidade admirável domina minha alma inteira, semelhante à doce manhã primaveril que eu gozo de todo o coração. Estou tão só e minha vida é feita de alegrias por viver numa região que parece ter sido criada para almas como a minha. Estou tão feliz, meu amigo, tão mergulhado na sensação de minha calma existência, que a minha arte sofre com isso. Não poderia desenhar nada agora, nem sequer um traço, embora jamais tenha sido tão grande pintor quanto neste instante. Quando a bruma do vale se levanta a minha volta,e o sol altaneiro descansa sobre a abóbada escura e impenetrável da minha floresta, e apenas alguns escassos raios deslizam até o fundo do santuário, ao passo em que eu, deitado no chão entre a relva alta, na encosta de um riacho, descubro no chão mil plantinhas desconhecidas... Quando sinto mais perto de meu coração a existência desse minúsculo mundo que formiga por entre a relva, essa incontável multidão de ínfimos vermes e insetinhos de todas as formas e imagino a presença do Todo-poderoso, que nos criou a sua imagem e semelhança, e o hálito do Todo amado que nos leva consigo e nos ampara a pairar em eternas delícias... Ah, meu amigo, quando o mundo infinito começa a despontar assim ante meus olhos e o céu se reflete todo ele em minha alma, como a imagem de uma amada... Então suspiro profundamente e penso: Ah! pudesses tu voltar a expressá-lo, pudesses tu exalar o sentimento e fixar no papel aquilo que vive em ti com tanta abundância e tanto calor, de maneira que o mesmo papel pudesse se fazer o espelho de tua alma, como tua alma é o espelho do Deus infinito! Meu amigo! Mas vou ao chão ante isso, sucumbo ante o poder e a majestade dessas aparições.
Die Leiden des jungen Werthers - Goethe

政e

Eine wunderbare Heiterkeit hat meine ganze Seele eingenommen, gleich den süßen Frühlingsmorgen, die ich mit ganzem Herzen genieße. Ich bin allein und freue mich meines Lebens in dieser Gegend, die für solche Seelen geschaffen ist wie die meine. Ich bin so glücklich, meinBester, so ganz in dem Gefühle von ruhigem Dasein versunken, daß meine Kunst darunter leidet. Ich könnte jetzt nicht zeichnen, nicht einen Strich, und bin nie ein größerer Maler gewesen als in diesen Augenblicken. Wenn das liebe Tal um mich dampft, und die hohe Sonne an der Oberfläche der undurchdringlichen Finsternis meines Waldes ruht, und nur einzelne Strahlen sich in das innere Heiligtum stehlen, ich dann im hohen Grase am fallenden Bache liege, und näher an der Erde tausend mannigfaltige Gräschen mir merkwürdig werden; wenn ich das Wimmeln der kleinen Welt zwischen Halmen, die unzähligen, unergründlichen Gestalten der Würmchen, der Mückchen näher an meinem Herzen fühle, und fühle die Gegenwart des Allmächtigen, der uns nach seinem Bilde schuf, das Wehen des Alliebenden, der uns in ewiger Wonne schwebend trägt und erhält; mein Freund! Wenn's dann um meine Augen dämmert, und die Welt um mich her und der Himmel ganz in meiner Seele ruhn wie die Gestalt einer Geliebten--dann sehne ich mich oft und denke : ach könntest du das wieder ausdrücken, könntest du dem Papiere das einhauchen, was so voll, so warm in dir lebt, daß es würde der Spiegel deiner Seele, wie deine Seele ist der Spiegel des unendlichen Gottes!--mein Freund--aber ich gehe darüber zugrunde, ich erliege unter der Gewalt der Herrlichkeit dieser Erscheinungen.

\section{$\beta$}

\begin{tabular}{l}
\hline Fragmento Póstumo de 1885, 34[181] \\
Assim eu quero, como homem ocioso que não tem \\
nada melhor para fazer, contar mais uma vez o que \\
entendo pela filosofia de Dioniso: pois, que os deuses \\
também filosofam me parece uma ideia digna e piedosa \\
[fromme] de que o crente mais ardente também possa \\
se alegrar. Talvez, segundo o gosto de meus amigos, eu \\
possa ir demasiado longe na franqueza de minha \\
narrativa: porém, este Deus, em diálogo comigo, foi \\
muito mais além e, se acaso eu pudesse dar a ele nomes
\end{tabular}
$N F 1885,34[181]$

So will ich, als ein müssiger Mensch, der nichts Besseres zu thun hat, meinen Freunden einmal erzählen, was ich mir unter der Philosophie des Dionysos denke: denn daß auch Götter philosophiren, scheint mir eine würdige und fromme Vorstellung, an der auch der Gläubigste noch seine Freude haben kann. Ich werde vielleicht, dem Geschmacke meiner Freunde nach, in der Freimüthigkeit meiner Erzählung zu weit gehn: dieser Gott selber aber ist, im Zwiegespräch mit mir, viel weiter gegangen und 
pomposos, belos e hipócritas, teria que fazer muitos elogios de meu encorajamento, de minha sinceridade, veracidade, honestidade [Ehrlichkeit Wahrhaftigkeit Redlichkeit], "amor à verdade" e semelhantes. Mas com todo esse belo lixo [schönen Plunder] e pompa, tal deus não sabe o que fazer - duas palavras bastam para minha justificativa, o que certamente na Alemanha não é fácil de traduzir "ao alemão": gaia ciência.

Guarde isto para ti e para os da tua espécie: eu não tenho motivos para cobrir minha "nudez" [Blöße].

Chega, é um tipo de divindade completamente desenvergonhada.

Era primavera e todo o bosque estava repleto de seiva jovem: enquanto eu caminhava pela floresta e pensava sobre coisas de criança [Kinderei], talhei para mim uma flauta, sem saber ao certo o que fazia. Porém, assim que a levei à boca e assobiei, apareceu diante de mim o deus que eu conheci há muito tempo.

Bem, você, apanhador de ratos, o que você está fazendo aí? Você, meio jesuíta e músico - quase um alemão!

Fiquei surpreso que o Deus procurou me lisonjear dessa maneira: e me propus fingir estar de guarda contra ele.

Fiz de tudo para entontecê-los, os fiz suar na cama, deilhes bolinhos [Klöße] para comer, disse-lhes para beber até cair, os fiz homens sedentários [Stubenhockern] e eruditos, dei-lhes sentimentos miseráveis de uma alma servil.

Parece-me que está propondo algo mal, destruir os homens?

Talvez, respondeu o deus; mas de um modo que com isso retire algo para mim.

- O quê? Perguntei curiosamente. -

Quem? deveria perguntar. Assim me falou Dioniso. ich würde, falls ich ihm schöne heuchlerische Prunknamen zulegen dürfte, viel Rühmens von meinem Muthe, von meiner Ehrlichkeit Wahrhaftigkeit Redlichkeit „Liebe zur Wahrheit“ und dergleichen, zu machen haben. Aber mit allem diesem schönen Plunder und Prunk weiß ein solcher Gott nichts anzufangen - zu meiner Rechtfertigung genügen zwei Worte, welche man freilich in Deutschland nicht leicht ,ins Deutsche“ übersetzt: gai saber.

Behalte dies doch für dich und deinesgleichen: ich habe keinen Grund, meine „Blöße“ zu decken. Genug, es ist eine ganz unverschämte Art von Gottheit.

Es war Frühling, und alles Holz stand in jungem Safte: als ich so durch den Wald gieng und über eine Kinderei nachdachte, schnitzte ich mir eine Pfeife zurecht, ohne daß ich recht wußte, was ich that. Sobald ich aber sie zum Mund führte und pfiff, erschien der Gott vor mir, den ich seit langem schon kenne.

Nun, du Rattenfänger, was treibst du da? Du halber Jesuit und Musikant -, beinahe ein Deutscher!

Ich wunderte mich, daß mir der Gott auf diese Art zu schmeicheln suchte: und nahm mir vor, gegen ihn auf der Hut zu sein.

Ich habe alles gethan, sie dumm zu machen, ließ sie in Betten schwitzen, gab ihnen Klöße zu fressen, hieß sie trinken, bis sie sanken, machte sie zu Stubenhockern und Gelehrten, gab ihnen erbärmliche Gefühle einer Bedientenseele ein

Du scheinst mir Schlimmes im Schilde zu führen, die $\mathrm{M}<$ enschen> zu Grunde zu richten?

Vielleicht, antwortete der Gott; aber so, daß dabei Etwas für mich herauskommt.

- Was denn? fragte ich neugierig. -

Wer denn? solltest du fragen. Also sprach zur mir Dionysos.

\section{$\gamma$}

Fragmento póstumo 1886, 4[9]

Epílogo - Mas aqui você me interrompe, ó espíritos livres. "Chega! Chega! Eu ouço você gritar e rir, nós não aguentamos mais! Oh, este horrível tentador e perturbador da consciência! Você quer estragar a reputação ante todo o mundo? Denegrir nosso bom nome? E anexar sobrenomes que são incorporados não só na pele? - E para que em um dia claro e azul esses fantasmas sombrios, aqueles gorgolejos morais, toda aquela música trágica, negra como um corvo! Ainda que digas verdades: com essas verdades não há pés que possam dançar, portanto estão longe de serem verdades para nós! Ecce nostrum veritatis sigillum! [Eis aqui nosso selo da verdade!] E aqui está um prado e um solo macio: o que é melhor do que afugentar rapidamente tuas quimeras e, depois de sua noite, construir um bom dia? Seria tempo de finalmente estender-se outro arco-íris sobre a terra, e alguém nos
NF 1886, 4[9]

Nachspiel.- Aber hier unterbrecht ihr mich, ihr freien Geister. „Genug! Genug! höre ich euch schrein und lachen, wir halten es nicht mehr aus! Oh über diesen schauerlichen Versucher und Gewissens-Störenfried! Willst du uns denn bei der ganzen Welt den Ruf verderben? Unsren guten Namen anschwärzen? Uns Zunamen anhängen, die sich nicht nur in die Haut einfressen? - Und wozu am hellen blauen Tage diese düstern Gespenster, diese moralischen Gurgeltöne, diese ganze tragische rabenschwarze Musik! Sprichst du Wahrheiten: nach solchen Wahrheiten können keine Füße tanzen, also sind es noch lange keine Wahrheiten für uns! Ecce nostrum veritatis sigillum! Und hier ist Rasen und weicher Grund: was gäbe es Besseres als geschwind deine Grillen wegjagen und uns, nach deiner Nacht, einen guten Tag machen? Es wäre endlich Zeit, daß sich wieder ein Regenbogen über dies Land 
dê doces canções para ouvir e leite para beber: - todos nós voltamos a ter sede de um pensar piedoso, cordialmente tolo e lácteo." - Meus amigos, eu vejo, vocês estão perdendo a paciência comigo - e quem lhe disse que eu não estava esperando há muito tempo precisamente por isso? Mas estou à sua vontade; e eu tenho o que precisa. Você não vê saltar ali meus rebanhos, todos os tenros, radiantes e calmos cordeiros de meus pensamentos? E aqui está também preparado para você um balde cheio de leite; uma vez que o tenha bebido - porque todos vocês têm sede de virtude, eu vejo isso - não haverá escassez de músicas como as que querem! Começando com uma canção para dançar, para as pernas e os corações mais alegres: e na verdade, que canta o faz em honra de alguém que merece a honra, um do mais livre entre os espíritos livres, o que faz novamente todo o céu brilhar e todo o mar bramir. ausspannte, und daß uns Jemand sanfte tolle Lieder zu hören und Milch zu trinken gäbe: - wir Alle haben wieder Durst nach einer frommen, von Herzen thörichten und milchichten Denkungsart." - Meine Freunde, ich sehe es, ihr verliert meine Geduld, - und wer sagt euch, daß ich nicht längst schon gerade darauf wartete? Aber ich bin zu eurem Willen; und ich habe auch, was ihr braucht. Seht ihr nicht dort meine Heerden springen, alle meine zarten sonnigen windstillen Gedanken-Lämmer und Gedanken-Böcke? Und hier steht auch schon für euch ein ganzer Eimer Milch bereit; habt ihr aber erst getrunken - denn ihr dürstet alle nach Tugend, ich sehe es - so soll es nicht an Liedern fehlen, wie ihr sie wollt! Anzufangen mit einem Tanzliede für die muntersten Beine und Herzen: und wahrlich, wer es singt, der thut es Einem zu Ehren, der Ehre verdient, einem der Freiesten unter freien Geistern, der alle Himmel wieder hell und alle Meere brausen macht. -

\section{$\delta$}

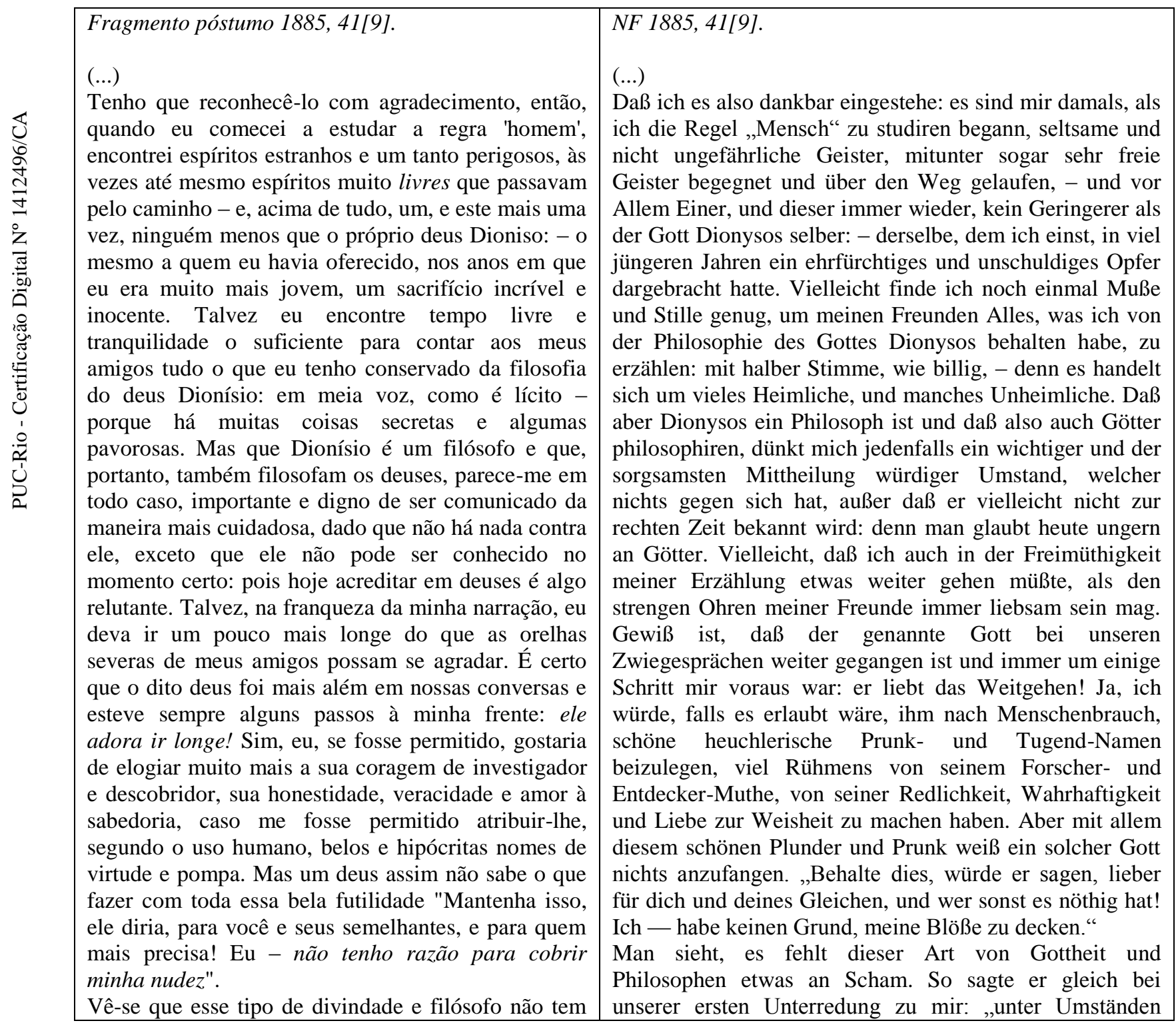


um pouco de vergonha. Ele disse assim em nossa primeira conversa: "em algumas situações eu amo os homens - e com isso aludia a Ariadne -: é um animal agradável inventivo que não tem igual na terra, pode ser encontratado em qualquer labirintos. Costumo pensar em como posso levá-lo adiante e torná-lo mais forte, mais maligno e mais profundo do que é. " Mais forte, mais maligno e mais profundo?" Eu perguntei alarmado. "Sim", disse ele mais uma vez: "mais forte, mais malvado e mais profundo: e ainda mais bonito" - e em seguida o deus sorriu como se tivesse acabado de dizer uma delicadeza encantadora Ao mesmo tempo, vê-se aqui duas coisas: para esta divindade não falta apenas vergonha; e há boas razões para supor que, em algumas partes, os deuses poderiam vir a aprender conosco, os homens. Nós somos mais humanos.

E assim chegamos e no lugar certo: no final. Porque já terá entendido em poucas palavras o que significa: "humano, muito humano". E por que este livro é "um livro para espíritos livres". liebe ich den Menschen - und dabei spielte er auf Ariadne an -: es ist ein angenehmes erfinderisches Thier, das auf Erden nicht seines Gleichen hat, es findet sich in allen Labyrinthen noch zurecht. Ich denke oft darüber nach, wie ich ihn noch vorwärts bringe und ihn stärker, böser und tiefer mache als er ist.“ - Stärker, böser und tiefer? fragte ich erschreckt. „Ja, sagte er noch Ein Mal, stärker, böser und tiefer: auch schöner" - und dazu lächelte der Gott, wie als ob er eben eine bezaubernde Artigkeit gesagt habe. Man sieht hier zugleich: es fehlt dieser Gottheit nicht nur an Scham -; und es giebt überhaupt gute Gründe dafür, zu muthmaaßen, daß in einigen Stücken die Götter insgesammt bei uns Menschen in die Schule gehen könnten. Wir sind menschlicher.

Und hiermit sind wir angelangt und am rechten Orte: nämlich am Ende. Denn man wird bereits sattsam begriffen haben, was es heißen soll: „Menschliches, Allzumenschliches“. Und warum dieses Buch „ein Buch für freie Geister" ist.

Martin Heidegger (1889 - 1976); Michel Foucault (1926 - 1984); Gilles Deleuze (1925 - 1995) são considerados os maiores expoentes no que concerne a interpretação da vontade de poder, cada qual desenvolvendo uma filosofia própria a partir de tal interpretação.

\section{A Franz Overbeck em Baseleia} 7. Abril de 1884

(...)

Nos últimos meses tenho me dedicado à "história do mundo" com entusiasmo, embora com alguns resultados aterrorizantes. Uma vez eu lhe mostrei a carta de Jacob Burckhardt, que empurrou meu nariz para a "história do mundo"? Se eu for a Sils-Maria neste verão, então quero fazer uma revisão de minhas visões metafísicas e epistemológicas. Agora tenho que passar por uma série de disciplinas passo a passo, pois agora decidi passar os próximos cinco anos elaborando minha "filosofia", para a qual construí um uma antecâmera través de meu Zaratustra" (...)
An Franz Overbeck in Basel
$<$ Nizza,> Montag. <7. April 1884>

(...)

Die letzten Monate habe ich „Welt-Historie“ getrieben, mit Entzücken, obschon mit manchem schauerlichen Resultate. Habe ich Dir einmal Jacob Burckhardt's Brief gezeigt, der mich mit der Nase auf die „Welt-Historie“ gestoßen hat? Falls ich den Sommer nach Sils-Maria komme, so will ich eine Revision meiner Metaphysica und erkenntnißtheoretischen Ansichten vornehmen. Ich muß jetzt Schritt für Schritt durch eine ganze Reihe von Disciplinen hindurch, denn ich habe mich nunmehr entschlossen, die nächsten fünf Jahre zur Ausarbeitung meiner „Philosophie“ zu verwenden, für welche ich mir, durch meinen Zarathustra, eine Vorhalle gebaut habe. (...) 


\begin{tabular}{l}
\hline À Malwida de Meysenbug em Roma \\
Turim, 4 de outubro de 1888 \\
Querida amiga, \\
Acabei de encomendar ao meu editor para envie \\
imediatamente ao seu endereço de Versailler três \\
cópias do meu trabalho recém-publicado, O Caso \\
Wagner.
\end{tabular}

Um problema para músico. Este escrito, uma declaração de guerra in aestheticis, mais radical do que qualquer outra que se possa pensar, parece produz um movimento significativo. Meu editor escreveu-me que o primeiro anúncio da existência de um escrito meu sobre esse problema e com isso recebeu tantos pedidos que a edição já pode ser considerada esgotada. Você vai ver que neste duelo eu não perdi meu bom humor. Sinceramente, liquidar a um Wagner em meio à excepcionalmente difícil tarefa da minha vida, é uma verdadeira recreação. Eu escrevi este pequeno trabalho na primavera, aqui em Turim: enquanto isso, o primeiro livro da minha Transvaloração de todos os valores foi concluído - o maior evento filosófico de todos os tempos, com o qual a história da humanidade se parte pela metade ... (...)

\section{A Franz Overbeck em Basel \\ Turim, 18 de outubro de 1888}

Querido amigo,

Ontem, com a sua carta nas mãos, fiz a minha habitual caminhada vespertina pelas imediações de Turim. A mais pura luz de outubro em todos os lugares; o magnífico caminho das árvores, que mais ou menos em uma hora, levou-me próximo ao Largo do Po, mas estava tocado apenas pelo sol de outono. Eu sou agora a pessoa mais grata do mundo - com uma mentalidade outonal em todos os sentidos da palavra: é o minha grande época de colheita. Tudo é fácil para mim, tudo vem para mim, embora dificilmente alguém tenha tido coisas tão grandes entre as mãos. Que o primeiro livro da Transvaloração de todos os valores esteja acabado, pronto para impressão, eu lhes anuncio com um sentimento para o qual não tenho palavras. Existem quatro livros; eles aparecerão separadamente. Desta vez, como um velho atirador, eu aponto minha grande arma: temo que com o seu disparo eu dividirei a história da humanidade pela metade. (...)
An Malwida von Meysenbug in Rom

Turin, den 4. Okt. 1888

Verehrteste Freundin,

eben gab ich meinem Verleger Auftrag, umgehend drei Exenrplare meiner eben erscheinenden Schrift Der Fall Wagner.

Ein Musikanten-Problem an Ihre Versailler Adresse abgehn zu lassen. Diese Schrift, eine Kriegserklärung in aestheticis, wie sie radikaler gar nicht gedacht werden kann, scheint eine bedeutende Bewegung zu machen. Mein Verleger schrieb, daß auf die allererste Meldung von einer bevorstehenden Schrift von mir über dies Problem und in diesem Sinne soviel Bestellungen eingelaufen sind, daß die Auflage als erschöpft gelten kann. - Sie werden sehn, daß ich bei diesem Duell meine gute Laune nicht eingebüßt habe. Aufrichtig gesagt, einen Wagner abthun gehört, inmitten der über alle Maaßen schweren Aufgabe meines Lebens, zu den wirklichen Erholungen. Ich schrieb diesen kleine Schrift im Frühling, hier in Turin: inzwischen ist das erste Buch meiner Umwerthung aller Werthe fertig geworden — das größte philosophische Ereigniß aller Zeiten, mit dem die Geschichte der Menschheit in zwei Hälften auseinander bricht...

(...)

An Franz Overbeck in Basel

Turin, den 18. Okt. 1888

Lieber Freund,

ich machte gestern, mit Deinem Brief in der Hand, meinen gewohnten Nachmittags-Spaziergang außerhalb Turins. Reinstes Oktoberlicht überall; der herrliche Baumweg, der mich ungefähr eine Stunde dicht am Po entlang führte, vom Herbste noch kaum berührt. Ich bin jetzt der dankbarste Mensch von der Welt - herbstlich gesinnt in jedem guten Sinne des Wortes: es ist meine große Erntezeit. Alles wird mir leicht, Alles geräth mir, obwohl schwerlich schon Jemand so große Dinge unter den Händen gehabt hat. Daß das erste Buch der Umwerthung aller Werthe fertig ist, druckfertig, das melde ich Dir mit einem Gefühle, für das ich kein Wort habe. Es werden vier Bücher; sie erscheinen einzeln. Dies Mal führe ich, als alter Artillerist, mein großes Geschütz vor: ich fürchte, ich schieße die Geschichte der Menschheit in zwei Hälften aus einander. (...) 
Além do bem e do mal $\$ 296$

Oh, que são vocês afinal, meus pensamentos escritos e pintados! Há pouco tempo ainda eram irisados, tão jovens e maldosos, com espinhos e temperos secretos, que me faziam espirrar e rir - e agora? Já se despojaram de sua novidade, e alguns estão prestes, receio, a tornarse verdades: tão imortal já é seu aspecto, tão pateticamente honrado, tão enfadonho! E alguma vez foi diferente? Que coisas escrevemos e pintamos, nós, mandarins com pincel chinês, eternizadores do que consente em ser escrito, que coisa conseguimos apenas pintar? Oh, somente aquilo que está a ponto de murchar e perder seu aroma! Oh, somente pássaros que se fatigaram e extraviaram no voo, e agora se deixam apanhar com a mão - com a nossa mão! Eternizados o que já não pode viver e voar muito tempo, somente coisas gastas e exaustas! Apenas para sua tarde eu tenho cores, meus pensamentos escritos e pintados, muitas cores talvez, várias delicadezas multicolores, e cinquenta amarelos e vermelhos e marrons e verdes: mas com isso ninguém adivinhará como eram vocês em sua manhã, vocês, imprevistas centelhas e prodígios de minha solidão, vocês, velhos e amados - maus pensamentos!" (Trad. Paulo Cesar de Souza)

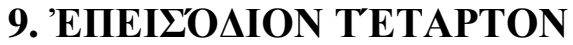

$\alpha$

Fragmento póstumo de 1888, 17[5]

Que poder tem a embriaguez que se chama amor e que ainda continua sendo algo diferente do amor! - Mas, sobre isso cada qual tem a sua ciência. A força muscular de uma jovem aumenta tão logo um homem acerca-se dela; há instrumentos que medem isso. Quando a relação entre sexos se torna ainda mais próxima, como, por exemplo, na dança, ou em diversos outros encontros sociais, esta força aumenta a tal ponto que capacita para verdadeiras proezas de força: acabase por não se acredita em seus próprios olhos - nem em seu relógio! Deve-se contar aqui com o fato de que a dança em si mesma, assim como todo movimento muito rápido, já traz consigo uma espécie de embriaguez para todo o sistema vascular, nervoso e muscular. Deve-se contar, nesse caso, com os efeitos combinados de uma dupla embriaguez. - E como é sábio, às vezes, permitirse um pequeno excesso!... Há realidades que não é lícito se confessar; isso é ser mulher, para tanto, para isso tem-se todos os pudores femininos... Essas jovens criaturas que ali dançam estão, evidentemente, além de

Nachgelassene Fragmente 1888, 17[5].
Was der Rausch Alles vermag, der Liebe heißt und der
noch Etwas Anderes ist als Liebe! — Doch darüber hat
Jedermann seine Wissenschaft. Die Muskelkraft eines
Mädchens wächst, sobald nur ein Mann in seine Nähe
kommt; es giebt Instrumente, dies zu messen. Bei einer
noch näheren Beziehung der Geschlechter, wie sie zum
Beispiel der Tanz und andre gesellschaftliche
Gepflogenheiten mit sich bringen, nimmt diese Kraft
dergestalt zu, um zu wirklichen Kraftstücken zu
befähigen: man traut endlich seinen Augen nicht - und
seiner Uhr! Hier ist allerdings einzurechnen, daß der
Tanz an sich schon, gleich jeder sehr geschwinden
Bewegung eine Art Rausch für das gesamte Gefäß-
Nerven- und Muskelsystem mit sich bringt. Man hat in
diesem Fall mit den combinirten Wirkungen eines
doppelten Rausches zu rechnen. — Und wie weise es
mitunter ist, einen kleinen Stich zu haben!... Es giebt
Realitäten, die man nie sich eingestehen darf; dafür ist
man Weib, dafür hat man alle weiblichen pudeurs...
Diese jungen Geschöpfe, die dort tanzen, sind ersichtlich

Was der Rausch Alles vermag, der Liebe heißt und der noch Etwas Anderes ist als Liebe! - Doch darüber hat Jedermann seine Wissenschaft. Die Muskelkraft eines Mädchens wächst, sobald nur ein Mann in seine Nähe kommt; es giebt Instrumente, dies zu messen. Bei einer noch näheren Beziehung der Geschlechter, wie sie zum Beispiel der Tanz und andre gesellschaftliche Gepflogenheiten mit sich bringen, nimmt diese Kraft dergestalt $\mathrm{Zu}, \mathrm{um} \mathrm{zu}$ wirklichen Kraftstücken $\mathrm{zu}$ befähigen: man traut endlich seinen Augen nicht - und seiner Uhr! Hier ist allerdings einzurechnen, daß der Tanz an sich schon, gleich jeder sehr geschwinden Nerven- und Muskelsystem mit sich bringt. Man hat in diesem Fall mit den combinirten Wirkungen eines doppelten Rausches zu rechnen. - Und wie weise es Realitäten, die man nie sich eingestehen darf; dafür is Diese jungen Geschöpfe, die dort tanzen, sind ersichtlich 
toda a realidade: dançam apenas com ideais palpáveis, mais ainda, veem sentadas em circulo em torno delas outros ideais: as mães!... É o caso de citar Fausto... Elas são incomparavelmente mais lindas quando estão um pouco mais loucas, essas belas criaturas, - oh, como elas também sabem perfeitamente disso! Tornam-se mesmo amáveis porque sabem disso! - Por fim, os seus adornos as inspiram; seu adorno é, para elas, uma terceira pequena embriaguez: acreditam em seu alfaiate como acreditam no seu Deus: - e quem lhes faria renunciar a essa fé? Essa fé as torna felizes! E a admiração de si é saudável! - A admiração de si protege do resfriado. Alguma vez uma bela mulher que soubesse estar bem-vestida já apanhou resfriado? Nunca e jamais! Mesmo no caso em que estivesse pouco vestida... jenseits aller Realität: sie tanzen nur mit lauter handgreiflichen Idealen, sie sehen sogar, was mehr ist, noch Ideale um sich sitzen: die Mütter!... Gelegenheit, Faust zu citiren... Sie sehen unvergleichlich besser aus, wenn sie dergestalt ihren kleinen Stich haben, diese hübschen Creaturen, - oh wie gut sie das auch wissen! sie werden sogar liebenswürdig, weil sie das wissen! Zuletzt inspirirt sie auch noch ihr Putz; ihr Putz ist ihr dritter kleiner Rausch: sie glauben an ihren Schneider, wie sie an Gott glauben: - und wer widerriethe ihnen diesen Glauben? dieser Glaube macht selig! Und die Selbstbewunderung ist gesund! - Selbstbewunderung schützt vor Erkältung. Hat sich je ein hübsches Weib erkältet, das sich gut bekleidet wußte? Nie und nimmermehr! Ich setze selbst den Fall, daß sie kaum bekleidet war... 